UNIVERSIDADE DE SÃO PAULO

INSTITUTO DE GEOCIÊNCIAS

\title{
ESTUDOS EXPERIMENTAIS DE ALTERAÇÃO ACELERADA EM ROCHAS GRANÍTICAS PARA REVESTIMENTO
}

Maria Heloisa Barros de Oliveira Frascá

Orientador: Prof. Dr. Jorge Kazuo Yamamoto

TESE DE DOUTORAMENTO

Programa de Pós-Graduação em Recursos Minerais e Hifrogeologia

SÃO PAULO

2003 
À Fernanda, minha fonte de inspiração, Nando, Dalva e José Roberto 


\section{AGRADECIMENTOS}

A realização e elaboração de uma tese é um trabalho único, e um tanto solitário, para cujo termo são necessários três suportes básicos: o apoio da família e amigos; intercâmbios e colaborações de instituições e profissionais; e a paixão pelo tema.

Considero-me privilegiada por ter contado com todos os três; e foram tantos os que me apoiaram, forneceram informações e discutiram o assunto que, felizmente, poucas linhas são insuficientes para nomear a todos. Mas, nem por isso, sou menos grata àqueles que, direta ou indiretamente, colaboraram para a execução deste estudo e meu crescimento profissional.

Primeiramente, destaco o amigo e orientador, Jorge Kazuo Yamamoto, que sempre apoiou minhas idéias, guiou para que a meta fosse atingida e suportou, sempre positivamente, os momentos finais de cansaço e dúvidas.

Este trabalho, como poderão ver, contém centenas de determinações laboratoriais, que só foram possíveis com a colaboração, perseverança e aprendizado mútuo dos colegas do Laboratório de Petrologia e Tecnologia de Rochas; Fábio Conrado de Queiróz, Eli A. Toledo, Jilson Cardoso, Magno Bueno, Nilson de Paula e Valentim José da Silva Filho, com especial menção ao Eduardo Quitete, pelo acompanhamento e apoio durante todo o trabalho, pela disposição para discussões e editoração das fotos. À Priscila R. M. Leal, minha gratidão pela colaboração nas descrições petrográficas e no trabalhoso ajuste das informações ao foco desta pesquisa.

Aos amigos e colegas Ely B. Frazão, Ivan Mello e Lúcia Dozzi agradeço as conversas, a leitura paciente, as discussões e sugestões que muito contribuíram para o texto final. As referências bibliográficas são produto do trabalho minucioso da amiga e colega Maria Solange O. P. Fierro. Mesmo com as urgências de final de prazo, as sugestões ortográficas e gramaticais de Marlene Santana contribuíram para melhorar clareza do texto.

Ao Dr. Fábio Taioli, agradeço pelas sugestões, por ocasião do exame de qualificação, que muito contribuíram para reorientações da pesquisa.

Os trabalhos de campo foram possíveis graças à colaboração de entidades e pessoas que se dispuseram a apoiar e realizar os contatos necessários para visitas às minas, providenciar facilidades de acesso e outros: registro meu agradecimento a Attílio Travaglia, do Sindirochas (ES); a Francisco W. Hollanda Vidal, do Cetem/MCT (RJ); Maria Angélica Lima, do Nutec (CE); e a Gilberto Rangel, da Mineração Corcovado. 
A colaboração das empresas produtoras dos materiais ensaiados foi fundamental para a realização deste estudo, às quais agradeço pela recepção nas minas e pelo fornecimento e envio das (grandes) amostras; Granasa - Granitos Nacionais Ltda; Granistone S.A.; Granitos Brasileiros S.A.; Granitos Pires - Mineração e Comércio Ltda.; Granos - Granitos S.A.; Imarf Granitos S.A.; Marbrasa - Mármores e Granitos do Brasil S.A.; Mineração Corcovado Ltda.; Nemer - Mármores e Granitos S.A.; Rocha Branca - Mineração Comércio e Exportação Ltda; e Somibrás - Sociedade de Mineração Brasileira Ltda.

Ao Laboratório de Corrosão e Tratamento de Superfície, do IPT, pela realização dos ensaios em câmaras climáticas.

Para execução deste trabalho, também foi de grande importância a colaboração de vários colegas, especialmente no atendimento de demandas administrativas, abundantes no exercício profissional, aos quais exprimo minha gratidão, especialmente para Pedro A. Abel Fabiani, Mírian C. B. Oliveira e Vilmondes Ribeiro. À Renata M. de Cavalcante, pelos trabalhos de digitalizações de imagens. À Maria Lúcia F. Gonçalves, que digitou os dados e boa parte do texto, devo minha gratidão ao seu sempre presente auxílio nas atividades profissionais cotidianas e, inclusive, por suportar as crises nos momentos mais tumultuados.

Meu agradecimento para aos colegas e amigos do IGc; Thelma e Marcos, pela cuidados elaboração das figuras; à Sonia e Ana Paula, que sempre atenderam prontamente as questões, sempre urgentes, dessa pós-graduanda; e a Marcelo Monteiro da Rocha, no auxílio à trabalhosa impressão final.

Agradeço ao IPT, por meio de Omar Y. Bittar, que colocou à disposição a infraestrutura laboratorial e sempre apoiou todas as etapas deste trabalho, até sua conclusão.

Ao IGc, agradeço pela acolhida, aceite do desafio de apoiar o desenvolvimento desta pesquisa e o apoio fornecido em todas as etapas da pós-graduação.

Finalmente, agradeço à Fapesp, cujo suporte financeiro (Processo 99-06250-0) foi fundamental para a realização desta pesquisa. 


\section{SUMÁRIO}

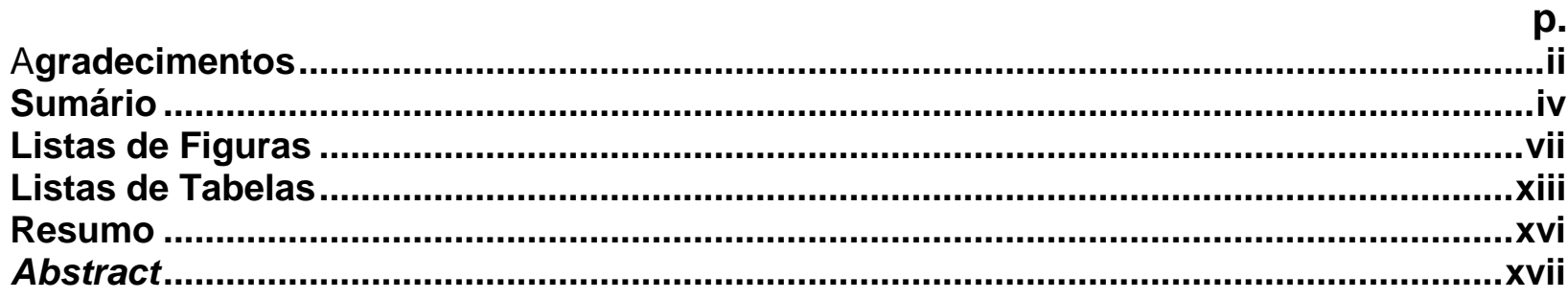

\section{CAPÍTULO 1}

INTRODUÇÃO

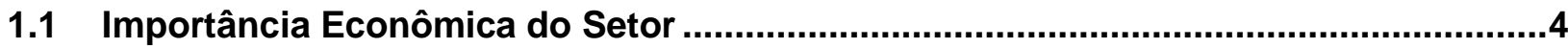

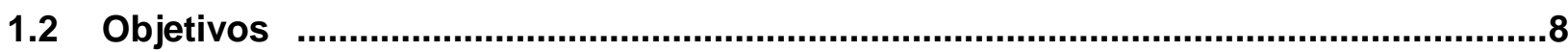

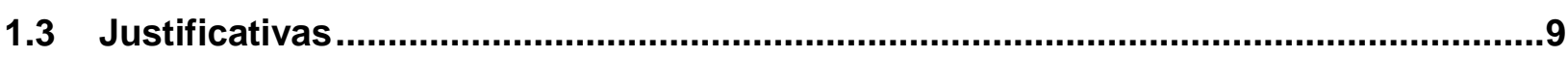

\section{CAPÍTULO 2}

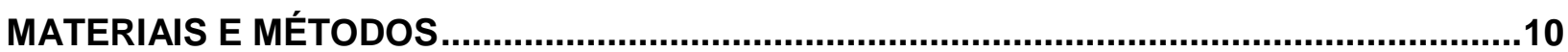

2.1 Seleção dos Materiais e Áreas de Estudo..............................................................10

2.2 Levantamento Bibliográfico.........................................................................................11

2.3 Visitas às Minas Selecionadas ............................................................................12

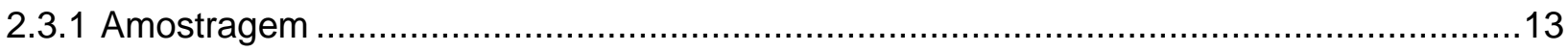

2.4 Visita a Centros de Beneficiamento ........................................................................13

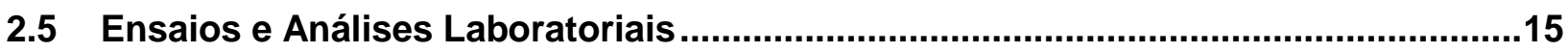

\section{CAPÍTULO 3}

DETERIORAÇÃO DE ROCHAS..................................................................................19

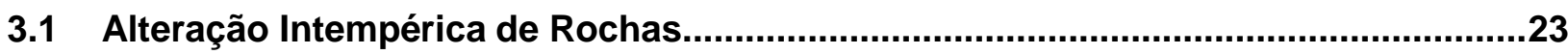

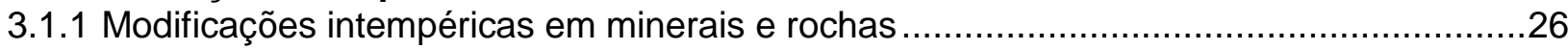

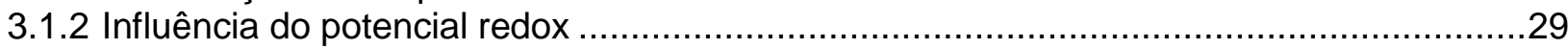

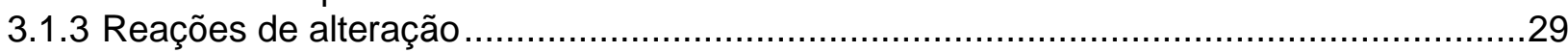

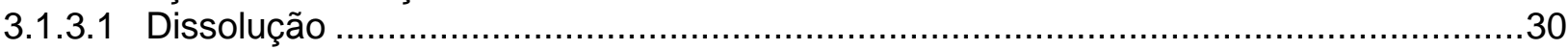

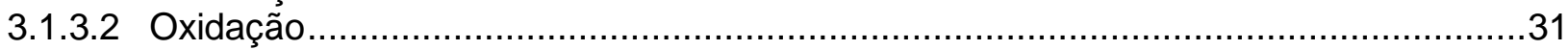

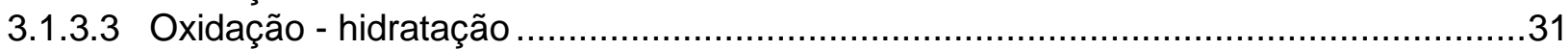

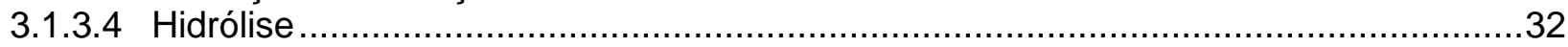

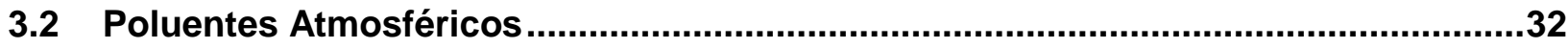

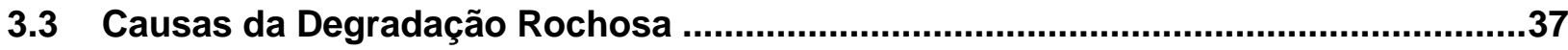

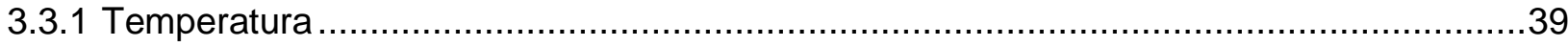

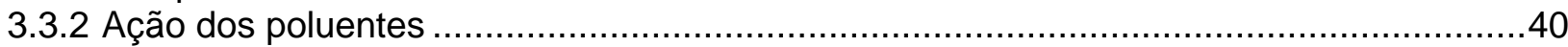

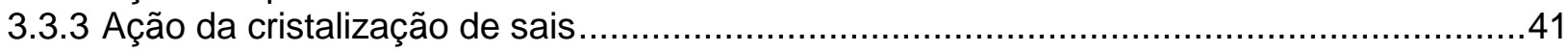

3.4 Alterabilidade e Durabilidade de Rochas ............................................................45

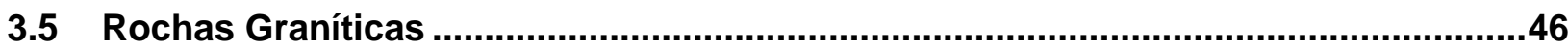

3.5.1 Granitos e sua alteração em ambientes naturais .................................................47 


\section{CAPÍTULO 4}

ASPECTOS GEOLÓGICOS DAS ROCHAS SELECIONADAS

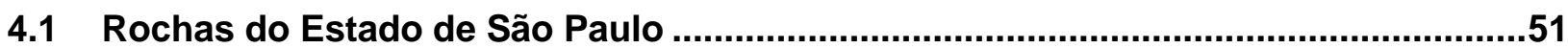

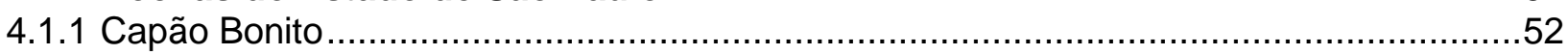

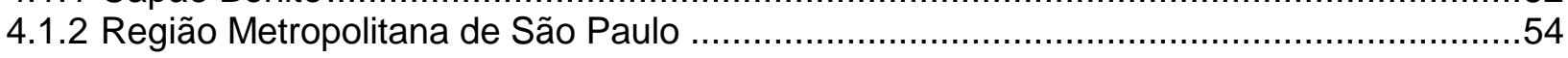

4.2 Rochas do Estado do Espírito Santo .................................................................54

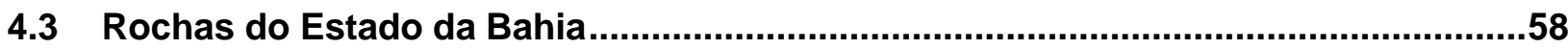

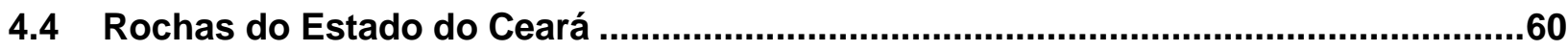

\section{CAPÍTULO 5}

TRABALHOS DE LABORATÓRIO ..............................................................................65

5.1 Análises Petrográficas e Mineralógicas..............................................................65

5.1.1 Ensaios de coloração seletiva de feldspatos.....................................................67

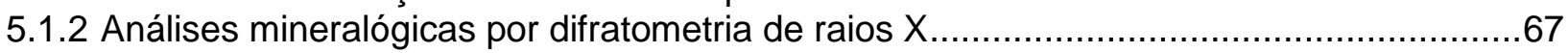

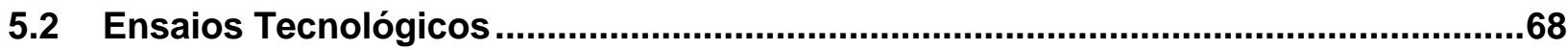

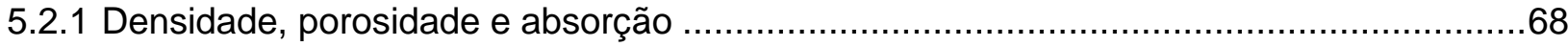

5.2.1.1 Breve consideração sobre métodos e procedimentos adotados................................71

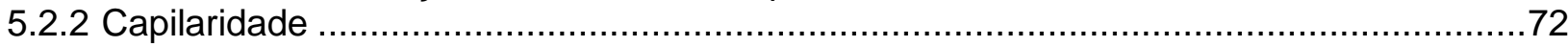

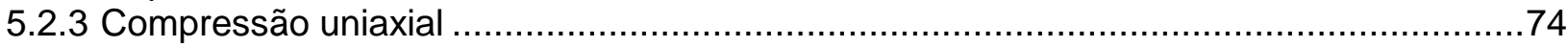

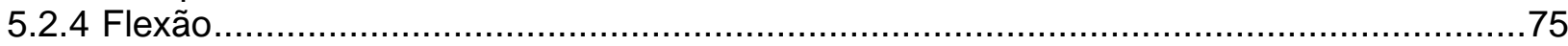

5.2.5 Velocidade de propagação de ondas ultra-sônicas longitudinais ..................................77

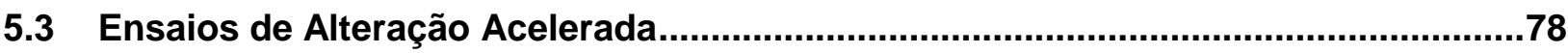

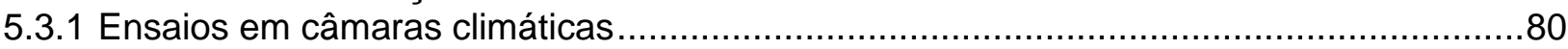

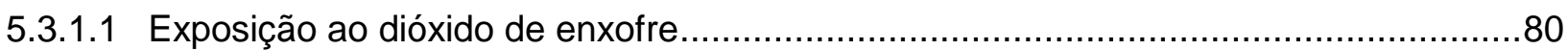

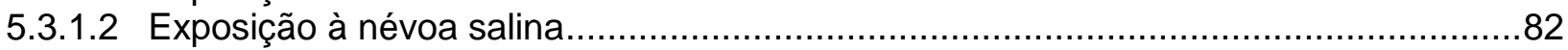

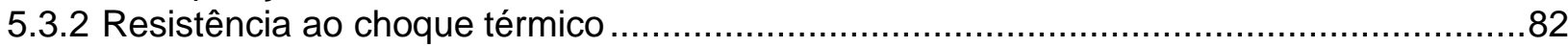

5.3.3 Ensaios de alteração por imersão parcial em soluções ácidas e alcalinas .......................84

\section{CAPÍTULO 6}

APRESENTAÇÃO E ANÁLISE DOS RESULTADOS .....................................................86

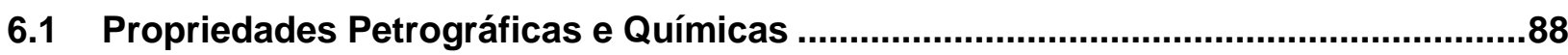

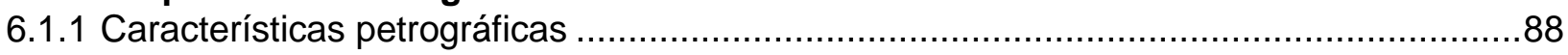

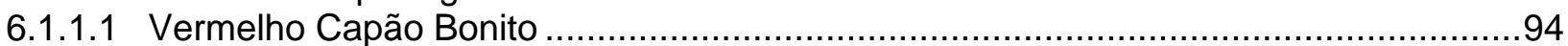

6.1.1.2 Azul Paulista Frente Nova e Prata Interlagos ................................................97

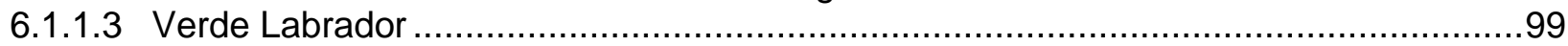

6.1.1.4 Branco Itaúnas e Branco Caravelas ....................................................................101

6.1.1.5 Rosa Iracema, Branco Cristal e Branco Savana ....................................................106

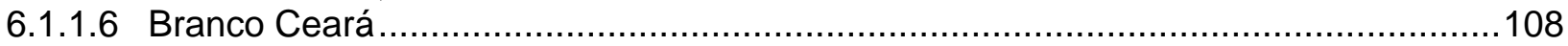

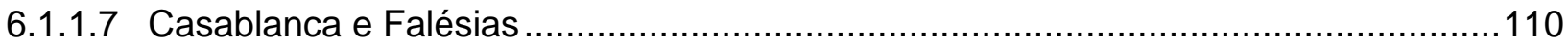

6.1.1.8 Giallo Veneciano, Arabesco e Santa Cecília .......................................................112

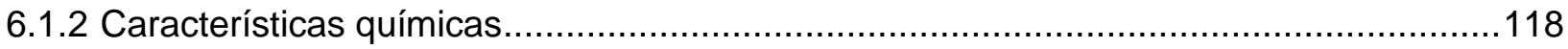

6.2 Propriedades Físicas (Densidade Aparente e Absorção) .........................................124

6.2.1 Grupos discriminados segundo densidade e absorção ...........................................130 


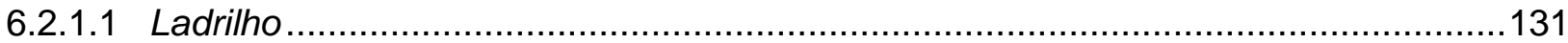

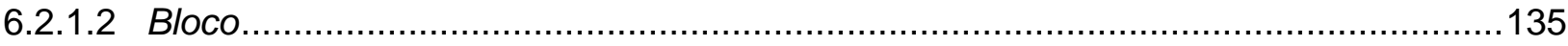

6.2.2 A influência do método de ensaio e forma dos corpos-de-prova .................................136

6.2.2.1 Variações de propriedades físicas de bloco para ladrilho .......................................141

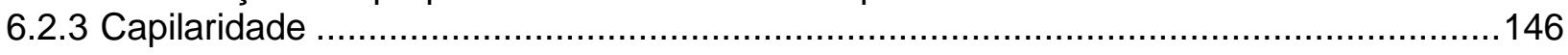

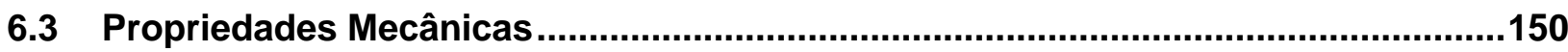

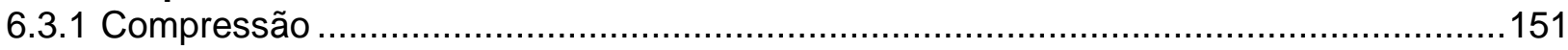

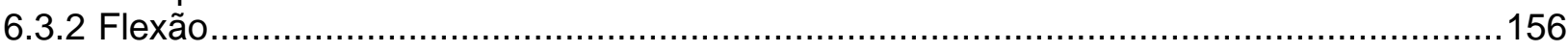

6.3.2.1 Resistência ao choque térmico ................................................................. 160

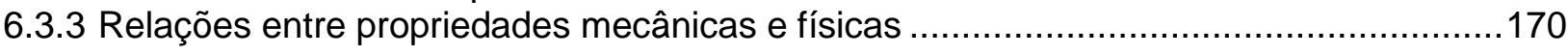

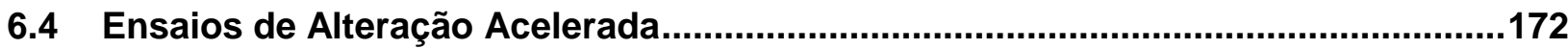

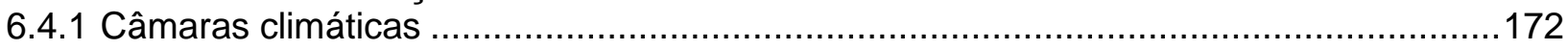

6.4.1.1 Exposição ao dióxido de enxofre ...................................................................177

6.4.1.2 Exposição à névoa salina.............................................................................. 181

6.4.2 Imersão parcial em soluções ácida e alcalina .........................................................183

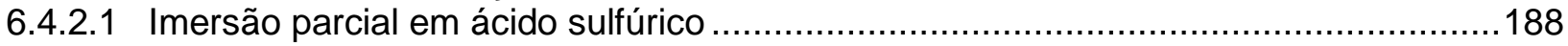

6.4.2.2 Imersão parcial em hidróxido de sódio ..............................................................194

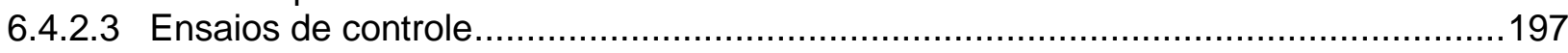

\section{CAPÍTULO 7}

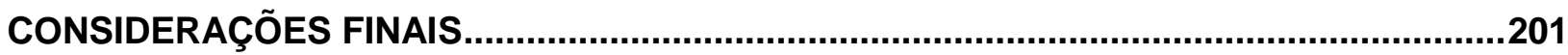

\section{CAPÍTULO 8}

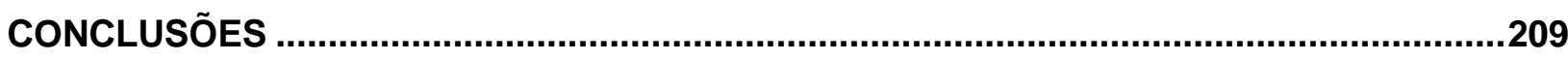

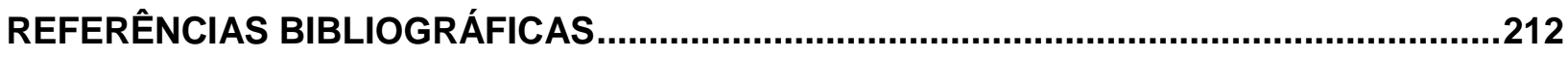

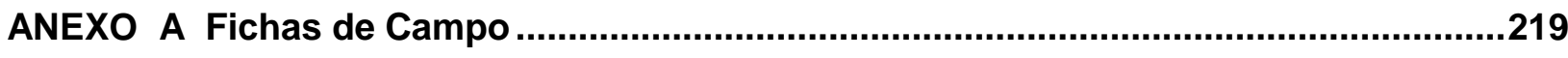

ANEXO B Resultados de determinações de massa específica aparente, porosidade aparente e absorção d'água aparente (ABNT NBR 12766/92)...

ANEXO C Resultados de determinações de densidade aparente e coeficiente de absorção de água a pressão atmosférica (prEN WI 036:1998)

ANEXO D Resultados de determinações de densidade aparente, porosidade aberta e volume de poros abertos (BS EN 1936:1999)

ANEXO E Resultados dos ensaios de resistência à compressão uniaxial (NBR ABNT

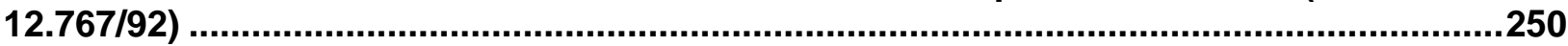

ANEXO F Resultados dos ensaios de resistência à flexão (ASTM C 880/98) ................257 


\section{LISTAS DE FIGURAS}

p.

Figura 1.1 - Distribuição dos usos de rochas ornamentais.

Figura 2.1 - Blocos cúbicos com cerca de $30 \mathrm{~cm} \times 30 \mathrm{~cm} \times 30 \mathrm{~cm}$, para ensaios de laboratório.

Figura 2.2 - Blocos montados para serragem em tear de grandes dimensões (à esquerda), e processo de serragem de chapas a partir de bloco de granito (à direita).

Figura 2.3 - Máquina de polir, automática, de origem italiana. Conforme progride o processo de polimento (na foto, do fundo para o primeiro plano), são utilizados abrasivos cada vez mais finos.

Figura 2.4 - Fluxograma dos ensaios de caracterização petrográfica, física, mecânica e de alteração acelerada.

Figura 3.1 - Acrópole, Atenas, Grécia. As estátuas foram de tal forma danificadas, que as originais foram guardadas no interior dos edifícios, em containeres de vidro.

Figura 3.2 - Escultura de arenito, no castelo Herten (Alemanha), construído em 1702. Foto à esquerda, de 1908, mostrando leve a moderada alteração. À direita, foto de 1969, mostrando destruição quase completa.

Figura 3.3 - Estátua de calcário travertino na fachada da Basílica de São Pedro (Vaticano) deteriorada pela ação de poluentes trazidos para a superfície da rocha pelo ar (na forma de gases ou aerossóis) ou pela água (chuva ácida).

Figura 3.4 - Inchamento e destacamento de minerais da superfície polida de granito "Santa Cecília", assentado em piso, com argamassa.

Figura 3.5 - Influência do clima nos processos intempéricos.

Figura 3.6 - Série de estabilidade mineral no intemperismo (Série de Goldich).

Figura 3.7 - Representação esquemática dos processos intempéricos.

Figura 3.8 - Limites de estabilidade de determinados minerais primários.

Figura 3.9 - Padrão típico diário dos níveis de óxido nítrico, dióxido de nitrogênio e ozônio, em Los Angeles, EUA.

Figura 3.10 - Cristalização de sais em função da concentração das soluções e da temperatura.

Figura 4.1 - Mapa de localização das pedreiras de rochas ornamentais selecionadas para este estudo, no Estado de São Paulo.

Figura 4.2 - Esquadrejamento manual de bloco de granito em Capão Bonito, SP.

Figura 4.3 - Lavra semimecanizada - Capão Bonito, SP.

Figura 4.4 - Aspecto da lavra de matacões do Azul Paulista Frente Nova, em São Paulo, $\mathrm{SP}$.

Figura 4.5 - Mapa de localização das pedreiras de rochas ornamentais selecionadas para este estudo, no Estado do Espírito Santo.

Figura 4.6 - Lavra do Giallo Veneciano, em Nova Venécia, ES.

Figura 4.7 - Lavra do Arabesco em Nova Venécia, ES.

Figura 4.8 - Mina do Santa Cecília, em Ecoporanga, ES.

Figura 4.9 - Aspecto da lavra do Verde Labrador, Baixo Guandu, ES. Em parte, ainda explorado a partir de grandes matacões aflorantes em alto topográfico.

Figura 4.10 - Mapa de localização das pedreiras de rochas ornamentais selecionadas 
para este estudo, no Estado da Bahia.

Figura 4.11 - Mina do Branco Itaúnas, em Medeiros Neto, BA.

Figura 4.12 - Mina do Branco Caravelas, em Medeiros Neto, BA.

Figura 4.13 - Mapa de localização das pedreiras de rochas ornamentais selecionadas para este estudo, no Estado do Ceará.

Figura 4.14 - Mina do granito Rosa Iracema, em Forquilha, CE.

Figura 4.15 - Mina do granito Branco Cristal, em Forquilha, CE.

Figura 4.16 - Mina do Branco Ceará, em Santa Quitéria, CE.

Figura 4.17 - Mina do Casablanca, em Independência, CE.

Figura 4.18 - Mina do Falésias, em Independência, CE.

Figura 5.1 - Determinação do peso submerso em dispositivo hidrostático.

Figura 5.2 - Corpo-de-prova rompido após aplicação de esforços compressivos.

Figura 5.3 - Detalhe de corpos-de-prova com esforços aplicados perpendicular (à esquerda) e paralelamente (à direita) à estruturação da rocha.

Figura 5.4 - Detalhe de corpo-de-prova, obtido de rocha polida, rompido após a aplicação de esforços.

Figura 5.5 - Ilustração dos aparatos e procedimento de medida da velocidade de propagação de ondas ultra-sônicas.

Figura 5.6 - llustração das medidas de velocidade de propagação de ondas em corposde-prova cúbicos.

Figura 5.7 - llustração das medidas de velocidade de propagação de ondas em corposde-prova destinados aos ensaios de resistência à flexão.

Figura 5.8 - Câmara climática para exposição ao $\mathrm{SO}_{2}$.

Figura 5.9 - Corpos-de-prova com a face não-polida recoberta com tinta óleo, para exposição ao $\mathrm{SO}_{2}$.

Figura 5.10 - Câmara climática de exposição à névoa salina.

Figura 5.11 - llustração esquemática das zonas de imersão e capilar.

Figura 6.1 - Resultados da coloração seletiva para feldspatos.

Figura 6.2 - Correlações entre contagens em amostra de mão e análise modais para quartzo, plagioclásio e feldspato alcalino.

Figura 6.3 - Distribuição do tamanho de quartzo, plagioclásio e feldspato alcalino nas diferentes rochas estudadas.

Figura 6.4 - Amostra VCB-3. Aspecto geral do granito Vermelho Capão Bonito. Notar cristais tabulares de plagioclásio (pl) com os núcleos alterados e com hidróxidos de ferro associados.

Figura 6.5-Amostra VCB-3. Aspecto de cristal de plagioclásio alterado em argilominerais, hidróxidos de ferro e sericita/muscovita.

Figura 6.6 - Amostra AZF. Aspecto geral do granito Azul Paulista Frente Nova. Notar cristais de plagioclásio com núcleos alterados em argilominerais e sericita. Fissuras mais largas cortam feldspatos e quartzo.

Figura 6.7 - Amostra PIT. Aspecto geral do granito Prata Interlagos. Detalhe de núcleos de feldspatos alterados, especialmente segundo as linhas de crescimento.

Figura 6.8 - Amostra PIT. Aspecto da alteração de plagioclásio em muscovita.

Figura 6.9 - Amostra LBD. Aspecto geral do charnockito Verde Labrador. Notar as dimensões milimétricas de feldspatos (KF) e intenso microfissuramento os afetando. Hornblenda (hb), hiperstênio (hy), biotita (bi) e opacos (op), geralmente 
em agregados, se distribuem esparsamente pela rocha.

Figura 6.10 - Amostra LBD. Aspecto do forte microfissuramento em feldspatos, que propicia alteração em argilominerais (+ hidróxidos de ferro) ao seu redor, e da alteração de hiperstênio (hy), também em hidróxidos de ferro.

Figura 6.11 - Amostras ITN. Aspecto geral do granito Branco Itaúnas. Notar heterogeinedade granulométrica e contatos interlobados, entre os grãos;

Figura 6.12 - Amostra ITN-2. Aspecto do microfissuramento intragranular em plagioclásio (PI) e do preenchimento de espaços intragranulares, em feldspatos, por argilominerais (am).

Figura 6.13 - Amostra ITN-1. Aspecto de biotitas substituídas por argilominerais, por provável ação deutérica. Notar microfissuramento intra e transgranular e sericitização de plagioclásio (setas).

Figura 6.14 - Amostra CRV. Aspecto geral do granito Branco Caravelas. Notar a heterogeneidade granulométrica.

Figura 6.15 - Amostra CRV. Argilominerais, comumente observadospela rocha, ocupando espaços intergranulares (a). Notar microfissuramento intergranular, sem preenchimento e ligeiramente aberto (em azul) (b).

Figura 6.16-Amostra RIC. Aspecto geral do granito Rosa Iracema. Notar homogeneidade granulométrica e biotita em agregados de pequenas lamelas.

Figura 6.17 - Amostra BCR. Aspecto geral do granito Branco Cristal. Notar hipidiomorfismo dos feldspatos.

Figura 6.18 - Amostra BCR. Aspecto de lamelas de biotita intercrescidas com filossilicato incolor.

Figura 6.19 - Amostra BCE. Aspecto geral do granito Branco Ceará. Notar, em (b), a presença de mica litinífera ocupando espaços intergranulares ou fissuras em feldspatos.

Figura 6.20 - Amostra CSB. Aspecto geral do gnaisse Casablanca.

Figura 6.21 - Amostra FLS. Aspecto geral do gnaisse Falésias. Aspecto de banda tonalítica. Notar a presença de fissuras inter e transgranulares, mais largas, preenchidas por filossilicatos e hidróxidos de ferro.

Figura 6.22 - Amostra GVN. Aspecto geral do gnaisse Giallo Veneciano. Notar forte microfissuramento e alteração em argilominerais e hidróxidos de ferro, nas paredes dos minerais, próximas a essas fissuras.

Figura 6.23 - Amostra GVN. Detalhe da alteração de plagioclásio e de argilominerais ocupando espaços intergranulares.

Figura 6.24 - Amostra GVN. Visão geral da alteração e microfissuramento.

Figura 6.25 - Amostra ARB. Aspecto geral do gnaisse Arabesco. Notar heterogeneidade granulométrica e cristais tabulares de plagioclásio (porção superior, centro, foto à esquerda).

Figura 6.26 - Amostra ARB. Aspecto dos cordões de sillimanita (sill) e de agregados de biotita (bi) e opacos.

Figura 6.27 - Amostra ARB. Aspecto de provável cordierita alterada.

Figura 6.28 - Amostra SCC. Aspecto geral do gnaisse Santa Cecília. Notar microfissuramento intragranular, especialmente em feldspatos, e turvação e alteração desses.

Figura 6.29 - Amostra SCC. Aspecto da alteração de plagioclásio e presença de argilominerais preenchendo espaços intragranulares.

Figura 6.30 - Diagramas de dispersão $\mathrm{SiO}_{2} x$ elementos maiores. 
Figura 6.31 - Diagramas de dispersão $\mathrm{SiO}_{2} \times \mathrm{Ba}, \mathrm{Sr}$ e Rb.

Figura 6.32 - Diagramas de dispersão $\mathrm{Fe}_{2} \mathrm{O}_{3}$ e $\mathrm{FeO} \times \mathrm{TiO}_{2}$.

Figura 6.33 - Relação densidade aparente x absorção (CEN,1998a), para ladrilho: a) 10 $\mathrm{cm} \times 12 \mathrm{~cm}$; b) $10 \mathrm{~cm} \times 10 \mathrm{~cm}$.

Figura 6.34 - Relação densidade aparente $x$ absorção (ABNT, 1992a), para ladrilho: a) $10 \mathrm{~cm} \times 15 \mathrm{~cm}$, b) $10 \mathrm{~cm} \times 12 \mathrm{~cm} \mathrm{e} \mathrm{c)} 10 \mathrm{~cm} \times 10 \mathrm{~cm}$.

Figura 6.35 - Relação densidade aparente $x$ porosidade aberta (BSI, 1999a), para ladrilho: a) $10 \mathrm{~cm} \times 15 \mathrm{~cm}$; b) $10 \mathrm{~cm} \times 12 \mathrm{~cm}$; c) $10 \mathrm{~cm} \times 10 \mathrm{~cm}$.

Figura 6.36 - Relação densidade aparente $x$ absorção, para bloco (ABNT, 1992a).

Figura 6.37 - Correlações entre densidade aparente e absorção entre bloco e ladrilho de diferentes dimensões, segundo ABNT (1992a), CEN (1998a) e BSI (1999a).

Figura 6.38 - Relação poros abertos x porosidade aberta (BSI, 1999a), para ladrilho: a) $10 \mathrm{~cm} \times 15 \mathrm{~cm}$; b) $10 \mathrm{~cm} \times 12 \mathrm{~cm}$; c) $10 \mathrm{~cm} \times 10 \mathrm{~cm}$.

Figura 6.39 - Diferentes valores obtidos para poros abertos, conforme o tamanho do corpo-de-prova.

Figura 6.40 - Correlações entre porosidade aberta e volume de poros abertos para ladrilho, de diferentes dimensões (BSI, 1999a).

Figura 6.41 - Distribuição das variações de densidade de ladrilho em relação a bloco.

Figura 6.42 - Distribuição das variações de absorção ladrilho em relação a bloco.

Figura 6.43 - Freqüências das variações de absorção (a) e densidade (b) entre bloco e os diferentes tamanhos de ladrilho (ABNT, 1992a).

Figura 6.44 - Correlações entre densidade (bloco) e variações desse parâmetro, para os diferentes tamanhos de ladrilho.

Figura 6.45 - Correlações entre absorção e variação de absorção entre bloco e ladrilho, (ABNT, 1992a), para corpos-de-prova com tamanhos: a) $10 \mathrm{~cm} \times 15 \mathrm{~cm}$, b) $10 \mathrm{~cm} \mathrm{x}$ $12 \mathrm{~cm}, \mathrm{c}) 10 \mathrm{~cm} \times 10 \mathrm{~cm}$.

Figura 6.46 - Curvas de absorção por capilaridade para as amostras em estudo.

Figura 6.47 - Correlação entre coeficiente de capilaridade e volume de poros abertos (BSI, 1999a).

Figura 6.48 - Correlação entre coeficiente de capilaridade e absorção (ABNT, 1992a e CEN, 1998a), e porosidade aberta (BSI, 1999a).

Figura 6.49 - Relação entre coeficiente de capilaridade e poros abertos (BSI, 1999a) para corpos-de-prova $10 \mathrm{~cm} \times 10 \mathrm{~cm}$ e $10 \mathrm{~cm} \times 12 \mathrm{~cm}$. Detalhamento da Fig. 6.47, exibindo as rochas equivalentes a cada ponto.

Figura 6.50 - Resistência à compressão nas condições seda (barras à esquerda) e saturada (barras à direita) e variação (linha).

Figura 6.51 - Freqüência das variações de compressão entre seco e saturado, relativo à estruturação das rochas estudadas.

Figura 6.52 - Correlação entre a resistência à compressão uniaxial, nas condições seca e saturada.

Figura 6.53 - Resistência à flexão, na condição seca, antes e após choque térmico, e decaimento relativo.

Figura 6.54 - Velocidade de propagação de ondas, na condição seca, antes e após choque térmico, e decaimento relativo.

Figura 6.55-Freqüência dos decaimentos da resistência mecânica e de velocidade de propagação de ondas.

Figura 6.56 - Correlação entre resistência à flexão na condição seca, antes e após ciclos 
de choque térmico.

Figura 6.57 - Correlação entre a velocidade de propagação de ondas, antes e após ciclos de choque térmico.

Figura 6.58 - Densidade aparente antes (pontos à esquerda) e após (pontos à direita) choque térmico e respectivas variações.

Figura 6.59 - Absorção d'água antes (pontos à esquerda) e após (pontos à direita) choque térmico e respectivas variações.

Figura 6.60 - Amostra LBD. Generalizado aumento da coloração acastanhada da rocha, provavelmente resultante do incremento da oxidação preexistente.

Figura 6.61 - Amostra ITN-2. Amarelamento da rocha e oxidação de máficos. Foto à direita, detalhe dos minerais oxidados.

Figura 6.62 - Amostra CRV. Amarelamento e aparecimento de manchas ferruginosas, milimétricas, esparsas. Foto à direita, detalhe do amarelamento, coincidente com os pontos microscopicamente constituídos de agregados cauliníticos.

Figura 6.63 - Amostra SCC. Amarelamento segundo a foliação e oxidação nas regiões quartzo-feldspáticas.

Figura 6.64 - Amostra ITN-1 após ensaio de choque térmico. Notar incremento da coloração ferruginosa de argilominerais de preenchimento de microfissuras (a), e oxidação de filossilicatos de alteração de biotita (b).

Figura 6.65 - Amostra CRV após ensaio de choque térmico. Aspecto da oxidação nos locais de ocorrência de argilominerais de alteração de mineral original.

Figura 6.66 - Amostra SCC após ensaio de choque térmico. Aspecto do incremento da coloração ferruginosa de argilominerais de preenchimento de microfissuras.

Figura 6.67-Amostra LBD. Exposição à névoa salina. Aumento da oxidação preexistente (acima, corpo-de-prova de controle).

Figura 6.68 - Amostra ITN-2. Exposição à nevoa salina. Oxidação de granada, máficos e opacos.

Figura 6.69 - Amostra CRV. Exposição à nevoa salina. Aumento do amarelamento preexistente (oxidação?) e local oxidação de granada.

Figura 6.70 - Amostra CSB. Exposiçãoà névoa salina. Leve coloração ferruginosa surge nos agregados micáceos.

Figura 6.71 - Amostra LBD. Exposição ao dióxido de enxofre. Total branqueamento da rocha.

Figura 6.72 - Amostra VCB. Exposição ao dióxido de enxofre. Formação de sais em fissuras superficiais e, localmente, sobre biotita

Figura 6.73-Amostra ITN-2. Exposição ao dióxido de enxofre. Pontos amarelados esparsos referentes à oxidação de minerais.

Figura 6.74 - Amostra CRV. Exposição ao dióxido de enxofre. "Amarelamento" da rocha.

Figura 6.75 - Amostra GVN. Exposição ao dióxido de enxofre. Abundantes eflorescências em agregados máficos e fissuras intergranulares.

Figura 6.76 - Amostra BCR. Fratura originada no processo de confecção do corpo-deprova foi um dos locais preferenciais para cristalização de sais. Esse aspecto também foi observado nas amostras gnáissicas, especialmente as SCC e GVN.

Figura 6.77 - Amostra PIT. Despegamento de lamelas de biotita (em azul).

Figura 6.78 - Amostra SCC. Microfissuras aparentemente alargadas após exposição ao dióxido de enxofre.

Figura 6.79 - Amostra VCB-3. Intensificação da cor de hidróxidos de ferro associados a argilominerais de alteração nos núcleos de feldspatos e de preenchimento de 
microfissuras. Notar cavidade em biotita (em azul, no centro da foto à esquerda).

Figura 6.80 - Aspectos dos diferentes comportamentos das rochas após imersão parcial em soluções alcalina e ácida. LBD e ITN-1 não mostraram modificações aparentes, ao final do ensaio de imersão de $\mathrm{NaOH}$; enquanto exibiram intensa mudança de coloração após imersão em $\mathrm{H}_{2} \mathrm{SO}_{4}$.

Figura 6.81-Aspectos resultantes da cristalização de sais (eflorescências e subeflorescências), após imersão parcial contínua em soluçãode ácido sulfúrico. Notar a formação de cavidade e quebra de arestas nas CRV e SCC.

Figura 6.82 - Cristalização de sais nas bordas (SCC) e nos cantos (CSB), preferencialmente sobre biotita.

Figura 6.83 - Aspecto da quebra de arestas dos corpos-de-prova da amostra CRV, em decorrência da pressão de expansão dos sais em descontinuidades e, provavelmente, nos espaços intergranulares originalmente ocupados por argilominerais de alteração.

Figura 6.84 - Diferentes aspectos das eflorescências formadas por imersão parcial em ácido sulfúrico. Amostra AZF: notar despegamento de lamelas de biotita, que ficam aderidas na superfície dos grumos de sais.

Figura 6.85 - Amostra ITN-2. Leve oxidação dos argilomienrais intersticiais e pequenas perdas de materiais próximos.

Figura 6.86 - Amostra CRV. Despegamento dos argilominerais intersticiais, de alteração.

Figura 6.87 - Amostra ARB. Despegamento de biotita e "clareamento" dos materiais de preenchimento de microfissuras.

Figura 6.88 - Amostra SCC. Despegamentos em cristais de granada.

Figura 6.89 - Aspectos da cristalização salina, em crostas, sobre os corpos-de-prova parcialmente imersos em solução alcalina. Os corpos-de-prova à direita foram lavados periodicamente, durante o ensaio, para melhor observação dos possíveis efeitos. Aqueles à esquerda deixaram de ser lavados cerca de 15 dias após o inicio dos ensaios.

Figura 6.90 - Amostra ITN-2. evolução do manchamento amarelo ferruginoso, desde seu aparecimento (dois dias dias após a imersão), o inicio de seu retorno à cor original e ao final, já sem aparentar a modificações de cor.

Figura 7.1 - Somatória dos graus relativos atribuídos às deteriorações observadas na face polida das rochas estudadas. 


\section{LISTAS DE TABELAS}

Tabela 1.1 - Cenário mundial da produção e usos das rochas ornamentais.

Tabela 1.2 - Principais países produtores e exportadores de rochas ornamentais.

Tabela 1.3 - Panorama brasileiro do setor de rochas ornamentais.

Tabela 2.1 - Tipos rochosos selecionados e regiões produtoras.

Tabela 2.2 - Empreendimentos minerários visitados e materiais amostrados.

Tabela 2.3 - Ensaios de caracterização de rochas ornamentais e respectivas normas utilizadas.

Tabela 3.1 - Mobilidade relativa de elementos químicos das rochas (Aires-Barros, 1991).

Tabela 3.2 - Características dos principais poluentes do ar (Amoroso; Fassina, 1983 e Kupchella; Hyland, 1992).

Tabela 3.3 - Efeitos de poluentes em algumas rochas.

Tabela 3.4 - Pressão de cristalização de alguns sais.

Tabela 5.1 - Classificação do tamanho de grãos adotada nas descrições petrográficas

Tabela 5.2 - Procedimentos e parâmetros obtidos nas determinações de índices físicos.

Tabela 5.3 - Situações potencialmente degradadoras de rochas ornamentais.

Tabela 6.1 - Designações adotadas para as amostras estudadas.

Tabela 6.2 - Níveis de correlação considerados nesse trabalho.

Tabela 6.3 - Graus de alteração intempérica e de microfissuramento adotados nesse trabalho.

Tabela 6.4 - Categorias e descrição de granitos alterados.

Tabela 6.5 - Resultados da quantificação de minerais.

Tabela 6.6 - Variações de tamanho de grão e tamanho de grão predominante.

Tabela 6.7 - Resultados de análises petrográficas das amostras VCB-1, VCB-2 e VCB-3.

Tabela 6.8 - Resultados de análises petrográficas das amostras AZF, PIT e LBD.

Tabela 6.9 - Resultados de análises petrográficas das amostras ITN-1, ITN-2 e CRV.

Tabela 6.10 - Resultados de análises petrográficas das amostras RIC, BCR, BSV.

102

Tabela 6.11 - Resultados de análises petrográficas das amostras BCE, CSB, FLS.

Tabela 6.12 - Resultados de análises petrográficas das amostras GVN, ARB e SCC.

Tabela 6.13 - Composição química das rochas graníticas em estudo - Elementos maiores (\%).

Tabela 6.14 - Composição química das rochas graníticas em estudo - Elementos menores e traço (ppm).

Tabela 6.15 - Índices físicos determinados segundo ABNT (1992a) e BSI (1999a) Corpos-de-prova: $10 \mathrm{~cm} \times 15 \mathrm{~cm}$.

Tabela 6.16 - Índices físicos segundo ABNT (1992a), CEN (1998a) e BSI (1999a) Corpos-de-prova $10 \mathrm{~cm} \times 12 \mathrm{~cm}$.

Tabela 6.17 - Índices físicos determinados segundo ABNT (1992a), CEN (1998a) e BSI (1999a) - Corpos-de-prova: $10 \mathrm{~cm}$ x $10 \mathrm{~cm}$.

Tabela 6.18 - Índices físicos determinados segundo ABNT (1992a) - Corpos-de-prova: $7,5 \mathrm{~cm} \times 7,5 \mathrm{~cm} \times 7,5 \mathrm{~cm}$.

Tabela 6.19 - Dados estatísticos de índices físicos obtidos para as amostras ensaiadas. 
Tabela 6.20 - Distribuição das rochas estudadas segundo intervalos de resultados médios (ABNT, 1992a e CEN, 1998a) de densidade aparente e absorção para ladrilho.

Tabela 6.21 - Distribuição das rochas estudadas segundo intervalos de resultados médios (BSI, 1999a) de densidade aparente e porosidade aberta para ladrilho.

Tabela 6.22 - Distribuição das rochas estudadas segundo intervalos de resultados médios (ABNT, 1992a) de densidade aparente e absorção.

Tabela 6.23 - Rochas com resultados homogêneos nas determinações de propriedades físicas.

Tabela 6.24 - Variações máxima e mínima de propriedades físicas (ABNT, 1992a) de bloco para ladrilho.

Tabela 6.25 - Valores médios de resistência à compressão uniaxial, seca e saturada, variação de resistência entre as condições seca e saturada e velocidade de propagação de ondas ultra-sônicas longitudinais.

Tabela 6.26 - Valores máximos, mínimos e mediana obtidos para a resistência à compressão e velocidade de propagação de ondas.

Tabela 6.27 - Resistência à flexão, velocidade de propagação de ondas e variações de massa, de resistência à flexão e de propagação de ondas, antes e após choque térmico.

Tabela 6.28 - Resistência à flexão, velocidade de propagação de ondas e variações de massa, de resistência à flexão e de propagação de ondas, antes e após choque térmico.

Tabela 6.29 - Correlações entre as determinações de resistência à flexão e de velocidade de propagação de ondas nas condições secas e após choque térmico.

Tabela 6.30 - Valores médios e variações de densidade aparente e absorção (CEN, 1998a) após ciclos de choque térmico (CT).

Tabela 6.31 - Modificações de coloração observadas em amostras submetidas a choque térmico e graduação atribuída.

Tabela 6.32 - Aspectos microscópicos das deteriorações visualmente detectadas após ensaio de choque térmico.

Tabela 6.33 - Coeficientes de correlação entre valores de resistências à compressão uniaxial e à flexão.

Tabela 6.34 - Agrupamento das rochas estudadas segundo especificações da ASTM (1999c).

Tabela 6.35 - Principais resultados obtidos pela exposição das amostras em estudo a câmaras de dióxido de enxofre e névoa salina.

Tabela 6.36 - Principais modificações verificadas nos monitoramentos do ensaio de exposição ao dióxido de enxofre.

Tabela 6.37 - Principais modificações em amostras selecionadas daquelas submetidas à exposição em câmara de dióxido de enxofre.

Tabela 6.38 - Principais modificações verificadas nos monitoramentos do ensaio de exposição à névoa salina.

Tabela 6.39 - Principais modificações microscópicas em amostras submetidas à exposição em câmara de névoa salina.

Tabela 6.40 - Principais resultados da alteração por imersão parcial das rochas graníticas em soluções ácida e alcalina.

Tabela 6.41 - Principais modificações verificadas nos monitoramentos do ensaio de imersão parcial em ácido sulfúrico. 
Tabela 6.42 - Descrição das eflorescências salinas resultantes do ensaio de imersão parcial em ácido sulfúrico e deteriorações observadas.

Tabela 6.43 - Tipos de sais que compõem as eflorescências formadas por imersão parcial em ácido sulfúrico.

Tabela 6.44 - Principais modificações em amostras selecionadas submetidas à imersão parcial em ácido sulfúrico.

Tabela 6.45 - Principais modificações verificadas nos monitoramentos do ensaio de imersão parcial em hidróxido de sódio.

Tabela 6.46 - Sais cristalizados, em crostas, nas amostras submetidas à imersão parcial em solução alcalina.

Tabela 6.47 - Variações de velocidade de propagação de ondas após ensaios de imersão parcial.

Tabela 6.48 - Variações de massa e de absorção d'água, após ensaios de imersão parcial.

Tabela 7.1 - Principais propriedades físicas e mecânicas de rochas com forte e incipiente modificações após ensaios de alteração acelerada. 


\section{RESUMO}

FRASCÁ, M.H.B.O. (2003) Estudos experimentais de alteração acelerada em rochas graníticas para revestimento. São Paulo, 281p. Tese (Doutorado) - Instituto de Geociências, Universidade de São Paulo.

As rochas para revestimento tendem, naturalmente, a se alterar pela exposição às novas condições ambientais e de uso, o que pode se acelerar ante as agressividades climáticas, a ação de poluentes atmosféricos e a adoção de procedimentos construtivos e de manutenção inadequados. As deteriorações resultantes são de caráter irreversível. A adoção das medidas preventivas adequadas, melhor recurso disponível, é dificultada pela carência de informações técnicas relativas aos tipos de alterações que podem ocorrer, conforme o tipo rochoso e as condições de uso. A caracterização tecnológica de rochas graníticas selecionadas e estudos experimentais de alteração acelerada, simulando situações como as descritas acima, visaram ao estabelecimento de uma metodologia para ensaios laboratoriais que permitam antecipar as deteriorações do material rochoso e, também, agregar a questão da durabilidade dentre os critérios de escolha dessas rochas para uso como revestimento. Os resultados mostraram deteriorações, em diferentes intensidades e formas (oxidação de minerais, eflorescências, escamações e outros), relacionadas às características intrínsecas de cada rocha, atribuindo-se papel condicionante aos minerais previamente alterados e ao microfissuramento. A petrografia revelou-se a ferramenta mais importante nos estudos de alterabilidade. Foi possível verificar que a qualificação tecnológica da rocha contempla dois aspectos complementares: determinação das propriedades de engenharia (parâmetros físicos e mecânicos) e da alterabilidade. 


\begin{abstract}
Rock for cladding or flooring will be naturally weathered when exposed to the new environmental and use conditions. This alteration may be modified or accelerated in contact to climatic aggressiveness, by the action of atmospheric pollutants and improper constructive and maintenance procedures. Resulting deteriorations are irreversible. Therefore, the only available way is to prevent such alteration using adequate techniques. However, it is made difficult due to the lack of technical information regarding to the types of deterioration that may occur according to rock type and use conditions. Technological characterization of selected granitic rocks and experimental studies on accelerated alteration under simulated environmental and uses situations, similar to those described above were carried out aiming at the establishment of a methodology for laboratorial tests that could anticipate deteriorations of the rocky material. Moreover, they also aimed to add the question of durability as a choice criterion of rocks used for covering. Results showed stone deteriorations, in different intensities and ways (mineral oxidation, efflorescence, scaling and others), related to the intrinsic characteristics of each rock from which previously altered minerals and microcracks played significant role in stone degradation. Petrography was the main technique in the alterability studies. It was also possible to verify that the technological qualification of rocks contemplates two complementary aspects: determination of engineering properties (physical and mechanical parameters) and alterability.
\end{abstract}




\section{CAPÍTULO 1}

\section{INTRODUÇÃO}

O uso de rocha faz parte da história da civilização desde os seus primórdios, já que foi empregada na construção de obras civis e monumentos (pontes, estradas, aquedutos, palácios, castelos, igrejas, túmulos) sempre que houvesse a disponibilidade dessa matéria-prima em condições mínimas de aproveitamento. Segundo Vicente et al. (1996), a rocha é o principal material de construção dos monumentos e edifícios históricos europeus, não somente pela sua abundância, mas pela sua resistência e durabilidade.

No Brasil, tem-se conhecimento do uso de rochas como revestimento, especialmente dos mármores importados da Europa (italianos e portugueses), desde o período colonial, o que se incrementou a partir da segunda metade do século passado.

Os termos rochas ornamentais e para revestimento têm as mais variadas definições e ainda não são consensuais as definições para ele. No projeto de norma 2.02.105.012 da ABNT - Associação Brasileira de Normas Técnicas (ABNT, no prelo) rocha ornamental é definida como "material rochoso natural, submetido a diferentes graus ou tipos de beneficiamento ou afeiçoamento (bruta, aparelhada, apicoada, esculpida ou polida), utilizado para exercer uma função estética".

Rocha para revestimento é definida pela ABNT (no prelo) como "rocha natural que, submetida a processos diversos e graus variados de desdobramento $e$ beneficiamento, é utilizada no acabamento de superfícies, especialmente pisos e fachadas, em obras de construção civil". Essa definição pode ser considerada similar à que consta na ASTM C119 (ASTM, 2001a), que propõe para dimension stone: "pedra natural que tenha sido selecionada, aparelhada ou cortada em tamanhos e formas especificados ou indicados, com ou sem uma ou mais superfícies mecanicamente acabados".

Neste estudo, todos os materiais rochosos selecionados e trabalhados serão tratados como rochas para revestimento, tendo em vista sua aplicação mais comum e o objetivo de investigar suas propriedades e alterações no emprego no revestimento de edificações.

As duas grandes categorias comerciais de rochas para revestimento são a dos 
"granitos", que, nesse sentido, englobam rochas silicáticas (ígneas plutônicas e/ou vulcânicas, charnockitos, gnaisses e migmatitos), e a dos "mármores", comercialmente entendidos como qualquer rocha carbonática, tanto de origem sedimentar como metamórfica, passível de polimento.

Outros materiais como ardósias e quartzitos, comercializados pelas suas designações corretas ou englobados nas categorias anteriores, também são largamente utilizados como rochas para revestimento.

Essas rochas têm seu mais nobre e valorizado uso como elementos ornamentais (arte estatuária, arte funerária, pias, tampos de mesa e outras peças decorativas) e, mais largamente, como material de construção civil, sendo aplicadas como elementos estruturais (colunas e pilares) e, especialmente, nos revestimentos verticais (paredes e fachadas) e horizontais (pisos), de interiores e exteriores de edificações.

As rochas graníticas, pela sua durabilidade e enorme variedade de cores e padrões texturais e estruturais, são as mais utilizadas nos revestimentos de exteriores, tanto em pisos quanto em fachadas. Os mármores, que no Brasil são, em geral, importados, seguem próximo, sendo largamente empregados no revestimento de interiores.

O padrão estético, estabelecido pela cor, textura e estrutura da rocha, é determinado pelo modo de formação, composição mineral, padrões de orientação ou deformação nela impressos por sua história geológica. Constitui o principal condicionante para o comércio e uso da rocha, que é imposto por modismos e não necessariamente pelas características tecnológicas dos materiais.

O aproveitamento da rocha para fins ornamentais e para revestimento está relacionado a fatores adicionais ao padrão estético, ligados à geologia do material rochoso, aqui referidos como fatores intrínsecos:

- tipologia do jazimento: definida pela intensidade e tipo de alteração da rocha, presença de tensões confinadas, heterogeneidade estrutural e textural, entre outros;

- propriedades petrográficas, físicas e mecânicas: condicionam os usos mais adequados da rocha no revestimento de edificações, pois fornecem parâmetros para a escolha dos materiais perante solicitações tais como: intempéries, desgaste abrasivo pelo tráfego de pedestres, danos relacionados à expansão e contração térmicas, etc. 
Outros fatores, muitas vezes de igual importância, mas de caráter extrínseco aos materiais pétreos são:

- técnicas de extração e beneficiamento: devem ser adequadas a cada tipo de material, pois eventuais defeitos decorrentes do emprego inadequado de métodos extrativos ou industriais (serragem, polimento e lustração), poderão modificar características naturais (microfissuras, por exemplo), e vir a favorecer ou acelerar a alteração dos constituintes ao serem expostos a novas condições ambientais;

- técnicas de aplicação e condições de uso e manutenção.

As rochas para revestimento são produtos obtidos do desmonte de materiais rochosos em blocos e de seu subseqüente desdobramento em chapas, posteriormente polidas e cortadas em placas e ladrilhos.

A degradação ou deterioração de rochas (segundo Houaiss e Villar, 2001) são termos utilizados para se referir ao estado alterado para pior, ou seja, danificação, decomposição, estrago do material rochoso.

Os processos de deterioração têm sido empiricamente relacionados à interação das características petrográficas, físicas e mecânicas das rochas com os agentes do meio ambiente e os procedimentos de fixação, limpeza e manutenção. Resultam na alteração da superfície exposta da rocha, seja pela modificação de seu aspecto estético (perda de brilho e manchamentos), seja pela sua danificação ou ainda pela perda de resistência mecânica.

Alterações cromáticas e manchamentos de ladrilhos de rocha são freqüentemente associados às interações com reagentes químicos que compõem produtos de limpeza. Degradações da face exposta da rocha, como inchamento, escamação, despegamento de fragmentos minerais e outros, são muitas vezes decorrentes da formação de eflorescências e subeflorescências, a partir de sais provenientes de argamassas, pelo emprego de procedimentos inadequados de assentamento.

Estudos diagnósticos de deteriorações de rochas para revestimento indicam que a maior parte dos problemas está relacionada ao desconhecimento do usuário sobre as interações da rocha com o ambiente externo, tanto pelas condições criadas pelas inúmeras variáveis impostas pelos sistemas empregados no beneficiamento e na aplicação da rocha, como pela poluição e intervenções antrópicas. 


\subsection{Importância Econômica do Setor}

O setor de rochas ornamentais e para revestimento é um dos segmentos com maior e mais constante desenvolvimento da indústria mineral brasileira.

Os principais aspectos econômicos, a seguir relatados, procuram mostrar a importância nacional e internacional desse setor, que, por sua vez, justificam o aprimoramento dos conhecimentos relativos às propriedades tecnológicas dos materiais rochosos e o desenvolvimento de procedimentos para sua qualificação e previsão de durabilidade.

O mercado mundial de rochas ornamentais e para revestimento movimenta, ao ano, próximo de US\$ 40 bilhões, entre vendas nos mercados internos dos países produtores, trocas internacionais e negócios com tecnologia, máquinas e equipamentos (Peiter, 2001)

Mesmo com o impacto negativo dos ataques terroristas de setembro de 2001 nos EUA, e da crise nos segmentos construtivos da Europa e Japão na economia mundial, naquele ano a produção desses materiais cresceu, segundo Montani (2002) cerca de $8 \%$, alcançando 65 milhões de toneladas, dos quais 11,8 milhões de toneladas foram comercializados no mercado internacional (correspondendo a cerca de US $\$ 13$ bilhões), determinando aumento de cerca de $6 \%$, bem próximo da média dos anos anteriores.

O consumo mundial, por sua vez, atingiu os 700 milhões de $\mathrm{m}^{2}, 25 \%$ do qual nos mercados da China, Itália e EUA (Montani, 2002). Tais indicadores sugerem que este setor tem boa capacidade de enfrentamento ante a flutuações relacionadas a problemas econômicos e não-econômicos, ainda que críticos.

A Tabela 1.1 mostra uma compilação dos dados de produção e uso mundiais acerca desses materiais rochosos.

A Figura 1.1 ilustra a distribuição das principais aplicações da produção mundial, que são predominantemente de chapas e ladrilhos para revestimento (70\%), arte funerária $(16,5 \%)$ e trabalhos estruturais (12\%). 
Tabela 1.1 - Cenário mundial da produção e usos das rochas ornamentais.

\begin{tabular}{|c|c|c|c|}
\hline \multicolumn{4}{|c|}{ CENÁRIO MUNDIAL - ROCHAS ORNAMENTAIS - 2001} \\
\hline \multicolumn{4}{|c|}{ PRODUÇÃO } \\
\hline & $x 10^{3} \mathrm{~m}^{3}$ & & $x 10^{3} t$ \\
\hline Extração bruta & 48.450 & & 130.800 \\
\hline Rejeitos da extração & 24.370 & & 65.800 \\
\hline Produção bruta & 24.080 & & 65.000 \\
\hline Rejeitos do beneficiamento & 9.870 & & 26.650 \\
\hline Produção líquida & 14.210 & & 38.350 \\
\hline \multicolumn{4}{|c|}{ APLICAÇÃO } \\
\hline & $x 10^{3} m^{2}$ & $x 10^{3} t$ & $\%$ \\
\hline pisos e pavimentos & 258.970 & 14.000 & 36,5 \\
\hline trabalhos especiais & 102.870 & 5.560 & 14,5 \\
\hline fachadas & 60.310 & 3.260 & 8,5 \\
\hline paredes internas & 49.670 & 2.690 & 7,0 \\
\hline escadarias & 24.830 & 1.340 & 3,5 \\
\hline subtotal - construção civil & 496.650 & 26.850 & 70,0 \\
\hline arte funerária & 117.060 & 6.350 & 16,5 \\
\hline trabalhos estruturais & 85.140 & 4.600 & 12,0 \\
\hline usos diversos & 10.650 & 580 & 1,5 \\
\hline subtotal - outros usos & 212.850 & 11.530 & 30,0 \\
\hline TOTAL & 709.500 & 38.380 & 100,0 \\
\hline
\end{tabular}

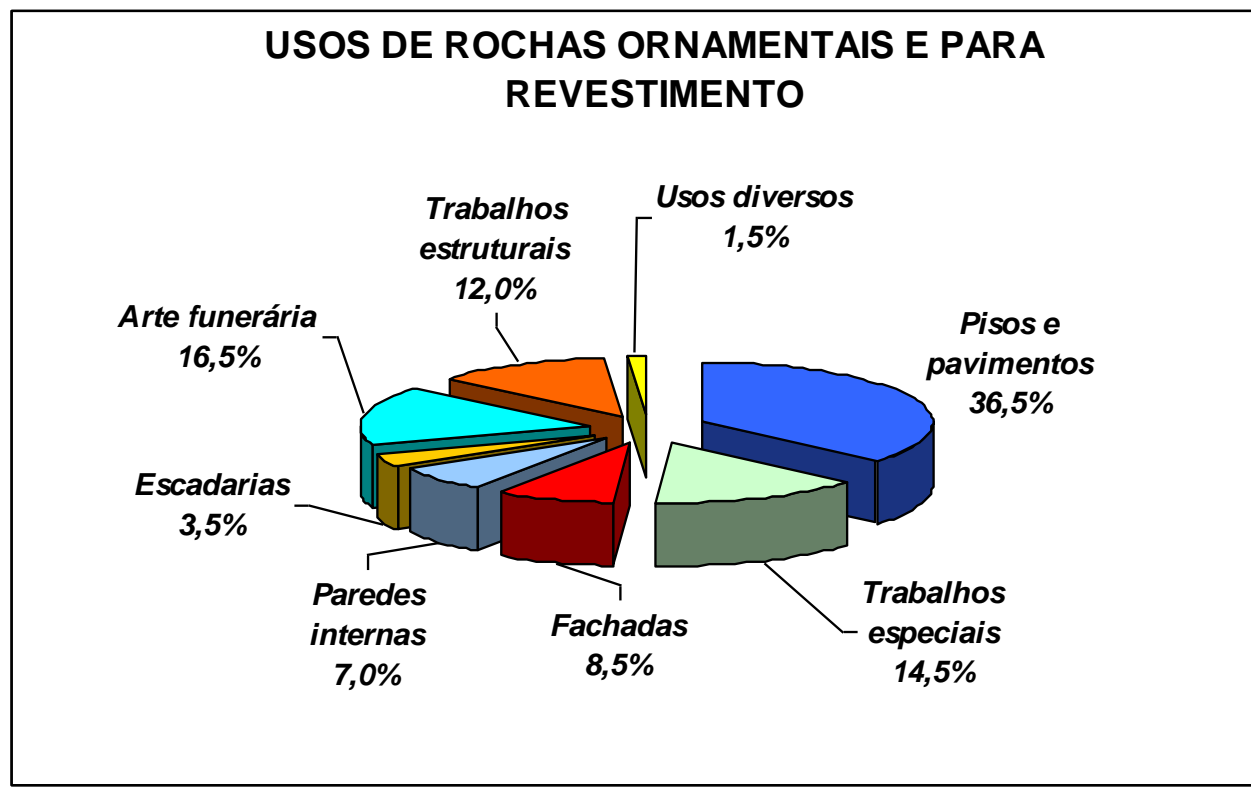

Figura 1.1 - Distribuição dos usos de rochas ornamentais.

A Tabela 1.2 lista os países líderes do mercado de rochas ornamentais, atualmente encabeçado pela China, que responde por cerca de $18 \%$ da produção e $20 \%$ da exportação mundiais; seguido pela Itália (cerca de 13\% da produção e 15\% 
das exportações mundiais).

Tabela 1.2 - Principais países produtores e exportadores de rochas ornamentais.

\begin{tabular}{ccc}
\hline PAÍS & PRODUÇÃO MINERAL $\left(\mathbf{x} \mathbf{1 0}^{\mathbf{3}} \mathbf{t}\right)$ & EXPORTAÇÃO $\left(\mathbf{x 1 0} \mathbf{t}^{\mathbf{t}} \mathbf{)}\right.$ \\
\hline China & $11.500(17,6 \%)$ & $4.692(19,5 \%)$ \\
\hline Itália & $8.400(12,9 \%)$ & $3,550(14,7 \%)$ \\
\hline Índia & $6.000(9,2 \%)$ & $2.294(9,5 \%)$ \\
\hline Espanha & $5.500(8,5 \%)$ & $1.861(7,7 \%)$ \\
\hline Irã & $4.000(6,2 \%)$ & - \\
\hline Brasil & $2.500(3,8 \%)$ & $1.222(5,1 \%)$ \\
\hline Portugal & $2.400(3,7 \%)$ & $1.217(5,0 \%)$ \\
\hline Turquia & $2.250(3,5 \%)$ & $985(5,0 \%)$ \\
\hline & & Fonte: Montani $(2002)$
\end{tabular}

A Itália, tradicional líder na produção e exportação das rochas ornamentais, foi superada pela China, a partir do ano 2000. Permanece, no entanto, na liderança do desenvolvimento, produção e exportação de equipamentos para o setor.

O Brasil, segundo Montani (2002), em 2001 ocupou o sexto lugar na produção mundial (2.500 milhões de $t$, que correspondem a $3,8 \%$ da produção total) e o quinto lugar nas exportações mundiais (1.222 milhões de t e 5,0\% do volume total).

A média de preços das rochas para revestimento, nos mercados interno e externo, indica que a agregação de valor na venda de blocos é equivalente a três vezes o seu custo de produção. Por outro lado, cada metro cúbico de rocha desdobra-se em 30 a $35 \mathrm{~m}^{2}$ de chapas, o que permite, considerando os preços médios praticados, obter-se, por $\mathrm{m}^{3}$ industrializado, cerca de $\mathrm{R} \$ 3.200,00$ em produtos semi-acabados no mercado interno, ou US $\$ 3,000.00$ no mercado externo (Peiter, 2001).

Em 2001, o Brasil participou com 10,3\% das exportações mundiais de rochas silicáticas brutas (blocos); $2,1 \%$ de rochas processadas simples (pedras de cantaria, pedras de calcetar); 2,3\% de rochas processadas especiais (chapas e ladrilhos de granitos e mármores) e 8,2\% de ardósias; totalizando 5,0\% do volume físico mundial das exportações. A exportação de rochas carbonáticas brutas é muito pequena, menor que $0,1 \%$ do volume mundial (Montani, 2002).

A Tabela 1.3 exibe as principais características do setor, no Brasil. 
Tabela 1.3 - Panorama brasileiro do setor de rochas ornamentais.

\begin{tabular}{|c|c|c|}
\hline \multicolumn{3}{|c|}{ CENÁRIO BRASILEIRO (2001) } \\
\hline PRODUÇÃO & $\begin{array}{l}3.059 \times 10^{3} \mathrm{t} \text { (blocos de mármores } € \\
\text { relativo a } 2000\end{array}$ & granitos): crescimento de $7,8 \%$ \\
\hline $\begin{array}{l}\text { PRINCIPAIS ESTADOS } \\
\text { PRODUTORES }\end{array}$ & $\begin{array}{l}\text { Espírito Santo, Minas Gerais, Bahia } \\
\text { Sul e Rio de Janeiro (em ordem de }\end{array}$ & $\begin{array}{l}\text { São Paulo, Ceará, Rio Grande do } \\
\text { nportância). }\end{array}$ \\
\hline $\begin{array}{c}\text { EXPORTAÇÃO } \\
\text { granitos brutos } \\
\text { (volume e valores) }\end{array}$ & $763\left(\times 10^{3} t\right)$ & $\begin{array}{l}\text { US } \$ 109,7 \text { milhões (diminuição de } \\
6,1 \% \text { em relação a } 2000 \text { ) }\end{array}$ \\
\hline $\begin{array}{l}\text { EXPORTAÇÃO } \\
\text { mármore bruto }\end{array}$ & $8,5\left(\times 10^{3} t\right)$ & \\
\hline $\begin{array}{l}\text { EXPORTAÇÃO } \\
\text { rochas processadas } \\
\text { (volume e valores) }\end{array}$ & $\begin{array}{l}263 \times 10^{3} \text { t, crescimento de } 13,9 \% \\
\text { em relação a } 2000\end{array}$ & $\begin{array}{l}\text { US\$ } 153 \text { mi: aumento de } 8 \% \text { em } \\
\text { relação a } 2000\end{array}$ \\
\hline $\begin{array}{l}\text { EXPORTAÇÃO } \\
\text { blocos (destino) }\end{array}$ & \multicolumn{2}{|c|}{$\begin{array}{l}\text { Itália (43\%), Espanha (19\%), EUA (10\%), China (8\%), Taiwan (7\%), } \\
\text { Hong Kong (6\%) }\end{array}$} \\
\hline $\begin{array}{l}\text { EXPORTAÇÃO } \\
\text { rochas processadas } \\
\text { (destino) }\end{array}$ & \multicolumn{2}{|c|}{$\begin{array}{l}\text { EUA (60\%), Espanha (4\%), Bélgica (3\%). Reino Unido (3\%) e México } \\
(3 \%)\end{array}$} \\
\hline CONSUMO & $\begin{array}{l}\text { Blocos: } 2.293 \times 10^{3} \mathrm{t} \\
\text { Produtos acabados: } 23,8 \text { milhões d }\end{array}$ & $\begin{array}{l}\text { Crescimento: } 13,5 \% \text {, } \\
\text { em relação a } 2000\end{array}$ \\
\hline
\end{tabular}

Fonte: DNPM (2002)

Estima-se, no Brasil, a existência de mais de 500 variedades comerciais de rochas ornamentais (Peiter, 2001), incluindo, além dos granitos, mármores, ardósias, quartzitos, e outros, explorados a partir de aproximadamente 1.300 frentes de lavra. $\mathrm{O}$ beneficiamento e/ou processamento dessas rochas é feito por cerca de 250 serrarias e 6.500 marmorarias.

O setor brasileiro de mármores e granitos movimenta cerca de US\$ 2,1 bilhões/ano (Peiter, 2001), aí incluindo as transações nos mercados interno (80\%) e externo, e com máquinas, insumos, equipamentos, materiais de consumo e serviços. Gera ao redor de 105.000 empregos diretos em aproximadamente 10.000 empresas (65\% marmorarias).

Em 2001, o setor apresentou crescimento na produção bruta e na exportação de rochas processadas, ensejado também pela instalação de novas unidades de beneficiamento (principalmente no Estado do Espírito Santo) e a aquisição de 63 novos teares (seis deles importados), que eleva para cerca de 2.095 teares instalados no País (DNPM, 2002).

Paralelamente a isto, continua o crescimento do consumo de rochas ornamentais, em especial nos grandes centros urbanos, para revestimento de piso, 
paredes e fachadas.

Ainda que decrescente (0,6\% em peso e 26,9\% em valor), especialmente em razão da desvalorização do real frente ao dólar, as importações de mármores e travertinos italianos, espanhóis e gregos vêm suprir a carência nacional deste tipo de rocha, muito valorizada pelos arquitetos. Para esses, os únicos concorrentes nacionais são os mármores brancos explorados nos estados do Espírito Santo e Paraná, e o calcário denominado Bege Bahia, explorado na região de Ourolândia, BA.

\subsection{Objetivos}

Os materiais rochosos usados no revestimento de edificações tendem a se modificar e deteriorar, naturalmente, com o tempo. Esse processo pode se acelerar em condições climáticas agressivas, ambientes poluídos ou pela utilização de procedimentos construtivos ou de manutenção inadequados.

Dado que os processos de deterioração, ao se instalarem, são praticamente irreversíveis, é de fundamental importância o conhecimento antecipado das possíveis deteriorações em situações de uso.

Para isso, entretanto, carece-se de informações técnicas relativas aos tipos de deteriorações que tendem a se instalar conforme o tipo rochoso e as condições de uso, para subsidiarem o planejamento e adoção das medidas preventivas.

Muitas questões importantes, relativas a esse assunto, continuam especulativas. Em particular, quanto à contribuição das propriedades petrográficas, físicas e/ou mecânicas para a alteração de rochas para revestimento usadas na construção civil; quanto à possibilidade de estender a análise das propriedades tecnológicas para a previsão de durabilidade da rocha; quanto à influência das possíveis modificações no decorrer do beneficiamento do material rochosos na alterabilidade da rocha, dentre outras.

Os objetivos dos estudos experimentais desenvolvidos, por meio da simulação da ação climática (variações térmicas), da ação de poluentes dispersos na atmosfera e da ação da cristalização de sais (eflorescências), com foco em materiais graníticos, estiveram voltados, por um lado ao estabelecimento de uma metodologia para ensaios laboratoriais que permitam antecipar as deteriorações do material rochoso em situações de uso e, por outro, agregar a questão da durabilidade aos critérios de escolha dessas rochas, quando utilizadas como revestimento, pela indústria de 
construção civil.

\subsection{Justificativas}

Se, por um lado, estão sendo introduzidas novas e mais eficientes técnicas extrativas e industriais para a exploração e beneficiamento de rochas para revestimento, em consonância com seu emprego crescente pela construção civil, por outro, verifica-se que ainda há relativamente pouco conhecimento a respeito desses materiais, especialmente quanto à sua alterabilidade e durabilidade sob as condições a que se expõem, quando em uso.

O desenvolvimento de estudos intempéricos experimentais, a partir da década de 30 , foi conduzido principalmente de arquitetos e engenheiros, preocupados com a resistência e durabilidade de rochas para construção, dos concretos e outros.

O estudo dos processos intempéricos, dos mecanismos fundamentais para sua atuação e a determinação das taxas de alteração foram até recentemente considerados desnecessários ou negligenciados, especialmente pelos geólogos, que tendem a considerar evidente o fenômeno de alteração e óbvia a natureza dos diferentes processos envolvidos (Robinson; Williams, 1994).

Permanecem, no entanto, muito escassos os estudos científicos que correlacionem os produtos de alterações aos condicionantes petrográficos e ambientais (especialmente os fatores climáticos e as condições de assentamento e/ou manutenção).

Dessa forma, investigações visando ao desenvolvimento de procedimentos para a previsão da alteração e sobre durabilidade de rochas tornam-se necessárias e atuais, razão pela qual instituições normatizadoras nacionais e internacionais já estão firmemente voltadas à adoção de procedimentos que visem à previsão da durabilidade de materiais rochosos usados na construção civil (Frascá e Frazão, 2002).

O granito foi o material rochoso escolhido como foco do estudo, em razão de seu vasto uso como revestimento, em todo o mundo, e de sua posição de amplo destaque na produção brasileira. 


\section{CAPÍTULO 2}

\section{MATERIAIS E MÉTODOS}

Para a consecução dos objetivos desta pesquisa, considerou-se o conhecimento das propriedades petrográficas e físicas e da resistência mecânica de rochas graníticas, antes e após sua transformação em chapas e ladrilhos polidos. Estes últimos constituíram o material investigado nos ensaios de alteração acelerada, que procuraram simular situações semelhantes àquelas que poderão estar sujeitos no seu uso no revestimento de edificações.

Tipos graníticos comerciais, correspondentes a granitos stricto sensu e lato sensu são objeto do estudo proposto, por serem as rochas mais exploradas e consumidas no Brasil. Além disso, apresentam relativa homogeneidade mineralógica, textural e estrutural; o que permitiu melhor comparação dos resultados laboratoriais entre os diferentes tipos selecionados.

A qualificação e/ou quantificação das alterações mineralógicas e mecânicas ocorridas foram realizadas por meio da petrografia e técnicas analíticas complementares (difratometria de raios $\mathrm{X}$ e outras); e de determinações físicas $\mathrm{e}$ mecânicas (porosidade e absorção d'água, resistências à compressão e flexão, e velocidade de propagação de ondas).

As atividades desenvolvidas são relatadas a seguir.

\subsection{Seleção dos Materiais e Áreas de Estudo}

Os critérios para a seleção das rochas graníticas estudadas foram: cor, que em geral reflete a composição mineralógica e/ou grau de alteração intempérica; o histórico de alterações e/ou deteriorações em uso, a partir de informações obtidas a partir de dezenas de atendimentos a consumidores, e de contatos com outros profissionais de diversos estados. Também foram ponderadas a valorização e a tradição no mercado.

As rochas graníticas selecionadas para estudo estão relacionadas na Tabela 2.1 e correspondem a rochas brasileiras de grande aceitação nos mercados interno e externo. 
Tabela 2.1 - Tipos rochosos selecionados e regiões produtoras.

\begin{tabular}{|c|c|c|}
\hline COR PREDOMINANTE & NOME COMERCIAL & $\begin{array}{l}\text { REGIÃO PRODUTORA } \\
\text { (ESTADO) }\end{array}$ \\
\hline verde & Verde Labrador & Colatina (ES) \\
\hline \multirow{3}{*}{ vermelha } & Capão Bonito - 1 & Capão Bonito (SP) \\
\hline & Capão Bonito - $2^{*}$ & Capão Bonito (SP) \\
\hline & Capão Bonito - $3^{*}$ & Capão Bonito (SP) \\
\hline rosa & Rosa Iracema & Sobral (CE) \\
\hline \multirow{2}{*}{ branco-rosado } & Branco Cristal $^{\star}$ & Sobral (CE) \\
\hline & Branco Savana* & Sobral (CE) \\
\hline \multirow{2}{*}{ cinza } & Prata Interlagos & São Paulo (SP) \\
\hline & Azul Paulista Frente Nova* & São Paulo (SP) \\
\hline \multirow{2}{*}{ branco-amarelado } & Branco Itaúnas (Microponto II) & Medeiros Neto (BA) \\
\hline & Branco Itaúnas (Microponto III)* & Medeiros Neto (BA) \\
\hline branco-esverdeado & Branco Caravelas* & Medeiros Neto (BA) \\
\hline branca & Branco Ceará & Santa Quitéria (CE) \\
\hline \multirow{2}{*}{$\begin{array}{l}\text { branca com faixas cinzentas } \\
\text { amarela com faixas cor de } \\
\text { ferrugem }\end{array}$} & Casablanca & Independência (CE) \\
\hline & Falésias* & Independência (CE) \\
\hline \multirow{3}{*}{ "amarela" } & Giallo Veneciano & Nova Venécia (ES) \\
\hline & Arabesco & Nova Venécia (ES) \\
\hline & Santa Cecília & Ecoporanga (ES) \\
\hline
\end{tabular}

Nota: * amostras que constituem conjuntos de litotipos de ocorrência geológica e geográfica próxima, por vezes com pequenas variações, especialmente no grau de alteração.

\subsection{Levantamento Bibliográfico}

O levantamento bibliográfico compreendeu a recuperação das informações disponíveis, mais recentes, sobre contexto geológico, dados petrológicos e petrográficos, de modo a se obter um quadro sucinto das características de jazimento dos diferentes tipos de rochas comercializados.

A pesquisa bibliográfica também abrangeu a revisão dos principais trabalhos desenvolvidos nos temas alteração, deterioração, alterabilidade e durabilidade de rochas, principalmente aquelas destinadas ao uso em revestimento de edificações. Contemplou, também, consulta a livros-texto e artigos atuais em diversos periódicos técnico-científicos. Em caráter ilustrativo, foi efetuada uma breve compilação do panorama mercadológico brasileiro atual. 


\subsection{Visitas às Minas Selecionadas}

Após a escolha dos tipos graníticos que foram estudados, foram planejados os trabalhos de campo para reconhecimento geológico dos corpos rochosos e do método de extração, enfocando as heterogeneidades, principalmente aquelas referentes à atuação intempérica e presença de descontinuidades (presença de fraturamento, dobramentos e outros).

Para visita aos jazimentos nos estados da Bahia e de São Paulo foram contatados, respectivamente, os produtores dos granitos selecionados, que forneceram as autorizações e informações necessárias durante as visitas.

Nos demais estados foram consultados centros tecnológicos (Fundação Núcleo de Tecnologia Industrial - Nutec, por meio da Divisão de Tecnologia Mineral - Ditem, em Fortaleza, CE) e entidades de classe (Sindicato da Indústria de Rochas Ornamentais, Cal e Calcário do Estado do Espírito Santo - SindiRochas, em Cachoeiro do Itapemirim, ES), que também forneceram informações sobre os produtores dos materiais selecionados e providenciaram autorização para acesso aos empreendimentos minerários.

Os empreendimentos visitados acham-se listados na Tabela 2.2.

Tabela 2.2 - Empreendimentos minerários visitados e materiais amostrados.

\begin{tabular}{cl}
\hline NOME COMERCIAL & \multicolumn{1}{c}{ EMPRESA } \\
\hline Vermelho Capão Bonito & $\begin{array}{l}\text { Somibrás - Sociedade de Mineração Brasileira Ltda. } \\
\text { Granitos Brasileiros S.A. } \\
\text { Granitos Pires - Mineração e Comércio Ltda. }\end{array}$ \\
\hline Prata Interlagos & YKK do Brasil Ltda. \\
\hline Azul Paulista Frente Nova & Granitos Brasileiros S.A. \\
\hline Branco Itaúnas & Mineração Corcovado Ltda. \\
\hline Branco Caravelas & Marbrasa - Mármores e Granitos do Brasil S.A. \\
\hline Santa Cecília & Nemer - Mármores e Granitos S.A. \\
\hline Arabesco & Rocha Branca - Mineração Comércio e Exportação Ltda. \\
\hline Giallo Veneciano & Granasa - Granitos Nacionais Ltda. \\
\hline Branco Ceará & Granistone S.A. \\
\hline Rosa Iracema & Imarf Granitos S.A. \\
Banco Cristal & \\
\hline Casablanca & Granos - Granitos S.A. \\
\hline Falésias &
\end{tabular}




\subsubsection{Amostragem}

A amostragem dos materiais para a realização dos ensaios e análises pretendidos foi orientada durante os trabalhos de campo. Essas amostras constituíramse de pequenos blocos cúbicos com cerca de $30 \mathrm{~cm}$ x $30 \mathrm{~cm} \times 30 \mathrm{~cm}$ (Figura 2.1), na quantidade de duas para cada tipo de rocha.

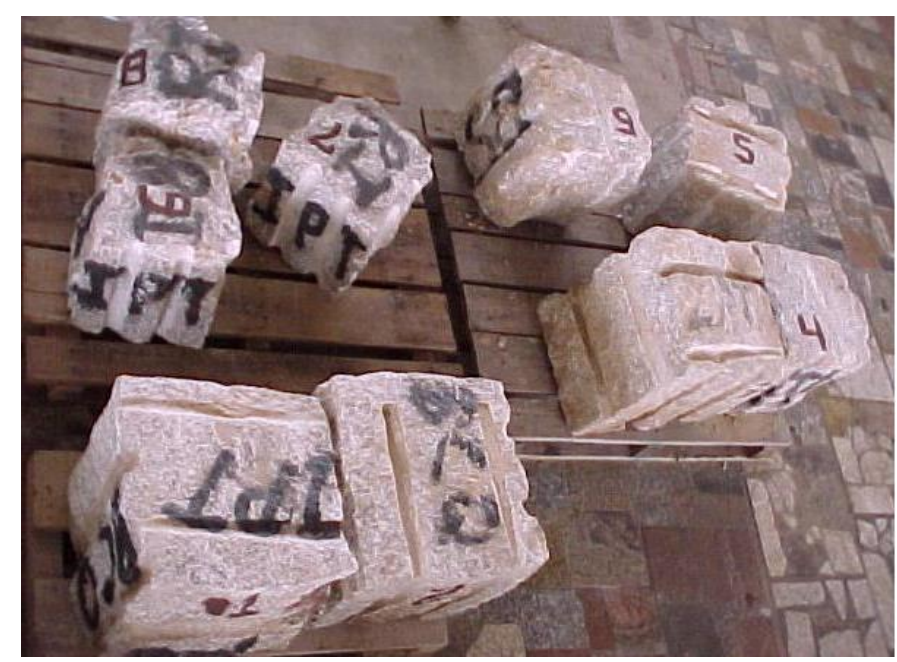

Figura 2.1 - Blocos cúbicos com cerca de $30 \mathrm{~cm} \times 30 \mathrm{~cm} \times 30 \mathrm{~cm}$, para ensaios de laboratório.

Complementarmente foram necessárias oito placas polidas com dimensões de $40 \mathrm{~cm} \times 40 \mathrm{~cm} \times 2 \mathrm{~cm}$ a $3 \mathrm{~cm}$, para os ensaios de alteração e de determinação das propriedades físicas e mecânicas "pós-beneficiamento" e "pós- ensaios de alteração".

\subsection{Visita a Centros de Beneficiamento}

A visita a centros de beneficiamento, de uma parte dos tipos litológicos amostrados na etapa de campo, foi fundamental para conhecer as técnicas e equipamentos em uso, para produçã de chapas e ladrilhos polidos.

Esta atividade também teve por objetivo tomar conhecimento das solicitações a que as rochas são submetidas e que poderiam conduzir a modificações nas propriedades físicas, em relação àquelas apresentadas por estes materiais in natura.

A importância do conhecimento desses parâmetros acha-se ligada à consideração de que os processos e equipamentos de corte e polimento podem imprimir modificações diversas nas propriedades tecnológicas dos produtos (chapas e ladrilhos polidos).

Foram visitadas as unidades de beneficiamento listadas abaixo: 
- Marbrasa - Mármores e Granitos do Brasil S.A., em Cachoeiro do Itapemirim, ES;

- Granos Granitos S.A., em Caucaia, CE;

- Imarf Granitos S.A., em Caucaia, CE;

- YKK do Brasil Ltda., em Arujá, SP.

Essas empresas utilizam técnicas modernas e equipamentos geralmente importados da Itália, cujo processo produtivo é realizado conforme descrito a seguir.

Todas as rochas estudadas foram desdobradas em teares automáticos ou semiautomáticos, que permitem a elaboração de chapas com espessura bastante regular, que varia de $1,5 \mathrm{~cm}$ a $3,0 \mathrm{~cm}$ (Figura 2.2).
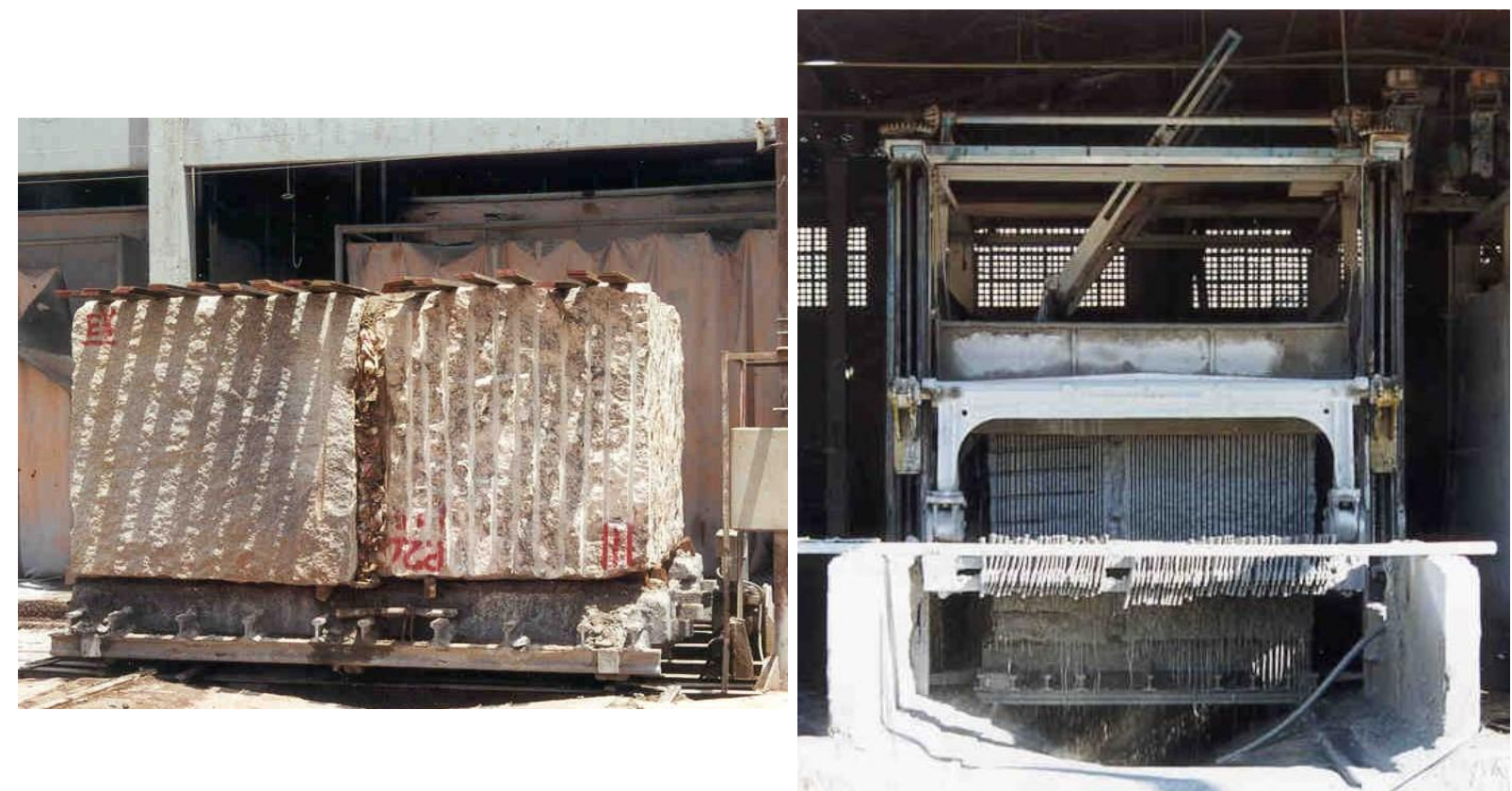

Figura 2.2 - Blocos montados para serragem em tear de grandes dimensões (à esquerda), e processo de serragem de chapas a partir de bloco de granito (à direita).

As chapas obtidas são, então, submetidas a polimento, em equipamentos automáticos, que em cerca de 15 a 20 minutos realizam todo o processo (Figura 2.3). 


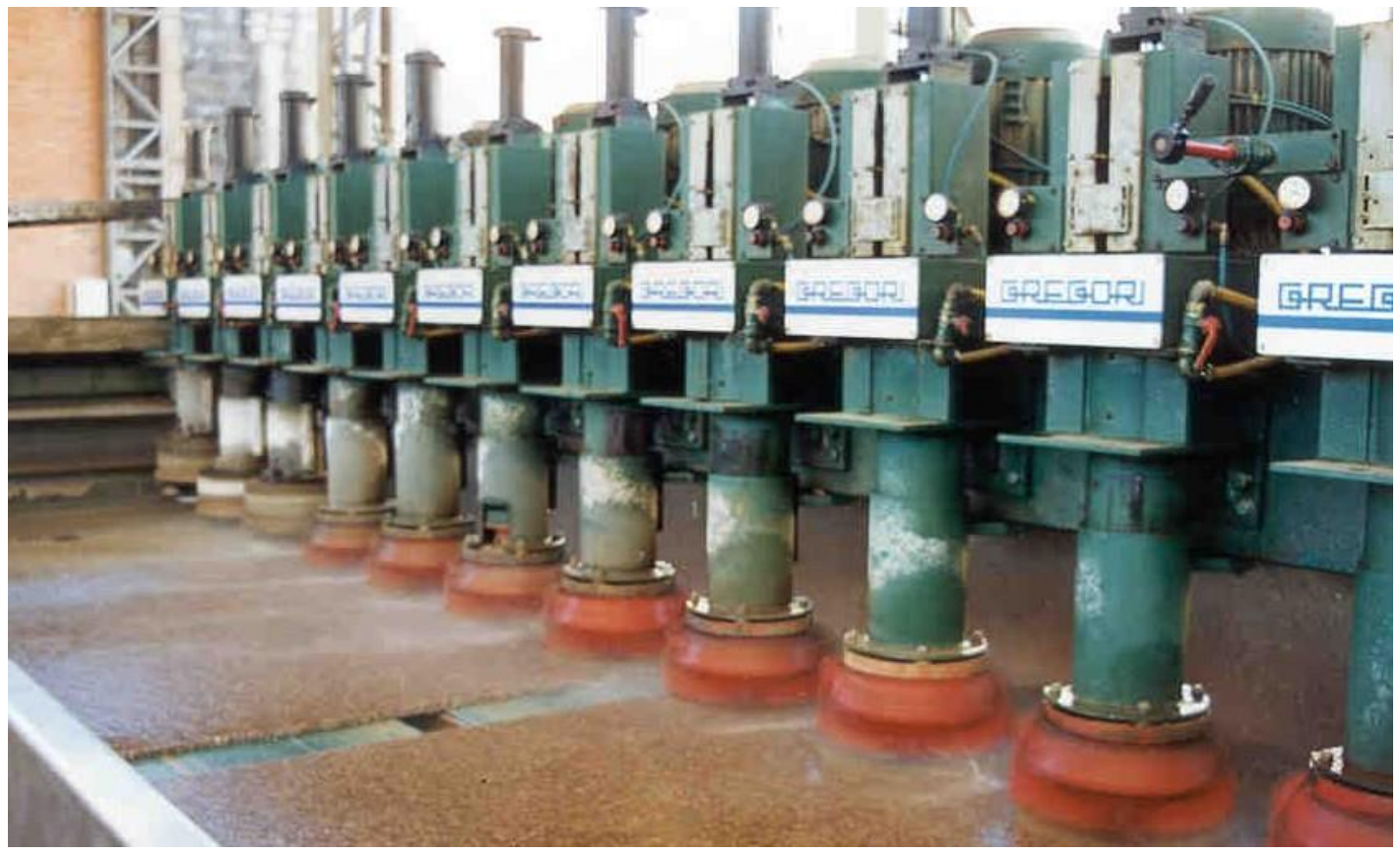

Figura 2.3 - Máquina de polir, automática, de origem italiana. Conforme progride o processo de polimento (na foto, do fundo para o primeiro plano), são utilizados abrasivos cada vez mais finos.

A quase totalidade dos materiais estudados, nesta pesquisa, foi submetida a polimentos somente com o uso dos abrasivos cerâmicos, normalmente utilizados nas máquinas automáticas de polir. Aparentemente não foram empregadas resinas sintéticas (polímeros) para melhoria do grau de lustro, o que leva a presumir que os eventuais efeitos das simulações de alteração devam se ater somente às características e a este processo.

\subsection{Ensaios e Análises Laboratoriais}

A caracterização tecnológica de rochas é realizada por meio de ensaios e análises, cujo principal objetivo é a obtenção de parâmetros petrográficos, químicos, físicos e mecânicos do material in natura, que permitem a qualificação da rocha para uso no revestimento de edificações.

Os ensaios procuram representar as diversas solicitações às quais a rocha estará submetida durante todo o processamento até seu uso final, quais sejam, extração, esquadrejamento dos blocos, serragem destes em chapas, polimento, corte em placas e ladrilhos etc.

Ainda são raros os ensaios normalizados em rochas beneficiadas (ladrilhos ou 
chapas polidos), que visem a parâmetros de previsão de desempenho e durabilidade de rochas para revestimento de fachadas e pisos. Em geral, propõem-se à determinação de parâmetros físicos e mecânicos para o dimensionamento das placas para revestimento de fachadas e pisos.

Os ensaios e/ou análises realizados visaram à caracterização química, petrográfica, mineralógica e tecnológica dos materiais rochosos selecionados, para o reconhecimento das propriedades naturais, bem como das possíveis alterações impostas pelas solicitações mecânicas durante o desdobramento dos blocos em placas e posterior polimento.

A caracterização química objetivou determinar a composição das rochas, verificar as proporções dos diferentes elementos e subsidiar a interpretação das alterações observadas nos ensaios intempéricos realizados.

Como parâmetros físicos, foram determinados densidade, porosidade, absorção d'água e velocidade de propagação de ondas ultra-sônicas e, como parâmetros mecânicos, as resistências à compressão e à flexão.

Os ensaios se basearam nos procedimentos de ensaios e análises da ABNT, ASTM - American Society for Testing and Materials, BSI - British Standard Institution e CEN - European Committee for Standardization, listados na Tabela 2.3.

Tabela 2.3 - Ensaios de caracterização de rochas ornamentais e respectivas normas utilizadas.

\begin{tabular}{cc}
\hline ENSAIO & NORMA \\
\hline & ABNT NBR 12 766 (ABNT, 1992a) \\
ASTM C97 (ASTM, 1996) \\
Densidade e porosidade/ absorção & CEN prEN WI 036 (CEN, 1998a)* \\
& BS EN 1936 (BSI, 1999a) \\
\hline Capilaridade & BS EN 1925 (BSI, 1999b) \\
\hline Compressão Uniaxial & ABNT NBR 12.767 (ABNT, 1992b) \\
ASTM C170 (ASTM,1990) \\
\hline Choque Térmico & CEN prEN WI 016 (CEN, 1998b) \\
\hline Análise Petrográfica & ABNT NBR 12.768 (ABNT, 1992c) \\
FS Elexão & ASTM C 880 (ASTM, 1998) \\
\hline Velocidade de Propagação de Ondas & ASTM D 2845 (ASTM, 2000) \\
\hline * Em consulta na Internet (http://bsonline.techindex.co.uk), verificou-se que esse projeto de norma foi \\
$\begin{array}{c}\text { publicado, em 2002, pela British Standard Institution: BS EN 13755:2002 - Natural stone. Test method. } \\
\text { Determination of water absorption at atmospheric pressure. }\end{array}$
\end{tabular}

Ensaios de alteração acelerada foram concebidos para simular condições 
semelhantes àquelas em que as rochas estarão expostas após sua aplicação no revestimento de edificações: fatores climáticos (choque térmico), comportamento perante atmosferas poluídas ou quimicamente agressivas (exposição em câmaras climáticas de dióxido de enxofre e névoa salina, respectivamente) e ação da cristalização de sais (imersão parcial em soluções ácida e alcalina).

As modificações diante dessas simulações foram monitoradas visualmente e controladas por ensaios físicos (medida de velocidade de ondas ultra-sônicas longitudinais e absorção de água) e mecânicos (resistência à flexão). Técnicas petrográficas (microscopia óptica e difratometria de raios $\mathrm{X}$ ) auxiliaram a análise dos resultados.

Os índices físicos e velocidades de propagação de ondas ultra-sônicas longitudinais, juntamente com o estudo petrográfico, são parâmetros de controle fundamentais, pois caracterizam e melhor refletem os aspectos intrínsecos das rochas.

Análises estatísticas exploratórias, especialmente regressão linear e determinação de coeficientes de correlação de Pearson $(R)$, procuraram estabelecer as possíveis correlações entre as características intrínsecas das várias rochas estudadas e as alterações nos ensaios intempéricos adotados (aspectos extrínsecos).

A Figura 2.4 sintetiza o conjunto de procedimentos utilizados e seus principais objetivos. 


\section{FLUXOGRAMA DE ENSAIOS}

\section{1 - caracterização química e determinação do estado de alteração inicial e de feições potencialmente alteráveis}

PARÂMETROS:

- composição mineralógica

- feições petrográficas: microfissuramento, tamanho dos grãos, heterogeneidade

textural, minerais alterados - composição química

\section{TÉCNICAS EMPREGADAS:}

- petrografia

- difratometria de raios $X$

- análises químicas

\section{2 - determinação das propriedades físicas e mecânicas}

\section{PARÂMETROS:}

- absorção de água, porosidade, densidade aparente

- resistência à compressão, resistência à flexão

- velocidade de propagação de ondas ultrasônicas longitudinais

\section{TÉCNICAS EMPREGADAS:}

- determinações de propriedades físicas e de resistências mecânicas baseadas em normas nacionais e internacionais

\section{3 - ensaios de alteração}

- secagem em estufa e imersão imediata em água (choque térmico) - imersão parcial em soluções ácida e alcalina, em condições ambientais - câmaras climáticas, por exposição ao dióxido de enxofre e névoa salina

\section{4 - caracterização pós-alteração}

\section{PARÂMETROS:}

- feições petrográficas e modificações mineralógicas

- velocidade de propagação de ondas ultrasônicas

- variações de peso e absorção de água

- variações nas propriedades mecânicas
TÉCNICAS EMPREGADAS:

- ensaios físicos e mecânicos

- microscopia óptica

- difratometria de raios $X$

Figura 2.4 - Fluxograma dos ensaios de caracterização petrográfica, física, mecânica e de alteração acelerada. 


\section{CAPÍTULO 3}

\section{DETERIORAÇÃO DE ROCHAS}

A alteração intempérica das rochas se inicia, na natureza, quando estas entram em contato com as condições atmosféricas reinantes na superfície terrestre.

A degradação ou deterioração dessas rochas, ao serem utilizadas na construção civil, ocorre por meio de mudanças nas propriedades desses materiais, em contato com o ambiente natural, no decorrer do tempo (Viles, 1997). Inclui mudanças físicas e químicas, que resultam na diminuição da resistência da rocha e modificações na aparência estética; desde incipientes alterações cromáticas até esfoliações de camadas superficiais.

Nesse estudo, os termos degradação, deterioração e intemperismo serão empregados como sinônimos, para as rochas para revestimento.

A deterioração de materiais rochosos usados no revestimento de edificações, ou em monumentos, é mais pronunciada nos centros urbanos e industriais, pois o ambiente urbano, enriquecido em poluentes de variadas fontes, acelera e modifica os processos de alteração destes materiais (Figuras 3.1 a 3.3), ou seja, altera ou acelera os processos naturais. Devido principalmente à ação dos ventos, os efeitos nocivos das atmosferas urbanas também podem ser observados nas regiões rurais.

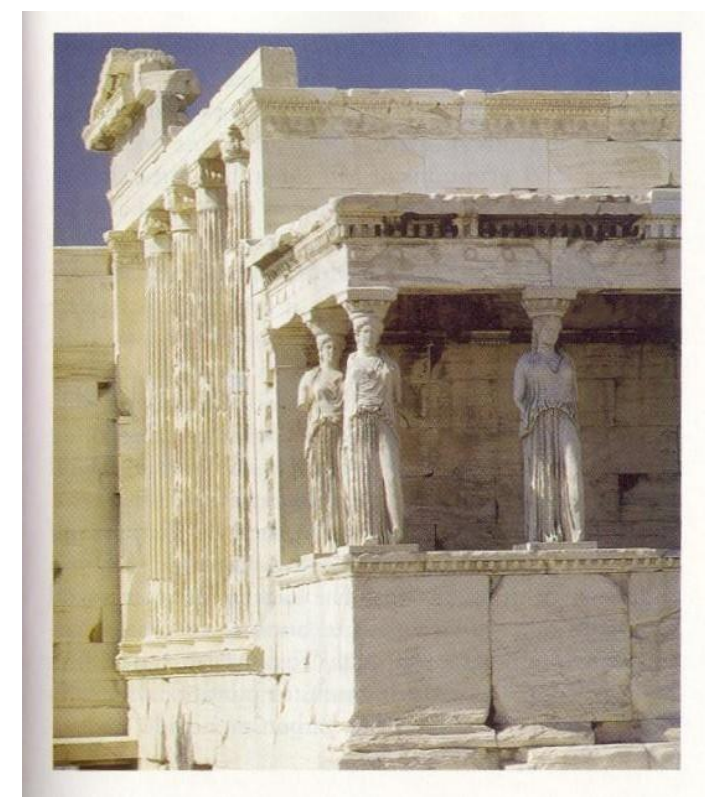

Fonte: Keller (1996)
Figura 3.1 - Acrópole, Atenas, Grécia. As estátuas foram de tal forma danificadas, que as originais foram guardadas no interior dos edifícios, em containeres de vidro. 

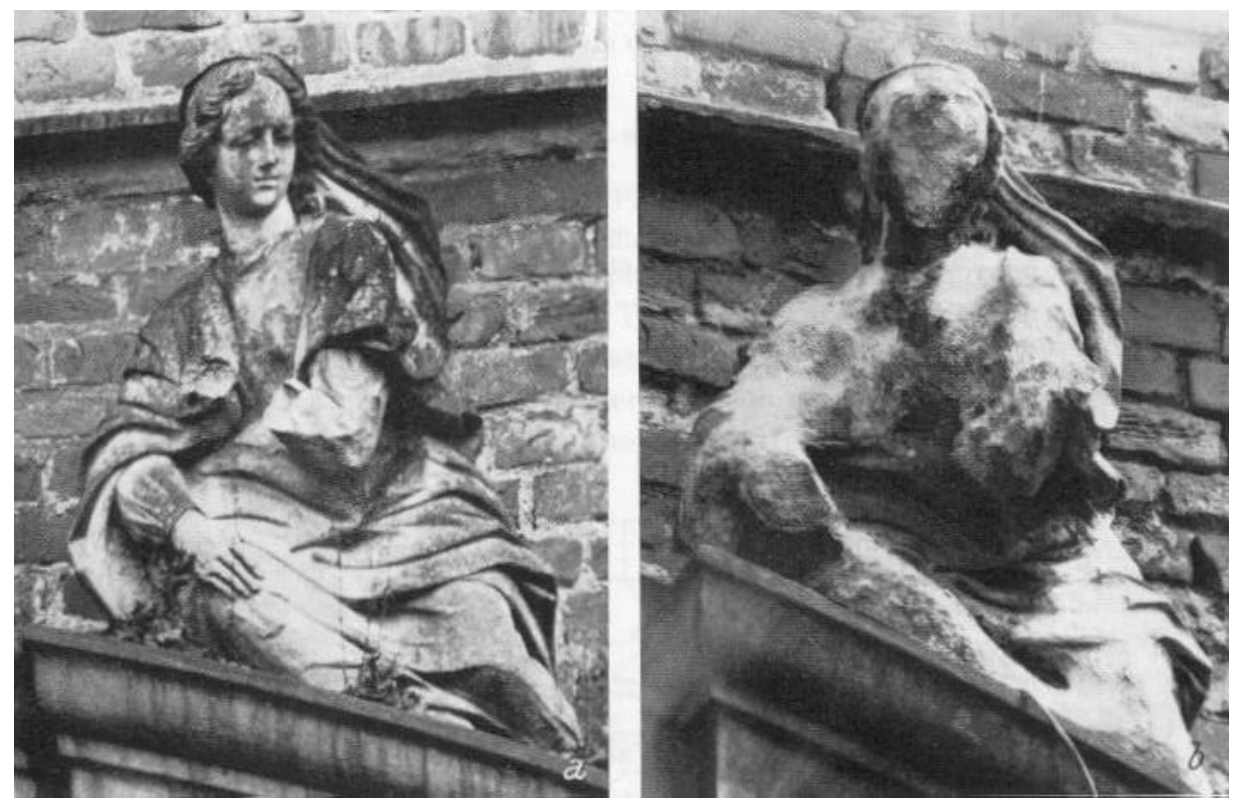

Fonte: Winkler (1997)

Figura 3.2 - Escultura de arenito, no castelo Herten (Alemanha), construído em 1702. Foto à esquerda, de 1908, mostrando leve a moderada alteração. À direita, foto de 1969, mostrando destruição quase completa.

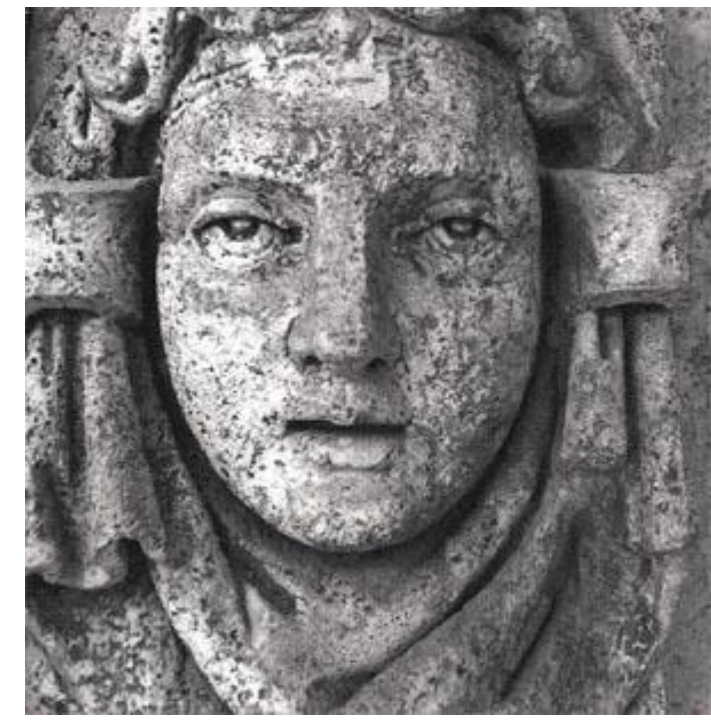

Fonte: Giacomelli; Perego (s.d.)
Figura 3.3 - Estátua de calcário travertino na fachada da Basílica de São Pedro (Vaticano) deteriorada pela ação de poluentes trazidos para a superfície da rocha pelo ar (na forma de gases ou aerossóis) ou pela água (chuva ácida).

A taxa e o tipo de degradação são determinados pela natureza dos materiais envolvidos e do ambiente ao qual estão expostos. Segundo Viles (1997), a deterioração é um problema notável quando uma ou mais das três condições a seguir são encontradas:

- o processo natural de deterioração é acelerado, pois: 
- o ambiente é naturalmente corrosivo, tal qual áreas costeiras e desérticas com abundantes aerossóis salinos; e/ou

- os materiais são relativamente fracos, já predispostos a degradar e desintegrar.

- a atuação humana acelera a deterioração por causa da poluição atmosférica, manutenção inadequada etc.;

- edifícios e monumentos de grande valor ou significância são afetados.

É importante reconhecer que a deterioração também é um fenômeno natural e, portanto, um "problema" não inteiramente induzido pela atividade humana e que possa ser inteiramente "resolvido" (Viles, 1997).

A deterioração envolve mudanças físicas e químicas da superfície do material, ou da camada superficial onde materiais porosos são incluídos. Isto resulta em numerosos efeitos visíveis e invisíveis, como descoloração, formação de crostas e manchas ferruginosas, escurecimento superficial e produção de cavidades, descamação superficial, buracos e fragmentação (Figura 3.4). Também resultam em custos financeiros ligados à necessidade de reparação dos danos, limpeza e restauração.

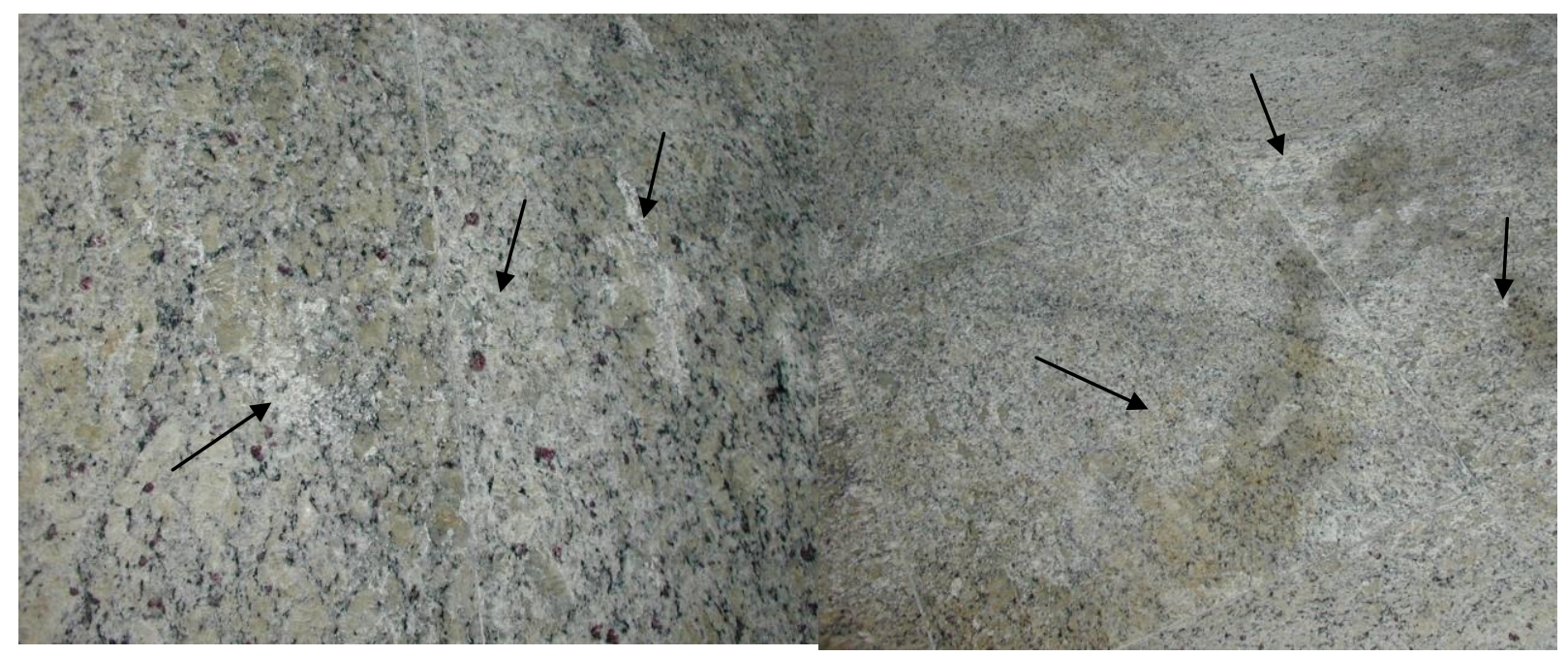

Figura 3.4 - Inchamento e destacamento de minerais da superfície polida de granito "Santa Cecília", assentado em piso, com argamassa.

Aires-Barros (1991) aponta três tipos principais de degradação de rochas para revestimento ou de monumentos:

- químico: considera as reações químicas que se processam na superfície e nas descontinuidades das rochas, com a formação de minerais secundários; 
- físico: resulta de fenômenos de expansão e/ou retração diferencial dos minerais, provocados por variações térmicas, abalos físicos de várias origens, e ainda por expansões decorrentes da geração de minerais secundários (hidratação de minerais argilosos expansivos, ação da tensão superficial da água no decurso de processos naturais de saturação e secagem e ação das forças de cristalização de sais);

- biológico: provocado pelo crescimento de microorganismos sobre as rochas.

Feilden (1994) atribuiu à deterioração das construções e seus materiais as seguintes causas:

- externas: relacionadas aos fenômenos climáticos e agentes biológicos/ botânicos;

- internas: relacionadas à umidade ou secura excessivas, ar contaminado e negligência;

- humana: incluindo a poluição ambiental, vibrações, vandalismo e outros.

Para Viles (1997), as causas da deterioração estão ligadas tanto aos fatores ambientais como arquitetônicos, esses compreendendo o posicionamento e modo de colocação da rocha, defeitos inerentes (propriedades intrínsecas a algumas rochas, que reduzem a sua durabilidade), projeto e técnicas inadequadas de manutenção.

O tipo litológico (mineralogia, alteração, textura e estrutura), a presença de fraturas e/ou fissuras (porosidade) e o clima (temperatura e intensidade de chuvas, entre outros) podem ser considerados os fatores que mais influenciam a susceptibilidade e taxa do intemperismo físico e químico em rochas para revestimento. Adicionalmente, há a ação dos poluentes atmosféricos, nos ambientes urbanos, e o emprego de processos inadequados para o assentamento e manutenção de rochas.

Amoroso; Fassina (1983) apontam que o grau de alteração depende da alterabilidade dos minerais constituintes, da homogeneidade da rocha e da superfície específica exposta aos agentes degradadores.

Modificações físicas das rochas para revestimento atribuídas às técnicas empregadas na extração e de beneficiamento, podem levar ao aumento do fissuramento, porosidade e outros (Dib et al., 1999), que irão contribuir para a acentuação dos efeitos deletérios dos agentes intempéricos ou da ação antrópica (manutenção e limpeza inadequadas, entre outras) (Frascá; Quitete, 1999).

Desta forma, as principais causas da degradação destes materiais rochosos, 
tendo em vista as condições climáticas e técnicas construtivas empregadas no Brasil, conforme Frascá (2002a), são:

- clima tropical (intensas variações de temperatura e umidade);

- agentes de limpeza, os quais atuam através de diversas substâncias químicas, cujos componentes podem causar modificações, especialmente no aspecto estético das rochas;

- poluição ambiental, na qual os diversos elementos dispersos na atmosfera têm grande influência;

- cristalização de sais, principalmente quando as rochas são usadas no revestimento de pisos e assentadas com argamassa.

Com foco nos aspectos anteriormente relatados, apresenta-se uma compilação dos principais conceitos e informações ligados à degradação intempérica de rochas, ou seja, o estado da arte conforme trabalhos anteriores, cujos conceitos e experimentos serão considerados para orientar o presente trabalho.

\subsection{Alteração Intempérica de Rochas}

Convencionalmente, como citado por Delgado-Rodrigues (1996), os processos intempéricos são divididos em dois tipos: físico e químico, que, na realidade, ocorrem concomitantemente, com a prevalência de um sobre o outro, dependendo das condições atmosféricas.

O intemperismo físico é dado principalmente pelas mudanças de temperatura (e.g. dilatação térmica diferencial dos minerais das rochas), por tensões mecânicas (descompressão e deformações tectônicas), pelas pressões internas causadas por agentes degradadores especiais (congelamento de água em poros ou fissuras, cristalização de sais na superfície da rocha e expansão de minerais por absorção de água) e agentes externos (antrópicos, animais e plantas).

O intemperismo químico ocorre pela ação da água e outros componentes transportados em solução e atua principalmente pelas reações de oxidação e hidrólise.

A alteração de rochas pode ser considerada um processo fundamentalmente químico, no qual os minerais silicáticos originais são afetados pelas soluções inorgânicas e orgânicas de baixa temperatura (Carroll, 1970). As reações químicas entre os minerais silicáticos e as soluções são governadas pelas leis de solução 
química e equilíbrio, energia livre e potenciais de redox e controladas por numerosas variáveis. Resultam num ambiente químico estável, para uma região particular da superfície terrestre.

As principais variáveis que controlam a natureza e a taxa dos processos intempéricos têm sido, desde longo tempo, reconhecidas como a composição e estrutura da rocha-mãe, o clima e o tempo de atuação do processo intempérico.

O efeito dos vários agentes e processos intempéricos nas rochas é mostrado por mudanças mineralógicas, químicas e granulométricas, evidenciadas pela parcial ou total decomposição de alguns minerais, oxidação de ferro ferroso a férrico, parcial ou total mobilização de elementos maiores e menores, e outras. As reações são controladas tanto pela solubilidade dos constituintes minerais como pela porosidade da rocha.

A saturação da rocha por soluções aquosas é muito importante, pois nesta condição podem ocorrer reações que resultarão na remoção dos materiais solúveis (e.g., calcita), reações entre minerais sãos e soluções e reações entre os produtos do intemperismo (argilominerais) e demais minerais.

O intemperismo, desta forma, é um ajuste, ou reajuste, de minerais e rochas às condições reinantes na superfície terrestre. A presença de oxigênio leva à oxidação, e a de umidade, à hidratação ou à solução. $O$ reajuste pode ocasionar a expansão do retículo cristalino.

De maneira geral, a despeito do intemperismo físico ser distinto do intemperismo químico, ambos geralmente atuam em conjunto. Este último é auxiliado pela quebra mecânica que leva ao rápido aumento das superfícies minerais, promovendo o pronto acesso de oxigênio e umidade e aceleração do processo, cuja taxa depende predominantemente do clima.

Dependendo do grau de empacotamento cristalino, os processos de reajustamento podem ser vagarosos como os processos geológicos, ou rápidos 0 suficiente para impor deterioração em menos de uma geração. A atmosfera urbana do último século criou problemas ambientais especiais às superfícies rochosas expostas, pois podem acelerar os processos intempéricos relativamente aos ambientes naturais rurais.

As atuações intempéricas preponderantes nas diversas correlações de intensidade de chuva e temperatura estão esquematizadas na Figura 3.5 (Murck; Skinner, 1999). 


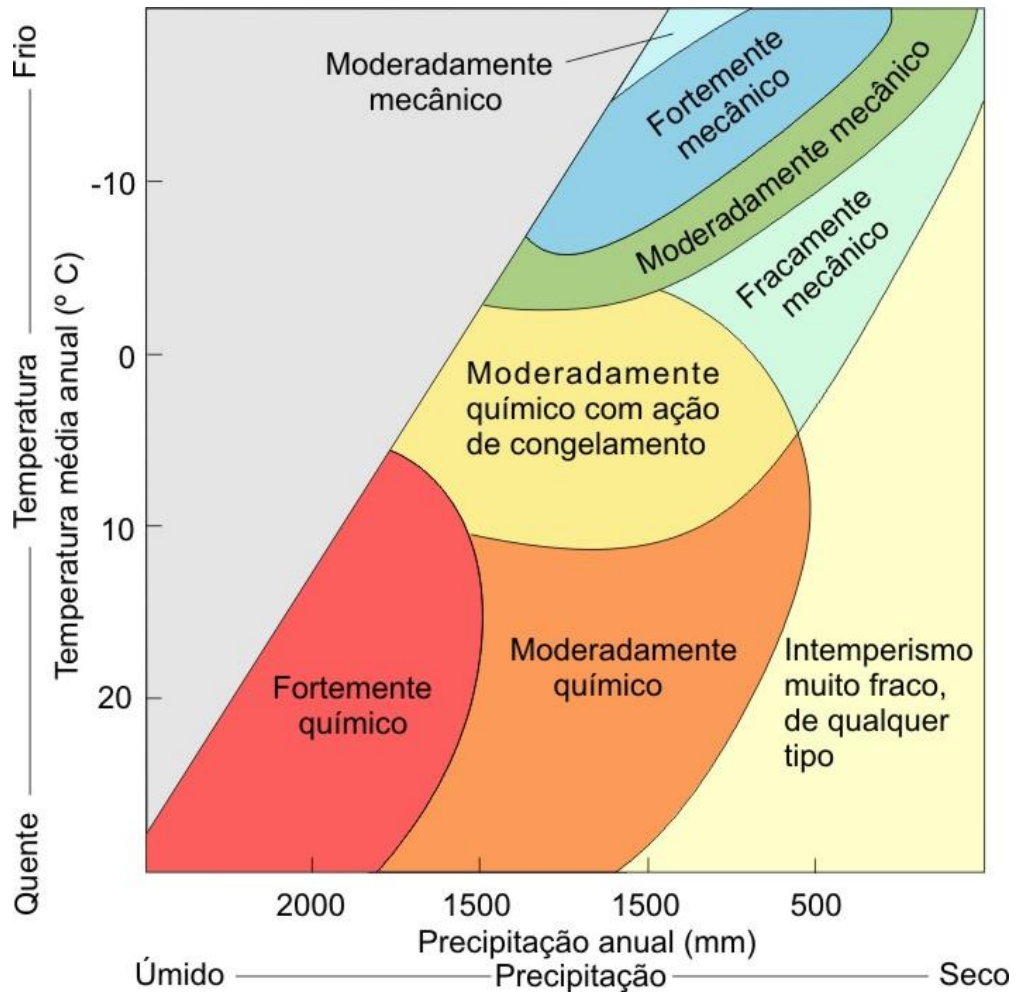

Fonte: Murck; Skinner (1999)
Figura 3.5 - Influência do clima nos processos intempéricos.

A chuva fornece a água que causa o intemperismo químico das rochas. $\mathrm{O} \mathrm{pH}$ da água da chuva tem um padrão sazonal e regional; quando em equilíbrio com o $\mathrm{CO}_{2}$ atmosférico, seu pH é 5,6. Nos climas úmidos, conduz à remoção dos cátions solúveis dos minerais, produzindo minerais de estrutura simplificada, em equilíbrio com a temperatura e pressão superficiais.

$\mathrm{Na}$ maioria das situações naturais, a água disponível para reagir com os minerais tem $\mathrm{pH}$ variando entre 3 e 9.

Segundo Skinner et al. (1999), o principal agente do intemperismo químico é uma solução fraca de ácido carbônico, formada conforme a água da chuva dissolve pequenas quantidades de $\mathrm{CO}_{2}$ atmosférico.

A água da chuva é, por si só, um eletrólito misto (Carroll, 1970) que contém quantidades variadas de cátions e ânions maiores e menores: $\mathrm{Si}^{4+}, \mathrm{Al}^{3+}, \mathrm{K}^{+}, \mathrm{Na}^{+}, \mathrm{Ca}^{2+}$, $\mathrm{Mg}^{2+}, \mathrm{Fe}^{2+}, \mathrm{Fe}^{3+}, \mathrm{Cl}^{-}, \mathrm{HCO}_{3}{ }^{-}, \mathrm{SO}_{4}{ }^{2-}, \mathrm{I}^{-}, \mathrm{Br}^{-}, \mathrm{B}^{3+}$, amônia $\left(\mathrm{NH}_{3}\right)$ e vários compostos de nitrogênio. Partículas de poeira podem lhe ser adicionadas, principalmente nas áreas industriais, nos grandes centros urbanos e zonas áridas. As fontes destes constituintes 
são os oceanos, lagos salinos ou não, massas de solo, indústrias e emanações vulcânicas.

A movimentação de água na zona de intemperismo é controlada pela gravidade, capilaridade, umidade e calor. A água de capilaridade age como um solvente e é o meio no qual ocorre a troca de íons.

Cada tipo de rocha se altera de acordo com sua composição, textura, e o ambiente químico, o qual está dentro de um conjunto de condições de $\mathrm{pH}$ e Eh característico da região em que ocorre.

\subsubsection{Modificações intempéricas em minerais e rochas}

Goldich (1938), com base em duas premissas, propôs a série de estabilidade mineral no intemperismo (Figura 3.6): (a) mudanças químicas e mineralógicas resultantes estudo do intemperismo de quatro rochas (um gnaisse granítico, dois diabásios e um anfibolito) e (b) princípio da estabilidade: conceito de que as taxas em que ocorrem as perdas dos constituintes químicos, no intemperismo, indicam que os minerais formadores de rochas têm diferentes graus de estabilidade.
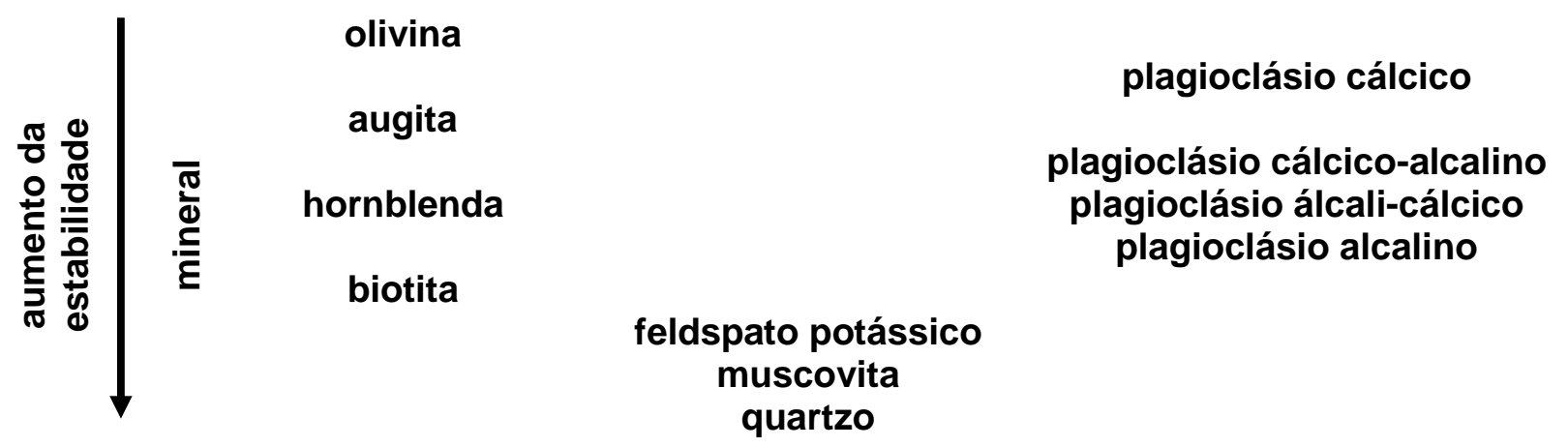

Figura 3.6 - Série de estabilidade mineral no intemperismo (Série de Goldich).

Goldich (1938) ressalta a similaridade inversa com a Série de Bowen e que sua proposição indica a estabilidade relativa dos minerais.

As principais modificações intempéricas em silicatos e os minerais e produtos resultantes (Figura 3.7) foram apresentados por Aires-Barros (1991). 


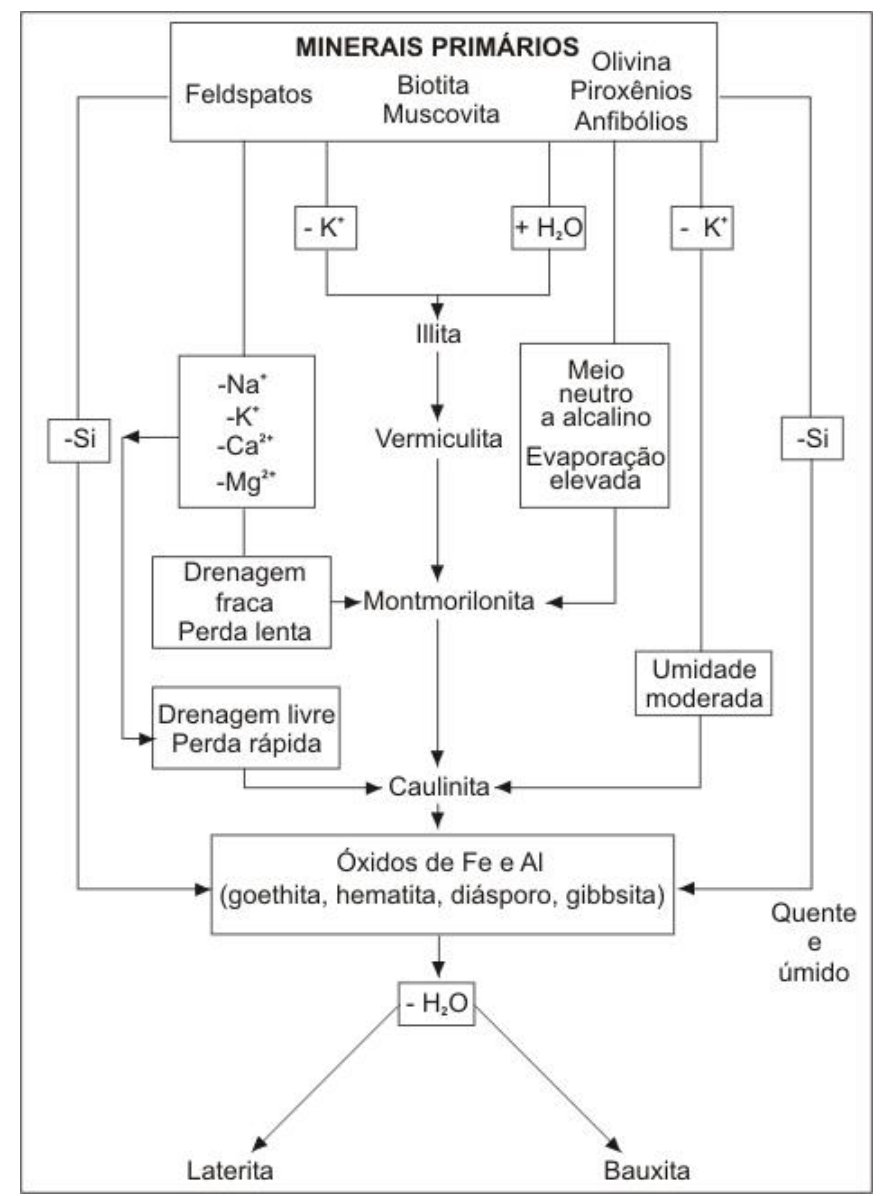

Fonte: Aires-Barros (1991), modificado.

Figura 3.7 - Representação esquemática dos processos intempéricos.

De maneira semelhante, Winkler (1997) aponta os minerais originais e os produtos de alteração mais estáveis: feldspatos e silicatos ferromagnesianos hidratam formando argilominerais; micas - após rápida perda de Fe - e quartzo são muito estáveis e permaneceriam na sua forma original; minerais carbonáticos e sulfatos dissolvem.

Sintetizando a alterabilidade dos minerais e das rochas ígneas, Aires-Barros (1991) aponta que as substituições de $\mathrm{Si}^{4+}$, nas entidades tetraédricas, por $\mathrm{Al}^{3+}$, conduzem a uma diminuição da resistência ao intemperismo.

As ligações mais fracas nos principais minerais das rochas silicáticas são:

- nesossilicatos, sorossilicatos e ciclossilicatos (sillimanita, zircão, titanita e minerais dos grupos da olivina, granada e epídoto): as que vinculam os conjuntos tetraédricos entre si. Tais ligações são feitas por cátions como 0 $\mathrm{Fe}^{2+}, \mathrm{Mg}^{2+}, \mathrm{Ca}^{2+}, \mathrm{Al}^{3+}$ etc. Quanto maior for o número de coordenação e menor 
a carga do cátion, mais débil é a ligação;

- inossilicatos (minerais dos grupos dos piroxênios e anfibólios): as que vinculam as cadeias umas às outras;

- filossilicatos (clorita, argilominerais e minerais do grupo das micas): as que ligam as diferentes folhas tetraédricas;

- tectossilicatos (quartzo e feldspatos): as ligações menos fortes são aquelas entre os cátions $\mathrm{K}^{+}, \mathrm{Na}^{+}, \mathrm{Ca}^{2+}, \mathrm{Ba}^{2+}$, etc.

A mobilidade relativa de elementos químicos das rochas é apresentada na Tabela 3.1 (Aires-Barros, 1991).

Tabela 3.1 - Mobilidade relativa de elementos químicos das rochas (Aires-Barros, 1991).

\begin{tabular}{|c|c|c|c|c|}
\hline \multirow{2}{*}{$\begin{array}{l}\text { MOBILIDADE } \\
\text { RELATIVA }\end{array}$} & \multicolumn{2}{|c|}{ pH } & \multicolumn{2}{|c|}{ Eh } \\
\hline & $\mathrm{pH}>7$ & $\mathrm{ph}<7$ & $E h>0$ & $E h<0$ \\
\hline muito elevada & $\begin{array}{c}\mathrm{Cl}, \mathrm{I}, \mathrm{Br}, \mathrm{S}, \mathrm{B}, \mathrm{Se} \\
\mathrm{Mo}, \mathrm{V}, \mathrm{U}\end{array}$ & $\mathrm{Cl}, \mathrm{I}, \mathrm{Br}, \mathrm{S}, \mathrm{B}$ & $\mathrm{Cl}, \mathrm{I}, \mathrm{Br}, \mathrm{S}, \mathrm{B}$ & $\mathrm{Cl}, \mathrm{I}, \mathrm{Br}$ \\
\hline elevada & $\mathrm{Na}, \mathrm{Ca}, \mathrm{Mg}, \mathrm{Sr}$ & $\begin{array}{c}\mathrm{Na}, \mathrm{Ca}, \mathrm{Mg}, \mathrm{Sr} \\
\mathrm{Zn}, \mathrm{Cd}, \mathrm{Hg}, \mathrm{Ni}, \mathrm{Co}\end{array}$ & $\begin{array}{c}\mathrm{Na}, \mathrm{Ca}, \mathrm{Mg}, \mathrm{Sr} \\
\mathrm{Mo}, \mathrm{V}, \mathrm{U}, \mathrm{Se}\end{array}$ & $\mathrm{Na}, \mathrm{Ca}, \mathrm{Mg}, \mathrm{Sr}$ \\
\hline média & $\mathrm{Mn}$ & $\mathrm{Al}, \mathrm{Pb}, \mathrm{Cu}, \mathrm{Cr}, \mathrm{V}$ & $\begin{array}{c}\text { Co, } \mathrm{Ni}, \mathrm{Cu}, \mathrm{Hg}, \\
\text { Zn, Cd }\end{array}$ & $\mathrm{Mn}$ \\
\hline baixa & $\begin{array}{c}\text { K, Si, P, Fe, Pb, } \\
\text { Zn, Cd }\end{array}$ & $\mathrm{K}, \mathrm{Fe}^{3+}$ & $\mathrm{K}, \mathrm{Si}, \mathrm{P}, \mathrm{Pb}$ & $\begin{array}{c}\text { K, Si, P, Ni, Zn, } \\
\text { Co, Fe }\end{array}$ \\
\hline muito baixa & $\mathrm{Al}, \mathrm{Cr}, \underset{\mathrm{Co}}{\mathrm{Hg}}, \mathrm{Cu}, \mathrm{Ni}$ & Si & $\mathrm{Al}, \mathrm{Cr}, \mathrm{Fe}, \mathrm{Mn}$ & $\begin{array}{c}\text { Al, Cr, Mo, V, U, } \\
\text { Se, S, B, Hg, Cu, } \\
\text { Cd, Pb }\end{array}$ \\
\hline
\end{tabular}

A estas considerações, válidas para a maioria dos minerais formadores de rochas, são acrescentados casos específicos de interesse relevante para esse estudo:

- feldspatos: primeiramente são removidos os cátions $\mathrm{K}^{+}, \mathrm{Na}^{+}$e $\mathrm{Ca}^{2+}$, seguindo o $\mathrm{Al}^{3+}$ da coordenação tetraédrica. $\mathrm{O} \mathrm{Si}^{4+}$ é o último a ser removido (AiresBarros, 1991). Segundo Wilson (1975), o plagioclásio freqüentemente está alterado em sericita, conjuntamente com argilominerais (dos quais a illita é o mais comum), cuja origem não é certamente atribuída ao intemperismo, podendo ser, pelo menos em parte devido à ação hidrotermal ou tardimagmática. A complexa alteração de feldspatos está ligada à sua composição e estrutura, além da marcante heterogeneidade, zoneamento, intercrescimento, entre outros, dos cristais individuais. 
- micas: o $\mathrm{K}^{+}$, que liga os conjuntos em triplas camadas, é o primeiro a ser removido, seguido pelo $\mathrm{Al}^{3+}$ de coordenação tetraédrica. Restam, assim, "fragmentos" de tetraedros $\left[\mathrm{SiO}_{4}\right]^{4-}$ e de $\mathrm{Al}(\mathrm{OH})_{3}$ ou $\mathrm{Mg}(\mathrm{OH})_{2}$.

\subsubsection{Influência do potencial redox}

Muitos elementos químicos podem ocorrer na crosta terrestre em diferentes estados de oxidação. $\mathrm{O}$ caso mais comum é o do ferro que pode aparecer como metal nativo (estado de oxidação 0 ), como $\mathrm{Fe}^{2+}$ e como $\mathrm{Fe}^{3+}$.

Nesse caso, o $\mathrm{Fe}^{2+}$ nas estruturas cristalinas é um fator de grande fragilidade, pois é característico dos meios endógenos. Em ambientes exógenos, oxida-se, passando a $\mathrm{Fe}^{3+}$, com concomitante variação do raio iônico, que produz distorção da rede e dá origem à sua instabilidade.

O conceito de oxidação que, originalmente, significava adição de oxigênio a uma substância, hoje implica a perda de elétrons por átomo. A redução é o ganho de elétrons. Designa-se por potencial redox, ou potencial de oxidação-redução, a energia para perda ou aquisição de elétrons nos sistemas reversíveis de oxidação-redução.

A importância do potencial redox nos fenômenos exógenos está relacionada ao fato de muitos elementos aparecerem na crosta em diversos estados de oxidação. O potencial redox, que varia com a concentração das substâncias que entram nas reações, é função do $\mathrm{pH}$ e Eh.

Krumbein; Garrels (1952) introduziram o conceito de "barreira geoquímica" para classificação de sedimentos químicos, baseada em valores de Eh, pH e salinidade da solução (Figura 3.8).

\subsubsection{Reações de alteração}

Quanto às ações químicas da água e do ar, podem ser do tipo: dissolução, redução, oxidação-hidratação, oxidação e hidrólise. As duas últimas são consideradas as mais importantes para a decomposição dos silicatos. 


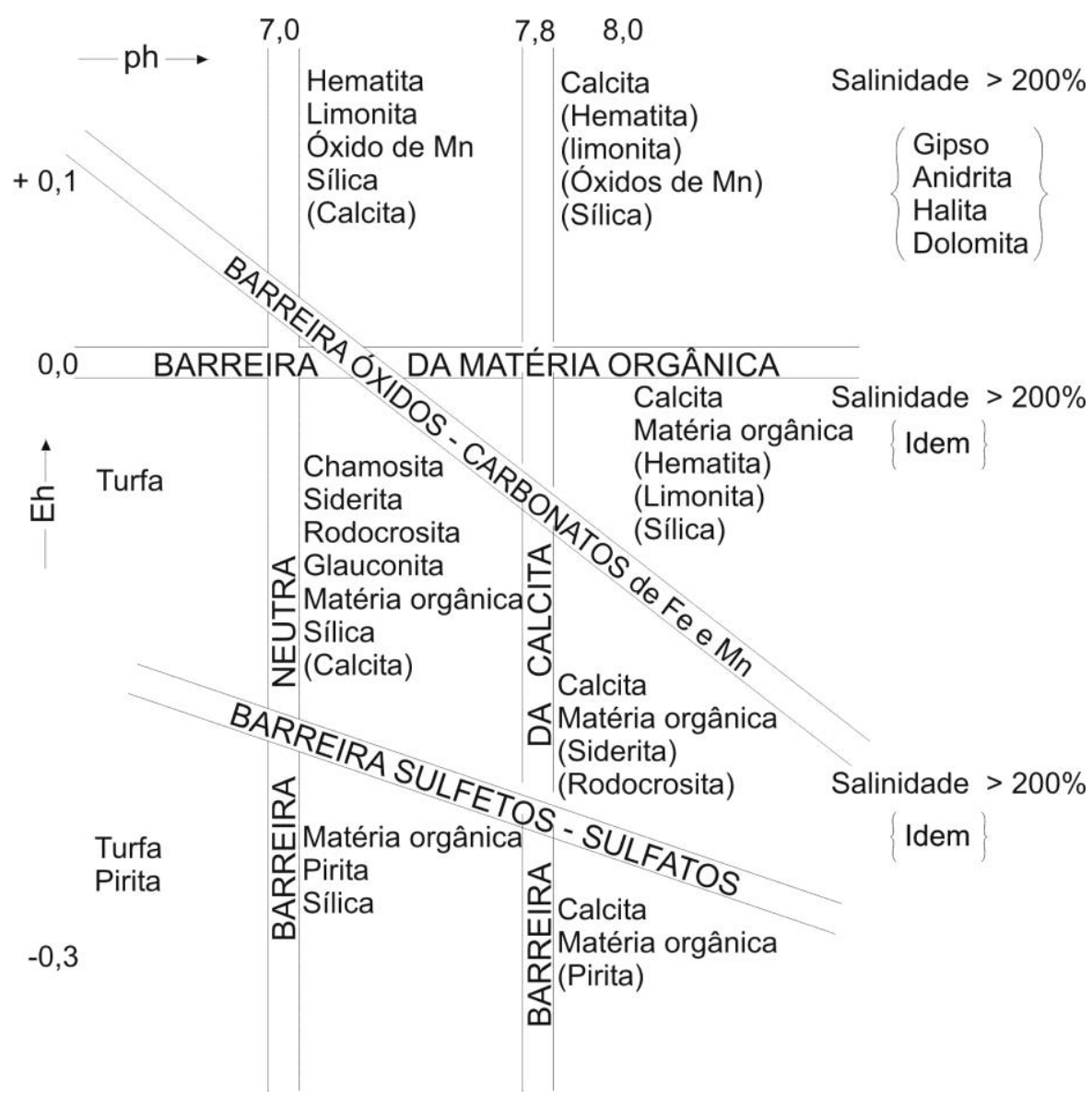

Fonte: Krumbein; Garrels (1952), adaptado.

Figura 3.8 - Limites de estabilidade de determinados minerais primários.

\subsubsection{Dissolução}

Dissolução é a completa dissociação de um mineral em um solvente, como a água. Os sais são os minerais mais comumente afetados.

A substância mineral tende a ser atacada pelo solvente até a saturação ser alcançada, e quanto menos saturada é a solução, mais agressivo é o progresso do seu ataque. A taxa de dissolução geralmente depende da solubilidade do sal, do grau de saturação original do solvente e da movimentação do solvente, de modo a mantê-lo subsaturado. Uma condição de permanente subsaturação é encontrada no contato da rocha em uma edificação com a água das chuvas.

As águas das chuvas, ou aquelas acidificadas com dióxido de carbono ou ácidos orgânicos em solução, podem exercer ação dissolvente sobre uma série numerosa de minerais, particularmente importante no caso das rochas calcárias.

Exemplo da produção do ácido carbônico pela solução de dióxido de carbono: 
É a presença deste ácido que explica a maior intensidade das ações intempéricas quando há abundância de pirita, pois acelerará a alteração não só dos sulfetos de ferro, como de sulfetos de outros metais.

\subsubsection{Hidrólise}

As reações de hidrólise mostram-se estreitamente relacionadas com as de hidratação, facilitando mutuamente o trabalho de decomposição das rochas, pois esta última, freqüentemente, é acompanhada por aumento de volume.

De maneira geral, uma parte da água encontra-se sempre dissociada, em função da temperatura, em ânions $\left((\mathrm{OH})^{-}\right)$e em cátions $\left(\mathrm{H}^{+}\right)$. Nas temperaturas normais da superfície da Terra, o grau de dissociação da água pura é bastante reduzido.

Porém, como as águas naturais contêm sempre outras substâncias dissolvidas (dióxido de carbono, ácidos minerais e ácidos orgânicos) que, por sua vez, dão origem a fenômenos de dissociação, a concentração hidrogeniônica dessas é muito superior à da água pura.

Deste fato resulta uma considerável capacidade hidrolítica das águas naturais, ou seja, de provocar fenômenos de hidrólise, pela atuação dos seus íons $(\mathrm{OH})^{-}$e $\mathrm{H}^{+}$, e a decomposição de outras substâncias pela fixação desses.

Esta ação hidrolítica sobre os feldspatos e os fedspatóides se traduz, em uma primeira fase, na formação de ácidos alumino-silícicos e de hidróxidos alcalinos e alcalino-terrosos, resultantes da substituição dos íons destes metais por hidrogênio e da fixação dos íons metálicos libertados pelos íons hidroxilas.

$\underset{\begin{array}{l}\text { feldspato } \\ \text { potássico }\end{array}}{4 \mathrm{KAISi}_{3} \mathrm{O}_{8}}+\underset{\substack{\text { ion } \\ \text { hidrogênio }}}{\mathrm{H}^{+}}+\underset{\text { água }}{\mathrm{H}_{2} \mathrm{O}} \rightarrow \underset{\substack{\text { íon } \\ \text { potássio }}}{4 \mathrm{~K}^{+}}+\underset{\text { caulinita }}{\mathrm{Al}_{4} \mathrm{Si}_{4} \mathrm{O}_{10}(\mathrm{OH})_{8}}+\underset{\text { sílica }}{8 \mathrm{SiO}_{2}}$

A hidrólise dos silicatos (feldspatos, micas, piroxênios, anfibólios, olivinas etc.) manifesta-se por fenômenos de argilização (caulinitização, montmorilonitização), de cloritização, de saussuritização e de serpentinização que, muitas vezes, se assemelham aos fenômenos congêneres promovidos pelos fluidos deutéricos.

\subsection{Poluentes Atmosféricos}

A atmosfera é uma mistura de gases que formam uma camada de 
aproximadamente $400 \mathrm{~km}$ de espessura, ao redor da Terra. A camada inferior (16-19 km) é a parte mais importante em termos meteorológicos e de outros aspectos do ciclo biogeoquímico. Os últimos $600 \mathrm{~m}$ constituem praticamente toda a porção atmosférica da ecosfera.

$\mathrm{O}$ ar normal contém cerca de $78 \%$ de $\mathrm{N}_{2}$ e $21 \%$ de $\mathrm{O}_{2}$; o restante é constituído de argônio, dióxido de carbono e traços de outros gases.

A poluição do ar é a transferência de quantidades nocivas de materiais sintéticos e naturais na atmosfera, como conseqüência direta ou indireta da atividade humana (Kupchella; Hyland, 1992).

A poluição do ar é um problema complexo, pois os poluentes podem advir de numerosas substâncias químicas, existentes na forma de gases (aproximadamente 90\%, em peso, dos poluentes), líquidos (aerossóis) ou particulados. Podem ser lançados diretamente no ar (poluentes primários) ou podem ser criados no ar (poluentes secundários), a partir de outros poluentes sob a influência da radiação eletromagnética do sol.

Poluentes podem erodir estátuas e superfícies pintadas, entre outros. Os custos muito elevados para a redução de tais efluentes indicam que seu controle deve ser realizado através de normas consistentes, internacionais.

A Tabela 3.2 mostra as principais características dos poluentes mais comuns.

Além dos poluentes mencionados, há também a presença de cloretos em ambientes marinhos (Zivica; Bajza, 2001).

Dos elementos poluentes, os potencialmente mais prejudiciais para as rochas para revestimento são:

-óxidos de enxofre: dos numerosos existentes, o mais notável é o $\mathrm{SO}_{2}$, também considerado o poluente mais importante na degradação de rochas (Amoroso; Fassina, 1983). 
Tabela 3.2 - Características dos principais poluentes do ar (Amoroso; Fassina, 1983 e Kupchella; Hyland, 1992).

\begin{tabular}{|c|c|c|c|c|}
\hline POLUENTE & FONTES & CARACTERÍSTICAS & $\begin{array}{l}\text { MECANISMOS DE } \\
\text { DISSIPAÇÃO }\end{array}$ & $\begin{array}{l}\text { TEMPO ESTIMADO } \\
\text { DE RESIDÊNCIA }\end{array}$ \\
\hline $\begin{array}{l}\text { dióxido de } \\
\text { enxofre }-\mathrm{SO}_{2}\end{array}$ & $\begin{array}{l}\text { combustão do carvão, óleos e outros } \\
\text { combustíveis fósseis contendo enxofre; } \\
\text { refino de petróleo, fusão de metais e } \\
\text { fabricação de papel. }\end{array}$ & $\begin{array}{l}\text { gás incolor, pesado, solúvel em água e } \\
\text { com odor irritante. }\end{array}$ & $\begin{array}{c}\text { precipitação e oxidação em partículas } \\
\text { de sulfato }\end{array}$ & $20 \mathrm{~min}-7$ dias \\
\hline particulados & - & $\begin{array}{c}\text { partículas sólidas ou gotas, incluindo } \\
\text { vapores venenosos, fumaça, poeira e } \\
\text { aerossóis. }\end{array}$ & - & - \\
\hline $\begin{array}{c}\text { óxido nítrico - } \\
\mathrm{NO} \\
\text { dióxido de } \\
\text { nitrogênio - } \mathrm{NO}_{2}\end{array}$ & $\begin{array}{l}\text { combinação de } \mathrm{N} \text { e O a altas } \\
\text { temperaturas de combustão, rejeito da } \\
\text { fabricação de fertilizantes. }\end{array}$ & $\begin{array}{l}\text { NO: gás incolor e levemente solúvel em } \\
\text { água } \\
\mathrm{NO}_{2} \text { : gás marrom-avermelhado, algo } \\
\text { solúvel em água. }\end{array}$ & $\begin{array}{c}\mathrm{NO} \text { : oxidação atmosférica para } \mathrm{NO}_{2} \\
\mathrm{NO}_{2} \text { : precipitação e oxidação para } \\
\text { nitrato }\end{array}$ & $3-5$ dias \\
\hline amônia $\left(\mathrm{NH}_{3}\right)$ & tratamento de resíduos & - & $\begin{array}{l}\text { reação com } \mathrm{SO}_{2} \text {, formando }\left(\mathrm{NH}_{4}\right)_{2} \mathrm{SO}_{4} \\
\text { oxidação para nitrato }\end{array}$ & 7 dias \\
\hline $\begin{array}{l}\text { monóxido de } \\
\text { carbono - CO }\end{array}$ & $\begin{array}{l}\text { queima de combustíveis, como a } \\
\text { gasolina. }\end{array}$ & $\begin{array}{l}\text { gás tóxico, incolor e inodoro, levemente } \\
\text { solúvel em água. }\end{array}$ & $\begin{array}{l}\text { incorporação pelo solo e conversão } \\
\text { para } \mathrm{CO}_{2} \text { por micróbios }\end{array}$ & $0,09-2,7$ anos \\
\hline $\begin{array}{c}\text { dióxido de } \\
\text { carbono - } \mathrm{CO}_{2}\end{array}$ & - & gás incolor, com fraco odor. & $\begin{array}{l}\text { dissolve nos oceanos; usado pelas } \\
\text { plantas na fotossíntese. }\end{array}$ & $2-10$ anos \\
\hline $\begin{array}{l}\text { hidrocarbonetos } \\
\text { (e outros } \\
\text { compostos } \\
\text { orgânicos } \\
\text { voláteis) } \\
\end{array}$ & $\begin{array}{l}\text { veículos automotores; processos } \\
\text { industriais envolvendo solventes. }\end{array}$ & $\begin{array}{l}\text { muitos e variados compostos de } \\
\text { hidrogênio e carbono. }\end{array}$ & $\begin{array}{c}\text { oxidação para } \mathrm{CO}_{2} \text {; absorção no solo e } \\
\text { degradação microbiana; degradação } \\
\text { fotoquímica. }\end{array}$ & $1,5-2$ anos (metano) \\
\hline ozônio - $\mathrm{O}_{3}$ & $\begin{array}{c}\text { produzidos por complexas reações } \\
\text { fotoquímicas na atmosfera, envolvendo } \\
\text { hidrocarbonetos, } \mathrm{NO}_{2} \text { e a radiação } \\
\text { ultravioleta. }\end{array}$ & $\begin{array}{c}\text { gás azul-claro, moderadamente solúvel } \\
\text { em água, instável, de odor adocicado. } \\
\text { É um agente oxidante extremamente } \\
\text { ativo. }\end{array}$ & $\begin{array}{l}\text { reação fotoquímica (reversão para } \mathrm{O}_{2} \text { ) } \\
\text { na atmosfera. }\end{array}$ & $2 \mathrm{~h}-3$ dias \\
\hline $\begin{array}{c}\text { sulfeto de } \\
\text { hidrogênio }-\mathrm{H}_{2} \mathrm{~S}\end{array}$ & $\begin{array}{c}\text { vários processos em vários tipos de } \\
\text { indústrias químicas: poços de óleo, } \\
\text { refinarias. }\end{array}$ & $\begin{array}{l}\text { gás incolor, com característico odor de } \\
\text { "ovo podre", levemente solúvel em } \\
\text { água. }\end{array}$ & oxidação para $\mathrm{SO}_{2}$ & $0,08-2$ dias \\
\hline $\begin{array}{l}\text { fluoretos } \\
\text { (fluoreto de } \\
\text { hidrogênio) } \\
\end{array}$ & $\begin{array}{l}\text { fabricação de fertilizantes e cerâmica, } \\
\text { fusão de alumínio. }\end{array}$ & $\begin{array}{l}\text { gás pungente, incolor e solúvel em } \\
\text { água. }\end{array}$ & -- & -- \\
\hline
\end{tabular}


$\mathrm{O} \mathrm{SO} 2$ pode reagir com o ozônio $\left(\mathrm{O}_{3}\right)$, peróxido de hidrogênio $\left(\mathrm{H}_{2} \mathrm{O}_{2}\right)$, vapor d'água e outras substâncias na atmosfera para formar o ácido sulfúrico $\left(\mathrm{H}_{2} \mathrm{SO}_{4}\right)$, que é um dos maiores contribuintes para a chuva ácida'

As chuvas ácidas afetam os mais diversos materiais de construção (aço, tintas, cimento e outros), inclusive vários tipos de rochas: mármores ou calcários, arenitos e até granitos (Kobayashi et al. 1994). Podem provocar mudanças estéticas (perda de brilho e descoloração) e até funcionais (queda da resistência mecânica, fraturamento e quebra) do material rochoso usado no revestimento de fachadas.

- óxidos de nitrogênio: o dióxido de nitrogênio $\left(\mathrm{NO}_{2}\right)$ (de considerável impacto ambiental) é gerado na atmosfera pela ação da radiação ultravioleta em óxido nítrico (NO) (de ação menos perigosa). Por meio de várias reações com substâncias na atmosfera, o $\mathrm{NO}_{2}$ é convertido em nitratos inorgânicos, nitrato peroxiacetílico (PAN) e, num equivalente ao ácido sulfúrico, o ácido nítrico $\left(\mathrm{HNO}_{3}\right)$.

$\mathrm{O} \mathrm{NO}_{2}$ é produzido na combustão do carvão, óleo, gás natural e de combustíveis para veículos automotores; também quando a temperatura é alta o bastante para causar a combinação do nitrogênio e oxigênio. Os $\mathrm{NO}_{x}$ são parte importante nas precipitações ácidas.

A influência dos nitratos nos processos de deterioração de rochas não é muito evidente (Amoroso; Fassina, 1983), mas pode ser correlacionada à ação como sais solúveis, nas paredes de edifícios.

A amônia (hidróxido de nitrogênio $-\mathrm{NH}_{3}$ ) tem efeito indireto na deterioração de rochas, pois faz parte do processo de oxidação do $\mathrm{SO}_{2}$ em meio aquoso.

Devido ao papel relevante da radiação ultravioleta na geração do $\mathrm{NO}_{2}$, há até o controle do padrão diário nas concentrações urbanas de $\mathrm{NO}$ e NO${ }_{2}$ (Figura 3.9).

\footnotetext{
${ }^{1}$ As chuvas ácidas, assim consideradas quando apresentam $\mathrm{pH}<5,6$, referem-se tanto à deposição ácida a seco (designação mais correta) como à úmida (Keller, 1996). São produtos ácidos (sulfúrico e nítrico) resultantes da combinação do vapor d'água com partículas de sulfatos $\left(\mathrm{SO}_{4}\right)$ ou nitratos $\left(\mathrm{NO}_{3}\right)$, formados a partir de $\mathrm{SO}_{2}$ e $\mathrm{NO}_{x}$ emitidos na atmosfera. As chuvas urbanas podem ter acidez equivalente a $\mathrm{pH} 4$, e freqüentemente apresentam $\mathrm{pH}=4,6$. Ressalta-se que a ação do ácido neste pH é cerca de 25 vezes maior que no $\mathrm{pH} 5,6$.
} 


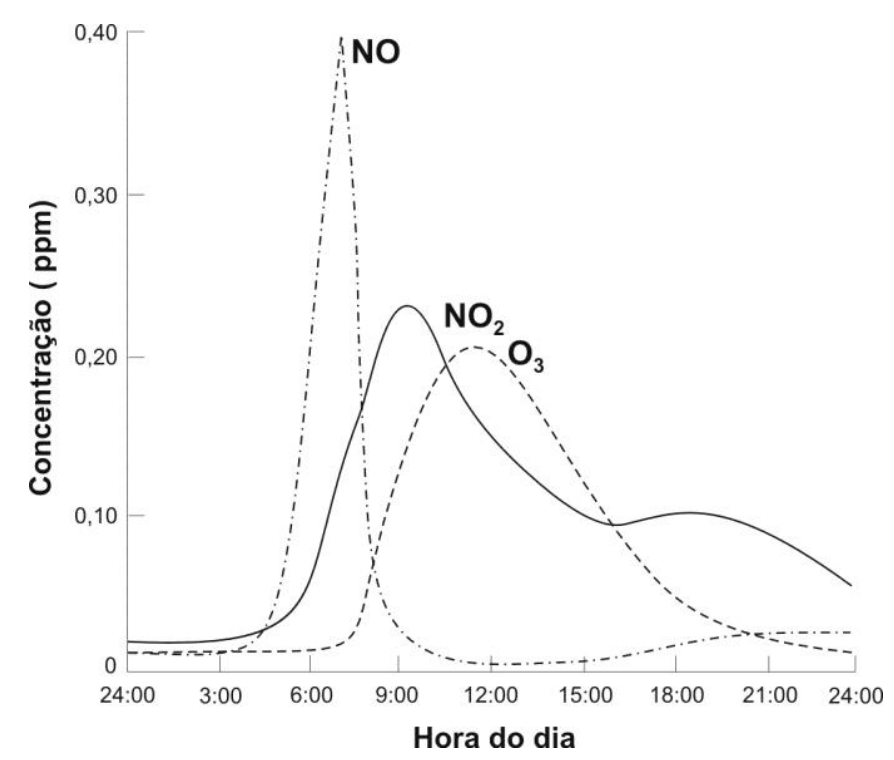

Fonte: Kupchella; Hyland (1992).

\author{
Figura 3.9 - Padrão \\ típico diário dos níveis de \\ óxido nítrico, dióxido de \\ nitrogênio e ozônio, em \\ Los Angeles, EUA.
}

- monóxido de carbono: é predominantemente resultante da queima incompleta de combustíveis, predominantemente de automóveis. Outras fontes "naturais" de CO: florestas, incêndios florestais, vulcões etc. Apesar de ser o poluente individual mais conhecido por afetar a saúde humana, é relativamente inócuo no tocante à deterioração de materiais.

- dióxido de carbono: é um componente menor (0,03\%) da atmosfera normal. É um dos produtos básicos da queima de madeira, carvão, tabaco, folhas, papel e outros materiais contendo carbono. Comparado a outros poluentes do ar, é relativamente não-reativo e não tem efeitos diretos sobre a saúde, sua ação deletéria está na absorção da radiação infravermelha, impedindo parte do calor terrestre seja irradiado prontamente para o espaço e, assim, tendo grande responsabilidade no efeito estufa.

O dióxido de carbono dissolvido na água da chuva pode provocar a dissolução de carbonatos (calcita e dolomita) em calcários, mármores e outros, formando bicarbonatos de $\mathrm{Ca}$ e Mg. Também pode lixiviar alguns íons metálicos contidos em silicatos (micas, feldspatos etc.) (Amoroso; Fassina, 1983).

- particulados ou aerossóis: são partículas de substancias sólidas (poeira) ou líquidas (gotículas) que permanecem em suspensão no ar. Aerossóis são definidos como misturas de partículas suficientemente finas, dispersas no ar (Amoroso; Fassina, 1983). Fumaças são suspensões particuladas formadas 
por um sólido suspenso em uma fase líquida; resultam da queima incompleta de combustíveis. Os particulados perfazem cerca de $5 \%$, em peso, dos poluentes atmosféricos e são constituídos de sais de sulfato, gotas de ácido sulfúrico, sais de metais (chumbo ou óxidos de ferro), poeira de partículas finamente divididas de carbono ou sílica, névoas e garoas líquidas, e muitas outras substâncias não-catalogadas.

As dimensões das partículas variam de 0,005 $\mu \mathrm{m}$ até cerca de $100 \mu \mathrm{m}$. Embora as poeiras naturais constituam metade da massa de material particulado na atmosfera, elas tendem a ter pequeno impacto, pois depositam rapidamente por causa do seu tamanho e peso. A chuva não é muito efetiva para remover partículas $<2 \mu \mathrm{m}$, que tendem a permanecer em suspensão e, dependendo das condições de turbulência e vento, podem ser transportadas por longa distância.

Todos os poluentes têm caráter ácido. Usualmente reagem em poucos dias sob a influência do oxigênio, luz do sol e temperatura. Juntamente com as partículas de água na atmosfera, podem formar aerossóis, névoa e chuva ácidas, cujo $\mathrm{pH}$, depois de dias ensolarados, pode ser muito baixo, entre 3 e 4,5 (Zivica; Bajza, 2001).

Quando os poluentes ácidos são carreados por meio de chuvas e outros fenômenos atmosféricos, podem-se depositar em edifícios e monumentos e causar a degradação dos materiais.

A Tabela 3.3 sumaria os efeitos de alguns poluentes nos materiais rochosos de construção.

Tabela 3.3 - Efeitos de poluentes em algumas rochas.

\begin{tabular}{ccc}
\hline POLUENTE & MATERIAIS ATACADOS & DEGRADAÇÕES TíPICAS \\
\hline dióxido de carbono & especialmente mármore & deterioração \\
óxidos de enxofre & $\begin{array}{c}\text { calcários, mármores, ardósia, } \\
\text { arenitos }\end{array}$ & $\begin{array}{c}\text { lixiviação, perda de coesão, } \\
\text { queda da resistência } \\
\text { mecânica }\end{array}$ \\
\hline $\begin{array}{c}\text { partículas sólidas (fuligem, } \\
\text { alcatrão) }\end{array}$ & $\begin{array}{c}\text { rochas e materiais de } \\
\text { construção em geral }\end{array}$ & sujeira, manchamentos \\
\hline
\end{tabular}

Fonte: Kupchella; Hyland (1992)

\subsection{Causas da Degradação Rochosa}

O clima, um dos agentes mais influentes na degradação das rochas, é definido 
pelo conjunto de fatores meteorológicos que caracterizam o estado médio da atmosfera numa dada região. Os elementos que intervêm na caracterização do clima são a temperatura e a umidade do ar, a precipitação pluviométrica, os ventos e a pressão atmosférica.

As ações físico-químicas das águas e as ações químicas dos componentes da atmosfera são importantes, sobretudo quando atuam em conjunto.

O clima, em todos seus aspectos, é uma das causas fundamentais da degradação das edificações, por meio da falência de seus materiais constituintes, os quais, por sua vez, afetam a estrutura (Feilden, 1994). A resistência dos materiais de construção aos agentes climáticos diminui com a exposição e idade. Mesmo em zonas temperadas, a radiação solar é tida como mais destrutiva que o congelamento. A água, em todas as suas formas, é o agente que provoca as reações químicas e a deterioração gradual dos materiais e, ativamente, também danifica as construções (inundações etc.).

Os dados climáticos fornecem informações relevantes para o entendimento, e possíveis previsões, das deteriorações. Seus principais componentes ativos, que afetam particularmente uma construção, são: radiação solar, mudanças de temperatura sazonais, chuvas, vento e transporte de partículas do solo.

Os fatores ou agentes atmosféricos que atuam diretamente as rochas são assim discriminados por Aires-Barros (1991):

- umidade: na forma de chuva, névoa ou como a própria umidade relativa do ar;

- temperatura do ar: que pode acelerar as reações químicas;

- insolação e resfriamento noturno: que podem provocar a condensação do vapor d'água existente na superfície da rocha ou afetar a taxa de deposição e os fenômenos de evaporação;

- vento e energia cinética: que promovem ação abrasiva sobre as paredes;

- constituintes do ar e poluentes atmosféricos (gasosos e aerossóis): condicionando as taxas de ataque químico.

A atmosfera e seus componentes sólidos, líquidos e gasosos atuam sobre as rochas para revestimento por meio de mecanismos físicos (umedecimento, cristalização de sais e outros fenômenos provocados por variações do estado higrométrico da atmosfera), químicos (desde sulfatação nas rochas carbonáticas a 
fenômenos de hidrólise nas rochas granitóides, atuantes na superfície e no interior das rochas) e biológicos (ações químicas e/ou físicas promovidas por microorganismos diversos: bactérias, algas, fungos e líquens, musgo e mesmo arbustos).

\subsubsection{Temperatura}

A causa das mudanças da temperatura do ar é quase inteiramente decorrente do aquecimento do sol durante o dia, pela radiação das ondas curtas e longas, e pela perda desse calor durante a noite, pela radiação e convecção de ondas longas.

Todos os materiais de construção, inclusive as rochas para revestimento, expandem quando aquecidos e contraem quando resfriados - movimento térmico -, que é a maior causa da degradação de edificações.

A cor e a refletividade do material alteram a absorção de calor, responsável pelo aumento da temperatura; assim, os materiais escuros absorvem (baixo albedo) mais calor que os claros (alto albedo). A extensão do movimento térmico depende do intervalo de temperatura resultante do calor incidente e é modificado pela capacidade térmica da estrutura e pela espessura, condutividade e coeficiente de expansão dos materiais.

O incremento de temperatura relativo ao aquecimento solar é função do ângulo de incidência da radiação incidente e das propriedades térmicas da superfície receptora. Estudos de intervalos de temperatura em superfícies de rochas indicaram que estas alcançam temperaturas muito mais altas que as da atmosfera.

O stress induzido aos materiais de construção pelas mudanças de temperatura é dependente dos seguintes fatores (Feilden, 1994):

- magnitude das mudanças dimensionais absolutas do material, que é produto das suas dimensões multiplicadas pelo coeficiente de expansão, diferencial de temperatura e efeitos das mudanças relativas de umidade;

- elasticidade do material ou sua capacidade de quebra ou deformação sob pressão;

- variações de umidade devido à evaporação;

- grau de restrição ao movimento por sua conexão com outros elementos da estrutura do edifício. 


\subsubsection{Ação dos poluentes}

Uma importante propriedade das rochas para revestimento é sua durabilidade, que se refletirá em maior e mais efetiva proteção das estruturas, por sua vez colaborando para o prolongamento do tempo de serviço destas.

A interação da rocha com fenômenos externos torna, porém, a sua durabilidade comprometida, devido às variações de temperatura, ataque ácido de poluentes e outros.

O conhecimento dos mecanismos e da taxa de atuação dos poluentes pode ser muito útil para o uso de medidas preventivas e de proteção do material rochoso e aumento da sua vida útil.

Um parceiro inevitável do ataque químico dos poluentes é a água; pois age: (a) como solvente dos agentes agressivos; (b) meio de transporte desses agentes e dos produtos de reação; (c) em alguns casos, componente dos produtos de reação (ex. gipso) (Zivica; Bajza, 2001).

A conseqüência prática dos efeitos químicos do ataque ácido é a gradual degradação das propriedades tecnológicas do material rochoso. O processo se inicia com a deterioração da superfície exposta, como inchamento, escamação e despegamento. Com sua progressão do exterior para o interior da rocha, passa a ocorrer gradual perda da resistência pelo aumento da porosidade.

Clifford Price (1989, apud Feilden, 1994) afirma que: "poluentes gasosos podem encontrar seu caminho na superfície de um edifício através de duas rotas principais: dissolvidos na chuva que cai sobre ele, ou reagindo diretamente com a construção". O primeiro é chamado deposição úmida, e o outro, deposição seca:

- deposição úmida: incorporação, nas películas superficiais das paredes rochosas de edificações ou monumentos, de componentes atmosféricos transportados pelas gotículas da chuva e a remoção de substâncias das mesmas superfícies por lavagem e escorrimento;

- deposição seca: acúmulo de componentes da atmosfera normal ou poluída sobre a superfície da rocha, na forma de partículas, gases ou aerossóis, transportados por ação eólica.

A deposição úmida, relacionada à precipitação atmosférica, apresenta caráter intermitente, com variações temporais e espaciais. Os poluentes podem ser incorporados nas gotículas no interior das nuvens (rain-out) ou removidas pelas chuvas 
durante as precipitações (wash-out). A deposição seca é um processo mais lento que a deposição úmida, mas tem, caracteristicamente, um caráter contínuo.

O rain-out é o mecanismo mais importante e responsável por cerca de $85 \%$ do $\mathrm{SO}_{4}$ e NO 3 das precipitações atmosféricas.

É possível que a degradação atribuída à chuva ácida, juntamente com os minerais secundários daí resultantes, possa também ser causada por meios bioquímicos tanto no interior da rocha como na sua superfície (Jefferson, 1993). Muitos organismos são mais ativos em condições de baixo pH e, assim, a chuva ácida propiciaria um ambiente no qual as bactérias seriam mais ativas e seriam, neste sentido, um agente indireto da deterioração das rochas.

A umidade higroscópica, relacionada à absorção da umidade do ar, é considerada fundamental para a deposição seca de gases ácidos. A adsorção higroscópica depende da umidade do ar, da natureza do material, do diâmetro dos poros e da superfície específica. Spiker et al. (1992 apud Grossi; Murray,1999) consideram que a deposição de $\mathrm{SO}_{2}$ é proporcional à área superficial da rocha umedecida pela água adsorvida.

Sais higroscópicos podem influenciar no teor de umidade de materiais porosos (Grossi; Murray, 1999), pois atraem a umidade do ar e seriam importantes na manutenção do filme de umidade na superfície da rocha. Materiais não, ou muito pouco, higroscópicos podem se tornar muito higroscópicos quando esses sais (incluindo nitratos, cloretos e depósitos anteriores de $\mathrm{SO}_{2}$ ) são aprisionados nos seus poros, o que pode aumentar as taxas de absorção e oxidação do $\mathrm{SO}_{2}$ atmosférico para a formação de sulfato de cálcio.

\subsubsection{Ação da cristalização de sais}

A cristalização de sais é um dos agentes intempéricos mais poderosos, pois é por meio dela que ocorre a degradação de rochas em ambientes marinhos, climas úmidos e ambientes poluídos. Sua ação em um meio poroso, especialmente rochas sedimentares, causa a perda de coerência entre os grãos.

O mecanismo de degradação é a pressão de cristalização dos sais e depende do grau de saturação e do tamanho do poro (Winkler; Singer, 1972; Theoulakis; Moropoulou, 1997; Benavente et al., 1999).

Em uma edificação, nas proximidades do solo, uma solução salina pode 
ascender através da rocha por capilaridade ("efeito Wick", segundo designação dada por Goudie (1986 apud Benavente et al., 2001)), até a altura potencial de ascensão capilar, denominada zona capilar, na qual ocorre a evaporação e conseqüente cristalização dos sais.

A zona capilar, que depende do sistema poroso da rocha, é caracterizada pelas eflorescências (quando sais se cristalizam na superfície da rocha), subeflorescências (quando sais se cristalizam abaixo da superfície exposta da rocha) e pelas perdas de material (Uchida et al., 1999). Zona de imersão, nessa concepção, é a porção de rocha que fica mais próxima ao solo. A cristalização de sais se dá preferencialmente na zona de capilaridade.

Os sais solúveis podem ser originários do próprio solo, da argamassa de assentamento ou mesmo da própria rocha (López-Acevedo et al., 1997). Sua cristalização dentro de poros gera pressões capazes de superar os limites elásticos do material, causando sua quebra. Esse mecanismo pode levar à completa degradação e destruição da rocha.

A concentração de sal pode ocorrer na superfície do material rochoso, onde se cristaliza; e dentro dos capilares próximo à superfície da rocha, onde a ação mecânica de sais, nas fissuras, pode iniciar seu trabalho destrutivo.

Correns (1949 apud Winkler; Singer, 1972) sintetizou as informações disponíveis, à época, para descrever o crescimento e dissolução dos cristais sob pressão linear para demonstrar a magnitude dessas pressões durante a formação de veios de minério. O cálculo de Correns baseou-se no princípio de Riecke:

$$
P=\frac{R T}{V_{s}} \cdot \ln \frac{C}{C_{s}}
$$

onde, $\mathrm{P}=$ pressão exercida pelo crescimento do cristal (atm); $\mathrm{R}=$ constante de gás (0,082 L.atm/mol.K); $\mathrm{T}=$ temperatura absoluta $(\mathrm{K}) ; \mathrm{V}_{\mathrm{S}}=$ volume molar do sal sólido $(\mathrm{L} / \mathrm{mol}) ; \mathrm{C} / \mathrm{C}_{\mathrm{s}}=$ grau de supersaturação, onde $\mathrm{C}$ é a concentração do soluto existente e $\mathrm{C}_{\mathrm{s}}$ é a concentração de saturação.

O estado de supersaturação é essencial para todo processo de cristalização, conforme Figura 3.10. 


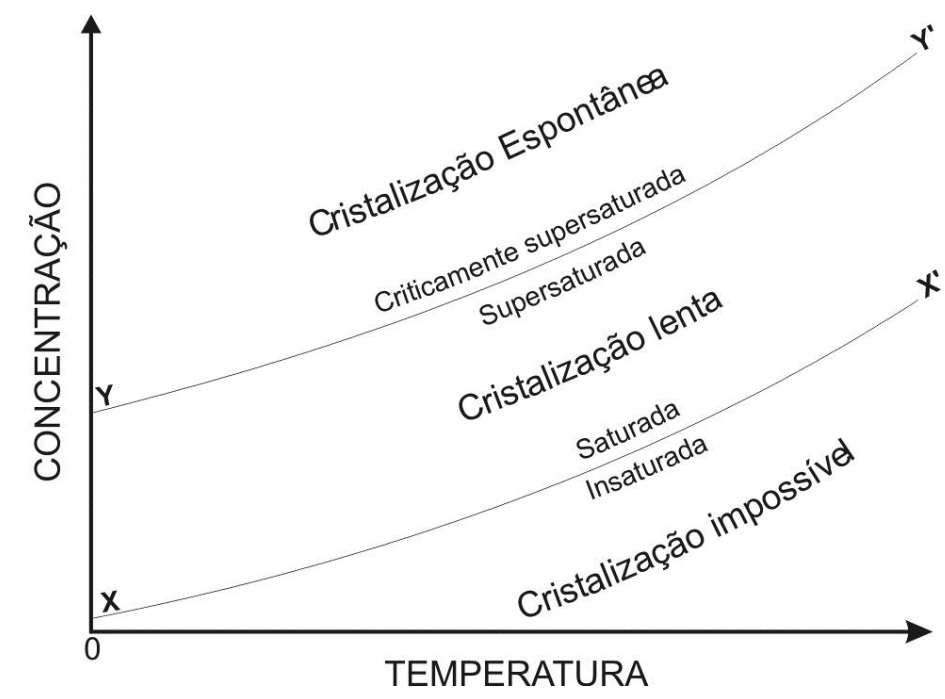

Fonte: Winkler; Singer (1972)

Figura 3.10 - Cristalização de sais em função da concentração das soluções e da temperatura.

Winkler; Singer (1972) descreveram matematicamente todo o processo de cristalização e calcularam a pressão de cristalização de alguns sais (Tabela 3.4), para várias concentrações molares.

Tabela 3.4 - Pressão de cristalização de alguns sais.

\begin{tabular}{|c|c|c|c|c|c|c|c|c|c|c|}
\hline \multirow{3}{*}{ Sal } & \multirow{3}{*}{ Fórmula } & \multirow{3}{*}{$\begin{array}{c}\rho \\
\left(\mathbf{g} / \mathrm{cm}^{3}\right)\end{array}$} & \multirow{3}{*}{$\begin{array}{c}\text { Peso } \\
\text { molecular } \\
(\mathrm{g} / \mathrm{mol})\end{array}$} & \multirow{3}{*}{$\begin{array}{c}\text { Volume } \\
\text { molar } \\
\left(\mathrm{cm}^{3} / \mathrm{mol}\right)\end{array}$} & \multicolumn{6}{|c|}{ Pressão de cristalização (atm) } \\
\hline & & & & & \multicolumn{2}{|c|}{$\mathrm{C} / \mathrm{Cs}=2$} & \multicolumn{2}{|c|}{$\mathrm{C} / \mathrm{Cs}=10$} & \multicolumn{2}{|c|}{$\mathrm{C} / \mathrm{Cs}=50$} \\
\hline & & & & & $0^{\circ} \mathrm{C}$ & $50^{\circ} \mathrm{C}$ & $0^{\circ} \mathrm{C}$ & $50 \circ \mathrm{C}$ & $0^{\circ} \mathrm{C}$ & $50 \div \mathrm{C}$ \\
\hline Anidrita & $\mathrm{CaSO}_{4}$ & 2,96 & 136,14 & 46,00 & 335 & 398 & 1120 & 1325 & 1900 & 2262 \\
\hline Bischofita & $\mathrm{MgCl}_{2} .6 \mathrm{H}_{2} \mathrm{O}$ & 1,57 & 203,31 & 129,50 & 119 & 142 & 397 & 470 & 675 & 803 \\
\hline Dodecahidrato & $\mathrm{MgSO}_{4.12 \mathrm{H}_{2} \mathrm{O}}$ & 1,45 & 336,00 & 231,90 & 67 & 80 & 222 & 264 & 378 & 450 \\
\hline Epsomita & $\mathrm{MgSO}_{4.7 \mathrm{H}_{2} \mathrm{O}}$ & 1,68 & 246,48 & 147,00 & 105 & 125 & 350 & 415 & 595 & 708 \\
\hline Gipso & $\mathrm{CaSO}_{4} .2 \mathrm{H}_{2} \mathrm{O}$ & 2,32 & 127,00 & 54,80 & 282 & 334 & 938 & 1110 & 1595 & 1900 \\
\hline Halita & $\mathrm{NaCl}$ & 2,17 & 58,54 & 27,85 & 554 & 654 & 1845 & 2190 & 3135 & 3737 \\
\hline Heptahidrita & $\mathrm{Na}_{2} \mathrm{CO}_{3} .7 \mathrm{H}_{2} \mathrm{O}$ & 1,51 & 232,10 & 153,80 & 100 & 119 & 334 & 365 & 568 & 677 \\
\hline Hexahidrita & $\mathrm{MgSO}_{4} .6 \mathrm{H}_{2} \mathrm{O}$ & 1,75 & 228,00 & 130,10 & 118 & 141 & 395 & 469 & 671 & 300 \\
\hline Kieserita & $\mathrm{MgSO}_{4} \cdot \mathrm{H}_{2} \mathrm{O}$ & 2,45 & 138,39 & 56,55 & 272 & 324 & 910 & 1079 & 1543 & 1840 \\
\hline Mirabilita & $\mathrm{Na}_{2} \mathrm{SO}_{4} .10 \mathrm{H}_{2} \mathrm{O}$ & 1,46 & 322,19 & 220,00 & 72 & 83 & 234 & 277 & 397 & 473 \\
\hline Natronita & 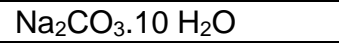 & 1,44 & 286,14 & 198,70 & 78 & 92 & 259 & 308 & 440 & 524 \\
\hline Taquidrita & $2 \mathrm{MgCl}_{2} \cdot \mathrm{CaCl}_{2} .12 \mathrm{H}_{2} \mathrm{O}$ & 1,66 & 514,40 & 309,50 & 50 & 59 & 166 & 198 & 282 & 336 \\
\hline$\overline{T e n a r d i t a}$ & $\mathrm{Na}_{2} \mathrm{SO}_{4}$ & 2,68 & 142,04 & 53,0 & 292 & 345 & 970 & 1150 & 1650 & 1965 \\
\hline Termonatrita & $\mathrm{Na}_{2} \mathrm{CO}_{3} \cdot \mathrm{H}_{2} \mathrm{O}$ & 2,25 & 124,00 & 55,0 & 280 & 333 & 935 & 1109 & 1590 & 1891 \\
\hline
\end{tabular}

A variação do volume molar do sal ao mudar o estado de hidratação pode gerar elevadas pressões em poros e fissuras e, por isso, as características texturais do sistema poroso são fatores determinantes da pressão de cristalização em rochas. Shaffer (1932 apud La Iglesia et al.,1997) indicou que o dano causado por sais é maior 
em materiais com alta microporosidade do que naqueles com baixa.

La Iglesia et al. (1997) apontam que, conforme já apresentado na literatura, os cristais salinos crescem preferencialmente nos poros maiores e a solução salina é retirada dos poros menores. Segundo esses autores, a resistência à tensão $\left(\sigma_{t}\right)$ é um valor que reflete a resistência coesiva do sólido, governada pela carga máxima por área superficial que pode ser suportada sem fraturar. Quando a pressão de cristalização supera a resistência à tensão, o material é danificado.

Os poros com diâmetros muito menores que $0,1 \mu \mathrm{m}$ são sensíveis à condensação a baixas umidades relativas, como resultado do efeito Kelvin (Camuffo, 1983 apud Theoulakis; Moropoulou, 1997), o que possibilita que rochas com poros menores absorvam água rapidamente e a retenha por períodos maiores, conferindoIhes comportamento distinto daquele de rochas com poros maiores.

Isso significa que rochas com poros maiores podem conter maior quantidade de água que aquelas com poros muito menores, porém, essas podem, por condensação, reter a água por muito mais tempo (Theoulakis; Moropoulou, 1997).

Theoulakis; Moropoulou (1997) acrescentam que, na fase inicial de cristalização, os sais crescem seletivamente nos poros maiores que $10 \mu \mathrm{m}$. Quando em equilíbrio com a solução saturada, cristais maiores crescerão às expensas dos menores. Em geral, ao preencherem totalmente os poros maiores, os cristais continuam a crescer contra os esforços impostos pelas paredes dos poros, expandindo-os e quebrando a rocha.

Nessa situação, segundo Theoulakis; Moropoulou (1997), a cristalização pode continuar segundo dois caminhos alternativos, dependendo da energia livre de formação do cristal ( $\Delta G_{\text {total }}$ e $\Delta G_{\text {interfacial }}$ ) e do trabalho necessário para a quebra das

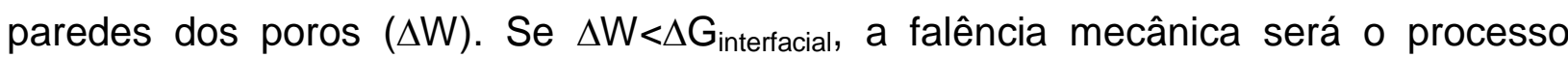
termodinamicamente preferencial; caso contrário, ocorrerá o preenchimento dos poros menores sucessivamente.

Finalmente, esses autores consideraram - para o caso de degradação por cristalização de sais em biocalcarenitos de monumentos históricos de Rhodes - que as rochas com maiores volumes de poros maiores são mais duráveis que aquelas com maior proporção de poros pequenos; e que a susceptibilidade à degradação é função das propriedades mecânicas e estruturais (resistência à compressão, porosidade e distribuição de tamanho dos poros e área superficial interna total). 
Grossi; Murray (1999) consideraram que a quantidade de água absorvida se relaciona à porosidade aberta (quantidade de poros acessíveis) enquanto o teor de umidade higroscópica (adsorção de água e condensação capilar) depende da distribuição do tamanho de poros e conseqüentemente da área superficial específica.

\subsection{Alterabilidade e Durabilidade de Rochas}

Aires-Barros (1991) define alterabilidade de rochas como um conceito dinâmico, que se refere à aptidão de uma rocha em se alterar, em função do tempo. Esse tempo, considerado na alteração intempérica como geológico, na alterabilidade é considerado um tempo humano, ou seja, os fenômenos ocorrem concomitantemente ao uso, à escala do homem e das suas obras de engenharia.

Desta forma, Aires-Barros (1991) define a alterabilidade (M):

$$
M=f(i, e, t)
$$

onde: $\mathrm{t}$ = tempo; $\mathrm{i}$ = fatores intrínsecos, dependentes do tipo de rocha (natureza do material, grau de fissuramento ou porosidade, ou seja, da superfície exposta à alteração); e = fatores extrínsecos, função do meio em que se processa a alteração (temperatura, $\mathrm{pH}$, Eh, quantidade de água, forças bióticas).

Para a avaliação da alterabilidade, podem ser utilizadas várias técnicas, todas elas medindo a variação, no tempo, de uma grandeza intrínseca ou com ela intimamente correlacionada.

O estudo da alterabilidade, tomando este conceito na sua característica fundamental que é a dinâmica temporal, serve-se de técnicas e princípios do estudo da alteração (processo estático, na medida em que avalia um dado estado e não a sua evolução no tempo), adaptados à introdução da variável tempo.

Na norma ASTM C 119 (ASTM, 2001a), durabilidade é definida como a medida da capacidade da rocha ornamental de sustentar e manter as características essenciais e distintivas de estabilidade, resistência à degradação e a aparência. A durabilidade é baseada no período de tempo em que a rocha, em uso, pode manter suas características inatas. Este tempo dependerá do meio ambiente e do uso da rocha em questão (p. ex., em exteriores ou interiores).

Grossi et al. (1998) definem durabilidade como a aptidão de materiais rochosos resistirem à ação das intempéries. Assim como Aires-Barros (1991), estes autores 
estabelecem que a durabilidade está relacionada a diversos fatores, que podem ser englobados em duas grandes categorias:

- intrínsecas: que dependem dos materiais e correspondem às características petrográficas e físicas destes;

- extrínsecas: relacionadas fundamentalmente ao meio ambiente, tendo em conta não só a intensidade como a freqüência das variações externas, ou seja, seu caráter cíclico.

A durabilidade também está condicionada a certas propriedades físicas, entre as quais a porosidade e a configuração do sistema poroso, a superfície específica e as propriedades hídricas, relacionadas com o movimento dos fluidos no material rochoso.

Do ponto de vista da alteração, o sistema poroso é considerado, pela maior parte dos pesquisadores, como a principal característica física das rochas, pois é determinante nas demais propriedades físicas e mecânicas.

\subsection{Rochas Graníticas}

As informações e observações apresentadas ao longo deste trabalho mostram claramente que as rochas podem-se alterar em tempo real, ao contrário do que muitos consideravam até as décadas de 70 e 80.

Isto se deve ao emprego cada vez maior da rocha na construção e no revestimento de edificações, associado ao desconhecimento das técnicas e/ou materiais mais adequados para sua fixação e das interações com atmosferas urbanas poluídas e o uso de produtos químicos modificadores das condições de estabilidade dos minerais formadores das rochas.

Muitos trabalhos podem ser encontrados na literatura, a respeito da deterioração de rochas calcárias ou areníticas, tanto por terem sido praticamente os únicos materiais rochosos utilizados nos séculos passados - principalmente pela sua maior facilidade de extração e beneficiamento - como pelos seus mecanismos de deterioração mais facilmente interpretados e reproduzidos.

No tocante às rochas graníticas, ainda existem relativamente poucos estudos, a maioria deles ainda não reproduzindo ou investigando detalhadamente os mecanismos petrográficos e geoquímicos das deteriorações mais comuns destas rochas.

Com base na literatura pesquisada e nas informações nelas contidas, verifica-se 
que muito já tem sido acrescentado quanto ao papel das atmosferas poluídas na degradação das rochas em monumentos ou no revestimento de edificações. Muitos estudos, que visam o entendimento dos mecanismos de decaimento e sua aplicação na prevenção e conservação destes materiais, estão sendo executados por pesquisadores de todo o mundo.

Neste contexto, a ciência geológica tem importância fundamental, pois nela se incluem os principais conhecimentos e técnicas para o avanço científico no entendimento dos mecanismos de alteração das rochas graníticas.

\subsubsection{Granitos e sua alteração em ambientes naturais}

Delgado-Rodrigues (1996) coordenou amplo trabalho, intitulado: "Conservação de rochas graníticas com aplicação em monumentos megalíticos", que aborda grande parte dos tópicos relacionados ao tema dessa pesquisa.

Segundo Delgado-Rodrigues (1996), os granitos são expostos na superfície terrestre pela erosão das camadas superiores da crosta terrestre. Neste processo, os granitos sofrem seu primeiro decaimento, de natureza química (alteração deutérica) ou física (devido aos processos de descompressão e resfriamento). A presença de minerais secundários e o grau de fissuração mais ou menos intenso são conseqüência direta desta evolução.

Uma vez na superfície, ou próxima desta, os granitos estarão expostos ao intemperismo, sujeitos a todas transformações decorrentes desse processo, dependendo do clima e outras condições atmosféricas reinantes.

O aumento do fissuramento, porosidade e permeabilidade e a formação de minerais secundários são um fenômeno conspícuo e importante em ambientes naturais. Caulinita e halloysita são os minerais secundários mais comuns em granitos, embora esmectitas e/ou illita possam se formar em ambientes pouco drenados.

A composição mineral, os espaços porosos e a textura são os fatores determinantes na evolução do intemperismo. Em especial, os feldspatos são susceptíveis à hidrólise e contrastam mecanicamente com o quartzo, tornando-os elementos chave na alteração da rocha (Delgado-Rodrigues, 1996). A biotita, quando em quantidade, pode influenciar o comportamento global da rocha.

A presença de umidade na superfície das rochas é muito deletéria, pois as gotículas de água têm grande força de aderência, e as substâncias dissolvidas podem 
penetrar na rocha até profundidades importantes, por causa da porosidade e permeabilidade da rocha e da quantidade de solução disponível sobre a superfície (Aires-Barros, 1991). Por esta via se desencadeia a hidrólise dos silicatos.

A alternância de ciclos de saturação e secagem permite a continuidade das reações hidrolíticas, podendo conduzir à desagregação das rochas, com a quebra das ligações físicas, traduzidas na esfoliação, lascamento e escamação.

Estudos de caracterização e de alteração acelerada de rochas, no Brasil, ainda são pouco comuns, especialmente aqueles especificamente voltados para granitos. Puderam ser recuperados na literatura os de Figueiredo et al. (2001 e 2002) e de Mesquita (2002), ambos, coincidentemente, contemplando rochas aqui também estudadas, procedentes do Estado do Ceará; porém, com enfoque muito distinto.

Figueiredo et al. (2001) realizaram a determinação de um índice de alterabilidade para o granito Rosa Iracema, baseado em ensaios cíclicos de aquecimento (a $70^{\circ} \mathrm{C}$ ), que denominaram de insolação, por 10 minutos, seguido pela imersão em água por 5 minutos. O ensaio foi executado a seco e utilizando água do mar e água deionizada. Os controles de decaimento foram, entre outros: refletância, variação de peso, composição química e pH da água de imersão.

O índice de alterabilidade $(\mathrm{K})$, calculado com base nas perdas de peso e lixiviação química, indicou, ao final do ensaio, a seqüência: $K$ água do mar $>K$ água deionizada $>\mathrm{K}_{\text {seco }}$.

Mesquita (2002) verificou que as correlações entre os parâmetros físicos, mecânicos e de alterabilidade revelam nitidamente que o comportamento dos granitos explorados na jazida do Branco Ceará é controlado diretamente pela conjugação dos aspectos composicionais, texturais e estruturais das rochas. A alterabilidade foi avaliada por meio de ensaios de lixiviação contínua e de resistência ao ataque químico, sendo as quatro variedades estudadas mais intensamente atacadas por soluções à base de ácidos clorídrico e cítrico. Verificou que a resistência mecânica é uma propriedade vetorial variável com a direção de aplicação dos esforços em função da disposição da anisotropia planar, definida principalmente pelos planos de extração dos blocos, na mina.

\subsubsection{Degradação de granitos em edificações}

Quando sãos ou inalterados, os granitos são bastante resistentes e, por isso, 
sua extração é uma empreitada difícil e cara. Assim, é freqüente o minerador preferir a extração de material em zonas leve ou moderadamente, ou mesmo altamente, alteradas. Entretanto, esta escolha traz graves conseqüências relativamente ao ambiente a que a rocha estará exposta subseqüentemente, devido à grande quantidade de minerais secundários que a poderão levar a uma rápida degradação (Delgado-Rodrigues, 1996).

Ao se observarem obras civis utilizando granitos ou rochas assemelhadas, dois processos principais de degradação são identificados:

- formação de placas: destacamento de fragmentos da superfície da rocha, com formas aproximadamente regulares, paralelos à superfície original. Placas, plaquetas e escamas diferem no tamanho e são processos de degradação devastadores. É um processo descontínuo, mas, uma vez instalado, as placas e conseqüentemente toda a superfície poderão se perder num curto período de tempo;

- perda de pequenas partículas, similares, na forma e dimensões, aos componentes minerais da rocha, chamado de arenização (ou desagregação). Trata-se de um processo global, afetando toda a rocha, contínuo e progressivo. A arenização algumas vezes está relacionada a ambientes costeiros e, em outras, a ciclos térmicos e de umidade.

Delgado-Rodrigues (1996) também observou que o material publicado a respeito da deterioração de granitos empregados em obras civis não é muito abundante, mas cita alguns estudos que apontam fatores externos como relevantes contribuintes para este processo:

- gipso, correntemente encontrado em atmosferas urbanas e com significante importância nas deteriorações, pode provir dos poluentes ou de soluções ascendentes das fundações dos edifícios (Casal Porto, 1989 apud DelgadoRodrigues, 1996);

- argamassas usadas em juntas de revestimentos também podem ser fonte de gipso, visto que o Ca não é facilmente disponível em granitos (Cooper et al., 1989 apud Delgado-Rodrigues, 1996);

- deterioração de granitos por formação de placas estaria relacionada à cristalização de gipso nas camadas mais externas do rocha (Casal Porto et al., 1989 apud Delgado-Rodrigues, 1996). 
Outros termos comumente utilizados para caracterizar as degradações de rochas para revestimento, extraídos de López Jimeno (1996) são:

- crosta: extrato superficial de alteração da rocha ou de produtos utilizados em eventuais tratamentos;

- depósito superficial: acumulação de materiais estranhos, de natureza diversa, como pó, algas, lama, excrementos;

- desagregação: perda de coesão, caracterizada pela separação de grânulos ou cristais sob os menores esforços mecânicos;

- despegamento: separação dos estratos superficiais do material seja entre eles ou em relação ao substrato. Para rochas, é preferível crosta, escamação, esfoliação etc.;

- eflorescência: formação, geralmente esbranquiçada, de aspecto cristalino, pulverulento ou filamentoso sobre a superfície do material. No caso de eflorescências salinas, a cristalização pode-se desenvolver no interior do material, freqüentemente provocando o destacamento das partes mais superficiais. O fenômeno tem 0 nome de subeflorescência ou criptoeflorescência;

- esfoliação: degradação que se manifesta com o despegamento, quase sempre seguido da caída, de um ou mais estratos superficiais, paralelos entre si (lâminas);

- fraturamento ou fissuração: degradação que se manifesta com a formação de aberturas no material, independente do deslocamento recíproco das partes;

- mancha: alteração que se manifesta com pigmentação acidental e localizada da superfície. Está relacionada com a presença de material estranho ao substrato (óxidos, sais de cobre, substâncias orgânicas, ceras etc.);

- inchamento: levantamento superficial e localizado do material, que pode assumir forma e consistência variáveis;

- escamação: degradação que se manifesta pela separação total ou parcial de zonas (escamas) do material original. As escamas têm formas e espessuras irregulares e desenvolvimento tridimensional. Geralmente, são constituídas de material aparentemente intacto e, embaixo delas, podem ser observadas eflorescências. 


\section{CAPÍTULO 4}

\section{ASPECTOS GEOLÓGICOS DAS ROCHAS SELECIONADAS}

Os tipos litológicos aqui estudados, como mencionado anteriormente, foram selecionados, entre outros, pela sua cor e dados a respeito de seu desempenho após aplicação como revestimento de edificações. As principais informações sobre a geologia e geomorfologia dos corpos rochosos a partir dos quais são explorados foram compiladas e apresentadas a seguir. Informações sobre acesso, coordenadas geográficas e outros se encontram nas Fichas de Campo, no ANEXO A.

\subsection{Rochas do Estado de São Paulo}

No Estado de São Paulo foram selecionados dois tipos rochosos para este estudo:

- Vermelho Capão Bonito, explorado na região de Capão Bonito (Figura 4.1), escolhido por se tratar de material clássico no mercado produtor e que tem apresentado grande durabilidade e com relatos pontuais de alterações, em geral relacionados a problemas na estocagem (Frascá; Quitete, 1999) ou no seu assentamento;

- Prata Interlagos, também comercializado sob a designação Azul Paulista Frente Nova, explorado na Região Metropolitana de São Paulo (Figura 4.1), em Parelheiros. É um material relativamente novo no mercado, praticamente restrito ao Estado de São Paulo, mas que mostra potencial alterabilidade ante produtos ácidos de limpeza (IPT, 2000; Frascá et al., 2000). 


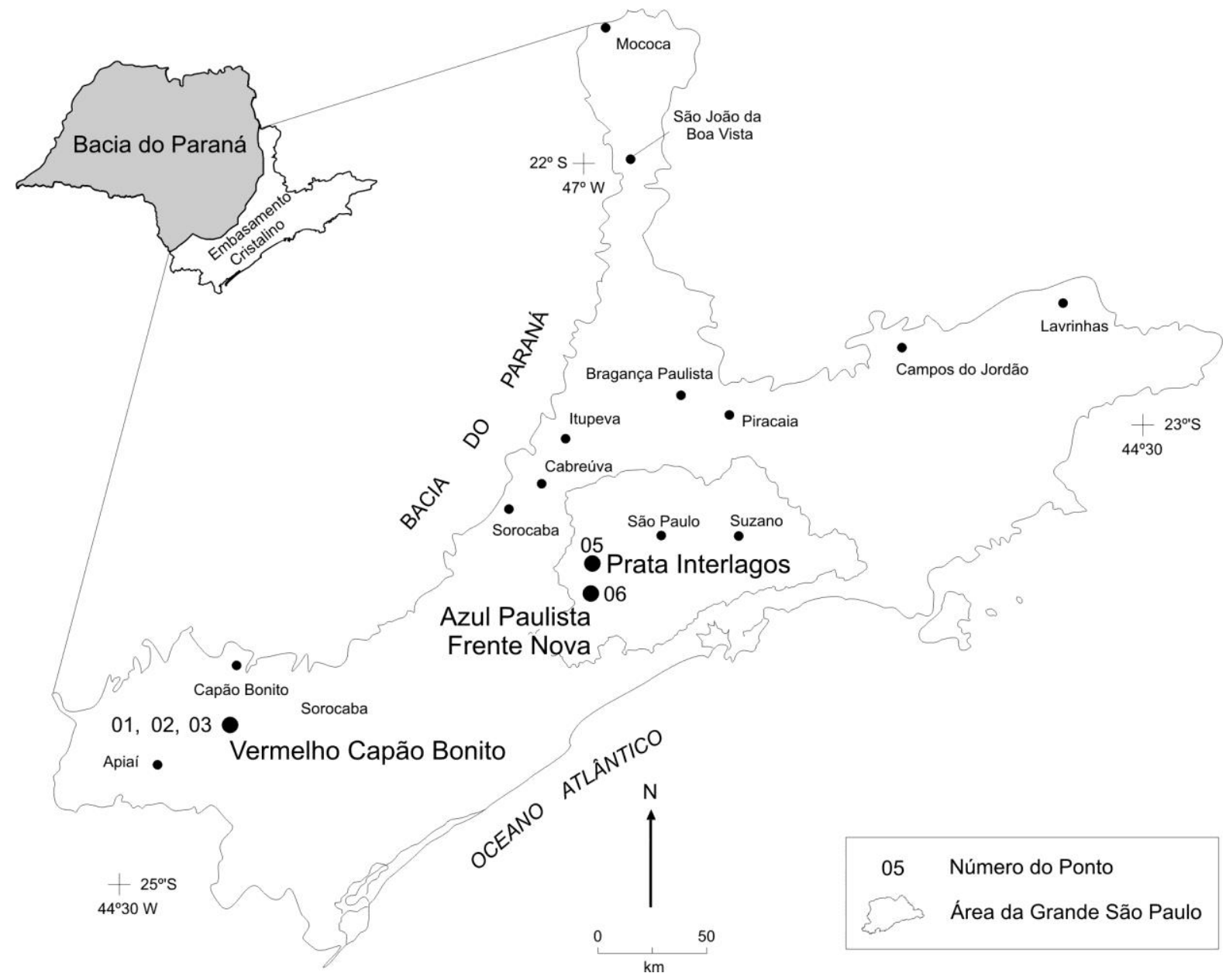

Fonte: IPT (2000), simplificado

Figura 4.1 - Mapa de localização das pedreiras de rochas ornamentais selecionadas para este estudo, no Estado de São Paulo.

\subsubsection{Capão Bonito}

O município de Capão Bonito está situado no sudeste do Estado, a $220 \mathrm{~km}$ da cidade de São Paulo. Neste ocorre a mineração de algumas variações de granitos vermelhos, homogêneos, comercializados sob a designação de Vermelho Capão Bonito.

Esse material é extraído a partir do Granito Capão Bonito, corpo pós-tectônico, diferenciado do embasamento cristalino, presente na área do Complexo Três Córregos (IPT, 1995), dentro do Domínio Açungui. Segundo Chiodi Filho et al. (1983), trata-se de rocha isótropa, avermelhada e de granulação grossa, que exibe características invariáveis por toda extensão do maciço.

Nesta região são comuns campos de matacões, que afloram nos altos 
topográficos ou à meia-encosta, em geral, objetos da exploração mineral.

$\mathrm{Na}$ maioria das minas, a lavra se dá a partir de matacões, de acordo com procedimento moroso, já obsoleto, mesmo para extração neste tipo de jazimento. Em geral, utiliza-se de marteletes e explosivos para liberar as faces dos blocos, que depois são esquadrejados com o uso de ponteiros (Figura 4.2).

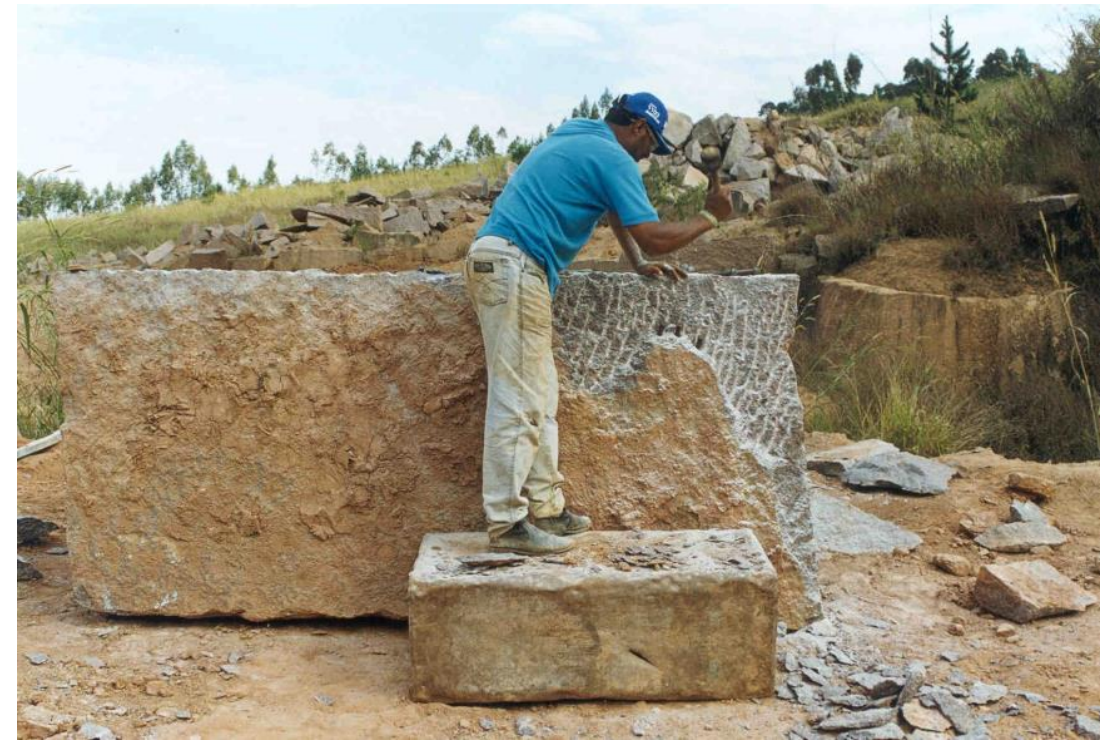

Figura $4.2-$

Esquadrejamento manual de bloco de granito em Capão Bonito, SP.

A prática de lavra semimecanizada, em grandes matacões subaflorantes, já parcialmente abrangendo o maciço granítico (Figura 4.3), é realizada pela empresa Somibrás, por meio do uso de flame jet e explosivos, com esquadrejamento dos blocos com marteletes e ponteiros.

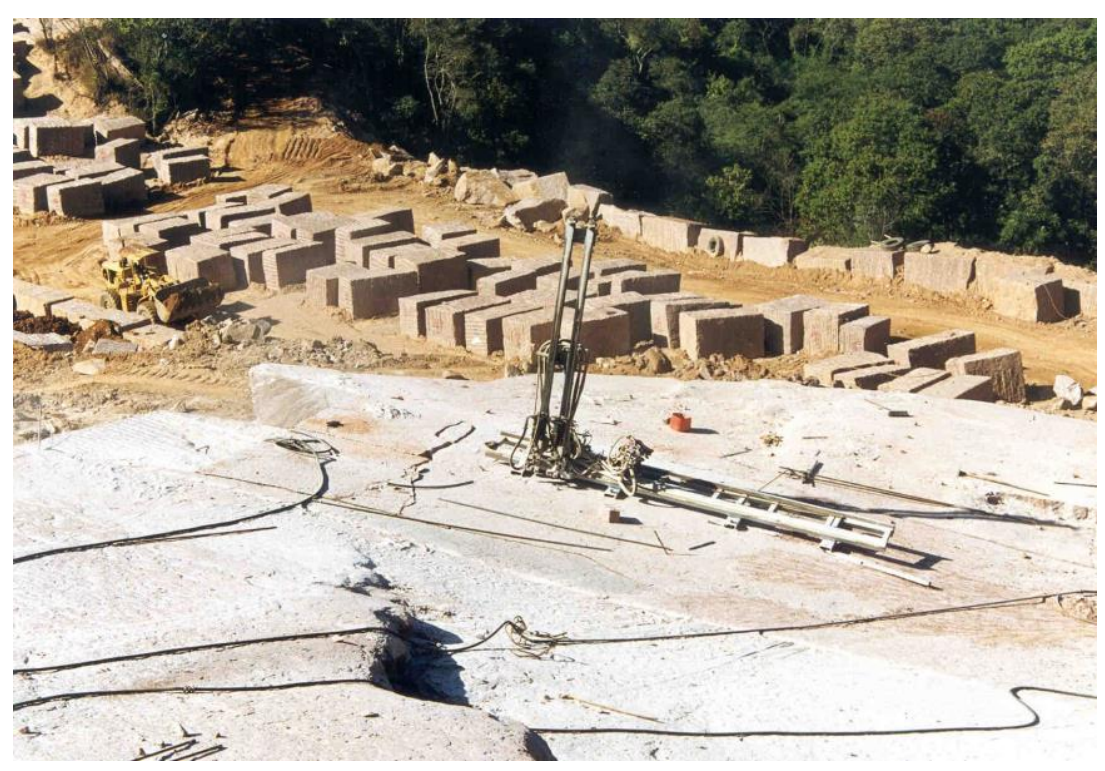

Figura 4.3 - Lavra semimecanizada Capão Bonito, SP. 
Estas rochas são descritas, petrograficamente, como biotita monzogranitos (IPT, 2000), de cor vermelha a vermelho-amarronzada, homogêneos e de granulação média a grossa. Mostram ligeiras variações nos teores de feldspato potássico (microclínio) e biotita, podendo também ser classificadas de sienogranitos.

Variedades "amarronzadas" mostram-se relativamente mais alteradas intempericamente que as vermelhas. Em geral apresentam hidróxidos de ferro em microfissuras ou impregnando minerais, principalmente os feldspatos.

\subsubsection{Região Metropolitana de São Paulo}

No município de São Paulo é extraído um granito cinza, homogêneo, designado, conforme o produtor, de Prata Interlagos e Azul Paulista Frente Nova.

São rochas graníticas, intrusivas nos terrenos cristalinos do Domínio Embu. Constituem o Granito Parelheiros, considerado por Vieira (1989 apud IPT, 1996) como um corpo autóctone, sin a tardi-tectônico, gerado por anatexia de rochas aluminosas, ou como um corpo híbrido, cálcio-alcalino, de média profundidade, como determinado por Wernick (1984 apud IPT, 1996), baseado na tipologia do zircão.

Os Prata Interlagos e Azul Paulista Frente Nova são biotita monzogranitos, de cor cinza-clara amarelada e azulada, respectivamente, e granulação fina a média. Aparentam tratar-se de variedades levemente intemperizadas e inalteradas do mesmo tipo rochoso.

O processo mineiro envolve o aproveitamento de matacões, no qual a rocha é explorada como co-produto da mineração de areia, material presente no manto de alteração rochoso (Figura 4.4).

\subsection{Rochas do Estado do Espírito Santo}

No Estado do Espírito Santo, atualmente o maior produtor de rochas ornamentais do Brasil, pois responde por cerca de $50 \%$ da produção nacional (Peiter, 2001), há caracteristicamente uma grande variedade de rochas graníticas ou gnáissicas cuja porção comercialmente mais valorizada é a capa intemperizada de cor amarelada. 


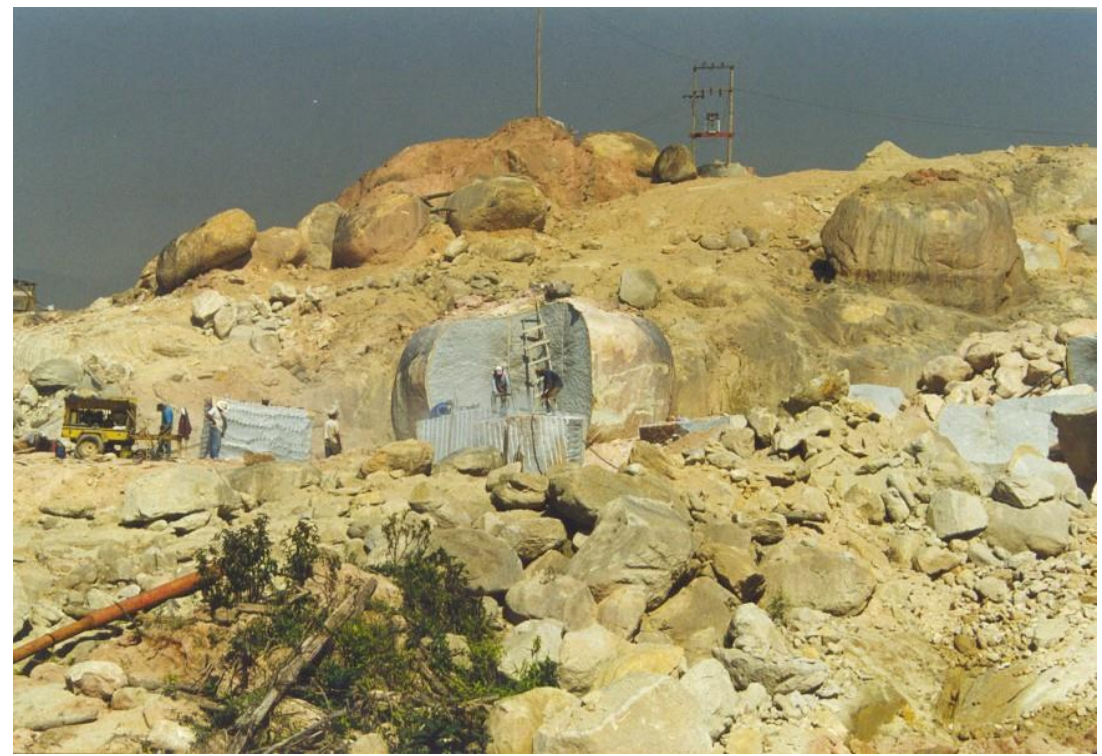

Figura 4.4 - Aspecto da lavra de matacões do Azul Paulista Frente Nova, em São Paulo, SP.

Esses materiais ocorrem predominantemente na parte norte do Estado, notadamente na região abrangida por Barra do São Francisco, Colatina, Ecoporanga e Nova Venécia. Há muito pouca informação geológica e cartográfica do Estado do Espírito Santo, principalmente relativas a esta porção, com trabalhos de cunho petrológico praticamente ausentes.

Alguns destes tipos rochosos têm apresentado problemas como manchamentos e destacamento de fragmentos minerais da superfície polida (Frascá; Quitete, 1999). Por isto, foram escolhidos para este estudo, independente de antecedentes de alteração, para verificar quais feições petrográficas e/ou mineralógicas estariam favorecendo a alteração dessas rochas.

As rochas amostradas para estudo (Figura 4.5) foram: Arabesco, Santa Cecília e Giallo Veneciano. Esse último, tipo clássico brasileiro, explorado há cerca de 25 anos, com produção quase que exclusivamente voltada para o mercado externo.

O Santa Cecília é um material relativamente novo no mercado (em extração há menos de 10 anos) e com vários relatos de deterioração da superfície polida, após assentamento em piso, com uso de argamassa. 


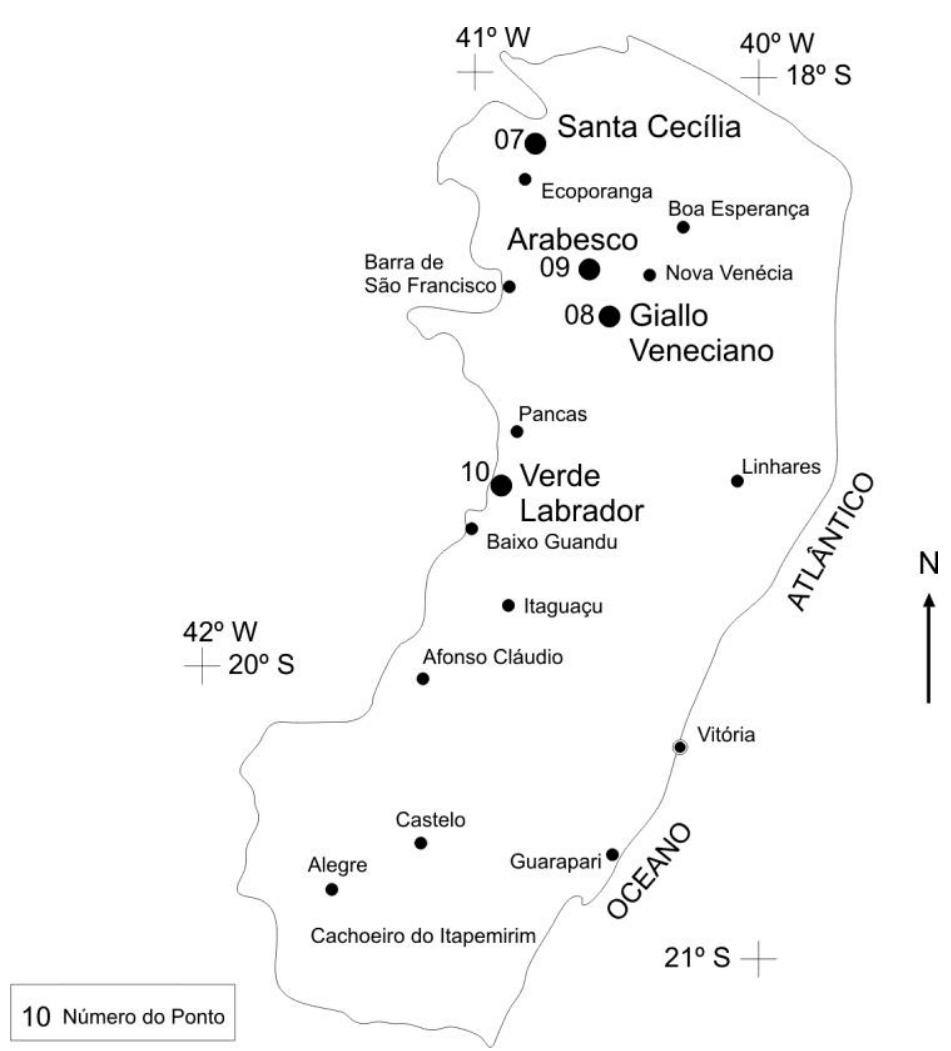

Fonte: Frazão et al. , 1993, simplificado

Figura 4.5 - Mapa de localização das pedreiras de rochas ornamentais selecionadas para este estudo, no Estado do Espírito Santo.

Segundo Almeida; Letwinski (1984), uma das características marcantes desta área é ser constituída quase que exclusivamente de rochas pré-cambrianas e, também, de ser a menos conhecida da região oriental do País, devido a motivos diversos, como a profundidade da alteração intempérica dessas rochas, aliada à escassez de datações radiométricas e de mapeamentos geológicos de detalhe. Esta assertiva parece perdurar até hoje, vista a dificuldade encontrada para resgatar trabalhos geológicos recentes.

Em geral, essas rochas são gnaisses monzo a sienograníticos, com biotita, granada e sillimanita, associação metamórfica indicativa de grau médio a alto. Constituem terrenos migmatítico-granulíticos, de idade Transamazônica, rejuvenescidos durante o ciclo Brasiliano (Schobenhaus et al., 1984), no setor setentrional da província Mantiqueira (Almeida; Letwinski, 1984).

São lavras em maciço, com uso de métodos modernos, que permitem alta produtividade, chegando-se à produção acima de $1.000 \mathrm{~m} / \mathrm{mês}$ em algumas delas. Para o corte e levante da rocha, utiliza-se de fios diamantados ou flame jet. $\mathrm{O}$ desdobramento em pranchas é realizado por meio do uso de marteletes, explosivos 
e/ou ponteiros. As Figuras 4.6 a 4.8 ilustram a situação de lavra das minas visitadas.
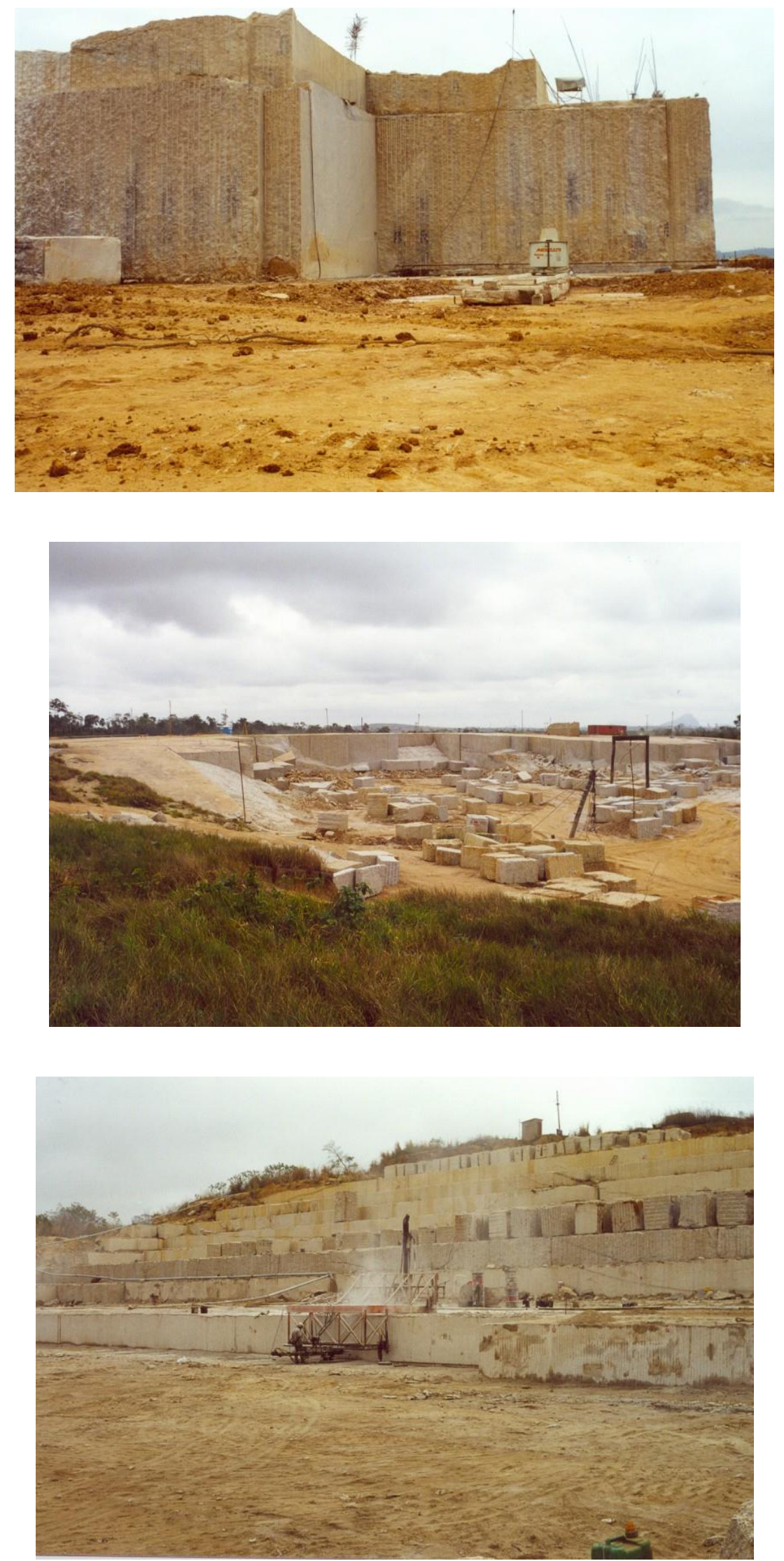

Figura 4.6 - Lavra do Giallo Veneciano, em Nova Venécia, ES.

Figura 4.7 - Lavra do Arabesco em Nova Venécia, ES.

Figura 4.8 - Mina do Santa Cecília, em Ecoporanga, ES. 
Adicionalmente, foi escolhido outro tipo clássico no mercado produtor, um charnockito, comercializado sob a designação Verde Labrador e explorado na região de Baixo Guandu. Este corpo rochoso está incluído no Complexo MigmatíticoGranulítico de Minas Gerais (Schobenhaus et al., 1984).

Normalmente durável, é relatado que pode exibir alteração de cor (clareamento) depois de fixado por argamassa, em fachadas.

A lavra é semimecanizada, com corte através de perfurações e uso de explosivos, e esquadrejamento com uso de marteletes e de ponteiros. A exploração dáse em um alto topográfico, com algum capeamento. Os blocos são lançados por gravidade até cotas mais baixas, de onde são transportados para beneficiamento (Figura 4.9).

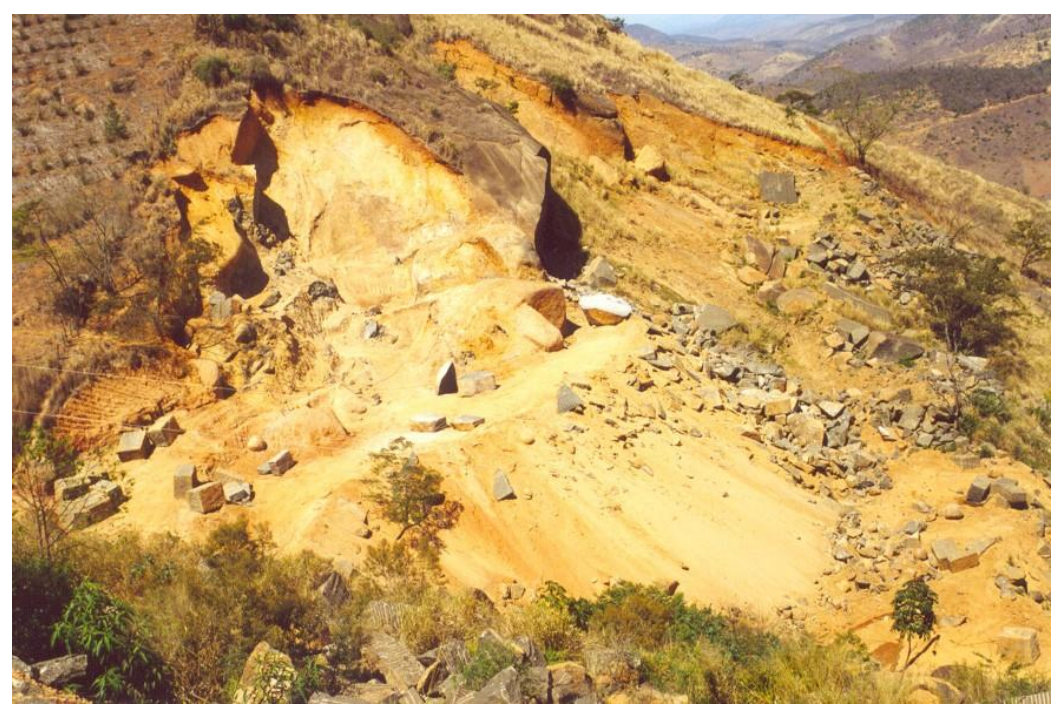

Figura 4.9 - Aspecto da lavra do Verde Labrador, Baixo Guandu, ES. Em parte, ainda explorado a partir de grandes matacões aflorantes em alto topográfico.

\subsection{Rochas do Estado da Bahia}

Neste Estado foram especialmente escolhidos os granitos Branco Itaúnas e Branco Caravelas, rochas de coloração branca a branca-esverdeada, petrograficamente classificadas de granada gnaisses monzograníticos. O primeiro pode apresentar alteração de cor para amarelo-alaranjado quando em contato com ácidos, em especial o clorídrico, ou quando assentado, em pisos, com argamassa convencional.

Estas rochas são exploradas em Medeiros Neto, região de Teixeira de Freitas, BA (Figura 4.10). 


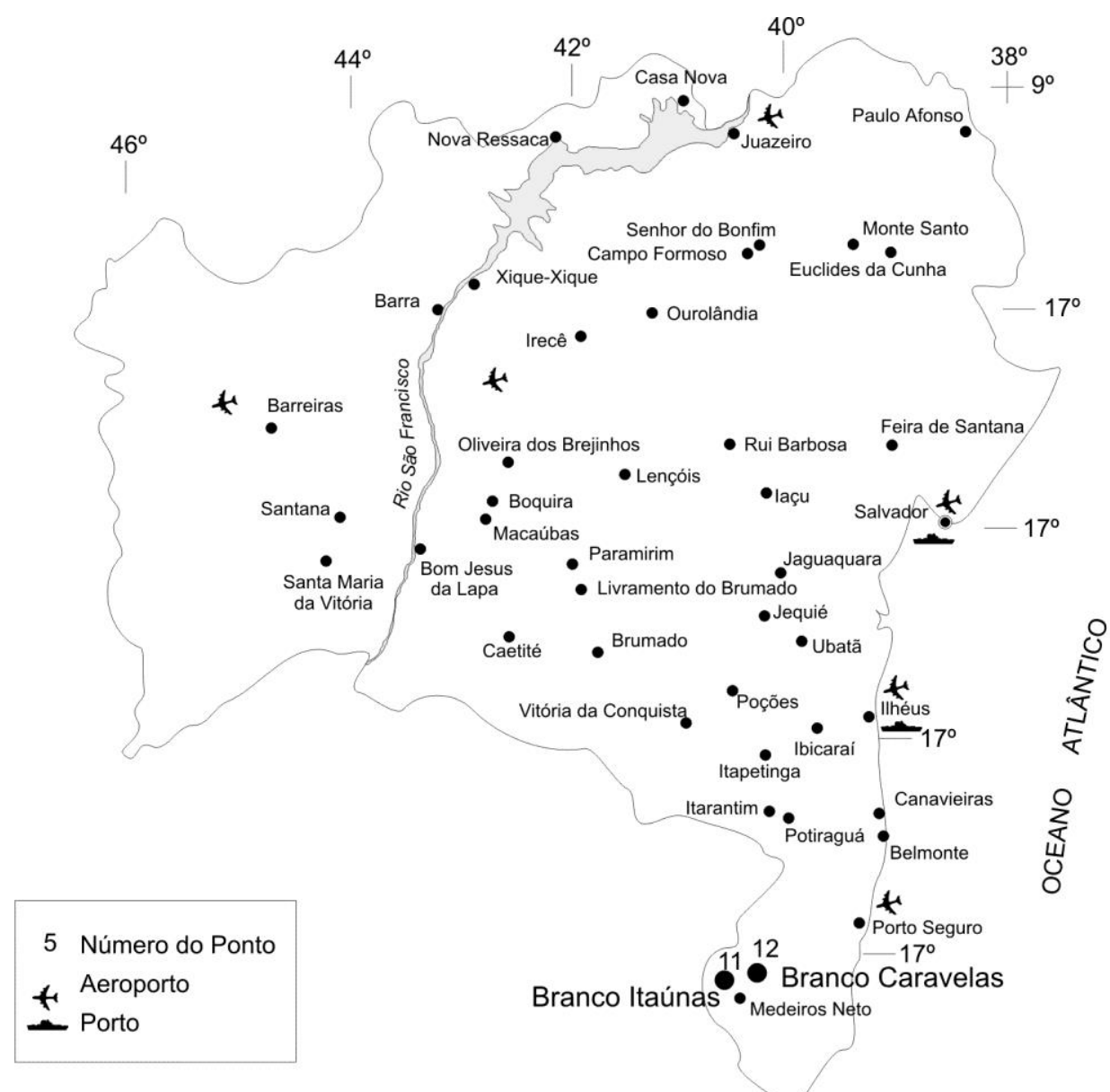

Fonte: Azevedo; Costa (1994), simplificado

Figura 4.10 - Mapa de localização das pedreiras de rochas ornamentais selecionadas para este estudo, no Estado da Bahia.

À semelhança do Espírito Santo, a região aqui amostrada carece de informações geológicas, tanto em escala regional como de detalhe.

É considerada integrante da Província Mantiqueira (Almeida; Letwinski, 1984) e constitui terrenos migmatítico-granulíticos, de idade Transamazônica, rejuvenescidos durante o ciclo Brasiliano (Schobenhaus et al., 1984). Barbosa; Dominguez (1996) consideram estes terrenos, também conhecidos como leucogranitos do sul da Bahia, como pertencentes à Província Kinzigítica da Região de Dobramentos Araçuaí.

Nas minas visitadas (Figuras 4.11 e 4.12), estavam em prática lavras mecanizadas, com uso de fio diamantado para o corte da rocha e marteletes e explosivos para o desdobramento dos blocos. 

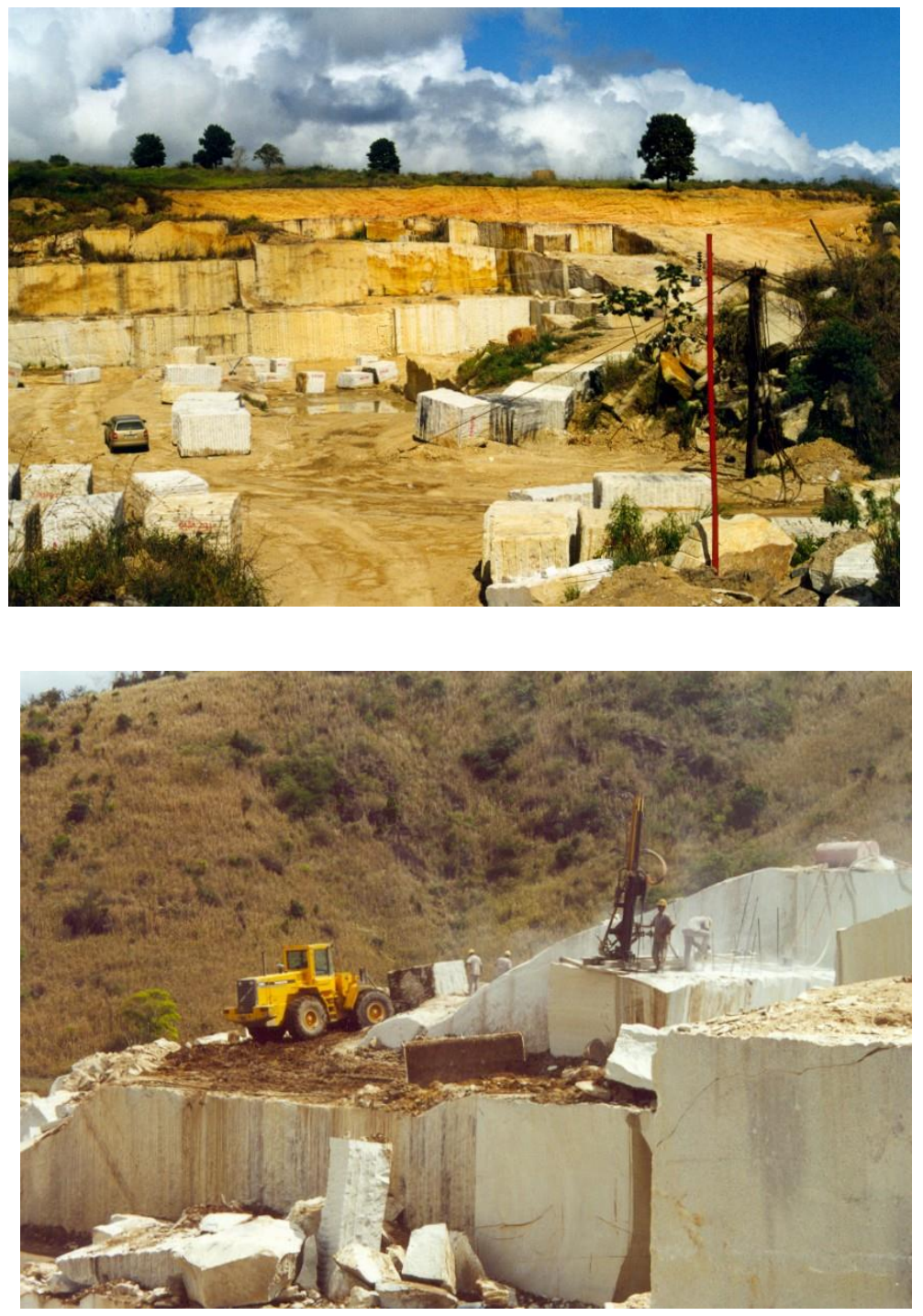

Figura 4.11 - Mina do Branco Itaúnas, em Medeiros Neto, BA.

\subsection{Rochas do Estado do Ceará}

O Estado do Ceará oferece uma grande variedade de rochas ornamentais incluindo vários "granitos brancos", entre eles o Branco Ceará, um tipo único e que constitui uma das rochas ornamentais brasileiras mais valorizadas nos mercados interno e externo.

Além da escolha desta rocha, também foram selecionados os granitos Branco Cristal Quartz e Branco Savana, de cor branco-rosada; o Rosa Iracema, de cor rosa; o Casablanca, de cor branca com faixas cinzentas e o Falésias, de cor branco-amarelado a amarelo-ferruginoso, com faixas de cor castanho-ferruginosa (Figura 4.13). 


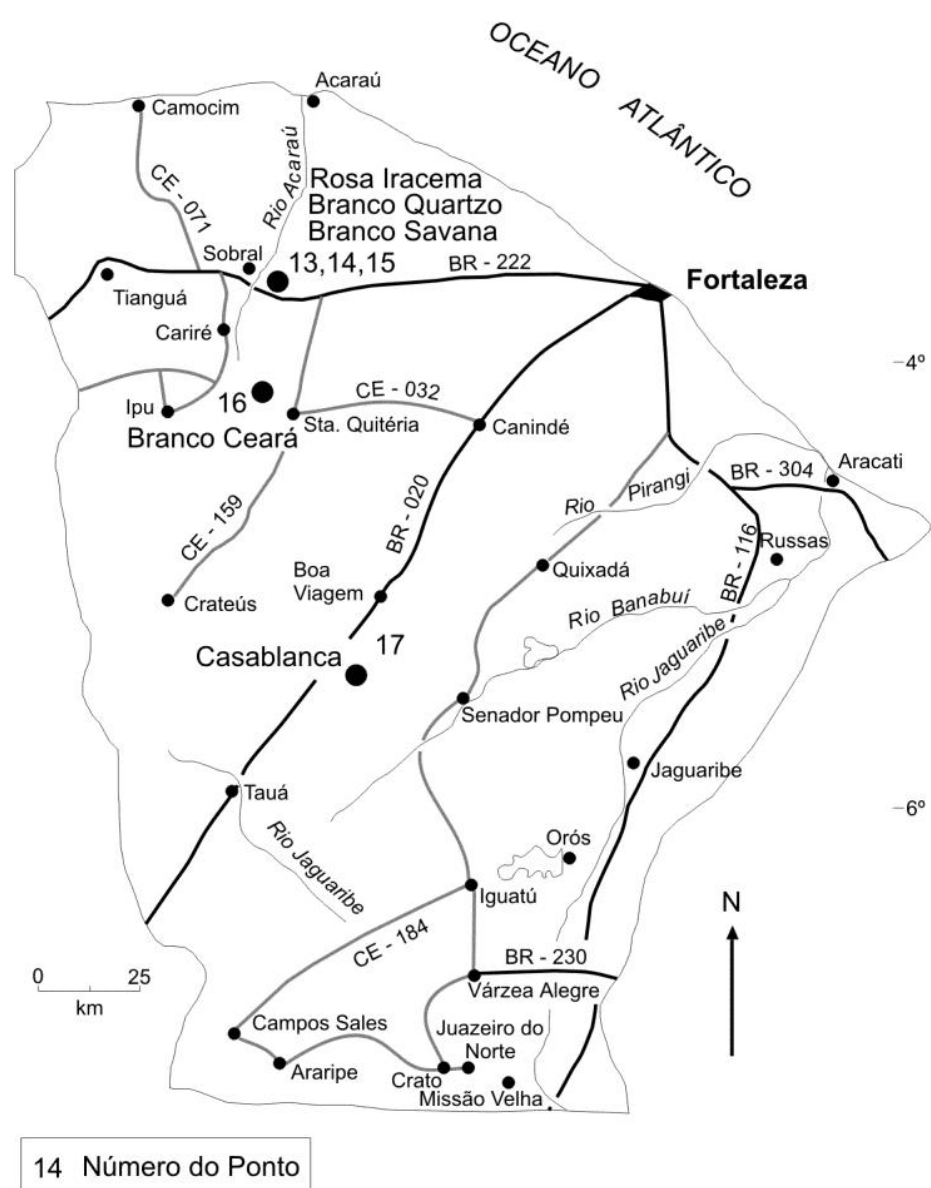

Fonte: Roberto (1998), simplificado

Figura 4.13 - Mapa de localização das pedreiras de rochas ornamentais selecionadas para este estudo, no Estado do Ceará.

Não são comuns patologias relacionadas às rochas amostradas, mas há relatos de mudança de cor do Branco Ceará, após assentamento em piso com argamassa.

Estes materiais rochosos estão inseridos em contextos geológicos distintos, com idade variando do Proterozóico Inferior até ao final do Brasiliano (Roberto, 1998 e Vidal, 1999).

A lavra, em geral, é realizada a partir do maciço rochoso já exposto, pois o capeamento é praticamente inexistente, com o emprego de técnicas modernas de corte e desdobramento.

Em Forquilha, são explorados os granitos Rosa Iracema, Branco Savana e Branco Cristal (também conhecido como Branco Cristal Quartz).

Apesar de serem frentes de lavra geograficamente muito próximas, estas rochas aparentemente apresentam diferenças mineralógicas e texturais. O Branco Savana, provavelmente, é uma variação intempericamente alterada do Rosa Iracema. 
As Figuras 4.14 e 4.15 mostram as principais características distintivas dos jazimentos dos Rosa Iracema e Branco Cristal; o primeiro se trata de rocha in situ, enquanto o segundo, provavelmente corresponde a blocos provenientes de cotas mais altas.
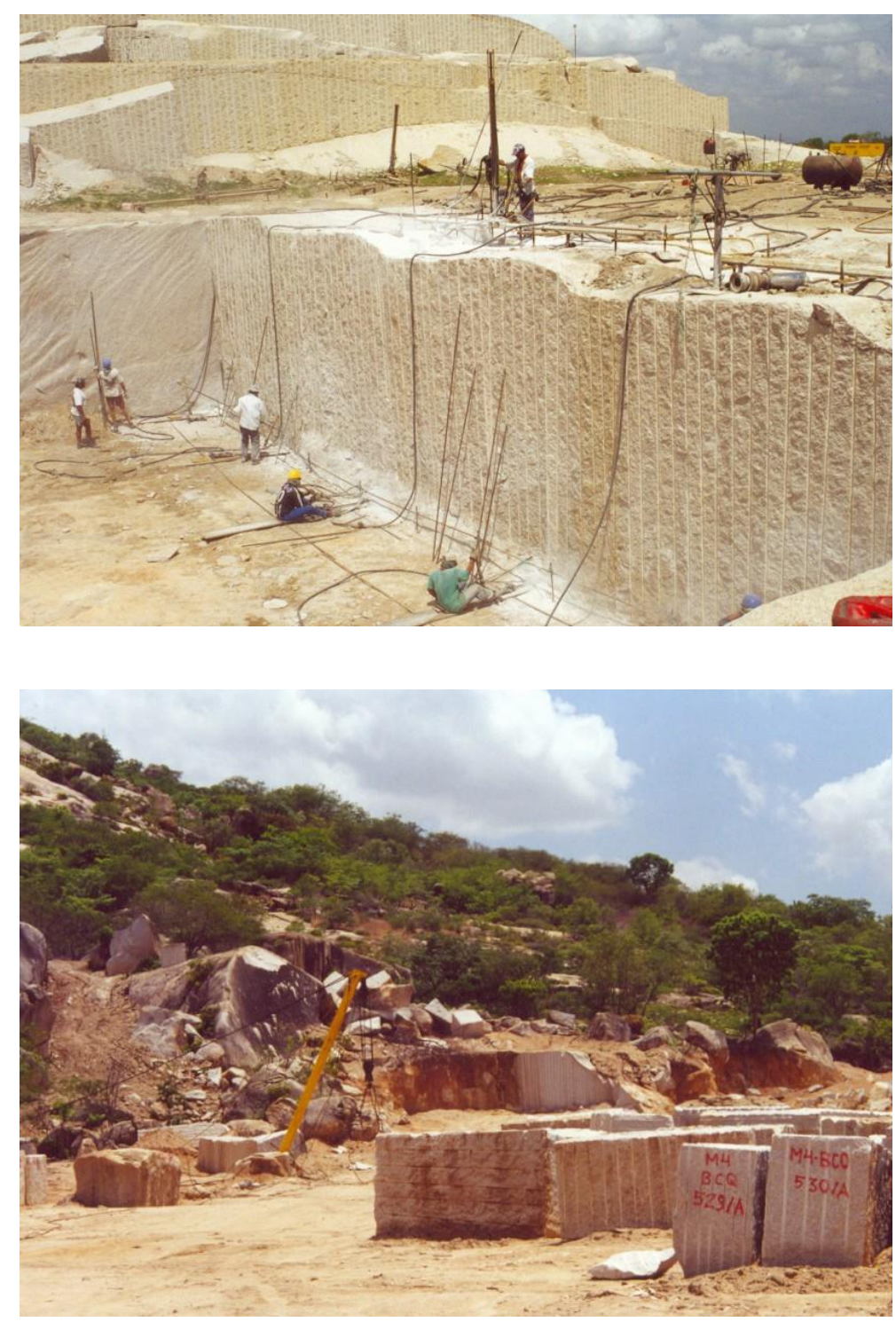

Figura 4.14 - Mina do granito Rosa Iracema, em Forquilha, CE.
Figura 4.15 - Mina do granito Branco Cristal, em Forquilha, CE.

O Branco Ceará, explorado em Santa Quitéria, também pode ser conhecido por grande variedade de nomes, que às vezes chega a confundir o mercado: Branco Asa Branca, Branco Cotton, Branco Polar, Branco Cristal, entre outros. É um albita granito que constitui o stock Morrinhos, alojado no Maciço Granítico-Migmatítico de Santa Quitéria (Brito Neves, 1975 apud Mesquita, 2002).

Modernas técnicas de lavra são empregadas para sua extração (Figura 4.16), fio diamantado e marteletes para o corte e massa expansiva para desdobramento. Pás 
carregadeiras de grandes dimensões, a exemplo das outras minas no Espírito Santo, Bahia e mesmo Ceará, bem como o acompanhamento das características do maciço com a prática freqüente de sondagens contribuem grandemente para a alta produtividade.

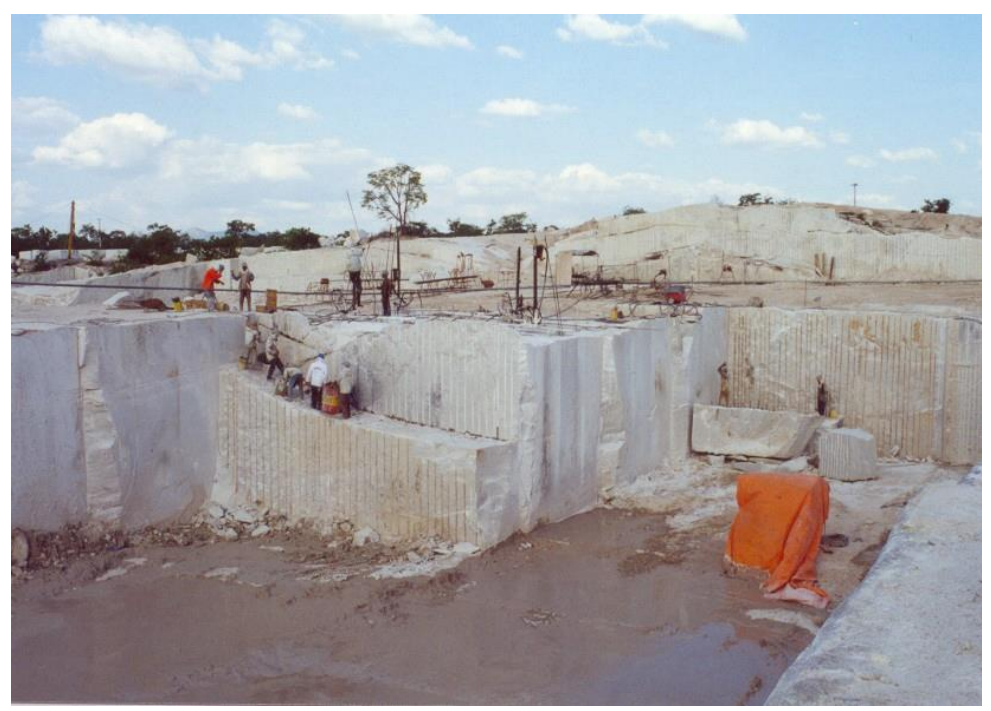

Figura 4.16 - Mina do Branco Ceará, em Santa Quitéria, CE.

O Casablanca, no município de Independência, é um gnaisse monzogranítico, parte integrante dos leptinitos Tróia, de idade Arqueana. Trata-se de seqüência de ortognaisses leucocráticos e anortositos interestratificados com rochas máficoultramáficas, que ocuparia a porção central do Maciço de Tróia (Brito Neves, 1975 apud Roberto, 1998).

Estão em exploração dois materiais referentes à mesma rocha; um deles equivale à porção sã (Casablanca - Figura 4.17) e o outro à porção intempericamente alterada (Falésias - Figura 4.18). A lavra é realizada por meio de técnicas modernas, já comentadas.

Os corpos ocorrem geograficamente próximos, separados por drenagem, que provavelmente condicionou o fenômeno intempérico só em parte do maciço. 


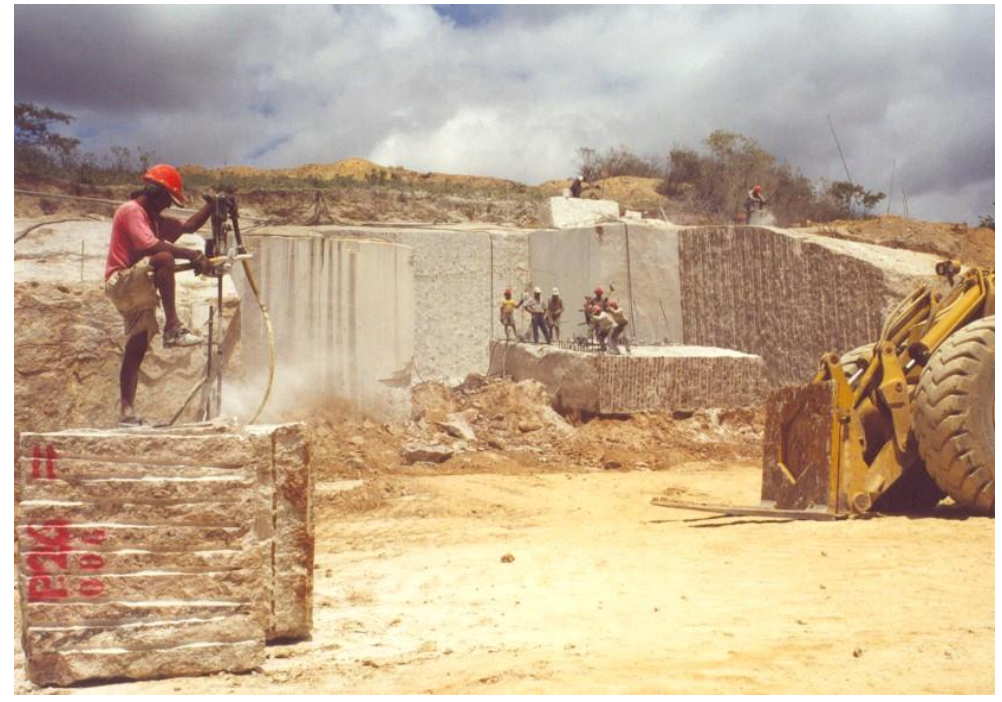

Figura 4.17 - Mina do Casablanca, em Independência, CE.

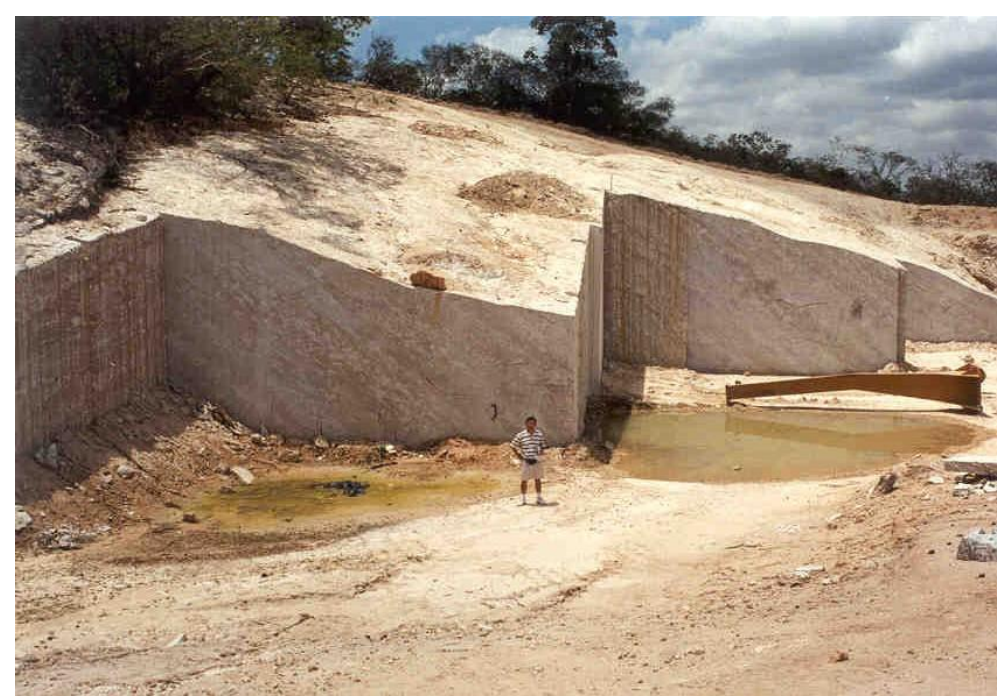

Figura 4.18 - Mina do Falésias, em Independência, CE. 


\section{CAPÍTULO 5}

\section{TRABALHOS DE LABORATÓRIO}

O principal enfoque da pesquisa desenvolvida foi a concepção e realização de um conjunto de ensaios, análises e determinações laboratoriais visando ao conhecimento dos parâmetros físicos, químicos e mecânicos, que possam ser modificados em situações química ou fisicamente agressivas.

Os trabalhos laboratoriais realizados para alcançar os objetivos propostos abrangeram estudo das propriedades petrográficas, mineralógicas e químicas; determinações de resistências à compressão e flexão e a simulação da ação climática (choque térmico), de poluentes dispersos na atmosfera (câmaras de dióxido de enxofre), de atmosferas agressivas (câmaras de névoa salina) e da ação de eflorescências (imersão parcial em soluções ácida e alcalina).

Determinações de resistência mecânica, de velocidade de propagação de ondas ultra-sônicas longitudinais, de densidade aparente e de absorção de água, nos corposde-prova após os ensaios de alteração foram os parâmetros de controle das alterações e/ou degradações ocorridas.

Tais informações subsidiaram, então, as verificações das hipóteses estabelecidas e fundamentaram as proposições acerca de aspectos condicionantes da alterabilidade de tipos rochosos graníticos.

\subsection{Análises Petrográficas e Mineralógicas}

As análises petrográficas foram realizadas para determinação da natureza, mineralogia e classificação da rocha. As descrições enfatizaram a presença de minerais e feições de alteração, bem como aqueles potencialmente alteráveis perante as solicitações de beneficiamento e uso, que possam afetar a durabilidade e aparência estética da rocha.

É uma ferramenta muito importante para análise dos dados tecnológicos, esclarecendo freqüentemente as diferentes propriedades físicas e/ou mecânicas de rochas aparentemente semelhantes. Também é essencial para diagnosticar e caracterizar as deteriorações de rochas. 
A análise fundamenta-se na observação de seções delgadas das amostras, escolhidas e confeccionadas segundo os critérios descritos a seguir:

- seleção da área representativa do aspecto geral da rocha. Nas rochas gnáissicas foi considerado plano de maior isorientação mineral;

- antes da confecção das seções delgadas, as amostras foram impregnadas a vácuo, com resina epóxi à qual foram acrescentados corantes (tipo Oracet ou Orazol), de forma a destacar as microdescontinuidades presentes na rocha quando examinada por microscopia óptica;

- foram confeccionadas lâminas especiais, a partir de porções selecionadas nos blocos, com dimensões de $20 \mathrm{~mm}$ x $40 \mathrm{~mm}$. A espessura de estudo foi de aproximadamente $30 \mu \mathrm{m}$;

- também foram confeccionadas lâminas delgadas a partir de corpos-de-prova que exibiram modificações moderadas a intensas, após os ensaios de alteração acelerada.

Após sua preparação, foram estudadas ao microscópio óptico de luz transmitida, segundo as diretrizes básicas das normas ABNT NBR 12768 (ABNT, 1992c) e BS EN 12407 (BSI, 2000).

As técnicas auxiliares geralmente utilizadas para a identificação e quantificação de minerais foram: ensaios de coloração seletiva de feldspatos e difratometria de raios $X$.

A classificação petrográfica, para as rochas graníticas estudadas, baseou-se em Le Maitre (1989), Streckeisen (1975) e Winkler (1976).

A classificação do tamanho de grãos adotada seguiu os limites usuais de petrografia, conforme Frascá; Sartori (1998) (Tabela 5.1).

Tabela 5.1 - Classificação do tamanho de grãos adotada nas descrições petrográficas

\begin{tabular}{cc}
\hline GRANULAÇÃO & TAMANHO $(\mathbf{m m})$ \\
\hline muito grossa & $>30$ \\
\hline grossa & $5-30$ \\
\hline média & $1-5$ \\
\hline fina & $<1$ \\
\hline
\end{tabular}

As feições consideradas potencialmente qualificadoras, ou seja, aquelas que foram selecionadas como principais determinantes da alterabilidade da rocha foram: 
- grau de microfraturamento e possíveis incrementos derivados dos processos de beneficiamento;

- presença de minerais em desequilíbrio, instáveis e/ou alterados;

- heterogeneidade textural e granulométrica;

- tamanho dos grãos.

\subsubsection{Ensaios de coloração seletiva de feldspatos}

A coloração seletiva foi efetuada em amostras de mão, com o objetivo de melhor visualizar e quantificar feldspato potássico, plagioclásio e quartzo, constituintes essenciais das rochas graníticas estudadas.

O método adotado baseia-se em Rodrigues; Moraes (1978). Consiste em mergulhar uma face da rocha, previamente lixada, em contato com ácido hidrofluorídrico e, em seguida, com solução de cobaltinitrito de sódio. Os feldspatos reagem prontamente com a solução, adquirindo coloração específica (amarela para feldspatos potássicos e branca para os plagioclásios) e distinguindo-se dos demais, facilitando sua identificação e quantificação.

Dada a granulação geralmente grossa dos minerais constituintes das rochas estudadas, privilegiou-se a quantificaçã dos minerais em amostras de mão submetidas a ensaio de coloração seletiva para feldspatos, utilizando-se folha de acetato com finas linhas milimetradas.

\subsubsection{Análises mineralógicas por difratometria de raios $X$}

A difratometria de raios $X$ foi utilizada para a identificação de minerais de argila ou secundários, resultantes da alteração da rocha tanto in situ, como nos ensaios de alteração acelerada; e de sais formados nas eflorescências das rochas submetidas a ensaios de imersão parcial e em câmaras climáticas.

Para os minerais de argila, a análise por difratometria de raios $X$ foi realizada em fração da amostra com granulometria menor que $0,002 \mathrm{~mm}$, disposta em lâmina orientada. Para os demais minerais, foi retirada uma porção da amostra, que, depois de homogeneizada, foi disposta em lâminas e submetida à difração de raios $\mathrm{X}$.

A interpretação dos resultados obtidos foi baseada nas fichas de JCPDS (1974, 1980, 1981) e em Thorez (1976). 


\subsection{Ensaios Tecnológicos}

Os ensaios tecnológicos adotados nesse trabalho foram: determinação de índices físicos (densidade aparente, porosidade aparente e absorção d'água), do coeficiente de capilaridade, de velocidade de propagação de ondas ultra-sônicas e de resistências à flexão e compressão.

Os dois primeiros fornecem dados considerados como parâmetros físicos (estado fissural e de alteração), que se esperavam refletidos nos parâmetros mecânicos (flexão e compressão) das rochas em estudo.

$\mathrm{O}$ coeficiente de capilaridade foi determinado em todas as amostras visando à obtenção de informações complementares, que pudessem auxiliar no entendimento de diferentes respostas às simulações de alteração em amostras com características físicas e petrográficas semelhantes.

Os procedimentos para a execução desses ensaios acham-se descritos a seguir.

\subsubsection{Densidade, porosidade e absorção}

As propriedades de densidade, porosidade e absorção d'água, geralmente designadas de índices físicos, são consideradas, pela grande maioria dos pesquisadores, como características muito influentes na alterabilidade da rocha, pois seriam fatores determinantes para a resistência e durabilidade da rocha (Winkler, 1997).

Os valores de densidade, porosidade e absorção fornecem indicação do estado fissural e de alteração de rochas, que podem ser utilizados para a avaliação comparativa de um conjunto de rochas.

A porosidade é a relação entre o volume de vazios e o volume total, em porcentagem.

Nas rochas ígneas, em geral, há pouco espaço poroso devido à grande pressão e temperatura de sua formação. Os poros são representados principalmente pelas microfissuras, alterações em minerais (ex. núcleos de feldspatos sericitizados), contatos entre grãos, etc.

Nas rochas metamórficas, de composição granítica, a isorientação mineral lineações, xistosidade, etc. - constitui planos de descontinuidade que podem contribuir para o incremento da porosidade. 
A absorção é a capacidade de assimilação ou incorporação de água pela rocha. Segundo Winkler (1997), capilares menores que 0,1 $\mu \mathrm{m}$ não absorvem água, mas, sob vácuo, a maioria deles é preenchida. A norma ASTM C 97 (ASTM, 1996) considera que a determinação dessas propriedades é útil para indicar as diferenças de absorção entre vários tipos de rochas ornamentais ou fornecer elemento comparativo para rochas do mesmo tipo.

Para essa pesquisa foram efetuadas várias determinações de índices físicos, baseadas em diversos procedimentos de ensaio estabelecidos por diferentes entidades normatizadoras: ABNT NBR 12766 (ABNT, 1992a), ASTM C 97 (ASTM, 1996), CEN prEN WI 036 (CEN, 1998a), BS EN 1936 (BSI, 1999a), que serão doravante referidas pelas citações bibliográficas ou pela sigla da instituição de normalização.

Os procedimentos das normas adotadas estão sumariados na Tabela 5.2.

Registra-se que em todas as determinações, independentemente da norma em execução, após a saturação em água, foram obtidos os pesos saturados e submersos (Figura 5.1).

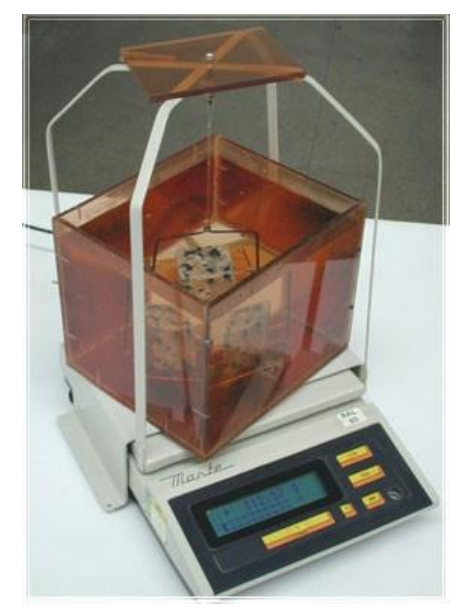

Figura 5.1 - Determinação do peso submerso em dispositivo hidrostático.
O objetivo da determinação desses parâmetros, por meio das várias normas disponíveis, foi verificar se os resultados são comparáveis e se a incorporação de água nos corpos-de-prova é mais ou menos eficiente conforme a situação de saturação.

A principal modificação introduzida foi a utilização de corpos-de-prova obtidos de ladrilhos polidos das rochas em estudo e nos tamanhos e formatos destes. A razão disso é que o material objeto desse estudo é a alteração acelerada de rochas para revestimento, ou seja, a rocha já beneficiada e acabada; e, portanto, os parâmetros físicos a serem conhecidos e controlados são aqueles referentes a esses materiais. 
Tabela 5.2 - Procedimentos e parâmetros obtidos nas determinações de índices físicos.

NORMA OBJETIVO

\begin{tabular}{|c|c|}
\hline ABNT 12766 & $\begin{array}{l}\text { determinação da massa específica aparente (seca e saturada com a superfície seca), } \\
\text { porosidade e absorção d'água aparentes de rochas, que se destinam ao uso como } \\
\text { materiais de revestimento de edificações. }\end{array}$ \\
\hline ASTM C97 & $\begin{array}{l}\text { testes para determinação da absorção e massa específica de todos os tipos de rochas } \\
\text { ornamentais, exceto ardósia. }\end{array}$ \\
\hline prEN WI 036 & método para a determinação da absorção de água a pressão atmosférica \\
\hline BS EN 1936 & $\begin{array}{l}\text { método para a determinação da densidade real, densidade aparente, e da porosidade total } \\
\text { e aberta de rochas ornamentais (natural stone). }\end{array}$ \\
\hline
\end{tabular}

\section{CORPOS-DE-PROVA (CPs)}

\begin{tabular}{cl}
\hline ABNT 12766 & dez para cada amostra, com diâmetro ao redor de $7 \mathrm{~cm}$ ou peso ao redor de $250 \mathrm{~g}$. \\
\hline ASTM C97 & $\begin{array}{l}\text { pelo menos três para cada amostra. Podem ser cubos, prismas, cilindros, com a menor } \\
\text { dimensão não inferior a } 50,8 \mathrm{~mm} \text { e a maior não superior a 76,2 mm. }\end{array}$ \\
\hline prEN WI 036 & $\begin{array}{l}\text { pelo menos seis CPs representativos da rocha testada, com forma cúbica, cilíndrica ou } \\
\text { prismática, obtidos por corte em serra ou perfuratriz. }\end{array}$ \\
\hline BS EN 1936 & idem prEN WI 036. \\
\hline
\end{tabular}

ABNT 12766 imergir em água até o tempo total de $24 \mathrm{~h}$, ou proceder à saturação com auxílio de bomba de vácuo por 3h: $m_{\text {sat }}$ (massa saturada) e $m_{\text {sub }}$ (massa submersa).

\begin{tabular}{|c|c|c|c|}
\hline ASTM C97 & \multicolumn{3}{|c|}{$\begin{array}{l}\text { secar os CPs a }(60 \pm 2){ }^{\circ} \mathrm{C} \text { por } 48 \mathrm{~h} \text {, em estufa ventilada, até massa constante: } \mathrm{m}_{\text {seca }} \text {; } \\
\text { imergir os CPs em água filtrada ou destilada a }(22 \pm 2){ }^{\circ} \mathrm{C} \text { por } 48 \mathrm{~h}: \mathrm{m}_{\text {sat }} \text { e } \mathrm{m}_{\text {sub. }}\end{array}$} \\
\hline prEN WI 036 & \multicolumn{3}{|c|}{$\begin{array}{l}\text { secar os CPs a }(70 \pm 5){ }^{\circ} \mathrm{C} \text {, em estufa ventilada, até massa constante: } \mathrm{m}_{\text {seca }} \text {; } \\
\text { colocar os CPs em bandeja sob suporte plástico e colocar água, na temperatura ambiente, } \\
\text { até a metade da altura dos CPs }\left(\mathrm{t}_{0}\right) \text {. Em } \mathrm{t}_{0}+(60 \pm 5) \text { min, colocar água até } 3 / 4 \text { da altura CPs } \\
\text { e em } \mathrm{t}_{0}+(120 \pm 5) \text { min imergir completamente os CPs. Continuar o ensaio por }(72 \pm 2) \mathrm{h}: \mathrm{m}_{\text {sat }}\end{array}$} \\
\hline BS EN 1936 & \multirow{2}{*}{\multicolumn{3}{|c|}{$\begin{array}{l}\text { secar os CPs a }(70 \pm 5){ }^{\circ} \mathrm{C} \text {, em estufa ventilada, até massa constante: } \mathrm{m}_{\text {seca; }} \text {; } \\
\text { colocar os CPs sob vácuo, por aproximadamente }(24 \pm 2) \mathrm{h} \text {; } \\
\text { introduzir água desmineralizada vagarosamente nos recipientes, manter a pressão durante } \\
\text { a colocação da água e por }(24 \pm 2) \mathrm{h} \text { subseqüentes } \\
\text { depois desse período, deixar os CPs por mais }(24 \pm 2) \mathrm{h} \text { à pressão atmosférica: } \mathrm{m}_{\text {sat }}{\text { e } \mathrm{m}_{\text {sub }}}\end{array}$}} \\
\hline & & & \\
\hline \multicolumn{4}{|c|}{ PARÂMETROS OBTIDOS } \\
\hline \multirow{4}{*}{ ABNT 12766} & massa específica aparente seca $\left(\mathrm{kg} / \mathrm{m}^{3}\right)$ & $\rho_{\mathrm{sec}}=m_{\mathrm{sec} a} /\left(m_{\text {sat }}-m_{\text {sub }}\right)$ & Eq. 1 \\
\hline & $\begin{array}{l}\text { massa especifica aparente saturada } \\
\left(\mathrm{kg} / \mathrm{m}^{3}\right)\end{array}$ & $\rho_{\text {sat }}=m_{\text {sat }} /\left(m_{\text {sat }}-m_{\text {sub }}\right)$ & Eq. 2 \\
\hline & porosidade aparente (\%) & $\eta=\left(m_{\text {sat }}-m_{\text {sec } a}\right) /\left(m_{\text {sat }}-m_{\text {sub }}\right) \times 100$ & Eq. 3 \\
\hline & absorção d'água aparente (\%) & $\alpha=\left(m_{\text {sat }}-m_{\mathrm{sec} a}\right) /\left(m_{\mathrm{sec} a}\right) \times 100$ & Eq. 4 \\
\hline \multirow{2}{*}{ ASTM C97 } & massa específica $\left(\mathrm{kg} / \mathrm{m}^{3}\right)$ & $m_{\mathrm{sec} a} /\left(m_{\text {sat }}-m_{\text {sub }}\right) \times 1000$ & Eq. 5 \\
\hline & absorção, em peso (\%) & $\left(m_{\text {sat }}-m_{\mathrm{sec} a}\right) /\left(m_{\mathrm{sec} a}\right) \times 100$ & Eq. 6 \\
\hline prEN WI 036 & $\begin{array}{l}\text { coeficiente de absorção d'água a } \\
\text { pressão atmosférica (\%) }\end{array}$ & $A_{b}=\left(m_{\text {sat }}-m_{\mathrm{sec} a}\right) /\left(m_{\mathrm{sec} a}\right) \times 100$ & Eq. 7 \\
\hline \multirow{3}{*}{ BS EN 1936} & volume de poros abertos (mL) & $V_{o}=\left(m_{\text {sat }}-m_{\mathrm{sec} a}\right) /\left(\rho_{d a}\right) \times 1000$ & Eq. 8 \\
\hline & densidade aparente seca $\left(\mathrm{kg} / \mathrm{m}^{3}\right)$ & $\rho_{b}=\left(m_{\mathrm{sec} a} /\left(m_{\text {sat }}-m_{\text {sub }}\right)\right) \times \rho_{d a}$ & Eq. 9 \\
\hline & porosidade aberta (\%) & $p_{o}=\left(m_{\text {sat }}-m_{\mathrm{sec} a}\right) /\left(m_{\text {sat }}-m_{\text {sub }}\right) \times 100$ & Eq. 10 \\
\hline
\end{tabular}




\subsubsection{Breve consideração sobre métodos e procedimentos adotados}

A compilação apresentada anteriormente evidencia que os métodos normatizados disponíveis exibem diferenças que podem ser consideradas sutis, em vista das heterogeneidades do material em análise (a rocha) e as imprecisões inerentes. Outras fontes de imprecisão, mesmo em condições laboratoriais adequadas, são a homogeneidade de temperatura de secagem de corpos-de-prova e de procedimentos para obtenção do peso submerso, a repetitividade das mensurações, as diferenças de manuseio entre operadores e outros.

A norma NBR 12766 (ABNT, 1992a) não especifica a temperatura de secagem dos corpos-de-prova e não é precisa quanto à sua imersão, em água. Assim, estabeleceu-se o seguinte procedimento no presente trabalho, que é basicamente aquele utilizado pelo Laboratório de Petrologia e Tecnologia de Rochas, da Divisão de Geologia do IPT - Instituto de Pesquisas Tecnológicas: secagem em estufa ventilada, a $(100 \pm 5){ }^{\circ} \mathrm{C}$, por $24 \mathrm{~h}$, e imersão em água deionizada, por um tempo total de $24 \mathrm{~h}$, após 3h sob vácuo.

Não foi apresentada a massa específica aparente saturada, pois esse parâmetro não é calculado em nenhuma outra norma, e seu valor pode ser facilmente obtido acrescentando-se o valor porcentual da absorção d'água ao da massa específica aparente seca.

Outra consideração é quanto à nomenclatura, pois, conforme o Sistema Internacional de unidades derivadas (http://physics.nist.gov/cuu/Units/units.html), o valor fornecido nas normas NBR 12766 (ABNT, 1992a) e C 97 (ASTM, 1996) como massa específica é mais corretamente designado de densidade de massa (mass density), cuja unidade é $\mathrm{kg} / \mathrm{m}^{3}$.

No tocante às normas CEN (1998a) e BSI (1999a), verificou-se que a massa dos corpos-de-prova tornava-se constante após cerca de $72 \mathrm{~h}$ em estufa ventilada, a $(70 \pm 5){ }^{\circ} \mathrm{C}$. Dessa forma, para todas as determinações, segundo essas normas, estabeleceu-se que o peso seco foi aquele obtido depois de decorrido esse tempo.

Tendo em vista tais considerações, os resultados obtidos serão apresentados, neste trabalho, conforme a seguir:

- massa específica aparente - também chamada de densidade aparente, no texto - porosidade aparente e absorção d'água: determinadas segundo ABNT 
NBR 12766 (ABNT, 1992a), pois é similar à ASTM C 97 (ASTM, 1996);

- densidade aparente e absorção: determinadas segundo prEN WI 036 (CEN, 1998a);

- densidade aparente, porosidade aberta e poros abertos: determinadas segundo BS EN 1936 (BSI, 1999a).

\subsubsection{Capilaridade}

Entre os vários agentes deletérios à rocha, a umidade, que pode ter diferentes origens, é considerada um dos mais importantes (Amoroso; Fassina, 1983). Segundo esses autores, na ausência de água não haveria reação química entre os constituintes da rocha (intemperismo); sais solúveis não seriam transportados e não migrariam, cristalizariam ou recristalizariam; os poluentes atmosféricos não se dissolveriam nas gotas de chuva e não poderiam permanecer em contato com a rocha por tempo suficiente para reagir com os constituintes minerais. Adicionalmente, a água é considerada um fator essencial para a geração de stress interno (Torraca, 1979 apud Amoroso; Fassina, 1983).

A porosidade da rocha é responsável pela permeabilidade à água, cujo grau depende da estrutura capilar. Isto torna mais importante conhecer a distribuição do tamanho dos poros na rocha do que a porosidade integral, pois o transporte de água é realizado por meio dos capilares.

A sucção capilar é a pressão de sucção, que aumenta com a diminuição do diâmetro dos poros e é muito maior para poros com diâmetro menor que $1 \mu \mathrm{m}$. É causada pela atração da água em direção às paredes dos poros. A razão para essa atração é que os corpos porosos são compostos de carbonatos, silicatos, aluminatos ou óxidos, que contêm átomos de oxigênio, com carga elétrica negativa, ou íons hidroxila. Superfícies porosas, com átomos ou grupos polarizados, que têm forte atração eletrostática para moléculas polares, tais como a água, são denominadas superfícies hidrofílicas.

A determinação do coeficiente de absorção d'água por capilaridade baseou-se na norma BS EN 1925 (BSI, 1999b), a despeito da orientação de que essa norma não é adequada para rochas com porosidade aberta <1\%, conforme BS EN 1936 (BSI, 1999a).

De acordo com Prof. Fernando L. González-Messones (comunicação pessoal), 
da E. T. S. I. de Madri e membro do TC-248 (Natural Stone) da CEN, os resultados obtidos nesse ensaio não podem ser considerados em seus valores absolutos, pois a norma não é apropriada para granitos.

Entretanto, em vista da pouca disponibilidade de técnicas e equipamentos para medida de porosidade e/ou permeabilidade de rochas graníticas, a realização desse ensaio buscou, neste trabalho, verificar as variações relativas entre as rochas estudadas e a análise comparativa dos dados.

Novamente, por se enfocar a determinação de propriedades físicas e mecânicas de rochas beneficiadas (serradas em chapas e polidas), diferentemente das dimensões especificadas na norma, os corpos-de-prova ensaiados mediram $10 \mathrm{~cm}$ x $10 \mathrm{~cm}$ × 2 ou $3 \mathrm{~cm}$ de espessura.

O procedimento de ensaio consistiu em secar o corpo-de-prova, por 72h, a $(70 \pm 5)^{\circ} \mathrm{C}$ em estufa ventilada, para obtenção do peso seco $\left(\mathrm{m}_{\text {seca }}\right)$. Em seguida, foram colocados em bandejas, sobre suporte plástico, estando a base do corpo-de-prova parcial e constantemente imersa (cerca de $4 \pm 1 \mathrm{~cm}$ ) em água. Após a imersão, os corpos-de-prova foram pesados em tempos preestabelecidos: $30 \mathrm{~min}, 60 \mathrm{~min}, 180 \mathrm{~min}$, $480 \mathrm{~min}, 1440 \mathrm{~min}, 2880 \mathrm{~min}$ e $4320 \mathrm{~min}$, ou mais, conforme o material ensaiado.

Os resultados foram apresentados em gráfico exibindo a massa de água absorvida, em gramas, dividida pela área da base imersa, em metros quadrados, em função da raiz quadrada do tempo de cada determinação, em segundos.

O cálculo do coeficiente de absorção d'água por capilaridade foi realizado por meio de regressão não-linear, dada pela equação (BSI, 1999b):

$$
y_{i}=a\left(1-e^{-b \sqrt{t_{i}}}\right)
$$

onde $y_{i}=$ massa de água absorvida em relação à área da superfície; $a=$ massa de água máxima relacionada à área da superfície imersa da base $\left(\mathrm{g} / \mathrm{m}^{2}\right) ; b=$ coeficiente de penetração de água, relacionado ao comprimento, que é a recíproca da raiz quadrada do tempo $\left(t_{i}\right)$, em $\mathrm{s}$.

Pela linearização da função exponencial, a Equação 11 torna-se, conforme BSI (1999b):

$y_{i}=a \cdot b \sqrt{t_{i}}$ 
sendo $C_{1}$ ou $C_{2}=$ coeficientes de absorção d'água por capilaridade $\left(\mathrm{g} / \mathrm{m}^{2} \cdot \mathrm{s}^{1 / 2}\right)$, determinados perpendicular e paralelamente aos planos de anisotropia da rocha, expressos com três algarismos significativos.

\subsubsection{Compressão uniaxial}

Este procedimento determina a tensão que provoca a ruptura da rocha quando submetida a esforços compressivos (Figura 5.2).

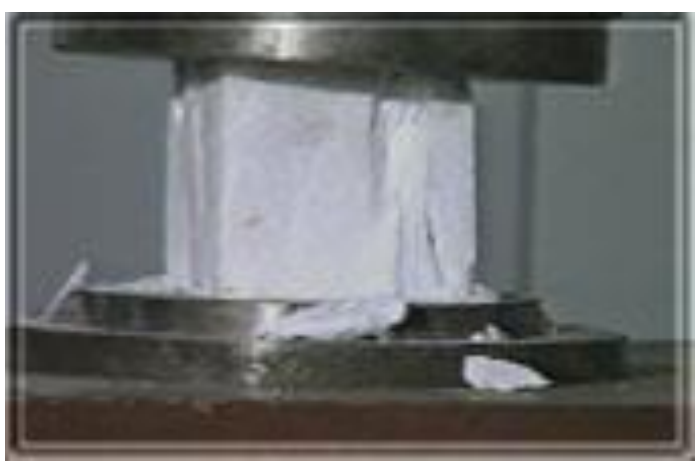

Figura 5.2 - Corpo-de-prova rompido após aplicação de esforços compressivos.

Segundo ASTM (1990), a resistência à compressão permite a comparação entre rochas semelhantes e é um indicativo de sua integridade física. Também é utilizada para avaliar a resistência da rocha quando empregada como elemento estrutural.

A determinação da resistência à compressão uniaxial foi realizada segundo a norma NBR ABNT 12767 (ABNT, 1992b), correlata à ASTM C 170 (ASTM, 1990) em dez corpos-de-prova cúbicos, medindo $(7,5 \pm 0,5) \mathrm{cm}$, que tiveram seus topos e bases retificados em torno mecânico, sendo cinco deles ensaiados na condição seca, após $48 \mathrm{~h}$ em estufa ventilada, a $100{ }^{\circ} \mathrm{C}$, e cinco na condição saturada, após $156 \mathrm{~h}$ imersos em água.

O equipamento utilizado foi uma máquina de ensaio marca Maruto, com taxa de carregamento de aproximadamente $0,6 \mathrm{MPa} / \mathrm{s}$.

Quando se tratava de rocha gnáissica, a tensão de ruptura foi determinada paralela e perpendicularmente à direção da estruturação (Figura 5.3). Diferentemente da norma, devido à grande quantidade de corpos-de-prova a serem preparados, 
nessas amostras, o ensaio foi realizado em três corpos-de-prova, para cada condição.
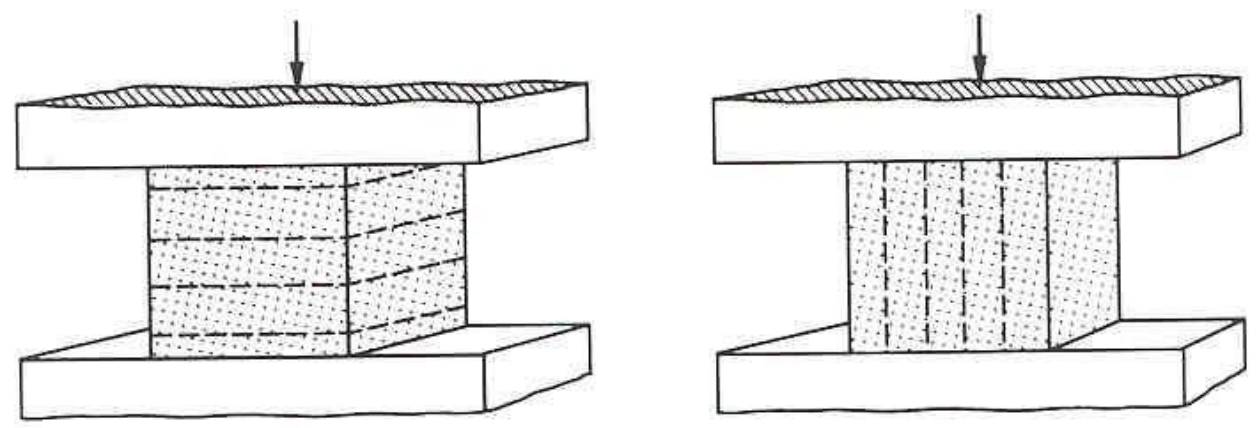

Fonte: Winkler (1997) e ASTM (1990).

Figura 5.3 - Detalhe de corpos-de-prova com esforços aplicados perpendicular (à esquerda) e paralelamente (à direita) à estruturação da rocha.

A resistência à compressão é calculada pela relação entre a carga de ruptura e a área do corpo-de-prova onde é aplicada:

$$
C=P / A
$$

Equação 14

onde $\mathrm{C}=$ resistência à compressão $(\mathrm{MPa}) ; \mathrm{P}=$ carga total de ruptura $(\mathrm{N}) ; \mathrm{A}=$ área de aplicação da carga $\left(\mathrm{mm}^{2}\right)$.

O ensaio de compressão uniaxial $\left(\sigma_{c}\right)$ é considerado um dos índices mais confiáveis para a estimativa da resistência das rochas. A atuação do intemperismo resulta em uma imediata e significante redução na resistência à compressão.

Beavis (1985 apud Gupta; Rao, 2000) atribuíram essa queda na resistência à quebra das ligações entre os grãos minerais e ao desenvolvimento de microfraturas. Apesar da pronta resposta da resistência à compressão para a medida de intemperismo de rochas de um mesmo contexto geológico, esses autores, entretanto, apontam que a presença de microfraturas em rochas cristalinas (ígneas e metamórficas) é mais bem controlada pela resistência à tração do que à compressão.

\subsubsection{Flexão}

O ensaio de flexão (ou flexão por carregamento em quatro pontos) simula os esforços flexores em placas de rocha, com espessura predeterminada. Os corpos-deprova são apoiados em dois cutelos de suporte, com dois cutelos de carregamento (Figura 5.4). 


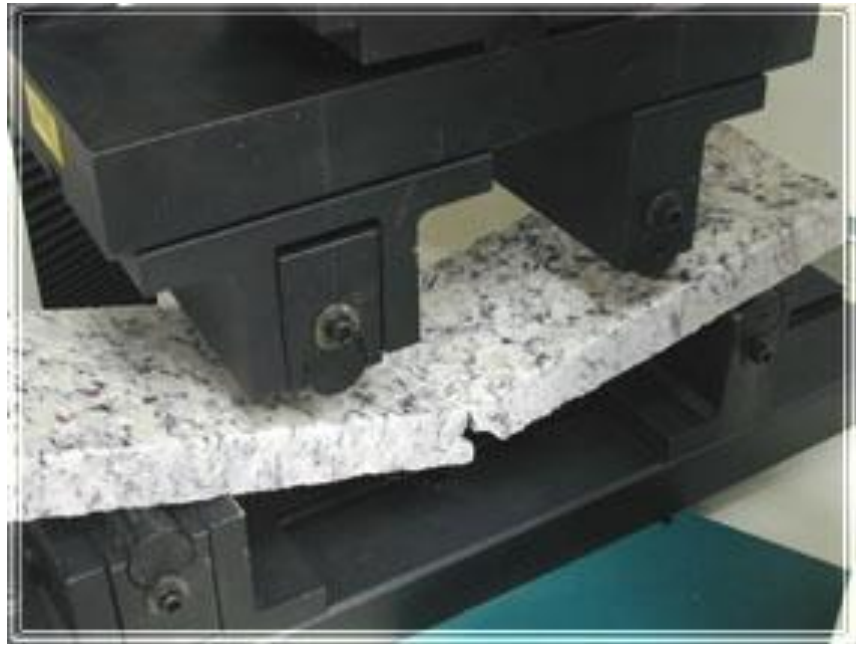

Figura 5.4 - Detalhe de corpo-de-prova, obtido de rocha polida, rompido após a aplicação de esforços.

Este ensaio determina a resistência de placas a se curvar ou flexionar, quando submetidas aos esforços de ventos, cargas ou outros, em edificações. Por isso, é particularmente importante para dimensionamento de materiais rochosos a serem utilizados no revestimento de fachadas, especialmente com o uso de sistemas de ancoragem metálica para a sua fixação.

O ensaio foi baseado na norma ASTM C 880 (ASTM, 1998) e realizado em dez corpos-de-prova, confeccionados a partir de ladrilhos polidos das rochas estudadas, com dimensões de $40 \mathrm{~cm} \times 10 \mathrm{~cm}$ x espessura do ladrilho. Nas rochas anisotrópicas foram obtidos doze corpos-de-prova, seis deles cortados perpendicularmente à estruturação e seis, segundo a estruturação.

A determinação da resistência à flexão foi determinada na condição seca, sendo metade dos corpos-de-prova no estado natural e metade após a realização de ensaio de choque térmico, conforme será descrito no item 5.3.2. Foi utilizada a máquina de ensaio Tinius Olsen, modelo H10K-S, com taxa de carregamento de 4,14 MPa/min.

A resistência à flexão é calculada a partir da equação:

$$
\sigma_{f}=\frac{3 W L}{4 b d^{2}}
$$

onde $\sigma_{f}=$ resistência à flexão $(\mathrm{MPa}) ; W=$ carga máxima $(\mathrm{N}) ; L=$ distância entre os cutelos inferiores $(\mathrm{mm})(L=10 d) ; b=$ largura do corpo-de-prova $(\mathrm{mm})(b \leq 1,5 d) ; d=$ espessura do corpo-de-prova $(\mathrm{mm})$. 


\subsubsection{Velocidade de propagação de ondas ultra-sônicas longitudinais}

A determinação da velocidade de propagação de ondas ultra-sônicas longitudinais (Figura 5.5) permite avaliar, indiretamente, o grau de alteração e de coesão das rochas. Sua vantagem reside em ser um dos poucos ensaios nãodestrutivos, disponíveis para verificação de propriedades rochosas.

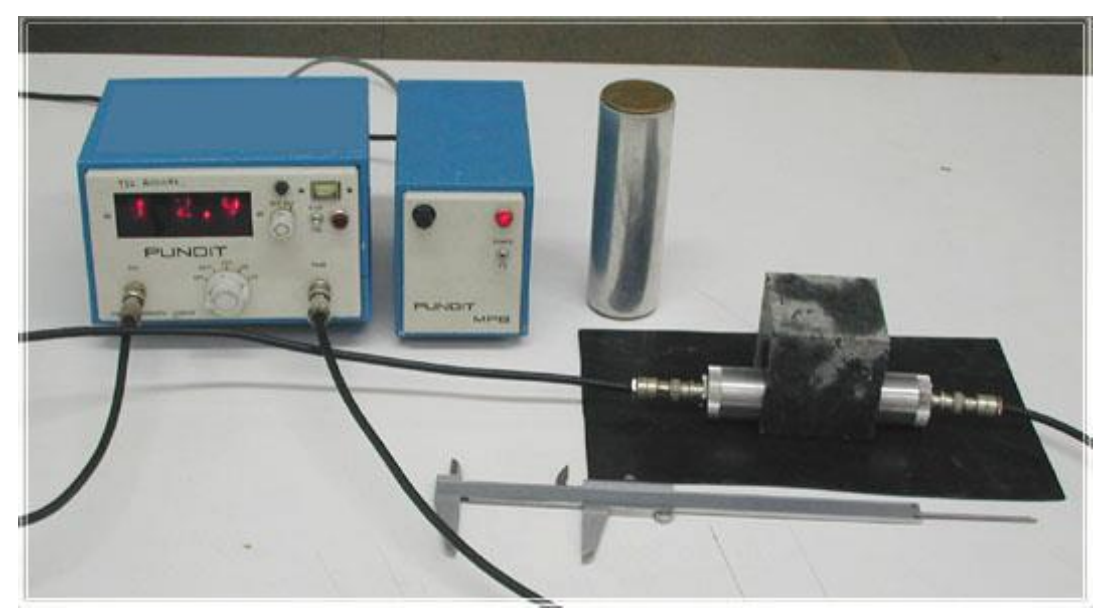

$$
V_{p}=L_{p} / T_{p}
$$

Figura 5.5 - llustração dos aparatos e procedimento de medida da velocidade de propagação de ondas ultra-sônicas.

onde, $V_{p}=$ velocidade de propagação de pulsos de ondas compressivas (longitudinais) $(\mathrm{m} / \mathrm{s}) ; L=$ distância percorrida pelo pulso $(\mathrm{m}) ; T=$ tempo efetivo de caminhamento do pulso (s).

Vários fatores influenciam a velocidade de propagação de ondas, entre as quais: tipo de rocha, densidade, tamanho e forma dos grãos, porosidade, anisotropia, temperatura etc. (Kahraman, 2002).

Por isso, é especialmente útil para comparação das propriedades físicas entre corpos-de-prova de uma mesma amostra ou entre amostras petrograficamente semelhantes. Em geral, os valores relativamente mais altos indicam menor grau de alteração e maior coesão entre os minerais formadores.

A determinação da velocidade de propagação de ondas, baseada na norma ASTM D 2845 (ASTM, 2000), foi efetuada em todos os corpos-de-prova destinados aos ensaios de compressão e flexão, sempre na condição seca, como ferramenta auxiliar na interpretação dos resultados. O aparelho utilizado foi o Portable Ultrasonic 
Non-Destructive Digital Indicating Test - PUNDIT.

Nos corpos-de-prova destinados ao ensaio de resistência à compressão, as medidas foram feitas segundo a direção de aplicação da carga, ou seja, nos topos e bases dos cubos. As rochas anisotrópicas tiveram determinações de acordo e perpedicularmente às direções principais de orientação (Figura 5.6).
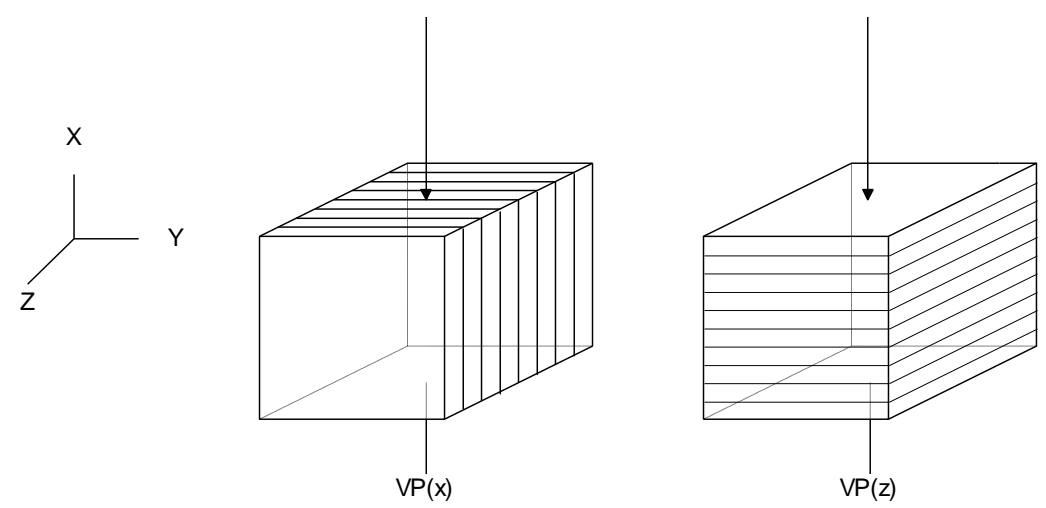

Figura 5.6 - llustração das medidas de velocidade de propagação de ondas em corpos-de-prova cúbicos.

Nos corpos-de-prova destinados ao ensaio de flexão, a velocidade de propagação de ondas foi determinada segundo o comprimento dos corpos-de-prova, conforme ilustrado na Figura 5.7.

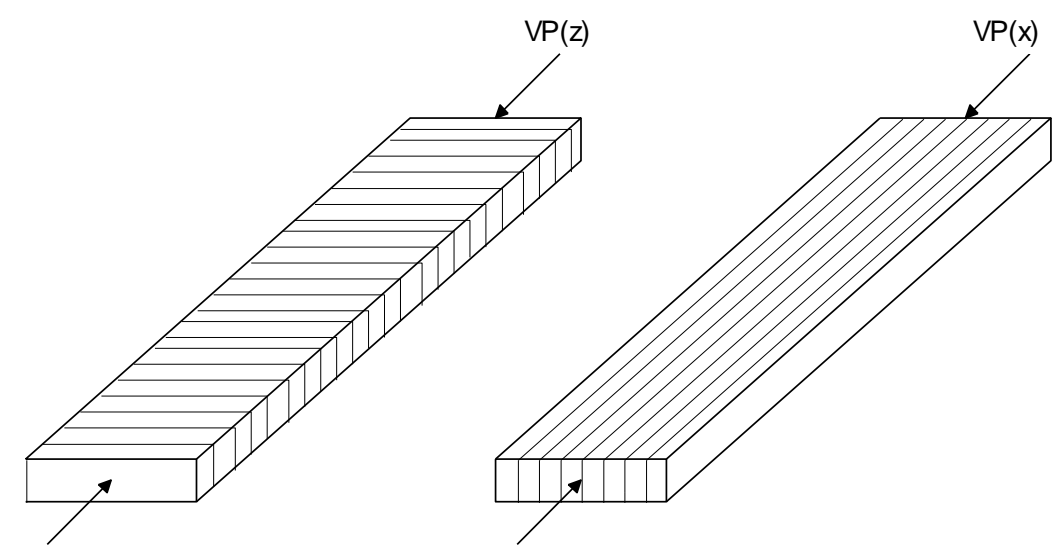

Figura 5.7 - llustração das medidas de velocidade de propagação de ondas em corpos-de-prova destinados aos ensaios de resistência à flexão.

\subsection{Ensaios de Alteração Acelerada}

A alteração e deterioração de rochas em edifícios e monumentos, como já comentado, estão ligadas à interação de fatores intrínsecos e extrínsecos.

Dentre as várias causas e mecanismos de deterioração rochosa apresentados 
no Capítulo 3, foram considerados relevantes e objetos de investigação a exposição ao meio ambiente, marinhos e poluídos, as variações térmicas e a ação da cristalização de sais, conforme Tabela 5.3.

Tabela 5.3 - Situações potencialmente degradadoras de rochas ornamentais.

\begin{tabular}{|c|c|c|}
\hline SITUAÇÃO & ENSAIO & OBJETIVO \\
\hline $\begin{array}{l}\text { VARIAÇÕES } \\
\text { TÉRMICAS }\end{array}$ & $\begin{array}{c}\text { Exposição de ladrilhos polidos e } \\
\text { amostras de rochas in natura a } \\
\text { choque térmico. }\end{array}$ & $\begin{array}{l}\text { Verificar eventual queda de resistência da } \\
\text { rocha, após ciclos de aquecimento e } \\
\text { resfriamento imediato em água. }\end{array}$ \\
\hline $\begin{array}{l}\text { AÇÃO DE } \\
\text { POLUENTES }\end{array}$ & $\begin{array}{c}\text { Exposição de ladrilhos polidos a } \\
\text { atmosferas ácidas e salinas, em } \\
\text { câmaras climáticas. }\end{array}$ & $\begin{array}{c}\text { Simulação de ambientes urbanos poluídos } \\
\text { (umidade e } \mathrm{H}_{2} \mathrm{SO}_{4} \text { ) e marinhos (névoa salina), } \\
\text { potencialmente degradadores de materiais } \\
\text { rochosos. }\end{array}$ \\
\hline $\begin{array}{l}\text { AÇÃO DA } \\
\text { CRISTALIZAÇÃO } \\
\text { DE SAIS }\end{array}$ & $\begin{array}{l}\text { Imersão parcial em soluções ácida e } \\
\text { alcalina. }\end{array}$ & $\begin{array}{c}\text { Simulação da cristalização de sais } \\
\text { (eflorescências e subeflorescências) na face } \\
\text { polida de ladrilhos de rocha para a observação } \\
\text { da sua ocorrência e possíveis efeitos } \\
\text { deletérios. }\end{array}$ \\
\hline
\end{tabular}

Os ensaios de alteração acelerada, em laboratório, simulando essas situações, visaram a fornecer informações quanto à alterabilidade da rocha em relação aos agentes intempéricos, além da investigação dos mecanismos de degradação para cada caso. As simulações de alteração procuraram verificar - dentro de um grupo de rochas graníticas relativamente homogêneas, quanto à composição mineralógica e química, mas heterogêneas em relação à ambiência geológica - as respostas dessas características intrínsecas quando expostas aos mesmos ambientes potencialmente degradadores.

Estes ensaios foram idealizados a partir da verificação de degradações em situações reais, de cujas causas não foram obtidas informações adequadas na literatura, e tampouco de investigações acerca de sua previsibilidade. Foram, dessa forma, realizados ensaios objetivando conhecer as respostas das rochas selecionadas às ações de poluição, ambientes marinhos e variações bruscas de temperatura, que pudessem subsidiar o conhecimento da durabilidade de rochas no revestimento externo de edificações.

Paralelamente, vistos os inúmeros casos de deteriorações por eflorescências, em pisos de residências e edifícios comerciais, foram realizados ensaios, inéditos, de imersão parcial em soluções ácidas e salinas (alcalinas).

Essas investigações buscam, finalmente, inserir os conceitos de durabilidade 
para os materiais em questão. A durabilidade de materiais, e mais recentemente de rochas, para construção civil ou em monumentos históricos é de fundamental importância, pois as agressividades do meio ambiente, como exposto no Capítulo 3, estão cada vez mais acentuadas.

Para a análise dos dados foram utilizadas as recomendações da norma ASTM G 169 (ASTM, 2001b), que visa à aplicação de métodos estatísticos práticos para os problemas reais que surgem nos campos da durabilidade e intemperismo. Esses métodos são úteis para tomada de decisões quando os procedimentos são planejados para testar hipóteses com uma única variável dependente.

Em testes de intemperismo e de durabilidade, a variável dependente é considerada a medida quantitativa de uma propriedade como densidade, massa, resistência à tensão etc. Algumas vezes, dados qualitativos como a hierarquização visual constitui a variável dependente e, nesses casos, métodos estatísticos não paramétricos são mais apropriados.

A variável independente é aquela que contribui para a mudança da variável independente e, essencialmente, está sob controle do experimento. Muitas vezes, uma variável não está sob contrlole do experimento, chamada variável bloqueadora (por exemplo, temperatura e precipitações em experimentos ao meio ambiente), que é lidada pelo fato de todas as amostras terem sido expostas aos mesmos efeitos.

\subsubsection{Ensaios em câmaras climáticas}

Foram selecionadas para ensaios as câmaras com exposição a $\mathrm{SO}_{2}$ e à névoa salina.

\subsubsection{Exposição ao dióxido de enxofre}

O ensaio por exposição ao $\mathrm{SO}_{2}$ baseia-se nas normas ABNT NBR 8096 (ABNT, 1983a) e DIN 50018 (DIN, 1997). Consiste em um determinado número de ciclos, de 24 horas cada, nos quais a câmara (Figura 5.8) é mantida aquecida por 8 horas a

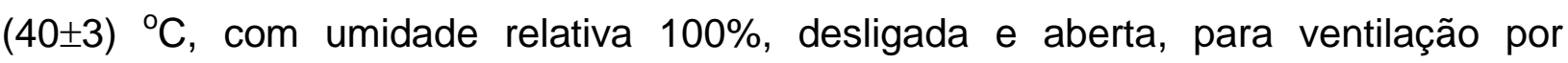
16 horas. Após isso, a água da câmara é renovada e inicia-se novo ciclo. 


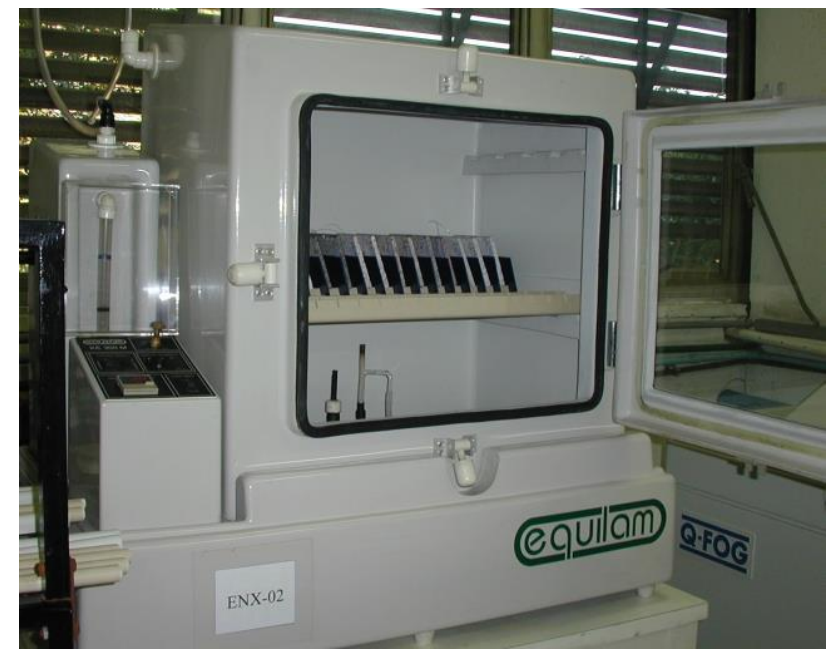

Figura 5.8 - Câmara climática para exposição ao $\mathrm{SO}_{2}$.

Grossi; Murray (1999) mencionaram, sem outras argumentações ou citações da literatura, que um período de exposição de 30 dias, nessas condições, simula um ano de exposição em área com precipitação média anual de $800 \mathrm{~mm}$.

A concentração de $\mathrm{SO}_{2}$, na água da bandeja na porção inferior da câmara, estipulada pela norma é de $0,67 \%$, que corresponde ao volume de $2,0 \mathrm{~L}$ de $\mathrm{SO}_{2}$ a ser adicionado a cada $300 \mathrm{~L}$ de volume da câmara.

Foram ensaiados três corpos-de-prova medindo $5 \mathrm{~cm} \times 15 \mathrm{~cm} \times 0,5 \mathrm{~cm}$, por amostra. Para cada tipo, foi reservado um corpo-de-prova padrão para controle.

Um dos corpos-de-prova teve a face não-polida e as laterais recobertas por tinta a óleo (Figura 5.9), para verificação de possível influência da exposição de somente uma face do CP (no caso, a face polida) nos resultados do ensaio.

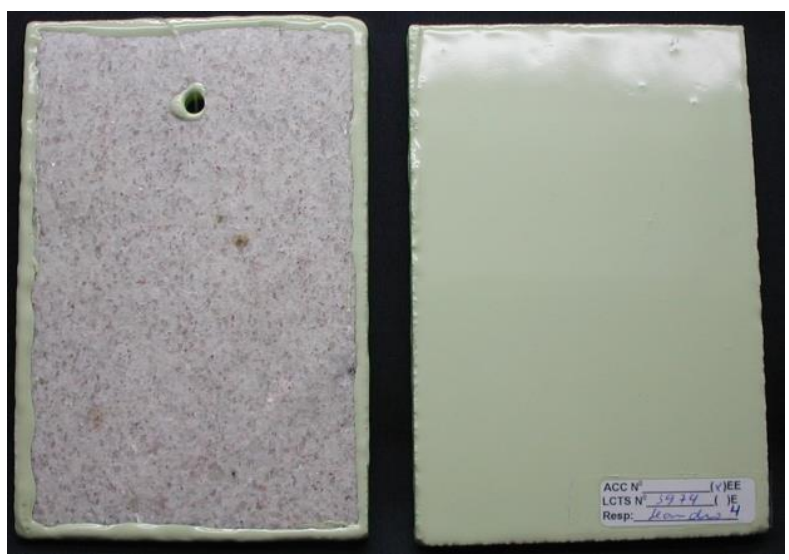

Figura 5.9 - Corpos-de-prova com a face não-polida recoberta com tinta óleo, para exposição ao $\mathrm{SO}_{2}$.

As inspeções foram realizadas após 16 horas de abertura da câmara; as modificações foram registradas em planilhas, e os corpos-de-prova fotografados. Não houve lavagem dos corpos-de-prova. 


\subsubsection{Exposição à névoa salina}

O ensaio de intemperismo artificial por exposição à névoa salina baseou-se nas normas ABNT NBR 8094 (ABNT, 1983b) e ASTM B 117 (ASTM, 1997).

Nesse ensaio, os corpos-de-prova são colocados em suportes na câmara, de modo a ficar com um ângulo de $15^{\circ}$ a $30^{\circ}$ com a vertical e permitir livre acesso da névoa a todos eles.

A solução salina é preparada dissolvendo-se $5 \pm 1$ partes, em massa, de cloreto de sódio em $95 \pm 1$ partes de água. $0 \mathrm{pH}$ da solução salina deve ser tal que, quando atomizada, a $35^{\circ} \mathrm{C}$, a solução tenha $\mathrm{pH}$ entre 6,5 e 7,2 .

Os corpos-de-prova ficam permanentemente no interior da câmara (Figura 5.10), sendo retirados somente para inspeções periódicas.

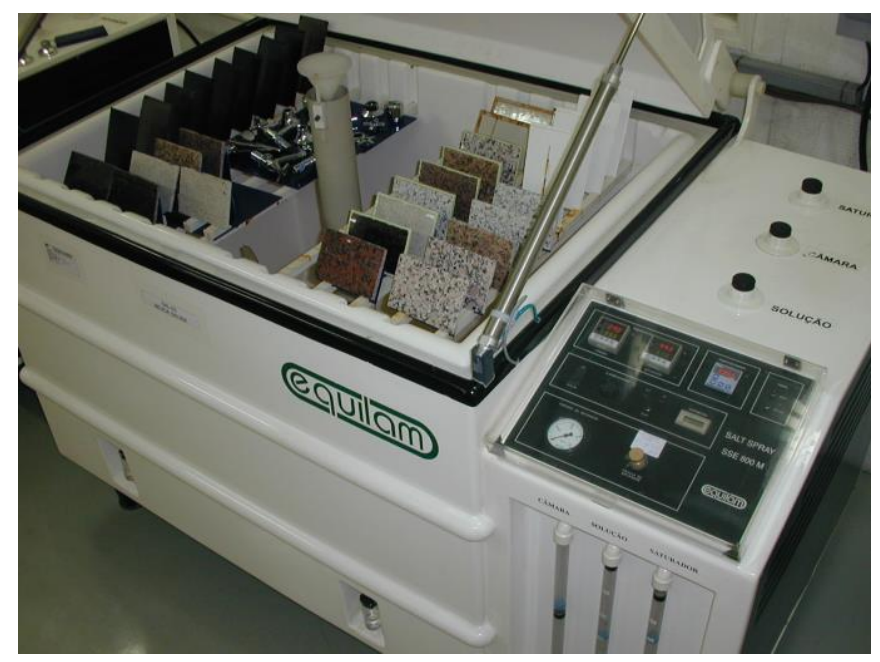

Figura 5.10 - Câmara climática de exposição à névoa salina.

À semelhança do ensaio de exposição ao $\mathrm{SO}_{2}$, foram ensaiados três corpos-deprova por amostra selecionada, cada qual medindo $5 \mathrm{~cm} \times 15 \mathrm{~cm} \times 0,5 \mathrm{~cm}$ e um corpode-prova padrão foi utilizado como controle. Um deles também teve a face não-polida e laterais recobertas por tinta a óleo.

Em cada inspeção, não ultrapassando o período de 30 minutos, os corpos-deprova foram lavados para eliminação do sal da superfície. As modificações foram registradas em planilhas, e os corpos-de-prova fotografados.

\subsubsection{Resistência ao choque térmico}

O ensaio de alteração por choque térmico é baseado nos procedimentos 
estabelecidos na versão preliminar da norma prEN WI 016 (CEN, 1998b), em elaboração pela CEN.

Visa verificar o decaimento da rocha após ciclos de aquecimento e resfriamento rápido, ou seja, decorrente de variações térmicas bruscas que propiciem dilatação e contração constantes, causa de uma das principais degradações de materiais rochosos na construção civil.

González-Messones (2002) recomenda este ensaio para verificação da possível oxidação, em rochas ígneas, e de desagregação, em mármores e calcários.

Nesta pesquisa, cinco a seis (quando obtidos a partir de rochas gnáissicas) corpos-de-prova, no tamanho e formato daqueles submetidos a ensaio de flexão, foram secos em estufa a $100^{\circ} \mathrm{C}$ por $24 \mathrm{~h}$ (até peso constante). Em cada um deles foi medida a velocidade de propagação de ondas ultra-sônicas longitudinais $\left(\mathrm{VP}_{\mathrm{i}}\right)$.

O ensaio propriamente dito consistiu em 20 ciclos, definidos pela colocação dos corpos-de-prova por $(18 \pm 1)$ h em estufa a $105{ }^{\circ} \mathrm{C}$, em seguida imediatamente submersos em água, a temperatura ambiente, por $(6 \pm 0,5) \mathrm{h}$.

Após o $20^{\circ}$ ciclo, os corpos-de-prova foram secos em estufa, a $100{ }^{\circ} \mathrm{C}$, durante $24 \mathrm{~h}$ (até peso constante). As velocidades de propagação de ondas ultra-sônicas longitudinais foram novamente medidas $\left(\mathrm{VP}_{\mathrm{f}}\right)$.

Todos os corpos-de-prova foram, então, submetidos a ensaio de flexão.

O decaimento por choque térmico é verificado pelas expressões:

$$
\Delta_{R F}=\frac{R F_{f}-R F_{i}}{R F_{i}} \times 100
$$

Equação 17

onde $\Delta_{R F}=$ variação de resistência à flexão $(\%) ; R F_{f}=$ resistência à flexão após o ensaio $(\mathrm{MPa}) ; R F_{i}=$ resistência à flexão antes do ensaio (MPa).

$$
\Delta_{V P}=\frac{V P_{f}-V P_{i}}{V P_{i}} \times 100
$$

Equação 18

onde $\Delta_{V P}=$ variação de velocidade de propagação de ondas (\%); $V P_{f}=$ velocidade de propagação de ondas após o ensaio $(\mathrm{m} / \mathrm{s}) ; V P_{i}=$ de propagação de ondas antes do ensaio $(\mathrm{m} / \mathrm{s})$. 


$$
\begin{array}{lll}
\Delta_{m}=\frac{m_{f}-m_{i}}{m_{i}} \times 100 \quad(\%) \quad \text { Equação } 19
\end{array}
$$

onde $\Delta_{m}=$ variação de massa (\%); $m_{f}=$ massa após o ensaio $(\mathrm{g}) ; m_{i}=$ massa antes do ensaio (g).

\subsubsection{Ensaios de alteração por imersão parcial em soluções ácidas e alcalinas}

Visando simular a exposição da rocha a ambientes quimicamente agressivos, ácidos e alcalinos, os corpos-de-prova foram colocados em contato com soluções de ácido sulfúrico $\left(\mathrm{H}_{2} \mathrm{SO}_{4}-1 \%\right)$, com pH 1 a 1,5, e de hidróxido de sódio $(\mathrm{NaOH}-1 \mathrm{~N})$, com pH 13,5 a 14.

A escolha do ácido sulfúrico baseou-se nas informações relativas aos poluentes atmosféricos, que reportam o ataque ácido por $\mathrm{SO}_{2}$ como um dos maiores agentes degradadores de rocha.

O ensaio consiste em deixar os corpos-de-prova parcialmente submersos (até cerca de $1 \mathrm{~cm}$, a partir da base), em recipientes plásticos, de fundo liso e reto, contendo as soluções mencionadas. As faces polidas ficaram expostas ao meio ambiente, para que as eventuais modificações fossem aí registradas. Foi realizado em sala desumidificada, com temperatura de cerca de $25^{\circ} \mathrm{C}$.

A duração foi de 30 dias consecutivos, com monitoramento diário e troca de soluções em dias alternados, com o registro das modificações. Após esse período, as soluções foram retiradas, e os corpos-de-prova continuaram no mesmo ambiente por um período de mais 30 dias, com monitoramento periódico, até sua secagem total.

Somente após esse período, os corpos-de-prova foram lavados com água deionizada e secados para verificação das deteriorações ocorridas, por comparação com suas contrapartes. Os sais formados foram identificados por difração de raios X.

$\mathrm{Na}$ imersão parcial, as eflorescências se desenvolvem na zona capilar (Benavente et al., 2001), conforme ilustrado na Figura 5.11. 


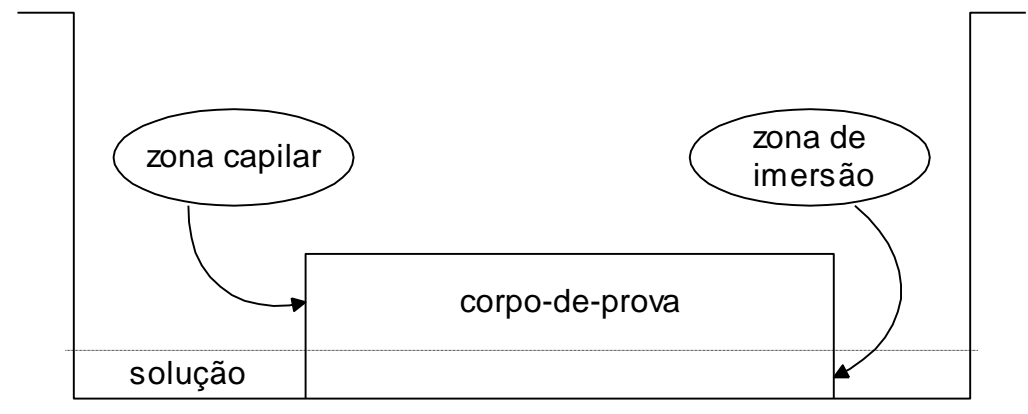

Figura 5.11 - llustração esquemática das zonas de imersão e capilar.

O mecanismo consiste na migração da solução, pela rocha, por capilaridade, da zona de imersão para a zona capilar, na qual, por evaporação e supersaturação, ocorre a cristalização dos sais. 


\section{CAPÍTULO 6}

\section{APRESENTAÇÃO E ANÁLISE DOS RESULTADOS}

Os resultados mostrados a seguir, foram analisados e discutidos à luz das informações anteriormente apresentadas, enfocando principalmente as características intrínsecas dos diferentes materiais estudados e as tendências que possam acrescentar conhecimento ao que já foi abordado ou de importância na alterabilidade deles.

No texto, são exibidos os valores médios, desvio padrão e coeficiente de variação dos principais parâmetros obtidos. Os resultados completos podem ser consultados nos ANEXOS B a F.

Sucintamente, os tópicos e aspectos abordados foram os seguintes:

- caracterização petrográfica e química: são apresentadas as características petrográficas importantes em relação a este estudo, quais sejam: tipo, tamanho e quantidade de minerais formadores de rocha, suas inter-relações e alterações, deformações e fissuramento.

A composição química é utilizada como um elemento qualificador, adicional, para complementar a caracterização da rocha e auxiliar na avaliação dos ensaios de alteração acelerada;

- índices físicos: apresentação e avaliação dos dados obtidos nas determinações de massa específica (densidade) aparente, porosidade e absorção pelos diferentes métodos adotados. Caracterização das propriedades intrínsecas das rochas estudadas;

- propriedades mecânicas: apresentação das resistências à compressão e flexão, obtidas no material in natura e beneficiado, respectivamente. Também foram realizados testes em corpos-de-prova dos mesmos materiais, submetidos à saturação em água e a ciclos de aquecimento e resfriamento (choque térmico), cujos resultados são apresentados e discutidos;

- alteração acelerada: os resultados dos diversos ensaios foram comparados entre $\mathrm{si}$, com os dados dos ensaios físicos e mecânicos e com as propriedades petrográficas. Modificações significantes foram verificadas por microscopia óptica. 
As amostras submetidas a esses ensaios foram designadas e agrupadas conforme mostrado na Tabela 6.1.

Tabela 6.1 - Designações adotadas para as amostras estudadas.

\begin{tabular}{|c|c|c|c|}
\hline $\begin{array}{l}\text { GRUPO DE } \\
\text { AMOSTRAS }\end{array}$ & DESIGNAÇÃO & NOME COMERCIAL & COR PREDOMINANTE \\
\hline 1 & LBD & Verde Labrador & verde \\
\hline \multirow{3}{*}{2} & VCB-1 & Capão Bonito - 1 & vermelha \\
\hline & VCB-2 & Capão Bonito - 2 & vermelha \\
\hline & VCB-3 & Capão Bonito - 3 & vermelha \\
\hline \multirow{3}{*}{3} & RIC & Rosa Iracema & rosa \\
\hline & BCR & Branco Cristal Quartz & branco-rosada \\
\hline & BSV & Branco Savana & branco-rosada \\
\hline \multirow{2}{*}{4} & PIT & Prata Interlagos & cinza \\
\hline & AZF & Azul Paulista Frente Nova & cinza \\
\hline 5 & BCE & Branco Ceará & branca \\
\hline \multirow{3}{*}{6} & ITN-1 & Branco Itaúnas (Microponto II) & branco-amarelada \\
\hline & ITN-2 & Branco Itaúnas (Microponto III) & branco-amarelada \\
\hline & CRV & Branco Caravelas & branco-esverdeada \\
\hline \multirow[b]{2}{*}{7} & CSB & Casablanca & branca, com faixas cinza \\
\hline & FLS & Falésias & $\begin{array}{l}\text { branco-amarelada, com faixas } \\
\text { amarelo-ferrugem }\end{array}$ \\
\hline \multirow{3}{*}{8} & GVN & Giallo Veneciano & amarela \\
\hline & ARB & Arabesco & verde-clara \\
\hline & ScC & Santa Cecília & amarela \\
\hline
\end{tabular}

Os oito grupos foram discriminados com base no critério de proximidade geológica e/ou geográfica e cores predominantes.

Este grupamento procura facilitar a apresentação e análise dos dados, ao mesmo tempo em que discrimina comercialmente os diferentes grupos de rochas. A relevância disso é que se procurou, neste trabalho, conjugar as generalizações praticadas pelo mercado com o conhecimento científico e tecnológico, de forma a proporcionar a aplicação mais direta dos resultados obtidos.

A regressão linear e a determinação de coeficientes de correlação $(R)$ - Pearson - foram as técnicas estatísticas utilizadas. Para a análise conjunta dos resultados obtidos nesse trabalho, consideraram-se os níveis de correlação conforme Tabela 6.2. 
Tabela 6.2 - Níveis de correlação considerados nesse trabalho.

\begin{tabular}{cc}
\hline valor & correlação \\
\hline$R=0$ & nula \\
\hline $0<R<0,30$ & muito fraca \\
\hline $0,30<R<0,50$ & fraca \\
\hline $0,50<R<0,70$ & média \\
\hline $0,70<R<0,90$ & forte \\
\hline $0,90<R<1$ & muito forte \\
\hline$R=1$ & perfeita \\
\hline
\end{tabular}

\subsection{Propriedades Petrográficas e Químicas}

A análise petrográfica enfocou, principalmente, a identificação, quantificação e determinação das inter-relações dos minerais essenciais; a observação e descrição das feições julgadas, a priori, condicionadoras de degradações nos ensaios de alteração acelerada: fissuramento, granulação, alterações preexistentes, presença de minerais potencialmente instáveis e outras. Considerou-se que estas informações são essenciais para a caracterização petrográfica das rochas e fundamentais para estudos de alterabilidade e diagnósticos de degradação rochosa.

Embora pouco utilizada, especialmente no Brasil, a composição química da rocha é um importante complemento aos dados petrográficos. Devido à sua ainda incipiente utilização na caracterização de rochas ornamentais, não há disponibilidade de orientações quanto ao uso adequado dessas informações visando à alterabilidade. Desta forma, neste trabalho procurou-se estabelecer as tendências das diferentes rochas e sua integração com os resultados dos vários ensaios realizados, destacadamente os de alteração acelerada.

\subsubsection{Características petrográficas}

A análise petrográfica, nesse estudo, compreendeu os aspectos descritivos: tipo e quantidade dos minerais essenciais, acessórios e de alteração, relações texturais, granulação, com especial enfoque nos padrões de fissuramento e de alteração intempérica.

Por se tratar de uma pesquisa de caráter experimental, em que se utilizaram diferentes tipos de rochas graníticas para verificação de possíveis condicionantes de 
alterações, privilegiou-se o estudo comparativo àquele focado nas peculiaridades petrológicas de cada tipo rochosos selecionado.

Um outro enfoque, contribuindo para futuras proposições normativas, foi o de procurar padronizar as descrições de modo a torná-las suficientemente informativas da rocha analisada, ao mesmo tempo em que subsidiem a comparação com as outras rochas em estudo. As recomendações da norma BS EN 12407 (BSI, 2000) auxiliaram a definição e priorização dos principais aspectos abordados.

Uma grande dificuldade na descrição petrográfica é a padronização da abordagem de dois aspectos fundamentais: grau de alteração intempérica e grau de microfissuramento*. Mesmo quando se efetuam análises modais, que sem dúvida trazem maior precisão que estimativas visuais, permanece um grau de incerteza relativo à padronização do que se está computando na contagem.

Com base na experiência em análises petrográficas com esse enfoque, é aqui proposta a graduação dessas feições em quatro classes, quando avaliada, preferencialmente, em lupa estereoscópica binocular, no aumento aproximado de 50X, conforme Tabela 6.3.

Deve ser ressaltado que essa graduação se refere a rochas que, do ponto de vista da geologia de engenharia e da geotecnia, são consideradas frescas ou levemente alteradas, como pode ser observado na Tabela 6.4, compilada de Gupta; Rao (2000) e Frazão (2002).

A despeito da importância geológica das alterações hidrotermais e metassomáticas, não lhes foram dadas o mesmo destaque que para a alteração intempérica, visto que elas não estão relacionadas às modificações na porosidade ou nas resistências mecânicas aqui investigadas.

\footnotetext{
* De acordo com Houaiss; Villar (2001): Fissura "GEOL. Qualquer fratura ou fenda pouco alargada em terreno, rocha ou mesmo mineral". Segundo essa mesma fonte: Fissuração "condição do que está rachado ou fendido"; Fissuramento "ação ou efeito de fissurar". Ou seja, o mais correto parece ser o termo fissuração, a despeito do uso já tradicional do termo fissuramento, também aqui empregado.
} 
Tabela 6.3 - Graus de alteração intempérica e de microfissuramento adotados nesse trabalho.

\begin{tabular}{|c|c|c|}
\hline GRAU & ALTERAÇÃO INTEMPÉRICA & MICROFISSURAMENTO \\
\hline Incipiente & $\begin{array}{l}\text { Cristais praticamente límpidos e sem presença de } \\
\text { hidróxidos de ferro, mesmo em fissuras. }\end{array}$ & fissuras praticamente imperceptíveis. \\
\hline Fraco & $\begin{array}{l}\text { Muito leve turbidez de cristais de plagioclásio, } \\
\text { incipientes modificações em minerais máficos e } \\
\text { poucos hidróxidos de ferro associados. }\end{array}$ & $\begin{array}{l}\text { microfissuras perceptíveis; } \\
\text { predominantemente intragranulares, } \\
\text { fechadas e, freqüentemente, sem } \\
\text { preenchimento }\end{array}$ \\
\hline Moderado & $\begin{array}{l}\text { Cristais de plagioclásio estão, especialmente nos } \\
\text { núcleos, turvos por argilominerais, freqüentemente } \\
\text { com carbonato, sericita e hidróxidos de ferro } \\
\text { associados. } \\
\text { Biotita está parcialmente alterada, com liberação de } \\
\text { hidróxidos de ferro. } \\
\text { Outros minerais também podem estar parcialmente } \\
\text { alterados, como, por exemplo, sillimanita, em } \\
\text { filossilicatos secundários. }\end{array}$ & $\begin{array}{l}\text { microfissuras totalmente perceptíveis; } \\
\text { predominantemente intra e } \\
\text { intergranulares, preenchidas, mas } \\
\text { pouco largas. }\end{array}$ \\
\hline Forte & $\begin{array}{l}\text { Feldspatos, especialmente plagioclásio, estão } \\
\text { parcialmente alterados em argilominerais, com } \\
\text { sericita, carbonato e hidróxidos de ferro associados. } \\
\text { Demais minerais, exceto quartzo, apresentam-se, } \\
\text { em diferentes intensidades, também parcial a } \\
\text { totalmente alterados, principalmente em } \\
\text { argilominerais e hidróxidos de ferro. }\end{array}$ & $\begin{array}{l}\text { microfissuras totalmente perceptíveis, } \\
\text { trans, inter e intragranulares, } \\
\text { preenchidas e largas. }\end{array}$ \\
\hline
\end{tabular}

Tabela 6.4 - Categorias e descrição de granitos alterados.

\begin{tabular}{|c|c|}
\hline Graduações & Descrição da identificação visual \\
\hline Rocha sã $\left(\mathrm{A}_{0}\right)$ & $\begin{array}{l}\text { Sem indícios macroscópicos de alteração. Sem descoloração. Grãos têm brilho } \\
\text { vítreo. Virtualmente sem fraturas presentes. Quebra-se com dificuldade ao golpe } \\
\text { de martelo. }\end{array}$ \\
\hline $\begin{array}{l}\text { Pouco alterada } \\
\qquad\left(A_{1}\right)\end{array}$ & $\begin{array}{c}\text { Alteração incipiente dos minerais; em geral a rocha exibe pouca descoloração. } \\
\text { Oxidação incipiente. Minerais estão foscos, mas os grãos estão firmemente } \\
\text { ligados. Alguns feldspatos podem estar pulverulentos. Finas fraturas são } \\
\text { visíveis, em pequena quantidade. }\end{array}$ \\
\hline $\begin{array}{l}\text { Moderadamente } \\
\text { alterada }\left(\mathrm{A}_{2}\right)\end{array}$ & $\begin{array}{l}\text { Levemente oxidadas. Minerais medianamente alterados, geralmente sem brilho. } \\
\text { Poucos grãos têm aparência arenosa. Microfissuras alteradas, mas fechadas, } \\
\text { são visíveis. Plagioclásio está alterado. Feldspatos podem ser riscados. A rocha } \\
\text { pode ser quebrada com um golpe firme de martelo. }\end{array}$ \\
\hline $\begin{array}{l}\text { Intensamente } \\
\text { alterada }\left(A_{3}\right)\end{array}$ & $\begin{array}{l}\text { Descolorida e fortemente oxidada, com cor marrom clara. Minerais estão muito } \\
\text { alterados, muitas vezes friáveis e pulverulentos. Microfissuras estão preenchidas } \\
\text { por argilominerais. Maioria dos feldspatos está decomposta. }\end{array}$ \\
\hline $\begin{array}{l}\text { Completamente } \\
\text { alterada }\left(\mathrm{A}_{4}\right)\end{array}$ & $\begin{array}{l}\text { Completamente descolorida. Pontos de argila branca estão presentes. Minerais } \\
\text { estão totalmente friáveis. Microfissuras estão abertas ou preenchidas por argila. } \\
\text { Amostras podem ser destorroadas com os dedos. }\end{array}$ \\
\hline Solo residual $\left(A_{5}\right)$ & $\begin{array}{c}\text { Textura original desaparece. A rocha torna-se granular, virtualmente sem } \\
\text { resistência. }\end{array}$ \\
\hline
\end{tabular}

Fonte: Gupta; Rao (2000) e Frazão (2002).

A quantificação dos minerais essenciais foi realizada por meio da avaliação visual da distribuição dos minerais na rocha, conforme item 5.1.1, após ensaio de coloração seletiva de feldspatos (Figura 6.1). 


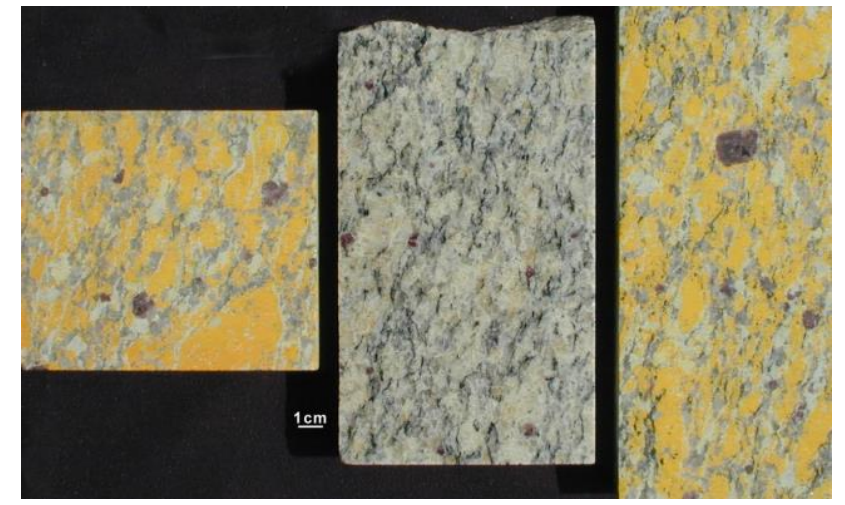

SCC

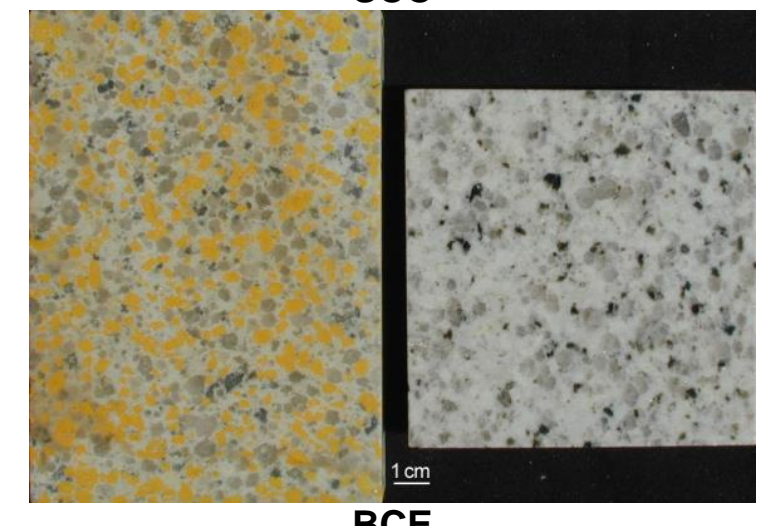

BCE

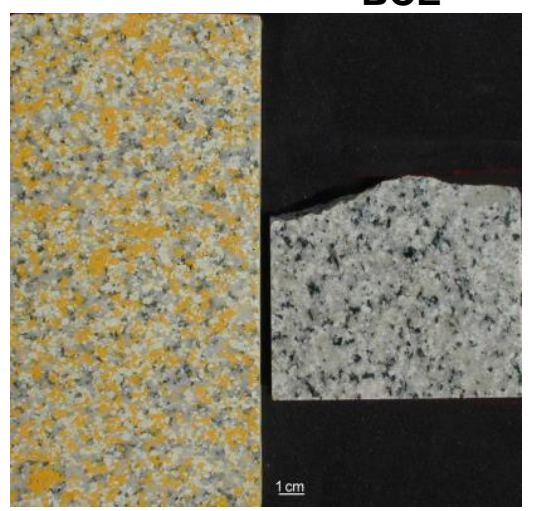

PIT

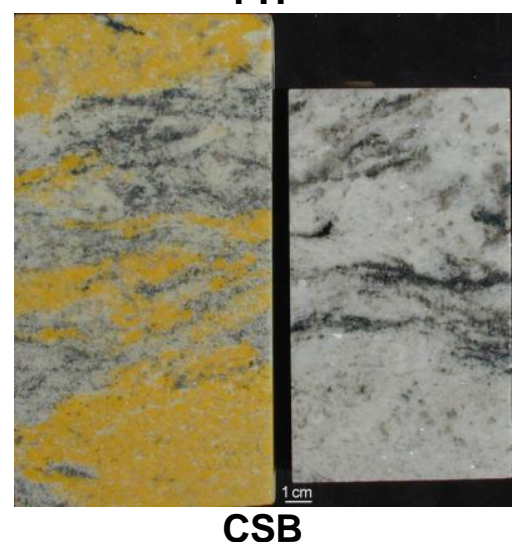

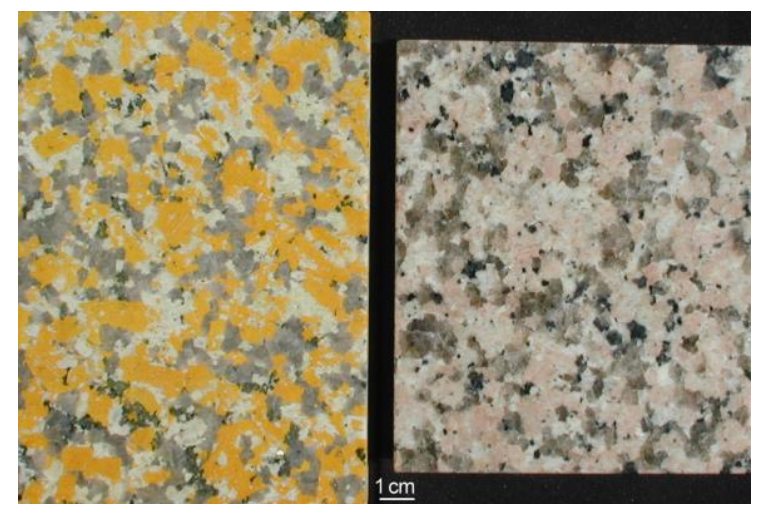

RIC
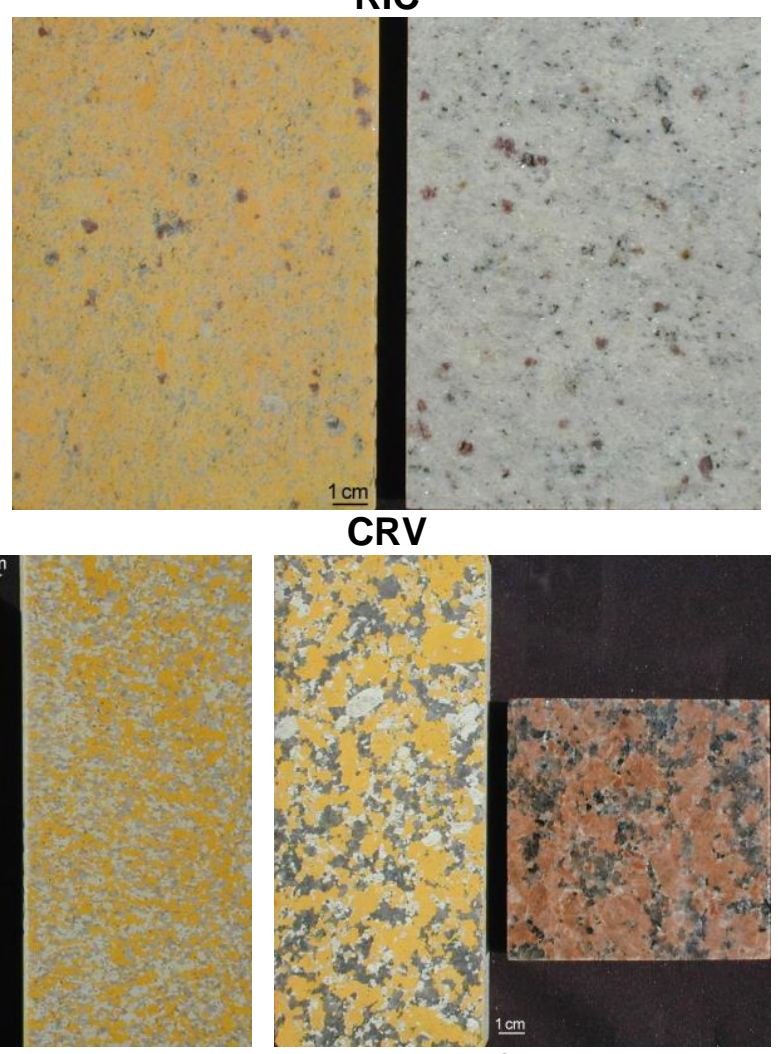

VCB-2

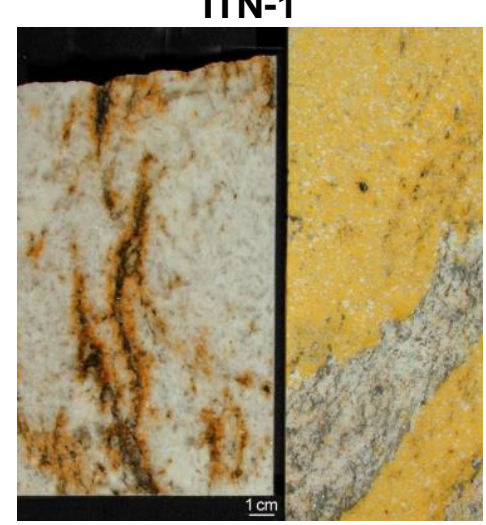

FLS

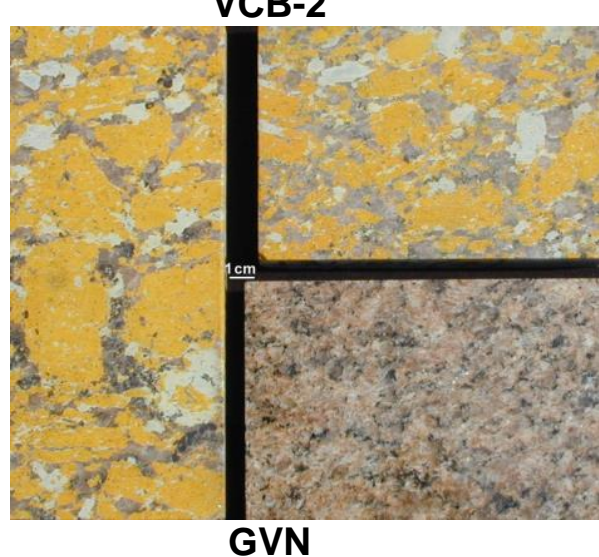

Figura 6.1 - Resultados da coloração seletiva para feldspatos. 
A análise modal, baseada nas recomendações de Jones (1987), foi feita com o intuito de comparar as porcentagens computadas por esses dois métodos. Contemplou a contagem de 600 a 800 pontos, conforme a granulação da rocha, e cujos resultados são apresentados na Tabela 6.5 .

Tabela 6.5 - Resultados da quantificação de minerais.

\begin{tabular}{|c|c|c|c|c|c|c|c|c|c|c|c|}
\hline & \multicolumn{2}{|c|}{$\mathbf{Q}$} & \multicolumn{2}{|c|}{ PI } & \multicolumn{2}{|c|}{ KF } & \multicolumn{2}{|c|}{$\mathrm{Gr}$} & \multicolumn{2}{|c|}{$\mathbf{B i}$} & \multirow{2}{*}{$\begin{array}{l}\mathrm{Mu} \\
\mathrm{AM}\end{array}$} \\
\hline & CS & AM & CS & AM & CS & AM & CS & AM & CS & AM & \\
\hline LBD & 25 & 13 & 18 & 36 & 57 & 44 & 0 & 6 & 0 & 2 & \\
\hline VCB-1 & 33 & 32 & 14 & 19 & 50 & 45 & & & 3 & 5 & \\
\hline VCB-2 & 28 & 30 & 17 & 16 & 51 & 50 & & & 4 & 4 & \\
\hline VCB-3 & 32 & 30 & 16 & 24 & 51 & 41 & & & & 6 & \\
\hline RIC & 34 & 35 & 22 & 27 & 38 & 35 & & & 5 & 3 & \\
\hline BSV & 30 & 37 & 26 & 27 & 43 & 32 & & & 1 & 4 & \\
\hline BCR & 31 & 33 & 29 & 42 & 39 & 22 & & & 1 & 3 & \\
\hline PIT & 27 & 43 & 29 & 26 & 38 & 25 & & & 5 & 4 & 2 \\
\hline AZF & 30 & 30 & 31 & 33 & 37 & 31 & & & 3 & 5 & 1 \\
\hline BCE & 28 & 42 & 36 & 22 & 30 & 30 & & & 5 & 0 & 6 \\
\hline ITN-1 & 25 & 33 & 25 & 11 & 50 & 50 & & 2 & 0 & 4 & \\
\hline ITN-2 & 25 & 35 & 31 & 28 & 45 & 36 & & & 0 & 1 & 1 \\
\hline CVR & 11 & 23 & 0 & 1 & 87 & 75 & 3 & 1 & & & \\
\hline CSB - A & 15 & 49 & 33 & 31 & 48 & 5 & & & 5 & 2 & 13 \\
\hline CSB - B & 9 & 30 & 9 & 15 & 77 & 49 & & & 5 & 1 & 5 \\
\hline FLS - A & 26 & 46 & 49 & 20 & 22 & 22 & & & 3 & 1 & 10 \\
\hline FLS - B & 3 & - & 18 & - & 67 & - & - & - & 12 & - & - \\
\hline ARB & 35 & 48 & 22 & 8 & 39 & 39 & 3 & 3 & & 2 & 1 \\
\hline Scc & 24 & 36 & 18 & 12 & 54 & 44 & 2 & 6 & 3 & 1 & \\
\hline
\end{tabular}

Nota: CS = contagem em amostra de mão com coloração seletiva de feldspatos; $A M=$ análise modal. $\mathrm{Q}=$ quartzo (\%); $\mathrm{PI}$ = plagioclásio (\%); KF = feldspato potássico (\%); $\mathrm{Gr}=$ granada (\%); $\mathrm{Bi}=$ biotita \%); $\mathrm{Mu}=$ muscovita $(\%)$.

Teoricamente, é esperado que as contagens realizadas pelos dois procedimentos apresentem valores próximos ou alguma correlação positiva. Para a verificação disso, foram calculadas as correlações entre os resultados obtidos, conforme apresentados na Figura 6.2.

As correlações obtidas são positivas; muito fraca para quartzo, fraca a média para plagioclásio e média a forte para feldspato alcalino. A distribuição dos grãos na rocha, seus tamanhos relativos e a área de contagem abrangida nesses dois procedimentos parecem ser a explicação mais adequada para as diferenças encontradas. A maior área de amostragem na contagem de minerais em amostras de mão, submetidas a ensaio de coloração seletiva, reflete melhor a composição global da rocha, 


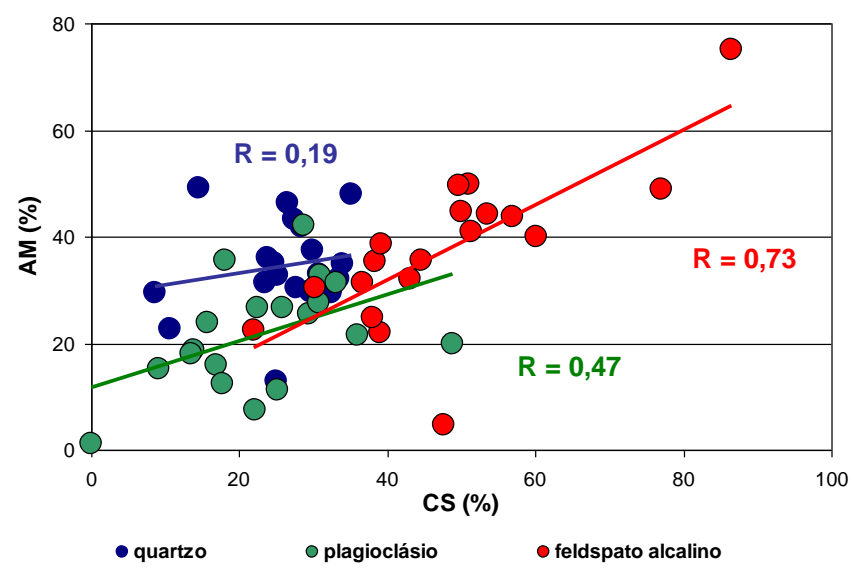

Figura 6.2 - Correlações entre contagens em amostra de mão e análise modais para quartzo, plagioclásio e feldspato alcalino.

A granulação média a grossa das rochas em estudo, as maiores dimensões e a menores variações de tamanhos de feldspato alcalino e plagioclásio, como mostrado na Tabela 6.6 e na Figura 6.3, também colaboraram para que a análise modal, freqüentemente, não fornecesse a composição mineralógica mais representativa da rocha.

Tabela 6.6 - Variações de tamanho de grão e tamanho de grão predominante.

\begin{tabular}{ccccccccc}
\hline & \multicolumn{2}{c}{$\mathbf{Q}$} & \multicolumn{2}{c}{ PI } & \multicolumn{2}{c}{ KF } & \multicolumn{2}{c}{ Bi } \\
\hline & $\Delta_{g r}$ & pred. & $\Delta_{g r}$ & pred. & $\Delta_{g r}$ & pred. & $\Delta_{g r}$ & pred. \\
\hline LBD & $1-18$ & 8 & $1-18$ & 5 & $4-23$ & 15 & $1-3$ & 2 \\
\hline VCB-1 & $2-5$ & 3 & $1-4$ & 2 & $2-18$ & 7 & 2 & - \\
\hline VCB-2 & $1-8$ & 6 & 5 & 2 & $5-15$ & 7 & $1-3$ & 1,5 \\
\hline VCB-3 & $1-8$ & 3 & $1-6$ & 2,5 & $3-18$ & 7 & 1 & 1 \\
\hline RIC & $1-8$ & 2,5 & $1-4$ & 2,5 & $4-16$ & 8 & $0,5-2,5$ & 1,5 \\
\hline BSV & $1-8$ & 5 & $0,5-3,5$ & 1,5 & $2-8$ & 5 & $0,5-3$ & 1 \\
\hline BCR & $1-6$ & 2 & $1-8$ & 5 & $3-12$ & 5 & $0,5-2,5$ & 1 \\
\hline PIT & $0,5-3,0$ & 1 & $0,5-5,0$ & 1,5 & $1-8$ & 3 & $0,5-1,5$ & 1 \\
\hline AZF & $1-5$ & 2,5 & $0,5-3,5$ & 1,5 & $1-18$ & 5 & $1,5-2,5$ & 1,5 \\
\hline BCE & $3-11$ & 8 & $0,5-2,0$ & 1,5 & $6-11$ & 8 & - & - \\
\hline ITN-1 & $1-15$ & 5 & $1-3$ & 3 & $1-8$ & 7 & - & - \\
\hline ITN-2 & $3-14$ & 8 & $1-3$ & 1,5 & $1-8$ & 7 & - & - \\
\hline CRV & $0,1-3,5$ & 0,5 & $0,2-1,0$ & 0,2 & $0,3-2,0$ & 0,5 & - & - \\
\hline CSB A & $0,5-15$ & 4 & $1-15$ & 5 & $1-7$ & 3 & 2,5 & - \\
\hline CSB B & 1 & 1 & $1-9$ & 2 & $1-9$ & 2,5 & 2,5 & - \\
\hline FLS & $0,5-1,5$ & 1 & 2 & 2 & 1,6 & 2,5 & 1 & - \\
\hline GVN & $0,5-15,0$ & 6 & $1-10$ & 8 & $4-30$ & 15 & $0,5-3,0$ & - \\
\hline ARB & $1-25$ & 8 & $1-9$ & 5 & 15 & 15 & 1 & - \\
\hline SCC & $0,5-15,0$ & 7 & $2-10$ & 3 & $2-7$ & 4 & $0,5-2,5$ & 1 \\
\hline
\end{tabular}

Nota: $\Delta_{g r}=$ variação de tamanho dos grãos $(\mathrm{mm})$; pred. = tamanho grão predominante $(\mathrm{mm})$. Demais símbolos, iguais à Tab. 6.5 . 


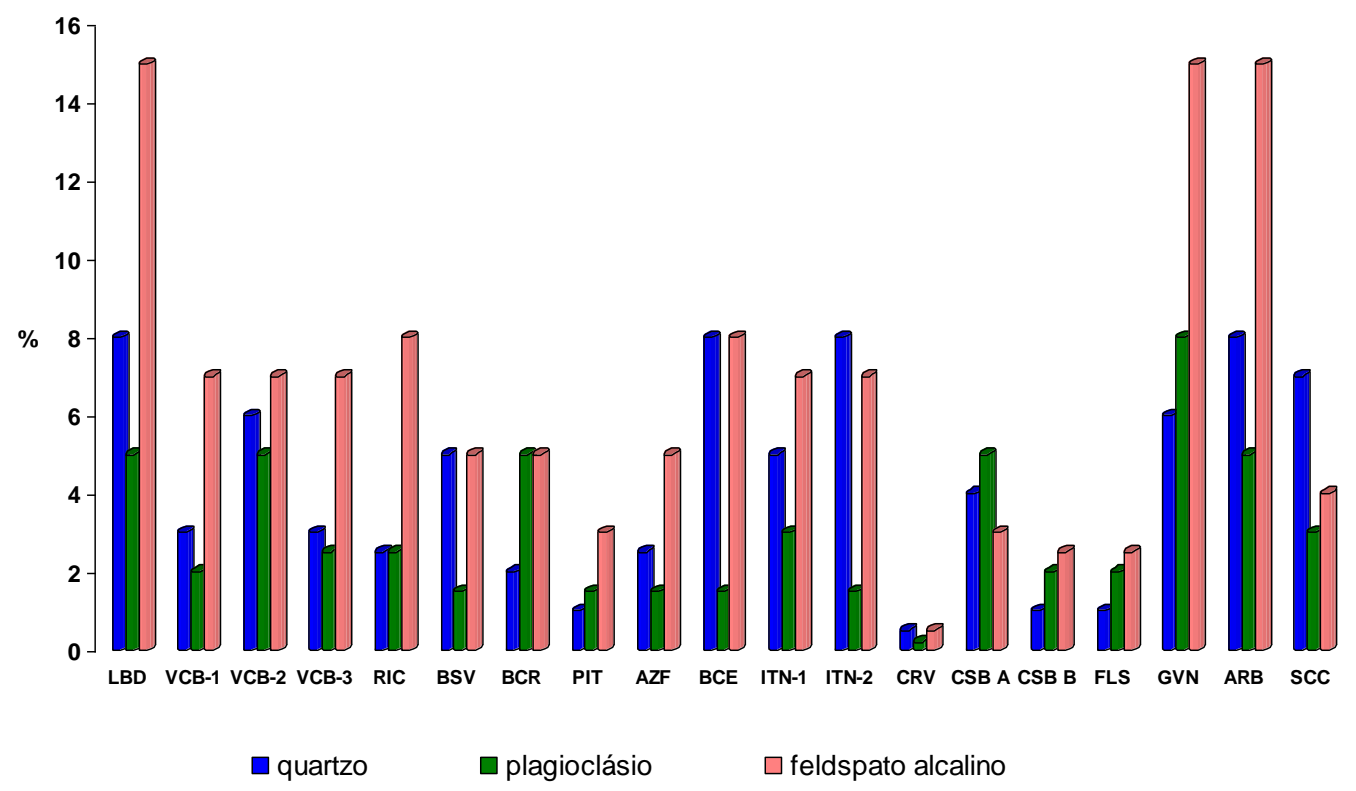

Figura 6.3 - Distribuição do tamanho de quartzo, plagioclásio e feldspato alcalino nas diferentes rochas estudadas.

O feldspato alcalino tende a apresentar o maior tamanho de grão, o plagioclásio, o menor e o quartzo, a maior variação granulométrica nas rochas estudadas, aspectos que devem influenciar o comportamento das rochas quanto às suas resistências mecânicas e alterabilidade.

Os resultados das análises petrográficas estão mostrados a seguir. A composição mineralógica apresentada nas tabelas síntese é o resultado dos dados obtidos nas contagens em amostra de mão, corrigidos pelos teores dos outros minerais observados nas várias lâminas delgadas confeccionadas.

\subsubsection{Vermelho Capão Bonito}

Na região de Capão Bonito, Estado de São Paulo, no contexto do corpo granítico Capão Bonito, ocorrem granitos vermelhos a vermelho amarronzados, homogêneos e de granulação média a grossa, comercialmente conhecidos como Vermelho Capão Bonito (VCB-1, VCB-2 e VCB-3). Petrograficamente classificam-se como biotita sienogranitos, muitas vezes com teores de plagioclásio limítrofes com o campo dos monzogranitos (Tabela 6.7). 
Tabela 6.7 - Resultados de análises petrográficas das amostras VCB-1, VCB-2 e VCB-3.

\begin{tabular}{|c|c|c|c|c|}
\hline \multicolumn{2}{|c|}{ AMOSTRA } & VCB-1 & VCB-2 & VCB-3 \\
\hline \multirow{2}{*}{ cor } & natural & vermelho médio a escuro & vermelho-claro & $\begin{array}{l}\text { vermelho-claro } \\
\text { amarronzado }\end{array}$ \\
\hline & polida & vermelho médio a escuro & vermelho-claro & $\begin{array}{l}\text { vermelho-claro } \\
\text { amarronzado }\end{array}$ \\
\hline \multicolumn{2}{|c|}{ estrutura } & maciça & maciça & maciça \\
\hline \multicolumn{2}{|c|}{ textura } & $\begin{array}{l}\text { ineqüigranular } \\
\text { hipidiomórfica }\end{array}$ & $\begin{array}{l}\text { ineqüigranular } \\
\text { hipidiomórfica }\end{array}$ & $\begin{array}{l}\text { ineqüigranular } \\
\text { hipidiomórfica }\end{array}$ \\
\hline \multicolumn{2}{|c|}{ granulação } & $\begin{array}{l}\text { média a grossa: em geral } \\
\text { entre } 3-8 \mathrm{~mm} \text {; microclínio, } \\
\text { até } 18 \mathrm{~mm}\end{array}$ & $\begin{array}{l}\text { média a } \\
\text { predominantemente } \\
\text { grossa: } 5-15 \mathrm{~mm}\end{array}$ & $\begin{array}{l}\text { média a grossa: } 2-10 \mathrm{~mm} \text {; } \\
\text { microclínio até } 18 \mathrm{~mm}\end{array}$ \\
\hline \multicolumn{5}{|c|}{ mineralogia (\%) } \\
\hline \multicolumn{2}{|c|}{ quartzo } & $30-35$ & 30 & 30 \\
\hline \multicolumn{2}{|c|}{ plagioclásio } & 15 (oligoclásio) & 15 (oligoclásio) & 15-20 (oligoclásio) \\
\hline \multicolumn{2}{|c|}{ microclínio } & 45 (micropertítico) & 45-50 (micropertítico) & 40-45 (pertítico) \\
\hline \multicolumn{2}{|c|}{ biotita } & $5-10$ & $5-10$ & 10 \\
\hline \multicolumn{2}{|c|}{ acessórios (tr) } & $\begin{array}{l}\text { opacos, apatita, zircão, } \\
\text { fluorita }\end{array}$ & $\begin{array}{l}\text { titanita, opacos, fluorita, } \\
\text { apatita, zircão }\end{array}$ & $\begin{array}{l}\text { opacos, apatita, zircão, } \\
\text { fluorita, muscovita, biotita } \\
\text { verde }\end{array}$ \\
\hline \multicolumn{2}{|c|}{ secundários } & $\begin{array}{l}\text { sericita, clorita, carbonato, } \\
\text { hidróxidos de ferro, } \\
\text { argilominerais }\end{array}$ & $\begin{array}{l}\text { clorita, sericita, carbonato, } \\
\text { hidróxidos de ferro, } \\
\text { argilominerais }\end{array}$ & $\begin{array}{l}\text { sericita, clorita, carbonato, } \\
\text { hidróxidos de ferro, } \\
\text { argilominerais }\end{array}$ \\
\hline \multicolumn{2}{|c|}{ alteração } & fraca a moderada & fraca a moderada & fraca a moderada \\
\hline \multicolumn{2}{|c|}{ intempérica } & $\begin{array}{l}\text { plagioclásio: parcialmente } \\
\text { alterado em } \\
\text { argilominerais, hidróxidos } \\
\text { de ferro e carbonato; } \\
\text { biotita: localmente, } \\
\text { alterada em clorita; } \\
\text { hidróxidos de ferro: } \\
\text { também ocorrem em } \\
\text { fissuras próximas a biotita; } \\
\text { carbonato: em espaços } \\
\text { intergranulares ou em } \\
\text { biotita. }\end{array}$ & $\begin{array}{l}\text { plagioclásio: turvo por } \\
\text { argilominerais e hidróxidos } \\
\text { de ferro, a parcialmente } \\
\text { alterado em sericita; } \\
\text { biotita: parcial a totalmente } \\
\text { alterada em clorita. }\end{array}$ & $\begin{array}{l}\text { plagioclásio: intensamente } \\
\text { alterado, a partir dos } \\
\text { núcleos, em sericita e } \\
\text { turvo por argilominerais e } \\
\text { hidróxidos de ferro; } \\
\text { biotita: parcial a, } \\
\text { localmente, totalmente } \\
\text { alterada em clorita e } \\
\text { hidróxidos de ferro, que } \\
\text { também ocupam fissuras } \\
\text { próximas. }\end{array}$ \\
\hline \multicolumn{2}{|c|}{ hidrotermal } & - & - & - \\
\hline \multicolumn{2}{|c|}{ fissuramento } & fraco a moderado & fraco a moderado & fraco \\
\hline \multicolumn{2}{|c|}{ intragranulares } & $\begin{array}{l}\text { x (predominante) - } \\
\text { quartzo e plagioclásio }\end{array}$ & $\begin{array}{l}\mathrm{x} \text { (predominante) - } \\
\text { quartzo e feldspatos }\end{array}$ & $\begin{array}{l}\text { x (predominante) - quartzo } \\
\text { e feldspatos }\end{array}$ \\
\hline \multicolumn{2}{|c|}{ intergranulares } & $\begin{array}{l}\text { x (predominante) - } \\
\text { quartzo }\end{array}$ & x (quartzo) & x (quartzo) \\
\hline \multicolumn{2}{|c|}{ transgranulares } & x (quartzo e feldspatos) & $\mathrm{x}$ (raras) & $\mathrm{x}$ (raras) \\
\hline \multicolumn{2}{|c|}{ preenchimento } & $\begin{array}{l}\text { carbonato, filossilicatos e } \\
\text { hidróxidos de ferro }\end{array}$ & $\begin{array}{l}\text { hidróxidos de ferro, } \\
\text { carbonato e filossilicatos }\end{array}$ & $\begin{array}{l}\text { filossilicatos e hidróxidos } \\
\text { de ferro }\end{array}$ \\
\hline \multicolumn{2}{|c|}{ classificação } & (Biotita) Sienogranito & (Biotita) Sienogranito & Biotita Sienogranito \\
\hline
\end{tabular}

Exibem arranjo textural ineqüigranular hipidiomórfico, caracterizado por cristais anédricos de quartzo e subédricos de microclínio (micropertítico) e plagioclásio, esses freqüentemente tabulares (Figura 6.4). 


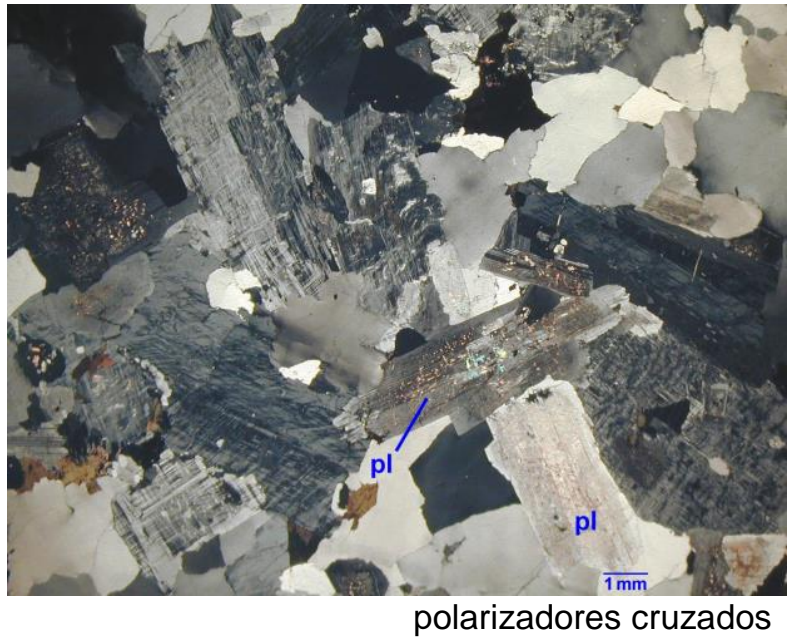

Figura 6.4 - Amostra VCB-3. Aspecto geral do granito Vermelho Capão Bonito. Notar cristais tabulares de plagioclásio $(\mathrm{pl})$ com os núcleos alterados e com hidróxidos de ferro associados.

Fraca a moderada alteração intempérica é evidenciada pela alteração de plagioclásio, especialmente nos núcleos e nas micropertitas, em argilominerais, hidróxidos de ferro e sericita/muscovita (Figura 6.5). Segundo identificação mineralógica por difratometria de raios $X$, em porção retirada dos núcleos de feldspatos alterados, os argilominerais seriam do grupo da illita e clorita (VCB-2).
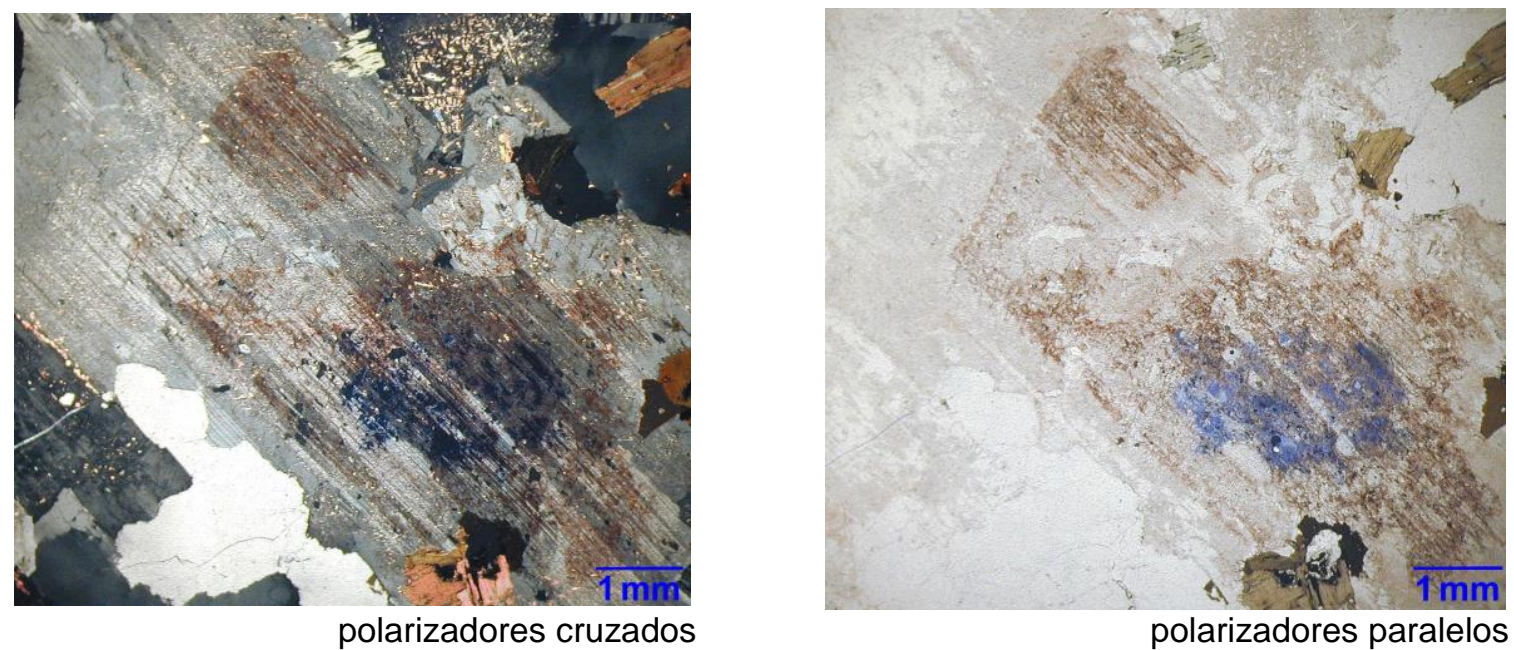

Figura 6.5 - Amostra VCB-3. Aspecto de cristal de plagioclásio alterado em argilominerais, hidróxidos de ferro e sericita/muscovita.

Hidróxidos de ferro presentes nas alterações de plagioclásio podem também ser observados em amostra de mão e fornecem a coloração avermelhada característica.

Algumas feições macroscopicamente distintivas entre as amostras não puderam ser reconhecidas ao microscópio, tampouco diferenças nos padrões de alteração intempérica. A VCB-2 é mais grossa e exibe maior homogeneidade granulométrica que as outras duas. 
No tocante ao fissuramento, esse varia de fraco a moderado, predominantemente do tipo intra e intergranular, afetando quartzo e feldspatos (plagioclásio, em especial). As fissuras acham-se preenchidas por filossilicatos, carbonato e hidróxidos de ferro.

Fluorita é relativamente comum, ocorrendo em vênulas ou como inclusões em feldspatos.

\subsubsection{Azul Paulista Frente Nova e Prata Interlagos}

Também do Estado de São Paulo, foram estudadas as rochas comercialmente designadas de Azul Paulista Frente Nova (AZF) e Prata Interlagos (PIT), de cor cinza levemente azulado e amarelado, respectivamente, cujas características petrográficas encontram-se sintetizadas na Tabela 6.8.

São biotita monzogranitos, de granulação fina a média e arranjo textural granular hipidiomófico, caracterizado por cristais anédricos de quartzo (geralmente em agregados granoblásticos finos, especialmente na PIT) e subédricos de microclínio e plagioclásio (freqüentemente tabulares) (Figuras 6.6 e 6.7).

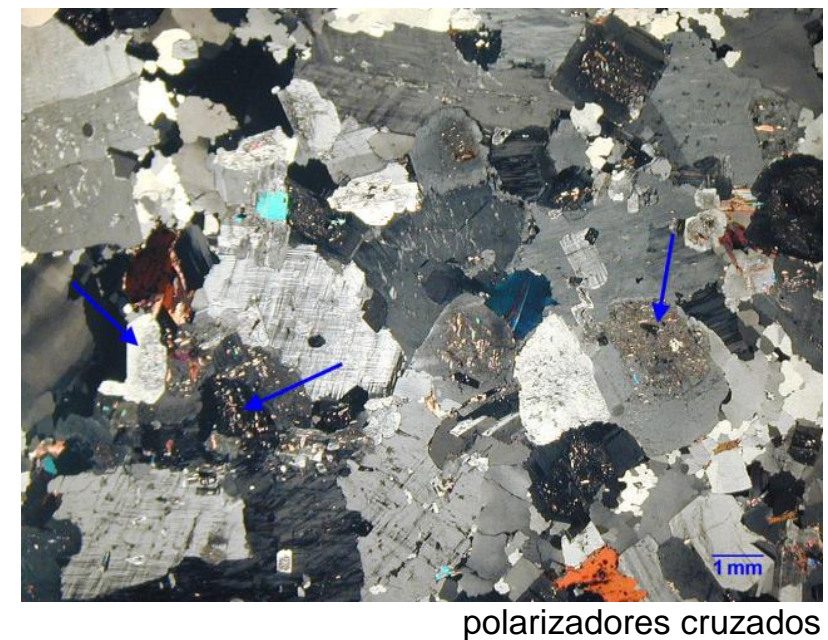

Figura 6.6 - Amostra AZF. Aspecto geral do granito Azul Paulista Frente Nova. Notar cristais de plagioclásio com núcleos alterados em argilominerais e sericita. Fissuras mais largas cortam feldspatos e quartzo.

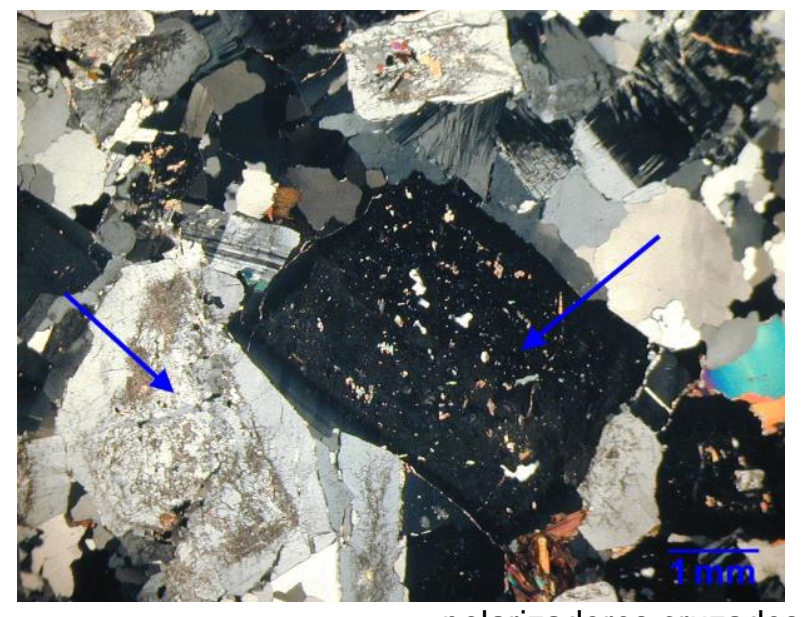

polarizadores cruzados

Figura 6.7 - Amostra PIT. Aspecto geral do granito Prata Interlagos.

Detalhe de núcleos de feldspatos alterados, especialmente segundo as linhas de crescimento. 
Tabela 6.8 - Resultados de análises petrográficas das amostras AZF, PIT e LBD.

\begin{tabular}{|c|c|c|c|c|}
\hline \multicolumn{2}{|c|}{ AMOSTRA } & AZF & PIT & LBD \\
\hline \multirow{2}{*}{ cor } & natural & cinza-claro azulado & cinza-claro amarelado & verde-escuro acastanhado \\
\hline & polida & cinza-médio azulado & cinza-médio amarelado & verde-escuro acastanhado \\
\hline \multicolumn{2}{|c|}{ estrutura } & maciça & maciça & maciça \\
\hline \multicolumn{2}{|c|}{ textura } & granular hipidiomórfica & granular hipidiomórfica & $\begin{array}{l}\text { ineqüigranular } \\
\text { hipidiomórfica }\end{array}$ \\
\hline \multicolumn{2}{|c|}{ granulação } & $\begin{array}{l}\text { fina a média: } \\
0,5-5 \mathrm{~mm}\end{array}$ & $\begin{array}{l}\text { fina a média: } 0,5-3 \mathrm{~mm} \text {, } \\
\text { localmente até } 6 \mathrm{~mm}\end{array}$ & $\begin{array}{l}\text { fina a grossa, variando de } \\
2-25 \mathrm{~mm} \text { (predomina.ao } \\
\text { redor de } 10 \mathrm{~mm} \text { ) }\end{array}$ \\
\hline \multicolumn{5}{|c|}{ mineralogia (\%) } \\
\hline \multirow{2}{*}{\multicolumn{2}{|c|}{$\begin{array}{l}\text { quartzo } \\
\text { plagioclásio }\end{array}$}} & 30 & 30 & $15-20$ \\
\hline & & 25-30 (oligoclásio) & 25-30 (oligoclásio) & 20 (oligoclásio-andesina) \\
\hline \multicolumn{2}{|c|}{ microclínio } & 30 (micropertítico) & 30 & $\begin{array}{l}40 \text { (feldspato potássico } \\
\text { cripto a micropertítico) }\end{array}$ \\
\hline \multicolumn{2}{|c|}{ biotita } & 10 & 10 & 5 \\
\hline \multicolumn{2}{|c|}{ hiperstênio } & - & - & 5 \\
\hline \multicolumn{2}{|c|}{ granada } & - & - & 5 \\
\hline \multicolumn{2}{|c|}{ opacos } & - & - & $<5$ \\
\hline \multicolumn{2}{|c|}{ hornblenda } & - & - & 5 \\
\hline \multicolumn{2}{|c|}{ acessórios } & $\begin{array}{l}\text { zircão, apatita, turmalina, } \\
\text { fluorita }(<5)\end{array}$ & $\begin{array}{l}\text { zircão, apatita, fluorita, } \\
\text { turmalina, opacos }(<5)\end{array}$ & $\begin{array}{l}\text { opacos, allanita, apatita, } \\
\text { zircão (tr) }\end{array}$ \\
\hline \multicolumn{2}{|c|}{ secundários } & $\begin{array}{l}\text { sericita, muscovita, } \\
\text { carbonato, argilominerais, } \\
\text { clorita, hidróxidos de ferro }\end{array}$ & $\begin{array}{l}\text { clorita, sericita, muscovita, } \\
\text { carbonato, argilominerais, } \\
\text { hidróxidos de ferro }\end{array}$ & $\begin{array}{l}\text { filossilicatos, carbonato, } \\
\text { hidróxidos de ferro }\end{array}$ \\
\hline \multicolumn{2}{|c|}{ alteração } & fraca a moderada & fraca a moderada & moderada \\
\hline \multicolumn{2}{|c|}{ intempérica } & $\begin{array}{l}\text { núcleos de cristais de } \\
\text { plagioclásio: parcial a } \\
\text { totalmente alterados em } \\
\text { argilominerais, sericita e } \\
\text { carbonato, com muscovita } \\
\text { e hidróxidos de ferro } \\
\text { associados; } \\
\text { biotita: localmente, altera- } \\
\text { se em clorita. }\end{array}$ & $\begin{array}{l}\text { núcleos de cristais de } \\
\text { plagioclásio: alterados em } \\
\text { sericita e argilominerais, } \\
\text { com muscovita, hidróxidos } \\
\text { de ferro e carbonato } \\
\text { associados; } \\
\text { biotita: parcialmente } \\
\text { alterada em clorita. }\end{array}$ & $\begin{array}{l}\text { feldspatos: } \\
\text { moderadamente alterados } \\
\text { em argilominerais e } \\
\text { sericita, com hidróxidos de } \\
\text { ferro associados; } \\
\text { hiperstênio: fortemente } \\
\text { alterado ao longo e } \\
\text { próximo de clivagens. }\end{array}$ \\
\hline \multicolumn{2}{|c|}{ hidrotermal } & incipiente & incipiente & - \\
\hline \multirow{2}{*}{\multicolumn{2}{|c|}{$\begin{array}{l}\text { fissuramento } \\
\text { intragranulares }\end{array}$}} & fraco & fraco & forte \\
\hline & & $\mathrm{x}$ (predominante) & $\mathrm{x}$ (predominante) & $x$ \\
\hline \multicolumn{2}{|c|}{ intergranulares } & $x$ & $x$ & - \\
\hline \multicolumn{2}{|c|}{ transgranulares } & - & - & $\begin{array}{l}x \text { (predominante) }- \\
\text { quartzo e feldspatos }\end{array}$ \\
\hline \multicolumn{2}{|c|}{ preenchimento } & \begin{tabular}{|l|} 
localmente, por \\
argilominerais e hidróxidos \\
de ferro
\end{tabular} & $\begin{array}{l}\text { localmente, por } \\
\text { argilominerais, hidróxidos } \\
\text { de ferro e carbonato }\end{array}$ & $\begin{array}{l}\text { filossilicatos, hidróxidos de } \\
\text { ferro e carbonato }\end{array}$ \\
\hline \multicolumn{2}{|c|}{ classificação } & Biotita Monzogranito & Biotita Monzogranito & $\begin{array}{l}\text { Charnockito } \\
\text { (Hiperstênio } \\
\text { Sienogranito) com } \\
\text { granada }\end{array}$ \\
\hline
\end{tabular}

Cristais de plagioclásio são zonados, e os núcleos estão, invariavelmente, parcial a totalmente alterados em argilominerais, sericita e carbonato, com hidróxidos de ferro associados. A análise por difratometria de raios $X$, em porções retiradas de núcleos de plagioclásio alterado, indicou argilominerais do grupo da illita. 
A despeito da tonalidade amarelada da amostra PIT, atribuível à maior ação intempérica que na amostra AZF, não se observaram, ao microscópio, feições que indicassem "proporcionalmente" tal incremento de alteração. A alteração de biotita em clorita foi a principal modificação detectada.

O fissuramento é incipiente a fraco, intragranular, mais freqüentemente atingindo cristais de plagioclásio, e apresentando preenchimento por argilominerais, hidróxidos de ferro e, raramente, carbonato.

É muito comum a ocorrência de muscovita, recristalizada, associada à biotita, em espaços intergranulares e ou em plagioclásio (Figura 6.8).
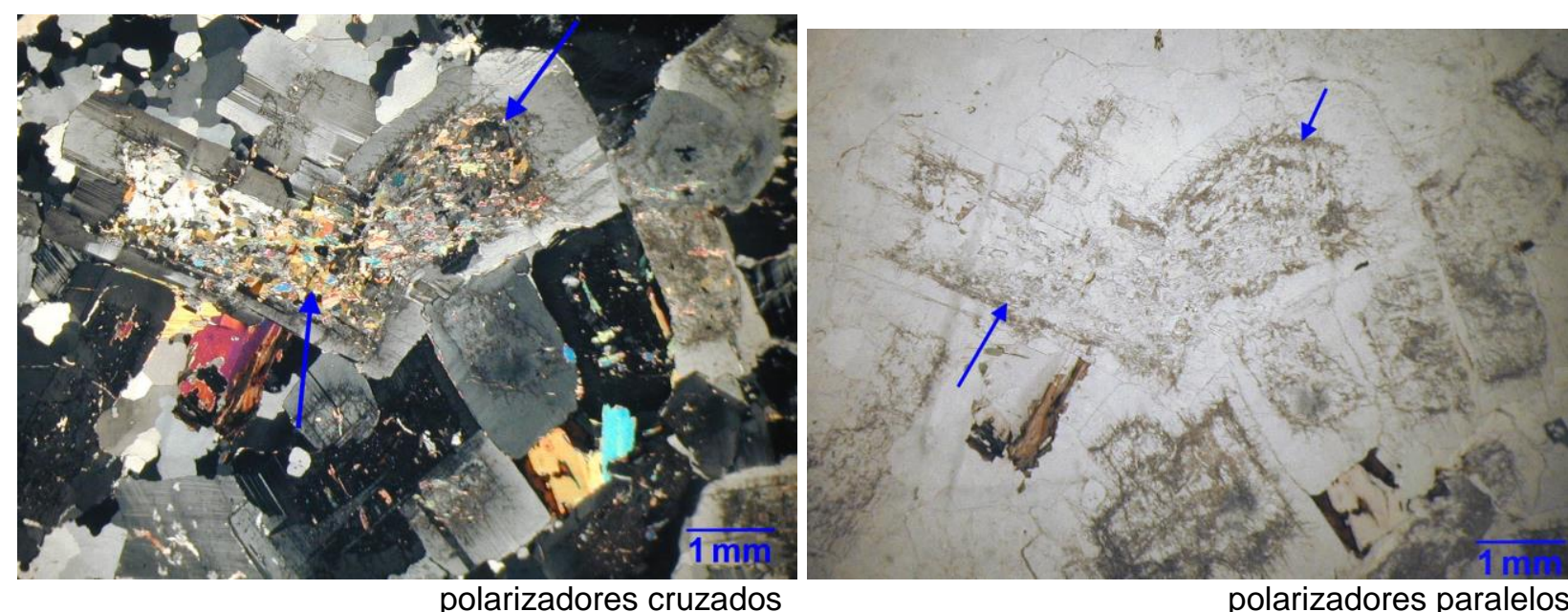

Figura 6.8 - Amostra PIT. Aspecto da alteração de plagioclásio em muscovita.

Turmalina verde-azulada e fluorita evidenciam ação hidrotermal tardi-magmática, que pode ser, nesse caso, ao menos em parte, responsável pela sericitização dos núcleos de plagioclásio.

\subsubsection{Verde Labrador}

0 Verde Labrador (LBD), rocha charnockítica explorada na região de Baixo Guandu, a oeste do Estado do Espírito Santo, no contexto geológico do Complexo Migmatítico-Granulítico de Minas Gerais, é, petrograficamente, um charnockito com granada (hiperstênio sienogranito com granada) (Tabela 6.8).

Apresenta cor verde-escuro acastanhada e granulação fina a grossa, predominantemente grossa. $O$ arranjo textural ineqüigranular hipidiomórfico é caracterizado por cristais subédricos a anédricos de feldspatos, milimétricos a 
centimétricos, e anédricos de quartzo (Figura 6.9).
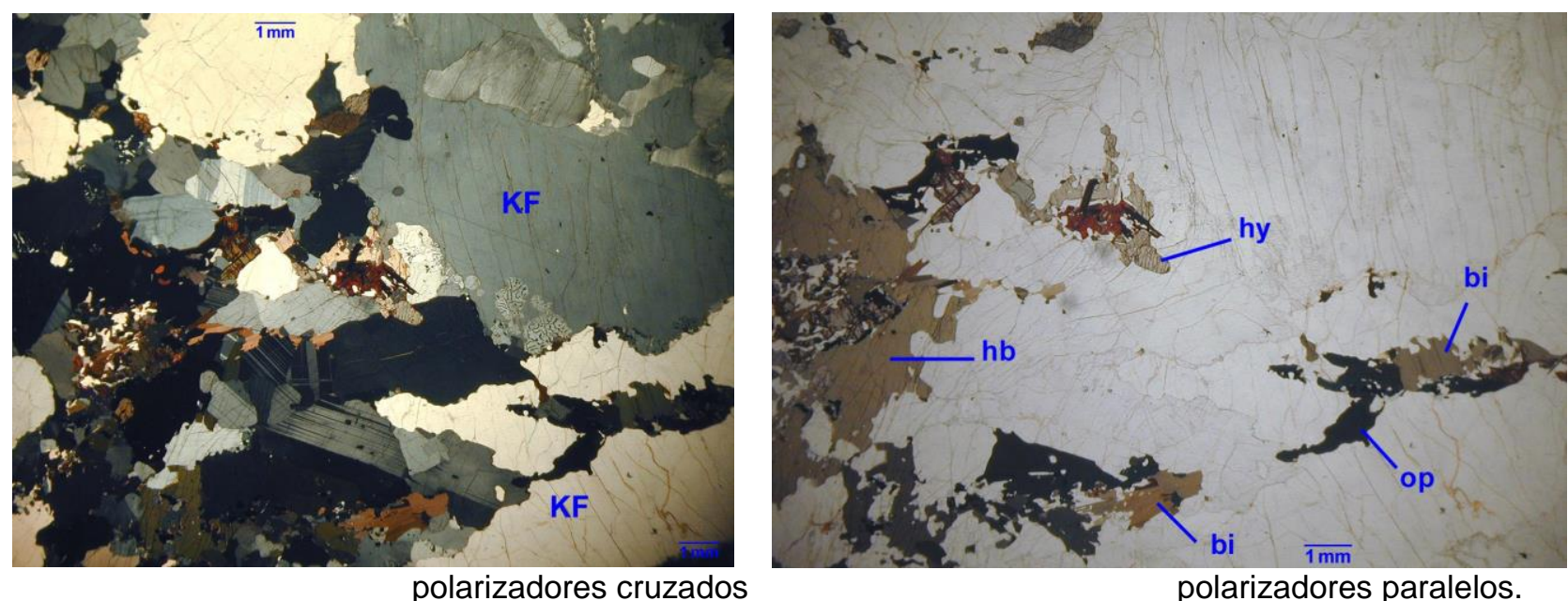

polarizadores paralelos.

Figura 6.9 - Amostra LBD. Aspecto geral do charnockito Verde Labrador. Notar as dimensões milimétricas de feldspatos (KF) e intenso microfissuramento os afetando. Hornblenda (hb), hiperstênio (hy), biotita (bi) e opacos (op), geralmente em agregados, se distribuem esparsamente pela rocha.

Em geral, os minerais máficos (hiperstênio, hornblenda e biotita) e opacos constituem agregados dispostos esparsamente pela rocha. A granada lhes pode estar associada ou ocorrer em porfiroblastos, subédricos a euédricos.

O fissuramento é intenso, o maior das rochas em estudo, predominantemente transgranular, configurando uma rede de microfissuras entrecortadas, preenchidas por filossilicatos e hidróxidos de ferro. Freqüentemente, também é radial a partir de cristais de ortopiroxênio ou hornblenda.

Intemperismo moderado é evidenciado pela alteração de feldspatos, a partir de microfissuras, em argilominerais e sericita, com hidróxidos de ferro associados. Ortopiroxênio se altera, ao longo de clivagens e fissuras em hidróxidos de ferro (Figura 6.10).

A identificação mineralógica por difratometria de raios $X$ indicou somente a presença de argilominerais do grupo da illita, como resultantes da alteração de feldspatos. 


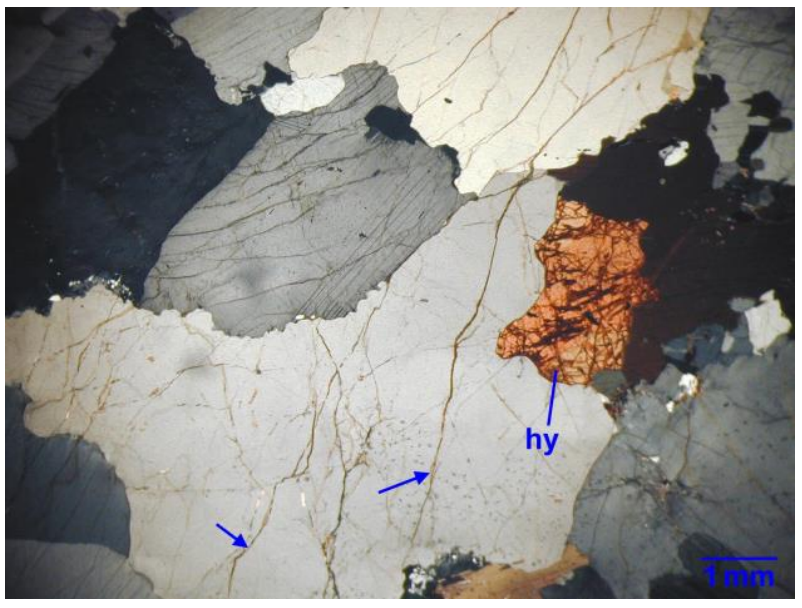

polarizadores cruzados

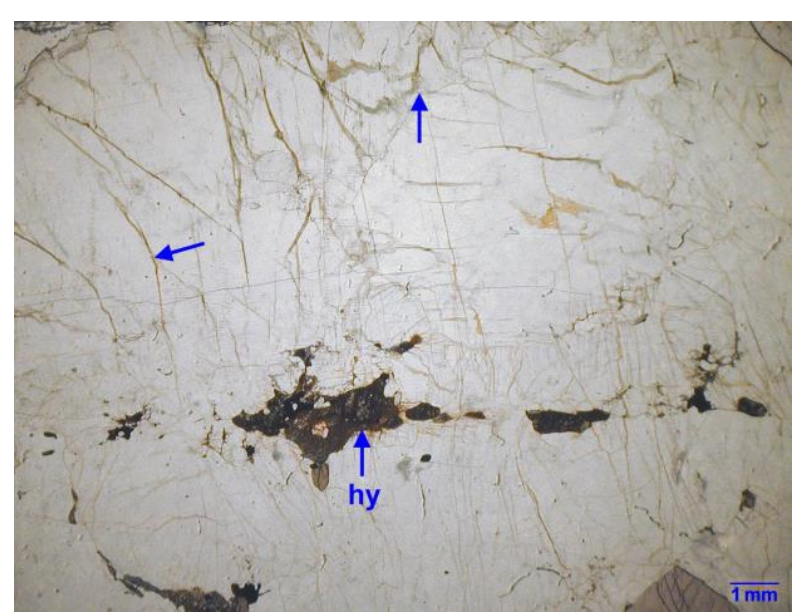

polarizadores paralelos

Figura 6.10 - Amostra LBD. Aspecto do forte microfissuramento em feldspatos, que propicia alteração em argilominerais (+ hidróxidos de ferro) ao seu redor, e da alteração de hiperstênio (hy), também em hidróxidos de ferro.

Deve-se ressaltar a presença de granada, relativamente incomum em charnockitos. Associação mineral semelhante (hornblenda + granada + ortopiroxênio + plagioclásio + quartzo \pm feldspato potássico \pm biotita \pm opacos) pôde ser encontrada na literatura, em corpos charnockíticos da Séries Highland, no Sri Lanka, os quais Schumacher et al. (1990) consideraram derivados de metamorfismo de alto grau (fácies granulito), com pressões entre 7,3 kbar e 9,0 kbar, podendo decrescer até 3,5 kbar para associações sem hornblenda, e temperaturas entre $760^{\circ} \mathrm{C}$ e $840^{\circ} \mathrm{C}$, podendo, da mesma forma decrescer até $600^{\circ} \mathrm{C}$.

\subsubsection{Branco Itaúnas e Branco Caravelas}

$\mathrm{Na}$ região de Medeiros Neto, BA, no contexto geológico da Província Mantiqueira, são explorados os Branco Itaúnas - Microponto II (ITN-1), Branco Itaúnas - Microponto III (ITN-2) e Branco Caravelas (CRV). Os dois primeiros explorados em frentes de lavra distintas, na mesma mina, e o último em mina localizada a alguns quilômetros daquela, aparentemente, dentro do mesmo contexto geológico. Suas características petrográficas acham-se na Tabela 6.9.

As amostras Branco Itaúnas são gnaisses monzograníticos com granada, macro e microscopicamente muito semelhantes. A ITN-1 acha-se cortada por vênulas quartzofeldspáticas, de granulação grossa, com abundantes máficos (biotita) associados. 
Tabela 6.9 - Resultados de análises petrográficas das amostras ITN-1, ITN-2 e CRV.

\begin{tabular}{|c|c|c|c|c|}
\hline \multicolumn{2}{|c|}{ AMOSTRA } & ITN-1 & ITN-2 & CRV \\
\hline \multirow{2}{*}{ cor } & natural & branco-esverdeado rosado & branco-esverdeado rosado & branco-esverdeado \\
\hline & polida & branco-esverdeado rosado & branco-esverdeado rosado & branco-esverdeado \\
\hline \multicolumn{2}{|c|}{ estrutura } & Maciça a orientada & maciça a orientada & maciça \\
\hline \multicolumn{2}{|c|}{ textura } & $\begin{array}{l}\text { granoblástica } \\
\text { ineqüigranular amebóide a } \\
\text { interlobada }\end{array}$ & $\begin{array}{l}\text { granoblástica } \\
\text { ineqüigranular interlobada } \\
\text { a amebóide }\end{array}$ & $\begin{array}{l}\text { granoblástica } \\
\text { ineqüigranular interlobada } \\
\text { a serrilhado / } \\
\text { porfiroblástica }\end{array}$ \\
\hline \multicolumn{2}{|c|}{ granulação } & $\begin{array}{l}\text { média a grossa: } 1-5 \mathrm{~mm} ; \\
\text { quartzo em cordões: até } \\
15 \mathrm{~mm}\end{array}$ & $\begin{array}{l}\text { média a grossa: } 1-5 \mathrm{~mm} ; \\
\text { quartzo em cordões: até } \\
15 \mathrm{~mm}\end{array}$ & $\begin{array}{l}\text { fina a média: } 0,1-2,0 \mathrm{~mm} \text {, } \\
\text { com cristais de quartzo } \\
\text { entre } 1-3 \mathrm{~mm} \\
\text { porfiroblastos de granada: } \\
\text { até } 50 \mathrm{~mm}\end{array}$ \\
\hline \multicolumn{5}{|c|}{ mineralogia (\%) } \\
\hline \multicolumn{2}{|c|}{ quartzo } & 25 & $25-30$ & $20-25$ \\
\hline \multicolumn{2}{|c|}{ plagioclásio } & 25-30 (oligoclásio) & 25-30 (oligoclásio) & 5 (albita-oligoclásio) \\
\hline \multicolumn{2}{|c|}{ microclínio } & $\begin{array}{l}40-45 \text { (feldspato potássico } \\
\text { cripto a micropertítico) }\end{array}$ & $\begin{array}{l}\text { 35-40 (feldspato potássico } \\
\text { micropertítico) }\end{array}$ & 55-60 (mesopertítico) \\
\hline \multicolumn{2}{|c|}{ biotita } & $\operatorname{tr}$ & $<5$ & - \\
\hline \multicolumn{2}{|c|}{ granada } & 5 & 5 & 5 \\
\hline \multirow{2}{*}{\multicolumn{2}{|c|}{$\begin{array}{l}\text { sillimanita } \\
\text { "cordierita" }\end{array}$}} & 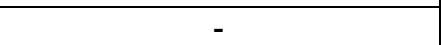 & - & $<5$ \\
\hline & & $\operatorname{tr}$ & - & $5-10$ \\
\hline \multicolumn{2}{|c|}{ acessórios (tr) } & opacos, titanita (?) & $\begin{array}{l}\text { Zircão, opacos (sulfetos e } \\
\text { óxidos) }\end{array}$ & opacos, espinélio verde \\
\hline \multicolumn{2}{|c|}{ secundários } & $\begin{array}{l}\text { muscovita, argilominerais } \\
\text { incolores, carbonato }\end{array}$ & $\begin{array}{l}\text { sericita, carbonato, } \\
\text { opacos, argilominerais } \\
\text { incolores, hidróxidos de } \\
\text { ferro }\end{array}$ & $\begin{array}{l}\text { carbonato, argilominerais } \\
\text { incolores, muscovita, } \\
\text { biotita }\end{array}$ \\
\hline \multicolumn{2}{|c|}{ alteração } & fraca & fraca & fraca a moderada \\
\hline \multicolumn{2}{|c|}{$\begin{array}{l}\text { Intempérica/ } \\
\text { hidrotermal }\end{array}$} & $\begin{array}{l}\text { feldspatos: turvos por } \\
\text { argilominerais e local } \\
\text { alteração em sericita e } \\
\text { carbonato; } \\
\text { argilominerais } \\
\text { intergranulares: alteração } \\
\text { de mineral primário, não } \\
\text { identificado. }\end{array}$ & $\begin{array}{l}\text { plagioclásio: altera-se em } \\
\text { carbonato e sericita e } \\
\text { outros filossilicatos } \\
\text { incolores; } \\
\text { granada: bordas e fraturas } \\
\text { alteradas em muscovita } \\
\text { e/ou sericita e carbonato. }\end{array}$ & $\begin{array}{l}\text { provável cordierita: } \\
\text { totalmente alterada em } \\
\text { argilominerais incolores; } \\
\text { granada: pode estar } \\
\text { alterada em muscovita, } \\
\text { biotita e carbonato. }\end{array}$ \\
\hline \multicolumn{2}{|c|}{ fissuramento } & moderado & moderado a forte & fraco a moderado \\
\hline \multicolumn{2}{|c|}{ intragranulares } & x (quartzo e feldspatos) & $\begin{array}{l}\mathrm{x} \text { (predominante) - quartzo } \\
\mathrm{e} \text { feldspatos }\end{array}$ & x (quartzo $(+$ granada)) \\
\hline \multirow{2}{*}{\multicolumn{2}{|c|}{$\begin{array}{l}\text { intergranulares } \\
\text { transgranulares }\end{array}$}} & $\mathrm{x}$ (raras) & - & - \\
\hline & & $\mathrm{x}$ (quartzo e feldspatos) & $\mathrm{x}$ (quartzo e feldspatos) & - \\
\hline \multicolumn{2}{|c|}{ preenchimento } & $\begin{array}{l}\text { carbonato ou sericita, } \\
\text { freqüentemente sem } \\
\text { preenchimento }\end{array}$ & \begin{tabular}{|l|} 
sericita, filossilicatos \\
incolores, raros hidróxidos \\
de ferro
\end{tabular} & $\begin{array}{l}\text { argilominerais ou sem } \\
\text { preenchimento }\end{array}$ \\
\hline \multicolumn{2}{|c|}{ classificação } & $\begin{array}{l}\text { Gnaisse Monzogranítico } \\
\text { com Granada }\end{array}$ & $\begin{array}{l}\text { gnaisse monzogranítico } \\
\text { com granada }\end{array}$ & $\begin{array}{l}\text { Gnaisse microclínio } \\
\text { Granítico com Granada e } \\
\text { "Cordierita" }\end{array}$ \\
\hline
\end{tabular}

Apresentam cor branco-esverdeada, levemente rosada, granulação média a grossa, com quartzo constituindo cordões, que medem até $15 \mathrm{~mm}$. O arranjo textural é granoblástico, ineqüigranular, com contato entre grãos do tipo interlobado a amebóide, 
raramente retilíneos (Figura 6.11). Granada ocorre como microporfiroblastos euédricos, em geral medindo cerca de $1 \mathrm{~mm}$.

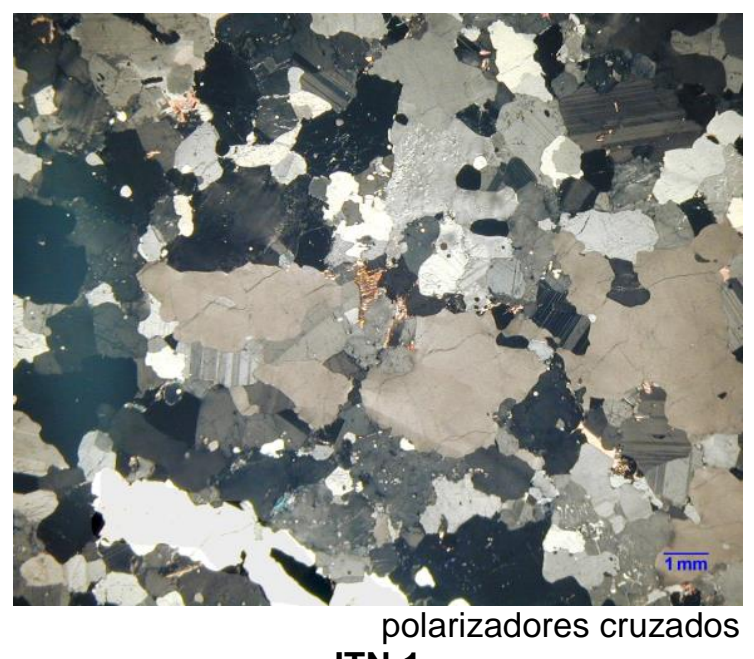

ITN-1

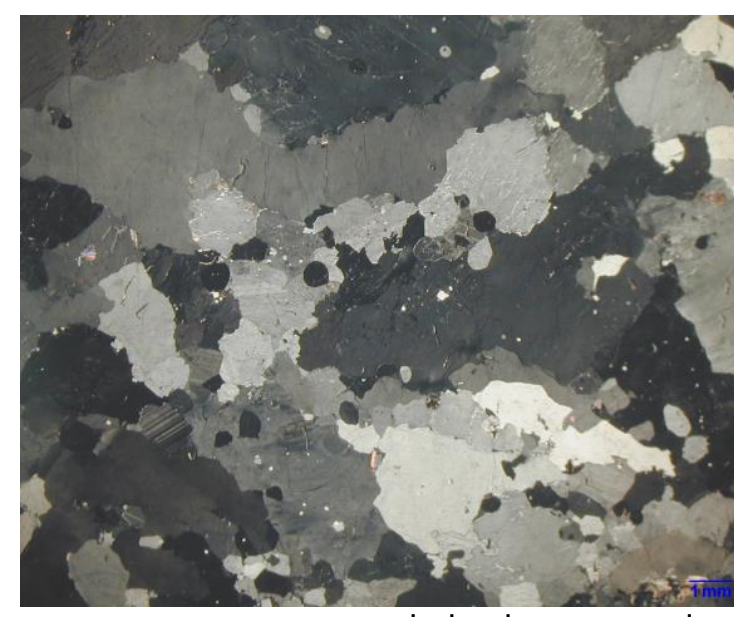

polarizadores cruzados ITN-2

Figura 6.11 - Amostras ITN. Aspecto geral do granito Branco Itaúnas. Notar heterogeneidade granulométrica e contatos interlobados, entre os grãos;

A fraca alteração é evidenciada por feldspatos turvos por argilominerais, que se formam a partir de microfissuras ou clivagens (Figura 6.12). Também podem estar, localmente, alterados em sericita e carbonato.

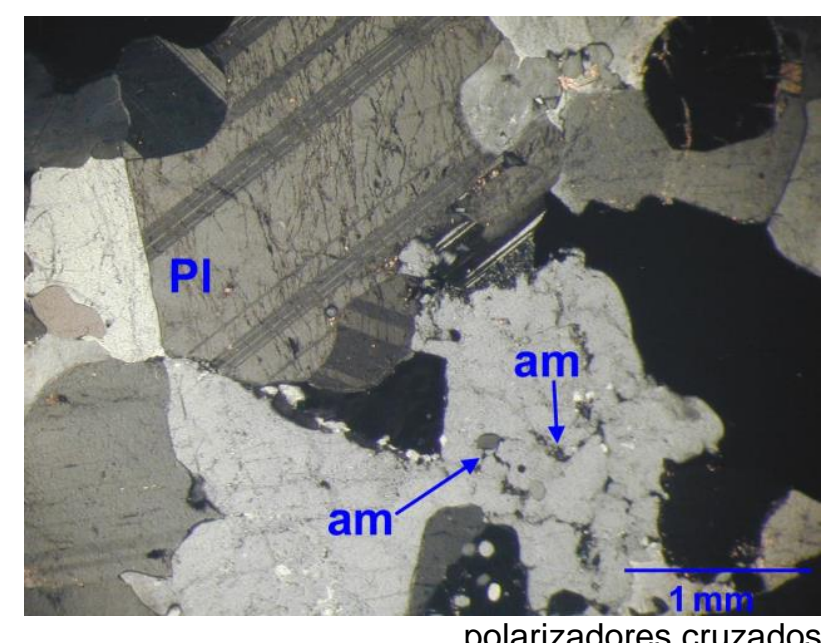

polarizadores cruzados
Figura 6.12 - Amostra ITN-2. Aspecto do microfissuramento intragranular em plagioclásio $(\mathrm{PI})$ e do preenchimento de espaços intragranulares, em feldspatos, por argilominerais (am).

Dispersamente, observam-se muscovita e/ou carbonato e/ou argilominerais incolores em espaços intergranulares. A identificação dos argilominerais presentes na rocha, por difratometria de raios $\mathrm{X}$, indicou que se trata de caulinita e, possivelmente, de argilominerais do grupo das esmectitas. 
Aparentemente, tais rochas apresentam pequena sobreposição de alteração intempérica com provável alteração deutérica, que seria a responsável pela substituição de supostos cordierita ou aluminossilicatos pelos argilominerais intersticiais. É relativamente comum bordas de plaquetas de biotita substituídas por argilominerais, possivelmente relacionados à ação de fluidos tardi-magmáticos (Figura 6.13).

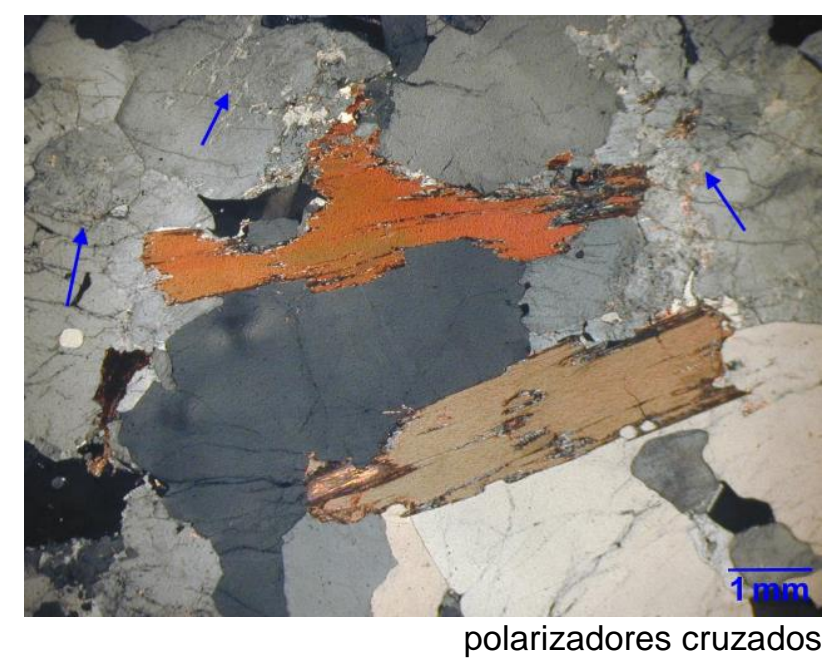

Figura 6.13 - Amostra ITN-1. Aspecto de biotitas substituídas por argilominerais, por provável ação deutérica. Notar microfissuramento intra e transgranular e sericitização de plagioclásio (setas).

Microfissuramento, fraco a moderado, intra e intergranular afeta quartzo e feldspatos. Essas rochas exibiram modificação do grau de microfissuramento entre as seções delgadas confeccionadas a partir de blocos e de ladrilhos, mais intenso nesses últimos, nos quais também se observa a presença de hidróxidos de ferro impregnando microfissuras.

Essas observações demonstram como são comuns pequenas variações nos materiais rochosos, que freqüentemente não são detectadas pelos métodos de investigação, por melhor que tenha sido a amostragem do material. Por outro lado, reforçam a argumentação de que determinações isoladas não devem ser tomadas como padrão ou como caracterização de um material rochoso.

O Branco Caravelas tem coloração branco-esverdeada, estrutura maciça e granulação fina. $O$ arranjo textural granoblástico caracteriza-se por grande heterogeneidade granulométrica (Figura 6.14). Os grãos têm contatos interlobados a serrilhados, muito raramente retilíneos. 


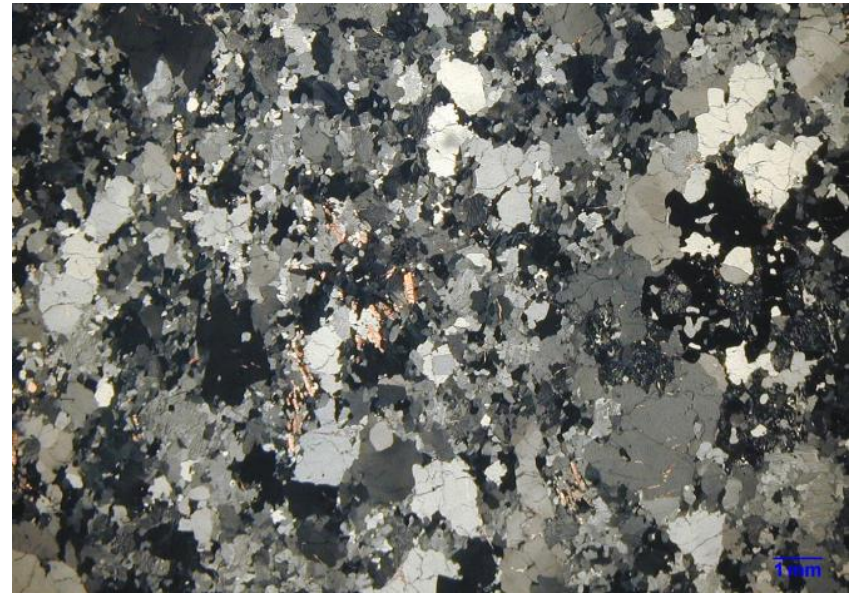

polarizadores cruzados
Figura 6.14 - Amostra CRV. Aspecto geral do granito Branco Caravelas.

Notar a heterogeneidade granulométrica.

Microfissuramento fraco a moderado, intragranular, é observado especialmente em quartzo.

Os minerais estão praticamente inalterados, mas é característica a ocorrência dispersa de argilominerais de cor levemente amarelada - que correspondem aos pontos verde-claro observados em amostra de mão - principalmente em espaços intergranulares, aqui também atribuídos à alteração deutérica de possível cordierita ou aluminossilicatos (Figura 6.15). Cristais submilimétricos de sillimanita ocorrem preferencialmente dispostos nessas áreas.

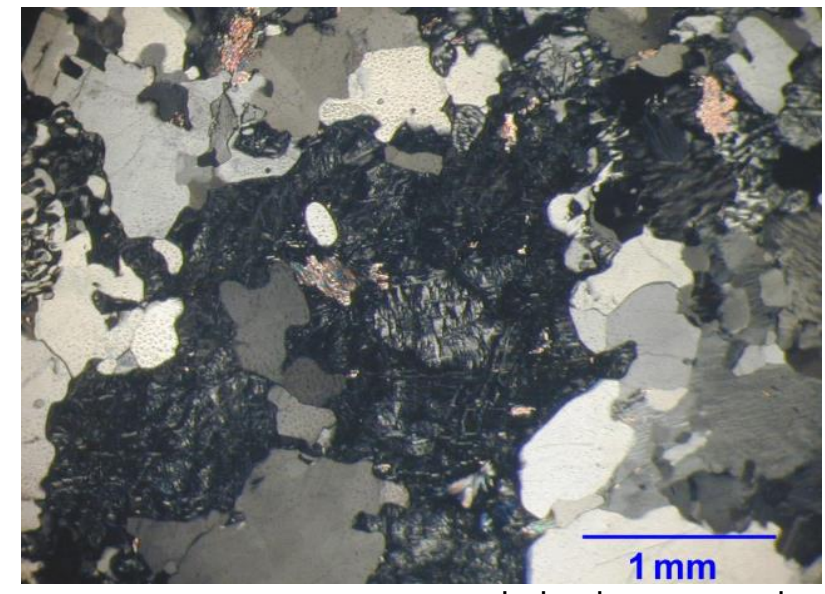

a)

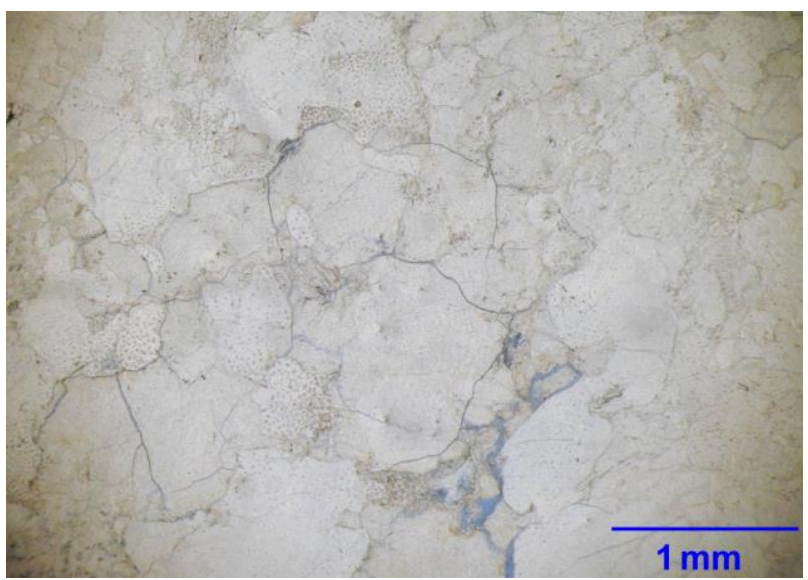

b)

Figura 6.15 - Amostra CRV. Argilominerais, comumente observados pela rocha, ocupando espaços intergranulares (a). Notar microfissuramento intergranular, sem preenchimento e ligeiramente aberto (em azul) (b).

A identificação mineralógica, por difratometria de raios $X$, da fração argila, indicou que os argilominerais presentes são essencialmente do grupo da caulinita. 


\subsubsection{Rosa Iracema, Branco Cristal e Branco Savana}

Na região de Forquilha $(\mathrm{CE})$, na região de Serra da Barriga, são explorados os Rosa Iracema, Branco Savana e Branco Cristal Quartz, rochas de cor rosa a rosaacinzentado ou levemente esverdeado, cujas principais propriedades petrográficas estão na Tabela 6.10.

Tabela 6.10 - Resultados de análises petrográficas das amostras RIC, BCR, BSV.

\begin{tabular}{|c|c|c|c|c|}
\hline \multicolumn{2}{|c|}{ AMOSTRA } & RIC & BCR & BSV \\
\hline \multirow{2}{*}{ cor } & natural & rosa & rosa-esverdeado & rosa -acinzentado \\
\hline & polida & rosa & rosa-esverdeado & rosa-acinzentado \\
\hline \multicolumn{2}{|c|}{ estrutura } & maciça & maciça & maciça \\
\hline \multicolumn{2}{|c|}{ textura } & granular hipidiomórfica & granular hipidiomórfica & granular hipidiomórfica \\
\hline \multicolumn{2}{|c|}{ granulação } & média a grossa: 3-10 mm & média a grossa: $1-8 \mathrm{~mm}$ & média a grossa: $3-8 \mathrm{~mm}$ \\
\hline \multicolumn{5}{|c|}{ mineralogia (\%) } \\
\hline \multicolumn{2}{|c|}{ quartzo } & 35 & 30 & $30-35$ \\
\hline \multicolumn{2}{|c|}{ plagioclásio } & 20-25 (oligoclásio) & $\begin{array}{l}\text { 30-35 (oligoclásio- } \\
\text { andesina) }\end{array}$ & 25 (oligoclásio-andesina) \\
\hline \multicolumn{2}{|c|}{ microclínio } & 35 (micropertítico) & 35 (micropertítico) & 35 (micropertítico) \\
\hline \multicolumn{2}{|c|}{ biotita } & $5-10$ & $5-10$ & $5-10$ \\
\hline \multicolumn{2}{|c|}{ acessórios (tr) } & $\begin{array}{l}\text { allanita, fluorita, apatita, } \\
\text { zircão, opacos }\end{array}$ & zircão, apatita, fluorita & $\begin{array}{l}\text { zircão, titanita, apatita, } \\
\text { allanita, fluorita }\end{array}$ \\
\hline \multicolumn{2}{|c|}{ secundários } & $\begin{array}{l}\text { carbonato, sericita, clorita, } \\
\text { filossilicatos, muscovita }\end{array}$ & $\begin{array}{l}\text { carbonato, argilominerais, } \\
\text { sericita, muscovita, clorita, } \\
\text { hidróxidos de ferro }\end{array}$ & $\begin{array}{l}\text { clorita, sericita, muscovita, } \\
\text { argilominerais, hidróxidos } \\
\text { de ferro, filossilicatos, } \\
\text { carbonato }\end{array}$ \\
\hline \multicolumn{2}{|c|}{ alteração } & fraca a moderada & moderada & fraca a moderada \\
\hline \multicolumn{2}{|c|}{ intempérica } & $\begin{array}{l}\text { plagioclásio: turvo por } \\
\text { argilominerais e com } \\
\text { núcleos alterados em } \\
\text { sericita. Muscovita ocorre } \\
\text { associada; } \\
\text { biotita: altera-se em clorita } \\
\text { e poucos hidróxidos de } \\
\text { ferro. }\end{array}$ & $\begin{array}{l}\text { plagioclásio: turvo por } \\
\text { argilominerais e com } \\
\text { núcleos alterados em } \\
\text { sericita, com muscovita } \\
\text { associada; } \\
\text { biotita: altera-se em clorita } \\
\text { (+filossilicato incolor) e } \\
\text { hidróxidos de ferro. }\end{array}$ & $\begin{array}{l}\text { plagioclásio: turvo por } \\
\text { argilominerais e com } \\
\text { núcleos alterados em } \\
\text { sericita. Muscovita ocorre } \\
\text { associada; } \\
\text { biotita: altera-se em clorita } \\
\text { e hidróxidos e/ou óxidos } \\
\text { de ferro. }\end{array}$ \\
\hline \multicolumn{2}{|c|}{ hidrotermal } & - & - & - \\
\hline \multicolumn{2}{|c|}{ fissuramento } & fraco & fraco a moderado & fraco a moderado \\
\hline \multicolumn{2}{|c|}{ intragranulares } & x (quartzo) & $\mathrm{x}$ (feldspatos) & x (quartzo e feldspatos) \\
\hline \multicolumn{2}{|c|}{ intergranulares } & $x$ & x (quartzo (+feldspatos)) & $\begin{array}{l}\text { x (predominante) - } \\
\text { quartzo (+ feldspatos) }\end{array}$ \\
\hline \multicolumn{2}{|c|}{ transgranulares } & $\begin{array}{l}\mathrm{x} \text { (predominante) - } \\
\text { quartzo e feldspatos }\end{array}$ & x (raras) & - \\
\hline \multicolumn{2}{|c|}{ preenchimento } & carbonato, filossilicatos & $\begin{array}{l}\text { carbonato, hidróxidos de } \\
\text { ferro (nas proximidades de } \\
\text { biotita) }\end{array}$ & $\begin{array}{l}\text { hidróxidos de ferro, } \\
\text { filossilicatos incolores }\end{array}$ \\
\hline \multicolumn{2}{|c|}{ classificação } & (Biotita) Monzogranito & (Biotita) Monzogranito & (Biotita) Monzogranito \\
\hline
\end{tabular}

Tratam-se de (biotita) monzogranitos, de granulação média a grossa e estrutura maciça, compostos por quartzo e feldspatos (plagioclásio e microclínio micropertítico) em arranjo granular hipidiomórfico, eqüigranular (Figuras 6.16 e 6.17). 

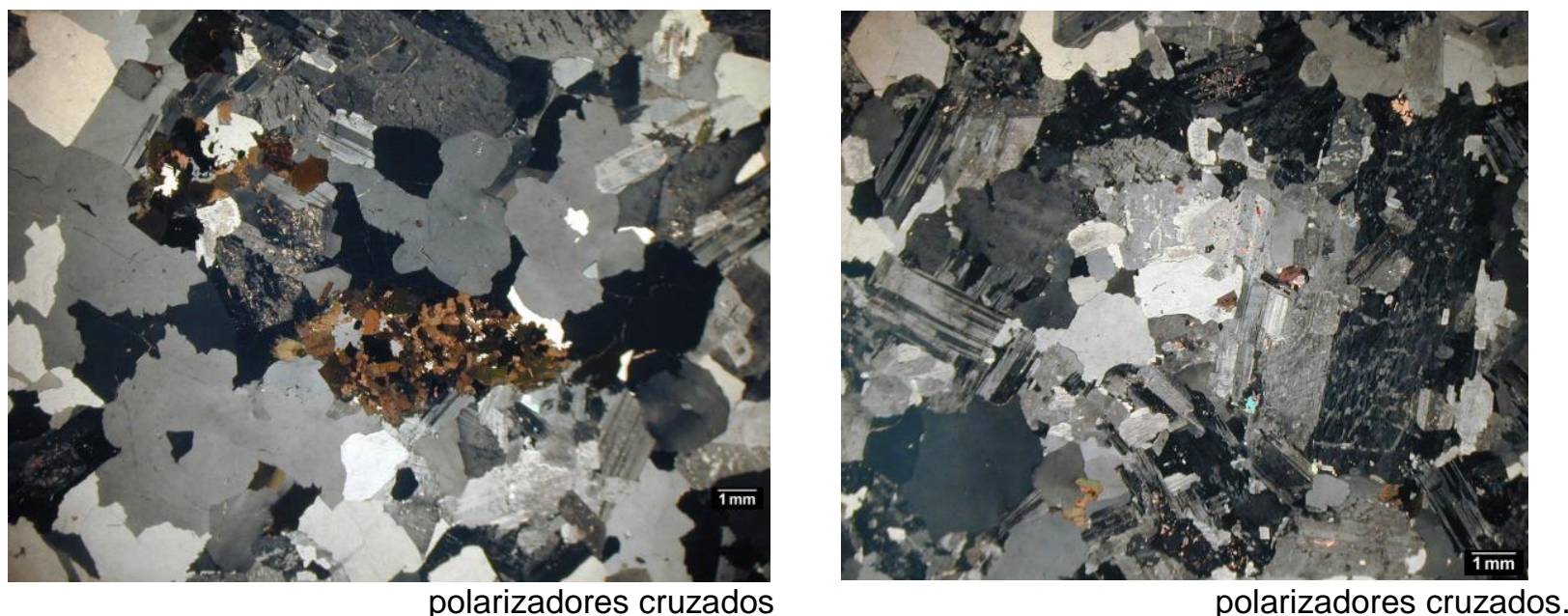

Figura 6.16 - Amostra RIC. Aspecto geral do Figura 6.17-Amostra BCR. Aspecto geral do granito Rosa Iracema. Notar homogeneidade granito Branco Cristal. Notar hipidiomorfismo granulométrica e biotita em agregados de dos feldspatos.

pequenas lamelas.

Fraco microfissuramento intragranular, cortando quartzo e feldspatos, predomina na RIC, geralmente preenchido por carbonato e filossilicatos. As amostras BSV e BCR têm maior microfissuramento que RIC, predominantemente intergranular e, subordinadamente, intragranular, esse observado principalmente em plagioclásio; e presença de hidróxidos de ferro, quase que invariavelmente associados ao material de preenchimento (filossilicatos e/ou carbonato).

O maior grau de fissuramento e a presença de hidróxidos de ferro nas microfissuras constituem as diferenças observadas entre RIC e BSV. Distintivamente dessas duas, BCR exibe granulação levemente menor.

Alteração intempérica fraca a moderada afeta RIC e BSV, caracterizada por plagioclásio, principalmente, turvo por argilominerais e exibindo núcleos parcialmente alterados em sericita; biotita está parcialmente alterada em clorita, com hidróxidos de ferro associados (em maior quantidade na BSV, inclusive com óxidos de ferro associados).

A alteração é pouco mais intensa em BCR, que exibe biotita alterada em clorita e hidróxidos de ferro, que por sua vez está interestratificada com filossilicato incolor, não identificado (Figura 6.18). Identificação mineralógica por difratometria de raios $X$, da porção alterada em núcleos de plagioclásio, da amostra BCR, indicou que os argilominerais são predominantemente do grupo da illita. 

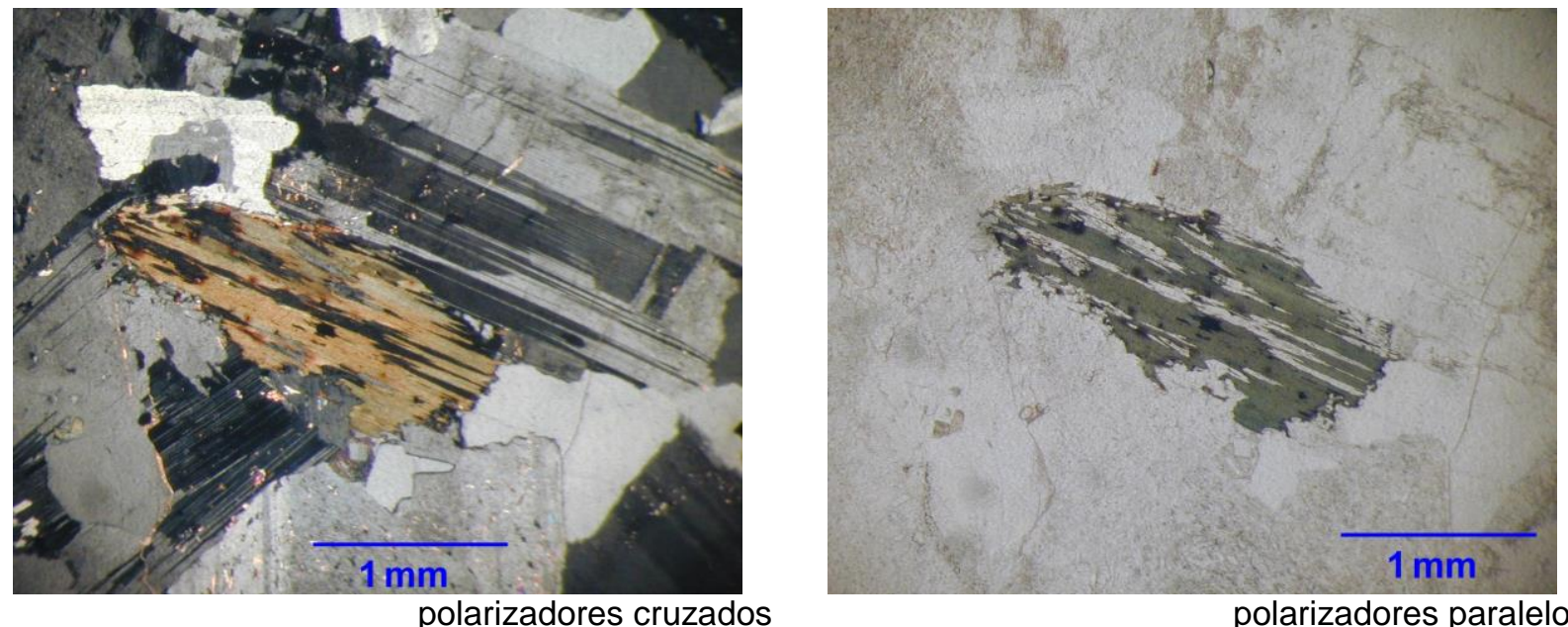

polarizadores cruzados

polarizadores paralelos

Figura 6.18-Amostra BCR. Aspecto de lamelas de biotita intercrescidas com filossilicato incolor.

Biotita também é observada em agregados milimétricos de pequenas plaquetas, aparentemente produto de substituição de mineral máfico.

Allanita está parcial a totalmente alterada em argilominerais.

Fluorita, em cristais milimétricos, ocorre esparsamente, ocupando espaços intergranulares.

Carbonato e hidróxidos de ferro estão, localmente, ocupando espaços intergranulares em BSV.

\subsubsection{Branco Ceará}

Na região de Santa Quitéria (CE), no Stock Morrinhos, é explorado o granito Branco Ceará. Trata-se de uma rocha com denominações comerciais muito diversificadas e uma das poucas rochas ornamentais brasileiras já objeto de vários estudos.

Segundo Mesquita (2002), na jazida do granito Branco Ceará, são explorados quatro tipos de granitos brancos, que se diferenciam por variações texturais e estruturais, que referiu como Clássico, Cotton, Tapajós e Super Branco. A amostra aqui estudada, aparentemente, corresponde ao tipo Clássico, conforme resultados petrográficos apresentados na Tabela 6.11. 
Tabela 6.11 - Resultados de análises petrográficas das amostras BCE, CSB, FLS.

\begin{tabular}{|c|c|c|c|c|c|c|}
\hline \multicolumn{2}{|c|}{ AMOSTRA } & BCE & \multicolumn{2}{|c|}{ CSB } & \multicolumn{2}{|c|}{ FLS } \\
\hline \multirow{2}{*}{ cor } & natural & $\begin{array}{l}\text { branca com pontos pretos } \\
\text { e esverdeados }\end{array}$ & \multicolumn{2}{|c|}{$\begin{array}{l}\text { branca levemente rosada } \\
\text { com faixas preto- } \\
\text { esverdeado }\end{array}$} & \multicolumn{2}{|c|}{$\begin{array}{l}\text { branco-amarelada com } \\
\text { faixas ferruginosas }\end{array}$} \\
\hline & polida & $\begin{array}{l}\text { branca com pontos pretos } \\
\text { e esverdeados }\end{array}$ & \multicolumn{2}{|c|}{$\begin{array}{l}\text { branca levemente rosada } \\
\text { com faixas preto- } \\
\text { esverdeado }\end{array}$} & \multicolumn{2}{|c|}{$\begin{array}{l}\text { branco-amarelada com } \\
\text { faixas ferruginosas }\end{array}$} \\
\hline \multicolumn{2}{|c|}{ estrutura } & maciça & \multicolumn{2}{|c|}{ gnáissica } & \multicolumn{2}{|l|}{ gnáissica } \\
\hline \multicolumn{2}{|c|}{ textura } & $\begin{array}{l}\text { ineqüigranular } \\
\text { hipidiomórfica, poiquilítica }\end{array}$ & \multicolumn{2}{|c|}{$\begin{array}{l}\text { granoblástica } \\
\text { ineqüigranular interlobada } \\
\text { a poligonal / } \\
\text { granolepidoblástica }\end{array}$} & \multicolumn{2}{|c|}{$\begin{array}{l}\text { granoblástica } \\
\text { ineqüigranular interlobada } \\
\text { a poligonal / } \\
\text { granolepidoblástica }\end{array}$} \\
\hline \multicolumn{2}{|c|}{ granulação } & $\begin{array}{l}\text { fina a média } \\
\text { matriz (albita): 0,5-1,0 mm } \\
\text { fenocristais (quartzo e } \\
\text { microclínio): } 3-10 \mathrm{~mm}\end{array}$ & \multicolumn{2}{|c|}{$\begin{array}{l}\text { fina a grossa, variável } \\
\text { segundo faixas. } \\
\text { predomina média a } \\
\text { grossa: } 1-10 \mathrm{~mm}\end{array}$} & \multicolumn{2}{|c|}{$\begin{array}{l}\text { fina a grossa, variável } \\
\text { segundo faixas. } \\
\text { predomina média a } \\
\text { grossa: 1-5 mm, até } 15 \\
\text { mm }\end{array}$} \\
\hline \multicolumn{3}{|c|}{ mineralogia (\%) } & \multirow{2}{*}{\multicolumn{2}{|c|}{$\mathbf{A}$}} & \multicolumn{2}{|l|}{$\mathbf{A}$} \\
\hline \multicolumn{2}{|c|}{ quartzo } & 30 & & & 15 & 40 \\
\hline \multicolumn{2}{|c|}{ plagioclásio } & 35 (albita) & 10 (oligocl.) & $25-30$ & 15 (oligocl.) & $25-30$ \\
\hline \multicolumn{2}{|c|}{ microclínio } & 30 & $\begin{array}{l}65 \\
\text { (micropert.) }\end{array}$ & $5-10$ & $\begin{array}{l}45 \\
\text { (micropert.) }\end{array}$ & $5-10$ \\
\hline \multicolumn{2}{|c|}{ biotita } & - & 5 & 5 & 5 & 5 \\
\hline \multicolumn{2}{|c|}{ muscovita } & - & 5 & 15 & 15 & 15 \\
\hline \multicolumn{2}{|c|}{ mica litinífera } & $5-10$ & - & - & - & - \\
\hline \multicolumn{2}{|c|}{ topázio } & $5-10$ & - & - & - & - \\
\hline \multicolumn{2}{|c|}{ granada } & - & 5 & 5 & 5 & 5 \\
\hline \multicolumn{2}{|c|}{ Acessórios (tr) } & zircão, fluorita & \multicolumn{2}{|l|}{ opacos } & \multicolumn{2}{|l|}{ opacos } \\
\hline \multicolumn{2}{|c|}{ secundários } & sericita & \multicolumn{2}{|c|}{$\begin{array}{l}\text { epídoto, sericita, } \\
\text { argilominerais, clorita }\end{array}$} & $\begin{array}{l}\text { sericita, arc } \\
\text { hidróxidos } \\
\text { epídoto }\end{array}$ & $\begin{array}{l}\text { ominerais, } \\
\text { ferro, clorita, }\end{array}$ \\
\hline altel & ção & incipiente & fraca & & fraca a mo & rada \\
\hline inte & périca & $\begin{array}{l}\text { microclínio e albita: } \\
\text { levemente turvos e } \\
\text { localmente pontilhados } \\
\text { por sericita; } \\
\text { topázio: incipiente } \\
\text { alteração para sericita. }\end{array}$ & $\begin{array}{l}\text { granada: al } \\
\text { biotita, seg } \\
\text { plagioclásic } \\
\text { turvos por } \\
\text { localmente } \\
\text { sericita. }\end{array}$ & $\begin{array}{l}\text { ra-se em } \\
\text { do fraturas; } \\
\text { núcleos } \\
\text { yilominerais e } \\
\text { terados em }\end{array}$ & $\begin{array}{l}\text { plagioclásic } \\
\text { argilominer } \\
\text { localmente } \\
\text { sericita; } \\
\text { granada al } \\
\text { clorita, seg } \\
\text { biotita: alte } \\
\text { clorita. }\end{array}$ & $\begin{array}{l}\text { turvo por } \\
\text { s e } \\
\text { terado em } \\
\text { a-se em } \\
\text { do fraturas; } \\
\text {-se em }\end{array}$ \\
\hline hidr & ermal & - & - & & - & \\
\hline fiss! & amento & incipiente & fraco & & fraco a mo & rado \\
\hline intra & ranulares & x (quartzo) & $\mathrm{x}$ (predomi & nte) - quartzo & $x-$ quartzo & feldspatos \\
\hline inte & ranulares & - & - & & $x$ & \\
\hline tran & yranulares & - & $\begin{array}{l}\mathrm{x}(\text { raras })- \\
\text { por carbon }\end{array}$ & eenchidas & $x$ & \\
\hline pree & chimento & sem preenchimento & carbonato, & ricita & $\begin{array}{l}\text { hidróxidos } \\
\text { argilominer }\end{array}$ & $\begin{array}{l}\text { ferro e } \\
\text { s castanhos }\end{array}$ \\
\hline clas & ficação & Albita Granito & $\begin{array}{l}\text { Gnaisse Qu } \\
\text { com faixas } \\
\text { Gnaisse To }\end{array}$ & $\begin{array}{l}\text { tzo Sienítico } \\
\text { le Muscovita } \\
\text { alítico }\end{array}$ & $\begin{array}{l}\text { Gnaisse Qu } \\
\text { (A) com fa } \\
\text { Muscovita } \\
\text { Tonalítico }\end{array}$ & $\begin{array}{l}\text { tzo Sienítico } \\
\text { as de } \\
\text { laisse } \\
\text { ) }\end{array}$ \\
\hline
\end{tabular}


É um albita granito, de cor branca, com pontos pretos e esverdeados, composto por cristais subédricos a euédricos de quartzo, microclínio e plagioclásio (albita) em arranjo granular hipidiomórfico a panidiomórfico fino (geralmente entre 0,5 e 1,0 mm).

Quartzo e microclínio freqüentemente constituem microfenocristais poiquilíticos, contendo inclusões de cristais tabulares de albita (Figura 6.19 a, b).

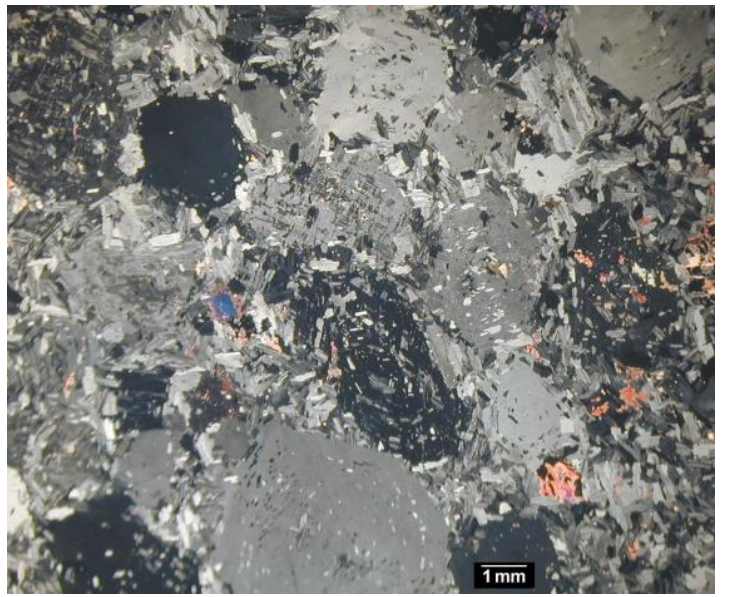

a)

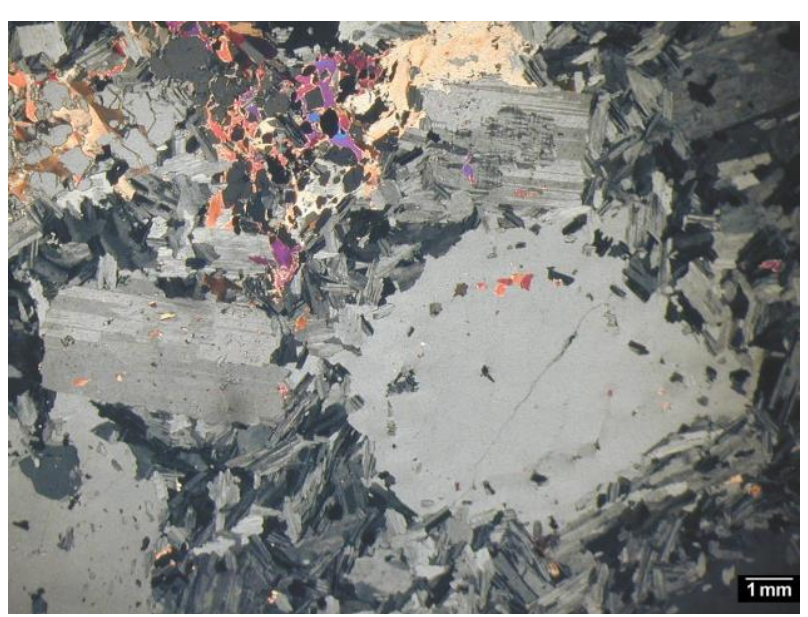

b)

Figura 6.19 - Amostra BCE. Aspecto geral do granito Branco Ceará. Notar, em (b), a presença de mica litinífera ocupando espaços intergranulares ou fissuras em feldspatos.

Mica litinífera e topázio, geralmente associados, ocorrem em quantidades subordinadas.

Alteração intempérica é praticamente ausente, denotada por leve turvamento dos cristais de microclínio e albita, localmente pontilhados de sericita. Topázio exibe alteração incipiente em sericita.

Metassomatismo associado à greisenização seria o processo responsável pela presença de albita, mica litinífera, fluorita e topázio

\subsubsection{Casablanca e Falésias}

Casablanca e Falésias são explorados em Pedra Branca (CE), no contexto dos leptinitos Tróia. Trata-se das variações praticamente inalterada e intempericamente alterada, respectivamente, de rocha gnáissica, com marcante bandamento caracterizado pela alternância faixas ou lentes irregulares, ora essencialmente quartzofeldspáticas, ora com minerais micáceos associados. No Casablanca essas faixas representam, respectivamente, áreas de cor branca e de cor cinza médio; e, no Falésias, aquelas de cor branco-amarelada e de cor ferrugem. 
Por meio de ensaio de coloração seletiva de feldspatos (Fig. 6.1) foi possível observar que as faixas quartzo-feldspáticas são compostas essencialmente por microclínio e subordinadamente quartzo (quartzo sieníticas), e as outras por plagioclásio, quartzo e micas (tonalíticas).

Não obstante a marcante alteração cromática, devido ao intemperismo, o exame microscópico revelou pequenas modificações: presença de clorita nas fraturas em granada e de fissuras mais largas, inter e transgranulares, preenchidas por filossilicatos castanhos e hidróxidos de ferro.

São rochas constituídas por quartzo e feldspatos, em quantidade e tipo variáveis conforme a banda, em arranjo granoblástico ineqüigranular interlobado a poligonal, tendendo a granolepidoblástico nas bandas enriquecidas em mica (muscovita e biotita) (Figura 6.20 e 6.21).

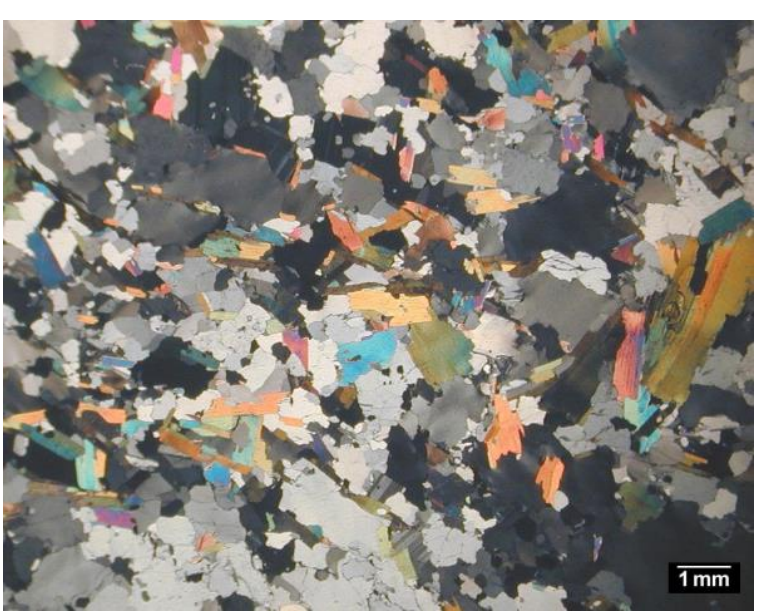

polarizadores cruzados

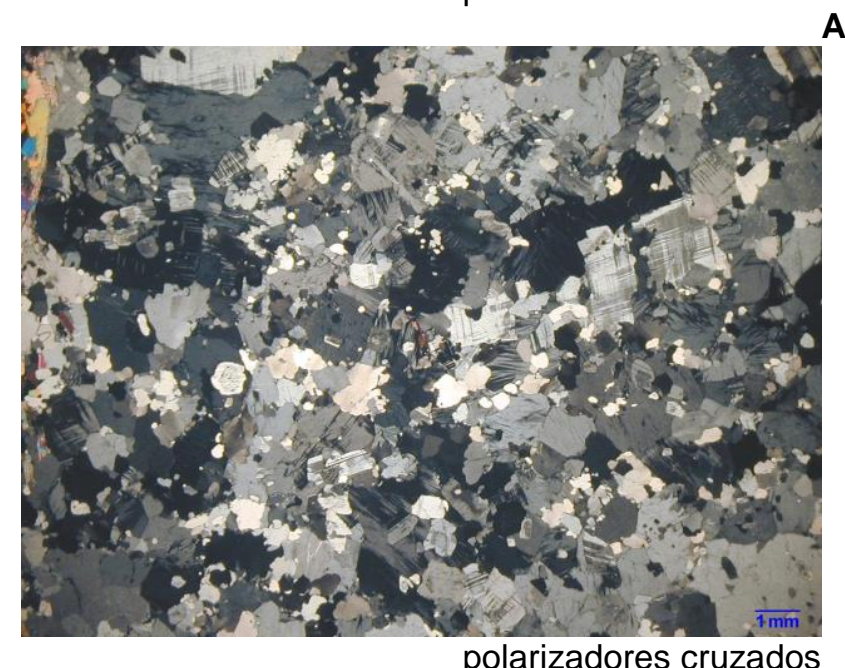

B

A

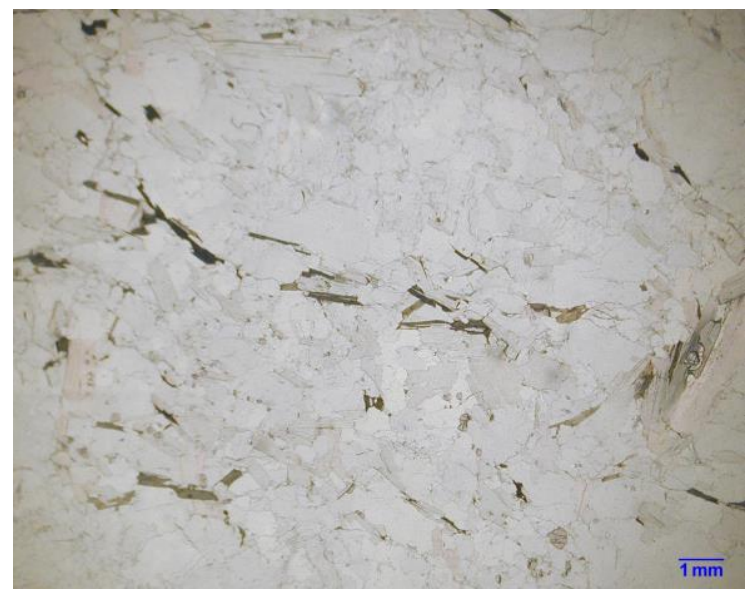

polarizadores paralelos

Figura 6.20 - Amostra CSB. Aspecto geral do gnaisse Casablanca.

A: bandas tonalíticas, ricas em muscovita e, subordinadamente, biotita; microclínio é praticamente ausente.

B: bandas quartzo sieníticas, ineqüigranulares, ricas em microclínio e com ausência de micas.

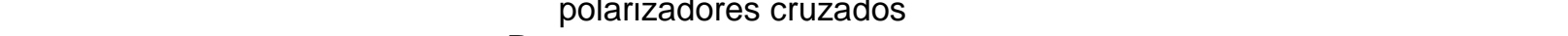




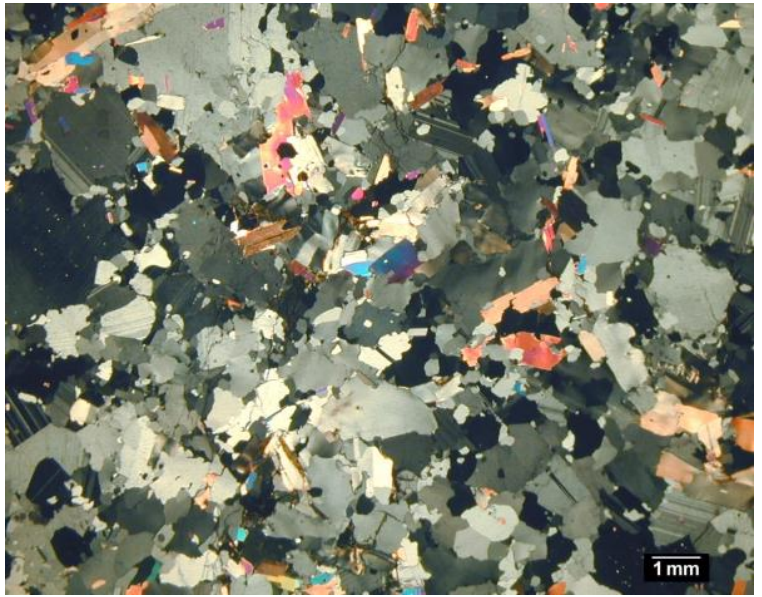

polarizadores cruzados

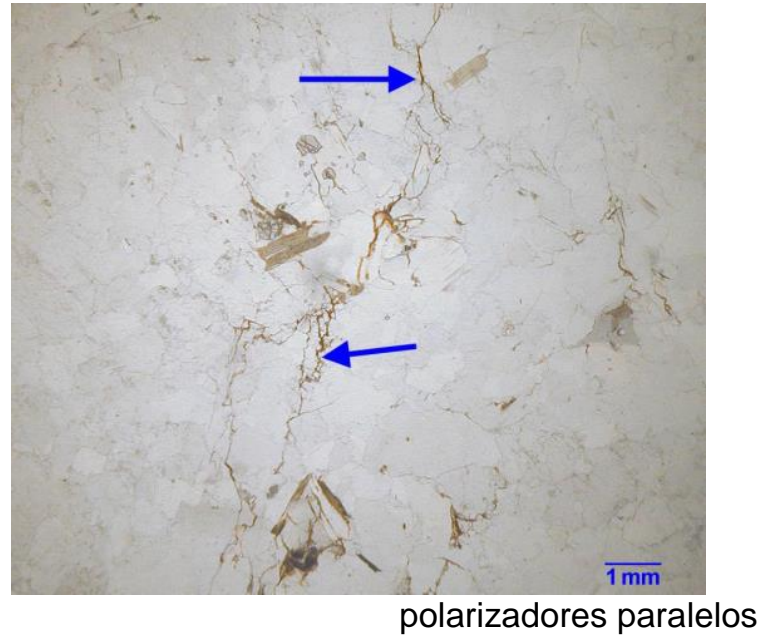

polarizadores paralelos

Figura 6.21 - Amostra FLS. Aspecto geral do gnaisse Falésias. Aspecto de banda tonalítica. Notar a presença de fissuras inter e transgranulares, mais largas, preenchidas por filossilicatos e hidróxidos de ferro.

A biotita em geral tem cor castanha e, menos freqüentemente, esverdeada. Epídoto ocorre esparsamente pela rocha.

$\mathrm{Na} \mathrm{CSB}$, as microfissuras são predominantemente intragranulares, não preenchidas ou com preenchimento de argilominerais incolores. Poucas microfissuras, intragranulares, irregulares e mais largas, acham-se preenchidas por carbonato.

A granada está intensamente microfissurada e substituída por filossilicatos castanhos, ao longo dessas.

Na FLS, adicionalmente, são comumente observadas fissuras transgranulares, largas, preenchidas por filossilicatos castanhos e hidróxidos de ferro (Fig. 6.21).

\subsubsection{Giallo Veneciano, Arabesco e Santa Cecília}

$\mathrm{Na}$ região norte do Estado do Espírito Santo, entre as localidades de Nova Venécia, Ecoporanga e Barra do São Francisco, são explorados vários tipos comerciais de gnaisses granatíferos, dentre os quais foram selecionados: Giallo Veneciano, Santa Cecília e Arabesco; o primeiro é uma das rochas ornamentais brasileiras mais exportadas para o mercado europeu e os outros, rochas muito consumidas no mercado interno.

Trata-se de granada-biotita gnaisses monzo a sienograníticos, que podem conter quantidades variáveis de aluminossilicatos (sillimanita, possível cordierita e outros), estrutura gnáissica e geralmente de granulação grossa (Tabela 6.12). 
Tabela 6.12 - Resultados de análises petrográficas das amostras GVN, ARB e SCC.

\begin{tabular}{|c|c|c|c|c|}
\hline \multicolumn{2}{|c|}{ AMOSTRA } & GVN & ARB & SCC \\
\hline \multirow[b]{2}{*}{ cor } & natural & rosa-amarelado & $\begin{array}{l}\text { cinza-esverdeado } \\
\text { levemente rosado }\end{array}$ & cinza-alaranjado \\
\hline & polida & rosa-amarelado & $\begin{array}{l}\text { cinza-esverdeado } \\
\text { levemente rosado }\end{array}$ & cinza-alaranjado \\
\hline \multicolumn{2}{|c|}{ estrutura } & gnáissica & gnáissica & gnáissica \\
\hline \multicolumn{2}{|c|}{ textura } & $\begin{array}{l}\text { granoblástica } \\
\text { ineqüigranular interlobada/ } \\
\text { porfiroclástica }\end{array}$ & $\begin{array}{l}\text { granoblástica } \\
\text { ineqüigranular interlobada }\end{array}$ & $\begin{array}{l}\text { granoblástica interlobada / } \\
\text { porfiroblástica }\end{array}$ \\
\hline \multicolumn{2}{|c|}{ granulação } & $\begin{array}{l}\text { média a muito grossa: } 1 \text { - } \\
15 \text { mm; megacristais: até } \\
60 \text { mm (amostra de mão) }\end{array}$ & $\begin{array}{l}\text { média a grossa: 1-6 mm; } \\
\text { porfiroclastos (feldspatos): } \\
\text { 10-15 mm; quartzo, em } \\
\text { cordões: até } 25 \mathrm{~mm}\end{array}$ & $\begin{array}{l}\text { média a grossa: predomina } \\
\text { entre } 3-10 \mathrm{~mm}\end{array}$ \\
\hline \multicolumn{5}{|c|}{ mineralogia (\%) } \\
\hline \multicolumn{2}{|c|}{ quartzo } & 25 & 30 & $25-30$ \\
\hline \multicolumn{2}{|c|}{ plagioclásio } & 15 (oligoclásio) & 20 (oligoclásio) & 15-20 (oligoclásio) \\
\hline \multicolumn{2}{|c|}{ microclínio } & 40-45 (micropertítico) & $\begin{array}{l}25 \text { (feldspato alcalino } \\
\text { micropertítico) }\end{array}$ & $\begin{array}{l}30 \text { (feldspato potássico } \\
\text { micropertítico) }\end{array}$ \\
\hline \multicolumn{2}{|c|}{ biotita } & $5-10$ & 10 & 10 \\
\hline \multicolumn{2}{|c|}{ granada } & $5-10$ & 5 & $5-10$ \\
\hline \multicolumn{2}{|c|}{ sillimanita } & $\operatorname{tr}$ & 5 & 5 \\
\hline \multicolumn{2}{|c|}{ "cordierita" } & - & $<5$ & $<5$ \\
\hline \multicolumn{2}{|c|}{ opacos } & $<5$ & $<5$ & - \\
\hline \multicolumn{2}{|c|}{ acessórios (tr) } & $\begin{array}{l}\text { apatita, zircão, rutilo, } \\
\text { biotita verde, espinélio } \\
\text { verde }\end{array}$ & $\begin{array}{l}\text { zircão, apatita, titanita, } \\
\text { rutilo (?), espinélio verde }\end{array}$ & $\begin{array}{l}\text { zircão, opacos, rutilo (?) } \\
\text { alterado, apatita }\end{array}$ \\
\hline \multicolumn{2}{|c|}{ secundários } & $\begin{array}{l}\text { hidróxidos de ferro, } \\
\text { carbonato, argilominerais, } \\
\text { sericita, muscovita, } \\
\text { leucoxênio, filossilicatos } \\
\text { castanhos }\end{array}$ & $\begin{array}{l}\text { carbonato, sericita, } \\
\text { muscovita, argilominerais, } \\
\text { hidróxidos de ferro, } \\
\text { leucoxênio }\end{array}$ & $\begin{array}{l}\text { sericita, muscovita, } \\
\text { hidróxidos de ferro, } \\
\text { argilominerais, carbonato }\end{array}$ \\
\hline \multicolumn{2}{|c|}{ alteração } & moderada & fraca a moderada & fraca a moderada \\
\hline \multicolumn{2}{|c|}{ intempérica } & $\begin{array}{l}\text { feldspatos: intensamente } \\
\text { alterados em sericita e } \\
\text { carbonato, principalmente } \\
\text { a partir de fissuras; } \\
\text { opacos: alteram-se em } \\
\text { leucoxênio e hidróxidos de } \\
\text { ferro; } \\
\text { biotita: altera-se em } \\
\text { óxidos/hidróxidos de ferro; } \\
\text { granada: fraturas } \\
\text { alteradas em filossilicatos } \\
\text { castanhos. }\end{array}$ & $\begin{array}{l}\text { feldspatos: turvos por } \\
\text { argilominerais, a partir de } \\
\text { fissuras; } \\
\text { plagioclásio: alterado em } \\
\text { argilominerais, sericita e } \\
\text { carbonato; } \\
\text { biotita: muito localmente, } \\
\text { altera-se em hidróxidos de } \\
\text { ferro. }\end{array}$ & $\begin{array}{l}\text { plagioclásio: em geral está } \\
\text { turvo a parcialmente } \\
\text { alterado em argilominerais } \\
\text { (que localmente } \\
\text { constituem "bolsões"), e } \\
\text { em carbonato; } \\
\text { sillimanita: altera-se em } \\
\text { filossilicatos incolores. }\end{array}$ \\
\hline \multicolumn{2}{|c|}{ hidrotermal } & - & - & - \\
\hline \multicolumn{2}{|c|}{ fissuramento } & forte & moderado a forte & moderado a forte \\
\hline \multicolumn{2}{|c|}{ intragranulares } & $\begin{array}{l}\mathrm{x}-\text { feldspatos, quartzo e } \\
\text { granada }\end{array}$ & $\begin{array}{l}\mathrm{x} \text { (predominante) - } \\
\text { quartzo e feldspatos }\end{array}$ & $\begin{array}{l}\mathrm{x} \text { (predominante) - } \\
\text { quartzo e feldspatos }\end{array}$ \\
\hline \multicolumn{2}{|c|}{ intergranulares } & $\mathrm{x}$ (raras) & - & - \\
\hline \multicolumn{2}{|c|}{ transgranulares } & $\begin{array}{l}\mathrm{x} \text { (predominante) - } \\
\text { feldspatos e quartzo }\end{array}$ & $x$ & $x$ \\
\hline
\end{tabular}




\begin{tabular}{c|l|l|l}
\hline AMOSTRA & \multicolumn{1}{|c|}{ GVN } & \multicolumn{1}{c}{ ARB } & \multicolumn{1}{c}{ SCC } \\
\hline preenchimento & $\begin{array}{l}\text { hidróxidos de ferro, } \\
\text { carbonato }\end{array}$ & $\begin{array}{l}\text { hidróxidos/ óxidos de } \\
\text { ferro,carbonato, } \\
\text { argilominerais }\end{array}$ & $\begin{array}{l}\text { hidróxidos de ferro, } \\
\text { filossilicatos secundários, } \\
\text { argilominerais, carbonato }\end{array}$ \\
\hline classificação & $\begin{array}{l}\text { Gnaisse Sienogranítico } \\
\text { com Granada }\end{array}$ & $\begin{array}{l}\text { Biotita Gnaisse } \\
\text { Monzogranítico Com } \\
\text { Granada e Sillimanita }\end{array}$ & $\begin{array}{l}\text { Biotita Gnaisse } \\
\text { Monzogranítico Com } \\
\text { Granada e Sillimanita }\end{array}$ \\
\hline
\end{tabular}

O Giallo Veneciano é um gnaisse sienogranítico com granada, de cor rosaamarelado, caracterizada por cristais anédricos de quartzo e anédricos a subédricos de feldspatos, em arranjo textural granoblástico ineqüigranular interlobado (Figura 6.22).

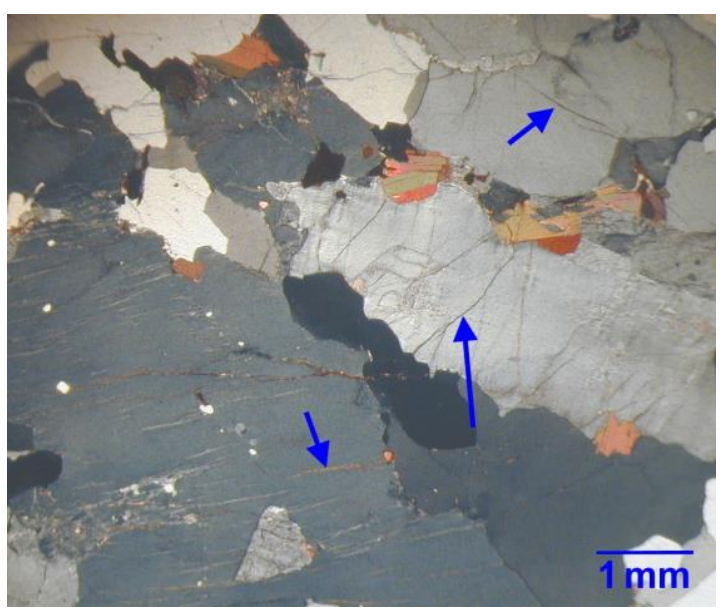

polarizadores cruzados

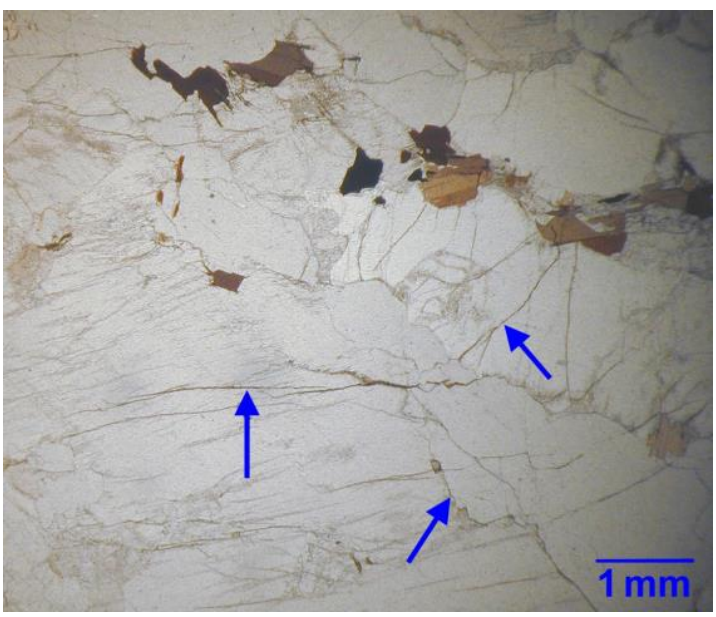

polarizadores paralelos

Figura 6.22 - Amostra GVN. Aspecto geral do gnaisse Giallo Veneciano. Notar forte microfissuramento e alteração em argilominerais e hidróxidos de ferro, nas paredes dos minerais, próximas a essas fissuras.

Biotita e granada constituem agregados suborientados segundo a estruturação da rocha. Minerais opacos e rutilo comumente ocorrem como inclusões em granada. Sillimanita foi observada muito localizadamente, já parcialmente alterada em argilominerais.

Alteração intempérica moderada a intensa é evidenciada por plagioclásio, principalmente, e, também, microclínio, alterados em argilominerais, sericita e carbonato, especialmente a partir de abundantes microfissuras intragranulares.

Muito localmente, argilominerais castanhos estão ocupando espaços intergranulares e, possivelmente, são produtos de alteração de plagioclásio (Figura 6.23).

O microfissuramento é moderado a intenso, transgranular e, subordinadamente, 
intragranular (plagioclásio), e geralmente preenchido por carbonato e hidróxidos de ferro (Figura 6.24).

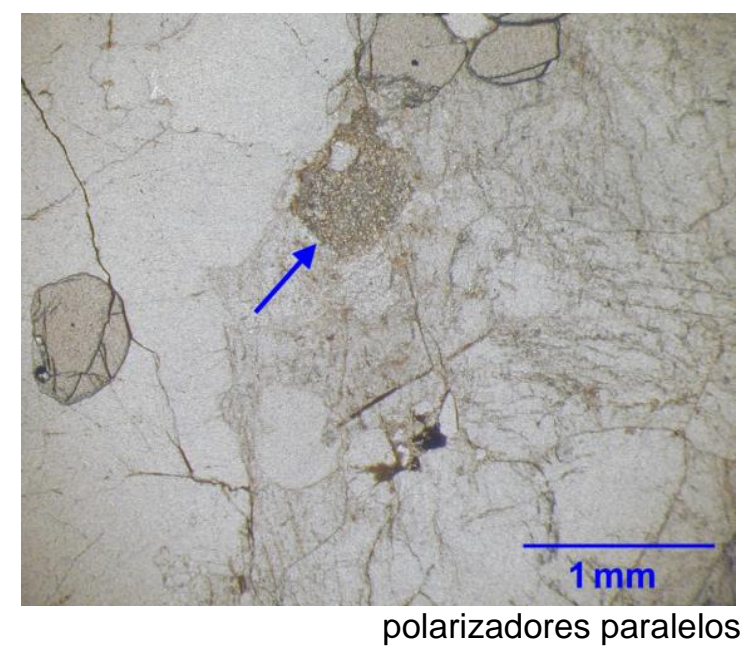

Figura 6.23 - Amostra GVN. Detalhe da alteração de plagioclásio e de argilominerais ocupando espaços intergranulares.

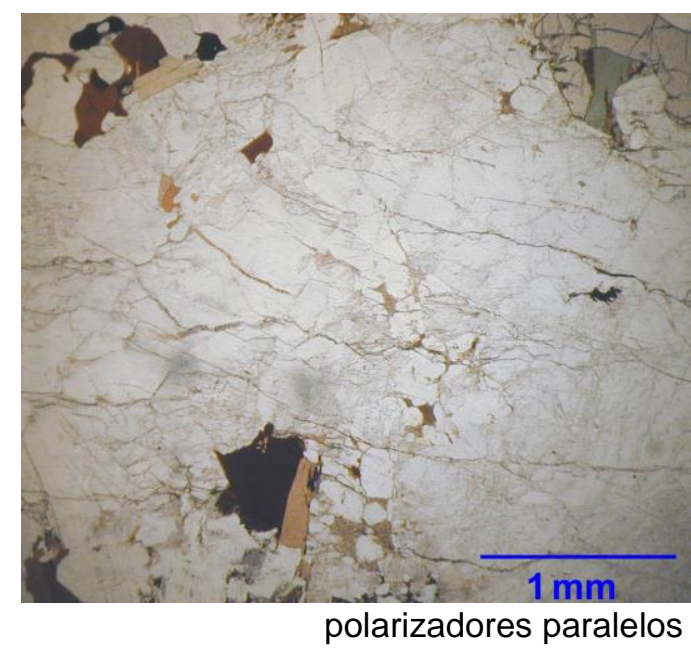

Figura 6.24 - Amostra GVN. Visão geral da alteração e microfissuramento.

Muscovita e biotita verde são neoformados e ocorrem preferencialmente junto ou substituindo biotita.

Arabesco é um biotita gnaisse monzogranítico com granada e sillimanita (Tabela 6.12), de coloração cinza-esverdeado, levemente rosado, e granulação muito heterogênea, variando de média a grossa.

Caracteriza-se pelo arranjo granoblástico de cristais anédricos de quartzo e subédricos a anédricos de feldspato alcalino e plagioclásio, medindo entre $5 \mathrm{~mm}$ e $15 \mathrm{~mm}$, segundo agregados lenticulares ou cordões, entre os quais ocorre "matriz" composta de quartzo e plagioclásio, principalmente, em arranjo granoblástico fino (1 $\mathrm{mm}$ a $3 \mathrm{~mm}$ ), eqüigranular (Figura 6.25).

Sillimanita ( \pm biotita, \pm granada) constitui agregados nematolepidoblásticos, finos, fortemente isorientados, e preferencialmente associados à matriz (Figura 6.26).

Opacos (+ rutilo) ocorrem associados ou inclusos em granada. Máficos e aluminossilicatos estão praticamente sãos, à exceção de alteração local de sillimanita em argilominerais. 

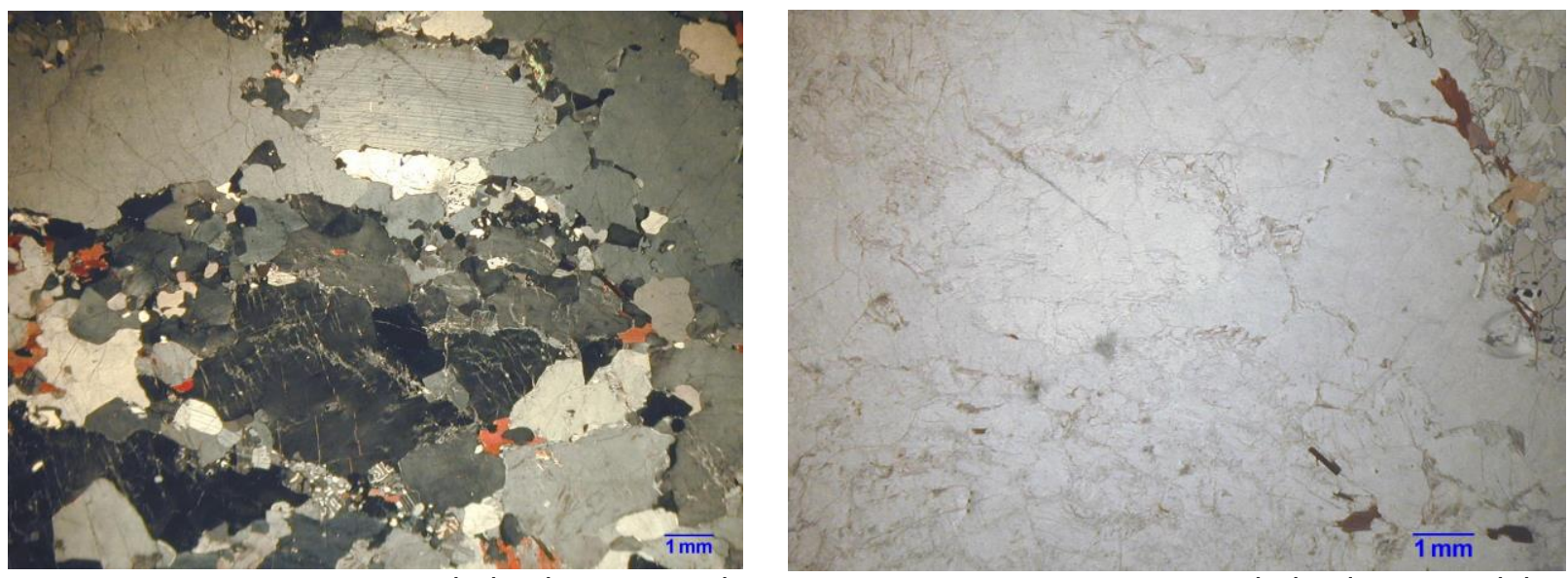

polarizadores cruzados

polarizadores paralelos

Figura 6.25 - Amostra ARB. Aspecto geral do gnaisse Arabesco. Notar heterogeneidade granulométrica e cristais tabulares de plagioclásio (porção superior, centro, foto à esquerda).

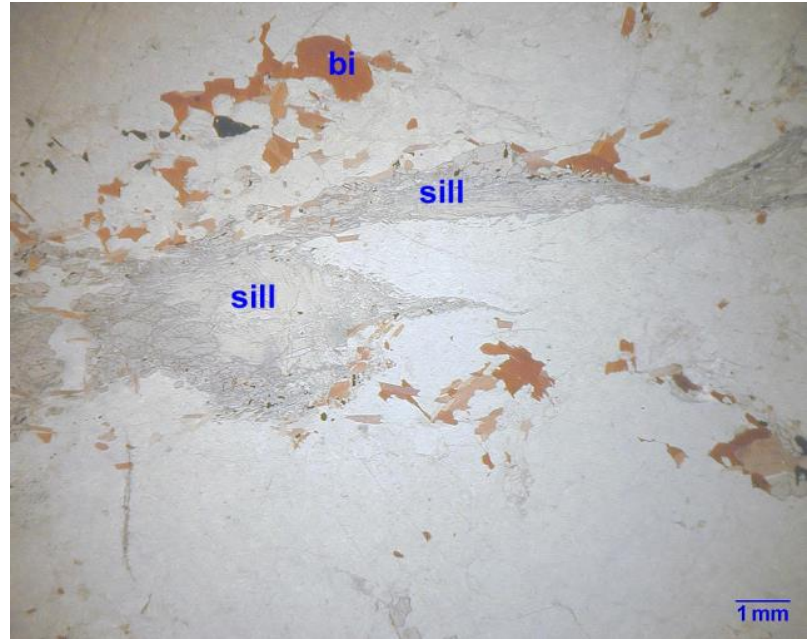

polarizadores paralelos
Figura 6.26 - Amostra ARB. Aspecto dos cordões de sillimanita (sill) e de agregados de biotita (bi) e opacos.

Os feldspatos estão turvos ou alterados em argilominerais, a partir de fissuras e clivagens; plagioclásio, adicionalmente, altera-se em sericita ou carbonato.

Provável cordierita é pontualmente observada, quase totalmente alterada em argilominerais, associada à biotita e sillimanita e em intercrescimento simplectítico entre quartzo e plagioclásio (Figura 6.27).

Microfissuramento moderado a intenso, predominantemente intragranular, é observado em quartzo e feldspatos. As microfissuras estão preenchidas por argilominerais e hidróxidos de ferro. 


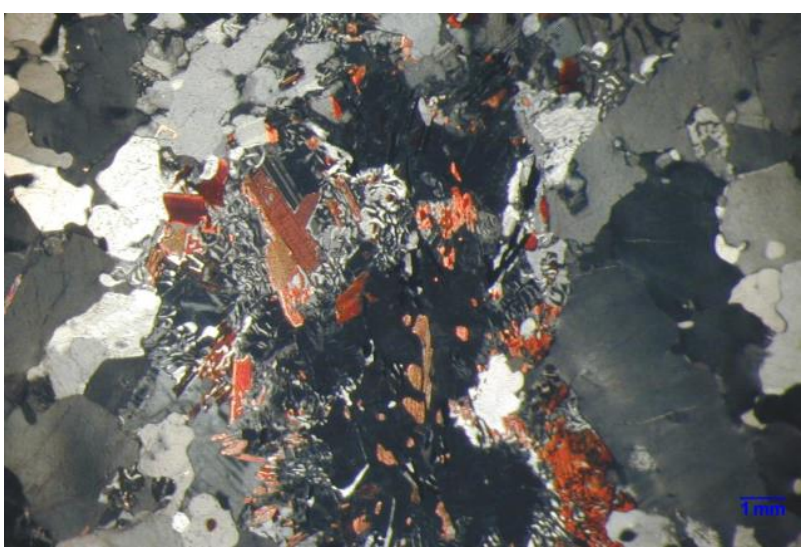

polarizadores cruzados.

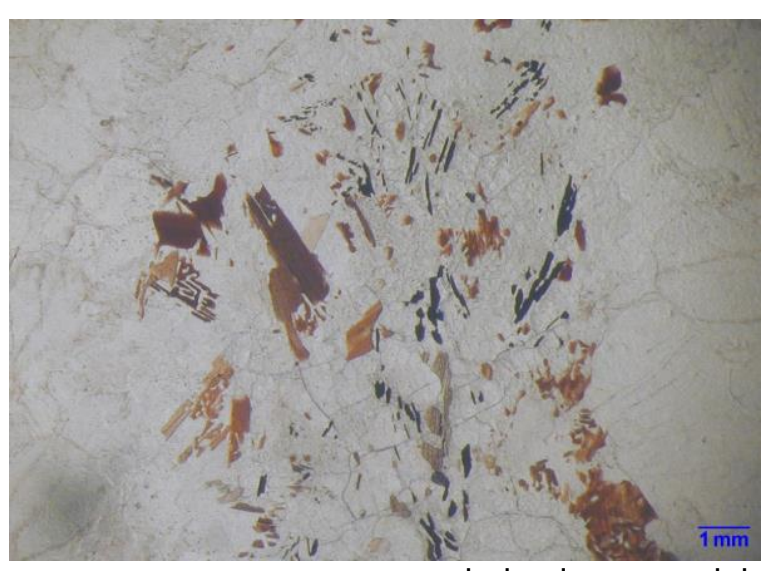

polarizadores paralelos

Figura 6.27 - Amostra ARB. Aspecto de provável cordierita alterada.

Santa Cecília é um biotita gnaisse monzogranítico com granada e sillimanita, de cor cinza-alaranjado e granulação média a muito grossa (Tabela 6.12). A estrutura é fortemente gnáissica, caracterizada por cristais anédricos de quartzo e feldspatos em arranjo granoblástico interlobado (Figura 6.28). Os cristais têm dimensões relativamente mais uniforme que GVN e $A R B$, geralmente variando entre $3 \mathrm{~mm}$ e $10 \mathrm{~mm}$.

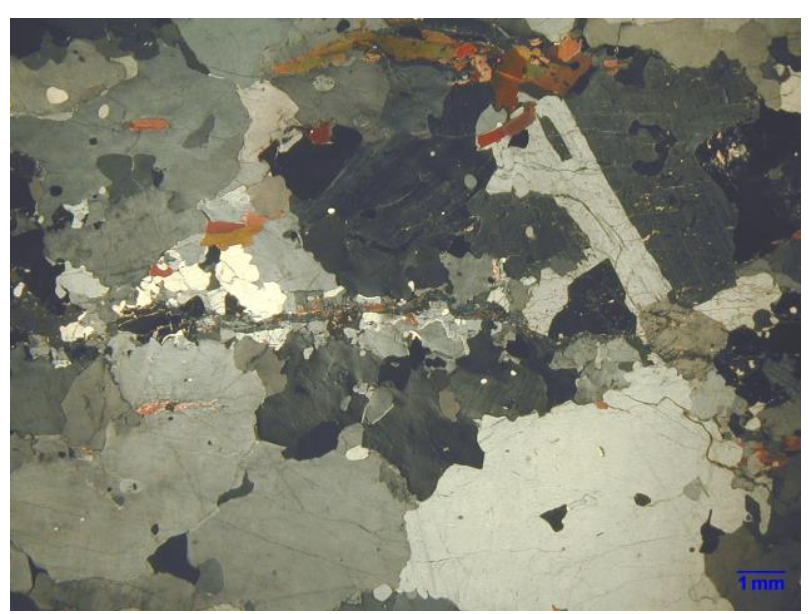

Polarizadores cruzados

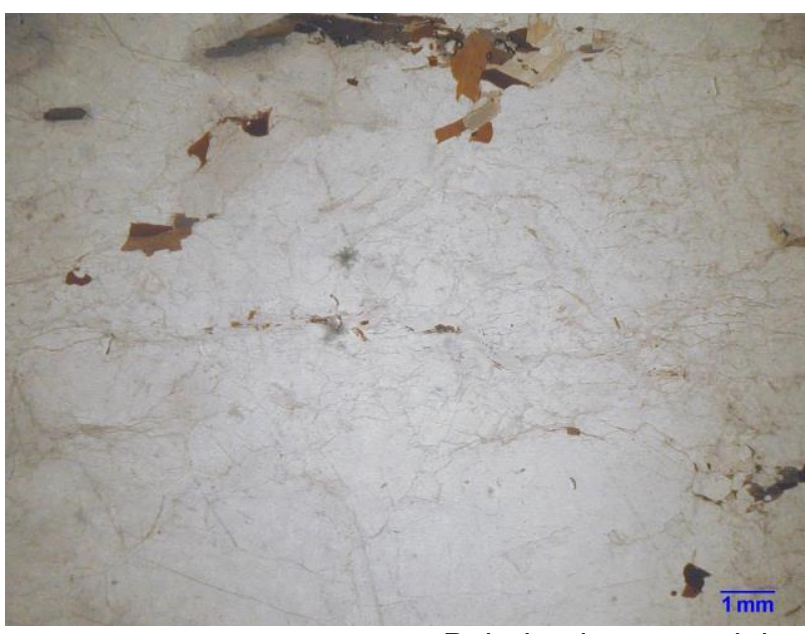

Polarizadores paralelos

Figura 6.28 - Amostra SCC. Aspecto geral do gnaisse Santa Cecília. Notar microfissuramento intragranular, especialmente em feldspatos, e turvação e alteração desses.

Biotita e/ou sillimanita tendem a constituir agregados alongados segundo a orientação da rocha. Granada ocorre em porfiroblastos (<5 $\mathrm{mm}$ ) esparsos.

Sillimanita altera-se em argilominerais incolores. Plagioclásio acha-se turvo a parcialmente alterado em argilominerais (Figura 6.29) e, menos comumente, em 
carbonato, a partir de fissuras e clivagens. Em parte, os argilominerais são produtos da alteração de minúsculos cristais de sillimanita, que se acham inclusos nos cristais de plagioclásio.

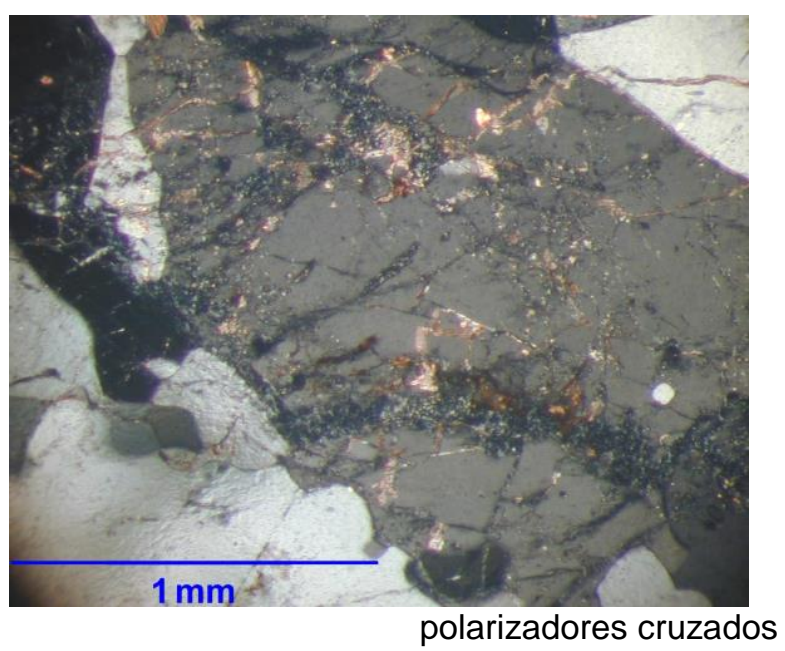

Figura 6.29 - Amostra SCC. Aspecto da alteração de plagioclásio e presença de argilominerais preenchendo espaços intragranulares.

Quartzo e feldspatos exibem intenso microfissuramento, predominantemente intragranular, com preenchimento de argilominerais e hidróxidos de ferro. São freqüentemente observadas microfissuras mais largas que nas GVN e ARB.

A identificação mineralógica por difratometria de raios $\mathrm{X}$, de porções retiradas de núcleos alterados de plagioclásio, indicou a presença de argilominerais do grupo da illita, nas amostras GVN e ARB.

\subsubsection{Características químicas}

As composições químicas das amostras em estudo, conforme exibido nas Tabelas 6.13 e 6.14, indicaram que o teor de sílica é bastante semelhante (entre $73 \% \mathrm{e}$ $79 \%)$, à exceção de LBD ( 69\%).

A comparação dos resultados obtidos, para rochas pertencentes aos grupos aqui discriminados, indicou uma grande similaridade química entre elas, refletindo as semelhanças observadas no estudo petrográfico.

Essa observação permite indicar que há consistência petrográfica e química, entre as rochas constituintes do grupo 8 , fornecendo maior segurança na comparação dos resultados obtidos nas determinações de propriedades físicas e mecânicas e nos ensaios de alteração acelerada. 
Tabela 6.13 - Composição química das rochas graníticas em estudo - Elementos maiores (\%).

\begin{tabular}{|c|c|c|c|c|c|c|c|c|c|c|c|c|c|c|c|c|c|c|}
\hline & LBD & VCB-1 & VCB-2 & VCB-3 & RIC & BCR & BSV & PIT & AZF & $\mathrm{BCE}$ & ITN 1 & ITN 2 & CRV & CSB & FLS & GVN & ARB & scc \\
\hline $\mathrm{SiO}_{2}$ & 69,39 & 74,50 & 76,20 & 75,29 & 75,21 & 77,55 & 74,91 & 75,68 & 75,18 & 74,89 & 74,21 & 75,75 & 75,24 & 76,21 & 74,76 & 73,20 & 77,42 & 79,10 \\
\hline $\mathrm{TiO}_{2}$ & 0,410 & 0,210 & 0,221 & 0,232 & 0,093 & 0,047 & 0,082 & 0,093 & 0,105 & 0,009 & 0,028 & 0,029 & 0,050 & 0,017 & 0,009 & 0,305 & 0,235 & 0,179 \\
\hline $\mathrm{Al}_{2} \mathrm{O}_{3}$ & 14,65 & 12,84 & 11,84 & 12,37 & 12,60 & 11,88 & 13,25 & 13,31 & 13,51 & 14,32 & 13,72 & 13,66 & 14,48 & 14,53 & 14,69 & 13,87 & 11,83 & 11,09 \\
\hline $\mathrm{Fe}_{2} \mathrm{O}_{3}$ & 0,52 & 0,37 & 0,42 & 0,53 & 0,24 & 0,19 & 0,19 & 0,15 & 0,18 & 0,26 & 0,11 & 0,11 & 0,40 & 0,21 & 0,32 & 0,11 & 0,01 & 0,26 \\
\hline $\mathrm{FeO}$ & 3,79 & 1,60 & 2,04 & 1,75 & 1,18 & 0,91 & 1,37 & 1,25 & 1,28 & 0,29 & 0,91 & 0,82 & 0,55 & 0,63 & 0,37 & 1,72 & 2,16 & 1,45 \\
\hline MnO & 0,077 & 0,034 & 0,041 & 0,033 & 0,020 & 0,018 & 0,028 & 0,058 & 0,047 & 0,027 & 0,017 & 0,014 & 0,050 & 0,017 & 0,018 & 0,018 & 0,050 & 0,038 \\
\hline $\mathrm{MgO}$ & 0,24 & 0,17 & 0,15 & 0,20 & 0,04 & 0,01 & 0,03 & 0,12 & 0,15 & $-0,01$ & 0,10 & 0,10 & 0,16 & 0,06 & 0,04 & 0,29 & 0,43 & 0,29 \\
\hline $\mathrm{CaO}$ & 2,01 & 0,81 & 0,76 & 0,90 & 0,77 & 0,68 & 0,94 & 0,89 & 0,80 & 0,36 & 1,63 & 1,37 & 0,68 & 1,26 & 0,58 & 1,29 & 1,82 & 0,94 \\
\hline $\mathrm{Na}_{2} \mathrm{O}$ & 2,92 & 2,97 & 2,86 & 3,10 & 3,38 & 3,83 & 3,97 & 3,69 & 3,67 & 5,45 & 3,15 & 2,97 & 3,99 & 5,83 & 3,80 & 2,69 & 2,50 & 2,32 \\
\hline $\mathrm{K}_{2} \mathrm{O}$ & 5,65 & 5,74 & 4,96 & 4,87 & 5,25 & 4,10 & 4,80 & 4,51 & 4,72 & 3,36 & 4,59 & 5,09 & 4,01 & 1,11 & 5,49 & 5,87 & 3,11 & 4,07 \\
\hline $\mathrm{P}_{2} \mathrm{O}_{5}$ & 0,13 & 0,05 & 0,04 & 0,06 & 0,02 & 0,02 & 0,02 & 0,06 & 0,06 & 0,01 & 0,04 & 0,06 & 0,28 & 0,03 & 0,03 & 0,28 & 0,14 & 0,15 \\
\hline S & 0,011 & 0,012 & 0,009 & 0,008 & 0,002 & 0,001 & 0,001 & 0,001 & 0,001 & 0,002 & 0,002 & 0,004 & 0,001 & $-0,001$ & $-0,001$ & 0,002 & 0,009 & 0,001 \\
\hline P.F. 1 & 0,05 & 0,46 & 0,51 & 0,51 & 0,26 & 0,38 & 0,42 & 0,42 & 0,33 & 0,35 & 0,15 & 0,08 & 0,32 & 0,26 & 0,23 & 0,32 & 0,02 & 0,14 \\
\hline TOTAL 1 & 99,84 & 99,75 & 100,05 & 99,85 & 99,06 & 99,61 & 100,01 & 100,23 & 100,02 & 99,33 & 98,65 & 100,06 & 100,19 & 100,16 & 100,33 & 99,96 & 99,73 & 100,02 \\
\hline P.F. 2 & 0,47 & 0,64 & 0,74 & 0,71 & 0,39 & 0,48 & 0,57 & 0,56 & 0,47 & 0,38 & 0,25 & 0,17 & 0,38 & 0,33 & 0,27 & 0,51 & 0,26 & 0,30 \\
\hline TOTAL 2 & 100,26 & 99,93 & 100,28 & 100,05 & 99,19 & 99,71 & 100,16 & 100,37 & 100,16 & 99,36 & 98,75 & 100,15 & 100,25 & 100,23 & 100,37 & 100,15 & 99,97 & 100,18 \\
\hline
\end{tabular}


Tabela 6.14 - Composição química das rochas graníticas em estudo - Elementos menores e traço (ppm).

\begin{tabular}{|c|c|c|c|c|c|c|c|c|c|c|c|c|c|c|c|c|c|c|}
\hline & LBD & VCB-1 & VCB-2 & VCB-3 & RIC & BCR & BSV & PIT & AZF & BCE & ITN 1 & ITN 2 & CRV & CSB & FLS & GVN & ARB & ScC \\
\hline $\mathrm{Ba}$ & 2486 & 310 & 139 & 267 & 185 & 23 & 96 & 112 & 195 & 11 & 576 & 574 & 131 & 2 & 8 & 354 & 213 & 182 \\
\hline $\mathbf{R b}$ & 132 & 248 & 290 & 265 & 252 & 310 & 312 & 265 & 228 & 728 & 140 & 130 & 155 & 53 & 256 & 165 & 95 & 175 \\
\hline $\mathrm{Sr}$ & 224 & 66 & 38 & 64 & 44 & 11 & 26 & 39 & 57 & 5 & 187 & 183 & 38 & 15 & 15 & 64 & 81 & 44 \\
\hline Cs & $-0,5$ & 4 & 5,3 & 6 & 4,2 & 6,1 & 6,6 & 22,1 & 9,3 & 4,7 & 0,8 & 0,7 & 2,7 & 2,4 & 6,4 & 1 & 1,1 & 1,8 \\
\hline $\mathrm{Ta}$ & -1 & 2 & 3 & 2 & -1 & -1 & 1 & 3 & 3 & 18 & -1 & -1 & -1 & -1 & 2 & -1 & -1 & -1 \\
\hline $\mathrm{Hf}$ & 12,8 & 5,7 & 7 & 6,3 & 4,3 & 5,7 & 5,2 & 2,9 & 3 & 4 & 1,6 & 1,6 & 1,1 & 2,1 & 1 & 4,6 & 3,7 & 3 \\
\hline $\mathrm{Zr}$ & 585 & 222 & 275 & 260 & 148 & 116 & 124 & 98 & 94 & 44 & 52 & 47 & 41 & 63 & 31 & 184 & 134 & 107 \\
\hline $\mathbf{Y}$ & 33 & 38 & 62 & 57 & 41 & 147 & 93 & 40 & 50 & 42 & 3 & 1 & 6 & 35 & 13 & 29 & 27 & 22 \\
\hline Th & 14,7 & 35,4 & 43,7 & 44,1 & 18,7 & 33 & 30,1 & 17,1 & 15,8 & 11,3 & $-0,5$ & 3,8 & 0,7 & 12,3 & 7,3 & 16 & 11 & 8,6 \\
\hline $\mathbf{U}$ & 1,7 & 8,8 & 9 & 9,2 & 5,5 & 13,7 & 8,4 & 5,9 & 8,5 & 10,4 & 0,7 & 1 & 2,3 & 7,7 & 6,4 & 1,8 & 2 & 2,8 \\
\hline $\mathrm{Cr}$ & 3 & 7 & -1 & -1 & 8 & -1 & -1 & -1 & -1 & 2 & 4 & -1 & 3 & -1 & -1 & 4 & 10 & 12 \\
\hline $\mathrm{Ni}$ & -1 & -1 & -1 & -1 & -1 & -1 & -1 & -1 & -1 & -1 & -1 & -1 & -1 & -1 & -1 & 1 & 1 & 2 \\
\hline Co & 3 & 2 & -1 & 3 & -1 & 1 & 2 & 2 & 2 & -1 & 1 & 1 & 2 & 1 & -1 & 3 & 4 & 4 \\
\hline Sc & 9,8 & 2,9 & 3,4 & 3,2 & 1,1 & 0,7 & 1 & 3,5 & 3,5 & 1,4 & 1,1 & 1,1 & 2,3 & 7,2 & 9,1 & 1,7 & 5,3 & 3,8 \\
\hline $\mathbf{V}$ & 12 & 10 & 5 & 15 & -5 & -5 & -5 & 9 & -5 & -5 & -5 & -5 & -5 & -5 & -5 & 7 & 15 & 13 \\
\hline $\mathrm{Cu}$ & 9 & 3 & 7 & 6 & 6 & 2 & 7 & 3 & 2 & 28 & 3 & 3 & 2 & 2 & 20 & 5 & 6 & 3 \\
\hline $\mathrm{Pb}$ & 24 & 41 & 36 & 39 & 39 & 47 & 42 & 33 & 36 & 43 & 30 & 34 & 29 & 37 & 65 & 34 & 19 & 24 \\
\hline $\mathrm{Zn}$ & 89 & 42 & 66 & 52 & 54 & 50 & 78 & 40 & 42 & 33 & 19 & 17 & 24 & 35 & 28 & 29 & 30 & 36 \\
\hline $\mathrm{Be}$ & 2 & 5 & 5 & 7 & 3 & 7 & 5 & 6 & 6 & 3 & 2 & 2 & 16 & 3 & 2 & 3 & 2 & 2 \\
\hline As & -2 & -2 & -2 & -2 & -2 & -2 & 2 & -2 & -2 & -2 & -2 & -2 & -2 & -2 & -2 & -2 & -2 & -2 \\
\hline
\end{tabular}


Algumas diferenças puderam ser notadas entre CRV e ITN-1 e ITN-2, e entre CSB e FLS, essas por motivo discutido mais adiante.

Para ilustrar e melhor visualizar as características químicas dessas rochas, foram elaborados diagramas de dispersão $\mathrm{SiO}_{2} x$ elementos maiores (Figura 6.30), com objetivo estritamente descritivo dos diferentes tipos de rochas.

A legenda utilizada nas figuras desse Capítulo é a mostrada a seguir:

\begin{tabular}{ll}
0 & Grupo 1 (Verde Labrador) \\
0 & Grupo 2 (Vermelho Capão Bonito) \\
0 & Grupo 3 (Rosa Iracema, Branco Cristal, Branco Savana) \\
0 & Grupo 4 (Prata Interlagos, Azul Paulista Frente Nova) \\
0 & Grupo 5 (Branco Ceará) \\
0 & Grupo 6 (Branco Itaúnas, Branco Caravelas) \\
\hline & Grupo 8 (Giallo Veneciano, Arabesco, Santa Cecília)
\end{tabular}

Os diagramas da Fig. 6.30 forneceram as seguintes informações, relativas ao comportamento dos elementos maiores e o teor de $\mathrm{SiO}_{2}$ :

- $\mathrm{Al}_{2} \mathrm{O}_{3}$ : há correlação negativa, mais claramente para as amostras $\mathrm{ARB}, \mathrm{SCC}$, BCR e VCB-2;

- $\mathrm{TiO}_{2}$ : VCBs, GVN, ARB e SCC se discriminam pelos teores relativamente maiores (>0,20\%);

- CaO: ARB, ITNs, GVN e CSB destacam-se pelos teores maiores que os demais $(>1,20 \%)$;

- MgO: SCC, GVN e ARB, discriminam-se pelos maiores teores (>0,20\%);

- $\mathrm{K}_{2} \mathrm{O}$ : FLS discrimina-se pelo baixo teor;

- $\mathrm{Na}_{2} \mathrm{O}: \mathrm{BCE}$ e CSB discriminam-se pelos maiores teores;

- $\mathrm{P}_{2} \mathrm{O}_{5}$ : CRV, GVN, SCC e ARB discriminam-se pelos maiores valores (>0,10\%).

A análise desses resultados indica que os valores obtidos para CSB e FLS não são representativos da rocha total. Dadas as pequenas quantidades (cerca de $1 \mathrm{~g}$ ) usualmente utilizadas para análise química, aparentemente os resultados da CSB são representativos das bandas tonalíticas e os da FLS, das bandas quartzo sieníticas. 

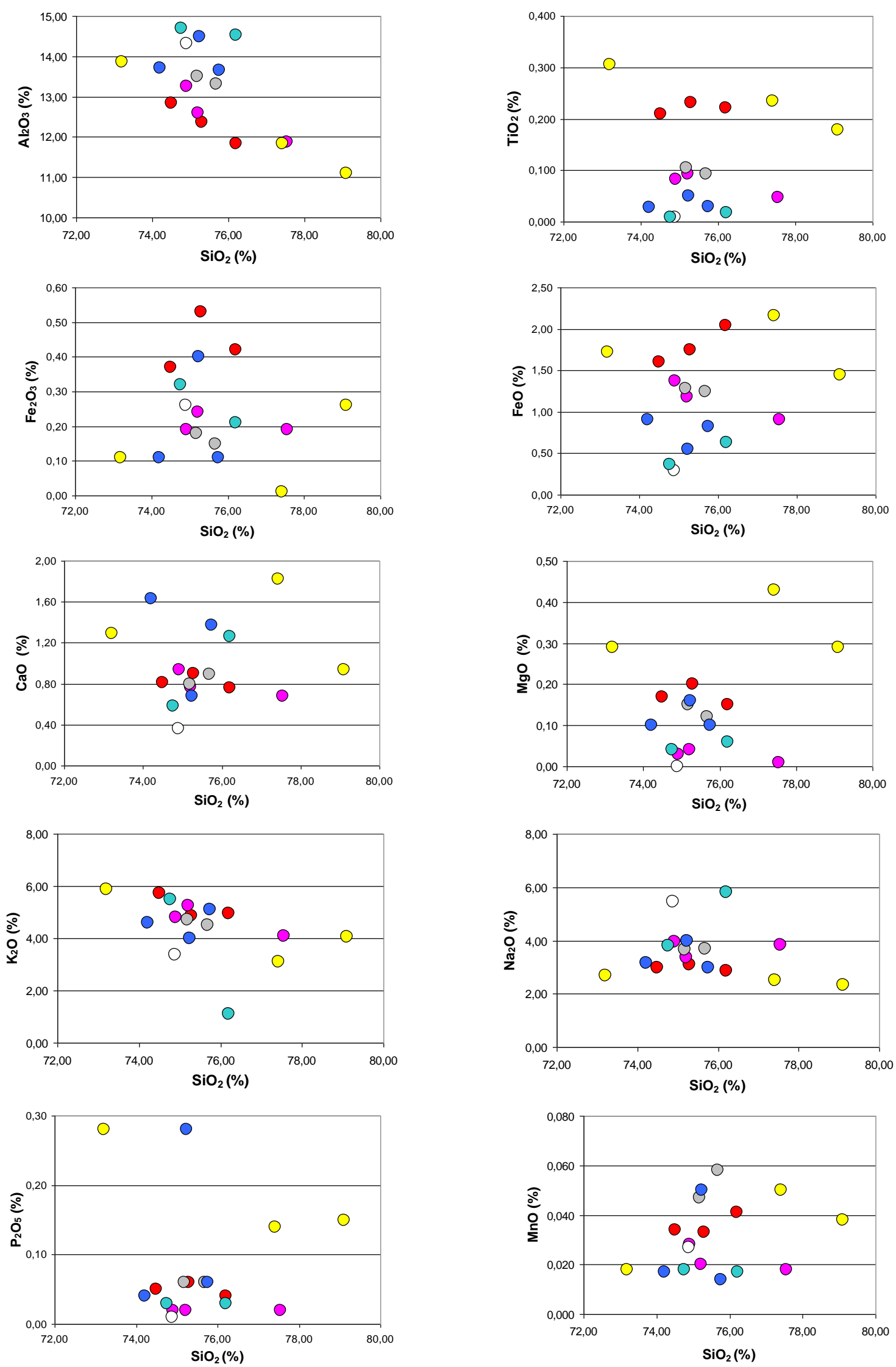

Figura 6.30 - Diagramas de dispersão $\mathrm{SiO}_{2} \times$ elementos maiores. 
O LBD não foi incluído nesse conjunto, pois quimicamente tem algumas características distintas das outras rochas estudadas, quais sejam:

- teor de $\mathrm{SiO}_{2}$ relativamente menor;

- maiores teores de $\mathrm{FeO}(3,79 \%), \mathrm{CaO}(2,01 \%), \mathrm{TiO}_{2}(0,41 \%), \mathrm{Sr}$ (224ppm), $\mathrm{Ba}$ (2.486ppm), esse muitas vezes superior aos demais;

- $\mathrm{Fe}_{2} \mathrm{O}_{3}$ também é relativamente alto, mas se iguala ao de VCB-3 e é próximo de VCB-2 e CRV;

- quanto ao MgO, o teor é intermediário aos de GVN, ARB e SCC e os demais.

A Figura 6.31 exibe os diagramas de dispersão $\mathrm{SiO}_{2} \times \mathrm{Ba}, \mathrm{Sr}$ e $\mathrm{Rb}$, nos quais se destacam os ITN, pelos maiores teores de Ba e Sr; e o BCE, pelo de Rb. Infere-se que, por se tratarem de rochas, respectivamente, ricas em feldspato potássico e em albita, esses elementos tenham relação com os feldspatos predominantes.
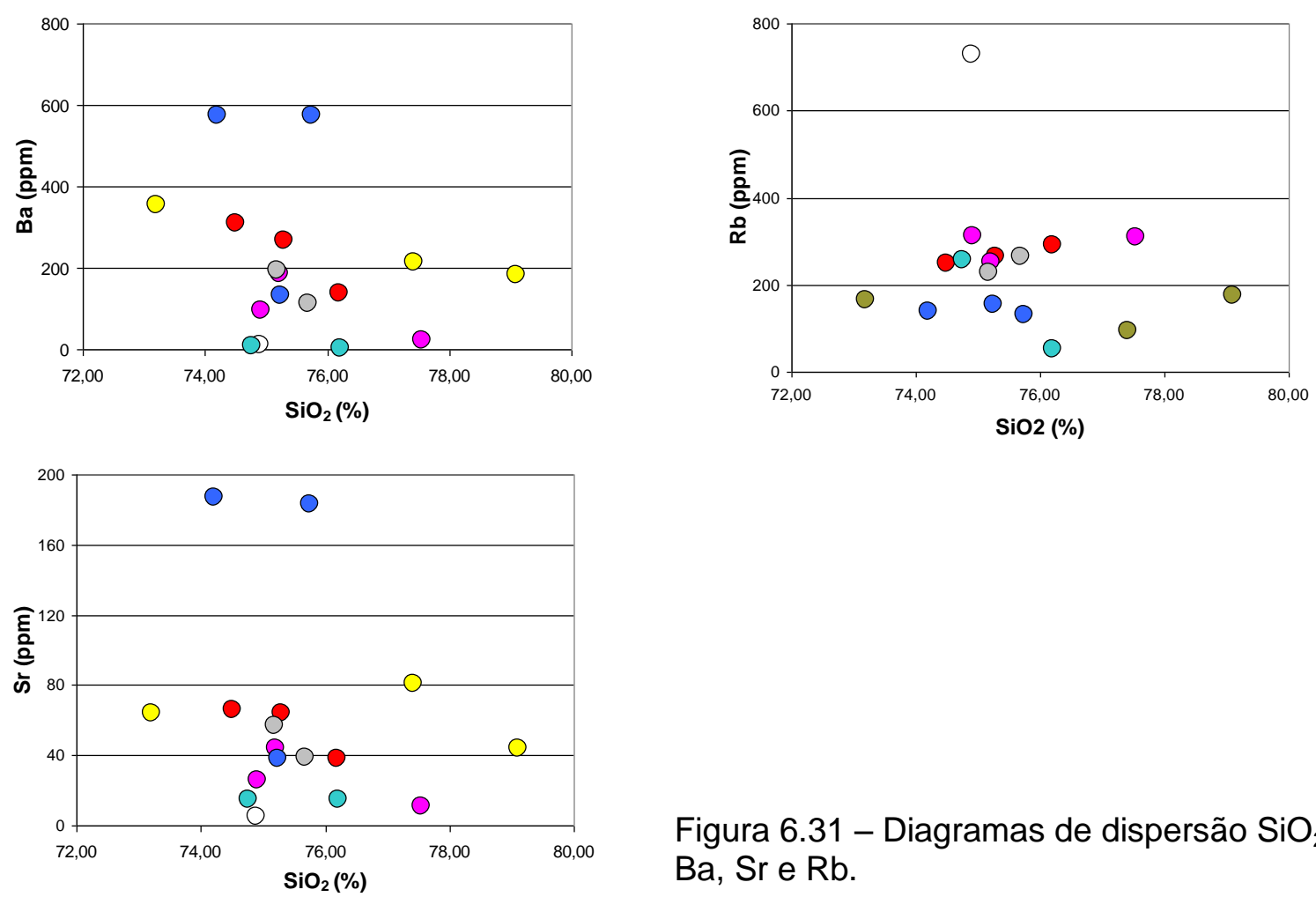

Figura 6.31 - Diagramas de dispersão $\mathrm{SiO}_{2} x$ $\mathrm{Ba}$, Sr e Rb.

Dada a preocupação com os possíveis condicionantes químicos da oxidação de natureza intempérica observada em algumas amostras, foram elaborados alguns gráficos exploratórios considerando o elemento Fe (Figura 6.32). 

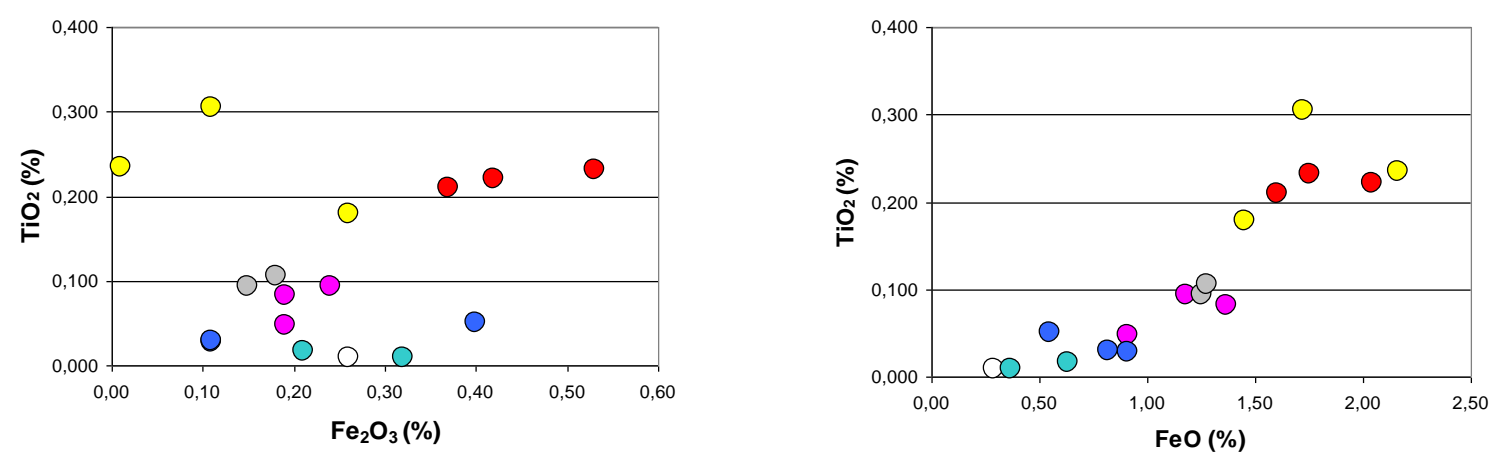

Figura 6.32 - Diagramas de dispersão $\mathrm{Fe}_{2} \mathrm{O}_{3}$ e $\mathrm{FeO} x \mathrm{TiO}_{2}$.

A tendência de correlação positiva $\mathrm{FeO} \times \mathrm{TiO}_{2}$ sugere que esses devem ocorrer associados (constituindo minerais como ilmenita, por exemplo, ou associados aos máficos) e destaca os grupos 2 e 8 .

Relativamente ao $\mathrm{Fe}_{2} \mathrm{O}_{3}$, aqui interpretado como o $\mathrm{Fe}$ já oxidado, provavelmente presente em óxidos/hidróxidos de ferro (hematita, goethita e outros) resultantes do intemperismo, destacam-se o grupo 2 e as amostras CRV e FLS. O grupo 8, constituído de rochas variavelmente intemperizadas, não apresentou o mesmo comportamento que o grupo 2. Os teores de $\mathrm{Fe}_{2} \mathrm{O}_{3}$ foram relativamente baixos, com ARB praticamente exibindo inexistência de $\mathrm{Fe}^{3+}$.

\subsection{Propriedades Físicas (Densidade Aparente e Absorção)}

As densidade, porosidade e absorção d'água aparentes forneceram a caracterização das propriedades físicas das rochas em estudo.

As Tabelas 6.15 a 6.18 exibem os valores médios, desvios padrão e coeficientes de variação obtidos para as amostras estudadas. Os símbolos de densidade aparente, porosidade e absorção correspondem àqueles definidos na Tab. 5.2, reproduzidos a seguir:

- $\rho_{\mathrm{sec}}=$ massa específica aparente seca $\left(\mathrm{kg} / \mathrm{m}^{3}\right)$;

$-\eta$ = porosidade aparente (\%);

- $\alpha=$ absorção d'água aparente (\%);

- $A_{b}=$ coeficiente de absorção d'água a pressão atmosférica (\%);

$-V_{o}=$ volume de poros abertos $(\mathrm{mL})$;

$-\rho_{b}=$ densidade aparente seca $\left(\mathrm{kg} / \mathrm{m}^{3}\right)$;

$-p_{o}=$ porosidade aberta (\%). 
Tabela 6.15 - Índices físicos determinados segundo ABNT (1992a) e BSI (1999a) - Corpos-de-prova: $10 \mathrm{~cm}$ x $15 \mathrm{~cm}$.

\begin{tabular}{|c|c|c|c|c|c|c|}
\hline \multirow{2}{*}{$\begin{array}{l}\text { AMOSTRA } \\
\text { (espessura do } \\
\text { ladrilho) }\end{array}$} & \multicolumn{3}{|c|}{ ABNT (1992a) } & \multicolumn{3}{|c|}{ BSI (1999a) } \\
\hline & $\rho_{\mathrm{sec}}\left(\mathbf{k g} / \mathrm{m}^{3}\right)$ & $\eta \quad(\%)$ & $\alpha(\%)$ & $\rho_{b}(\mathbf{k g} / \mathrm{m} 3)$ & $p_{o}(\%)$ & $v_{o}(\mathbf{m L})$ \\
\hline $\begin{array}{c}\text { LBD } \\
(3 \mathrm{~cm})\end{array}$ & $\begin{array}{c}2.662 \pm 6 \\
(0,23)\end{array}$ & $\begin{array}{c}0,64 \pm 0,01 \\
(2,20)\end{array}$ & $\begin{array}{c}0,24 \pm 0,01 \\
(2,16)\end{array}$ & $\begin{array}{c}2.657 \pm 6 \\
(0,21)\end{array}$ & $\begin{array}{c}0,68 \pm 0,03 \\
(4,67)\end{array}$ & $\begin{array}{c}2,8 \pm 0,2 \\
(5,51)\end{array}$ \\
\hline $\begin{array}{l}\text { VCB-1 } \\
(3 \mathrm{~cm})\end{array}$ & $\begin{array}{c}2.635 \pm 3 \\
(0,13)\end{array}$ & $\begin{array}{c}0,48 \pm 0,03 \\
(6,42)\end{array}$ & $\begin{array}{c}0,18 \pm 0,01 \\
(6,47)\end{array}$ & $\begin{array}{c}2.633 \pm 4 \\
(0,14) \mathrm{v}\end{array}$ & $\begin{array}{c}0,43 \pm 0,05 \\
(11,84)\end{array}$ & $\begin{array}{l}2,0 \pm 0,2 \\
(10,58)\end{array}$ \\
\hline $\begin{array}{l}\text { VCB-2 } \\
(3 \mathrm{~cm})\end{array}$ & $\begin{array}{c}2.631 \pm 2 \\
(0,09)\end{array}$ & $\begin{array}{c}0,41 \pm 0,02 \\
(5,74)\end{array}$ & $\begin{array}{c}0,15 \pm 0,01 \\
(5,77)\end{array}$ & $\begin{array}{c}2.629 \pm 1 \\
(0,06)\end{array}$ & $\begin{array}{c}0,34 \pm 0,02 \\
(5,42)\end{array}$ & $\begin{array}{c}1,5 \pm 0,1 \\
(3,75)\end{array}$ \\
\hline $\begin{array}{l}\text { VCB-3 } \\
(3 \mathrm{~cm}) \\
\end{array}$ & $\begin{array}{c}2.639 \pm 5 \\
(0,18)\end{array}$ & $\begin{array}{c}0,45 \pm 0,01 \\
(1,92)\end{array}$ & $\begin{array}{c}0,17 \pm 0,00 \\
(2,00)\end{array}$ & $\begin{array}{c}2.635 \pm 5 \\
(0,19)\end{array}$ & $\begin{array}{c}0,48 \pm 0,02 \\
(4,11)\end{array}$ & $\begin{array}{c}2,2 \pm 0,1 \\
(4,14) \\
\end{array}$ \\
\hline $\begin{array}{c}\text { RIC } \\
(2 \mathrm{~cm})\end{array}$ & $\begin{array}{c}2.622 \pm 7 \\
(0,26)\end{array}$ & $\begin{array}{c}0,46 \pm 0,01 \\
(1,88)\end{array}$ & $\begin{array}{c}0,17 \pm 0,00 \\
(1,93)\end{array}$ & $\begin{array}{c}2.613 \pm 1 \\
(0,04)\end{array}$ & $\begin{array}{c}0,48 \pm 0,03 \\
(5,40)\end{array}$ & $\begin{array}{c}1,5 \pm 0,1 \\
(5,50)\end{array}$ \\
\hline $\begin{array}{l}\text { BCR } \\
(2 \mathrm{~cm})\end{array}$ & $\begin{array}{c}2.610 \pm 1 \\
(0,02)\end{array}$ & $\begin{array}{c}0,87 \pm 0,01 \\
(1,64)\end{array}$ & $\begin{array}{c}0,33 \pm 0,01 \\
(1,65)\end{array}$ & $\begin{array}{c}2.605 \pm 1 \\
(0,03)\end{array}$ & $\begin{array}{c}0,65 \pm 0,03 \\
(4,01)\end{array}$ & $\begin{array}{c}2,2 \pm 0,1 \\
(3,77)\end{array}$ \\
\hline $\begin{array}{l}\text { BSV } \\
(2 \mathrm{~cm})\end{array}$ & $\begin{array}{c}2.616 \pm 2 \\
(0,09)\end{array}$ & $\begin{array}{c}0,68 \pm 0,03 \\
(4,39)\end{array}$ & $\begin{array}{c}0,26 \pm 0,01 \\
(4,44)\end{array}$ & $\begin{array}{c}2.611 \pm 2 \\
(0,08)\end{array}$ & $\begin{array}{c}0,69 \pm 0,01 \\
(1,98)\end{array}$ & $\begin{array}{c}2,0 \pm 0,0 \\
(2,26)\end{array}$ \\
\hline $\begin{array}{c}\text { PIT } \\
(2 \mathrm{~cm})\end{array}$ & $\begin{array}{c}2.624 \pm 0 \\
(0,01)\end{array}$ & $\begin{array}{c}0,78 \pm 0,01 \\
(1,10)\end{array}$ & $\begin{array}{c}0,30 \pm 0,00 \\
(1,11)\end{array}$ & $\begin{array}{c}2.618 \pm 0 \\
(0,01)\end{array}$ & $\begin{array}{c}0,63 \pm 0,02 \\
(2,49) \\
\end{array}$ & $\begin{array}{c}2,0 \pm 0,1 \\
(2,94)\end{array}$ \\
\hline $\begin{array}{c}\text { AZF } \\
(3 \mathrm{~cm})\end{array}$ & $\begin{array}{c}2.629 \pm 2 \\
(0,07)\end{array}$ & $\begin{array}{c}0,64 \pm 0,01 \\
(2,20)\end{array}$ & $\begin{array}{c}0,24 \pm 0,01 \\
(2,27)\end{array}$ & $\begin{array}{c}2.624 \pm 1 \\
(0,05)\end{array}$ & $\begin{array}{c}0,55 \pm 0,01 \\
(2,53)\end{array}$ & $\begin{array}{c}2,5 \pm 0,1 \\
(2,28) \\
\end{array}$ \\
\hline $\begin{array}{c}\text { BCE } \\
(3 \mathrm{~cm})\end{array}$ & $\begin{array}{c}2.615 \pm 1 \\
(0,04)\end{array}$ & $\begin{array}{c}0,61 \pm 0,02 \\
(3,62)\end{array}$ & $\begin{array}{c}0,23 \pm 0,01 \\
(3,61)\end{array}$ & $\begin{array}{c}2.613 \pm 4 \\
(0,15)\end{array}$ & $\begin{array}{c}0,65 \pm 0,02 \\
(3,46)\end{array}$ & $\begin{array}{c}3,0 \pm 0,1 \\
(3,99)\end{array}$ \\
\hline $\begin{array}{l}\text { ITN-1 } \\
(2 \mathrm{~cm})\end{array}$ & $\begin{array}{c}2.611 \pm 3 \\
(0,10)\end{array}$ & $\begin{array}{c}0,92 \pm 0,03 \\
(3,57)\end{array}$ & $\begin{array}{c}0,35 \pm 0,01 \\
(3,66)\end{array}$ & $\begin{array}{c}2.606 \pm 3 \\
(0,10)\end{array}$ & $\begin{array}{c}0,90 \pm 0,03 \\
(3,05)\end{array}$ & $\begin{array}{c}2,7 \pm 0,1 \\
(3,36)\end{array}$ \\
\hline $\begin{array}{l}\text { ITN-2 } \\
(2 \mathrm{~cm})\end{array}$ & $\begin{array}{c}2.610 \pm 4 \\
(0,15)\end{array}$ & $\begin{array}{c}0,91 \pm 0,10 \\
(11,07)\end{array}$ & $\begin{array}{c}0,35 \pm 0,04 \\
(11,10)\end{array}$ & $\begin{array}{c}2.606 \pm 3 \\
(0,13)\end{array}$ & $\begin{array}{c}0,95 \pm 0,06 \\
(5,80)\end{array}$ & $\begin{array}{c}3,0 \pm 0,2 \\
(5,96)\end{array}$ \\
\hline $\begin{array}{l}\text { CRV } \\
(2 \mathrm{~cm})\end{array}$ & $\begin{array}{c}2.621 \pm 1 \\
(0,03)\end{array}$ & $\begin{array}{c}0,86 \pm 0,03 \\
(3,43)\end{array}$ & $\begin{array}{c}0,33 \pm 0,01 \\
(3,44)\end{array}$ & $\begin{array}{c}2.615 \pm 2 \\
(0,06)\end{array}$ & $\begin{array}{c}0,77 \pm 0,03 \\
(3,51)\end{array}$ & $\begin{array}{c}2,2 \pm 0,1 \\
(3,89)\end{array}$ \\
\hline $\begin{array}{c}\text { CSB } \\
(3 \mathrm{~cm})\end{array}$ & $\begin{array}{c}2.632 \pm 6 \\
(0,22)\end{array}$ & $\begin{array}{c}0,62 \pm 0,06 \\
(10,27)\end{array}$ & $\begin{array}{c}0,23 \pm 0,02 \\
(10,32)\end{array}$ & $\begin{array}{c}2.627 \pm 6 \\
(0,24)\end{array}$ & $\begin{array}{c}0,61 \pm 0,02 \\
(2,83)\end{array}$ & $\begin{array}{c}1,9 \pm 0,1 \\
(2,96)\end{array}$ \\
\hline $\begin{array}{c}\text { FLS } \\
(3 \mathrm{~cm})\end{array}$ & $\begin{array}{c}2.624 \pm 15 \\
(0,55)\end{array}$ & $\begin{array}{c}0,68 \pm 0,03 \\
(3,80)\end{array}$ & $\begin{array}{c}0,26 \pm 0,01 \\
(4,18)\end{array}$ & $\begin{array}{c}2.619 \pm 15 \\
(0,57)\end{array}$ & $\begin{array}{c}0,67 \pm 0,03 \\
(4,84)\end{array}$ & $\begin{array}{c}1,9 \pm 0,1 \\
(4,81) \\
\end{array}$ \\
\hline $\begin{array}{l}\text { GVN } \\
(3 \mathrm{~cm})\end{array}$ & $\begin{array}{c}2.644 \pm 9 \\
(0,35)\end{array}$ & $\begin{array}{c}0,89 \pm 0,04 \\
(4,73)\end{array}$ & $\begin{array}{c}0,34 \pm 0,02 \\
(4,56)\end{array}$ & $\begin{array}{c}2.652 \pm 19 \\
(0,70)\end{array}$ & $\begin{array}{c}0,83 \pm 0,05 \\
(6,06)\end{array}$ & $\begin{array}{c}3,7 \pm 0,3 \\
(7,17)\end{array}$ \\
\hline $\begin{array}{c}\text { ARB } \\
(2 \mathrm{~cm})\end{array}$ & $\begin{array}{c}2.648 \pm 6 \\
(0,24)\end{array}$ & $\begin{array}{c}0,75 \pm 0,02 \\
(2,58)\end{array}$ & $\begin{array}{c}0,28 \pm 0,01 \\
(2,77)\end{array}$ & $\begin{array}{c}2.642 \pm 6 \\
(0,23)\end{array}$ & $\begin{array}{c}0,72 \pm 0,03 \\
(3,70)\end{array}$ & $\begin{array}{c}2,2 \pm 0,1 \\
(3,40)\end{array}$ \\
\hline $\begin{array}{c}\mathrm{SCC} \\
(3 \mathrm{~cm})\end{array}$ & $\begin{array}{c}2.643 \pm 9 \\
(0,35)\end{array}$ & $\begin{array}{c}0,75 \pm 0,08 \\
(10,08)\end{array}$ & $\begin{array}{c}0,28 \pm 0,03 \\
(10,11)\end{array}$ & $\begin{array}{c}2.636 \pm 11 \\
(0,40)\end{array}$ & $\begin{array}{c}0,72 \pm 0,10 \\
(14,16)\end{array}$ & $\begin{array}{l}3,2 \pm 0,5 \\
(14,25)\end{array}$ \\
\hline
\end{tabular}


Tabela 6.16 - Índices físicos segundo ABNT (1992a), CEN (1998a) e BSI (1999a) - Corpos-de-prova $10 \mathrm{~cm}$ x 12 cm.

\begin{tabular}{|c|c|c|c|c|c|c|c|c|}
\hline \multirow{2}{*}{$\begin{array}{l}\text { AMOSTRA } \\
\text { (espessura } \\
\text { do ladrilho) }\end{array}$} & \multicolumn{3}{|c|}{ ABNT (1992a) } & \multicolumn{2}{|c|}{ CEN (1998a) } & \multicolumn{3}{|c|}{ BSI (1999a) } \\
\hline & $\rho_{\mathrm{sec}}\left(\mathbf{k g} / \mathbf{m}^{\mathbf{3}}\right)$ & $\eta(\%)$ & $\alpha(\%)$ & $\rho_{b}\left(\mathbf{k g} / \mathbf{m}^{3}\right)$ & $A_{b}(\%)$ & $\rho_{b}(\mathbf{k g} / \mathrm{m} 3)$ & $p_{o}(\%)$ & $v_{o}(\mathrm{~mL})$ \\
\hline $\begin{array}{c}\text { LBD } \\
(3 \mathrm{~cm})\end{array}$ & $\begin{array}{c}2.658 \pm 2 \\
(0,09)\end{array}$ & $\begin{array}{c}0,70 \pm 0,03 \\
(3,60)\end{array}$ & $\begin{array}{c}0,26 \pm 0,01 \\
(3,58)\end{array}$ & $\begin{array}{c}2.659 \pm 3 \\
(0,11)\end{array}$ & $\begin{array}{c}0,19 \pm 0,01 \\
(6,44)\end{array}$ & $\begin{array}{c}2.655 \pm 3 \\
(0,12)\end{array}$ & $\begin{array}{c}0,58 \pm 0,02 \\
(3,05)\end{array}$ & $\begin{array}{c}1,9 \pm 0,0 \\
(2,33)\end{array}$ \\
\hline $\begin{array}{l}\text { VCB-1 } \\
(3 \mathrm{~cm})\end{array}$ & $\begin{array}{c}2.636 \pm 3 \\
(0,13)\end{array}$ & $\begin{array}{c}0,58 \pm 0,03 \\
(4,67)\end{array}$ & $\begin{array}{c}0,22 \pm 0,01 \\
(4,73)\end{array}$ & $\begin{array}{c}2.637 \pm 3 \\
(0,11)\end{array}$ & $\begin{array}{c}0,20 \pm 0,01 \\
(4,53)\end{array}$ & $\begin{array}{c}2.631 \pm 3 \\
(0,13)\end{array}$ & $\begin{array}{c}0,55 \pm 0,02 \\
(4,29)\end{array}$ & $\begin{array}{c}2,0 \pm 0,1 \\
(3,54)\end{array}$ \\
\hline $\begin{array}{l}\text { VCB-2 } \\
(3 \mathrm{~cm})\end{array}$ & $\begin{array}{c}2.632 \pm 2 \\
(0,08)\end{array}$ & $\begin{array}{c}0,31 \pm 0,03 \\
(9,31)\end{array}$ & $\begin{array}{c}0,12 \pm 0,01 \\
(9,35)\end{array}$ & $\begin{array}{c}2.634 \pm 2 \\
(0,07)\end{array}$ & $\begin{array}{c}0,15 \pm 0,01 \\
(4,05)\end{array}$ & $\begin{array}{c}2.627 \pm 2 \\
(0,08)\end{array}$ & $\begin{array}{c}0,41 \pm 0,02 \\
(4,45)\end{array}$ & $\begin{array}{c}1,4 \pm 0,1 \\
(5,89)\end{array}$ \\
\hline $\begin{array}{l}\text { VCB-3 } \\
(3 \mathrm{~cm}) \\
\end{array}$ & $\begin{array}{c}2.639 \pm 2 \\
(0,07)\end{array}$ & $\begin{array}{c}0,54 \pm 0,01 \\
(2,44)\end{array}$ & $\begin{array}{c}0,20 \pm 0,01 \\
(2,48)\end{array}$ & $\begin{array}{c}2.640 \pm 2 \\
(0,07)\end{array}$ & $\begin{array}{c}0,13 \pm 0,00 \\
(0,10)\end{array}$ & $\begin{array}{c}2.636 \pm 2 \\
(0,06)\end{array}$ & $\begin{array}{c}0,41 \pm 0,01 \\
(3,14)\end{array}$ & $\begin{array}{c}1,4 \pm 0,0 \\
(3,24)\end{array}$ \\
\hline $\begin{array}{c}\text { RIC } \\
(2 \mathrm{~cm})\end{array}$ & $\begin{array}{c}2.617 \pm 3 \\
(0,12)\end{array}$ & $\begin{array}{c}0,54 \pm 0,04 \\
(7,04)\end{array}$ & $\begin{array}{c}0,21 \pm 0,01 \\
(7,14)\end{array}$ & $\begin{array}{c}2.617 \pm 3 \\
(0,12)\end{array}$ & $\begin{array}{c}0,23 \pm 0,02 \\
(6,84)\end{array}$ & $\begin{array}{c}2.613 \pm 3 \\
(0,10)\end{array}$ & $\begin{array}{c}0,55 \pm 0,01 \\
(2,30)\end{array}$ & $\begin{array}{c}1,5 \pm 0,0 \\
(3,02)\end{array}$ \\
\hline $\begin{array}{c}\text { BCR } \\
(2 \mathrm{~cm}) \\
\end{array}$ & $\begin{array}{c}2.615 \pm 2 \\
(0,07)\end{array}$ & $\begin{array}{c}0,54 \pm 0,02 \\
(3,24)\end{array}$ & $\begin{array}{c}0,20 \pm 0,01 \\
(3,31)\end{array}$ & $\begin{array}{c}2.614 \pm 2 \\
(0,08)\end{array}$ & $\begin{array}{c}0,23 \pm 0,02 \\
(6,45)\end{array}$ & $\begin{array}{c}2.608 \pm 1 \\
(0,04)\end{array}$ & $\begin{array}{c}0,63 \pm 0,02 \\
(2,58)\end{array}$ & $\begin{array}{c}1,7 \pm 0,0 \\
(2,66)\end{array}$ \\
\hline $\begin{array}{c}\text { BSV } \\
(2 \mathrm{~cm})\end{array}$ & $\begin{array}{c}2.620 \pm 2 \\
(0,06)\end{array}$ & $\begin{array}{c}0,62 \pm 0,03 \\
(5,29)\end{array}$ & $\begin{array}{c}0,24 \pm 0,01 \\
(5,33)\end{array}$ & $\begin{array}{c}2.620 \pm 2 \\
(0,08)\end{array}$ & $\begin{array}{c}0,24 \pm 0,03 \\
(3,68)\end{array}$ & $\begin{array}{c}2.614 \pm 2 \\
(0,08)\end{array}$ & $\begin{array}{c}0,74 \pm 0,03 \\
(4,58)\end{array}$ & $\begin{array}{c}1,9 \pm 0,1 \\
(3,72) \\
\end{array}$ \\
\hline $\begin{array}{c}\text { PIT } \\
(2 \mathrm{~cm})\end{array}$ & $\begin{array}{c}2.628 \pm 1 \\
(0,02)\end{array}$ & $\begin{array}{c}0,52 \pm 0,03 \\
(6,66)\end{array}$ & $\begin{array}{c}0,20 \pm 0,01 \\
(6,68)\end{array}$ & $\begin{array}{c}2.627 \pm 1 \\
(0,02)\end{array}$ & $\begin{array}{c}0,19 \pm 0,01 \\
(3,54)\end{array}$ & $\begin{array}{c}2.622 \pm 1 \\
(0,03)\end{array}$ & $\begin{array}{c}0,59 \pm 0,02 \\
(2,55)\end{array}$ & $\begin{array}{c}1,5 \pm 0,0 \\
(2,94) \\
\end{array}$ \\
\hline $\begin{array}{c}\text { PIT } \\
(3 \mathrm{~cm})\end{array}$ & $\begin{array}{c}2.623 \pm 1 \\
(0,03)\end{array}$ & $\begin{array}{c}0,78 \pm 0,01 \\
(1,63)\end{array}$ & $\begin{array}{c}0,30 \pm 0,00 \\
(1,65)\end{array}$ & $\begin{array}{c}2.623 \pm 1 \\
(0,03)\end{array}$ & $\begin{array}{c}0,29 \pm 0,01 \\
(3,60)\end{array}$ & $\begin{array}{c}2.619 \pm 1 \\
(0,03)\end{array}$ & $\begin{array}{c}0,64 \pm 0,01 \\
(1,63)\end{array}$ & $\begin{array}{c}2,2 \pm 0,2 \\
(8,59)\end{array}$ \\
\hline $\begin{array}{c}\text { AZF } \\
(3 \mathrm{~cm})\end{array}$ & $\begin{array}{c}2.629 \pm 1 \\
(0,04)\end{array}$ & $\begin{array}{c}0,63 \pm 0,02 \\
(2,58)\end{array}$ & $\begin{array}{c}0,24 \pm 0,01 \\
(2,59)\end{array}$ & $\begin{array}{c}2.630 \pm 1 \\
(0,02)\end{array}$ & $\begin{array}{c}0,26 \pm 0,01 \\
(2,95)\end{array}$ & $\begin{array}{c}2.626 \pm 1 \\
(0,03)\end{array}$ & $\begin{array}{c}0,53 \pm 0,01 \\
(2,30)\end{array}$ & $\begin{array}{c}2,0 \pm 0,0 \\
(2,26)\end{array}$ \\
\hline $\begin{array}{c}\text { BCE } \\
(3 \mathrm{~cm})\end{array}$ & $\begin{array}{c}2.613 \pm 2 \\
(0,08)\end{array}$ & $\begin{array}{c}0,80 \pm 0,03 \\
(3,92)\end{array}$ & $\begin{array}{c}0,30 \pm 0,01 \\
(4,00)\end{array}$ & $\begin{array}{c}2.614 \pm 3 \\
(0,10)\end{array}$ & $\begin{array}{c}0,30 \pm 0,01 \\
(4,93)\end{array}$ & $\begin{array}{c}2.610 \pm 2 \\
(0,09)\end{array}$ & $\begin{array}{c}0,65 \pm 0,04 \\
(5,81)\end{array}$ & $\begin{array}{c}2,5 \pm 0,2 \\
(7,10)\end{array}$ \\
\hline $\begin{array}{l}\text { ITN-1 } \\
(2 \mathrm{~cm}) \\
\end{array}$ & $\begin{array}{c}2.612 \pm 6 \\
(0,24)\end{array}$ & $\begin{array}{c}0,77 \pm 0,04 \\
(5,00)\end{array}$ & $\begin{array}{c}0,30 \pm 0,01 \\
(5,02)\end{array}$ & $\begin{array}{c}2.610 \pm 6 \\
(0,23)\end{array}$ & $\begin{array}{c}0,36 \pm 0,03 \\
(7,26)\end{array}$ & $\begin{array}{c}2.606 \pm 6 \\
(0,22)\end{array}$ & $\begin{array}{c}0,95 \pm 0,06 \\
(6,77)\end{array}$ & $\begin{array}{c}2,4 \pm 0,1 \\
(5,39) \\
\end{array}$ \\
\hline $\begin{array}{l}\text { ITN-2 } \\
(2 \mathrm{~cm}) \\
\end{array}$ & $\begin{array}{c}2.614 \pm 3 \\
(0,13)\end{array}$ & $\begin{array}{c}0,86 \pm 0,05 \\
(6,39)\end{array}$ & $\begin{array}{c}0,33 \pm 0,02 \\
(6,50)\end{array}$ & $\begin{array}{c}2.613 \pm 3 \\
(0,11)\end{array}$ & $\begin{array}{c}0,34 \pm 0,02 \\
(4,81)\end{array}$ & $\begin{array}{c}2.609 \pm 3 \\
(0,13)\end{array}$ & $\begin{array}{c}0,96 \pm 0,04 \\
(4,42)\end{array}$ & $\begin{array}{c}2,4 \pm 0,1 \\
(4,67) \\
\end{array}$ \\
\hline $\begin{array}{c}\text { CRV } \\
(2 \mathrm{~cm})\end{array}$ & $\begin{array}{c}2.623 \pm 1 \\
(0,04)\end{array}$ & $\begin{array}{c}0,69 \pm 0,02 \\
(2,46)\end{array}$ & $\begin{array}{c}0,26 \pm 0,01 \\
(2,45)\end{array}$ & $\begin{array}{c}2.619 \pm 6 \\
(0,24)\end{array}$ & $\begin{array}{c}0,27 \pm 0,01 \\
(2,85)\end{array}$ & $\begin{array}{c}2.615 \pm 2 \\
(0,07)\end{array}$ & $\begin{array}{c}0,77 \pm 0,05 \\
(7,06)\end{array}$ & $\begin{array}{c}1,7 \pm 0,1 \\
(7,20)\end{array}$ \\
\hline $\begin{array}{c}\text { CSB } \\
(3 \mathrm{~cm})\end{array}$ & $\begin{array}{c}2.606 \pm 26 \\
(0,98)\end{array}$ & $\begin{array}{c}0,76 \pm 0,03 \\
(4,12)\end{array}$ & $\begin{array}{c}0,29 \pm 0,01 \\
(4,28)\end{array}$ & $\begin{array}{c}2.615 \pm 14 \\
(0,53)\end{array}$ & $\begin{array}{c}0,24 \pm 0,01 \\
(3,60)\end{array}$ & $\begin{array}{c}2.595 \pm 14 \\
(0,53)\end{array}$ & $\begin{array}{c}0,57 \pm 0,05 \\
(7,78)\end{array}$ & $\begin{array}{c}2,2 \pm 0,2 \\
(6,74)\end{array}$ \\
\hline $\begin{array}{c}\text { FLS } \\
(3 \mathrm{~cm})\end{array}$ & $\begin{array}{c}2.612 \pm 13 \\
(0,51)\end{array}$ & $\begin{array}{c}1,08 \pm 0,05 \\
(4,93)\end{array}$ & $\begin{array}{c}0,41 \pm 0,02 \\
(4,79)\end{array}$ & $\begin{array}{c}2.614 \pm 14 \\
(0,52)\end{array}$ & $\begin{array}{c}0,34 \pm 0,01 \\
(2,99)\end{array}$ & $\begin{array}{c}2.609 \pm 14 \\
(0,52)\end{array}$ & $\begin{array}{c}0,87 \pm 0,03 \\
(3,96)\end{array}$ & $\begin{array}{c}3,2 \pm 0,1 \\
(4,12)\end{array}$ \\
\hline $\begin{array}{l}\text { GVN } \\
(3 \mathrm{~cm})\end{array}$ & $\begin{array}{c}2.636 \pm 5 \\
(0,19)\end{array}$ & $\begin{array}{c}0,80 \pm 0,04 \\
(5,61)\end{array}$ & $\begin{array}{c}0,30 \pm 0,02 \\
(5,71)\end{array}$ & $\begin{array}{c}2.636 \pm 5 \\
(0,19)\end{array}$ & $\begin{array}{c}0,29 \pm 0,01 \\
(3,33)\end{array}$ & $\begin{array}{c}2.632 \pm 5 \\
(0,19)\end{array}$ & $\begin{array}{c}0,72 \pm 0,02 \\
(3,04)\end{array}$ & $\begin{array}{c}2,6 \pm 0,1 \\
(3,10)\end{array}$ \\
\hline $\begin{array}{c}\text { ARB } \\
(2 \mathrm{~cm})\end{array}$ & $\begin{array}{c}2.660 \pm 9 \\
(0,33)\end{array}$ & $\begin{array}{c}0,59 \pm 0,02 \\
(2,89)\end{array}$ & $\begin{array}{c}0,22 \pm 0,01 \\
(2,76)\end{array}$ & $\begin{array}{c}2.658 \pm 9 \\
(0,34)\end{array}$ & $\begin{array}{c}0,25 \pm 0,01 \\
(3,88)\end{array}$ & $\begin{array}{c}2.655 \pm 8 \\
(0,31)\end{array}$ & $\begin{array}{c}0,65 \pm 0,03 \\
(3,95)\end{array}$ & $\begin{array}{c}1,6 \pm 0,1 \\
(3,95)\end{array}$ \\
\hline $\begin{array}{c}\mathrm{SCC} \\
(3 \mathrm{~cm})\end{array}$ & $\begin{array}{c}2.637 \pm 6 \\
(0,21) \\
\end{array}$ & $\begin{array}{c}0,70 \pm 0,02 \\
(2,57)\end{array}$ & $\begin{array}{c}0,27 \pm 0,01 \\
(2,56)\end{array}$ & $\begin{array}{c}2.637 \pm 5 \\
(0,18) \\
\end{array}$ & $\begin{array}{c}0,27 \pm 0,01 \\
(3,61)\end{array}$ & $\begin{array}{c}2.632 \pm 5 \\
(0,21) \\
\end{array}$ & $\begin{array}{c}0,65 \pm 0,05 \\
(7,54)\end{array}$ & $\begin{array}{c}2,3 \pm 0,1 \\
(6,39) \\
\end{array}$ \\
\hline
\end{tabular}


Tabela 6.17 - Índices físicos determinados segundo ABNT (1992a), CEN (1998a) e BSI (1999a) - Corpos-de-prova: 10 cm x 10 cm.

\begin{tabular}{|c|c|c|c|c|c|c|c|c|}
\hline \multirow{2}{*}{$\begin{array}{c}\text { AMOSTRA } \\
\text { (espessura do } \\
\text { ladrilho) }\end{array}$} & \multicolumn{3}{|c|}{ ABNT (1992a) } & \multicolumn{2}{|c|}{ CEN (1998a) } & \multicolumn{3}{|c|}{ BSI (1999a) } \\
\hline & $\rho_{\mathrm{sec}}\left(\mathbf{k g} / \mathbf{m}^{3}\right)$ & $\eta \quad(\%)$ & $\alpha(\%)$ & $\rho_{b}\left(\mathrm{~kg} / \mathrm{m}^{3}\right)$ & $A_{b}(\%)$ & $\rho_{b}(\mathrm{~kg} / \mathrm{m} 3)$ & $p_{o}(\%)$ & $v_{o}(\mathbf{m L})$ \\
\hline $\begin{array}{c}\text { LBD } \\
(3 \mathrm{~cm})\end{array}$ & $\begin{array}{c}2.660 \pm 4 \\
(0,17) \\
\end{array}$ & $\begin{array}{c}0,70 \pm 0,01 \\
(1,51)\end{array}$ & $\begin{array}{c}0,26 \pm 0,00 \\
(1,39)\end{array}$ & $\begin{array}{c}2.663 \pm 4 \\
(0,16)\end{array}$ & $\begin{array}{c}0,16 \pm 0,01 \\
(4,02)\end{array}$ & $\begin{array}{c}2.658 \pm 4 \\
(0,16)\end{array}$ & $\begin{array}{c}0,43 \pm 0,02 \\
(5,72)\end{array}$ & $\begin{array}{c}1,2 \pm 0,1 \\
(6,36) \\
\end{array}$ \\
\hline $\begin{array}{l}\text { VCB-1 } \\
(3 \mathrm{~cm})\end{array}$ & $\begin{array}{c}2.637 \pm 2 \\
(0,07)\end{array}$ & $\begin{array}{c}0,41 \pm 0,05 \\
(11,34)\end{array}$ & $\begin{array}{c}0,16 \pm 0,02 \\
(11,34)\end{array}$ & $\begin{array}{c}2.636 \pm 2 \\
(0,07)\end{array}$ & $\begin{array}{c}0,21 \pm 0,02 \\
(8,32)\end{array}$ & $\begin{array}{c}2.633 \pm 2 \\
(0,08)\end{array}$ & $\begin{array}{c}0,43 \pm 0,04 \\
(9,73)\end{array}$ & $\begin{array}{c}1,3 \pm 0,1 \\
(8,51)\end{array}$ \\
\hline $\begin{array}{l}\text { VCB-2 } \\
(3 \mathrm{~cm})\end{array}$ & $\begin{array}{c}2.634 \pm 5 \\
(0,19)\end{array}$ & $\begin{array}{c}0,32 \pm 0,06 \\
(19,40)\end{array}$ & $\begin{array}{c}0,12 \pm 0,02 \\
(19,45)\end{array}$ & $\begin{array}{c}2.631 \pm 4 \\
(0,17)\end{array}$ & $\begin{array}{c}0,19 \pm 0,02 \\
(8,97)\end{array}$ & $\begin{array}{c}2.630 \pm 5 \\
(0,20)\end{array}$ & $\begin{array}{c}0,36 \pm 0,06 \\
(16,02)\end{array}$ & $\begin{array}{l}1,0 \pm 0,2 \\
(16,09)\end{array}$ \\
\hline $\begin{array}{l}\text { VCB-3 } \\
(3 \mathrm{~cm})\end{array}$ & $\begin{array}{c}2.641 \pm 3 \\
(0,12)\end{array}$ & $\begin{array}{c}0,53 \pm 0,02 \\
(4,21)\end{array}$ & $\begin{array}{c}0,20 \pm 0,01 \\
(4,26)\end{array}$ & $\begin{array}{c}2.642 \pm 3 \\
(0,12)\end{array}$ & $\begin{array}{c}0,13 \pm 0,01 \\
(10,09)\end{array}$ & $\begin{array}{c}2.638 \pm 3 \\
(0,11)\end{array}$ & $\begin{array}{c}0,34 \pm 0,02 \\
(6,07)\end{array}$ & $\begin{array}{c}1,0 \pm 0,1 \\
(5,77)\end{array}$ \\
\hline $\begin{array}{c}\text { RIC } \\
(2 \mathrm{~cm})\end{array}$ & $\begin{array}{c}2.618 \pm 2 \\
(0,08)\end{array}$ & $\begin{array}{c}0,68 \pm 0,02 \\
(3,31)\end{array}$ & $\begin{array}{c}0,26 \pm 0,01 \\
(3,32)\end{array}$ & $\begin{array}{c}2.620 \pm 2 \\
(0,08)\end{array}$ & $\begin{array}{c}0,21 \pm 0,01 \\
(4,87)\end{array}$ & $\begin{array}{c}2.614 \pm 2 \\
(0,08)\end{array}$ & $\begin{array}{c}0,50 \pm 0,02 \\
(3,27)\end{array}$ & $\begin{array}{c}1,1 \pm 0,0 \\
(3,66)\end{array}$ \\
\hline $\begin{array}{c}\text { BCR } \\
(2 \mathrm{~cm})\end{array}$ & $\begin{array}{c}2.614 \pm 1 \\
(0,03)\end{array}$ & $\begin{array}{c}0,65 \pm 0,03 \\
(3,95)\end{array}$ & $\begin{array}{c}0,25 \pm 0,01 \\
(3,96)\end{array}$ & $\begin{array}{c}2.614 \pm 1 \\
(0,05) \\
\end{array}$ & $\begin{array}{c}0,24 \pm 0,00 \\
(0,71)\end{array}$ & $\begin{array}{c}2.609 \pm 1 \\
(0,05)\end{array}$ & $\begin{array}{c}0,61 \pm 0,02 \\
(3,52)\end{array}$ & $\begin{array}{c}1,4 \pm 0,1 \\
(4,06)\end{array}$ \\
\hline $\begin{array}{l}\text { BSV } \\
(2 \mathrm{~cm})\end{array}$ & $\begin{array}{c}2.622 \pm 1 \\
(0,05)\end{array}$ & $\begin{array}{c}0,73 \pm 0,02 \\
(2,70)\end{array}$ & $\begin{array}{c}0,28 \pm 0,01 \\
(2,71)\end{array}$ & $\begin{array}{c}2.623 \pm 2 \\
(0,06)\end{array}$ & $\begin{array}{c}0,26 \pm 0,00 \\
(0,71)\end{array}$ & $\begin{array}{c}2.616 \pm 1 \\
(0,04)\end{array}$ & $\begin{array}{c}0,74 \pm 0,03 \\
(3,54)\end{array}$ & $\begin{array}{c}1,6 \pm 0,1 \\
(3,95)\end{array}$ \\
\hline $\begin{array}{c}\text { PIT } \\
(2 \mathrm{~cm})\end{array}$ & $\begin{array}{c}2.626 \pm 1 \\
(0,06)\end{array}$ & $\begin{array}{c}0,77 \pm 0,03 \\
(3,99)\end{array}$ & $\begin{array}{c}0,29 \pm 0,01 \\
(3,97)\end{array}$ & $\begin{array}{c}2.628 \pm 1 \\
(0,05)\end{array}$ & $\begin{array}{c}0,20 \pm 0,01 \\
(4,81)\end{array}$ & $\begin{array}{c}2.624 \pm 2 \\
(0,06)\end{array}$ & $\begin{array}{c}0,48 \pm 0,03 \\
(6,20)\end{array}$ & $\begin{array}{c}1,0 \pm 0,1 \\
(7,40)\end{array}$ \\
\hline $\begin{array}{c}A Z F \\
(3 \mathrm{~cm})\end{array}$ & $\begin{array}{c}2.629 \pm 1 \\
(0,05)\end{array}$ & $\begin{array}{c}0,73 \pm 0,01 \\
(0,92)\end{array}$ & $\begin{array}{c}0,28 \pm 0,00 \\
(0,96)\end{array}$ & $\begin{array}{c}2.632 \pm 2 \\
(0,06)\end{array}$ & $\begin{array}{c}0,20 \pm 0,01 \\
(3,78)\end{array}$ & $\begin{array}{c}2.627 \pm 1 \\
(0,06)\end{array}$ & $\begin{array}{c}0,47 \pm 0,02 \\
(3,57)\end{array}$ & $\begin{array}{c}1,5 \pm 0,0 \\
(3,02)\end{array}$ \\
\hline $\begin{array}{c}\text { BCE } \\
(3 \mathrm{~cm})\end{array}$ & $\begin{array}{c}2.612 \pm 1 \\
(0,03)\end{array}$ & $\begin{array}{c}0,85 \pm 0,02 \\
(2,66)\end{array}$ & $\begin{array}{c}0,32 \pm 0,01 \\
(2,66)\end{array}$ & $\begin{array}{c}2.614 \pm 1 \\
(0,03)\end{array}$ & $\begin{array}{c}0,24 \pm 0,01 \\
(5,89)\end{array}$ & $\begin{array}{c}2.610 \pm 1 \\
(0,03)\end{array}$ & $\begin{array}{c}0,60 \pm 0,04 \\
(6,16)\end{array}$ & $\begin{array}{c}2,0 \pm 0,1 \\
(5,38) \\
\end{array}$ \\
\hline $\begin{array}{l}\text { ITN-1 } \\
(2 \mathrm{~cm})\end{array}$ & $\begin{array}{c}2.610 \pm 5 \\
(0,18)\end{array}$ & $\begin{array}{c}1,01 \pm 0,09 \\
(9,26)\end{array}$ & $\begin{array}{c}0,39 \pm 0,04 \\
(9,41)\end{array}$ & $\begin{array}{c}2.610 \pm 5 \\
(0,17)\end{array}$ & $\begin{array}{c}0,40 \pm 0,04 \\
(9,95)\end{array}$ & $\begin{array}{c}2.605 \pm 5 \\
(0,17)\end{array}$ & $\begin{array}{c}0,96 \pm 0,11 \\
(11,64)\end{array}$ & $\begin{array}{l}2,1 \pm 0,2 \\
(10,26)\end{array}$ \\
\hline $\begin{array}{l}\text { ITN-2 } \\
(2 \mathrm{~cm})\end{array}$ & $\begin{array}{c}2.614 \pm 4 \\
(0,16)\end{array}$ & $\begin{array}{c}0,88 \pm 0,04 \\
(4,08)\end{array}$ & $\begin{array}{c}0,34 \pm 0,01 \\
(4,16)\end{array}$ & $\begin{array}{c}2.613 \pm 4 \\
(0,16)\end{array}$ & $\begin{array}{c}0,35 \pm 0,02 \\
(6,97)\end{array}$ & $\begin{array}{c}2.608 \pm 3 \\
(0,13)\end{array}$ & $\begin{array}{c}0,88 \pm 0,05 \\
(5,34)\end{array}$ & $\begin{array}{c}1,9 \pm 0,1 \\
(5,53)\end{array}$ \\
\hline $\begin{array}{c}\text { CRV } \\
(2 \mathrm{~cm})\end{array}$ & $\begin{array}{c}2.621 \pm 1 \\
(0,05)\end{array}$ & $\begin{array}{c}0,79 \pm 0,03 \\
(3,51)\end{array}$ & $\begin{array}{c}0,30 \pm 0,01 \\
(3,51)\end{array}$ & $\begin{array}{c}2.623 \pm 2 \\
(0,07)\end{array}$ & $\begin{array}{c}0,27 \pm 0,01 \\
(4,67)\end{array}$ & $\begin{array}{c}2.617 \pm 2 \\
(0,08)\end{array}$ & $\begin{array}{c}0,71 \pm 0,02 \\
(2,93)\end{array}$ & $\begin{array}{c}1,3 \pm 0,1 \\
(3,87)\end{array}$ \\
\hline $\begin{array}{c}\text { CSB } \\
(3 \mathrm{~cm})\end{array}$ & $\begin{array}{c}2.612 \pm 21 \\
(0,80)\end{array}$ & $\begin{array}{c}0,72 \pm 0,05 \\
(6,78)\end{array}$ & $\begin{array}{c}0,28 \pm 0,02 \\
(6,62)\end{array}$ & $\begin{array}{c}2.614 \pm 21 \\
(0,80)\end{array}$ & $\begin{array}{c}0,21 \pm 0,01 \\
(7,05)\end{array}$ & $\begin{array}{c}2.609 \pm 21 \\
(0,81)\end{array}$ & $\begin{array}{c}0,54 \pm 0,04 \\
(7,93)\end{array}$ & $\begin{array}{c}1,7 \pm 0,1 \\
(7,88) \\
\end{array}$ \\
\hline $\begin{array}{c}\text { FLS } \\
(3 \mathrm{~cm})\end{array}$ & $\begin{array}{c}2.610 \pm 13 \\
(0,51)\end{array}$ & $\begin{array}{c}0,92 \pm 0,07 \\
(7,10)\end{array}$ & $\begin{array}{c}0,35 \pm 0,02 \\
(6,90)\end{array}$ & $\begin{array}{c}2.612 \pm 13 \\
(0,51)\end{array}$ & $\begin{array}{c}0,32 \pm 0,02 \\
(7,77)\end{array}$ & $\begin{array}{c}2.606 \pm 14 \\
(0,54)\end{array}$ & $\begin{array}{c}0,87 \pm 0,06 \\
(7,03)\end{array}$ & $\begin{array}{c}2,7 \pm 0,2 \\
(7,83)\end{array}$ \\
\hline $\begin{array}{l}\text { GVN } \\
(3 \mathrm{~cm})\end{array}$ & $\begin{array}{c}2.639 \pm 7 \\
(0,28)\end{array}$ & $\begin{array}{c}0,87 \pm 0,02 \\
(2,24)\end{array}$ & $\begin{array}{c}0,33 \pm 0,01 \\
(2,48)\end{array}$ & $\begin{array}{c}2.641 \pm 8 \\
(0,28)\end{array}$ & $\begin{array}{c}0,25 \pm 0,01 \\
(2,95)\end{array}$ & $\begin{array}{c}2.636 \pm 7 \\
(0,28)\end{array}$ & $\begin{array}{c}0,70 \pm 0,02 \\
(3,21)\end{array}$ & $\begin{array}{c}2,1 \pm 0,1 \\
(2,42) \\
\end{array}$ \\
\hline $\begin{array}{c}\text { ARB } \\
(2 \mathrm{~cm})\end{array}$ & $\begin{array}{c}2.656 \pm 8 \\
(0,29)\end{array}$ & $\begin{array}{c}0,69 \pm 0,04 \\
(6,23)\end{array}$ & $\begin{array}{c}0,26 \pm 0,02 \\
(6,04)\end{array}$ & $\begin{array}{c}2.657 \pm 7 \\
(0,27)\end{array}$ & $\begin{array}{c}0,25 \pm 0,01 \\
(5,17)\end{array}$ & $\begin{array}{c}2.651 \pm 8 \\
(0,31)\end{array}$ & $\begin{array}{c}0,65 \pm 0,03 \\
(4,31)\end{array}$ & $\begin{array}{c}1,3 \pm 0,1 \\
(3,87)\end{array}$ \\
\hline $\begin{array}{c}\mathrm{SCC} \\
(3 \mathrm{~cm})\end{array}$ & $\begin{array}{c}2.641 \pm 9 \\
(0,33)\end{array}$ & $\begin{array}{c}0,79 \pm 0,05 \\
(6,56)\end{array}$ & $\begin{array}{c}0,30 \pm 0,02 \\
(6,79)\end{array}$ & $\begin{array}{c}2.644 \pm 9 \\
(0,34)\end{array}$ & $\begin{array}{c}0,23 \pm 0,01 \\
(5,93)\end{array}$ & $\begin{array}{c}2.636 \pm 8 \\
(0,31)\end{array}$ & $\begin{array}{c}0,66 \pm 0,05 \\
(7,67)\end{array}$ & $\begin{array}{c}2,0 \pm 0,1 \\
(6,95) \\
\end{array}$ \\
\hline
\end{tabular}


Tabela 6.18 - Índices físicos determinados segundo ABNT (1992a) - Corpos-de-prova: $7,5 \mathrm{~cm} \times 7,5 \mathrm{~cm} \times 7,5 \mathrm{~cm}$.

\begin{tabular}{|c|c|c|c|}
\hline \multirow{2}{*}{ AMOSTRA } & \multicolumn{3}{|c|}{ ABNT (1992a) } \\
\hline & $\rho_{\mathrm{sec}}\left(\mathbf{k g} / \mathbf{m}^{3}\right)$ & $\eta \quad(\%)$ & $\alpha(\%)$ \\
\hline LBD & $\begin{array}{c}2.677 \pm 6 \\
(0,23) \\
\end{array}$ & $\begin{array}{c}0,24 \pm 0,03 \\
(10,61) \\
\end{array}$ & $\begin{array}{c}0,09 \pm 0,01 \\
(10,72)\end{array}$ \\
\hline VCB-1 & $\begin{array}{c}2.641 \pm 1 \\
(0,05)\end{array}$ & $\begin{array}{c}0,26 \pm 0,02 \\
(7,36)\end{array}$ & $\begin{array}{c}0,10 \pm 0,01 \\
(7,37)\end{array}$ \\
\hline VCB-2 & $\begin{array}{c}2.637 \pm 2 \\
(0,07)\end{array}$ & $\begin{array}{c}0,26 \pm 0,01 \\
(3,86)\end{array}$ & $\begin{array}{c}0,10 \pm 0,00 \\
(3,85)\end{array}$ \\
\hline VCB-3 & $\begin{array}{c}2.633 \pm 2 \\
(0,07)\end{array}$ & $\begin{array}{c}0,37 \pm 0,02 \\
(5,42)\end{array}$ & $\begin{array}{c}0,14 \pm 0,01 \\
(5,45)\end{array}$ \\
\hline RIC & $\begin{array}{c}2.626 \pm 1 \\
(0,05) \\
\end{array}$ & $\begin{array}{c}0,40 \pm 0,02 \\
(5,32) \\
\end{array}$ & $\begin{array}{c}0,15 \pm 0,01 \\
(5,35)\end{array}$ \\
\hline BCR & $\begin{array}{c}2.618 \pm 2 \\
(0,07)\end{array}$ & $\begin{array}{c}0,37 \pm 0,02 \\
(6,11)\end{array}$ & $\begin{array}{c}0,14 \pm 0,01 \\
(6,14)\end{array}$ \\
\hline BSV & $\begin{array}{c}2.623 \pm 1 \\
(0,05)\end{array}$ & $\begin{array}{c}0,56 \pm 0,03 \\
(6,20)\end{array}$ & $\begin{array}{c}0,21 \pm 0,01 \\
(6,25)\end{array}$ \\
\hline PIT & $\begin{array}{c}2.634 \pm 1 \\
(0,03)\end{array}$ & $\begin{array}{c}0,27 \pm 0,02 \\
(6,93)\end{array}$ & $\begin{array}{c}0,10 \pm 0,01 \\
(6,94)\end{array}$ \\
\hline AZF & $\begin{array}{c}2.625 \pm 2 \\
(0,06) \\
\end{array}$ & $\begin{array}{c}0,44 \pm 0,02 \\
(4,58)\end{array}$ & $\begin{array}{c}0,17 \pm 0,01 \\
(4,63)\end{array}$ \\
\hline BCE & $\begin{array}{c}2.619 \pm 3 \\
(0,10)\end{array}$ & $\begin{array}{c}0,47 \pm 0,02 \\
(4,16)\end{array}$ & $\begin{array}{c}0,18 \pm 0,01 \\
(4,19)\end{array}$ \\
\hline ITN-1 & $\begin{array}{c}2.612 \pm 6 \\
(0,16)\end{array}$ & $\begin{array}{c}0,91 \pm 0,06 \\
(6,88)\end{array}$ & $\begin{array}{c}0,35 \pm 0,03 \\
(6,90)\end{array}$ \\
\hline ITN-2 & $\begin{array}{c}2.614 \pm 4 \\
(0,22)\end{array}$ & $\begin{array}{c}1,00 \pm 0,07 \\
(7,08)\end{array}$ & $\begin{array}{c}0,38 \pm 0,03 \\
(7,28)\end{array}$ \\
\hline CRV & $\begin{array}{c}2.628 \pm 1 \\
(0,03)\end{array}$ & $\begin{array}{c}0,56 \pm 0,03 \\
(6,26)\end{array}$ & $\begin{array}{c}0,21 \pm 0,01 \\
(6,28)\end{array}$ \\
\hline CSB & $\begin{array}{c}2.636 \pm 16 \\
(0,60)\end{array}$ & $\begin{array}{c}0,44 \pm 0,03 \\
(5,85)\end{array}$ & $\begin{array}{c}0,17 \pm 0,01 \\
(6,13)\end{array}$ \\
\hline FLS & $\begin{array}{c}2.616 \pm 22 \\
(0,83)\end{array}$ & $\begin{array}{c}0,61 \pm 0,08 \\
(13,92)\end{array}$ & $\begin{array}{c}0,23 \pm 0,03 \\
(14,46)\end{array}$ \\
\hline GVN & $\begin{array}{c}2.644 \pm 8 \\
(0,31)\end{array}$ & $\begin{array}{c}0,66 \pm 0,06 \\
(9,21)\end{array}$ & $\begin{array}{c}0,25 \pm 0,02 \\
(9,30)\end{array}$ \\
\hline ARB & $\begin{array}{c}2.654 \pm 7 \\
(0,26)\end{array}$ & $\begin{array}{c}0,55 \pm 0,04 \\
(7,80)\end{array}$ & $\begin{array}{c}0,21 \pm 0,02 \\
(7,85)\end{array}$ \\
\hline scc & $\begin{array}{c}2.635 \pm 3 \\
(0,13)\end{array}$ & $\begin{array}{c}0,78 \pm 0,05 \\
(6,01)\end{array}$ & $\begin{array}{c}0,29 \pm 0,02 \\
(6,01)\end{array}$ \\
\hline
\end{tabular}

Os parâmetros foram obtidos em corpos-de-prova de placas polidas, destinados aos vários ensaios de alteração acelerada; e, também, naqueles confeccionados para determinação da resistência à compressão, por sua vez retirados material in natura (blocos enviados para ensaios). Isso ensejou a verificação de modificações entre o material beneficiado e $o$ in natura e da influência do tamanho e forma dos corpos-deprova nos valores obtidos.

Para a realização dos ensaios foram seguidos os procedimentos recomendados 
por ABNT (1992a), CEN (1998a) e BSI (1999a), utilizando-se, então, corpos-de-prova com as seguintes dimensões:

- Iadrilhos polidos, aqui denominados ladrilho: $10 \mathrm{~cm} \times 10 \mathrm{~cm}, 10 \mathrm{~cm} \times 12 \mathrm{~cm}$, $10 \mathrm{~cm} \times 15 \mathrm{~cm}$, com espessura de $2 \mathrm{~cm}$ ou $3 \mathrm{~cm}$ (conforme aquela da placa polida),

- blocos in natura, aqui denominados bloco: cubos com 7,5 cm x 7,5 cm x $7,5 \mathrm{~cm}$.

Como pôde ser observado, para o tamanho $10 \mathrm{~cm} \times 15 \mathrm{~cm}$, não foram determinadas densidade aparente e absorção segundo (CEN, 1998a) (Tab. 6.16). Isto se explica por terem sido os primeiros corpos-de-prova a serem ensaiados e não se havia, até então, deparado, como será extensivamente discutido adiante, com as variações de valores conforme o método e tamanho do corpo-de-prova.

Quando se introduziu a determinação segundo (CEN, 1998a), esses corpos-deprova já haviam sido cortados para os ensaios de alteração em câmaras climáticas, o que inviabilizou o estudo comparativo.

Algumas estatísticas (valores médios, desvio padrão e coeficiente de variação; máximos, mínimos e mediana) das determinações realizadas para as 18 amostras estudadas encontram-se na Tabela 6.19.

Os valores médios determinados exibiram variação entre $2.632 \mathrm{~kg} / \mathrm{m}^{3}$ (ABNT bloco) e $2.621 \mathrm{~kg} / \mathrm{m}^{3}$ (BSI $-10 \mathrm{~cm} \times 12 \mathrm{~cm}$ ), para densidade; entre $0,28 \%$ (ABNT $10 \mathrm{~cm} \times 10 \mathrm{~cm}$ ) e $0,19 \%$ (ABNT - bloco), para absorção; e entre 0,73\% (ABNT $10 \mathrm{~cm} \times 10 \mathrm{~cm}$ ) e $0,51 \%$ (ABNT - bloco), para porosidade.

O maior valor obtido para a absorção d'água foi $0,41 \%$ (ABNT - ladrilho - $10 \mathrm{~cm}$ x $12 \mathrm{~cm}$ ), e o menor, 0,09\% (ABNT - bloco). A porosidade máxima foi 1,08\% (ABNT $10 \mathrm{~cm} \times 12 \mathrm{~cm}$ ) e a mínima, 0,24\% (ABNT - bloco).

Os coeficientes de variação, bastante reduzidos, para os valores de densidade, são relativamente altos para absorção e porosidade: $44 \%$ para bloco e entre $23 \%$ e $30 \%$ para ladrilhos, apontando para a variabilidade das propriedades intrínsecas desses materiais e ressaltando uma questão, aparentemente, fundamental quanto à alterabilidade; a capacidade de absorção da rocha e sua quantificação. 
Tabela 6.19 - Dados estatísticos de índices físicos obtidos para as amostras ensaiadas.

\begin{tabular}{|c|c|c|c|c|c|c|c|c|}
\hline Método/ & âmetro & $\begin{array}{l}\text { Área CP } \\
\text { (cm) }\end{array}$ & $\bar{x}$ & $s$ & C.V. & mínimo & mediana & máximo \\
\hline \multirow{3}{*}{ ABNT } & $\rho_{\mathrm{sec}}$ & \multirow{3}{*}{ BLOCO } & 2.632 & 16 & 0,6 & 2.612 & 2.631 & 2.677 \\
\hline & $\eta$ & & 0,51 & 0,22 & 43 & 0,24 & 0,45 & 1,00 \\
\hline & $\alpha$ & & 0,19 & 0,08 & 44 & 0,09 & 0,17 & 0,38 \\
\hline \multirow{9}{*}{ ABNT } & \multirow{3}{*}{$\rho_{\mathrm{sec}}$} & $10 \times 15$ & 2.629 & 15 & 0,6 & 2.610 & 2.627 & 2.662 \\
\hline & & $10 \times 12$ & 2.627 & 15 & 0,6 & 2.606 & 2.623 & 2.660 \\
\hline & & $10 \times 10$ & 2.628 & 16 & 0,6 & 2.610 & 2.624 & 2.660 \\
\hline & \multirow{3}{*}{$\eta$} & $10 \times 15$ & 0,69 & 0,17 & 24 & 0,41 & 0,68 & 0,92 \\
\hline & & $10 \times 12$ & 0,67 & 0,17 & 25 & 0,31 & 0,69 & 1,08 \\
\hline & & $10 \times 10$ & 0,73 & 0,17 & 24 & 0,32 & 0,73 & 1,01 \\
\hline & \multirow{3}{*}{$\alpha$} & $10 \times 15$ & 0,26 & 0,06 & 24 & 0,15 & 0,26 & 0,35 \\
\hline & & $10 \times 12$ & 0,26 & 0,06 & 25 & 0,12 & 0,26 & 0,41 \\
\hline & & $10 \times 10$ & 0,28 & 0,07 & 24 & 0,12 & 0,28 & 0,39 \\
\hline \multirow{9}{*}{ BSI } & \multirow{3}{*}{$\rho_{b}$} & $10 \times 15$ & 2.625 & 16 & 0,6 & 2.605 & 2.621 & 2.657 \\
\hline & & $10 \times 12$ & 2.621 & 16 & 0,6 & 2.595 & 2.619 & 2.655 \\
\hline & & $10 \times 10$ & 2.624 & 16 & 0,6 & 2.605 & 2.621 & 2.658 \\
\hline & \multirow{3}{*}{$p_{o}$} & $10 \times 15$ & 0,65 & 0,16 & 24 & 0,34 & 0,66 & 0,95 \\
\hline & & $10 \times 12$ & 0,65 & 0,15 & 23 & 0,41 & 0,64 & 0,96 \\
\hline & & $10 \times 10$ & 0,61 & 0,18 & 30 & 0,34 & 0,61 & 0,96 \\
\hline & \multirow{3}{*}{$V_{o}$} & $10 \times 15$ & 2,3 & 0,6 & 26 & 1,5 & 2,2 & 3,7 \\
\hline & & $10 \times 12$ & 2,0 & 0,5 & 24 & 1,4 & 2,0 & 3,2 \\
\hline & & $10 \times 10$ & 1,6 & 0,5 & 30 & 1,0 & 1,4 & 2,7 \\
\hline \multirow{4}{*}{ CEN } & \multirow{2}{*}{$\rho_{\mathrm{sec}}$} & $10 \times 12$ & 2.627 & 15 & 0,6 & 2.610 & 2.623 & 2.659 \\
\hline & & $10 \times 10$ & 2.629 & 16 & 0,6 & 2.610 & 2.625 & 2.663 \\
\hline & \multirow{2}{*}{$A_{b}$} & $10 \times 12$ & 0,25 & 0,06 & 25 & 0,13 & 0,25 & 0,36 \\
\hline & & $10 \times 10$ & 0,24 & 0,06 & 27 & 0,13 & 0,24 & 0,40 \\
\hline
\end{tabular}

Nota: $\rho_{\text {sec }}=$ massa específica aparente seca $\left(\mathrm{kg} / \mathrm{m}^{3}\right) ; \eta=$ porosidade aparente $(\%) ; \alpha=$ absorção d'água aparente (\%); $A_{b}=$ coeficiente de absorção d'água a pressão atmosférica (\%); $V_{o}=$ volume de poros abertos $(\mathrm{mL}) ; \rho_{b}=$ densidade aparente seca $\left(\mathrm{kg} / \mathrm{m}^{3}\right) ; \quad p_{o}=$ porosidade aberta (\%) $\bar{x}=$ média; $s=$ desvio-padrão; $C . V$. = coeficiente de variação.

\subsubsection{Grupos discriminados segundo densidade e absorção}

Em geral, os resultados mostraram-se consistentes, como indicado pelos desvios padrão e coeficientes de variação. As diferenças nos valores obtidos para parâmetros semelhantes, como será discutido adiante, se relacionaram especialmente aos métodos ensaio e tamanhos e formas dos corpos-de-prova.

É relevante ressaltar que, a despeito dessas variações, a hierarquia, definida 
pela relação densidade aparente, absorção d'água e porosidade aberta, é basicamente a mesma, não se supondo, então, interferência na integração dos dados.

Podem ser extraídas inúmeras informações que de tão rico conjunto de dados. Entretanto, dado o escopo deste trabalho, será sempre destacada a questão da absorção d'água, e sua determinação, na discussão dos resultados.

As rochas graníticas em estudo tendem a exibir correlação negativa entre densidade e porosidade e absorção, ou seja, aquelas com menor densidade, em geral, apresentam maior absorção d'água. Tal tendência pode ser explicada pelo fato de densidades menores estarem relacionadas a um volume maior de vazios (poros, fissuras etc.) no material, o que, por sua vez, potencialmente permite maior incorporação de água; resultando, assim, em valores menores.

Considerando o conjunto de dados obtidos, é possível distingüir tendências na distribuição dos grupos em relação à absorção e densidade que serão tratados separadamente, a seguir, quanto ao tipo de amostra; ladrilho e bloco.

\subsubsection{Ladrilho}

A Tabela 6.20 mostra a distribuição das rochas estudadas segundo intervalos de resultados médios de densidade e absorção (ABNT, 1992a e CEN, 1998a) para ladrilhos polidos, independentemente do tamanho. Os intervalos foram definidos arbitrariamente, baseando-se na análise dos valores máximos, intermediários e mínimos, em $2.615 \mathrm{~kg} / \mathrm{m}^{3}, 2.630 \mathrm{~kg} / \mathrm{m}^{3}$ e $2.645 \mathrm{~kg} / \mathrm{m}^{3}$ para densidade aparente e em $0,15 \%$ e 0,30\% para absorção d'água.

Tabela 6.20 - Distribuição das rochas estudadas segundo intervalos de resultados médios (ABNT, 1992a e CEN, 1998a) de densidade aparente e absorção para ladrilho.

\begin{tabular}{ccccc}
\hline & $\rho_{\text {sec }}\left(\mathbf{k g} / \mathbf{m}^{3}\right)$ & \multicolumn{4}{c}{$\alpha(\%)$} \\
\cline { 3 - 5 } & $<\mathbf{0 , 1 5}$ & $\mathbf{0 , 1 5 - 0 , 3 0}$ & $>\mathbf{0 , 3 0}$ \\
\hline A & $<\mathbf{2 . 6 1 5}$ & -- & $(\mathrm{CSB}),(\mathrm{BCR}),(\mathrm{CVR})$ & $\begin{array}{c}\text { ITN-1, ITN-2, FLS, } \\
\text { BCE, (BCR) }\end{array}$ \\
\hline B & $\mathbf{2 . 6 1 5 - 2 . 6 3 0}$ & -- & $\begin{array}{c}\text { PIT, AZF, RIC, BSV (BCE), } \\
\text { BCR, CSB, (CRV) }\end{array}$ & (CVR) \\
\hline C & $\mathbf{2 . 6 3 0 - 2 . 6 4 5}$ & VCB-3, (VCB-2) & $\begin{array}{c}\text { VCB-1, (VCB-3), SCC, VCB-2, } \\
\text { (BCE), GVN }\end{array}$ & (GVN) \\
\hline D & $>\mathbf{2 . 6 4 5}$ & -- & ARB, LBD & -- \\
\hline
\end{tabular}

Nota: mesmos símbolos da Tab. 6.19.

Designações entre parênteses indicam rochas que, subordinadamente, apresentaram valores diferentes do predominante. 
As determinações, segundo ABNT (1992a) e CEN (1998a), indicaram que a grande maioria das rochas estudadas apresenta densidade aparente entre $2.615 \mathrm{~kg} / \mathrm{m}^{3}$ e $2.645 \mathrm{~kg} / \mathrm{m}^{3}$, e absorção entre $0,15 \%$ e $0,30 \%$.

Com absorção entre $0,15 \%$ e $0,30 \%$ e densidade aparente entre $2.615 \mathrm{~kg} / \mathrm{m}^{3}$ e $2.630 \mathrm{~kg} / \mathrm{m}^{3}$,concentram-se os grupos 3 e 4 e as amostras CSB e CRV, e entre 2.630 $\mathrm{kg} / \mathrm{m}^{3}$ e $2.645 \mathrm{~kg} / \mathrm{m}^{3}$, acham-se as VCB, SCC e GVN. As amostras ITN e BCE, em geral, têm absorção $>0,30 \%$ e densidade $<2.615 \mathrm{~kg} / \mathrm{m}^{3}$ e os ARB e LBD, por sua vez, exibem absorção entre 0,15 e $0,30 \%$ e densidade $>2.645 \mathrm{~kg} / \mathrm{m}^{3}$.

Com comportamento errático, ora com densidade menor e/ou absorção maior citam-se as amostras CSB, CVR, BCR e GVN. Da mesma forma, com tendência à menor absorção, estão os VCB-3 e VCB-2.

A discriminação das rochas, segundo a densidade, parece ser primordialmente relacionada à composição mineralógica. No tocante à absorção, presume-se a influência da alteração e fissuramento.

As rochas menos densas ( $A$ - Tab. 6.20) são compostas essencialmente de feldspatos, com relativamente poucos máficos ou anisotropia ou intemperismo relativamente elevado (FLS).

As rochas com densidade entre $2.615 \mathrm{~kg} / \mathrm{m}^{3}$ e $2.630 \mathrm{~kg} / \mathrm{m}^{3}$ (B) têm maior quantidade de quartzo e de máficos (biotita, principalmente) que as anteriores $(A)$.

A crescente quantidade de máficos (biotita, principalmente) e de granada contribui para a diferenciação das rochas com densidade entre $2.630 \mathrm{~kg} / \mathrm{m}^{3}$ e 2.645 $\mathrm{kg} / \mathrm{m}^{3}$ e $>2.645 \mathrm{~kg} / \mathrm{m}^{3}$. A amostra LBD, um charnockito, caracteriza-se como a rocha mais densa deste estudo.

Deve ser mencionado que as CSB e FLS são rochas mais ricas em micas, distribuídas segundo bandas irregularmente dispostas conforme a estruturação. Essa heterogeneidade se reflete no coeficiente de correlação da densidade aparente e absorção, independentemente da forma do corpo-de-prova e do método de ensaio utilizado, pois dificulta obtenção de corpos-de-prova semelhantes. Como são amostras representativas da rocha inalterada e intempericamente alterada, a menor densidade da FLS reflete o aumento da porosidade e possíveis mudanças mineralógicas e/ou físicas.

Adotando-se os mesmos intervalos de densidade aparente dos resultados das normas ABNT NBR 12766 (ABNT, 1992a) e prEN WI 036 (CEN, 1998a), e 
estabelecendo os valores de 0,40\% e 0,80\% para porosidade aberta (BSI, 1999a), é notável o deslocamento de um grupo de rochas (Tabela 6.21) do intervalo de porosidade entre $0,40 \%$ e $0,80 \%$ (aproximadamente equivalente à faixa entre $0,15 \% \mathrm{e}$ $0,30 \%$ ) para a faixa $<2.615 \mathrm{~kg} / \mathrm{m}^{3}$; quais sejam as RIC, BCR, BSV, BCE e CSB. As demais rochas, na sua maioria, acham-se nos mesmos intervalos determinados na Tab. 6.20.

Tabela 6.21 - Distribuição das rochas estudadas segundo intervalos de resultados médios (BSI, 1999a) de densidade aparente e porosidade aberta para ladrilho.

\begin{tabular}{|c|c|c|c|}
\hline \multirow{2}{*}{$\rho_{b} \quad\left(\mathbf{k g} / \mathbf{m}^{3}\right)$} & \multicolumn{3}{|c|}{$p_{o}(\%)$} \\
\hline & $<0,40$ & $0,40-0,80$ & $>0,80$ \\
\hline$<2.615$ & -- & RIC, BSV, BCR, BCE, CSB, (CVR) & ITN-1, ITN-2, FLS \\
\hline $2.615-2.630$ & VCB-2 & PIT, AZF, CRV, (CSB), (FLS) & \\
\hline $2.630-2.645$ & (VCB-3) & VCB-1, VCB-3, SCC, GVN, (ARB) & \\
\hline$>2.645 \mathrm{~kg} / \mathrm{m}^{3}$ & -- & ARB, LBD & $(G \vee N)$ \\
\hline
\end{tabular}

Nota: mesmos símbolos da Tab. 6.19 .

Designações entre parênteses indicam rochas que, subordinadamente, apresentaram valores diferentes do predominante.

As Figuras 6.33 a 6.35 exibem as relações entre densidade aparente e absorção ou porosidade aberta e os coeficientes de correlação, de acordo com os vários métodos e tamanhos estabelecidos neste trabalho, e mostram a distribuição dos grupos discriminados nos intervalos estabelecidos nas Tab. 6.20 e 6.21 .

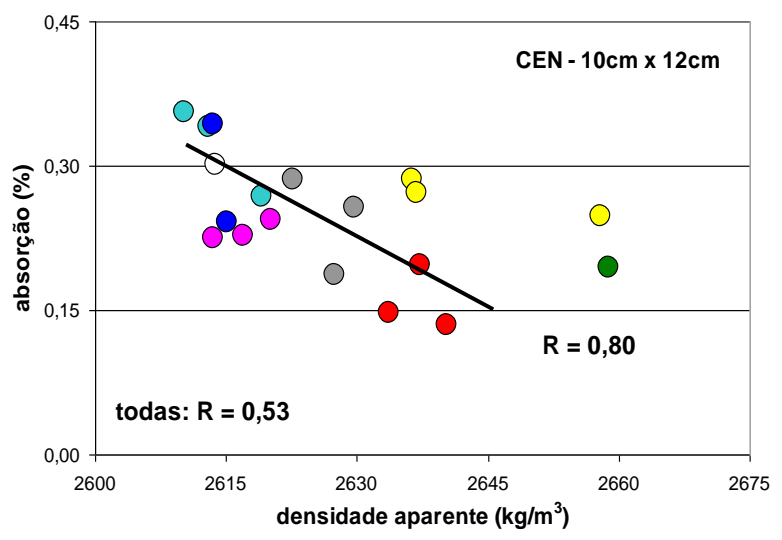

a)

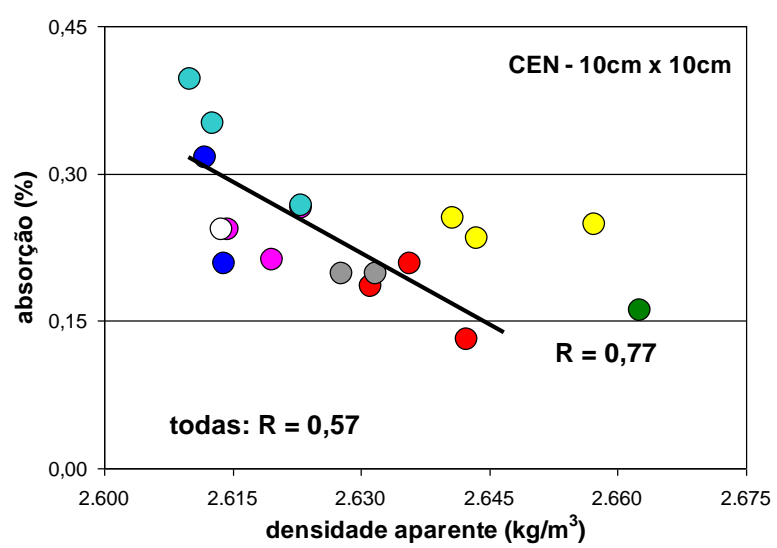

b)

Figura 6.33 - Relação densidade aparente x absorção (CEN,1998a), para ladrilho: a) $10 \mathrm{~cm} x$ $12 \mathrm{~cm}$; b) $10 \mathrm{~cm} \times 10 \mathrm{~cm}$. 


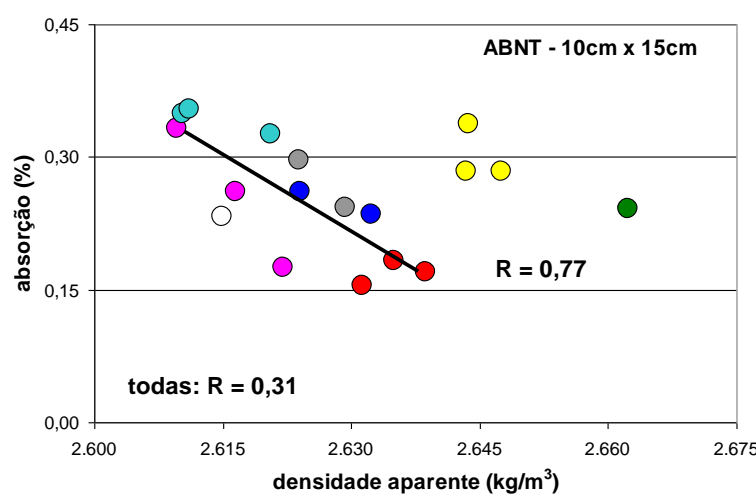

a)

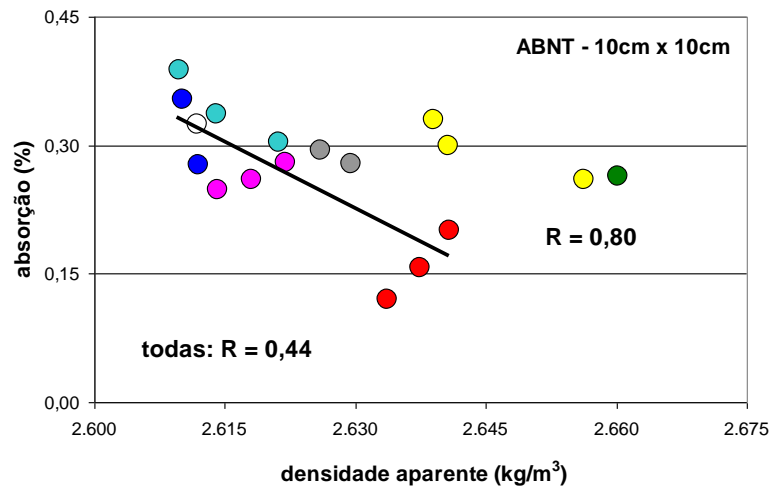

c)

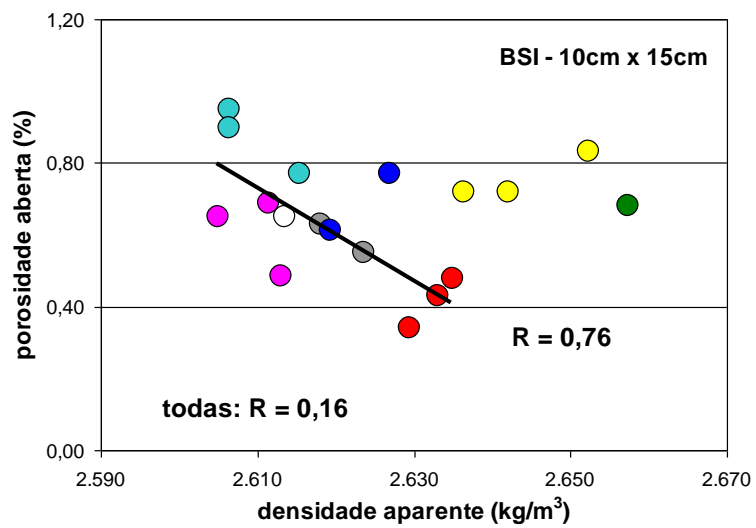

a)

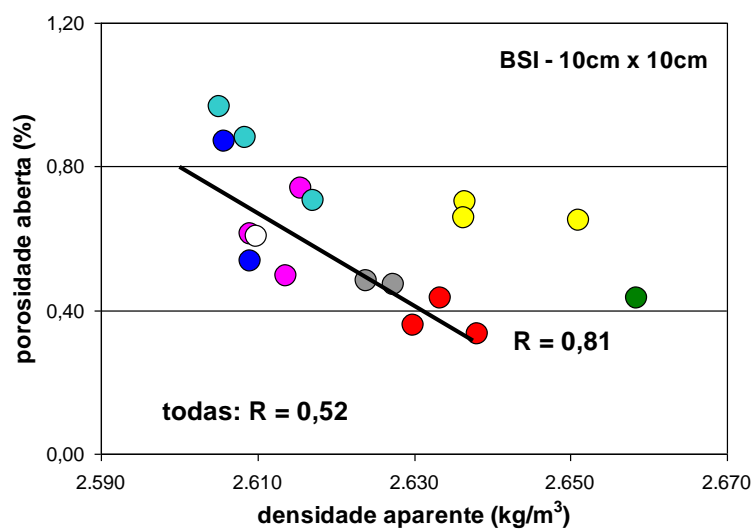

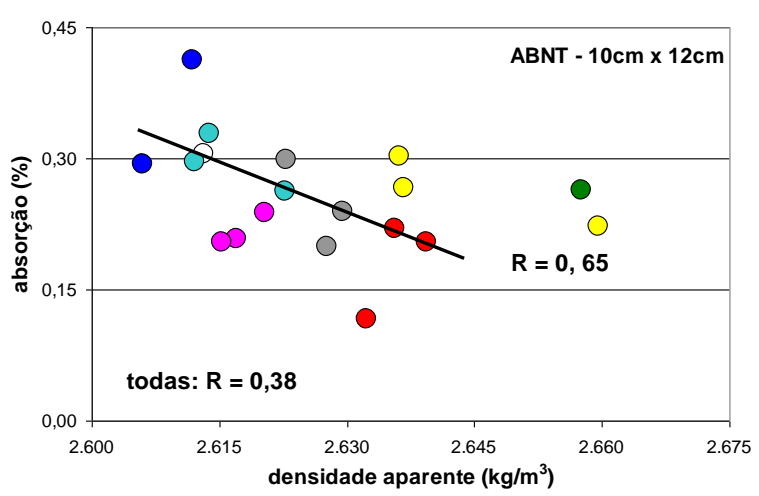

b)

Figura 6.34 - Relação densidade aparente $x$ absorção (ABNT, 1992a), para ladrilho: a) 10 $\mathrm{cm} \times 15 \mathrm{~cm}$, b) $10 \mathrm{~cm} \times 12 \mathrm{~cm} \mathrm{e} \mathrm{c)} 10 \mathrm{~cm} \times 10$ $\mathrm{cm}$.

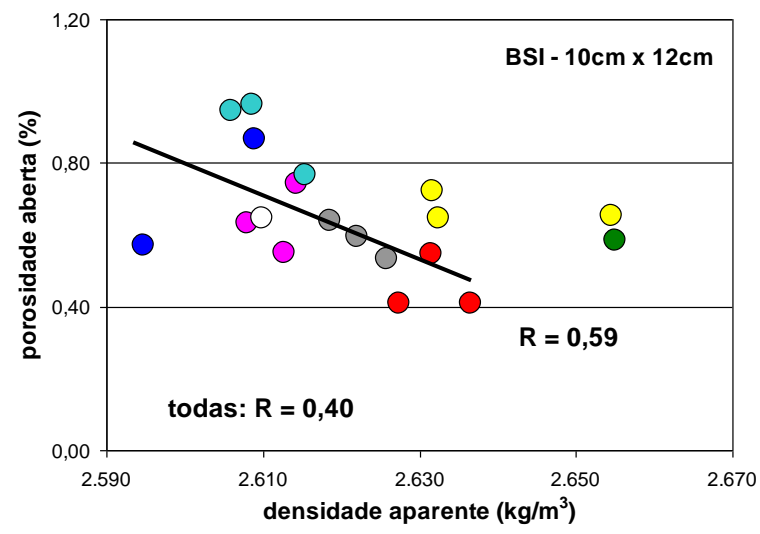

b)

Figura 6.35 - Relação densidade aparente $x$ porosidade aberta (BSI, 1999a), para ladrilho: a) $10 \mathrm{~cm} \times 15 \mathrm{~cm}$; b) $10 \mathrm{~cm} \times 12 \mathrm{~cm}$; c) $10 \mathrm{~cm}$ $\mathrm{x} 10 \mathrm{~cm}$.

c) 
A tendência geral de menores valores de absorção e porosidade aberta para rochas com densidades maiores discrimina dois conjuntos; um contemplando os grupos 2 a 7 e outro, os grupos 1 e 8 . A amostra LBD (gr. 1) é uma rocha charnockítica e já pôde ser observado que tem características que a discrimina das demais rochas estudadas. $O$ grupo 8 também se diferencia em alguns aspectos principais: estrutura fortemente gnáissica, granulação mais grossa, presença conspícua de granada e grau de alteração.

Entre os grupos 2 a 7 é possível verificar a tendência de ITN e BCE apresentarem maiores valores de absorção e menores de densidade e dos VCB, menores absorção e maiores densidade. Os valores de CRV são próximos, mas diferentes das ITN.

Coeficientes de correlação determinados para todas as amostras ("todas", nos gráficos anteriores) e somente para os grupos 2 a 7 (próximo à reta de regressão) indicaram:

- muito fraca a média correlação negativa $(0,16<R<0,57)$, para "todas", sendo as melhores encontradas para CEN (1998a) nos tamanhos $10 \mathrm{~cm} \times$ $12 \mathrm{~cm}$ e $10 \mathrm{~cm} \times 15 \mathrm{~cm}$;

- média a forte correlação negativa $(0,59<R<0,80)$ entre densidade $\mathrm{e}$ absorção ou porosidade para as rochas dos grupos 2 a 7 , geralmente com $\mathrm{R}>0,75$ para corpos-de-prova com tamanhos $10 \mathrm{~cm} \times 10 \mathrm{~cm}$ e $10 \mathrm{~cm} \times 15$ $\mathrm{cm}$.

\subsubsection{Bloco}

Os grupos discriminados para bloco, segundo os intervalos de densidade e absorção adotados para ladrilho, conforme ABNT NBR 12766 (ABNT, 1992a) (Tabela 6.22 e Figura 6.36), tendem a uma distribuição semelhante àquela encontrada para ladrilho, mas com valores menores de absorção d'água e pouco maiores de densidade. 
Tabela 6.22 - Distribuição das rochas estudadas segundo intervalos de resultados médios (ABNT, 1992a) de densidade aparente e absorção.

\begin{tabular}{|c|c|c|c|}
\hline \multirow{2}{*}{$\rho_{\mathrm{sec}}\left(\mathbf{k g} / \mathbf{m}^{3}\right)$} & \multicolumn{3}{|c|}{$\alpha(\%)$} \\
\hline & $<0,15$ & $0,15-0,30$ & $>0,30$ \\
\hline$<2.615$ & -- & - & ITN-1, ITN-2 \\
\hline $2.615-2.630$ & $\mathrm{RIC}, \mathrm{BCR}$ & FLS, BCE, AZF, CRV, BSV & -- \\
\hline $2.630-2.645$ & VCB-1, VCB-2, VCB-3, PIT & CSB, SCC, GVN & -- \\
\hline$>2.645$ & LBD & ARB & -- \\
\hline
\end{tabular}

Nota: mesmos símbolos da Tab. 6.19.

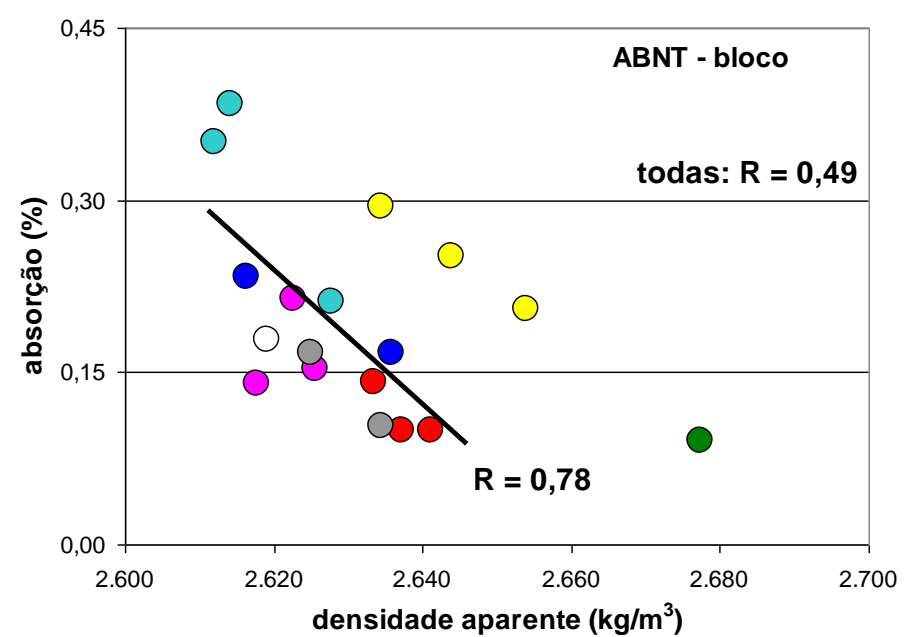

Figura 6.36 - Relação densidade aparente $x$ absorção, para bloco (ABNT, 1992a).

Os grupos 1 e 8 (Fig. 6.36) também são claramente discriminados, esse último pela absorção relativamente maior. O LBD se isola dos demais devido à alta densidade e baixa absorção. No lado oposto a LBD, as amostras ITN também se discriminam pela densidade relativamente menor e alta absorção.

\subsubsection{A influência do método de ensaio e forma dos corpos-de-prova}

Numa análise global das propriedades físicas determinadas, é possível generalizar a distribuição das rochas estudadas segundo faixas de densidade e absorção arbitrariamente estabelecidas, conforme abordado no item anterior.

Para algumas rochas, entretanto, é verificada grande heterogeneidade nos valores obtidos para densidade (CSB, RIC, BSV, BCR) ou absorção (BCE, VCB-1, VCB-2, GVN, CRV); enquanto para outras, aparentemente, há homogeneidade (Tabela $6.23)$. 
Tabela 6.23 - Rochas com resultados homogêneos nas determinações de propriedades físicas.

\begin{tabular}{ccc}
\hline amostras & \multicolumn{2}{c}{ propriedades físicas } \\
\hline ITN-1, ITN-2 & $\rho<2.615 \mathrm{~kg} / \mathrm{m}^{3}$ & $\alpha>0,30 \%$ \\
\hline PIT, AZF & $2.615 \mathrm{~kg} / \mathrm{m}^{3}<\rho<2.630 \mathrm{~kg} / \mathrm{m}^{3}$ & \\
\hline SCC & $2.630 \mathrm{~kg} / \mathrm{m}^{3}<\rho<2.645 \mathrm{~kg} / \mathrm{m}^{3}$ & $0,15 \%<\alpha<0,30 \%$ \\
\hline ARB, LBD & $\rho>2.645 \mathrm{~kg} / \mathrm{m}^{3}$ & \\
\hline
\end{tabular}

Nota: mesmos símbolos da Tab. 6.19.

Com o grande inconveniente de dificultar uma correlação imediata ou, numa análise superficial, aparentar erros, os diversos resultados obtidos para os vários métodos e formas de corpos-de-prova reiteram um dos pontos fundamentais do material em estudo: a heterogeneidade.

A heterogeneidade, característica inerente aos materiais rochosos, reflete 0 arranjo tridimensional dos minerais, segundo os processos geológicos de formação, que, posteriormente, podem ser rearranjados ou modificados, conforme atuação de novos processos geológicos.

Por mais cuidadosa e criteriosa que seja a escolha e preparação de corpos-deprova, há sempre uma "incerteza geológica", fornecida pela quantidade e distribuição relativa dos minerais, descontinuidades, alteração etc.

Por isso, como princípio, não se deve deixar de considerar os diferentes resultados obtidos também ligados às propriedades petrográficas do corpo-de-prova em questão.

As correlações exploratórias realizadas para bloco e para ladrilho de mesmas dimensões, entre valores densidade e absorção determinados segundo as três normas utilizadas ABNT (1992a), CEN (1998a) e BSI (1999a), são exibidas na Figura 6.37 e permitem as seguintes considerações:

- todos os métodos mostram correlação fraca a média entre densidade $\mathrm{e}$ absorção. As melhores correlações, $R=0,53(10 \mathrm{~cm} \times 12 \mathrm{~cm})$ e $R=0,57$ $(10 \mathrm{~cm} \times 10 \mathrm{~cm})$, foram obtidas pelo método CEN (1998a). 


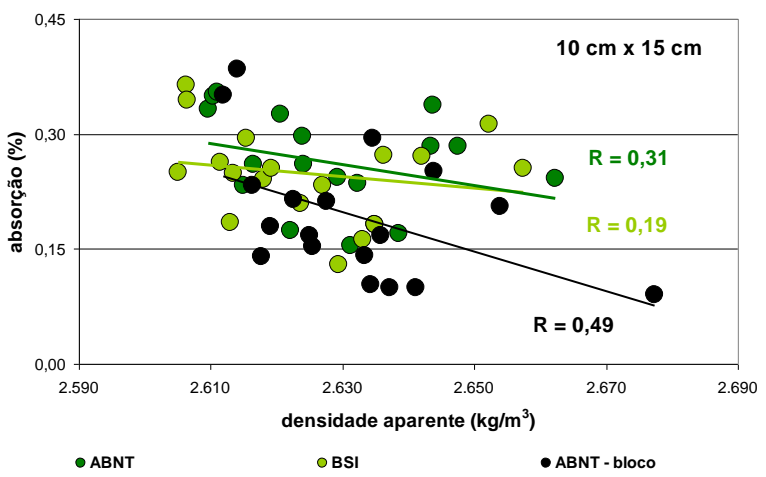

a)

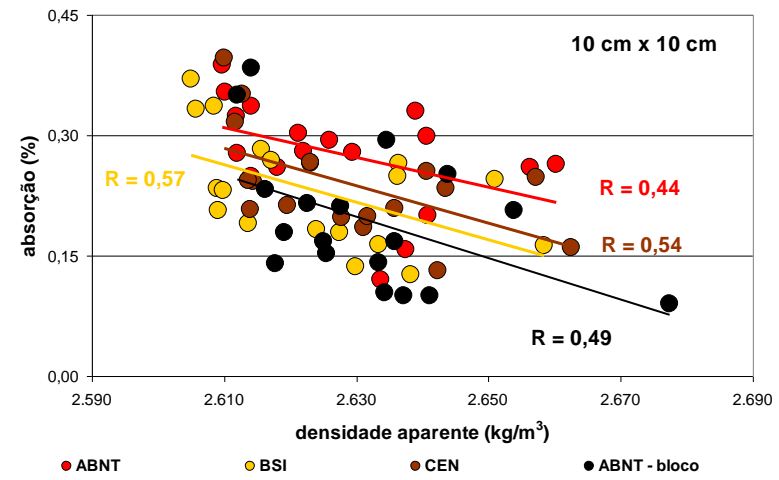

c)

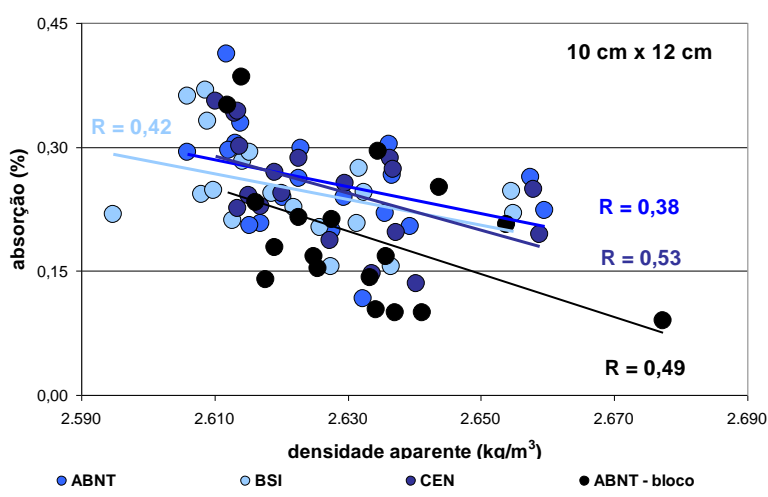

b)

Figura 6.37 - Correlações entre densidade aparente e absorção entre bloco e ladrilho de diferentes dimensões, segundo ABNT (1992a), CEN (1998a) e BSI (1999a).

- ABNT NBR 12766 (ABNT, 1992a), principalmente, permite uma boa diferenciação entre os valores obtidos para bloco e ladrilho, e não exibe variação muito grande desses valores (correlações semelhantes) quando obtidos para ladrilhos de diferentes tamanhos. Sistematicamente forneceu os maiores valores de absorção e porosidade aparente, que pode se relacionar à temperatura de secagem $\left(100^{\circ} \mathrm{C}\right)$ dos corpos-de-prova;

- o tamanho $10 \mathrm{~cm} \times 10 \mathrm{~cm}$, além de sempre exibir a melhor correlação para ladrilho, permite excelente discriminação, quanto à absorção, conforme o métodos utilizados (Fig. 6.37c). Sua observação indica a seqüência decrescente das correlações entre densidade aparente e absorção para ladrilho: $\mathrm{BSI}>\mathrm{CEN}>\mathrm{ABNT}$; que, na ordem inversa, significa que as maiores variações de valores de absorção foram fornecidas por ABNT > CEN > BSI.

A norma BS EN 1936 (BSI, 1999a) introduziu a determinação do volume de poros abertos, ou seja, a quantificação do volume de água incorporada nos corpos-deprova, que refletiria o mais próximo da realidade, a capacidade de absorção da rocha.

A Figura 6.38 também mostra a clara influência dos vários formatos estabelecidos para os ladrilhos polidos, bem como da sua espessura, no volume de 
poros abertos determinados para as rochas estudadas.

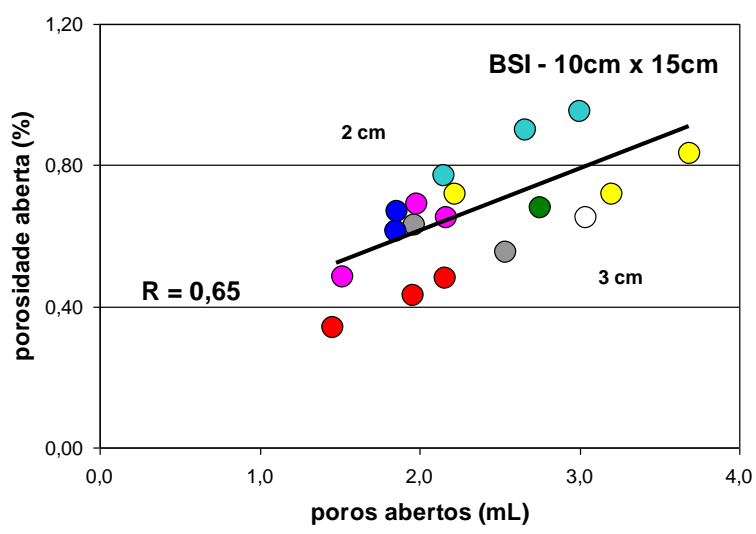

a)

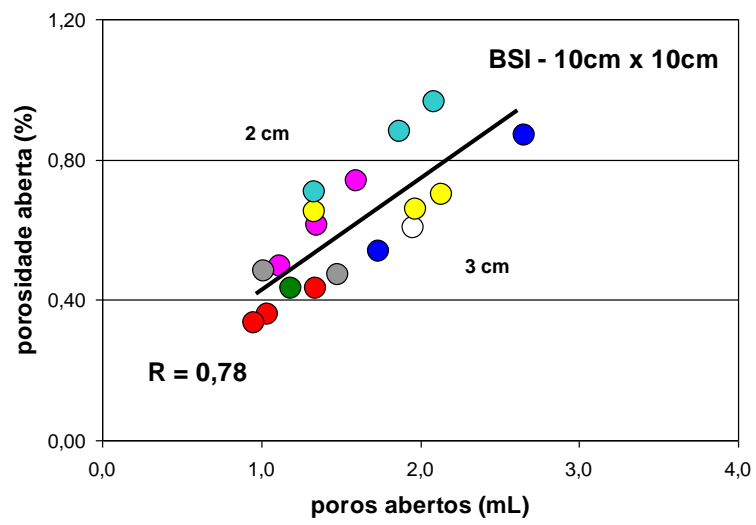

c)

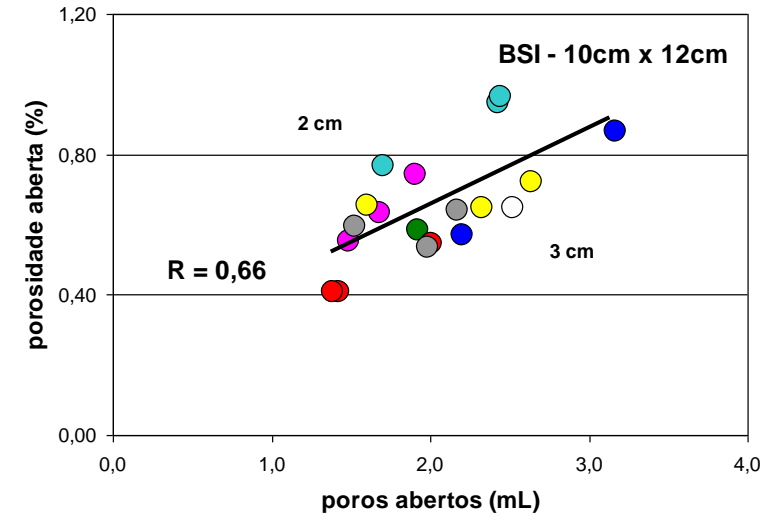

b)

Figura 6.38 - Relação poros abertos $\mathrm{x}$ porosidade aberta (BSI, 1999a), para ladrilho:

a) $10 \mathrm{~cm} \times 15 \mathrm{~cm}$; b) $10 \mathrm{~cm} \times 12 \mathrm{~cm}$;

c) $10 \mathrm{~cm} \times 10 \mathrm{~cm}$.

Notar o deslocamento do conjunto de amostras para menores valores de poros abertos de a) para c).

Dentre as várias considerações que podem ser feitas a partir da observação da distribuição das rochas na Fig. 6.38, destacam-se:

- poros abertos $x$ porosidade aberta permite a nítida distinção dos diferentes volumes dos corpos-de-prova;

- o volume de poros abertos e, conseqüentemente, a capacidade relativa de absorção de água pela rocha, como ressaltado pela amostra PIT, ensaiada com espessura de $2 \mathrm{~cm}$ e $3 \mathrm{~cm}$, tende a ser maior para espessuras maiores;

- a maior parte das amostras guardou, relativamente, a mesma hierarquização, independente da área ou volume dos corpos-de-prova;

- os valores de poros abertos e porosidade aberta mostraram média a forte correlação $(R>0,65)$, em especial para aqueles obtidos para corpos-de-prova com $10 \mathrm{~cm} \times 10 \mathrm{~cm}$.

A proporcionalidade entre o volume de poros abertos e a área dos corpos-deprova pode ser vista na Figura 6.39, à exceção de CSB e FLS (grupo 7). 


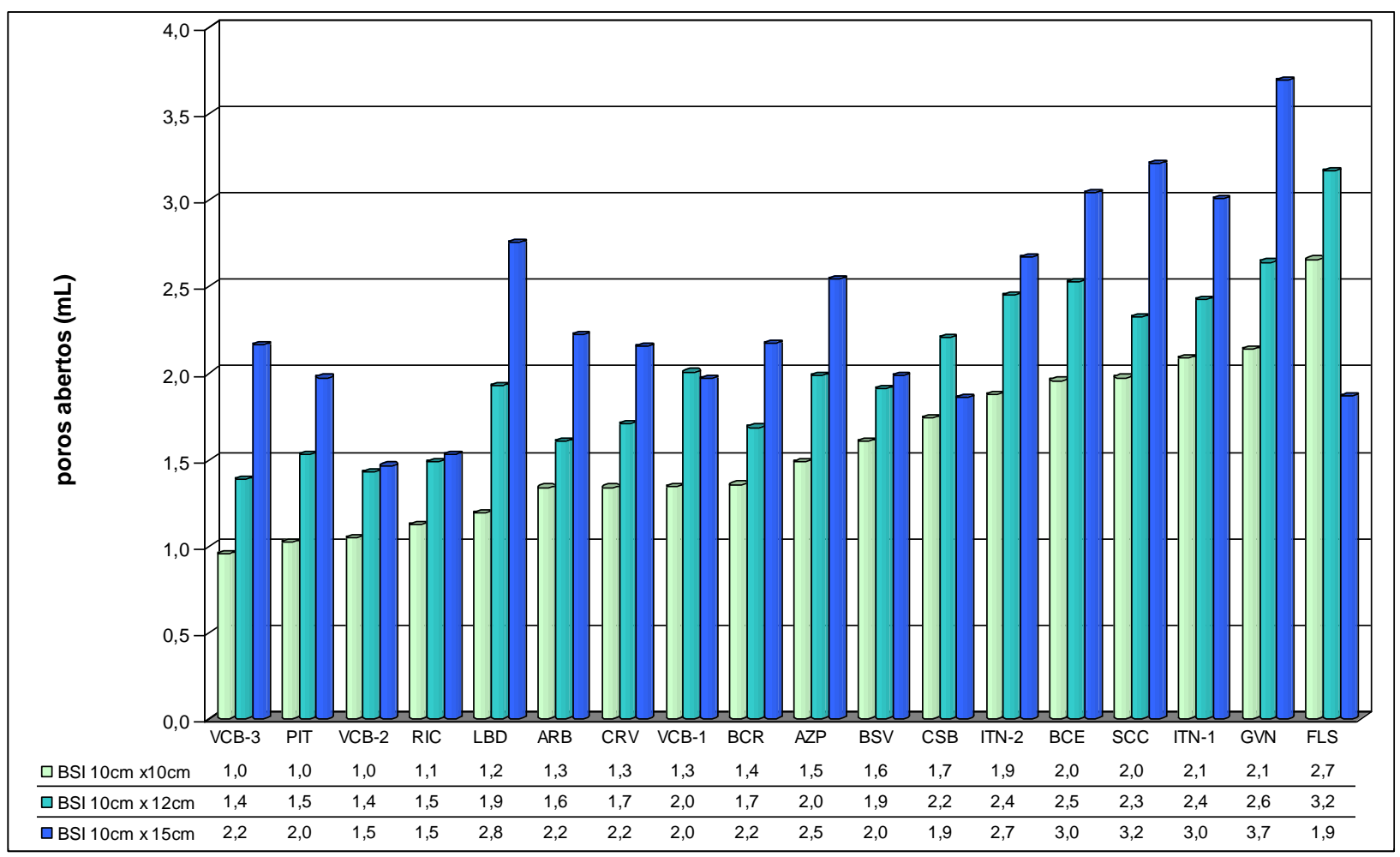

Figura 6.39 - Diferentes valores obtidos para poros abertos, conforme o tamanho do corpo-deprova.

As rochas do grupo 7 pertencem à mesma unidade geológica, porém representam litotipos com diferentes graus de alteração intempérica - FLS > CSB cujos resultados indicariam os efeitos degradadores do intemperismo nas propriedades físicas de rochas, a despeito das incipientes modificações exibidas no exame petrográfico. Também devem ser consideradas a forte anisotropia das rochas e a irregular distribuição de bandas quartzo-feldspáticas, ora ricas em feldspato potássico, ora ricas em plagioclásio, na heterogeneidade dos resultados.

Algumas rochas destacam-se das outras, aqui consideradas como pertencentes ao mesmo grupo (vide Tab. 6.1), por exibirem menor volume de poros abertos, nos tamanhos $10 \mathrm{~cm} \times 10 \mathrm{~cm}$ e $10 \mathrm{~cm} \times 12 \mathrm{~cm}$ : RIC (<BCR <BSV); ARB (<SCC <GVN); CRV (<ITN-1 <ITN-2).

As amostras LBD e GVN mostram grande deslocamento relativo de poros abertos, cujos valores migram de $1,2 \mathrm{~mL}$, com $10 \mathrm{~cm} \times 10 \mathrm{~cm}$, para 2,8 mL, com $10 \mathrm{~cm}$ $x 15 \mathrm{~cm}$ e de $2,1 \mathrm{~mL}$ para $3,7 \mathrm{~mL}$, respectivamente.

Há forte correlação positiva $(R=0,78)$ entre porosidade aberta e poros abertos (Figura 6.40), que também revela a influência dos diferentes tamanhos dos corpos-de- 
prova no volume de poros abertos, ou seja, quanto maior o volume do corpo-de-prova, maior o volume de poros abertos.

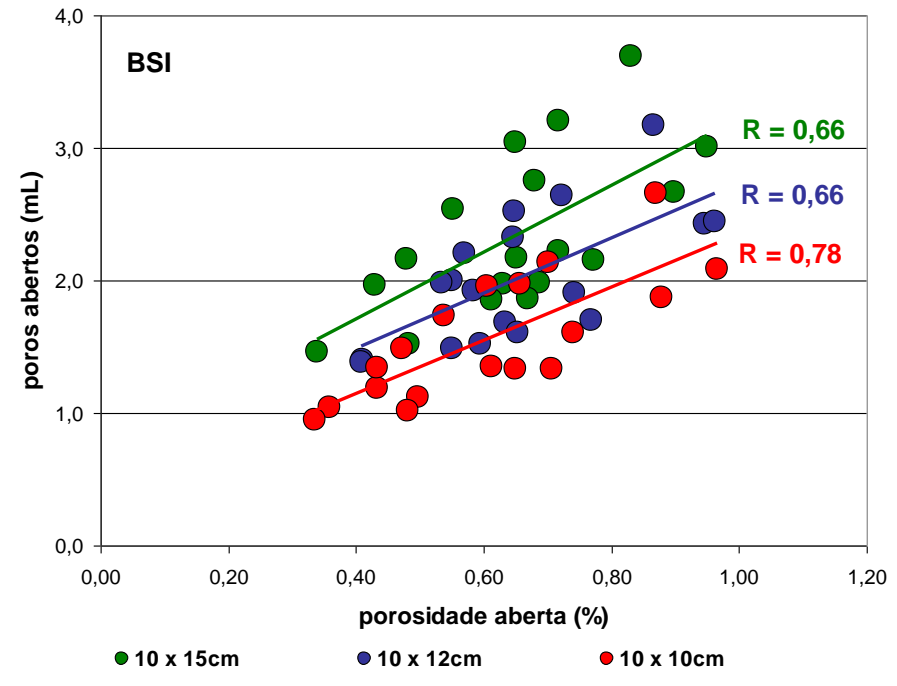

Figura 6.40 - Correlações entre porosidade aberta e volume de poros abertos para ladrilho, de diferentes dimensões (BSI, 1999a).

Observação importante para a padronização do tamanho do corpo-de-prova, de modo a que fique isento das variações verificadas. $O$ tamanho ótimo seria aquele em que se inicia a estabilização, entretanto tal dimensão não deverá ser adequada para as determinações, visto que no tamanho $10 \mathrm{~cm} \times 15 \mathrm{~cm}$, o corpo-de-prova, já tem volume e peso inadequados para os equipamentos usuais.

Com base nas várias análises estatísticas exploratórias, é possível indicar o tamanho $10 \mathrm{~cm} \times 10 \mathrm{~cm}$ para corpos-de-prova de ladrilho, visto que novamente exibem a melhor correlação, como o mais adequado, tanto do ponto estatístico, como laboratorial, para a determinação de índices físicos de rochas beneficiadas.

\subsubsection{Variações de propriedades físicas de bloco para ladrilho}

A possibilidade de mudanças nas propriedades físicas e mecânicas da rocha para revestimento, a partir daquelas que se apresentam no maciço rochoso - antes dos trabalhos de lavra - em decorrência das solicitações ao longo dos processos de extração, transporte, beneficiamento e colocação, é reconhecida por pesquisadores desse tema.

Como abordado por Amoroso; Fassina (1983), tanto os efeitos dos diferentes processos de beneficiamento, nas características físicas e estruturais dos materiais rochosos, nunca foram extensivamente estudados, como os poucos trabalhos, até então realizados, não revelaram diferenças relevantes nesses materiais. 
Frascá (2002b) investigou preliminarmente as possíveis modificações na densidade aparente, absorção d'água e porosidade, segundo ABNT NBR 12766 (ABNT, 1992a), de rochas para revestimento, de composição granítica, exploradas no Estado de São Paulo.

O estudo evidenciou modificações aleatórias nessas propriedades, a despeito da exaustiva repetição de ensaios para excluir possibilidade de erros. Concluiu-se que esse resultado se relacionava, preponderantemente, ao tamanho dos corpos-de-prova utilizados para essas determinações: $7 \mathrm{~cm} \times 4,5 \mathrm{~cm} \times 3 \mathrm{~cm}$ e $15 \mathrm{~cm} \times 2 \mathrm{~cm} \times 3 \mathrm{~cm}$, para aqueles representativos das rochas beneficiadas (ladrilho) e cubos com $4 \mathrm{~cm}$ ou 5 $\mathrm{cm}$ de arestas, para as rochas in natura (bloco).

Nessa oportunidade também foi investigada a influência do polimento, em uma das faces, nos resultados de densidade e absorção, nas determinações efetuadas segundo ABNT (1992a). A influência do polimento revelou-se pouco significativa nas determinações efetuadas, cerca de 1,5\%, em média, segundo o método utilizado.

Neste trabalho, com a finalidade de dar continuidade a essa investigação, para a determinação dos parâmetros de densidade e absorção representativos da rocha in natura foram confeccionados corpos-de-prova com arestas de $7,5 \mathrm{~cm}$. Os resultados das determinações, segundo ABNT NBR 12766 (ABNT, 1992a), já foram apresentados nas Tab. 6.15 a 6.18 .

As variações nos valores de densidade e absorção d'água entre os corpos-deprova de bloco e de ladrilho, são exibidas nas Figuras 6.41 e 6.42. Os valores máximo, mínimo e mediana das variações de densidade aparente, porosidade aparente e absorção d'água entre bloco e ladrilho acham-se na Tabela 6.24. 


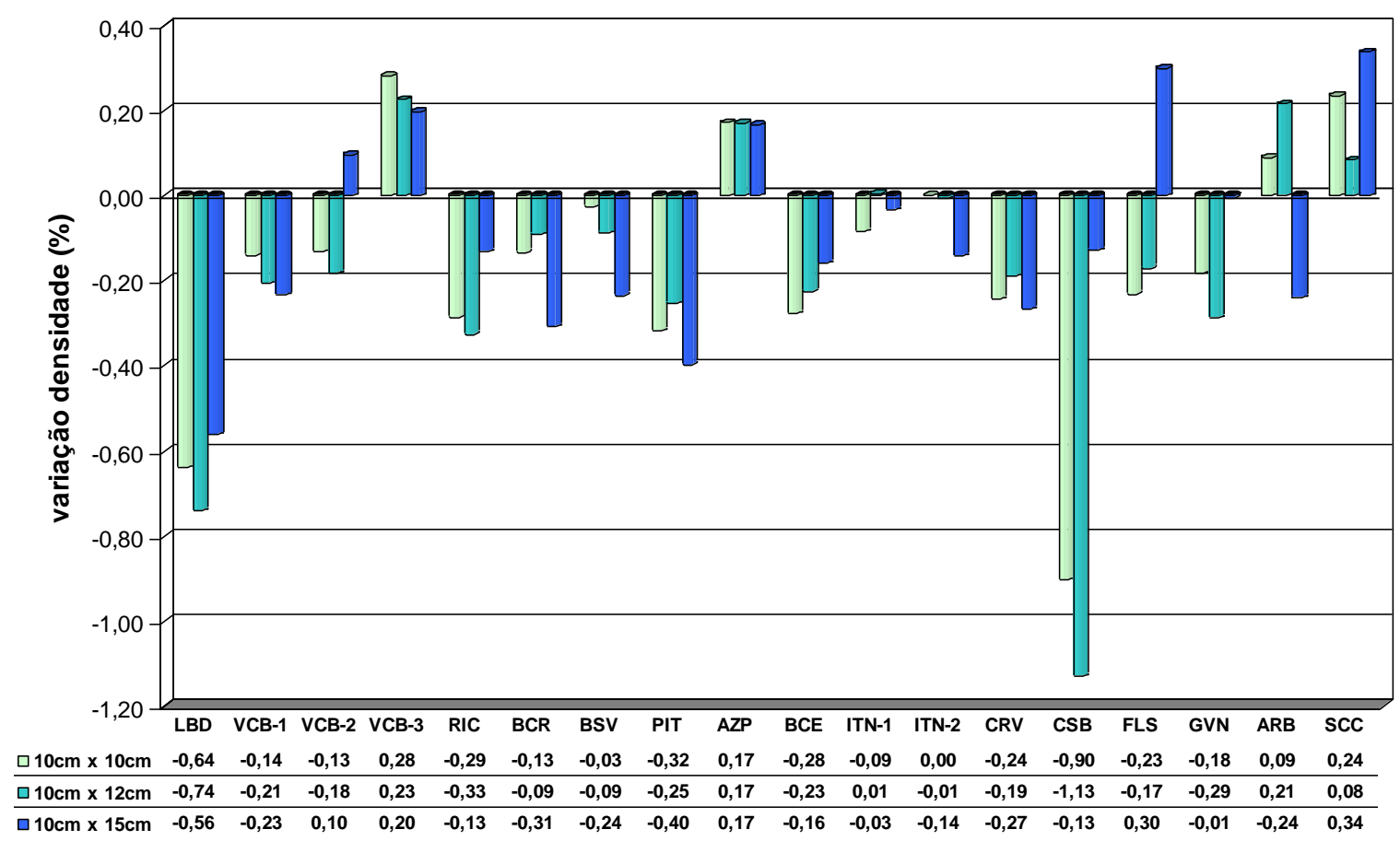

Figura 6.41 - Distribuição das variações de densidade de ladrilho em relação a bloco.

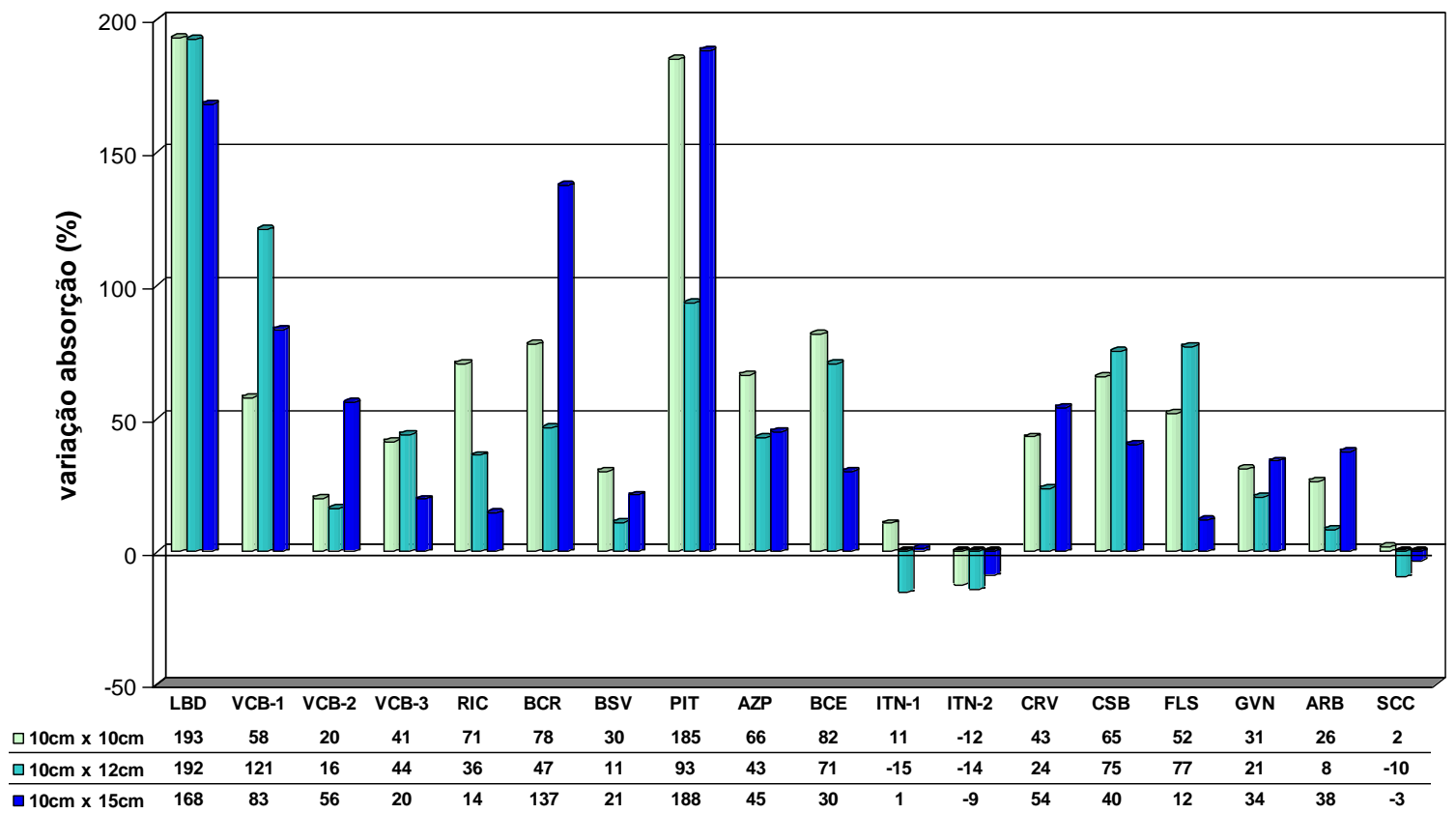

Figura 6.42 - Distribuição das variações de absorção ladrilho em relação a bloco. 
Tabela 6.24 - Variações máxima e mínima de propriedades físicas (ABNT, 1992a) de bloco para ladrilho.

\begin{tabular}{cccccccccc}
\hline \multirow{2}{*}{ Valores } & \multicolumn{3}{c}{$\Delta_{b l-10 \times 15}$} & \multicolumn{3}{c}{$\Delta_{b l-10 \times 12}$} & \multicolumn{3}{c}{$\Delta_{b l-10 \times 10}$} \\
\cline { 2 - 9 } & $\rho_{\text {sec }}$ & $\eta$ & $\alpha$ & $\rho_{\text {sec }}$ & $\eta$ & $\alpha$ & $\rho_{\text {sec }}$ & $\eta$ & $\alpha$ \\
\hline mínimo & $-0,56 \%$ & $-9 \%$ & $-9 \%$ & $-1,13 \%$ & $-15 \%$ & $-15 \%$ & $-0,90 \%$ & $-12 \%$ & $-12 \%$ \\
\hline mediana & $-0,14 \%$ & $36 \%$ & $36 \%$ & $-0,13 \%$ & $39 \%$ & $39 \%$ & $-0,14 \%$ & $47 \%$ & $48 \%$ \\
\hline máximo & $0,34 \%$ & $187 \%$ & $188 \%$ & $0,23 \%$ & $190 \%$ & $192 \%$ & $0,28 \%$ & $191 \%$ & $193 \%$ \\
\hline
\end{tabular}

Nota: $\rho_{\text {sec }}=$ massa específica aparente seca $\left(\mathrm{kg} / \mathrm{m}^{3}\right) ; \eta=$ porosidade aparente (\%); $\alpha$ = absorção d'água aparente (\%); $\Delta_{b l-10 \times 15}=$ variação entre bloco e ladrilho $(10 \mathrm{~cm} \times 15 \mathrm{~cm}) ; \Delta_{b l-10 x 12}=$ variação entre bloco e ladrilho $(10 \mathrm{~cm} \times 12 \mathrm{~cm}) ; \Delta_{b l-10 \times 10}=$ variação entre bloco e ladrilho $(10 \mathrm{~cm} \times 10 \mathrm{~cm})$

Os valores máximos e mínimos obtidos para os diferentes tamanhos de corposde-prova dos ladrilhos se mostraram bastante semelhantes, mas há grande irregularidade da sua distribuição, conforme a rocha e o tamanho do corpo-de-prova (Fig. 6.41 e 6.42).

Para o parâmetro densidade aparente, as variações foram muito reduzidas: aumento máximo de $0,34 \%$ e diminuição máxima de $1,13 \%$, avaliadas como nãosignificativas. As amostras CSB e LBD exibiram as maiores modificações de densidade aparente (negativas), destacando-se das demais.

Dado que os valores de porosidade aparente e de absorção d'água são proporcionais, nota-se que as variações de um e de outro são praticamente iguais. Esses parâmetros mostraram, para algumas rochas, variações significativas de bloco para ladrilho, podendo atingir 190\%. Isto sugere que a rocha beneficiada pode exibir absorção (e porosidade) quase duas vezes superiores àquelas in natura.

No entanto, essas variações são muito heterogêneas, pois em outras amostras, a absorção permaneceu estável ou até diminuiu. A amostra LBD apresentou o maior aumento relativo de absorção, seguido por PIT e BCR, e as ITN-1, ITN-2 e SCC permaneceram estáveis, rochas originalmente com absorção relativamente alta.

Em geral, as variações de absorção predominaram entre $0 \%$ e $40 \%$ e de densidade entre 0\% e -0,4\% (Figura 6.43). 


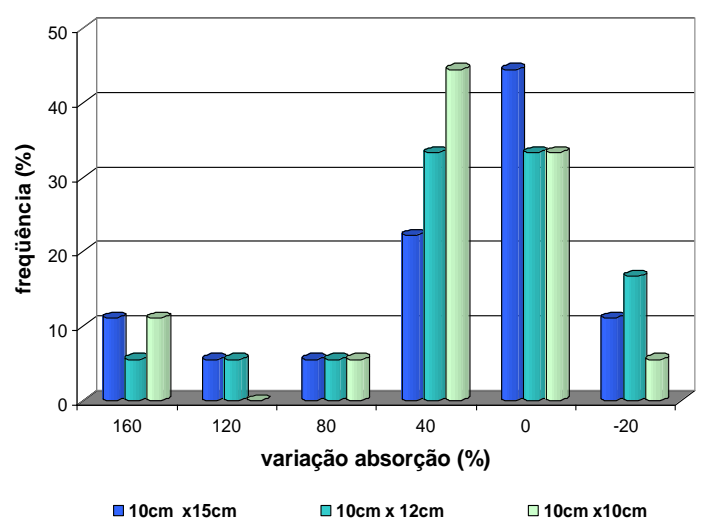

a)

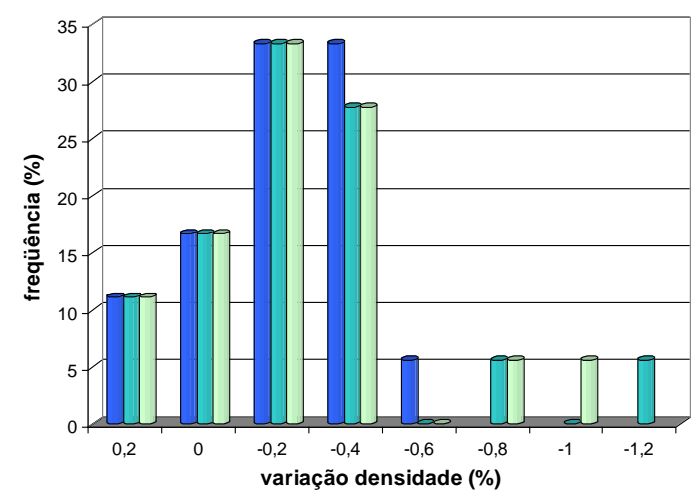

$\square 10 \mathrm{~cm} \times 15 \mathrm{~cm}$ $\square 10 \mathrm{~cm} \times 10 \mathrm{~cm}$

b)

Figura 6.43 - Freqüências das variações de absorção (a) e densidade (b) entre bloco e os diferentes tamanhos de ladrilho (ABNT, 1992a).

Foram obtidas fracas correlações, negativas, entre densidade aparente (bloco) e variação de densidade bloco-ladrilho (Figura 6.44).

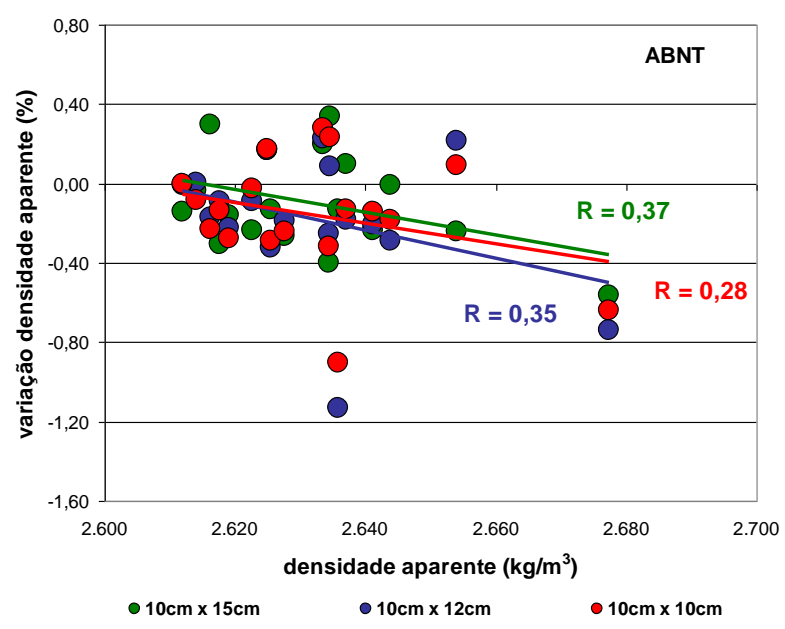

Figura 6.44-Correlações entre densidade (bloco) e variações desse parâmetro, para os diferentes tamanhos de ladrilho.

Entre absorção d'água (bloco) e variações para os diferentes tamanhos de ladrilhos (Figura 6.45) há média a forte correlação negativa, novamente indicando que as menores variações tenderam a ocorrer para as rochas originalmente com maiores valores de porosidade e absorção d'água. 


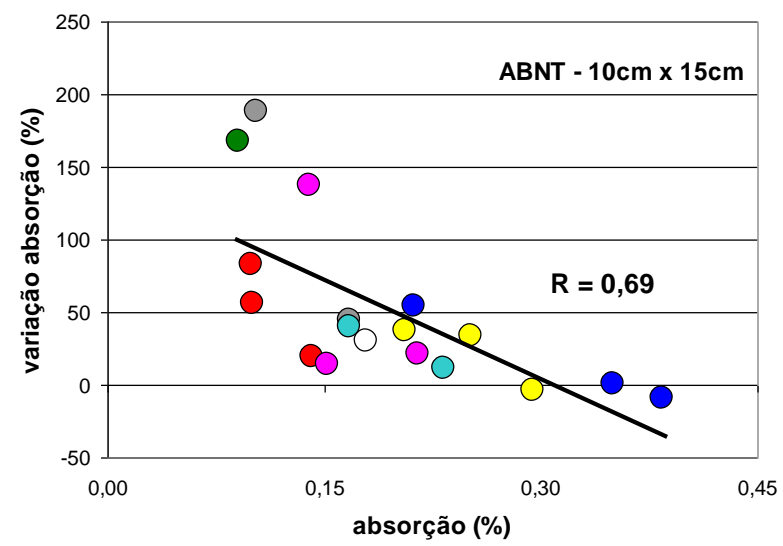

a)

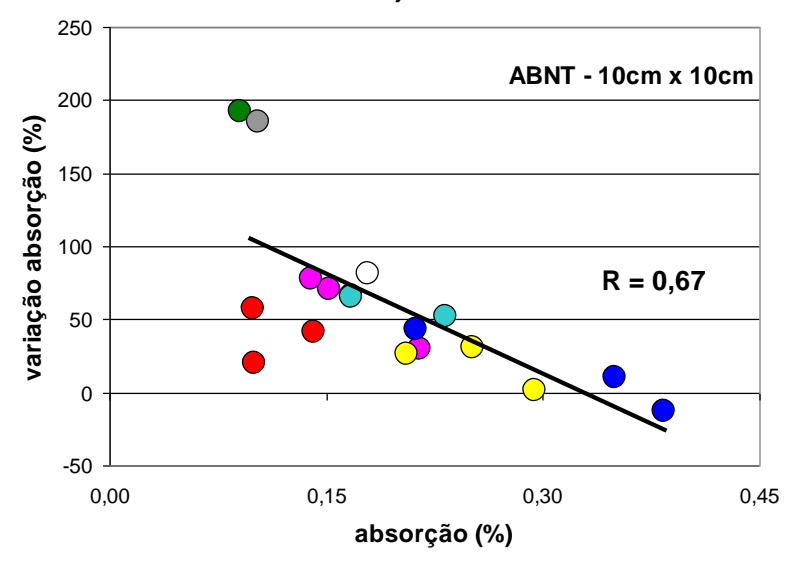

c)

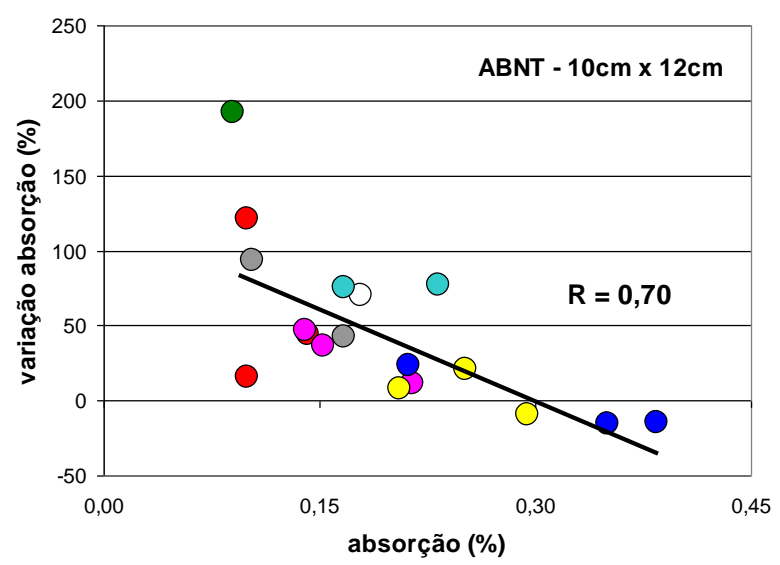

b)

Figura 6.45 - Correlações entre absorção e variação de absorção entre bloco e ladrilho, (ABNT, 1992a), para corpos-de-prova com tamanhos: a) $10 \mathrm{~cm} \times 15 \mathrm{~cm}$, b) $10 \mathrm{~cm} \times 12$ $\mathrm{cm}, \mathrm{c}) 10 \mathrm{~cm} \times 10 \mathrm{~cm}$.

\subsubsection{Capilaridade}

A determinação do coeficiente de capilaridade é relativamente recente no campo das rochas para revestimento, especialmente para as graníticas, pois como apontado na norma BS EN 1925 (BSI, 1999b) em que foram baseados os ensaios aqui realizados, ela não é recomendada para rochas com porosidade aberta menor que $1 \%$.

Entretanto, como é considerada a propriedade reguladora da incorporação de água pela rocha e um dos parâmetros mais importantes nos estudos de deterioração de rochas, experimentalmente optou-se pela sua determinação, em ladrilhos polidos, visando a análise comparativa com os resultados dos ensaios de alteração acelerada.

Os valores dos coeficientes de capilaridade (C) e as curvas de absorção $\left(\mathrm{g} / \mathrm{m}^{2}\right) x$ a raiz quadrada do tempo (s) acham-se na Figura 6.46. Notar que C é o coeficiente de capilaridade relativo a rochas isótropas e $\mathrm{C}_{1}$ aquele obtido para rochas gnáissicas, perpendicularmente à estruturação. 


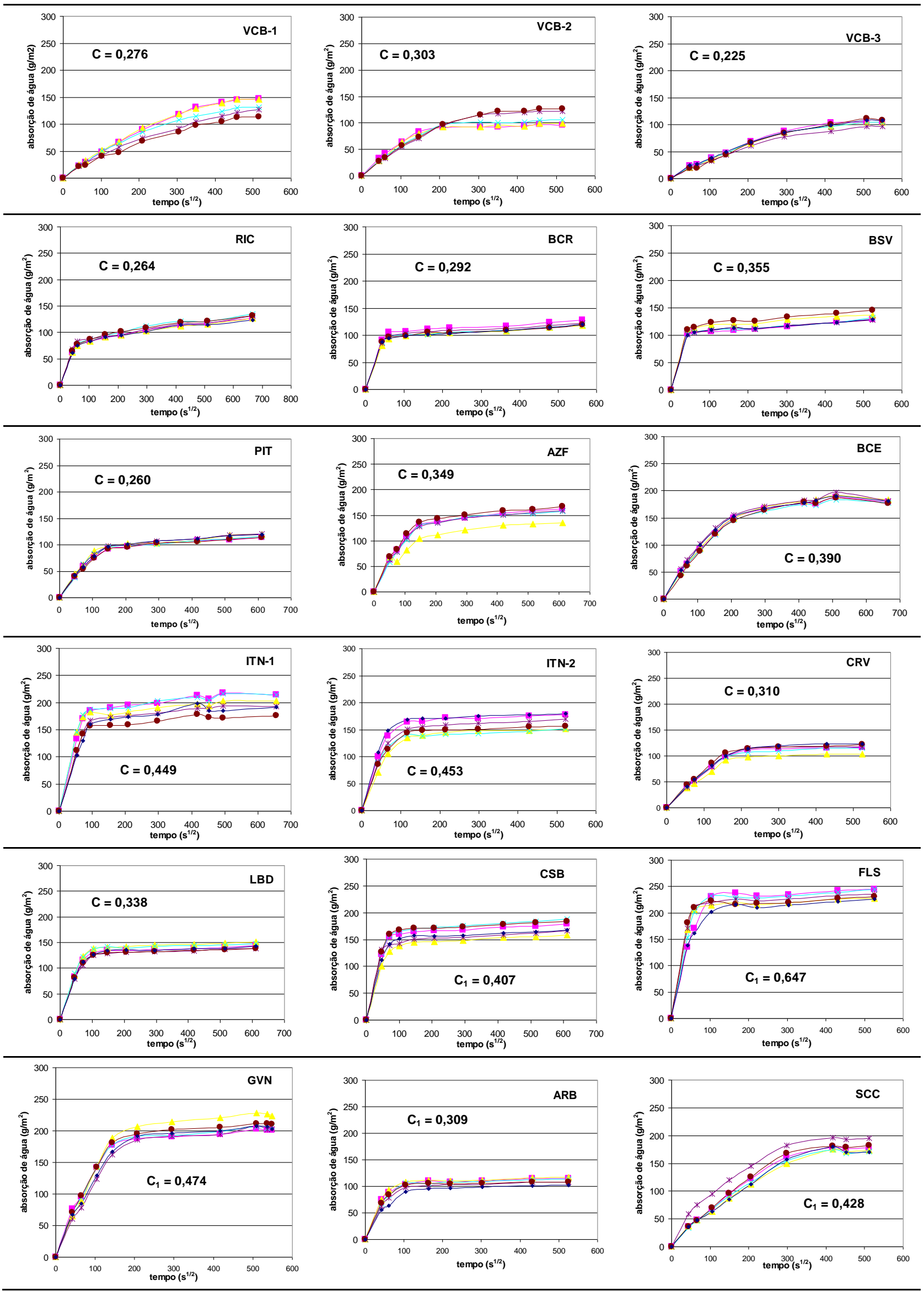

Figura 6.46 - Curvas de absorção por capilaridade para as amostras em estudo. 
A observação das curvas de capilaridade indica três padrões principais, quanto ao tempo de saturação de água:

- rochas que rapidamente absorveram água e estabilizaram: RIC, BCR e BSV (gr.3); ITN-1 e ITN-2; LBD (gr.1); CSB e FLS (gr.7);

- rochas que absorveram água mais lentamente, atingindo a estabilização praticamente ao final do ensaio: VCB-1, VCB-2, VCB-3 (gr. 2), BCE (gr. 5) e SCC;

- rochas com comportamento intermediário: PIT, AZF (gr. 4), CRV, GVN e ARB.

No tocante à quantidade de água absorvida, o comportamento, em geral, não foi coincidente com os grupos discriminados quanto às curvas de absorção. A maioria dos corpos-de-prova apresentou absorção entre $100 \mathrm{~g} / \mathrm{m}^{2}$ e $150 \mathrm{~g} / \mathrm{m}^{2}$. As amostras ITN-1, FLS e GVN mostraram absorção maior que $200 \mathrm{~g} / \mathrm{m}^{2}$; as amostras BCE, ITN-2, CSB e SCC, entre 150 e $200 \mathrm{~g} / \mathrm{m}^{2}$; e as ARB e VCB-3, próximo ou abaixo de $100 \mathrm{~g} / \mathrm{m}^{2}$.

Os coeficientes de capilaridade e os valores de absorção, porosidade aberta e volume de poros abertos, já anteriormente citados (Figuras 6.47 e 6.48), evidenciaram média a forte correlação positiva.

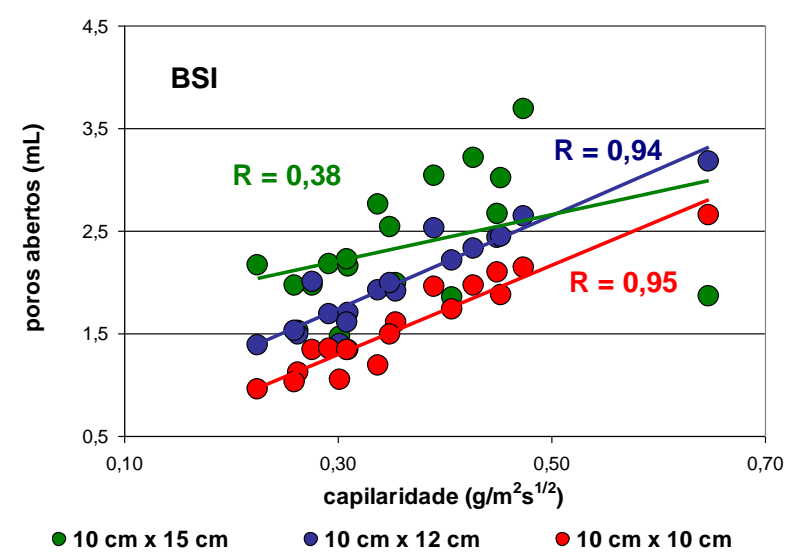

Figura 6.47 - Correlação entre coeficiente de capilaridade e volume de poros abertos (BSI, 1999a). 

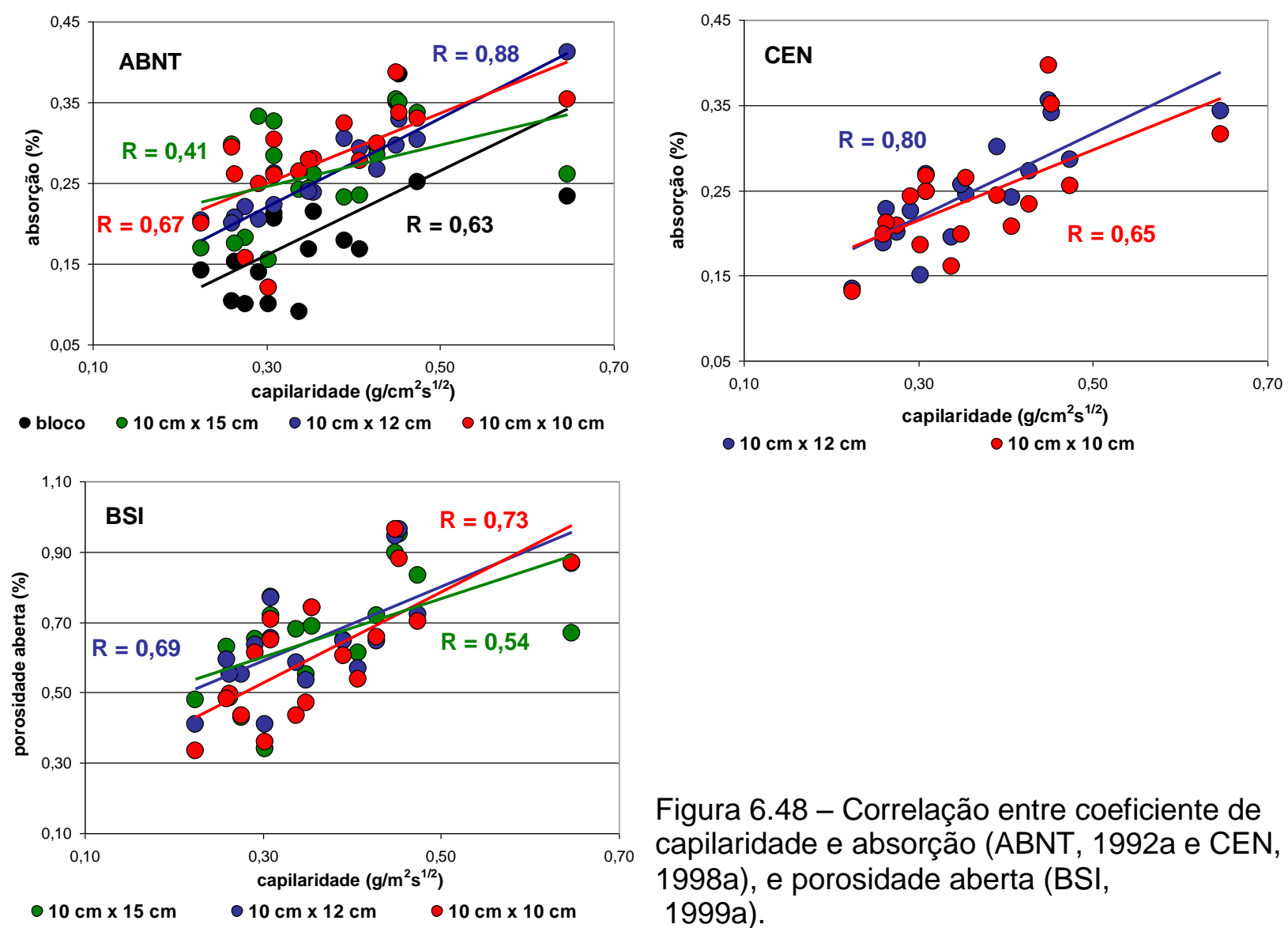

Figura 6.48 - Correlação entre coeficiente de capilaridade e absorção (ABNT, 1992a e CEN, 1998a), e porosidade aberta (BSI, 1999a).

Novamente se depara com a dependência geométrica do corpo-de-prova com as determinações dos parâmetros físicos. Os resultados para aqueles com dimensões $10 \mathrm{~cm} \times 15 \mathrm{~cm}$, em especial, têm mostrado correlações mais fracas e irregulares que para os outros tamanhos, não se encontrando uma justificativa satisfatória para isso. Erros sistemáticos referentes à dificuldade de manuseio dos corpos-de-prova, relativamente grandes para os equipamentos usuais nessas determinações, podem ser apontados como o principal motivo.

Os valores de absorção d'água para ladrilhos $10 \mathrm{~cm} \times 12 \mathrm{~cm}$, segundo ABNT (1992a) e CEN (1998a), apresentaram as melhores correlações com os coeficientes de capilaridade, esses obtidos em ladrilhos $10 \mathrm{~cm} \times 10 \mathrm{~cm}$.

Quanto às determinações do coeficiente de capilaridade e poros abertos para ladrilho, de dimensões $10 \mathrm{~cm} \times 10 \mathrm{~cm}$ e $10 \mathrm{~cm} \times 12 \mathrm{~cm}$ (Fig. 6. 48), as correlações foram muito fortes, próximas a 0,95.

As rochas dos Grupos 1, 2, 3 e 4 e a amostra ARB têm, relativamente, os menores valores de capilaridade e poros abertos, enquanto as dos grupos 5, 6, 7 e 8, os maiores (Figura 6.49). 

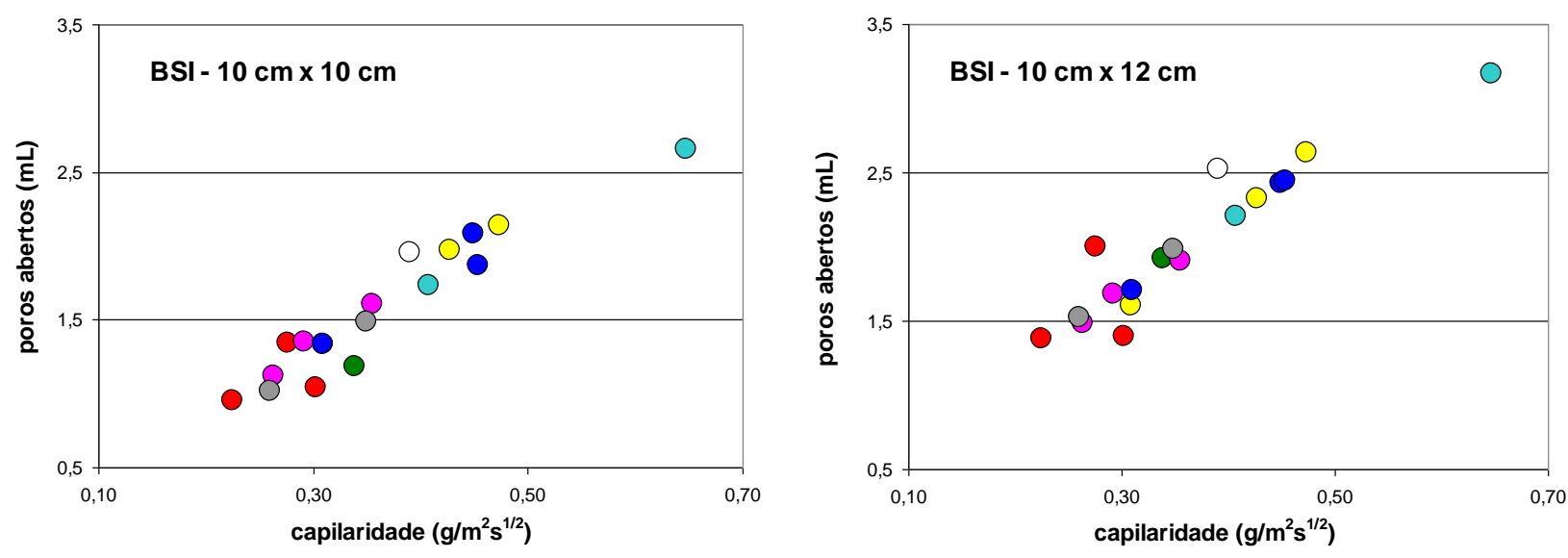

Figura 6.49 - Relação entre coeficiente de capilaridade e poros abertos (BSI, 1999a) para corpos-de-prova $10 \mathrm{~cm} \times 10 \mathrm{~cm}$ e $10 \mathrm{~cm} \times 12 \mathrm{~cm}$. Detalhamento da Fig. 6.47, exibindo as rochas equivalentes a cada ponto.

Essas fortes correlações permitem indicar que o volume de poros abertos é diretamente proporcional ao coeficiente de capilaridade das rochas graníticas em estudo, o que, por sua vez, possibilita a extrapolação desse diretamente dos valores obtidos para poros abertos.

\subsection{Propriedades Mecânicas}

Cardani; Meda (1999) atribuem a muitos dos erros cometidos na preservação de rochas em edifícios históricos o desconhecimento da influência das propriedades físicas e mecânicas na sua durabilidade, sobretudo em ambiente urbano-industrial. Consideram as resistências mecânicas como as propriedades mais importantes, pois são às forças de tensão que as rochas para revestimento estão sujeitas in situ, devido à ação de cargas e das condições ambientais.

Cardani; Meda (1999) ponderam a dificuldade de execução de ensaios diretos de tensão, especialmente na aplicação da carga, que sempre induz a um comportamento não-homogêneo, levando a resultados incorretos. Os ensaios normalizados permitem evitar essa situação por meio da determinação indireta da resistência à tensão da rocha. Apontam as resistência à compressão e à flexão como as técnicas mais freqüentemente utilizadas.

Em concordância com a argumentação de Cardani; Meda (1999), já se havia previamente selecionado, para a caracterização das propriedades mecânicas as resistências à compressão e à flexão, respectivamente determinadas nas condições 
seca e saturada, e seca e após ciclos de choque térmico.

Por meio desses ensaios, são também potencialmente obtidas informações sobre as anisotropias e heterogeneidades causadas por microdescontinuidades e diferentes inter-relações dos minerais formadores dos materiais rochosos enfocados. Possíveis modificações na hierarquia dos resultados desses ensaios, realizados a partir de corpos-de-prova de bloco e ladrilho, poderiam refletir a maior ou menor resistência às solicitações de lavra e beneficiamento dessas rochas.

\subsubsection{Compressão}

O ensaio de compressão uniaxial foi realizado para a determinação da resistência à tensão das rochas, ou seja, qual a capacidade de suportarem força por área. A norma ASTM C 170 (ASTM, 1990) recomenda a realização deste ensaio nas condições seca e saturada. Nas rochas isótropas, como mencionado no Capítulo 5, foram realizadas determinações em cinco corpos-de-prova, em cada condição. Nas rochas gnáissicas, as resistências à compressão foram determinadas em três corposde-prova, para cada condição: seca e saturada; e paralela e perpendicularmente à estrutura.

Diversos estudos mostram que a presença da água na rocha provoca vários efeitos nas propriedades mecânicas, dos quais a redução da resistência à tensão provavelmente seja o mais efetivo.

A água tende a reduzir a energia superficial e a resistência dos cristais, resultando na diminuição da resistência mecânica da rocha e no aumento da sua deformabilidade (Turk; Dearman, 1985 apud Gupta; Rao, 2000). Gupta; Rao (2000) sugerem que esse decaimento é relativo ao aumento da pressão de água nos poros, sendo mais efetivo nas rochas intempericamente alteradas, devido ao esperado aumento da porosidade.

Os resultados determinação de resistência à compressão uniaxial acham-se na Tabela 6.25. 
Tabela 6.25 - Valores médios de resistência à compressão uniaxial, seca e saturada, variação de resistência entre as condições seca e saturada e velocidade de propagação de ondas ultrasônicas longitudinais.

\begin{tabular}{|c|c|c|c|c|}
\hline \multirow{2}{*}{ amostra } & \multicolumn{2}{|c|}{$\sigma_{c}$} & \multirow{2}{*}{$\Delta_{\sigma_{c}}$} & \multirow{2}{*}{$V P_{\text {nat }}$} \\
\hline & seca & saturada & & \\
\hline LBD & $\begin{array}{c}112,9 \pm 17,3 \\
(15,3)\end{array}$ & $\begin{array}{c}101,2 \pm 17,3 \\
(17,1) \\
\end{array}$ & -10 & $\begin{array}{c}5.467 \pm 55 \\
(1,0)\end{array}$ \\
\hline VCB-1 & $\begin{array}{c}122,5 \pm 12,0 \\
(9,8)\end{array}$ & $\begin{array}{c}114,7 \pm 9,4 \\
(8,2)\end{array}$ & -6 & $\begin{array}{c}5.407 \pm 67 \\
(1,2)\end{array}$ \\
\hline VCB-2 & $\begin{array}{c}141,5 \pm 10,8 \\
(7,7)\end{array}$ & $\begin{array}{c}112,4 \pm 14,8 \\
(13,2)\end{array}$ & -21 & $\begin{array}{c}5.445 \pm 159 \\
(2,9)\end{array}$ \\
\hline VCB-3 & $\begin{array}{c}130,4 \pm 9,0 \\
(6,9)\end{array}$ & $\begin{array}{c}116,7 \pm 17,8 \\
(15,3) \\
\end{array}$ & -10 & $\begin{array}{c}5.309 \pm 103 \\
(1,9)\end{array}$ \\
\hline RIC & $\begin{array}{c}136,2 \pm 17,6 \\
(12,9)\end{array}$ & $\begin{array}{c}125,2 \pm 18,5 \\
(14,8)\end{array}$ & -8 & $\begin{array}{c}4.372 \pm 67 \\
(1,5)\end{array}$ \\
\hline BCR & $\begin{array}{c}141,0 \pm 20,4 \\
(14,5)\end{array}$ & $\begin{array}{c}119,6 \pm 17,6 \\
(14,7)\end{array}$ & -15 & $\begin{array}{c}4.485 \pm 134 \\
(3,0)\end{array}$ \\
\hline BSV & $\begin{array}{c}137,3 \pm 10,8 \\
(7,9) \\
\end{array}$ & $\begin{array}{c}121,5 \pm 15,9 \\
(13,1) \\
\end{array}$ & -12 & $\begin{array}{c}3.924 \pm 209 \\
(5,3)\end{array}$ \\
\hline PIT & $\begin{array}{c}171,5 \pm 26,6 \\
(15,5)\end{array}$ & $\begin{array}{c}143,4 \pm 14,7 \\
(10,3)\end{array}$ & -16 & $\begin{array}{c}5.236 \pm 28 \\
(0,5)\end{array}$ \\
\hline AZF & $\begin{array}{c}137,6 \pm 18,6 \\
(13,5) \\
\end{array}$ & $\begin{array}{c}119,0 \pm 6,4 \\
(5,4) \\
\end{array}$ & -14 & $\begin{array}{c}4.842 \pm 88 \\
(1,8)\end{array}$ \\
\hline BCE & $\begin{array}{c}157,0 \pm 8,0 \\
(5,1) \\
\end{array}$ & $\begin{array}{c}162,5 \pm 21,5 \\
(13,3) \\
\end{array}$ & 3 & $\begin{array}{c}4.658 \pm 187 \\
(4,0)\end{array}$ \\
\hline ITN-1 & $\begin{array}{c}113,5 \pm 8,1 \\
(7,1)\end{array}$ & $\begin{array}{c}89,1 \pm 19,4 \\
(21,8)\end{array}$ & -22 & $\begin{array}{c}4.292 \pm 167 \\
(3,9)\end{array}$ \\
\hline ITN-2 & $\begin{array}{c}113,5 \pm 16,2 \\
(14,3)\end{array}$ & $\begin{array}{c}92,2 \pm 8,8 \\
(9,5)\end{array}$ & -19 & $\begin{array}{c}3.806 \pm 222 \\
(5,8)\end{array}$ \\
\hline CRV & $\begin{array}{c}170,2 \pm 26,1 \\
(15,3) \\
\end{array}$ & $\begin{array}{c}141,0 \pm 8,6 \\
(6,1) \\
\end{array}$ & -17 & $\begin{array}{c}4.889 \pm 46 \\
(0,9)\end{array}$ \\
\hline CSB // & $\begin{array}{c}149,2 \pm 14,2 \\
(10,8)\end{array}$ & $\begin{array}{c}122,6 \pm 7,2 \\
(5,9)\end{array}$ & -18 & $\begin{array}{c}3.914 \pm 122 \\
(3,1)\end{array}$ \\
\hline $\mathrm{CSB} \perp$ & $\begin{array}{c}142,9 \pm 15,4 \\
(9,5)\end{array}$ & $\begin{array}{c}111,2 \pm 8,2 \\
(7,3)\end{array}$ & -22 & $\begin{array}{c}3.671 \pm 135 \\
(3,7)\end{array}$ \\
\hline FLS // & $\begin{array}{c}149,9 \pm 1,7 \\
(24,7)\end{array}$ & $\begin{array}{c}120,6 \pm 9,1 \\
(7,6)\end{array}$ & -20 & $\begin{array}{c}4.058 \pm 517 \\
(12,7)\end{array}$ \\
\hline FLS $\perp$ & $\begin{array}{c}132,8 \pm 32,9 \\
(1,1)\end{array}$ & $\begin{array}{c}127,0 \pm 30,4 \\
(24,0) \\
\end{array}$ & -4 & $\begin{array}{c}3.558 \pm 560 \\
(15,7)\end{array}$ \\
\hline GVN // & $\begin{array}{c}122,8 \pm 5,3 \\
(4,4)\end{array}$ & $\begin{array}{c}103,6 \pm 13,6 \\
(13,2)\end{array}$ & -16 & $\begin{array}{c}4.603 \pm 70 \\
(1,5)\end{array}$ \\
\hline $\mathbf{G V N} \perp$ & $\begin{array}{c}127,1 \pm 9,9 \\
(7,8)\end{array}$ & $\begin{array}{c}100,5 \pm 12,6 \\
(12,5)\end{array}$ & -21 & $\begin{array}{c}4.590 \pm 75 \\
(1,6)\end{array}$ \\
\hline ARB // & $\begin{array}{c}81,0 \pm 22,1 \\
(27,3)\end{array}$ & $\begin{array}{c}83,7 \pm 10,4 \\
(12,4)\end{array}$ & 3 & $\begin{array}{c}4.323 \pm 252 \\
(5,8)\end{array}$ \\
\hline $\mathrm{ARB} \perp$ & $\begin{array}{c}117,9 \pm 6,9 \\
(5,9)\end{array}$ & $\begin{array}{c}88,8 \pm 3,0 \\
(3,4)\end{array}$ & -25 & $\begin{array}{c}4.356 \pm 290 \\
(6,7)\end{array}$ \\
\hline SCC // & $\begin{array}{c}120,9 \pm 14,4 \\
(11,9)\end{array}$ & $\begin{array}{c}95,5 \pm 12,8 \\
(13,4)\end{array}$ & -21 & $\begin{array}{c}3.459 \pm 535 \\
(15,5)\end{array}$ \\
\hline $\operatorname{SCC} \perp$ & $\begin{array}{c}123,9 \pm 11,3 \\
(9,1) \\
\end{array}$ & $\begin{array}{c}105,7 \pm 16,8 \\
(15,9) \\
\end{array}$ & -15 & $\begin{array}{c}3.757 \pm 53 \\
(1,4) \\
\end{array}$ \\
\hline
\end{tabular}

Nota: // = carga aplicada paralelamente à estrutura da rocha; $\perp$ = carga aplicada perpendicularmente à estrutura da rocha.

$\sigma_{c}=$ resistência à compressão uniaxial $(\mathrm{MPa}) ; \Delta_{\sigma_{c}}=$ variação da resistência à compressão entre as condições seca e saturada $(\mathrm{MPa}) ; \mathrm{VP}_{\text {nat }}=$ velocidade de propagação de ondas no estado natural $(\mathrm{m} / \mathrm{s})$. 
Embora valores médios de resistência à compressão, para um dado tipo de rocha, tenha pequena aplicação direta em engenharia, eles permitem verificar a necessidade de detalhamento das investigações e testes subseqüentes (Johnson; De Graff, 1988).

Esses autores consideram que a redução da resistência à compressão é um dos mais óbvios e importantes aspectos causados pelo intemperismo, especialmente químico, ou pela alteração da rocha intacta. Também influenciam os valores de resistência à compressão o tamanho dos grãos e anisotropias; esperando-se maiores resistências para rochas da granulação fina e isótropas.

As resistências à compressão das diferentes rochas graníticas mostraram que os grupos estabelecidos no início do trabalho, com base na situação geológica, proximidade geográfica e similaridade petrográfica, exibem parâmetros equivalentes (Figura 6.50). Exceção à CRV, que exibe resistência mecânica muito superior às ITN. Também em desacordo com o esperado, PIT, correspondente naturalmente intemperizado da AZF, apresenta maiores valores de compressão que este.

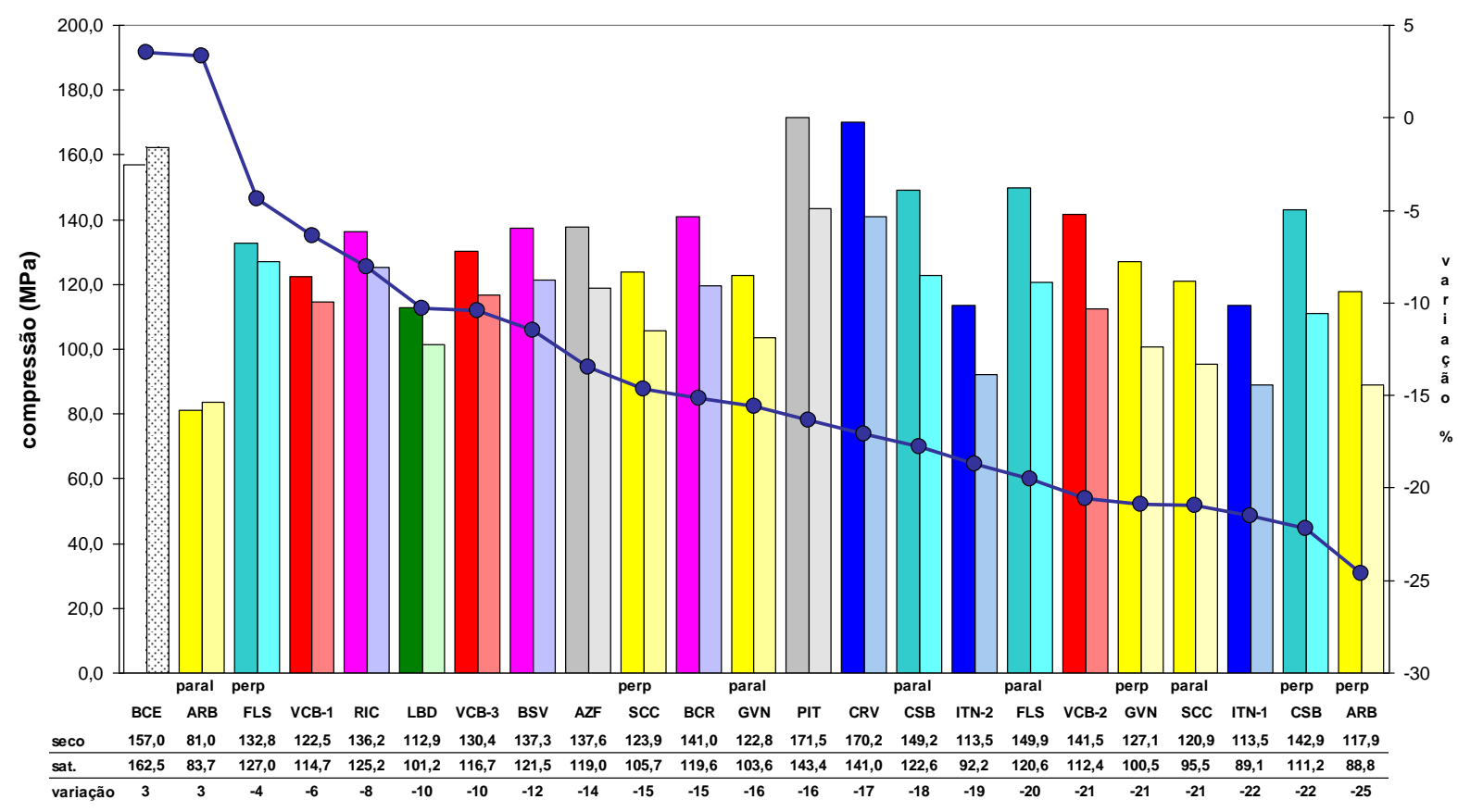

Figura 6.50 - Resistência à compressão nas condições seda (barras à esquerda) e saturada (barras à direita) e variação (linha).

As resistências relativamente elevadas de CSB e FLS devem-se à estruturação muito heterogênea dessas rochas, que praticamente impossibilitou a obtenção de corpos-de-prova representativos das diferenças estruturais e mineralógicas observadas 
em amostra de mão.

A observação da Fig. 6.50 mostra que as variações são relativas ao próprio material, aparentemente desconsiderando a estruturação da rocha. Todas as rochas exibiram variação negativa de resistência à compressão quando ensaiadas saturadas em água, à exceção de $\mathrm{BCE}$ e $\mathrm{ARB} / /(+3 \%$, cada). Com as maiores variações, destacam-se as ITN-1, ARB $\perp, \mathrm{CSB} \perp, \mathrm{GVN} \perp$, SCC// e FLS//.

As maiores resistências à compressão na condição seca $\left(\sigma_{c \text { sec }}>150 \mathrm{MPa}\right)$ foram apresentadas por PIT, CRV e BCE (gr. 5), que, por sua vez, também exibiram as maiores resistências quando saturadas. Deve ser ressaltado que BCE praticamente não apresentou modificação entre as condições seca e saturada.

As rochas dos grupos 2, 3, 5, 7 e 8 (exceto ARB) e a amostra AZF têm $\sigma_{c \text { sec }}$ entre $120 \mathrm{MPa}$ e $150 \mathrm{MPa}$, constituindo um grupo intermediário.

Com $\sigma_{c \text { sec }}<120 \mathrm{MPa}$, acham-se as ITN, LBD e ARB, esse último apresentando os menores valores entre as amostras estudadas, com aplicação da carga paralelamente à estruturação.

As rochas isotrópicas mostraram variações entre $113 \mathrm{MPa}$ e $171 \mathrm{MPa}$, na condição seca, e entre $89 \mathrm{MPa}$ e $162 \mathrm{MPa}$ (Tabela 6.26), na condição saturada; as gnáissicas apresentaram valores de compressão uniaxial, respectivamente, entre 81 $\mathrm{MPa}$ e $150 \mathrm{MPa}$ e entre $84 \mathrm{MPa}$ e $127 \mathrm{MPa}$. Isto evidencia valores relativamente maiores para as rochas isótropas, em todas as condições, que se refletem nas variações de resistência mecânica, mas que, neste caso, não constituiu uma regra.

Tabela 6.26 - Valores máximos, mínimos e mediana obtidos para a resistência à compressão e velocidade de propagação de ondas.

\begin{tabular}{cccccccccc}
\hline & \multicolumn{2}{c}{$\sigma_{c \mathrm{sec}}$} & \multicolumn{2}{c}{$\sigma_{c \text { sat }}$} & & $\Delta_{\sigma_{c}}$ & \multicolumn{2}{c}{$\mathbf{V P}_{\text {nat }}$} \\
\cline { 2 - 10 } & $\mathbf{A}$ & $\mathbf{B}$ & $\mathbf{A}$ & $\mathbf{B}$ & $\mathbf{A}$ & $\mathbf{B}$ & $\mathbf{A}$ & $\mathbf{B}$ \\
\hline mínimo & 113 & 81 & 89 & 84 & -22 & -25 & 3.806 & 3.558 \\
\hline mediana & 137 & 126 & 119 & 105 & -14 & -19 & 4.842 & 3.800 \\
\hline máximo & 171 & 150 & 162 & 127 & 3 & 3 & 5.467 & 4.596 \\
\hline
\end{tabular}

Nota: $\mathrm{A}$ = rochas isótropas; $\mathrm{B}$ = rochas gnáissicas.

$\sigma_{c \text { sec }}=$ resistência à compressão uniaxial na condição seca $(\mathrm{MPa}) ; \sigma_{c \text { sat }}=$ resistência à compressão uniaxial na condição saturada (MPa). Demais símbolos iguais aos da Tab. 6.35.

A maioria das rochas isótropas (Figura 6.51) tem variação entre $-15 \%$ e 
$-20 \%$. Naquelas gnáissicas, as variações tendem a valores entre $-20 \%$ e $-25 \%$, com predomínio da determinação de resistências segundo as direções normal e paralela à gnaissificação, respectivamente.

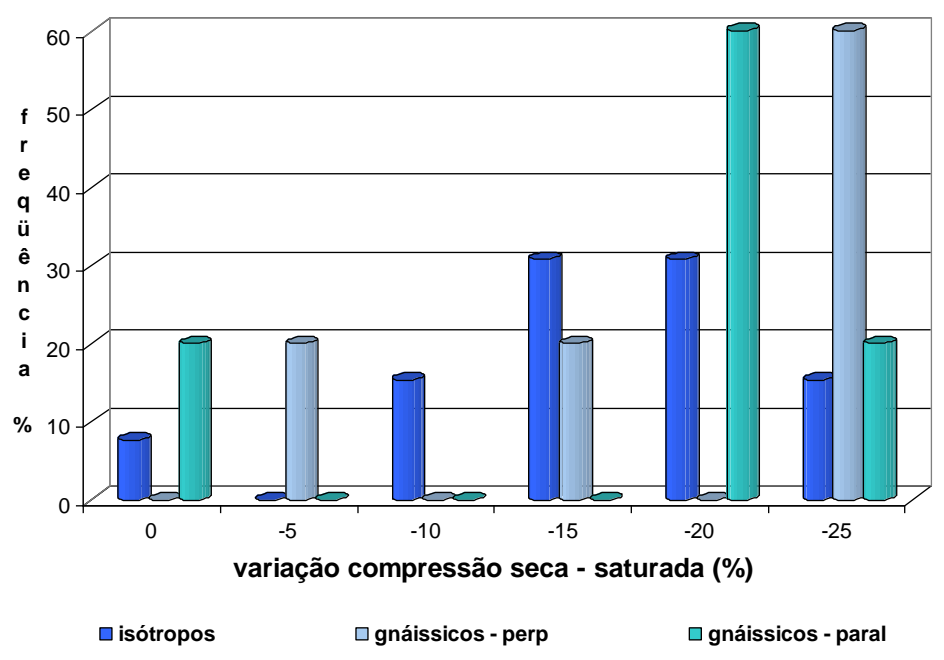

Figura 6.51 - Freqüência das variações de compressão entre seco e saturado, relativo à estruturação das rochas estudadas.

As correlações entre a resistência à compressão, seca e saturada, e velocidade de propagação de ondas, foram muito fracas. Também não se verificou tendências entre essas e as variações de resistência à compressão entre as condições seca e saturada.

Forte correlação positiva $(R=0,86)$ foi obtida entre as resistências à compressão seca e saturada, como pode ser observado na Figura 6.52.

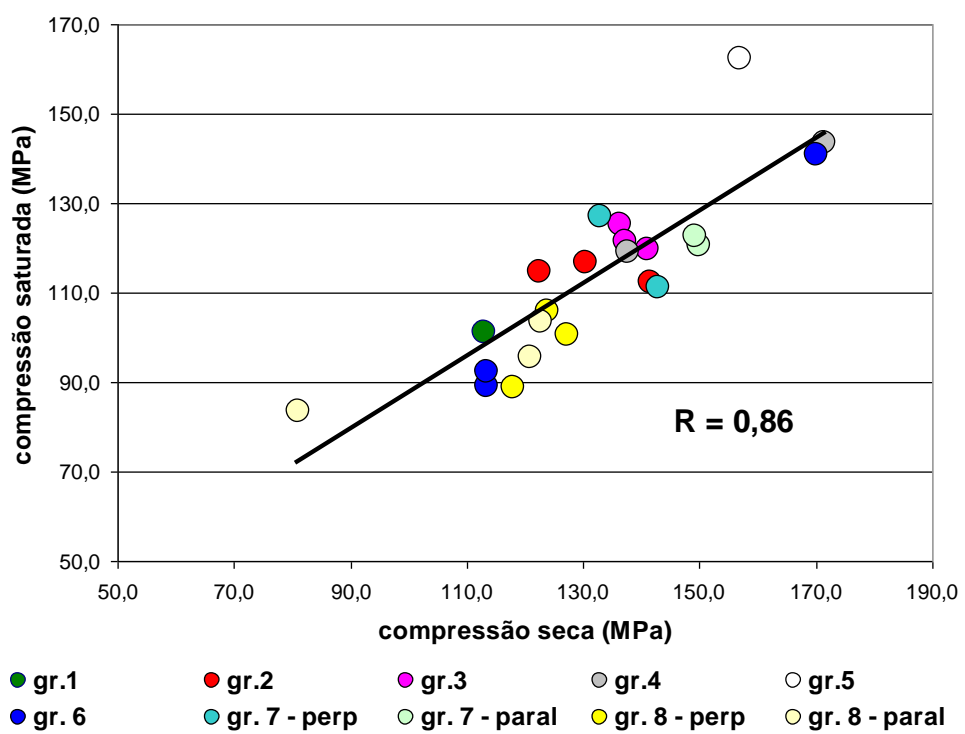

Figura 6.52 - Correlação entre a resistência à compressão uniaxial, nas condições seca e saturada. 
Kessler et al. (1940) realizaram um dos estudos pioneiros de caracterização de rochas graníticas, para determinação de propriedades que poderiam ser de "interesse para seleção de materiais para usos específicos". Foram executados ensaios de resistência à compressão e determinação da densidade, porosidade e absorção em cerca de 116 amostras.

Os ensaios de compressão foram realizados em corpos-de-prova cilíndricos e a resistência média, na condição seca, foi de $168 \mathrm{MPa}$, com valores máximo e mínimo de $413 \mathrm{MPa}$ e $69 \mathrm{MPa}$, respectivamente. A maioria exibiu diminuição da resistência à compressão na condição saturada, que, em média, foi $12 \%$ menor que na condição seca. Notaram que não houve modificação significativa nos valores obtidos para rochas anisótropas, nas determinações com aplicação de carga paralela e perpendicularmente à estruturação.

Desconsiderando os valores anômalos (VCB-1, RIC, BCE, FLS $\perp$, ARB //), a diminuição média da resistência à compressão das rochas estudadas, na condição saturada em relação à seca, é de $(17 \pm 4) \%$, com um alto coeficiente de variação (24\%).

\subsubsection{Flexão}

O ensaio de flexão foi realizado para a obtenção da resistência nominal das rochas selecionadas para este estudo. Visando a avaliação da resistência dessas rochas perante solicitações cotidianas de variações de temperatura, por vezes bastante bruscas, metade dos corpos-de-prova foi submetida a ciclos de choque térmico.

Como controle das possíveis modificações decorrentes desse ensaio, foram realizadas inspeções visuais, determinação dos pesos de todos os corpos-de-prova e das velocidades de propagação de ondas, antes e após o ensaio.

Os resultados obtidos acham-se na Tabela 6.27 e ilustrados nas Figuras $6.53 \mathrm{e}$ 6.54 . 
Tabela 6.27 - Resistência à flexão, velocidade de propagação de ondas e variações de massa, de resistência à flexão e de propagação de ondas, antes e após choque térmico.

\begin{tabular}{|c|c|c|c|c|c|c|c|}
\hline amostra & $\sigma_{f n a t}$ & $\sigma_{f C T}$ & $\Delta_{\sigma_{f}}$ & $V_{P_{\text {nat }}}$ & $\mathbf{V P}_{\mathrm{CT}}$ & $\Delta_{V P}$ & $\Delta_{\text {massa }}$ \\
\hline LBD & $\begin{array}{c}7,65 \pm 0,99 \\
(12,9) \\
\end{array}$ & $\begin{array}{c}4,70 \pm 0,57 \\
(12,1)\end{array}$ & -39 & $\begin{array}{c}5.118 \pm 404 \\
(7,9)\end{array}$ & $\begin{array}{c}2.561 \pm 169 \\
(6,6)\end{array}$ & -52 & 0,04 \\
\hline VCB-3 & $\begin{array}{c}13,00 \pm 0,43 \\
(3,3)\end{array}$ & $\begin{array}{c}9,63 \pm 1,03 \\
(10,7) \\
\end{array}$ & -26 & $\begin{array}{c}5.570 \pm 21 \\
(0,4) \\
\end{array}$ & $\begin{array}{c}4.315 \pm 154 \\
(3,6)\end{array}$ & -23 & 0,04 \\
\hline RIC & $\begin{array}{c}11,50 \pm 0,81 \\
(7,1)\end{array}$ & $\begin{array}{c}8,52 \pm 0,60 \\
(7,1)\end{array}$ & -26 & $\begin{array}{c}4.694 \pm 30 \\
(0,6)\end{array}$ & $\begin{array}{c}3.654 \pm 54 \\
(1,5)\end{array}$ & -22 & 0,02 \\
\hline BCR & $\begin{array}{c}11,07 \pm 1,99 \\
(18,0)\end{array}$ & $\begin{array}{c}10,35 \pm 1,93 \\
(18,7)\end{array}$ & -7 & $\begin{array}{c}4.105 \pm 191 \\
(4,7)\end{array}$ & $\begin{array}{c}3.643 \pm 171 \\
(4,7)\end{array}$ & -11 & 0,03 \\
\hline BSV & $\begin{array}{c}10,11 \pm 0,42 \\
(4,1) \\
\end{array}$ & $\begin{array}{c}8,70 \pm 0,85 \\
(9,8) \\
\end{array}$ & -14 & $\begin{array}{c}3.895 \pm 74 \\
(1,9) \\
\end{array}$ & $\begin{array}{c}3.548 \pm 88 \\
(2,5) \\
\end{array}$ & -9 & 0,03 \\
\hline PIT & $\begin{array}{c}15,32 \pm 1,12 \\
(7,30)\end{array}$ & $\begin{array}{c}12,49 \pm 1,06 \\
(8,49)\end{array}$ & -18 & $\begin{array}{c}4.989 \pm 111 \\
(2,2)\end{array}$ & $\begin{array}{c}3.992 \pm 71 \\
(1,8)\end{array}$ & -20 & 0,03 \\
\hline AZF & $\begin{array}{c}14,78 \pm 1,65 \\
(11,1)\end{array}$ & $\begin{array}{c}11,86 \pm 1,55 \\
(13,1)\end{array}$ & -20 & $\begin{array}{c}4.833 \pm 115 \\
(2,4)\end{array}$ & $\begin{array}{c}3.751 \pm 216 \\
(5,8)\end{array}$ & -22 & 0,04 \\
\hline BCE & $\begin{array}{c}16,88 \pm 0,51 \\
(3,0)\end{array}$ & $\begin{array}{c}13,87 \pm 0,71 \\
(5,2)\end{array}$ & -18 & $\begin{array}{c}5.155 \pm 50 \\
(1,0)\end{array}$ & $\begin{array}{c}4.289 \pm 25 \\
(0,6) \\
\end{array}$ & -16 & 0,02 \\
\hline ITN-1 & $\begin{array}{c}7,70 \pm 0,42 \\
(5,4)\end{array}$ & $\begin{array}{c}6,92 \pm 0,80 \\
(11,5)\end{array}$ & -10 & $\begin{array}{c}3.895 \pm 67 \\
(1,7)\end{array}$ & $\begin{array}{c}3.080 \pm 44 \\
(1,4)\end{array}$ & -21 & 0,04 \\
\hline ITN-2 & $\begin{array}{c}9,63 \pm 1,84 \\
(19,1)\end{array}$ & $\begin{array}{c}8,91 \pm 0,88 \\
(9,8)\end{array}$ & -7 & $\begin{array}{c}4.119 \pm 211 \\
(5,1)\end{array}$ & $\begin{array}{c}3.506 \pm 180 \\
(5,1)\end{array}$ & -15 & 0,04 \\
\hline CRV & $\begin{array}{c}16,50 \pm 2,12 \\
(12,9) \\
\end{array}$ & $\begin{array}{c}14,47 \pm 0,53 \\
(3,7)\end{array}$ & -12 & $\begin{array}{c}5.033 \pm 97 \\
(1,9) \\
\end{array}$ & $\begin{array}{c}4.404 \pm 80 \\
(1,8) \\
\end{array}$ & -12 & 0,03 \\
\hline $\mathrm{CSB} \perp$ & $\begin{array}{c}7,92 \pm 0,83 \\
(10,5)\end{array}$ & $\begin{array}{c}4,75 \pm 1,39 \\
(29,3) \\
\end{array}$ & -40 & $\begin{array}{c}3.418 \pm 238 \\
(7,0)\end{array}$ & $\begin{array}{c}3.185 \pm 233 \\
(7,3)\end{array}$ & -7 & \multirow{2}{*}{0,03} \\
\hline CSB // & $\begin{array}{c}5,62 \pm 0,67 \\
(12,0)\end{array}$ & $\begin{array}{c}3,42 \pm 1,10 \\
(32,1)\end{array}$ & -39 & $\begin{array}{c}3.646 \pm 155 \\
(4,3)\end{array}$ & $\begin{array}{c}3.396 \pm 192 \\
(5,6)\end{array}$ & -7 & \\
\hline FLS $\perp$ & $\begin{array}{c}8,38 \pm 0,55 \\
(6,6)\end{array}$ & $\begin{array}{c}7,57 \pm 0,92 \\
(12,1)\end{array}$ & -10 & $\begin{array}{c}3.038 \pm 156 \\
(5,1)\end{array}$ & $\begin{array}{c}2.757 \pm 127 \\
(4,6)\end{array}$ & -9 & \multirow{2}{*}{0,03} \\
\hline FLS // & $\begin{array}{c}3,72 \pm 0,33 \\
(8,9) \\
\end{array}$ & $\begin{array}{c}2,68 \pm 0,54 \\
(20,2) \\
\end{array}$ & -28 & $\begin{array}{c}3.768 \pm 195 \\
(5,2)\end{array}$ & $\begin{array}{c}3.529 \pm 140 \\
(4,0)\end{array}$ & -6 & \\
\hline $\mathbf{G V N} \perp$ & $\begin{array}{c}10,97 \pm 0,32 \\
(2,9)\end{array}$ & $\begin{array}{c}9,04 \pm 1,01 \\
(11,2)\end{array}$ & -18 & $\begin{array}{c}4.833 \pm 166 \\
(3,4)\end{array}$ & $\begin{array}{c}3.553 \pm 84 \\
(2,4)\end{array}$ & -26 & \multirow{2}{*}{0,01} \\
\hline GVN // & $\begin{array}{c}6,99 \pm 0,24 \\
(3,4)\end{array}$ & $\begin{array}{c}5,69 \pm 0,05 \\
(0,9)\end{array}$ & -19 & $\begin{array}{c}4.721 \pm 96 \\
(2,0)\end{array}$ & $\begin{array}{c}3.749 \pm 62 \\
(1,7)\end{array}$ & -21 & \\
\hline $\mathrm{ARB} \perp$ & $\begin{array}{c}10,70 \pm 1,25 \\
(11,6)\end{array}$ & $\begin{array}{c}10,20 \pm 0,59 \\
(5,8)\end{array}$ & -5 & $\begin{array}{c}4.257 \pm 79 \\
(1,9)\end{array}$ & $\begin{array}{c}3.511 \pm 128 \\
(3,6)\end{array}$ & -18 & \multirow{2}{*}{0,04} \\
\hline ARB // & $\begin{array}{c}7,32 \pm 0,91 \\
(12,5)\end{array}$ & $\begin{array}{c}4,64 \pm 0,62 \\
(13,3)\end{array}$ & -37 & $\begin{array}{c}4.651 \pm 81 \\
(1,7)\end{array}$ & $\begin{array}{c}4.012 \pm 92 \\
(2,3)\end{array}$ & -14 & \\
\hline $\mathrm{SCC} \perp$ & $\begin{array}{c}11,50 \pm 0,39 \\
(3,4)\end{array}$ & $\begin{array}{c}7,23 \pm 0,15 \\
(2,0)\end{array}$ & -37 & $\begin{array}{c}5.065 \pm 94 \\
(1,9)\end{array}$ & $\begin{array}{c}3.706 \pm 125 \\
(3,4)\end{array}$ & -27 & \multirow{2}{*}{0,03} \\
\hline SCC // & $\begin{array}{c}8,06 \pm 1,07 \\
(13,3) \\
\end{array}$ & $\begin{array}{c}4,12 \pm 2,11 \\
(51,2)\end{array}$ & -49 & $\begin{array}{c}5.205 \pm 86 \\
(1,7)\end{array}$ & $\begin{array}{c}4.007 \pm 74 \\
(1,8)\end{array}$ & -23 & \\
\hline
\end{tabular}

Nota: // = carga aplicada paralelamente à estrutura da rocha; $\perp$ = carga aplicada perpendicularmente à estrutura da rocha.

$\sigma_{f \text { nat }}=$ resistência à flexão no estado natural $(\mathrm{MPa}) ; \sigma_{f C T}=$ resistência à flexão após ensaio de choque térmico (MPa);

$\Delta_{\sigma_{f}}=$ decaimento da resistência à flexão após choque térmico (\%); $\mathrm{VP}_{\text {nat. }}=$ velocidade de propagação de ondas no estado natural; $\mathrm{VP}_{\mathrm{CT}}=$ velocidade de propagação de ondas após ensaio de choque térmico; $\Delta_{V P}=$ variação da velocidade de propagação de ondas após ensaio de choque térmico (\%); $\Delta_{m}=$ variação de massa (\%). 


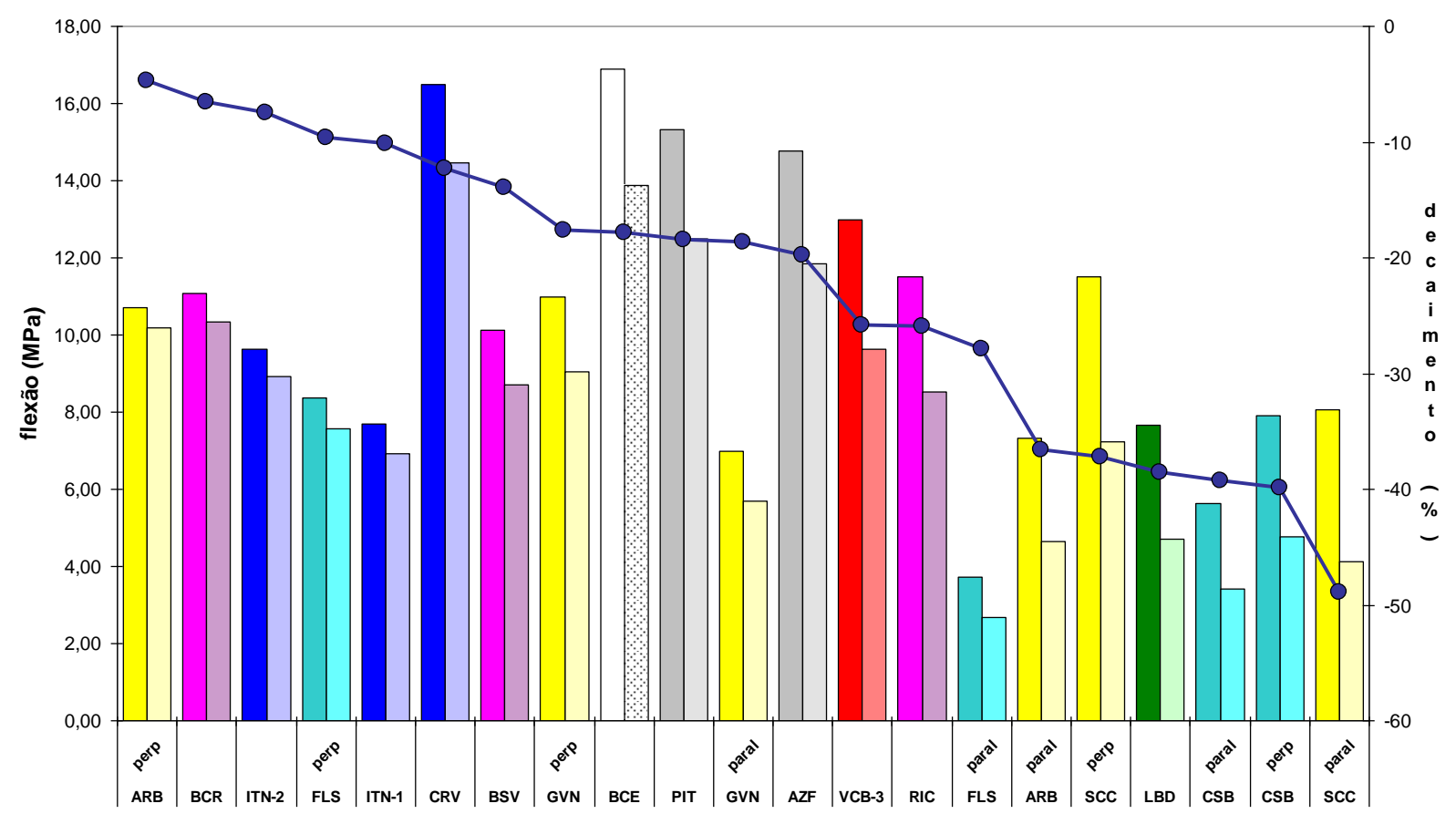

Figura 6.53 - Resistência à flexão, na condição seca, antes e após choque térmico, e decaimento relativo.

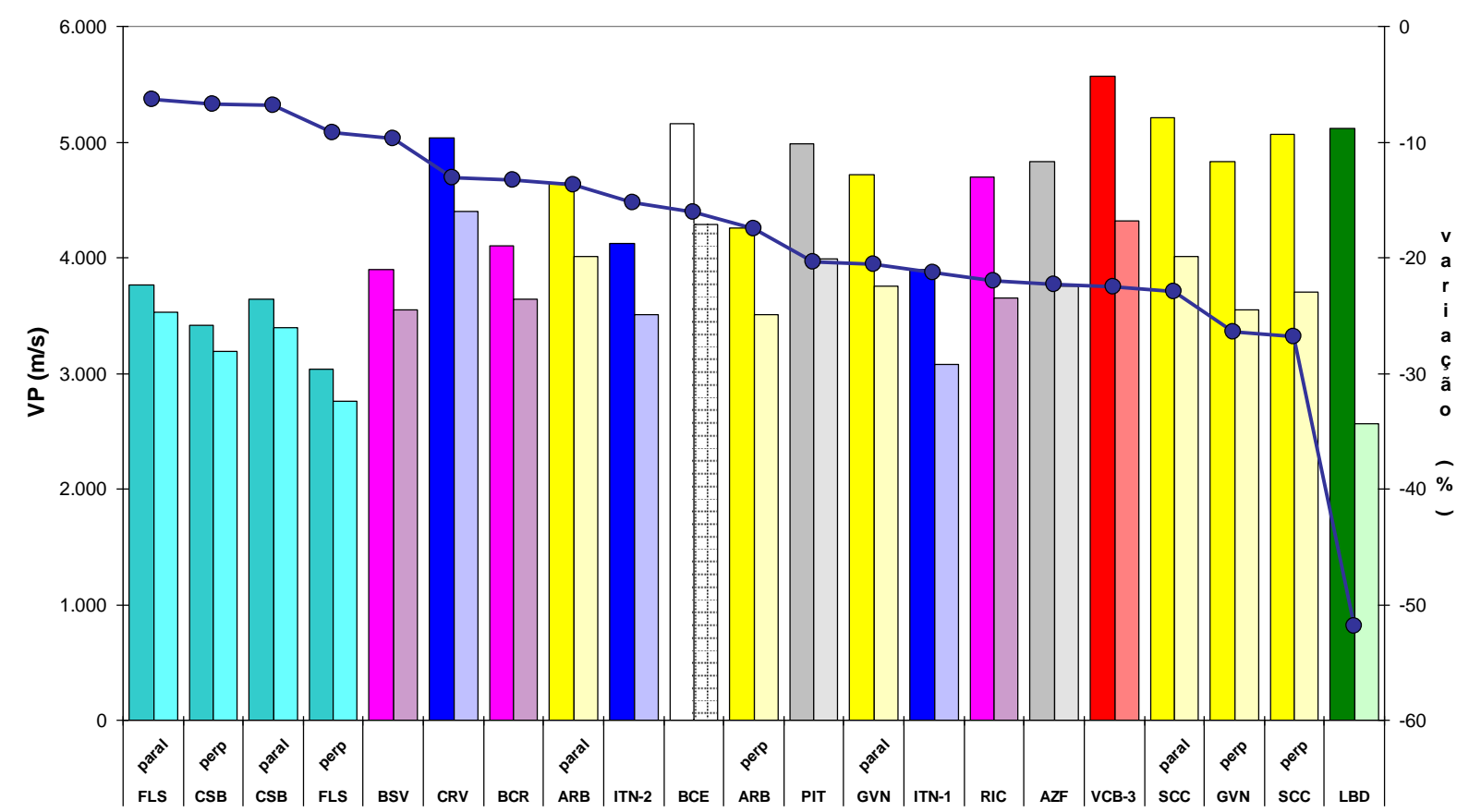

Figura 6.54 - Velocidade de propagação de ondas, na condição seca, antes e após choque térmico, e decaimento relativo.

A observação da Fig. 6.53 e Tab. 6.27 permite estabelecer a distribuição das rochas estudadas em três grupos, quanto à resistência à flexão, tomando-se a mediana como valor de referência: 
$-\sigma_{\text {f nat }}>12 \mathrm{MPa}$ : BCE, CRV, PIT, AZF e VCB-3, que podem ser consideradas de resistência elevada;

$-8 \mathrm{MPa}<\sigma_{\text {fnat }}<12 \mathrm{MPa}: \mathrm{RIC}, \mathrm{BSV}, \mathrm{BCR}, \mathrm{ITN}-2, \mathrm{GVN} \perp, \mathrm{ARB} \perp, \mathrm{SCC} \perp$, de resistência intermediária;

$-\sigma_{f \text { nat }}<8 \mathrm{MPa}$ (resistência baixa):

- $8 \mathrm{MPa}<\sigma_{\text {fnat }}<6 \mathrm{MPa}: \mathrm{LBD}, \mathrm{ITN}-1, \mathrm{CSB} \perp, \mathrm{FLS} \perp, \mathrm{GVN} / /, \mathrm{ARB} / /$ e SCC// e SCC $\perp$;

- $\sigma_{f \text { nat }}<6 \mathrm{MPa}: \mathrm{CSB} / /$ e FLS//.

Este último grupo tende a incluir as rochas gnáissicas, cuja determinação de resistência à flexão se deu quando a tensão foi aplicada segundo a estruturação. As exceções são: CSB e FLS, que apresentaram esses valores quando ensaiadas perpendicularmente à estruturação, e LBD, única rocha isotrópica do grupo estudado com RF <8 MPa.

Deve ser mencionado que $\mathrm{CSB} / /$ e $\mathrm{FLS} / /$ exibiram os menores valores de resistência à flexão, cerca de $6 \mathrm{MPa}$ e $3 \mathrm{MPa}$, respectivamente, o que é novamente atribuído à sua estrutura fortemente bandada e também à presença de microfissuras largas, muitas vezes sem preenchimento, dispostas subparalelamente à estruturação das bandas com minerais micáceos, como observado no exame petrográfico.

Quanto à LBD, considera-se a influência do tamanho relativamente grande dos minerais formadores, do intenso microfissuramento e da alteração intempérica da amostra ensaiada.

Diferentemente das determinações de resistência à compressão, os corpos-deprova aqui ensaiados representaram, mais adequadamente suas características litológicas. Além disso, os resultados refletem apropriadamente sua influência na resistência mecânica pós-beneficiamento, que deve ser obrigatoriamente observada na escolha do padrão estético a ser comercializado.

As rochas isótropas tenderam a apresentar maior resistência à flexão que as rochas gnáissicas (Tabela 6.28), mesmo quando ensaiadas perpendicularmente à estruturação; comportamento repetido em relação à velocidade de propagação de ondas e ao decaimento. 
Tabela 6.28 - Resistência à flexão, velocidade de propagação de ondas e variações de massa, de resistência à flexão e de propagação de ondas, antes e após choque térmico.

\begin{tabular}{ccccccccccccccc}
\hline & \multicolumn{2}{c}{$\sigma_{f n a t}$} & \multicolumn{2}{c}{$\sigma_{f C T}$} & \multicolumn{2}{c}{$\Delta_{\sigma_{f}}$} & \multicolumn{4}{c}{$\mathbf{V P}_{\text {nat }}$} & \multicolumn{3}{c}{$\mathbf{V P}_{\mathrm{cT}}$} & \multicolumn{2}{c}{$\Delta_{V P}$} \\
\cline { 2 - 13 } & $\mathbf{A}$ & $\mathbf{B}$ & $\mathbf{A}$ & $\mathbf{B}$ & $\mathbf{A}$ & $\mathbf{B}$ & $\mathbf{A}$ & $\mathbf{B}$ & $\mathbf{A}$ & $\mathbf{B}$ & $\mathbf{A}$ & $\mathbf{B}$ \\
\hline mínimo & 7,65 & 3,72 & 4,70 & 2,68 & -7 & -5 & 3.895 & 3.038 & 2.561 & 2.757 & -9 & -6 \\
\hline mediana & 11,50 & 7,99 & 9,63 & 5,22 & -18 & -32 & 4.833 & 4.454 & 3.654 & 3.541 & -20 & -16 \\
\hline máximo & 16,88 & 11,50 & 14,47 & 10,20 & -39 & -49 & 5.570 & 5.205 & 4.404 & 4.012 & -52 & -27 \\
\hline
\end{tabular}

Nota: $\mathbf{A}=$ rochas isótropas; $\mathbf{B}=$ rochas gnáissicas. Símbolos: iguais aos da Tab. 6.27.

\subsubsection{Resistência ao choque térmico}

$\mathrm{Na}$ literatura pesquisada, como para o restante das determinações neste estudo, foram encontrados muito poucos trabalhos acerca de determinações laboratoriais para verificação de degradações em rocha pela influência direta das flutuações de temperatura. Mas um deles (Warke; Smith, 1998) mostrou informações bastante abrangentes e diretamente aplicadas ao estudo em questão.

Warke; Smith (1998) realizaram simulação de intemperismo pelo aquecimento direto (por insolação) e indireto (em estufa) de rochas selecionadas, demonstraram e quantificaram as várias temperaturas características dos diferentes tipos rochosos (arenito, calcário, granito e basalto) sob aquecimento direto e indireto, com particular ênfase no papel do albedo.

Apontam que, no aquecimento indireto (em estufa), a temperatura da rocha é determinada pela temperatura do ar ao redor das amostras e não pelas propriedades térmicas das rochas, como o albedo, condutividade térmica e calor específico. Nas condições naturais, a rocha é aquecida indiretamente pelo ar e diretamente pela radiação solar, sob direta influência das propriedades térmicas. À noite, a temperatura do ar seria o único fator de controle, de modo que as simulações em estufa devem representar somente as condições noturnas.

Dessa forma, quaisquer diferenças entre os padrões e taxas de decaimento das rochas aqui ensaiadas devem refletir outras propriedades físicas, que afetam a movimentação de água e resistência mecânica. Conseqüentemente, os resultados podem não corresponder àqueles observados em condições naturais. Por outro lado, o aquecimento indireto pode contribuir para deteriorações mais severas.

Nesta pesquisa, dado seu caráter experimental, procurou-se estabelecer 
procedimentos laboratoriais que possibilitem antecipar a durabilidade de determinado material rochoso, comparativamente com outros. Portanto, deve-se levar em conta que, caracteristicamente, esses são mais agressivos que os ambientes naturais tendo em vista a obtenção de resultados em tempos e condições compatíveis com as expectativas de respostas pelos usuários e que, também, permitam reprodutibilidade e repetitividade.

Por outro lado, os tipos rochosos em estudo guardam grandes similaridades mineralógicas, exceto $L B D$, que relativamente tem baixo albedo.

A realização de 20 ciclos de aquecimento $\left(100^{\circ} \mathrm{C}\right)$ e resfriamento imediato em água, na temperatura ambiente, efetivamente promoveu a queda da resistência mecânica das rochas, comparativamente aos corpos-de-prova ensaiados ao natural, como pôde ser observado nas Tab. 6.27 e Fig. 6.53 e 6.54 .

Após choque térmico, os grupos anteriormente referidos quanto à resistência à flexão mostraram as modificações relacionadas abaixo:

- $\sigma_{f C T}>12 \mathrm{MPa}$ : BCE e CRV permaneceram com os maiores valores absolutos e PIT e AZF, valores próximos, mas superiores, a $12 \mathrm{MPa}$;

$-8 \mathrm{MPa}<\sigma_{f C T}<12 \mathrm{MPa}$ : VCB-3 (anteriormente no grupo resistência elevada), $\mathrm{RIC}, \mathrm{BSV}, \mathrm{BCR}, \mathrm{ITN}-2, \mathrm{GVN} \perp$ e $\mathrm{ARB} \perp$; $-\sigma_{f C T}<8 \mathrm{MPa}$ :

- $8 \mathrm{MPa}<\sigma_{f C T}<6 \mathrm{MPa}: \mathrm{ITN}-1, \mathrm{FLS} \perp$ e $\mathrm{SCC} \perp$ (anteriormente no grupo resistência intermediária);

- $\sigma_{f C T}<6 \mathrm{MPa}: \mathrm{CSB} / /$ e $\mathrm{FLS} / /$; LBD, CSB $\perp, \mathrm{GVN} / /$, ARB// e SCC// (anteriormente no grupo $8 \mathrm{MPa}<\sigma_{f C T}<6 \mathrm{MPa}$ ).

Os valores de decaimento variaram entre cerca de $-5 \%$ e $-50 \%$ (Figura 6.55). 


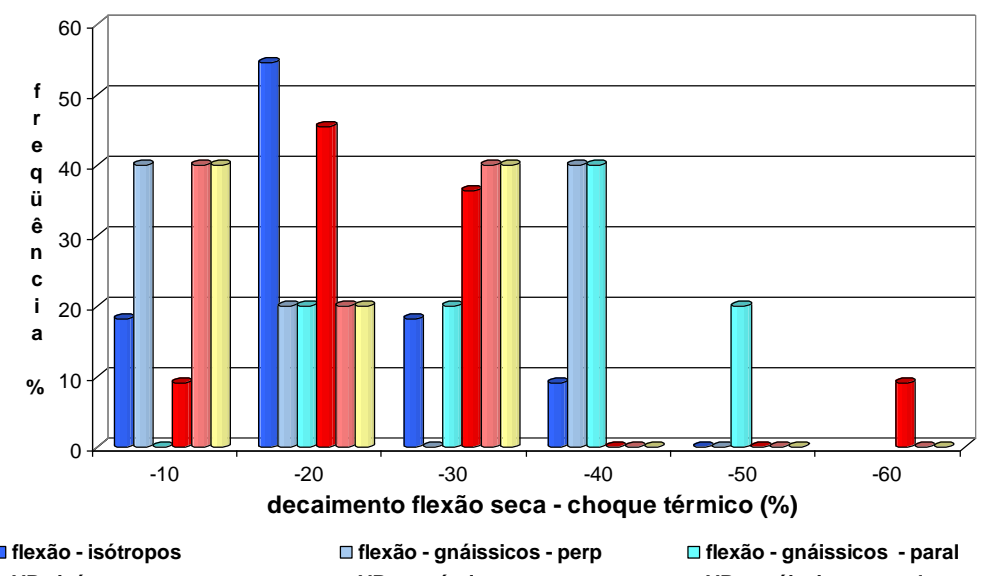

$\square$ VP - isótropos $\square$ flexão - gnáissicos - perp $\square$ VP - gnaíssicos - perp $\square$ VP - gnáissicos - paral
Figura 6.55 - Freqüência dos decaimentos da resistência mecânica e de velocidade de propagação de ondas.

As variações foram, em média, menores nas rochas isótropas, com predominância entre $-10 \%$ e $-20 \%$, quanto à flexão, e entre $-10 \%$ e $-30 \%$, quanto à propagação de ondas.

Uma parte das rochas gnáissicas, com determinação da resistência à flexão perpendicularmente à estruturação, mostrou decaimento entre $0 \%$ e $-10 \%$ (representadas por FLS e ARB) e outra parte entre $-40 \%$ e $-50 \%$ (CSB e SCC).

As características petrográficas e texturais (tamanho dos grãos e grau de fissuramento, especialmente) certamente contribuíram para o decaimento de LBD, em relação à resistência mecânica, antes e após choque térmico, e, especialmente, quanto à velocidade de propagação de ondas.

O decaimento médio na resistência à flexão e na velocidade de propagação de ondas $((-18 \pm 10) \%)$ foram bastante semelhantes, porém dificilmente generalizáveis, visto os coeficientes de variação de $57 \%$ e $56 \%$, respectivamente.

Os coeficientes de correlação determinados para resistência à flexão e velocidade de propagação de ondas, nas condições secas e após choque térmico (Tabela 6.29) indicaram correlação muito forte $(R=0,95)$ entre os resultados de resistência à flexão antes e após choque térmico, o que não se reproduziu para as velocidades de propagação de onda e entre essas e resistência à flexão. 
Tabela 6.29 - Correlações entre as determinações de resistência à flexão e de velocidade de propagação de ondas nas condições secas e após choque térmico.

\begin{tabular}{cccc} 
& $\sigma_{f \text { nat }}$ & $\sigma_{f C T}$ & $\mathbf{V P}_{\text {nat }}$ \\
\hline$\sigma_{f C T}$ & $\mathbf{0 , 9 5}$ & - & - \\
\hline $\mathbf{V P}_{\text {nat }}$ & $\mathbf{0 , 5 6}$ & 0,37 & - \\
\hline $\mathbf{V P}_{\text {pós-CT }}$ & $\mathbf{0 , 5 9}$ & 0,50 & $\mathbf{0 , 6 2}$ \\
\hline
\end{tabular}

Nota: símbolos iguais ao da Tab. 6.27.

As Figuras 6.56 e 6.57 ilustram a distribuição das amostras em estudo conforme os valores de resistência à flexão e de velocidade de propagação de ondas, antes e após ensaios de choque térmico.

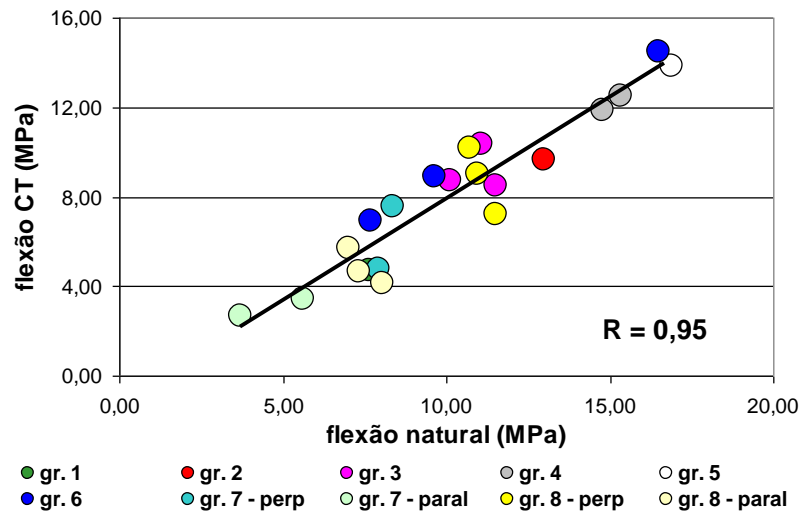

Figura 6.56 - Correlação entre resistência à flexão na condição seca, antes e após ciclos de choque térmico.

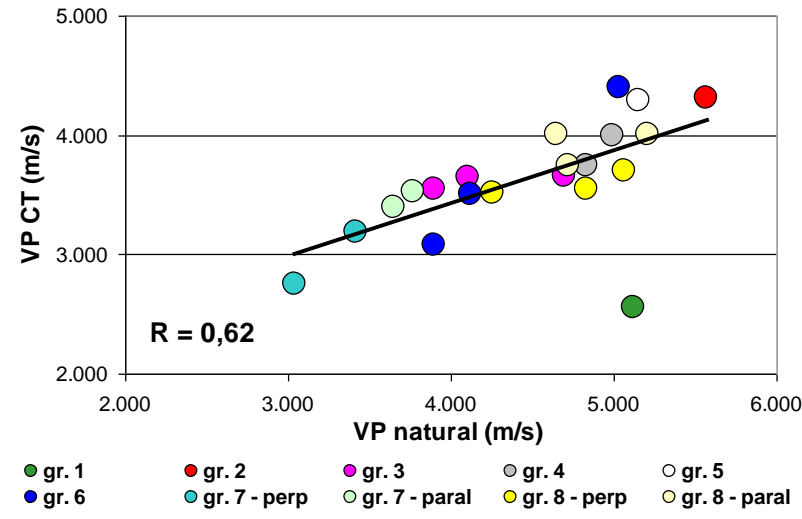

Figura 6.57 - Correlação entre a velocidade de propagação de ondas, antes e após ciclos de choque térmico.

Como pode ser observado, a distribuição dos resultados de velocidade de propagação de ondas não corresponde àqueles determinados nos ensaios de flexão, denotada especialmente pela a mudança de hierarquia das rochas gnáissicas.

Este comportamento indica que, embora a determinação da velocidade de propagação de ondas ultra-sônicas longitudinais seja, de fato, uma ferramenta importante para a seleção dos corpos-de-prova para ensaios e para controle de resultados de ensaios de alteração, não é efetiva para hierarquizar os materiais do ponto de vista de resistência mecânica propriamente dita. 
Para verificação de possíveis modificações nas propriedades físicas foram determinadas a densidade aparente e a absorção d'água, segundo CEN (1998a), em corpos-de-prova com $10 \mathrm{~cm} \times 12 \mathrm{~cm}$, confeccionados a partir daqueles submetidos a ensaio de choque térmico.

Diferentemente do esperado, pois foram notáveis as modificações visuais e mecânicas das amostras submetidas a esse ensaio, os índices físicos não exibiram variações compatíveis com os decaimentos da resistência à flexão e de velocidade de propagação de ondas (Tabela 6.30).

Tabela 6.30 - Valores médios e variações de densidade aparente e absorção (CEN, 1998a) após ciclos de choque térmico (CT).

\begin{tabular}{|c|c|c|c|c|c|c|}
\hline \multirow{2}{*}{ AMOSTRA } & \multicolumn{2}{|c|}{$\rho_{\mathrm{sec}}$} & \multirow{2}{*}{$\Delta_{\rho_{\mathrm{sec}}}$} & \multicolumn{2}{|c|}{$A_{b}$} & \multirow{2}{*}{$\Delta_{A_{b}}$} \\
\hline & antes-CT & pós-CT & & antes-CT & pós-CT & \\
\hline LBD & 2.659 & 2.659 & $-0,01$ & 0,19 & 0,19 & -2 \\
\hline VCB-3 & 2.640 & 2.636 & $-0,15$ & 0,13 & 0,13 & -7 \\
\hline RIC & 2.617 & 2.614 & $-0,10$ & 0,23 & 0,16 & -29 \\
\hline BCR & 2.614 & 2.609 & $-0,19$ & 0,23 & 0,24 & 6 \\
\hline BSV & 2.620 & 2.618 & $-0,08$ & 0,24 & 0,27 & 10 \\
\hline PIT & 2.627 & 2.625 & $-0,09$ & 0,19 & 0,22 & 17 \\
\hline AZF & 2.630 & 2.627 & $-0,10$ & 0,26 & 0,22 & -13 \\
\hline BCE & 2.614 & 2.612 & $-0,08$ & 0,30 & 0,22 & -26 \\
\hline ITN-1 & 2.610 & 2.612 & 0,09 & 0,36 & 0,30 & -16 \\
\hline ITN-2 & 2.613 & 2.613 & $-0,02$ & 0,34 & 0,29 & -14 \\
\hline CRV & 2.619 & 2.622 & 0,11 & 0,27 & 0,24 & -9 \\
\hline CSB & 2.615 & 2.626 & 0,43 & 0,24 & 0,21 & -12 \\
\hline FLS & 2.614 & 2.619 & 0,19 & 0,34 & 0,33 & -3 \\
\hline GVN & 2.636 & 2.642 & 0,20 & 0,29 & 0,25 & -14 \\
\hline ARB & 2.658 & 2.649 & $-0,33$ & 0,25 & 0,27 & 9 \\
\hline SCC & 2.637 & 2.635 & $-0,06$ & 0,27 & 0,29 & 5 \\
\hline
\end{tabular}

Notas:

- $\quad \rho_{\text {sec }}=$ densidade aparente $\left(\mathrm{kg} / \mathrm{m}^{3}\right) ; \Delta_{\rho_{\text {scc }}}=$ variação da densidade aparente (\%); $A_{b}=$ coeficiente de absorção d'água a pressão atmosférica (\%); $\Delta_{A_{b}}=$ variação do coeficiente de absorção d'água a pressão atmosférica (\%).

- Variações foram calculadas utilizando-se uma casa decimal adicional (uma para densidade e três, para absorção) de modo a se obter valores mais próximos das possíveis modificações.

- Em vermelho e azul estão ressaltados, respectivamente, valores maiores e menores após choque térmico.

Os valores de densidade aparente e absorção após ensaio de choque térmico tenderam a ser inferiores àqueles obtidos para corpos-de-prova in natura, ou seja, houve diminuição da densidade e da absorção, o que, entretanto, não foi generalizado, pois alguns exibiram valores maiores de densidade e absorção (Figuras 6.58 e 6.59). 


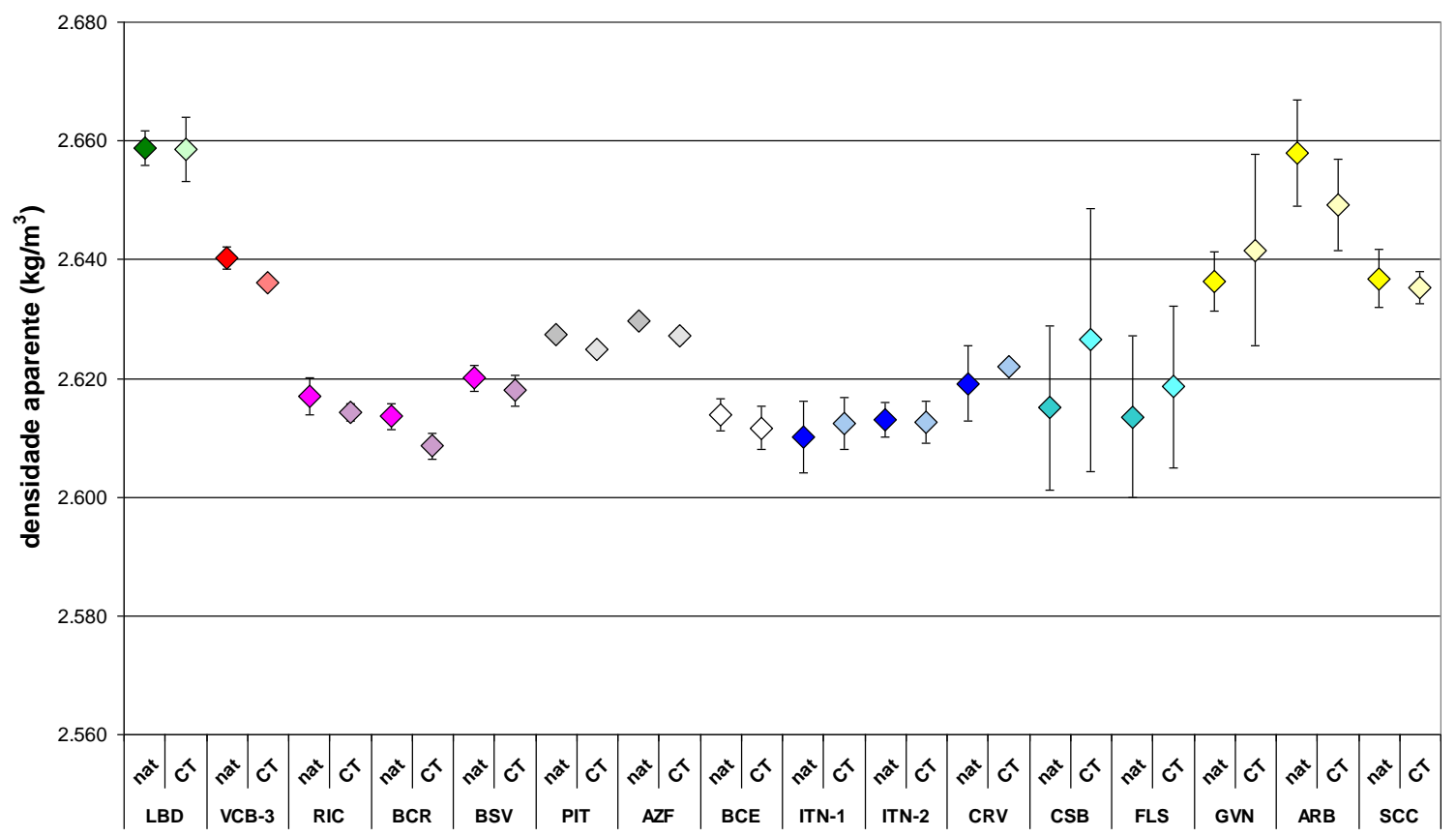

Figura 6.58 - Densidade aparente antes (pontos à esquerda) e após (pontos à direita) choque térmico e respectivas variações.

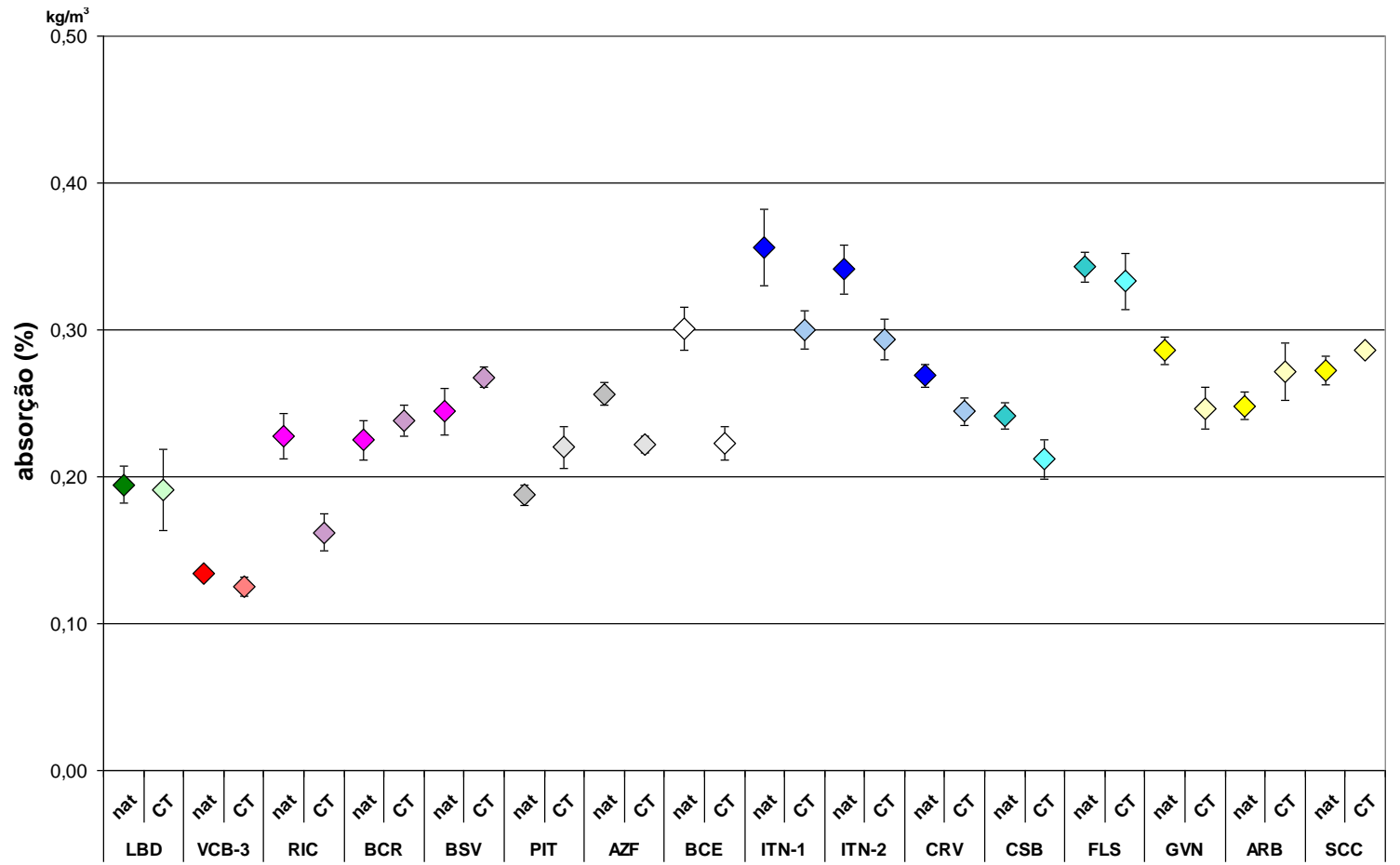

Figura 6.59 - Absorção d'água antes (pontos à esquerda) e após (pontos à direita) choque térmico e respectivas variações. 
A resistência à flexão e a velocidade de propagação de ondas mostraram evidente decaimento após o ensaio de choque térmico que, em princípio, reflete o aumento do fissuramento, decorrente do aquecimento e resfriamento cíclicos.

A grande variabilidade dos resultados obtidos e, ademais, a "melhoria" da absorção, leva a supor que incorporação de água se tornou menos eficiente após vários ciclos de aquecimento e umedecimento, provavelmente devido à mudança da morfologia e/ou da conexão dos poros, e não à ausência de degradação do material nesse processo.

Um importante resultado dos ensaios de alteração por choque térmico foi a mudança de coloração, por oxidação, de algumas rochas, geralmente provocando o amarelamento, por vezes com tonalidades esverdeadas, bem como o aparecimento de pontos ou pequenas manchas ferruginosos.

De modo a diferenciar e hierarquizar as rochas quanto à intensidade relativa de modificações observadas, atribuiu-se:

- Grau 1: rochas consideradas visualmente inalteradas;

- Grau 2: rochas com modificação moderada;

- Grau 3: rochas com conspícua modificação.

As principais modificações acham-se descritas na Tabela 6.31.

Tabela 6.31 - Modificações de coloração observadas em amostras submetidas a choque térmico e graduação atribuída.

\begin{tabular}{clc}
\hline AMOSTRA & \multicolumn{1}{c}{ MODIFICAÇÕES APÓS CHOQUE TÉRMICO } & GRAU \\
\hline LBD & $\begin{array}{l}\text { Todos os corpos-de-prova apresentaram modificação de cor (Figura } \\
\text { 6.60). Tornaram-se acastanhados, provavelmente devido à oxidação de } \\
\text { máficos. }\end{array}$ & $\mathbf{3}$ \\
\hline VCB & Leve perda de brilho na superfície polida de todos os corpos-de-prova. & $\mathbf{1}$ \\
\hline RIC & $\begin{array}{l}\text { Praticamente inalterados. Clareamento incipiente dos corpos-de-prova } \\
\text { fornecendo a impressão visual de esmaecimento da cor. }\end{array}$ & $\mathbf{1}$ \\
\hline BSV & $\begin{array}{l}\text { Praticamente inalterados. Tornaram-se relativamente mais brancas, } \\
\text { perdendo o tom acinzentado. }\end{array}$ & $\mathbf{1}$ \\
\hline BCR & $\begin{array}{l}\text { Praticamente inalterados. Tornaram-se relativamente mais brancas, } \\
\text { perdendo o tom acinzentado. }\end{array}$ & $\mathbf{1}$ \\
\hline GVN & $\begin{array}{l}\text { Intensificação do amarelamento preexistente e oxidação ao redor de } \\
\text { granada e agregados máficos. }\end{array}$ \\
\hline PIT & $\begin{array}{l}\text { Amarelamento da rocha e intensificação da tonalidade de pontos } \\
\text { ferruginosos preexistentes. Essa "oxidação" é pervasiva, também } \\
\text { observada no interior do corpo-de-prova, quando quebrado. }\end{array}$ \\
\hline AZF & $\begin{array}{l}\text { Clareamento de todos os corpos-de-prova, acompanhado de leve } \\
\text { amarelamento (menos intenso que no PIT). Perda de brilho da superfície } \\
\text { polida. }\end{array}$ & $\mathbf{1}$ \\
\hline
\end{tabular}




\begin{tabular}{clc}
\hline AMOSTRA & \multicolumn{1}{c}{ MODIFICAÇÕES APÓS CHOQUE TÉRMICO } & GRAU \\
\hline BCE & Sem modificações aparentes. & $\mathbf{1}$ \\
\hline ITN-1 & $\begin{array}{l}\text { Oxidação ao redor de minerais e/ou agregados máficos. O fenômeno é } \\
\text { pervasivo, podendo também ser observado no interior da rocha (CP-11), } \\
\text { quando quebrada. }\end{array}$ & $\mathbf{3}$ \\
\hline ITN-2 & $\begin{array}{l}\text { Desenvolvimento generalizado de coloração amarelo-esverdeada em } \\
\text { todos os corpos-de-prova, porém pouco intenso. Intenso amarelamento } \\
\text { acompanhado de oxidação ou incremento da oxidação de máficos } \\
\text { (Figura 6.61). }\end{array}$ & $\mathbf{3}$ \\
\hline CRV & $\begin{array}{l}\text { Intenso amarelamento em todos os corpos-de-prova e aparecimento de } \\
\text { manchas ferruginosas esparsas, devido a provável oxidação de máficos } \\
\text { (Figura 6.62). }\end{array}$ & $\mathbf{3}$ \\
\hline CSB & $\begin{array}{l}\text { Leve coloração esverdeada nas porções quartzo-feldspáticas e } \\
\text { coloração verde-amarelada próximo às bandas micáceas. }\end{array}$ & $\mathbf{1}$ \\
\hline FLS & Forte coloração amarelo-alaranjada em todos os corpos-de-prova. & $\mathbf{3}$ \\
\hline ARB & Leve amarelamento e pontuais manchas ferruginosas. & $\mathbf{1}$ \\
\hline SCC & $\begin{array}{l}\text { Amarelamento segundo a foliação e oxidação nas regiões quartzo- } \\
\text { feldspáticas. Possível destacamento de fragmentos de granadas (Figura } \\
\text { 6.63). }\end{array}$ & $\mathbf{2}$ \\
\hline
\end{tabular}

As modificações visuais mais relevantes estão ilustradas nas Figuras $6.60 \mathrm{a}$ 6.63.

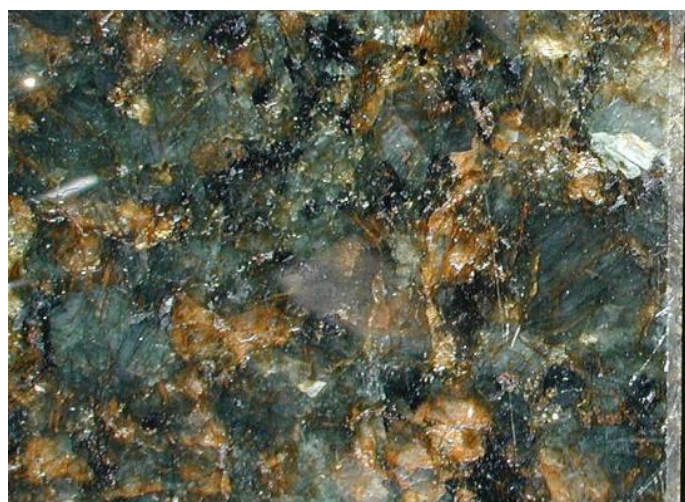

natural

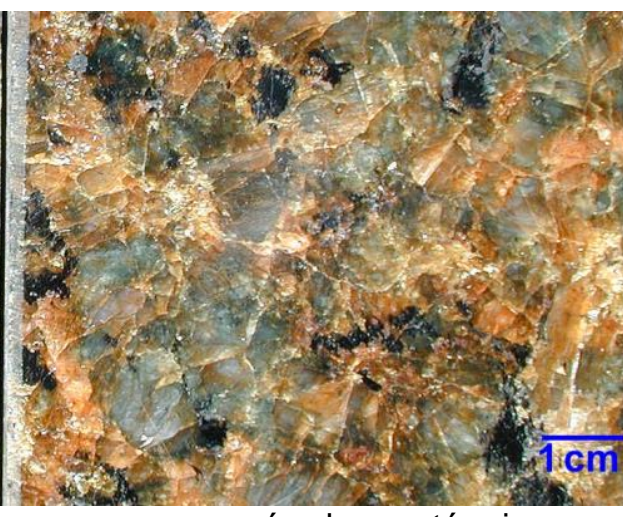

após choque térmico

Figura 6.60 - Amostra LBD. Generalizado aumento da coloração acastanhada da rocha, provavelmente resultante do incremento da oxidação preexistente. 


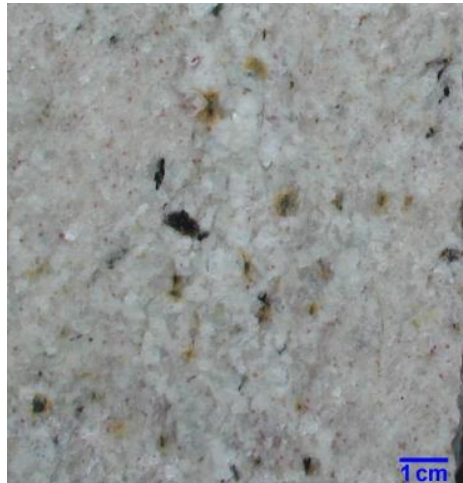

natural.

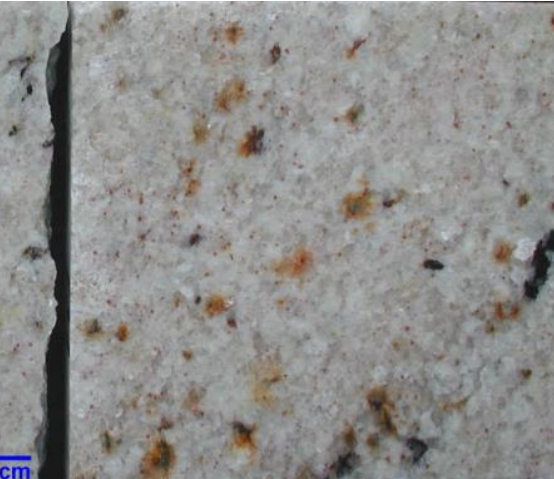

após choque térmico.

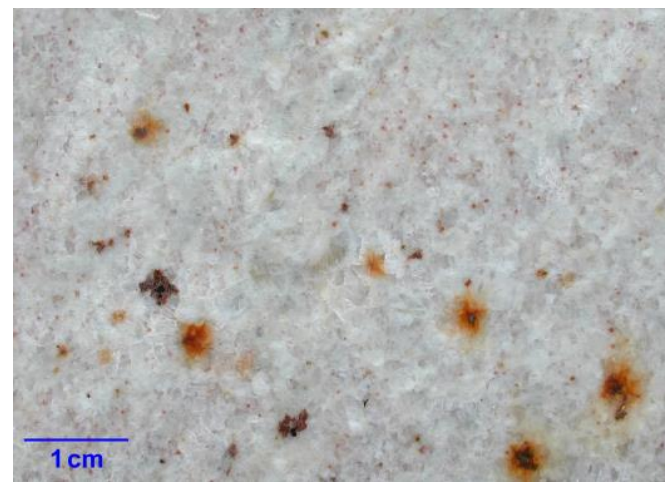

detalhe, após choque térmico

Figura 6.61 - Amostra ITN-2. Amarelamento da rocha e oxidação de máficos. Foto à direita, detalhe dos minerais oxidados.
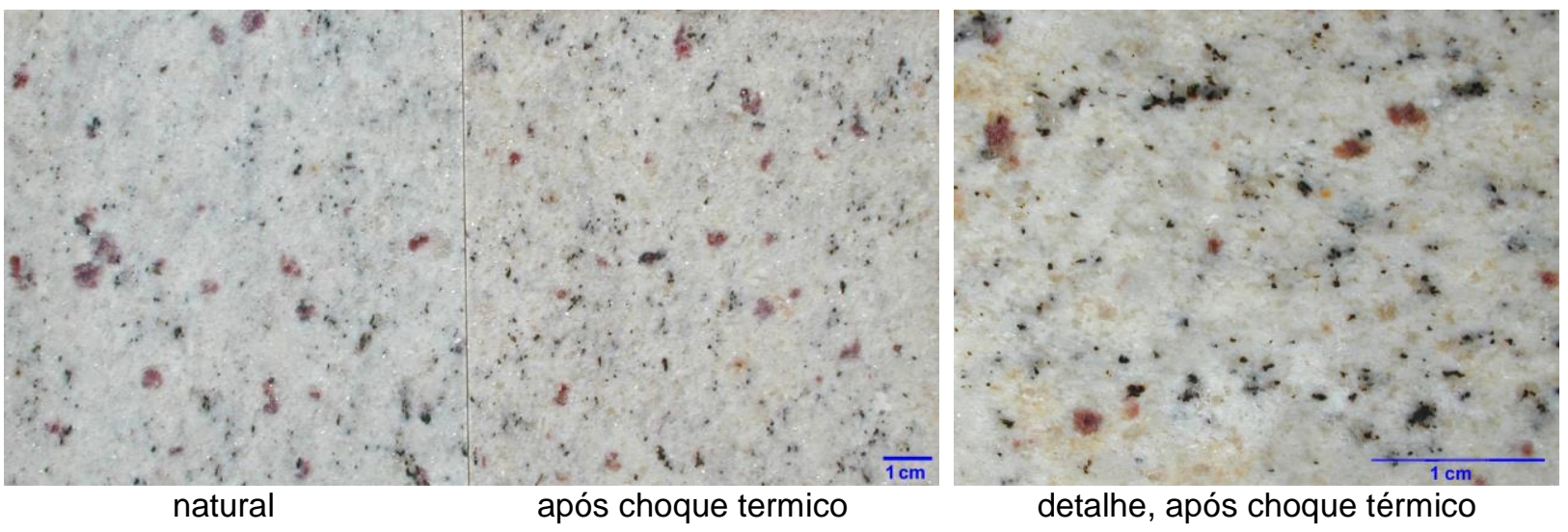

Figura 6.62 - Amostra CRV. Amarelamento e aparecimento de manchas ferruginosas, milimétricas, esparsas. Foto à direita, detalhe do amarelamento, coincidente com os pontos microscopicamente constituídos de agregados cauliníticos.

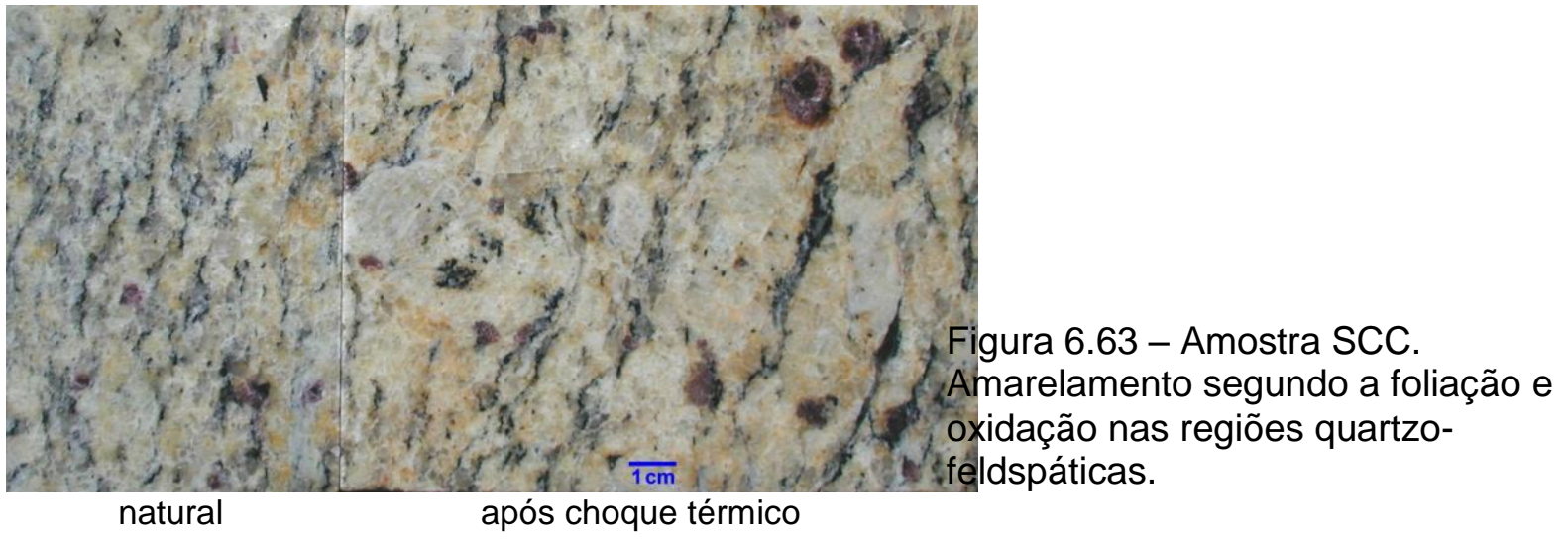

Algumas amostras foram selecionadas para verificação microscópica das modificações visualmente detectadas, que foram essencialmente oxidações pontuais ou generalizadas das rochas. A Tabela 6.32 sintetiza as principais feições microscópicas associadas ás deteriorações. 
Tabela 6.32 - Aspectos microscópicos das deteriorações visualmente detectadas após ensaio de choque térmico.

\begin{tabular}{|c|c|}
\hline amostra & deteriorações observadas ao microscópio óptico \\
\hline LBD & $\begin{array}{l}\text { - Incremento da oxidação em fissuras e oxidação de minerais } \\
\text { (ortopiroxênio, principalmente). }\end{array}$ \\
\hline PIT & - oxidação em fissuras. \\
\hline ITN-1 & $\begin{array}{l}\text { - oxidação dos "agregados" biotita e argilominerais; } \\
\text { - oxidação de sulfetos (Figura 6.64). }\end{array}$ \\
\hline CRV & $\begin{array}{l}\text { - oxidação dos argilominerais de alteração em espaços intergranulares } \\
\text { (Figura 6.65). }\end{array}$ \\
\hline CSB & $\begin{array}{l}\text { - aparecimento de fissuras abertas, ou aumento da abertura, } \\
\text { concordantes, perpendiculares ou oblíquas à estruturação; } \\
\text { - leve incremento de hidróxidos de ferro em fissuras. }\end{array}$ \\
\hline ARB & - aparente aumento da oxidação. \\
\hline SCC & - aumento de hidróxidos de ferro em microfissuras (Figura 6.66). \\
\hline
\end{tabular}

Nota: o termo oxidação aqui se refere à intensificação da tonalidade ferruginosa dos hidróxidos de ferro de preenchimento de microfissuras ou ao aparecimento de hidróxidos de ferro ou correlatos em minerais anteriormente inalterados.

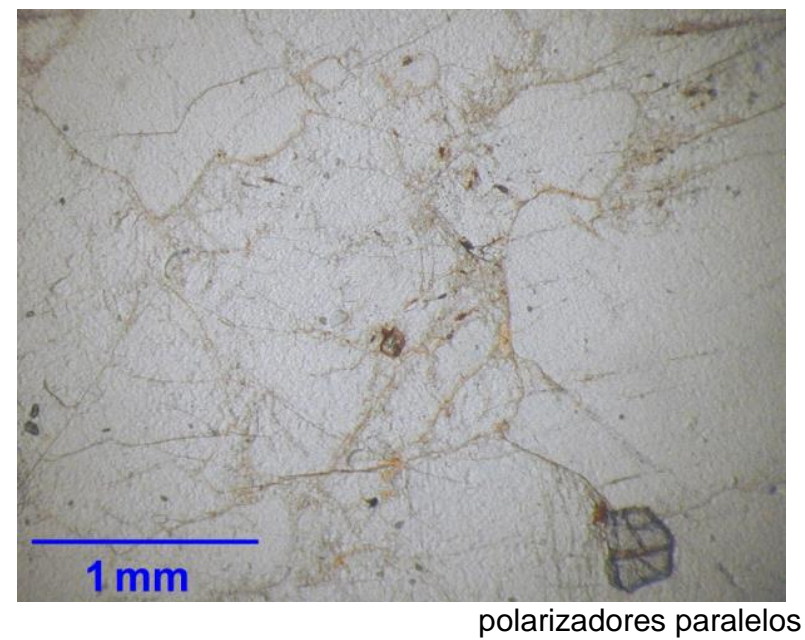

a)

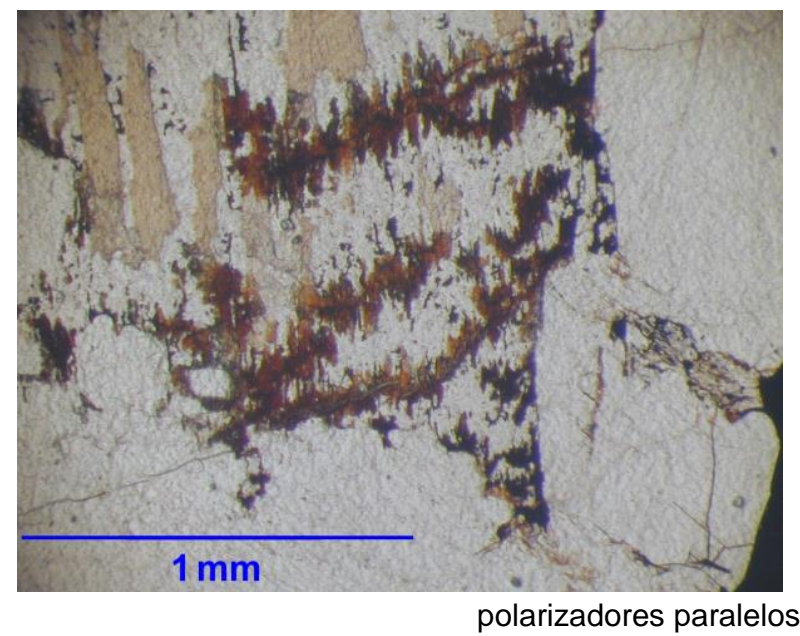

b)

Figura 6.64 - Amostra ITN-1 após ensaio de choque térmico. Notar incremento da coloração ferruginosa de argilominerais de preenchimento de microfissuras (a), e oxidação de filossilicatos de alteração de biotita (b). 


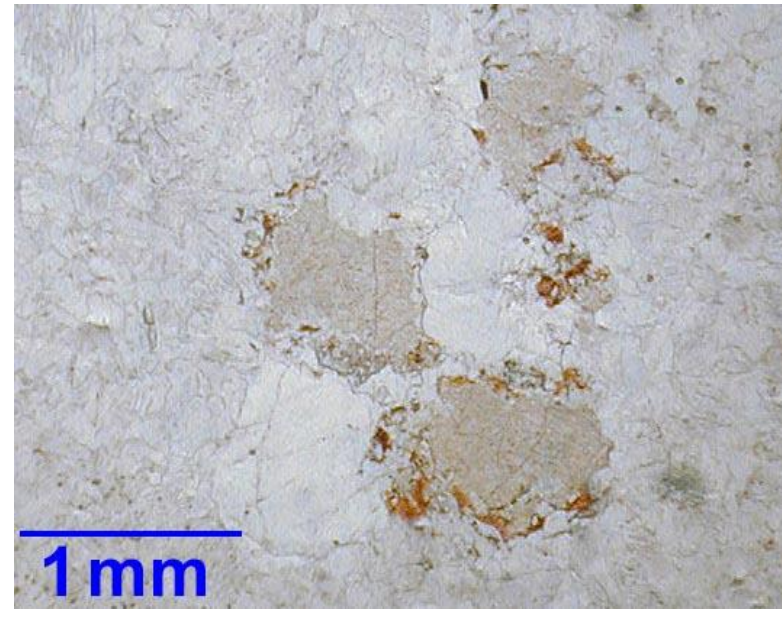

polarizadores paralelos

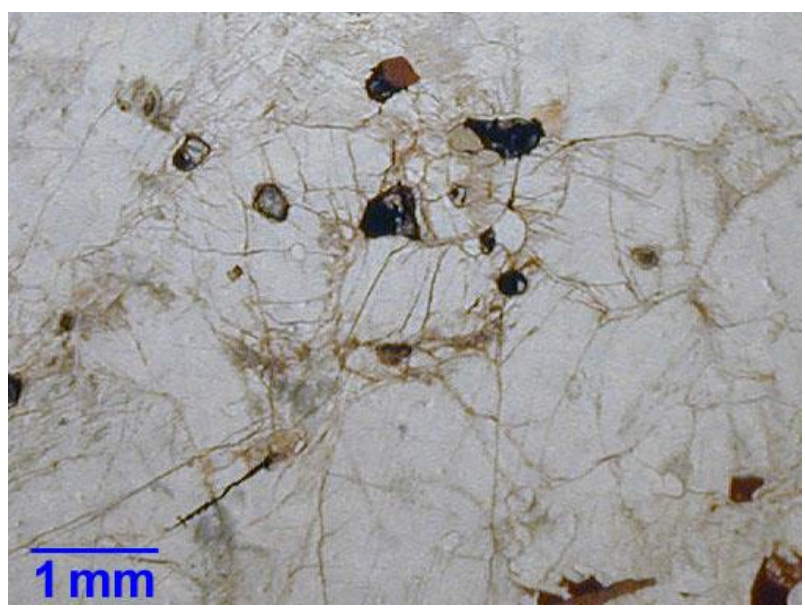

polarizadores paralelos

Figura 6.65 - Amostra CRV após ensaio de Figura 6.66-Amostra SCC após ensaio de choque térmico. Aspecto da oxidação nos choque térmico. Aspecto do incremento da locais de ocorrência de argilominerais de coloração ferruginosa de argilominerais de alteração de mineral original.

\subsubsection{Relações entre propriedades mecânicas e físicas}

A análise das relações entre as duas propriedades mecânicas enfocadas (compressão uniaxial e flexão) considerou os coeficientes de correlação para todas as amostras e outros conjuntos de valores, quais sejam, somente amostras isótropas, amostras isótropas e gnáissicas, somente gnáissicas etc. (Tabela 6.33).

Tabela 6.33 - Coeficientes de correlação entre valores de resistências à compressão uniaxial e à flexão.

\begin{tabular}{|c|c|c|c|}
\hline & $\sigma_{f n a t}(\mathbf{M P a})$ & & $\sigma_{f C T}(\mathbf{M P a})$ \\
\hline \multirow{6}{*}{$\sigma_{c \sec }(\mathrm{MPa})$} & $0,87(A)$ & \multirow{6}{*}{$\sigma_{\text {c sat }}(\mathbf{M P a})$} & $0,81(A)$ \\
\hline & $0,75(B)$ & & 0,65 (B) \\
\hline & 0,48 (C) & & $0,55(C)$ \\
\hline & $-0,85$ (D) & & $-0,59$ (D) \\
\hline & $-0,70(E)$ & & $-0,63(E)$ \\
\hline & $-0,35(\mathbf{F})$ & & $-0,32(\mathbf{F})$ \\
\hline
\end{tabular}

Nota: $A$ = rochas isótropas; $B$ = rochas isótropas e com determinação de resistência perpendicular à estruturação; $C=$ todas amostras; $D=$ rochas com determinação de resistência perpendicularmente à estruturação; $E$ = rochas com determinação de resistência paralelamente à estruturação; $F$ = rochas gnáissicas. Demais símbolos, iguais às Tab. 6.35 e 6.26 .

As resistências à compressão e flexão mostraram correlação positiva, nas condições seca, saturada e após choque térmico, quando considerados os conjuntos $A$ 
e B (Tab. 6.33), o que sugere que as rochas isótropas, especialmente na condição seca, tendem a apresentar características compatíveis tanto in natura (compressão uniaxial: bloco), como após beneficiamento (flexão: ladrilho); que se mantém nas condições saturada e após choque térmico.

Considerando as resistências à compressão e à flexão das rochas gnáissicas, nas diferentes condições de ensaio (seca, saturada e após choque térmico) e com aplicação de tensão paralela e perpendicularmente à estruturação, verificaram-se correlações negativas. Essa informação, ainda que se pondere a insuficiência de dados estatisticamente significantes e o fato de que as rochas gnáissicas em análise foram objeto, em diferentes graus, da ação intempérica, é sugestiva de que as rochas anisótropas com maiores resistências à compressão tenderam a apresentar menores resistências à flexão.

A título de conhecimento, as rochas estudadas oram agrupadas, segundo os valores limites, indicados na ASTM C 615 (ASTM 1999c), para capacidade de absorção e resistências à compressão uniaxial e flexão (Tabela 6.34).

Tabela 6.34 - Agrupamento das rochas estudadas segundo especificações da ASTM (1999c).

\begin{tabular}{|c|c|c|c|c|}
\hline & $\sigma_{\mathrm{c}}>8,27 \mathrm{MPa}$ & $\sigma_{\mathrm{c}}<8,27 \mathrm{MPa}$ & $\sigma_{\mathrm{f}}>131 \mathrm{MPa}$ & $\sigma_{\mathrm{f}}<131 \mathrm{MPa}$ \\
\hline$\alpha>0,40 \%$ & - & - & - & - \\
\hline \multirow[t]{2}{*}{$\alpha<0,40 \%$} & \multirow[t]{2}{*}{$\begin{array}{l}\text { VCB-3, RIC, } \\
\text { BCR, BSV, PIT, } \\
\text { AZF, BCE, ITN-2, } \\
\text { CRV, FLS } \perp \text {, } \\
\text { GVN } \perp, A R B \perp \text { e } \\
\text { SCC } \perp\end{array}$} & \multirow[t]{2}{*}{$\begin{array}{l}\text { LBD, ITN-1, } \\
\text { CSB } \perp \text {, CSB//, } \\
\text { GVN//, ARB// e } \\
\text { SCC// }\end{array}$} & $\begin{array}{l}\text { Condição seca: } \\
\text { VCB-2 (VCB-1, } \\
\text { VCB-2), RIC, } \\
\text { BCR, BSV, PIT, } \\
\text { AZF, BCE, CRV, } \\
\text { CSB } \perp, \text { CSB //, } \\
\text { FLS } \perp \text { e FLS// }\end{array}$ & $\begin{array}{l}\text { LBD, ITN-1, ITN- } \\
\text { 2, GVN }(\perp \mathrm{e} / /), \\
\text { ARB }(\perp \mathrm{e} / /), \\
\text { SCC }(\perp \mathrm{e} / /) .\end{array}$ \\
\hline & & & $\begin{array}{l}\text { Condição } \\
\text { saturada: PIT, } \\
\text { BCE, CRV }\end{array}$ & demais \\
\hline
\end{tabular}

Nota: absorção $(\alpha)$ determinada segundo ABNT (1992a), para bloco; $\sigma_{c}=$ resistência à compressão $(\mathrm{MPa}), \sigma_{\mathrm{f}}=$ resistência à flexão $(\mathrm{MPa})$.

As resistências mecânicas de muitas rochas se encontram abaixo dos valores limite sugeridos por ASTM C 615 (ASTM,1999c); 8,27 MPa para flexão e 131 MPa para compressão.

No caso dos ensaios de resistência à flexão, as restrições se referem, principalmente, à menor resistência da rocha quando se aplicam esforços perpendicularmente à estruturação. Isso alerta para a utilização de medidas de segurança (apoios, baixa solicitação de esforços e outros) em projetos visando o uso 
da rocha nessa condição.

Quanto à compressão uniaxial, há um número relativamente grande de amostras com resistência abaixo do valor especificado por ASTM C 615 (ASTM,1999c), principalmente nas determinações na condição saturada. Rochas graníticas isótropas, coesas e praticamente inalteradas em geral exibem $\sigma_{\mathrm{c}}>131 \mathrm{MPa}$, como mostram os dados tecnológicos desse trabalho e de vários catálogos de rochas ornamentais (Frazão et al.; 1993, Frascá et al., 2002 e Azevedo; Costa, 1994), que invariavelmente exibiram os valores de $\sigma_{\mathrm{c}}$ na condição seca.

Frazão; Farjallat (1996) realizaram o tratamento estatístico de mais de uma centena de rochas silicáticas brasileiras (incluindo granitos, gnaisses, dioritos etc.) e consideraram $\sigma_{c}=100 \mathrm{MPa}$ como o valor mínimo, para o uso desses tipos rochosos. $\mathrm{O}$ fato de o Brasil ter uma grande variedade de rochas graníticas e ser um dos maiores produtores e exportadores dos denominados "granitos amarelos" - entendidos como rochas graníticas, isótropas ou gnáissicas, com coloração amarelada fornecida pela ação do intemperismo, e, portanto, teoricamente menos resistentes - talvez explique o valor estabelecido por Frazão; Farjallat (1996), valor também próximo daqueles aqui obtidos .

Por outro lado, isso também é indicativo de que estes materiais não estão contemplados na norma ASTM C 615 (ASTM,1999c).

\subsection{Ensaios de Alteração Acelerada}

\subsubsection{Câmaras climáticas}

Os ensaios de alteração em câmaras climáticas visaram à exposição das rochas em estudo a simulações de ambientes marinhos (névoa salina) e ambientes urbanos poluídos. São situações muito mais agressivas que as reais para permitir a rápida resposta do material nesses ambientes.

Ressalta-se que não foram localizados trabalhos, na literatura, que estabeleçam correlação entre a deterioração da rocha em condições aceleradas com a manifestação desta no decorrer do tempo de uso, mesmo em condições assemelhadas.

Ao serem exibidas modificações na cor ou degradações na face exposta, no caso, a face polida, avaliadas tanto por inspeção táctil como visual, verifica-se que a rocha é potencialmente instável nas condições estipuladas. 
As rochas foram colocadas em câmaras de névoa salina e dióxido de enxofre pelo tempo necessário para que pudessem ser observadas modificações, devido à indisponibilidade de informações sistematizadas quanto ao monitoramento de rochas submetidas a intemperismo artificial.

Os principais resultados verificados ao final das exposições estão sumariados na Tabela 6.35, em colunas paralelas, para melhor comparação das modificações resultantes desses dois ambientes, cujos padrões mais representativos estão ilustrados nas Figuras 6.67 a 6.75.

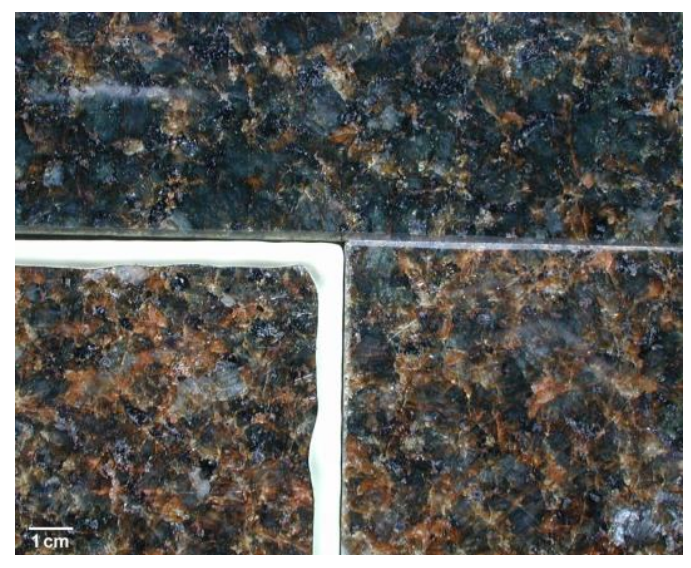

Figura 6.67 - Amostra LBD. Exposição à névoa salina.

Aumento da oxidação preexistente (acima, corpo-de-prova de controle).

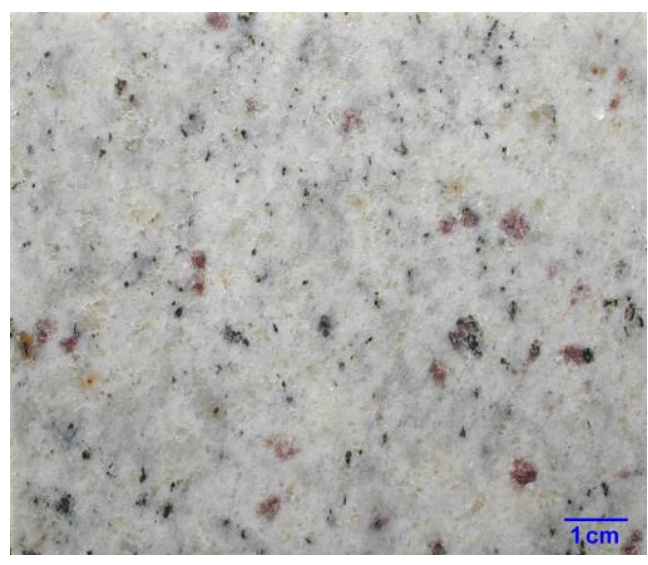

Figura 6.69 - Amostra CRV. Exposição à nevoa salina.

Aumento do amarelamento preexistente (oxidação?) e local oxidação de granada.

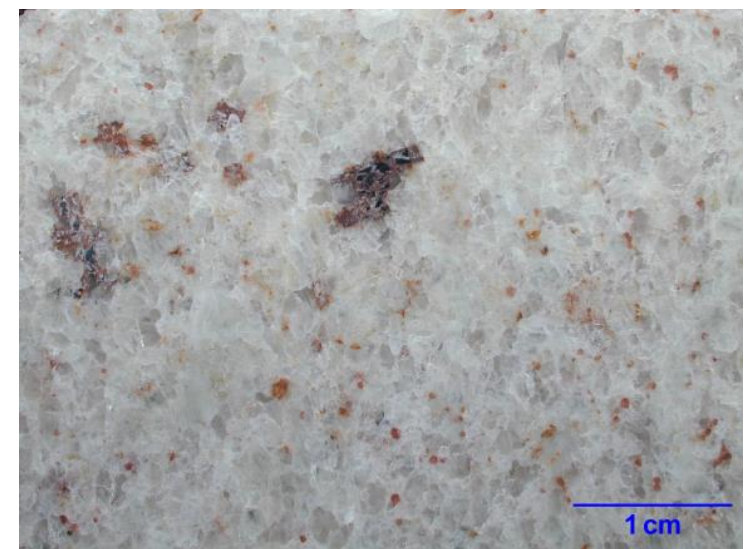

Figura 6.68 - Amostra ITN-2. Exposição à nevoa salina.

Oxidação de granada, máficos e opacos.

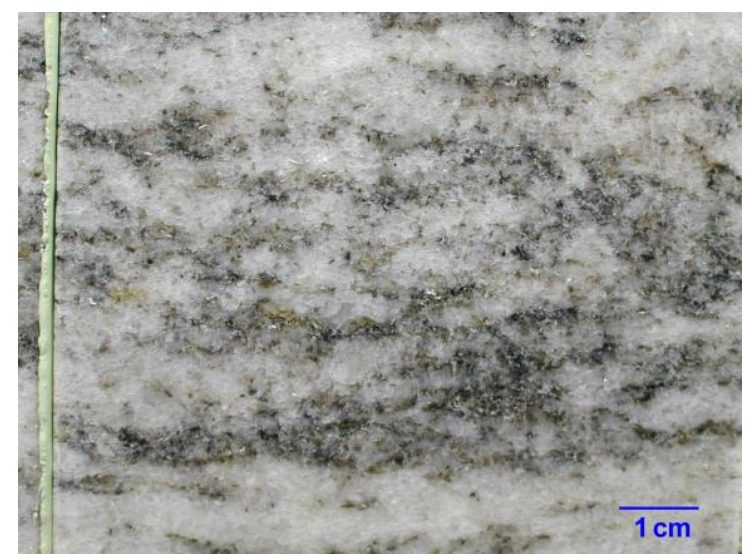

Figura 6.70 - Amostra CSB. Exposição à névoa salina.

Leve coloração ferruginosa surge nos agregados micáceos. 
Tabela 6.35 - Principais resultados obtidos pela exposição das amostras em estudo a câmaras de dióxido de enxofre e névoa salina.

\begin{tabular}{|c|c|c|c|c|}
\hline \multirow{2}{*}{ ROCHA } & \multicolumn{4}{|c|}{ CÂMARAS CLIMÁTICAS } \\
\hline & NÉVOA SALINA & GRAU & DIÓXIDO DE ENXOFRE & GRAU \\
\hline LBD & $\begin{array}{ll}\text { - } & \text { aumento da oxidação preexistente (Figura 6.67); } \\
\text { - } & \text { aspereza ao tato, na face polida, decorrente do inchamento } \\
& \text { de biotita; } \\
\text { - } & \text { local despegamento de biotita, com formação de pequenas } \\
& \text { cavidades. }\end{array}$ & 2 & $\begin{array}{l}\text { - } \text { notável modificação de cor (branqueamento) da rocha (Figura 6.71); } \\
\text { - } \quad \text { atenuação da oxidação preexistente; } \\
\text { - } \text { formação de sais em espaços intergranulares. }\end{array}$ & 3 \\
\hline VCB & $\begin{array}{l}\text { - } \begin{array}{l}\text { VCB-1, } 2 \text { e } 3 \text { mostraram-se ásperas, na face polida, pelo } \\
\text { inchamento de biotita; } \\
\text { - } \\
\text { - } \\
\text { presença de sal em fissuras superficiais, ressaltando-as; } \\
\text { VCB-1. }\end{array} \\
\end{array}$ & 2 & $\begin{array}{ll}\text { - } & \text { eflorescências em máficos (biotita) (Figura 6.72); } \\
\text { - } & \text { inchamento (expansão) de biotita provocando aspereza na face exposta; } \\
\text { - } & \text { ordem aproximada de modificações: VCB-2 > VCB-1 > VCB-3 (CP vedado) }\end{array}$ & 2 \\
\hline RIC & $\begin{array}{ll} & \text { aspereza, ao tato, na face polida; } \\
\text { - } & \text { local despegamento de biotita e formação de cavidades. }\end{array}$ & 2 & $\begin{array}{l}\text { - } \quad \text { pontos esparsos com sais, mas sem aspereza ao tato; } \\
\text { - } \quad \text { local escamação, em núcleos de plagioclásio. }\end{array}$ & 2 \\
\hline BSV & n.e. & - & n.e. & - \\
\hline BCR & $\begin{array}{l}\text { - } \quad \text { sem mudanças aparentes; } \\
\text { - leve aspereza ao tato e possível despegamento de biotitas. }\end{array}$ & 1 & $\begin{array}{ll}- & \text { minerais máficos tornaram-se mais claros, com coloração esverdeada; } \\
\text { - } & \text { formação de sais sobre biotita (e outros máficos?) e em fissuras } \\
\text { superficiais. }\end{array}$ & 2 \\
\hline PIT & $\begin{array}{ll}\text { - } & \text { perda de brilho torna opaca a face exposta à névoa salina; } \\
\text { - } & \text { leve aspereza ao tato e destacamento de biotitas. }\end{array}$ & 2 & $\begin{array}{l}\text { - } \quad \text { sutil clareamento dos pontos amarelados já existentes na rocha; } \\
\text { - } \text { formação de sais em fissuras superficiais e sobre biotita. }\end{array}$ & 1 \\
\hline AZF & $\begin{array}{l}\text { - } \quad \text { perda de brilho torna a face exposta opaca; } \\
\text { - } \quad \text { leve aspereza ao tato e destacamento de biotitas; } \\
\text { - } \quad \text { aparecimento de pequenos pontos amarelo-esverdeados } \\
\text { "sob" feldspatos, fornecendo a impressão visual de sutil } \\
\text { amarelamento. }\end{array}$ & 2 & 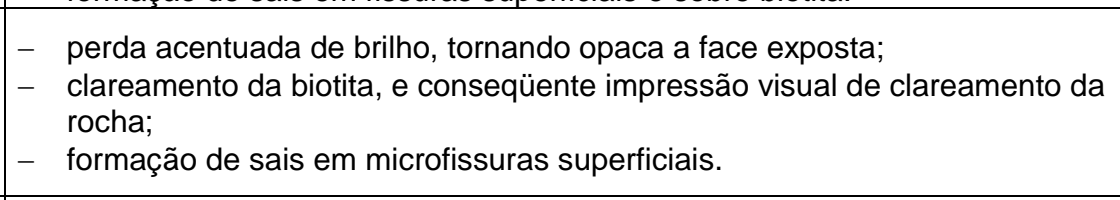 & 2 \\
\hline BCE & - sem modificações aparentes. & 1 & $\begin{array}{ll}\text { - } & \text { eflorescências sobre máficos; } \\
\text { - } & \text { sutil clareamento da rocha, especialmente dos minerais verdes da matriz. }\end{array}$ & 1 \\
\hline ITN-1 & n.e. & - & n.e. & - \\
\hline ITN-2 & $\begin{array}{ll} & \text { oxidação de granada e de máficos + minerais opacos (Figura } \\
& 6.68) ; \\
\text { - } & \text { fissuras superficiais preenchidas por sais. }\end{array}$ & 2 & $\begin{array}{ll}\text { - } & \text { alteração de minerais máficos (para coloração amarelo ouro) (Figura 6.73); } \\
\text { - } & \text { locais pontuações ferruginosas; } \\
- & \text { leve aspereza ao tato. }\end{array}$ & 3 \\
\hline
\end{tabular}


continuação...

\begin{tabular}{|c|c|c|c|c|}
\hline \multirow{2}{*}{ ROCHA } & \multicolumn{4}{|c|}{ CÂMARAS CLIMÁTICAS } \\
\hline & NÉVOA SALINA & GRAU & DIÓXIDO DE ENXOFRE & GRAU \\
\hline CRV & $\begin{array}{l}\text { - } \text { acentuada oxidação da matriz (aumento do amarelamento } \\
\text { preexistente) (Figura } 6.69 \text { ); } \\
\text { - locais oxidações de granada e máficos }\end{array}$ & 2 & 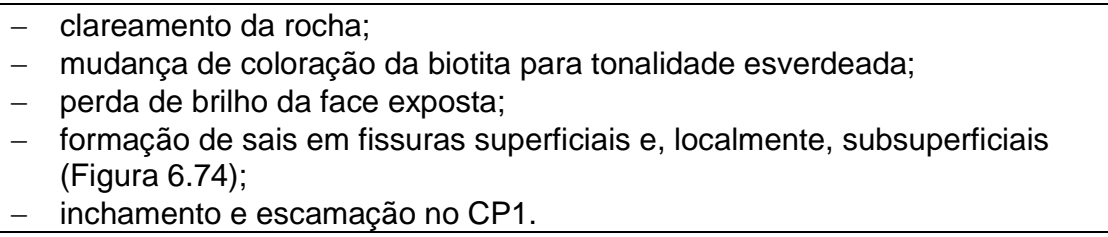 & 3 \\
\hline CSB & $\begin{array}{ll}\text { - } & \text { perda de material nas bordas; } \\
\text { - } & \text { destacamentos e inchamentos nos cordões micáceos; } \\
\text { - } & \text { aspereza ao tato, mais intensa no CP vedado; } \\
\text { - localmente, observam-se pontos amarelados (oxidados) } \\
\text { (Figura 6.70). }\end{array}$ & 3 & $\begin{array}{l}\text { - biotita parece ter se tornado mais acastanhada; } \\
\text { - } \text { formação de sais em fissuras superficiais. }\end{array}$ & 1 \\
\hline FLS & n.e. & - & n.e. & - \\
\hline GVN & - sem modificações aparentes. & 1 & $\begin{array}{ll}\text { - } & \text { abundantes eflorescências em agregados máficos e fissuras } \\
& \text { intergranulares (Figura 6.75); } \\
\text { - } & \text { face exposta tornou-se áspera, com inicio de protuberâncias. }\end{array}$ & 3 \\
\hline ARB & $\begin{array}{l}\text { - feldspatos estão pouco mais rosados que os do corpo-de- } \\
\text { prova padrão; } \\
\text { - } \text { micas parecem intumescidas, mas não há aspereza ao tato. }\end{array}$ & 2 & 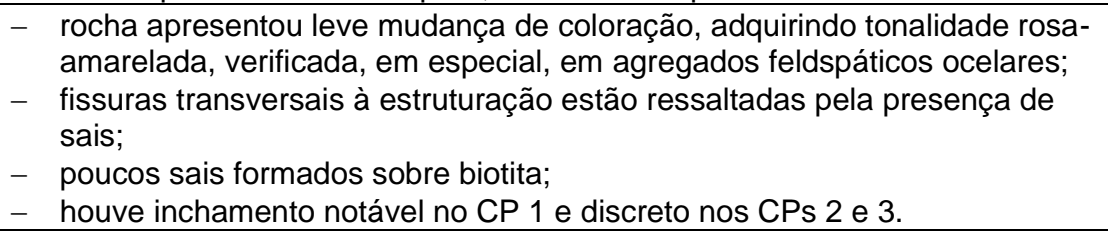 & 2 \\
\hline SCC & - amarelamento e ressaltamento dos cordões micáceos. & 3 & $\begin{array}{l}\text { - } \text { formação de sais em fissuras; } \\
\text { - } \text { aspereza ao tato; } \\
\text { - } \text { inchamento ao longo de fissuras concordantes com a estruturação da } \\
\text { rocha; } \\
\text { - } \quad \text { CP 1: inchamento e escamação de minerais, em especial na área central; } \\
\text { - } \\
\text { sutil clareamento nas áreas quartzo-feldspáticas. }\end{array}$ & 3 \\
\hline
\end{tabular}

Nota: grau $\mathbf{1}$ = rochas visualmente inalteradas; grau $\mathbf{2}$ = rochas com modificações moderadas; grau $\mathbf{3}=$ rochas que exibiram maiores modificações. n.e. = rocha não ensaiada. 

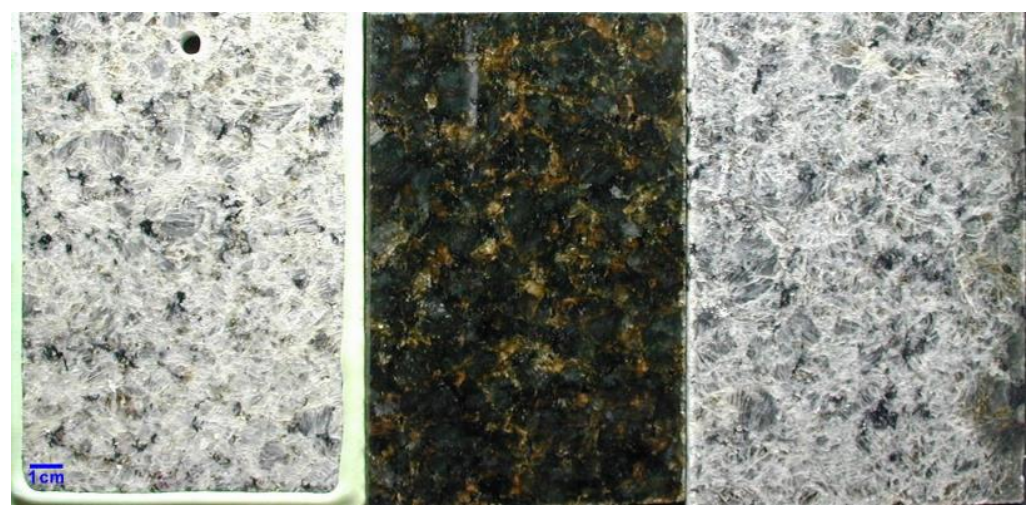

Figura 6.71 - Amostra LBD. Exposição ao dióxido de enxofre.

Total branqueamento da rocha.

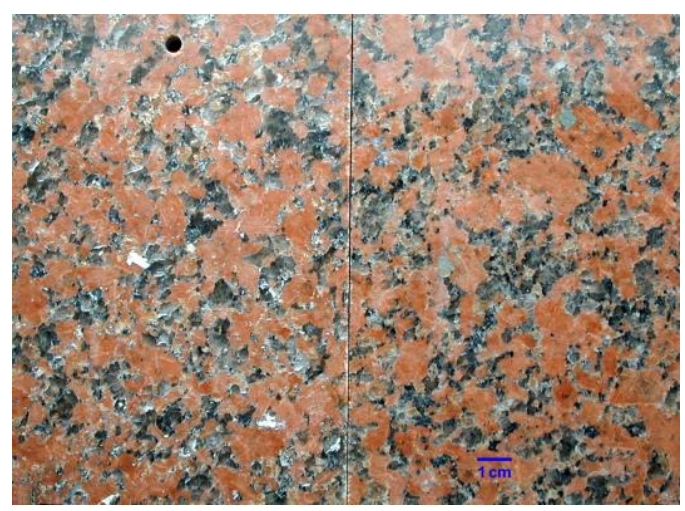

\section{VCB-1}

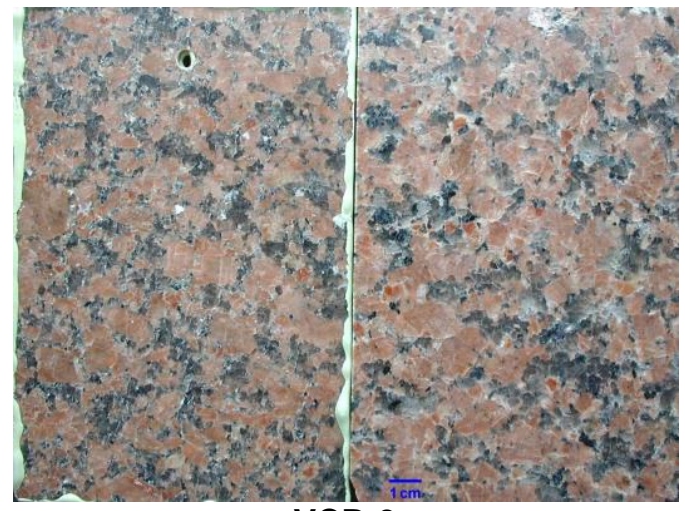

VCB-3

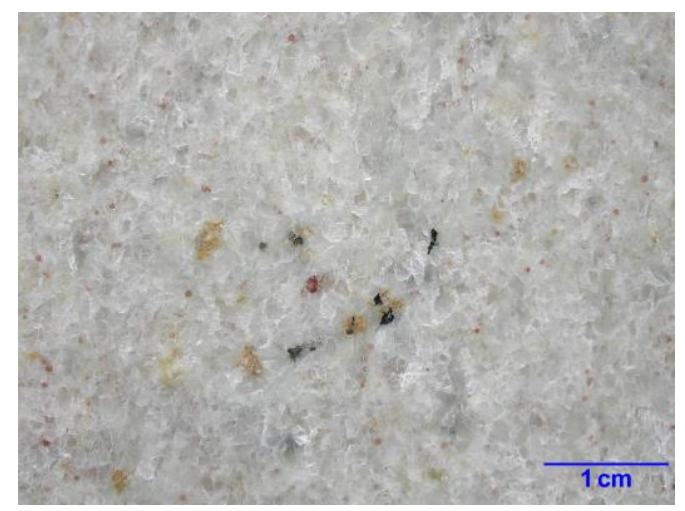

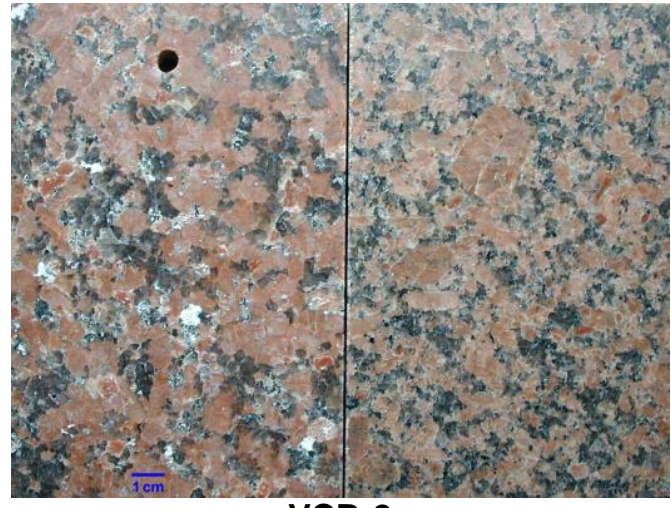

VCB-2

Figura 6.72 - Amostra VCB. Exposição ao dióxido de enxofre.

Formação de sais em fissuras superficiais e, localmente, sobre biotita

Nota: à direita, corpo-de-prova de controle.

Figura 6.73 - Amostra ITN-2. Exposição ao dióxido de enxofre.

Pontos amarelados esparsos referentes à oxidação de minerais. 


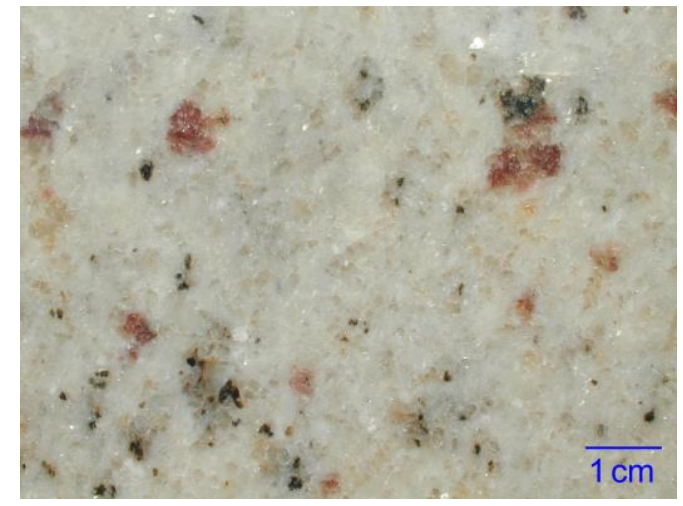

Figura 6.74 - Amostra CRV. Exposição ao dióxido de enxofre. "Amarelamento" da rocha.

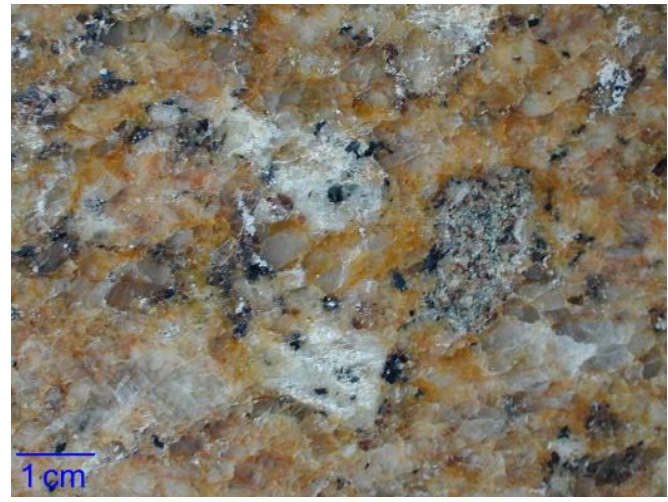

Figura 6.75 - Amostra GVN. Exposição ao dióxido de enxofre. Abundantes eflorescências em agregados máficos e fissuras intergranulares.

\subsubsection{Exposição ao dióxido de enxofre}

Os corpos-de-prova dos materiais selecionados foram expostos ao dióxido de enxofre e submetidos a 32 ciclos, que se referem a 8 horas diárias de exposição ao dióxido de enxofre e a 16 horas de exposição às condições ambientais, totalizando 768 horas de ensaio.

Os monitoramentos foram planejados para ocorrerem na seguinte seqüência: o primeiro após $24 \mathrm{~h}$ de exposição; do segundo ao quinto, a intervalos de cerca de $48 \mathrm{~h}$ (de dois em dois ciclos); e daí em diante a cerca de $136 \mathrm{~h}$ de intervalo (a cada cinco ciclos). Foram realizados 11 monitoramentos, aproximadamente nesses intervalos, que tiveram que ser ajustados em virtude do calendário (finais de semana, feriados, etc.).

A Tabela 6.36 sintetiza a cronologia das modificações relevantes observadas nos monitoramentos.

É um ensaio de alteração mais agressivo que o de exposição à névoa salina. $O$ pH da solução é cerca de 2, no interior da câmara, e entre 1 e 2 na "névoa" interna.

A despeito disso, alguns materiais ensaiados não exibiram modificações visuais notáveis e outros exibiram moderada (Branco Caravelas) ou intensa (Verde Labrador) mudança de cor.

Em outras amostras, a exposição ao dióxido de enxofre causou intensa deterioração da face polida devido à cristalização de sais (eflorescências) e inchamentos (SCC, GVN, ARB). 
Tabela 6.36 - Principais modificações verificadas nos monitoramentos do ensaio de exposição ao dióxido de enxofre.

\begin{tabular}{|c|c|c|}
\hline ciclo & amostra & modificações observadas \\
\hline \multirow{6}{*}{$2^{\circ}$ ciclo } & SCC & Aparente lixiviação da oxidação preexistente. \\
\hline & ARB & Muito poucos sais em biotita e granada. \\
\hline & PIT/AZF & Possíveis sais subsuperficiais. \\
\hline & BCR & Possíveis sais em biotita. \\
\hline & CRV & Oxidação de minerais e manchas amareladas esparsas. \\
\hline & CSB & Possíveis sais em biotita. Aparente clareamento. \\
\hline \multirow{6}{*}{$4^{\circ}$ ciclo } & VCB & Pontos esparsos com sais. \\
\hline & LBD & Clareamento de feldspatos. \\
\hline & GVN & Sais em fissuras e agregados de máficos+granada+feldspatos. \\
\hline & SCC & Sais em microfissuras paralelas à estruturação. Inchamentos localizados. \\
\hline & ARB & Sais em microfissuras paralelas à estruturação e em biotita. \\
\hline & PIT/AZF & PIT: sais em biotita. AZF: poucas modificações. \\
\hline \multirow{5}{*}{$6^{\circ}$ ciclo } & LBD & Sais em fissuras e amarelamento. \\
\hline & GVN & $\begin{array}{l}\text { Sais em feldspatos e máficos. Aparente concentração do amarelamento } \\
\text { segundo faixas. }\end{array}$ \\
\hline & ITN-2 & Amarelamento próximo a máficos. \\
\hline & SCC & Impressão visual de clareamento. \\
\hline & PIT/AZF & PIT: sais em biotita e feldspatos. AZF: poucos sais em biotita. \\
\hline \multirow{5}{*}{$8^{\circ}$ ciclo } & RIC & Sais em biotita. \\
\hline & ITN-2 & Formação de material alaranjado próximo a máficos. \\
\hline & Scc & $\begin{array}{l}\text { Aumento da quantidade de sais em fissuras subparalelas à estruturação e } \\
\text { em agregados quartzo-feldspáticos. }\end{array}$ \\
\hline & ARB & $\begin{array}{l}\text { Aumento da quantidade de sais em fissuras subparalelas à estruturação e } \\
\text { em agregados de biotita e granada. }\end{array}$ \\
\hline & CRV & Sais em fissuras e em feldspatos, granada e próximo a biotita. \\
\hline \multirow{4}{*}{$11^{\circ}$ ciclo } & LBD & Rocha tem coloração cinza chumbo. \\
\hline & SCC & Leve inchamento em agregados feldspáticos ocelares. \\
\hline & BCR & Sais recobrem biotita em todos os corpos-de-prova. \\
\hline & CRV & $\begin{array}{l}\text { Sais espalhados por toda a face exposta, especialmente segundo fissuras } \\
\text { subparalelas. }\end{array}$ \\
\hline \multirow{4}{*}{$15^{\circ}$ ciclo } & GVN & Possíveis inchamentos. \\
\hline & - & $\begin{array}{l}\text { Todas amostras mantém as mesmas modificações, em vagaroso } \\
\text { progresso. }\end{array}$ \\
\hline & SCC & Inchamento incipiente. \\
\hline & CRV & $\begin{array}{l}\text { Inchamentos esparsos (CP1) e aumento da concentração de sais em } \\
\text { fissuras subsuperficiais. }\end{array}$ \\
\hline \multirow{4}{*}{$18^{\circ}$ ciclo } & LBD & Continua branqueamento da rocha. \\
\hline & VCB & Sais em feldspatos. \\
\hline & ITN-2 & Incipiente clareamento da rocha. \\
\hline & CRV & Inchamentos e local escamação nas proximidades da borda do CP1. \\
\hline \multirow{2}{*}{$20^{\circ}$ ciclo } & ARB & Inchamento em áreas granolepidoblásticas. \\
\hline & BCR & Leve inchamento em fraturas. \\
\hline \multirow{2}{*}{$27^{\circ}$ ciclo } & GVN & Inchamentos são mais freqüentes no corpo-de-prova vedado. \\
\hline & VCB & VCB-3: inchamento de biotitas. \\
\hline
\end{tabular}

A identificação dos sais, por difratometria de raios $X$, realizada em amostras selecionadas (VCB-1, VCB-2, RIC, BCR e GVN) indicou invariavelmente que as eflorescências são compostas de gipso $\left(\mathrm{CaSO}_{4} \cdot 2 \mathrm{H}_{2} \mathrm{O}\right)$. Grossi; Murray (1999) também as encontraram na exposição de rochas carbonáticas ao dióxido de enxofre, em 
câmaras climáticas.

Segundo Gobbi et al. (1998), estudos sobre os efeitos de poluentes em rochas mostraram que o principal produto das reações de degradação é o gipso, resultando da interação entre $\mathrm{SO}_{2}$ ou $\mathrm{SO}_{4}{ }^{2-}$ e $\circ \mathrm{CaCO}_{3}$ da rocha (visto que as rochas carbonáticas são as únicas extensivamente estudadas). Também indicaram que estudos experimentais, levados a cabo por vários pesquisadores, em câmaras de dióxido de enxofre provaram que a sulfatação de rochas se dá por dois mecanismos: formação direta de gipso; ou formação de sulfito de cálcio hemidratado, como um estágio intermediário, seguido da oxidação em sulfato de cálcio dihidratado.

$\mathrm{O}$ estudo realizado mostrou que o gipso foi o produto da interação do $\mathrm{SO}_{2} \mathrm{com}$ as rochas graníticas estudadas, mas a ocorrência de sulfito de cálcio não foi detectada ou mais detalhadamente investigada.

As modificações e resultados relevantes decorrentes da exposição ao dióxido de enxofre são assim sintetizadas:

- formação de eflorescências e subeflorescências em biotita (ou máficos) e feldspatos, respectivamente, que provocaram inchamento, escamação e despegamento local de fragmentos minerais. As fissuras também constituíram locais preferenciais de cristalização de sais (Figura 6.76);

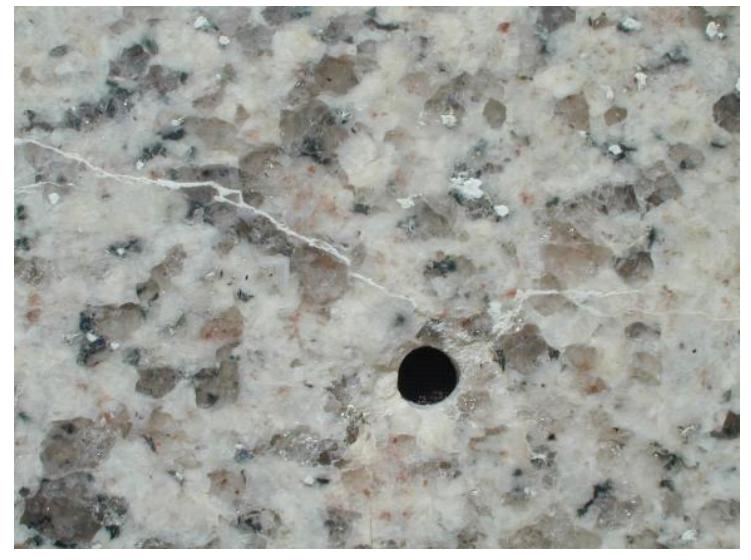

- oxidação de minerais máficos;

- conspícuo branqueamento da face exposta da amostra LBD (charnockito).

De modo a verificar microscopicamente os diferentes resultados, foram confeccionadas lâminas petrográficas de amostras selecionadas, cujas descrições encontram-se na Tabela 6.37.
Figura 6.76 - Amostra BCR. Fratura originada no processo de confecção do corpo-de-prova foi um dos locais preferenciais para cristalização de sais. Esse aspecto também foi observado nas amostras gnáissicas, especialmente as SCC e GVN. 
Tabela 6.37 - Principais modificações em amostras selecionadas daquelas submetidas à exposição em câmara de dióxido de enxofre.

\begin{tabular}{|c|c|c|}
\hline amostra & deterioração & observação ao microscópio óptico \\
\hline LBD & - branqueamento da rocha. & $\begin{array}{l}\text { - aparente lixiviação de hidróxidos de ferro, de } \\
\text { preenchimento das microfissuras; } \\
\text { - } \text { algumas fissuras acham-se, agora, sem preenchimento } \\
\text { (solubilização de carbonato (?)); } \\
\text { - cavidades pontuais em máfico alterado, possivelmente } \\
\text { piroxênio. }\end{array}$ \\
\hline PIT & 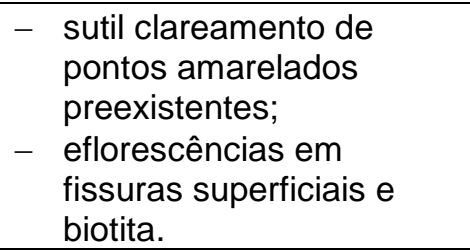 & $\begin{array}{l}\text { - pequenas cavidades em feldspatos ou segundo lamelas } \\
\text { de biotita, resultantes da perda de material (Figura 6.77); } \\
\text { - não foram observadas outras modificações, por } \\
\text { microscopia óptica. }\end{array}$ \\
\hline ITN-2 & $\begin{array}{l}\text { - oxidação de granada, de } \\
\text { máficos e minerais } \\
\text { opacos; } \\
\text { - fissuras superficiais com } \\
\text { eflorescências. }\end{array}$ & $\begin{array}{l}\text { - aparente intensificação do microfissuramento } \\
\text { preexistente; } \\
\text { - provável lixiviação de hidróxidos de ferro, pois o material } \\
\text { de preenchimento das microfissuras está mais límpido }\end{array}$ \\
\hline GVN & $\begin{array}{l}\text { - eflorescências; } \\
\text { - início de protuberâncias. }\end{array}$ & $\begin{array}{l}\text { - carbonatos, comumente associados à alteração de } \\
\text { feldspatos, não são mais observados, provavelmente } \\
\text { dando origem ao gipso; } \\
\text { - alteração de biotita evidenciada por lamelas levemente } \\
\text { descoloridas. }\end{array}$ \\
\hline scc & $\begin{array}{l}\text { - amarelamento e } \\
\text { ressaltamento dos } \\
\text { cordões micáceos. }\end{array}$ & $\begin{array}{l}\text { - } \text { aumento da turvação de feldspatos; } \\
\text { - } \text { aparente aumento da impregnação de filossilicatos de } \\
\text { alteração por hidróxidos de ferro; } \\
\text { - } \quad \text { alargamento de fissuras, especialmente próximas aos } \\
\text { filetes ricos em sillimanita (Figura 6.78); } \\
\text { - locais despegamentos de granada. }\end{array}$ \\
\hline
\end{tabular}

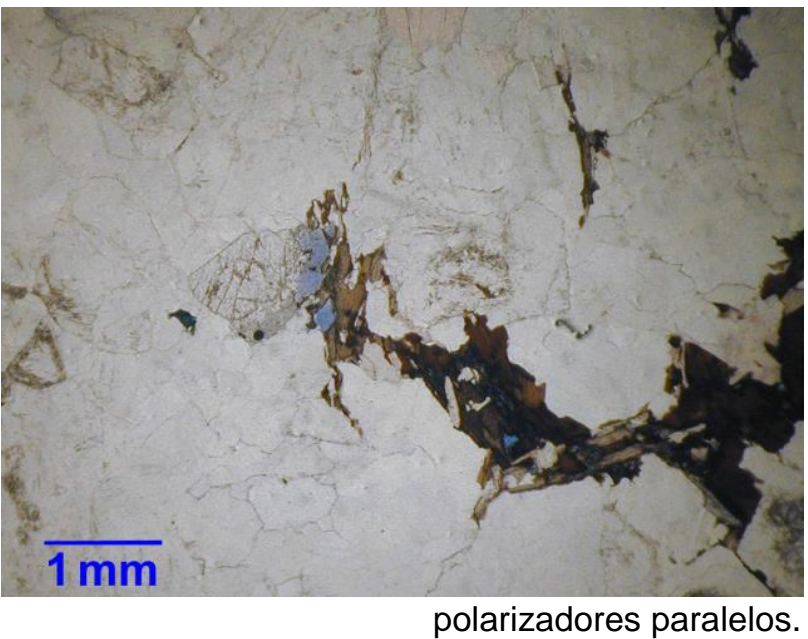

Figura 6.77 - Amostra PIT. Despegamento de lamelas de biotita (em azul).

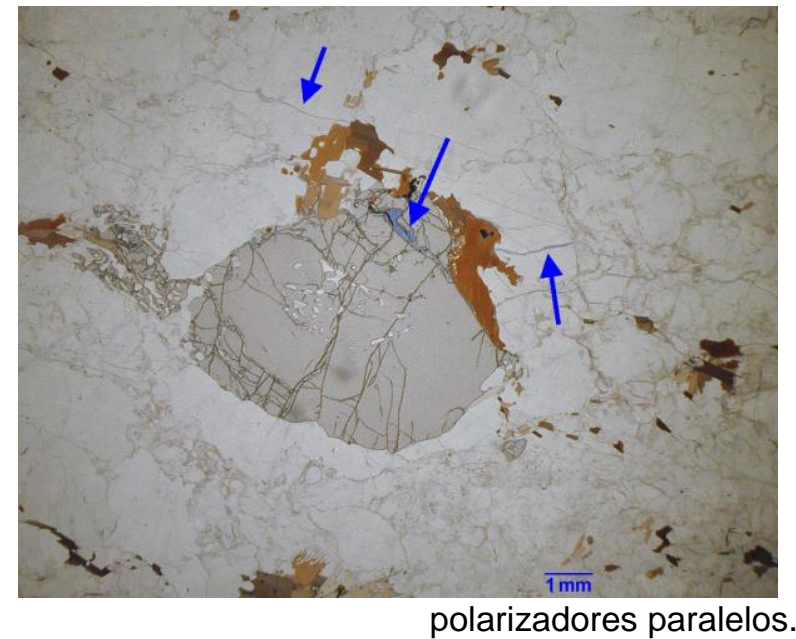

Figura 6.78 - Amostra SCC. Microfissuras aparentemente alargadas após exposição ao dióxido de enxofre. 
lâminas delgadas as rochas in natura, como produtos da alteração de feldspatos e material de preenchimento de microfissuras, permite supor que, ao menos em parte, o gipso cristalizado na rocha, pela exposição ao dióxido de enxofre, seja decorrente da reação desse dois componentes:

\subsubsection{Exposição à névoa salina}

Os corpos-de-prova dos materiais selecionados foram expostos à névoa salina durante o período de 44 dias (1 056 horas).

Inicialmente, os monitoramentos foram realizados em períodos de 48 horas que, com o decorrer do ensaio, passaram para cerca de 72 horas e finalmente para 168 horas. Também foram realizados 11 monitoramentos, com intervalos modificados em virtude do calendário.

Ao serem introduzidas nas câmaras, as amostras ficaram quase totalmente recobertas por sais, mais notados ao longo de microfissuras superficiais, intra, trans e intergranulares. Após lavagem, para inspeção visual, nos monitoramentos, os sais desapareciam totalmente, reaparecendo após o retorno dos corpos-de-prova para a câmara.

A Tabela 6.38 exibe, cronologicamente, as modificações relevantes verificadas nos monitoramentos.

Grande parte dos corpos-de-prova não exibiu modificações visualmente observáveis, mas alguns mostraram notável oxidação dos minerais (LBD, BCR) ou mesmo perda de material (bordas da CSB).

Houve, também, o aparecimento ou aumento de irregularidades na face exposta de corpos-de-prova das amostras BCR, PIT e AZF em decorrência de provável despegamento de plaquetas de biotita, dos agregados preexistentes, sem, entretanto, causar danos perceptíveis numa observação rápida.

No Vermelho Capão Bonito, houve inchamento (expansão) dos agregados biotíticos, principalmente nos corpos-de-prova da VCB-3. 
Tabela 6.38 - Principais modificações verificadas nos monitoramentos do ensaio de exposição à névoa salina.

\begin{tabular}{|c|c|c|}
\hline Ciclo & Amostra & Modificações Observadas \\
\hline \multirow{3}{*}{$2^{\circ}$ ciclo } & VCB, GVN & Provável presença de sais em fissuras em feldspatos. \\
\hline & CSB & Amarelamento de biotita. \\
\hline & CRV & Leve oxidação de máficos. \\
\hline \multirow{3}{*}{$6^{\circ}$ ciclo } & ITN-2 & $\begin{array}{l}\text { Oxidação de máficos e aparecimento de material alaranjado } \\
\text { próximos a esses. }\end{array}$ \\
\hline & ARB & Sais, aparentemente subsuperficiais. \\
\hline & CSB & Sais, preferencialmente em biotita \\
\hline \multirow{3}{*}{$8^{\circ}$ ciclo } & RIC, BCE & Aparentemente ainda inalteradas. \\
\hline & DEMAIS & Sais em fissuras. \\
\hline & PIT/AZF & Sugestivo amarelamento. \\
\hline \multirow{3}{*}{$14^{\circ}$ ciclo } & ITN-2 & Leve oxidação em granada. \\
\hline & PIT & Oxidação e inchamento de biotita. \\
\hline & CSB & Acastanhamento e inchamento das micas. \\
\hline $23^{\circ}$ ciclo & PIT/AZF, BCR & Destacamento de biotita. \\
\hline \multirow{4}{*}{$26^{\circ}$ ciclo } & VCB & Nota-se algum despegamento de biotita. \\
\hline & LBD & Intensificação da oxidação da rocha. \\
\hline & ITN-2 & Oxidação de máficos e granada. \\
\hline & RIC & Destacamento de biotita, quartzo e/ou feldspatos. \\
\hline $39^{\circ}$ ciclo & LBD, ITN-2 & Aumento da oxidação. \\
\hline \multirow{3}{*}{$42^{\circ}$ ciclo } & SCC/ARB & Fissuras intra e transgranulares ressaltadas por sais. \\
\hline & AZF/PIT & Destacamento de biotita (AZF>PIT). \\
\hline & CSB & Destacamento de material, nas bordas. \\
\hline \multirow{8}{*}{$44^{\circ}$ ciclo } & SCC & Amarelamento e ressaltamento de cordões de biotita. \\
\hline & ARB & Coloração levemente mais rosada. \\
\hline & AZF/PIT & Sutil amarelamento e destacamento de biotita. \\
\hline & BCR & Destacamento de biotita (mais intenso na vedada). \\
\hline & CRV & Aumento da oxidação. \\
\hline & CSB & Destacamento de material, oxidação de biotita e inchamento. \\
\hline & VCB & Nítido inchamento de biotita. \\
\hline & RIC & Aumento de cavidades nos agregados de biotita. \\
\hline
\end{tabular}

Sintetizando, a exposição das rochas graníticas, selecionadas para este estudo, à nevoa salina resultou em dois tipos principais de deterioração ocorridos em intensidades diferentes, conforme o tipo de rocha:

- inchamento de biotita, e locais despegamentos;

- oxidação de minerais ou intensificação da coloração de hidróxidos de ferro preexistentes.

$\mathrm{Na}$ Tabela 6.39 são apresentadas as principais modificações microscópicas observadas em lâminas delgadas de amostras selecionadas. 
Tabela 6.39 - Principais modificações microscópicas em amostras submetidas à exposição em câmara de névoa salina.

\begin{tabular}{|c|c|c|}
\hline amostra & deterioração & observação ao microscópio óptico \\
\hline VCB-3 & $\begin{array}{l}\text { - } \text { aspereza na face polida; } \\
\text { - } \text { sal em fissuras } \\
\text { superficiais. }\end{array}$ & $\begin{array}{l}\text { - cavidades pontuais em biotita; } \\
\text { - intensificação da coloração avermelhada de hidróxidos } \\
\text { de ferro, que preenchem microfissuras ou associados à } \\
\text { alteração de plagioclásio, por provável incremento da } \\
\text { oxidação (Figura 6.79). }\end{array}$ \\
\hline PIT & $\begin{array}{l}\text { - } \text { opacidade da face } \\
\text { exposta; } \\
\text { - leve aspereza ao tato; } \\
\text { - } \text { despegamento de biotita. }\end{array}$ & $\begin{array}{l}\text { - não foram observadas modificações perceptíveis ao } \\
\text { microscópio óptico. }\end{array}$ \\
\hline
\end{tabular}
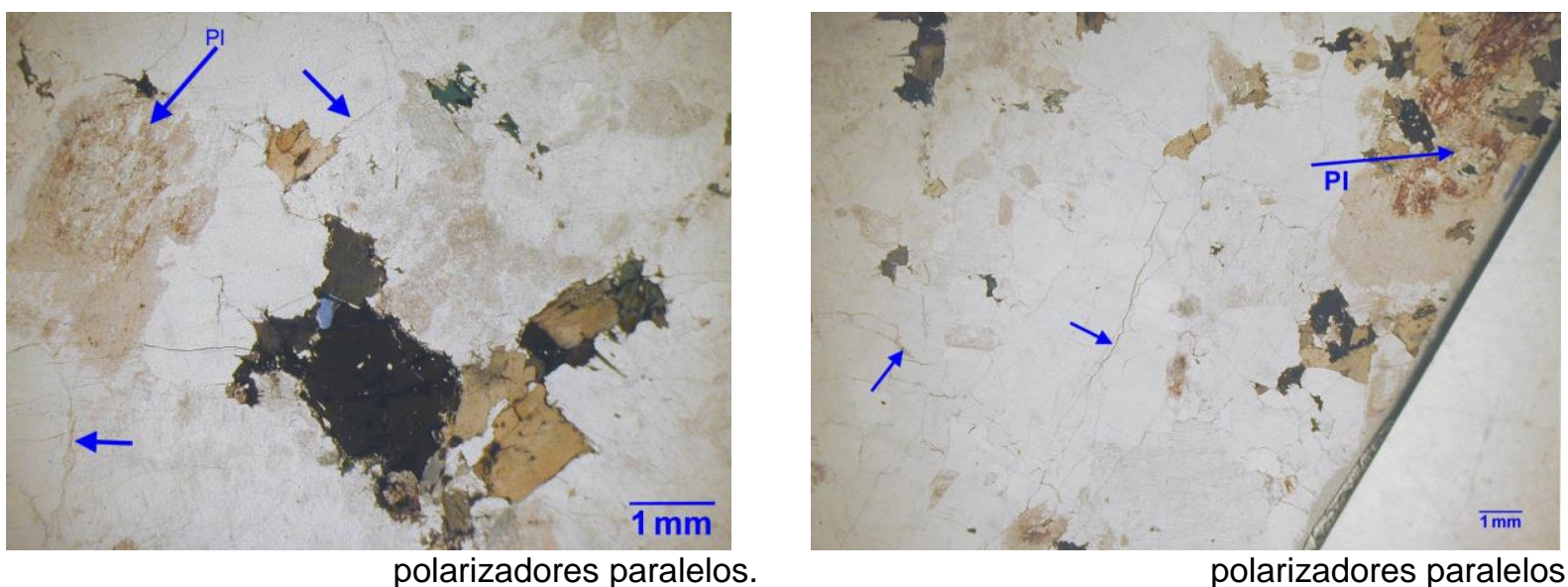

Figura 6.79 - Amostra VCB-3. Intensificação da cor de hidróxidos de ferro associados a argilominerais de alteração nos núcleos de feldspatos e de preenchimento de microfissuras. Notar cavidade em biotita (em azul, no centro da foto à esquerda).

\subsubsection{Imersão parcial em soluções ácida e alcalina}

A imersão parcial das rochas graníticas em soluções quimicamente agressivas objetivou a verificação da estabilidade química, especialmente por meio de possíveis modificações de cor, e da resistência à ação da cristalização de sais (eflorescências e subeflorescências).

Várias simulações já foram desenvolvidas para estabelecer a degradação de rochas por cristalização de sais. A despeito das diferenças entre tamanho da amostra, tipo de solução, concentração da solução, temperatura, umidade relativa e outros, Benavente et al. (2001) comentam que a maioria dos ensaios tem sido realizada por imersão total da amostra na solução estabelecida, que é ciclicamente imersa em soluções saturadas e seca em estufa. 
Benavente et al. (2001), então, realizaram testes experimentais de degradação por cristalização salina, pela imersão parcial de amostras de calcário, em solução de sulfato de sódio ( $14 \%$ ), com ciclos de aquecimento (a $40{ }^{\circ} \mathrm{C}$ e $80 \%$ de umidade relativa) e resfriamento (a $10{ }^{\circ} \mathrm{C}$ e $70 \%$ de umidade relativa), de modo a propiciar reações de dissolução e recristalização.

Embora guarde similaridades com os testes aqui realizados, devem-se ressaltar as diferenças entre os métodos e soluções químicas aqui empregados, quais sejam: imersão contínua, somente com troca periódica de reagentes, também incluindo a verificação da influência do pH na degradação de rochas graníticas.

Ensaio com características mais próximas ao aqui realizado foi o de La Iglesia et al. (1997), mas como na quase totalidade das citações já feitas, enfocou rochas carbonáticas parcialmente imersas em soluções salinas: $\mathrm{Na}_{2} \mathrm{SO}_{4}, \mathrm{~K}_{2} \mathrm{SO}_{4}$ e $\mathrm{MgSO}_{4}$, a $0,5 \mathrm{~mol}$, em várias combinações. Segundo esses autores, amostras parcialmente imersas em soluções, por um período contínuo e com volume catiônico constante, permitem a ascensão capilar, concentração por evaporação e cristalização de sais em uma estreita faixa do corpo-de-prova. Isso simularia situação em que as fundações e partes baixas de paredes de construções estariam na zona de ascensão capilar da água do solo e, conseqüentemente, expostas ao intemperismo salino.

Nesse estudo, ao menos em parte, os ensaios também simulam deteriorações, por eflorescências, de pisos térreos de edificações, assentados com argamassas (comum fonte de sulfato).

A contínua contribuição de soluções saturadas, a concentração e evaporação na área emersa, principalmente bordas e laterais dos corpos-de-prova, permitem a cristalização em poros menores e a geração de pressão suficiente para quebrar e destacar material rochoso.

De modo a permitir a comparação dos resultados obtidos nas duas situações de simulação, com $\mathrm{NaOH}$ a $1 \mathrm{~N}$ ( $\mathrm{pH}$ praticamente 14) e $\mathrm{H}_{2} \mathrm{SO}_{4}$ a $1 \%$ (pH próximo de 1), os principais resultados verificados após essas simulações acham-se na Tabela 6.40. 
Tabela 6.40 - Principais resultados da alteração por imersão parcial das rochas graníticas em soluções ácida e alcalina.

\begin{tabular}{|c|c|c|c|c|}
\hline \multirow{2}{*}{ ROCHA } & \multicolumn{4}{|c|}{ IMERSÃO PARCIAL } \\
\hline & $\mathrm{NaOH}$ & GRAU & $\mathrm{H}_{2} \mathrm{SO}_{4}$ & GRAU \\
\hline LBD & $\begin{array}{l}\text { - } \quad \text { sem modificações aparentes (Figura 6.80a); } \\
\text { - } \text { despegamentos pontuais (quartzo). }\end{array}$ & 2 & $\begin{array}{l}\text { - } \text { branqueamento da face imersa na solução, das laterais e } \pm 0,5 \mathrm{~cm} \text {, a } \\
\text { partir das bordas. Nessas áreas houve despegamento de biotita, que } \\
\text { carreou quartzo e/ou feldspatos próximos (Figura } 6.80 \mathrm{a} \text { ); } \\
\text { - } \text { área central dos corpos-de-prova praticamente inalteradas. }\end{array}$ & 3 \\
\hline VCB & - VCB-3: sem modificações aparentes. & 1 & $\begin{array}{l}\text { - } \text { VCB-3: núcleos praticamente inalterados; } \\
\text { - } \text { bordas (e laterais): despegamento de biotita e alteração (?) de } \\
\text { feldspatos. }\end{array}$ & 2 \\
\hline RIC & - sem modificações aparentes. & 1 & $\begin{array}{ll} & \text { núcleos inalterados; } \\
- & \text { bordas e laterais com algum clareamento e despegamento de biotita. }\end{array}$ & 2 \\
\hline BSV & - sem modificações aparentes. & 1 & $\begin{array}{l}\text { - } \begin{array}{l}\text { bordas e laterais modificadas (clareamento), com despegamento de } \\
\text { biotitas. }\end{array} \\
\end{array}$ & 2 \\
\hline BCR & - sem modificações aparentes. & 1 & $\begin{array}{l}\text { - } \text { clareamento de bordas e laterais; } \\
\text { - } \text { despegamento de biotita. }\end{array}$ & 2 \\
\hline $\begin{array}{l}\text { PIT } \\
(2 \text { e } 3 \\
\mathrm{cm})\end{array}$ & $\begin{array}{l}\text { - leve amarelamento (intensificação do já existente); } \\
\text { - } \text { bordas estão ligeiramente ásperas; } \\
\text { - } \text { corpos-de-prova com } 3 \mathrm{~cm} \text { estão mais amarelados que os } \\
\text { com } 2 \mathrm{~cm} \text {. Nos corpos-de-prova com } 3 \mathrm{~cm} \text { : amarelamento } \\
\text { decorre da "remobilização" de material (compostos químicos) } \\
\text { de pontos já alterados, que passa a impregnar fissuras em } \\
\text { quartzo e feldspatos, o que não foi observado nos corpos-de- } \\
\text { prova com } 2 \mathrm{~cm} \text {. }\end{array}$ & 3 & $\begin{array}{l}\text { - } \text { descoloração de biotita: laterais e face emersa (até } \pm 4 \mathrm{~cm} \text { das } \\
\text { bordas) } \\
\text { - } \\
\text { - } \\
\text { áreas centrais mais preservadas; } \\
\text { nas arestas e nas regiões próximas (Figura } \\
\text { - } \\
\text { corpos-de-prova com } 2 \mathrm{~cm} \text { : localmente há despegamento de } \\
\text { material em núcleos alterados de plagioclásio; também exibem } \\
\text { descoloração mais intensa da biotita (que praticamente só se } \\
\text { modificou próximo às arestas). }\end{array}$ & 3 \\
\hline AZF & - amarelamento próximo às bordas. & 2 & $\begin{array}{l}\text { - leve descoloração próxima às bordas e nas laterais; } \\
\text { - } \quad \text { escamações próximas às arestas; } \\
\text { Nota: modificações foram menos intensas que na PIT. }\end{array}$ & 2 \\
\hline BCE & - sem modificações aparentes. & 1 & $\begin{array}{l}\text { - sem modificações aparentes (a rocha parece ter ficado mais } \\
\text { cinzenta). }\end{array}$ & 1 \\
\hline
\end{tabular}

Nota: grau $\mathbf{1}$ = rochas visualmente inalteradas; grau $\mathbf{2}$ = rochas com modificações moderadas; grau $\mathbf{3}$ = rochas que exibiram maiores modificações. ${ }^{*}=$ imersão perpendicularmente aos planos de estruturação. 
continuação.

\begin{tabular}{|c|c|c|c|c|}
\hline \multirow{2}{*}{ ROCHA } & \multicolumn{4}{|c|}{ IMERSÃO PARCIAL } \\
\hline & $\mathrm{NaOH}$ & GRAU & $\mathrm{H}_{2} \mathrm{SO}_{4}$ & GRAU \\
\hline ITN-1 & $\begin{array}{l}\text { - sem modificações aparentes. Inicialmente apresentou } \\
\text { intenso manchamento amarelo ferruginoso, que } \\
\text { desapareceu ao final do ensaio (Figura 6.80b). }\end{array}$ & 2 & $\begin{array}{l}\text { - generalizada modificação de cor, para tonalidade ferrugem (Figura } \\
6.80 \mathrm{~b}) ; \\
\text { - } \\
\text { algum inchamento e despegamento de biotita nas bordas e próximo a } \\
\text { agregados de minerais máficos. }\end{array}$ & 3 \\
\hline ITN-2 & $\begin{array}{l}\text { - } \quad \text { sem modificações aparentes (idem ITN-1); } \\
\text { - } \quad \text { nota-se pontual oxidação de máficos. }\end{array}$ & 2 & $\begin{array}{l}\text { - generalizada modificação de cor, para tonalidade ferrugem; } \\
\text { - } \text { algum inchamento e destacamento nas bordas. }\end{array}$ & 3 \\
\hline CRV & $\begin{array}{l}\text { - leve amarelamento da rocha, que melhor se evidencia } \\
\text { nas áreas quartzo-feldspáticas } \\
\text { - } \quad \text { locais pontuações ferruginosas. }\end{array}$ & 3 & $\begin{array}{l}\text { - } \text { total branqueamento das bordas, com inchamento e despegamento } \\
\text { pervasivos (Figura } 6.81 \mathrm{a} \text { ); } \\
\text { - } \text { bordas: perdas de material com até } 1,0 \mathrm{~cm} \times 0,5 \mathrm{~cm} \text {; } \\
\text { - } \\
\text { cavidades na face emersa, em geral, são milimétricas, com até } 1 \mathrm{~mm} \text { de } \\
\text { profundidade; localmente chegam a } 0,5 \mathrm{~cm} \text { de "diâmetro", com } \pm 2 \mathrm{~mm} \\
\text { profundidade. }\end{array}$ & 3 \\
\hline CSB $^{\star}$ & $\begin{array}{l}\text { - sem modificações aparentes (sutil amarelamento nas } \\
\text { fissuras). }\end{array}$ & 1 & - inchamento (expansão) das biotitas e escamação nas bordas. & 1 \\
\hline FLS* & - sem modificações aparentes. & 1 & - sem modificações aparentes. & 1 \\
\hline $\mathbf{G V N}^{*}$ & $\begin{array}{l}\text { - sem modificações aparentes, exceto por alguns } \\
\text { destacamentos próximos às bordas. }\end{array}$ & 2 & $\begin{array}{l}\text { - } \quad \text { clareamento (descoloração) nas laterais, face imersa e bordas (até cerca } \\
\text { de } 2 \mathrm{~cm} \text { em direção ao centro); } \\
\text { - } \quad \text { áreas centrais, da face emersa, inalteradas; } \\
\text { - } \quad \text { alguma escamação e despegamentos (biotita); } \\
\text { - } \quad \text { nota-se pigmentação amarelada em fissuras superfície; } \\
\text { - } \quad \text { não houve inchamento como nas câmaras. }\end{array}$ & 2 \\
\hline ARB* $^{*}$ & - sem modificações aparentes. & 1 & $\begin{array}{l}\text { - } \text { descoloração de minerais nas bordas }( \pm 1-2 \mathrm{~cm} \text { ) e laterais (menos } \\
\text { intenso que na SCC); } \\
\text { - } \quad \text { nota-se inchamento segundo fissuras concordantes e oblíquas à } \\
\text { estruturação, com escamação ao longo destas (não só nas bordas como } \\
\text { na SCC) (Figura } 6.81 \mathrm{~b}) \text {; } \\
\text { - } \\
\text { face emersa tornou-se bastante áspera ao tato. }\end{array}$ & 2 \\
\hline $\mathrm{SCC}^{*}$ & $\begin{array}{l}\text { - } \begin{array}{l}\text { apesar de não se notar aspereza ao tato, visualmente } \\
\text { observam-se inchamentos (ou "craquelamento"). }\end{array} \\
\end{array}$ & 2 & $\begin{array}{l}\text { - } \quad \text { descoloração de minerais nas bordas e laterais (Figura 6.81c); } \\
\text { - } \text { inchamento em fissuras ou descontinuidades, segundo estruturação; } \\
\text { - }\end{array}$ & 3 \\
\hline
\end{tabular}


As degradações mais típicas observadas nas rochas graníticas em estudo, por imersão parcial em ácido sulfúrico, acham-se ilustradas nas Figuras 6.80 e 6.81 .

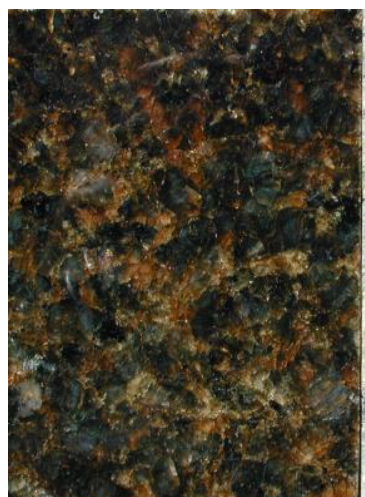

$\mathrm{NaOH}$

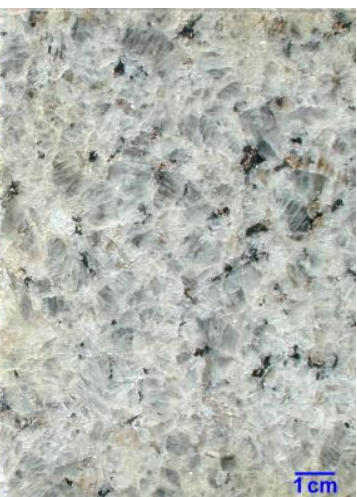

$\mathrm{H}_{2} \mathrm{SO}_{4}$

LBD

(a)

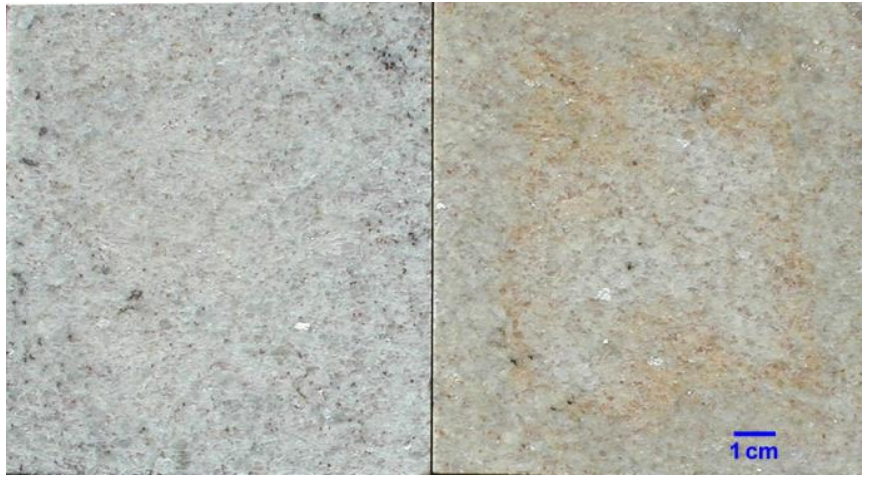

$\mathrm{NaOH}$

ITN-1

(b)

Figura 6.80 - Aspectos dos diferentes comportamentos das rochas após imersão parcial em soluções alcalina e ácida. LBD e ITN-1 não mostraram modificações aparentes, ao final do ensaio de imersão de $\mathrm{NaOH}$; enquanto exibiram intensa mudança de coloração após imersão em $\mathrm{H}_{2} \mathrm{SO}_{4}$.

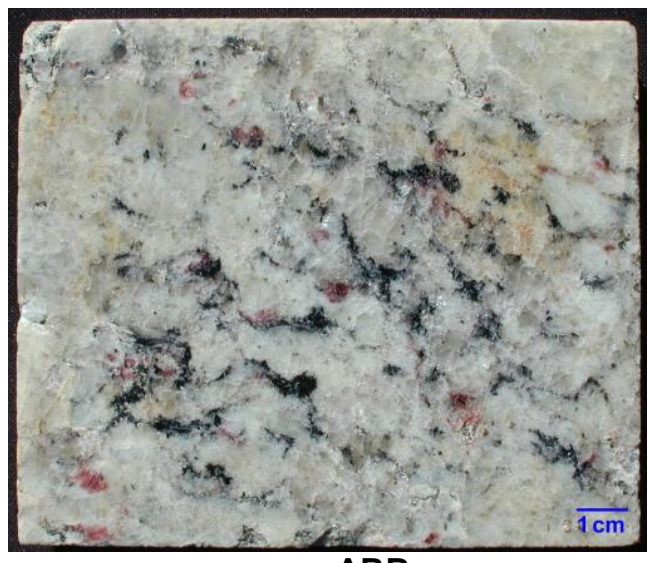

ARB

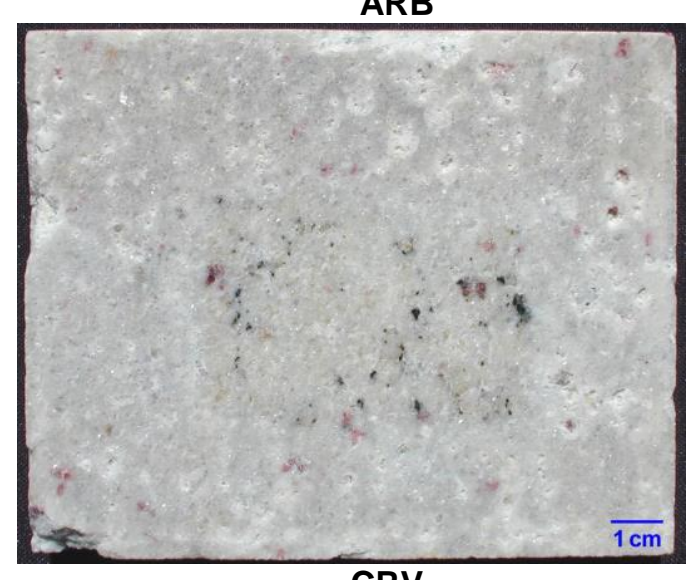

CRV a)

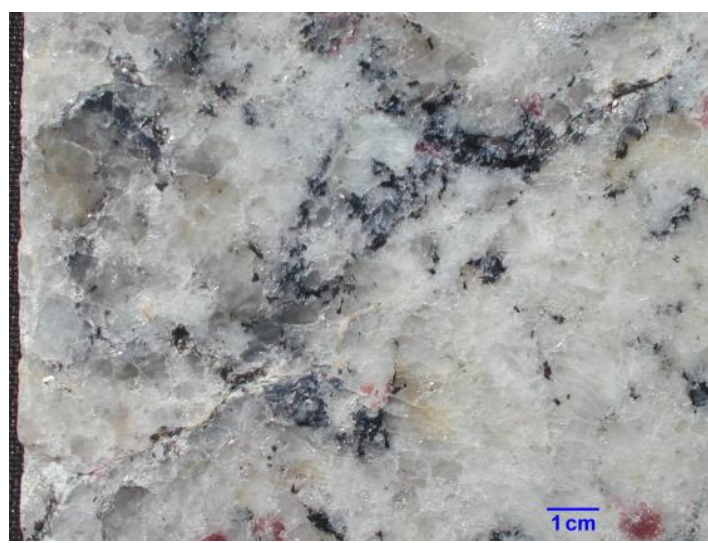

ARB - detalhe de alargamento de fissura

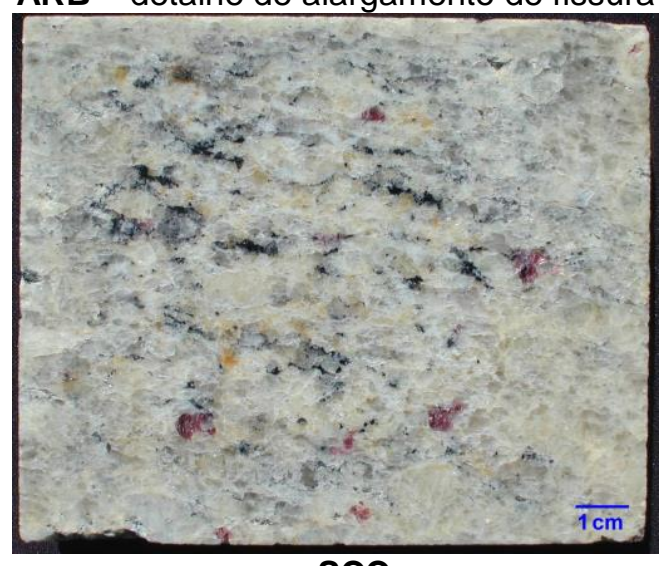

b) c)

Figura 6.81 - Aspectos resultantes da cristalização de sais (eflorescências e subeflorescências), após imersão parcial contínua em solução de ácido sulfúrico. Notar a formação de cavidade e quebra de arestas nas CRV e SCC. 


\subsubsection{Imersão parcial em ácido sulfúrico}

A seqüência das modificações observadas está sumariada na Tabela 6.41.

Tabela 6.41 - Principais modificações verificadas nos monitoramentos do ensaio de imersão parcial em ácido sulfúrico.

\begin{tabular}{|c|c|c|}
\hline $\begin{array}{c}\text { tempo de } \\
\text { ensaio }\end{array}$ & amostra & modificações \\
\hline 2o dia & - & Absorção total do reagente, exceto VCB e RIC. \\
\hline $4^{\circ}$ dia & GVN, ARB, SCC & Fissuras "brancas" por possíveis sais. \\
\hline \multirow{3}{*}{$5^{\circ}$ dia } & LBD & Clareamento da porção imersa. \\
\hline & ITN & Aparente oxidação de máficos. \\
\hline & CRV, ARB, SCC & Fissuras aparentemente exibindo inchamento. \\
\hline $12^{\circ}$ dia & - & $\begin{array}{l}\text { Todos os corpos-de-prova mostram eflorescências, especialmente } \\
\text { nas bordas, quinas e laterais. Destacam-se: CRV, PIT, BCR, BSV, } \\
\text { GVN, ARB, SCC. }\end{array}$ \\
\hline $14^{\circ}$ dia & - & Demais amostras passam a exibir conspícuas eflorescências. \\
\hline $30^{\circ}$ dia & BCE & Não exibiu eflorescências. \\
\hline
\end{tabular}

O mecanismo de degradação, conforme a seqüência de eventos descrita anteriormente, seria:

- ascensão da solução, por capilaridade, em todos os corpos-de-prova, com taxas diferentes, de acordo com aquelas observadas no ensaio de capilaridade;

- umedecimento, em todas as amostras, das bordas para o centro,

- concentração das soluções por evaporação, o que se tornou muito mais efetivo ao se desumidificar a sala de ensaio;

- ao se atingir a supersaturação, iniciou-se a cristalização de sais, formando eflorescências e prováveis subeflorescências, preferencialmente sobre biotita e máficos e também segundo os lineamentos ou descontinuidades;

- esses fenômenos ocorreram, em ordem de preferência: nos cantos, nas bordas e laterais dos corpos-de-prova (Figura 6.82). Não foram observadas eflorescências na área central da face emersa; 


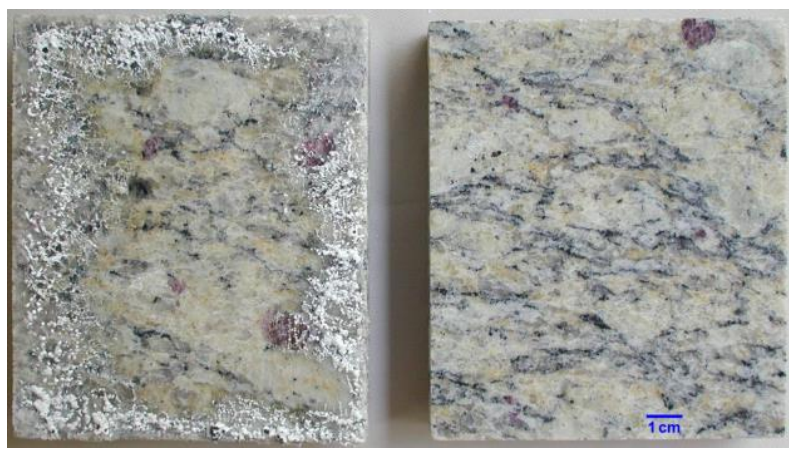

SCC

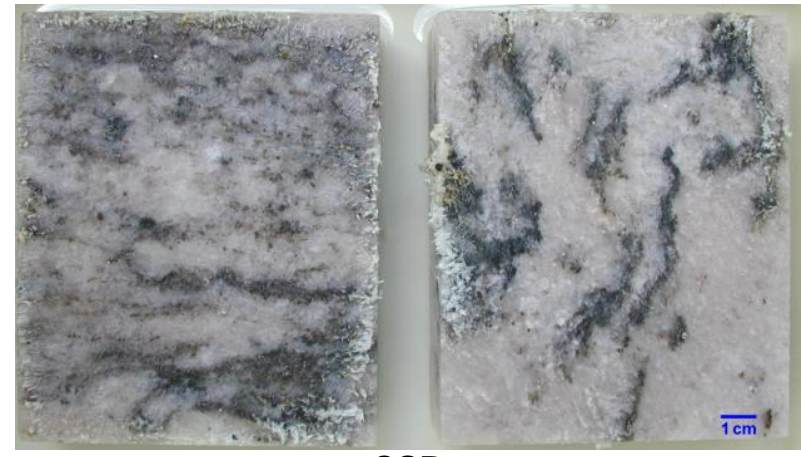

CSB

Figura 6.82 - Cristalização de sais nas bordas (SCC) e nos cantos (CSB), preferencialmente sobre biotita.

- até o final da permanência dos corpos-prova em imersão, não se observaram inchamentos ou escamação;

- as degradações nas rochas foram observadas, conforme descrito na Tab. 6.41, após o período de secagem, ou seja, após os corpos-de-prova permaneceram em sala desumidificada até sua total secagem.

$\mathrm{Na}$ Tabela 6.42 são descritos os aspectos das eflorescências formadas e as deteriorações observadas após secagem dos corpos-de-prova.

Tabela 6.42 - Descrição das eflorescências salinas resultantes do ensaio de imersão parcial em ácido sulfúrico e deteriorações observadas.

\begin{tabular}{|c|c|c|c|c|c|}
\hline & \multicolumn{4}{|c|}{ eflorescências } & \multirow{2}{*}{ deteriorações } \\
\hline & aspecto & quantidade & cor & locais & \\
\hline LBD & indistinto & abundante & verde-escuro & arestas e laterais & $\begin{array}{l}\text { escamação nas bordas } \\
\text { (biotita e feldspatos (?)) }\end{array}$ \\
\hline VCB-3 & $\begin{array}{c}\text { grumos em } \\
\text { biotita }\end{array}$ & moderada & $\begin{array}{c}\text { verde-claro a verde- } \\
\text { musgo }\end{array}$ & arestas e laterais & $\begin{array}{l}\text { escamação nas bordas } \\
\text { (biotita e feldspatos (?)) }\end{array}$ \\
\hline RIC & grumos & pouca & branco & bordas & $\begin{array}{c}\text { alguma escamação nas } \\
\text { bordas }\end{array}$ \\
\hline BSV & indistinto & $\begin{array}{l}\text { pouca a } \\
\text { moderada }\end{array}$ & $\begin{array}{c}\text { branco-esverdeado } \\
\text { a verde (sobre } \\
\text { biotita. fibrosos }\end{array}$ & $\begin{array}{l}\text { bordas } \\
(1 \mathrm{a} 2 \mathrm{~cm})\end{array}$ & $\begin{array}{c}\text { alguma escamação nas } \\
\text { bordas }\end{array}$ \\
\hline BCR & indistinto & $\begin{array}{l}\text { pouca a } \\
\text { moderada }\end{array}$ & $\begin{array}{c}\text { branco-esverdeado } \\
\text { a verde (sobre } \\
\text { biotita. fibrosos }\end{array}$ & $\begin{array}{l}\text { bordas } \\
(1 \mathrm{a} 2 \mathrm{~cm})\end{array}$ & $\begin{array}{c}\text { alguma escamação nas } \\
\text { bordas }\end{array}$ \\
\hline $\begin{array}{c}\text { PIT e } \\
\text { AZF } \\
(3 \mathrm{~cm})\end{array}$ & indistinto & $\begin{array}{l}\text { moderada a } \\
\text { abundante }\end{array}$ & $\begin{array}{l}\text { verde-amarelado } \\
\text { (AZF) e branco } \\
\text { esverdeado (PIT) }\end{array}$ & $\begin{array}{l}\text { arestas e bordas } \\
\qquad( \pm 1 \mathrm{~cm})\end{array}$ & $\begin{array}{l}\text { alguma escamação em } \\
\text { biotita, nas bordas }\end{array}$ \\
\hline $\begin{array}{c}\text { PIT } \\
(2 \mathrm{~cm})\end{array}$ & indistinto & moderada & branco-esverdeado & $\begin{array}{l}\text { arestas em direção } \\
\text { ao centro }\end{array}$ & $\begin{array}{c}\text { mais intensa que no } \\
\text { corpo-de-prova com } 3 \mathrm{~cm} \text {. }\end{array}$ \\
\hline BCE & indistinto & $\begin{array}{l}\text { praticamente } \\
\text { ausentes }\end{array}$ & transparentes & bordas & $\begin{array}{c}\text { sem modificações } \\
\text { aparentes }\end{array}$ \\
\hline $\begin{array}{l}\text { ITN-1 / } \\
\text { ITN-2 }\end{array}$ & indistinto & muito pouca & $\begin{array}{l}\text { transparentes a } \\
\text { esverdeados }\end{array}$ & bordas & $\begin{array}{l}\text { ITN-1: escamação nas } \\
\text { bordas (predomina em } \\
\text { biotita). } \\
\text { rocha ficou amarelada } \\
\text { (manchamento) }\end{array}$ \\
\hline
\end{tabular}




\begin{tabular}{|c|c|c|c|c|c|}
\hline & \multicolumn{4}{|c|}{ eflorescências } & \multirow{2}{*}{ deteriorações } \\
\hline & aspecto & quantidade & cor & locais & \\
\hline CRV & $\begin{array}{l}\text { grumos em } \\
\text { toda a face } \\
\text { emersa }\end{array}$ & moderada & branco & $\begin{array}{l}\text { bordas em direção } \\
\text { ao centro }\end{array}$ & $\begin{array}{c}\text { inchamento e descamação } \\
\text { na face polida, bordas e } \\
\text { laterais. Fissuramento nas } \\
\text { laterais (Figura 6.83). }\end{array}$ \\
\hline CSB & grumos & $\begin{array}{l}\text { pouca a } \\
\text { moderada }\end{array}$ & $\begin{array}{l}\text { branca a branco- } \\
\text { esverdeado. } \\
\text { fibrosos } \\
\end{array}$ & arestas e laterais & $\begin{array}{c}\text { escamação nas bordas } \\
\text { (preferencialmente em } \\
\text { biotita) }\end{array}$ \\
\hline FLS & grumos & $\begin{array}{l}\text { pouca a } \\
\text { moderada }\end{array}$ & $\begin{array}{l}\text { branco a branco } \\
\text { esverdeado. } \\
\text { fibrosos }\end{array}$ & $\begin{array}{l}\text { arestas e laterais } \\
\text { (grumos na área } \\
\text { central, ao fim do } \\
\text { ensaio) }\end{array}$ & $\begin{array}{l}\text { idem CSB, em menor } \\
\text { intensidade }\end{array}$ \\
\hline GVN & indistinto & pouca & $\begin{array}{l}\text { branco ou verde- } \\
\text { claro (biotita) }\end{array}$ & $\begin{array}{l}\text { laterais e bordas } \\
\qquad( \pm 1 \mathrm{~cm})\end{array}$ & $\begin{array}{l}\text { possível escamação nas } \\
\text { bordas }\end{array}$ \\
\hline ARB & grumos & moderada & verde-claro & $\begin{array}{l}\text { bordas } \\
( \pm 2 \mathrm{~cm})\end{array}$ & $\begin{array}{l}\text { inchamentos locais e } \\
\text { escamação das bordas } \\
\text { (biotita, granada e em } \\
\text { menor proporção, } \\
\text { feldspatos) }\end{array}$ \\
\hline SCC & grumos & $\begin{array}{l}\text { pouca a } \\
\text { moderada }\end{array}$ & verde-claro a branco & $\begin{array}{l}\text { bordas para o } \\
\text { centro } \\
( \pm 2 \text { a } 3 \mathrm{~cm}) \\
\end{array}$ & $\begin{array}{c}\text { inchamento e escamação } \\
\text { nas bordas. }\end{array}$ \\
\hline
\end{tabular}

Nota: biotita foi freqüentemente despegada durante a cristalização dos sais.
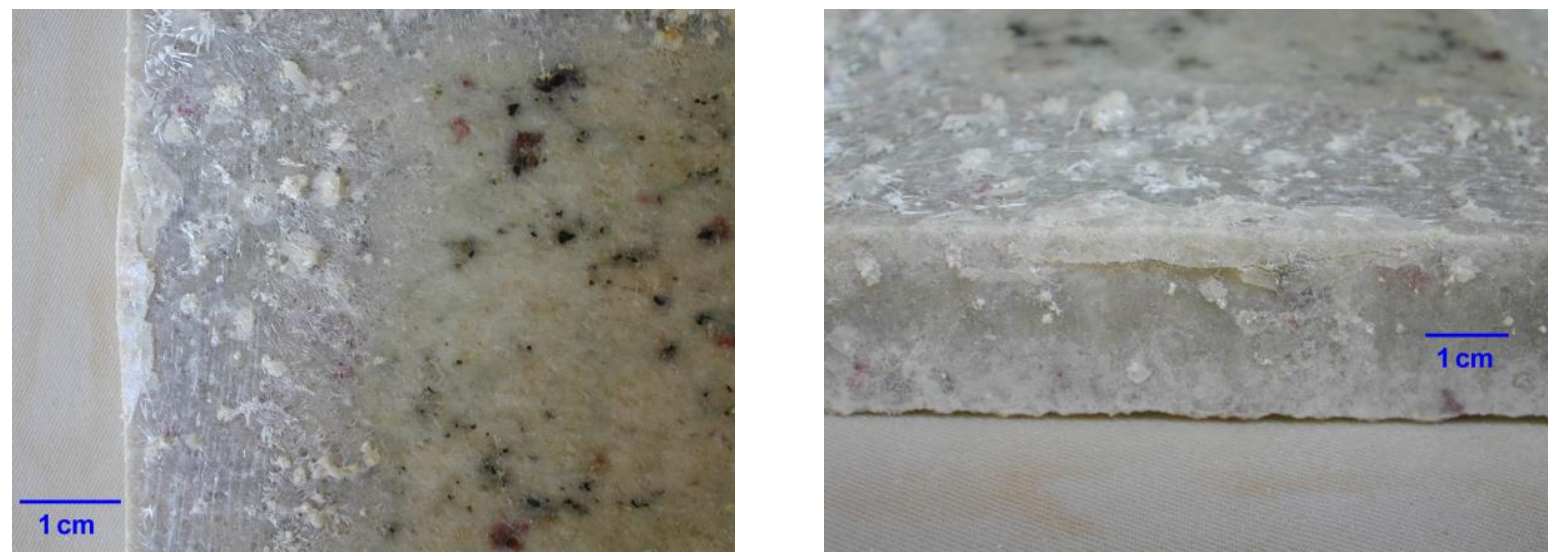

Figura 6.83 - Aspecto da quebra de arestas dos corpos-de-prova da amostra CRV, em decorrência da pressão de expansão dos sais em descontinuidades e, provavelmente, nos espaços intergranulares originalmente ocupados por argilominerais de alteração.

A Figura 6.84 ilustra os aspectos das eflorescências formadas durante o ensaio de imersão parcial em ácido sulfúrico. 


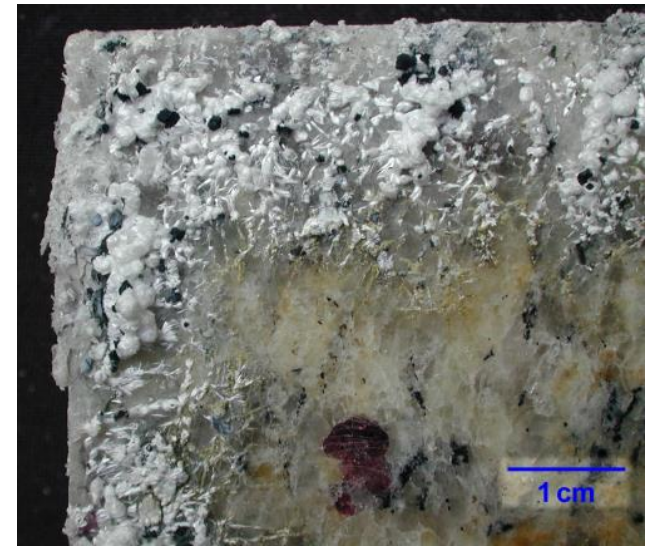

SCC

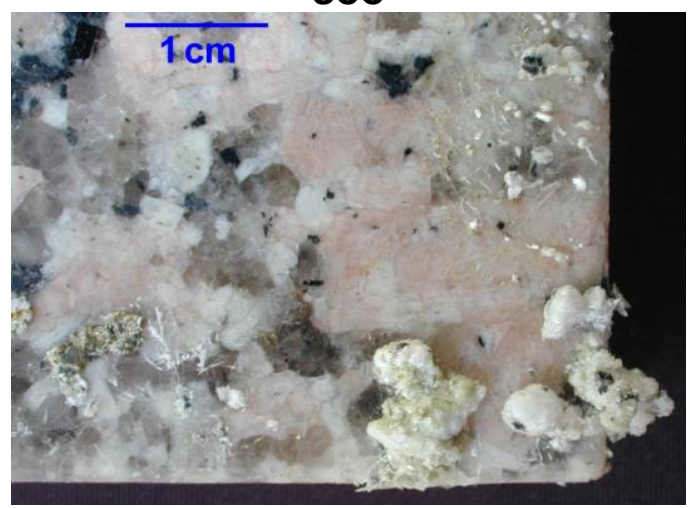

RIC

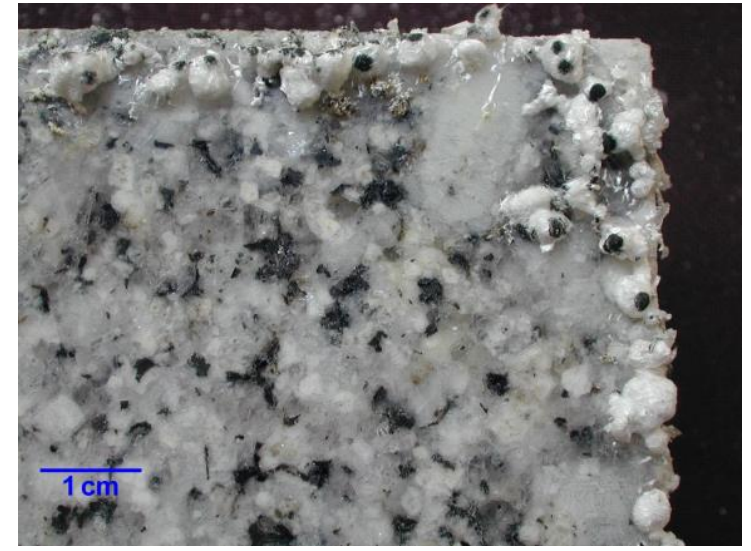

AZF

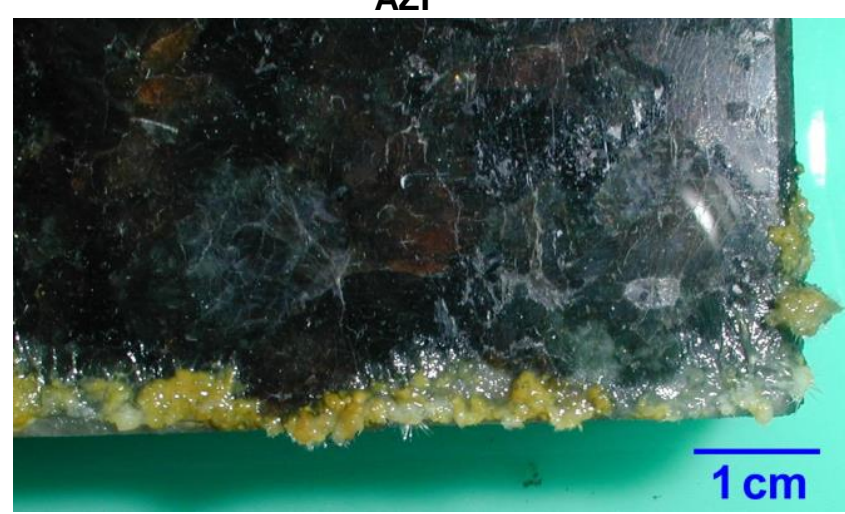

LBD

Figura 6.84 - Diferentes aspectos das eflorescências formadas por imersão parcial em ácido sulfúrico. Amostra AZF: notar despegamento de lamelas de biotita, que ficam aderidas na superfície dos grumos de sais.

Uma porção representativa dos sais formados foi submetida à difração de raios X. A Tabela 6.43 mostra os resultados obtidos com porcentagens semiquantificadas pelas áreas relativas dos picos de difração. Os principais produtos foram sulfatos resultantes da reação entre $\mathrm{H}_{2} \mathrm{SO}_{4}$ e os minerais constituintes. 
Tabela 6.43 - Tipos de sais que compõem as eflorescências formadas por imersão parcial em ácido sulfúrico.

\begin{tabular}{|c|c|c|c|c|c|}
\hline \multirow{2}{*}{ amostra } & \multicolumn{5}{|c|}{ sais (\%) } \\
\hline & Al & Vo & $\mathbf{K i}$ & Me & Po \\
\hline LBD & $5-10$ & $10-15$ & & & 80 \\
\hline VCB-3 & 100 & & & & \\
\hline RIC & $45-50$ & $20-25$ & $25-30$ & & \\
\hline BSV & 45 & $20-25$ & $30-35$ & & \\
\hline BCR & $30-35$ & 50 & $15-20$ & & \\
\hline PIT & $15-20$ & 45 & $35-40$ & & \\
\hline AZF & & $55-60$ & $40-45$ & & \\
\hline BCE & $90-95$ & $5-10$ & & & \\
\hline ITN-2 & 10 & $15-20$ & $70-75$ & & \\
\hline ITN-1 (verde) & $50-55$ & & & $45-50$ & \\
\hline ITN-1 (escuro) & & & & 100 & \\
\hline CRV & 100 & & & & \\
\hline CSB (parte branca) & 45 & $30-35$ & $20-25$ & & \\
\hline CSB (parte cinzenta) & 30 & $45-50$ & $20-25$ & & \\
\hline FLS & $60-65$ & $35-40$ & & & \\
\hline GVN (branco) & $50-55$ & $45-50$ & & & \\
\hline GVN (verde) & $65-70$ & $30-35$ & & & \\
\hline ARB & $25-30$ & $65-70$ & 5 & & \\
\hline SCC & $25-30$ & $70-75$ & & & \\
\hline
\end{tabular}

\section{Nota:}

- $\mathrm{Al}=$ alunogen $\left(\mathrm{Al}_{2}\left(\mathrm{SO}_{4}\right)_{3} \cdot 16 \mathrm{H}_{2} \mathrm{O}\right) ; \mathrm{Vo}=$ voltaita $\left(\mathrm{K}_{2} \mathrm{Fe}_{5}{ }^{2+} \mathrm{Fe}_{4}{ }^{3+}\left(\mathrm{SO}_{4}\right)_{12} \cdot 18 \mathrm{H}_{2} \mathrm{O}\right) ; \mathrm{Ki}=$ kieserita $\left(\mathrm{MgSO}_{4} \cdot \mathrm{H}_{2} \mathrm{O}\right) ; \mathrm{Me}=$ melanterita $\left(\mathrm{FeSO}_{4} \cdot 7 \mathrm{H}_{2} \mathrm{O}\right) ; \mathrm{Po}=$ poitevinita $(\mathrm{Cu}, \mathrm{Fe}, \mathrm{Zn}) \mathrm{SO}_{4} \cdot \mathrm{H}_{2} \mathrm{O}$.

- As porcentagens apresentadas são relativas aos sais cristalizados em cada amostra.

A formação desses sais pode ser inferida pela comparação entre as composições químicas dos sais e a composição mineralógica dos principais minerais formadores, integrada com as observações listadas anteriormente:

- alunogen: pela interação com silicatos de alumínio, especialmente argilominerais de alteração (caulinita - $\mathrm{Al}_{4} \mathrm{Si}_{4} \mathrm{O}_{10}(\mathrm{OH})_{8}$ ou illita $\left.\mathrm{K}_{1-1,5} \mathrm{Al}_{4}\left(\mathrm{Si}_{7-6,5} \mathrm{Al}_{1-1,5} \mathrm{O}_{20}(\mathrm{OH})_{4}\right)\right)$;

- kieserita e voltaita: formados por reações variadas com biotita $\left(\mathrm{K}(\mathrm{Mg}, \mathrm{Fe})_{3}\left(\mathrm{AlSi}_{3} \mathrm{O}_{10}\right)(\mathrm{OH})_{2}\right)$ e possíveis produtos de sua alteração intempérica;

- melanterita: detectado unicamente nas ITN, provavelmente resultante da reação do ácido sulfúrico com sulfetos presentes nessas rochas;

- poitevinita: identificado na LBD. Pode ser resultante da reação do ácido com minerais máficos e opacos.

$\mathrm{Na}$ Tabela 6.44 são apresentadas as principais modificações microscópicas observadas em lâminas delgadas de amostras selecionadas. 
Tabela 6.44 - Principais modificações em amostras selecionadas submetidas à imersão parcial em ácido sulfúrico.

\begin{tabular}{|c|c|c|}
\hline Amostra & deterioração & observação ao microscópio óptico \\
\hline LBD & $\begin{array}{l}\text { - branqueamento da face } \\
\text { imersa; } \\
\text { _ despegamento de biotita. }\end{array}$ & $\begin{array}{l}\text { - provável lixiviação de hidróxidos de ferro de } \\
\text { preenchimento de microfissuras; } \\
\text { - despegamento de quartzo e feldspatos. }\end{array}$ \\
\hline BSV & $\begin{array}{l}\text { - bordas e laterais com } \\
\text { clareamento e } \\
\text { despegamento de biotita. }\end{array}$ & $\begin{array}{l}\text { - lixiviação (?) ou oxidação (?) de biotita, que passa a } \\
\text { apresentar lamelas descoloridas; } \\
\text { - } \text { cavidades em biotita, segundo as lamelas; } \\
\text { - } \text { aparente diminuição de hidróxidos de ferro em fissuras. }\end{array}$ \\
\hline PIT & $\begin{array}{l}\text { - descoloração de biotita; } \\
\text { - despegamento de biotita } \\
\text { e quartzo/feldspato. }\end{array}$ & $\begin{array}{l}\text { - lixiviação (?) ou oxidação (?) de biotita, que passa a } \\
\text { apresentar lamelas descoloridas; } \\
\text { - cavidades em biotita, segundo as lamelas. }\end{array}$ \\
\hline ITN-2 & $\begin{array}{l}\text { - generalizado surgimento } \\
\text { de tonalidade ferrugem; } \\
\text { - inchamento e } \\
\text { despegamento nas } \\
\text { bordas. }\end{array}$ & $\begin{array}{l}\text { - intensificação da turvação de feldspatos; } \\
\text { - } \text { aparecimento de hidróxidos de ferro em fissuras e os } \\
\text { agregados de alteração (Figura 6.85) }\end{array}$ \\
\hline CRV & $\begin{array}{l}\text { total branqueamento das } \\
\text { bordas, com inchamento } \\
\text { e despegamento } \\
\text { pervasivos. }\end{array}$ & $\begin{array}{l}\text { - perda (despegamento) dos minerais de alteração } \\
\text { presentes nos espaços intergranulares (Figura 6.86). }\end{array}$ \\
\hline CSB & $\begin{array}{l}\text { - inchamento de biotitas e } \\
\text { escamação nas bordas. }\end{array}$ & $\begin{array}{l}\text { - } \text { forte descoloração de lamelas de biotita; } \\
\text { - } \text { despegamento de parte de lamelas de biotita. }\end{array}$ \\
\hline GVN & $\begin{array}{l}\text { - } \text { clareamento nas laterais, } \\
\text { face imersa e bordas; } \\
\text { - escamação e } \\
\text { despegamentos (biotita). }\end{array}$ & $\begin{array}{l}\text { - minerais acham-se mais límpidos, por provável lixiviação } \\
\text { de ferro associados às microfissuras } \\
\text { - carbonato de alteração não foi removido }\end{array}$ \\
\hline ARB & $\begin{array}{l}\text { - descoloração de minerais } \\
\text { nas bordas e laterais; } \\
\text { - inchamento segundo } \\
\text { fissuras. }\end{array}$ & $\begin{array}{l}\text { - minerais acham-se mais límpidos, por provável lixiviação } \\
\text { de ferro associados às microfissuras } \\
\text { - } \text { despegamento segundo filetes de sillimanita (Figura } \\
\text { 6.87); } \\
\text { - } \\
\text { aparente lixiviação de ferro segundo lamelas em biotita e } \\
\text { local despegamento }\end{array}$ \\
\hline ScC & $\begin{array}{l}\text { - } \text { descoloração de } \\
\text { minerais; } \\
\text { - } \text { inchamento em fissuras } \\
\text { ou descontinuidades; } \\
\text { - } \\
\text { escamação nas bordas e } \\
\text { granadas. }\end{array}$ & $\begin{array}{l}\text { - impressão visual de que os cristais estão mais límpidos, } \\
\text { sugerindo lixiviação dos hidróxidos de ferro das fissuras; } \\
\text { - } \text { despegamento de granada, segundo fraturas, e de biotita } \\
\text { (Figura 6.88); } \\
\text { - } \text { alteração de biotita (perda de ferro). }\end{array}$ \\
\hline
\end{tabular}



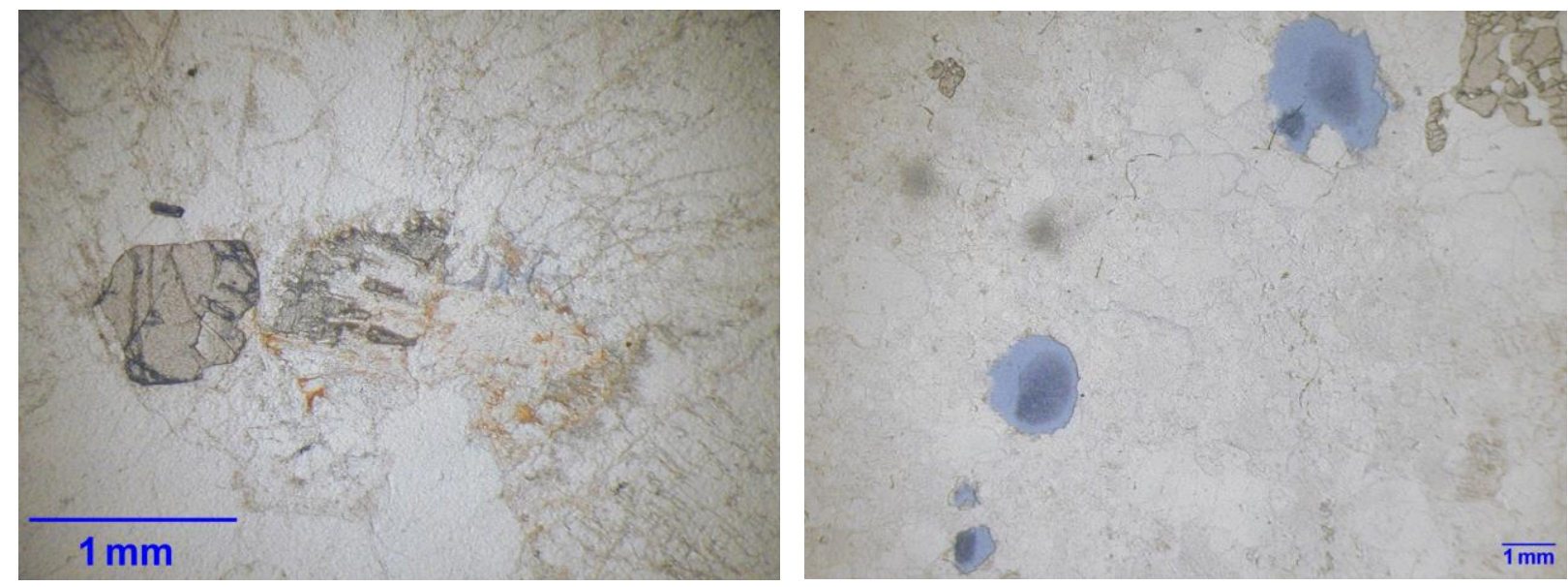

polarizadores paralelos.

polarizadores paralelos.

Figura 6.85 - Amostra ITN-2. Leve oxidação Figura 6.86-Amostra CRV. Despegamento dos argilominerais intersticiais e pequenas dos argilominerais intersticiais, de alteração. perdas de materiais próximos.
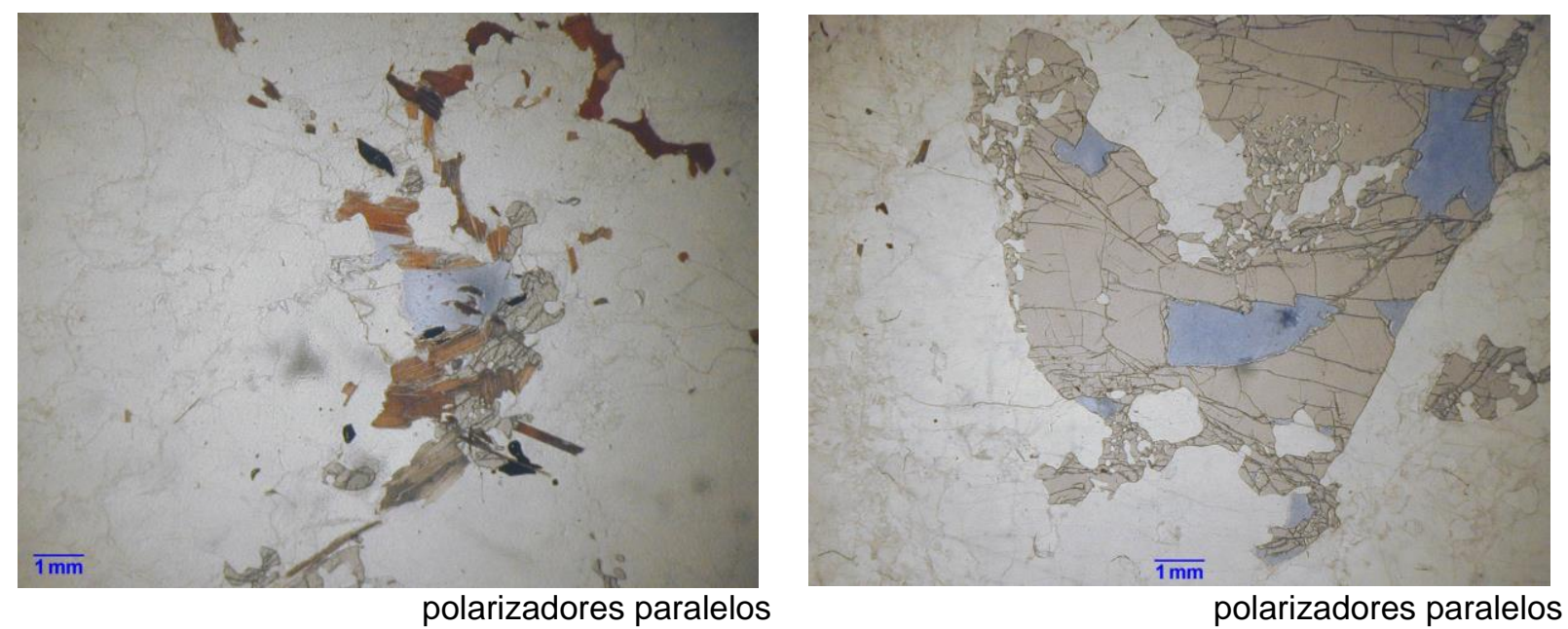

Figura 6.87 - Amostra ARB. Despegamento Figura 6.88-Amostra SCC. Despegamentos de biotita e "clareamento" dos materiais de em cristais de granada. preenchimento de microfissuras.

\subsubsection{Imersão parcial em hidróxido de sódio}

A seqüência das modificações observadas está sumariada na Tabela 6.45

A imersão em hidróxido de sódio praticamente não resultou em degradação das áreas emersas da rocha. Os sais se cristalizaram como crostas sobre a rocha (Figura 6.89) e, ao serem removidos, após o período de secagem (30 dias em sala desumifidicada), não se verificaram modificações notáveis. 
Tabela 6.45 - Principais modificações verificadas nos monitoramentos do ensaio de imersão parcial em hidróxido de sódio.

\begin{tabular}{|c|c|}
\hline tempo de ensaio & modificações \\
\hline 2o dia & $\begin{array}{l}\text { Amostras ainda sem sais: LBD, RIC, PIT }(3 \mathrm{~cm}) \text {, BCR, BSV e ARB. ITN } \\
\text { tem pouco sais, mas apresenta modificação de cor: ITN-1 } \\
\text { (manchamento no centro), ITN-2 (auréola amarelada). }\end{array}$ \\
\hline 3 dia & Houve solubilização dos sais. ITNs continuam a manchar. \\
\hline 5 dia & $\begin{array}{l}\text { GVN: máficos esbranquiçados. } \\
\text { CRV: oxidação de máficos. } \\
\text { PIT: leve amarelamento. } \\
\text { ITN: manchamento ferruginoso está mais escuro. }\end{array}$ \\
\hline 6\% dia & Mudança para sala desumidificada. Inicio da cristalização de sais \\
\hline 8 dia & $\begin{array}{l}\text { Formação de sais, como crostas (aspecto de flocos de algodão), nas } \\
\text { laterais dos corpos-de-prova com } 3 \mathrm{~cm} \text {. Naqueles com } 2 \mathrm{~cm} \text { há } \\
\text { tendência a se cristalizarem também na face emersa. }\end{array}$ \\
\hline $14^{\circ}$ dia & Continuidade da cristalização de sais. Início do clareamento das ITN. \\
\hline $26^{\circ}$ dia & ITNs sem manchamento, com retorno à cor original. \\
\hline
\end{tabular}

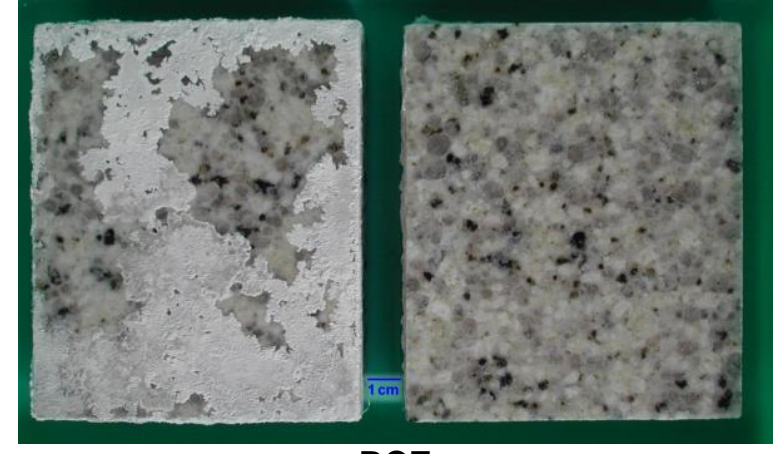

BCE

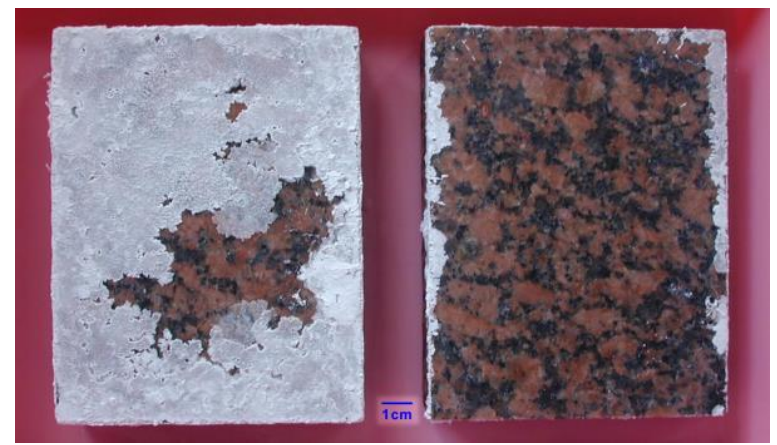

VCB-3

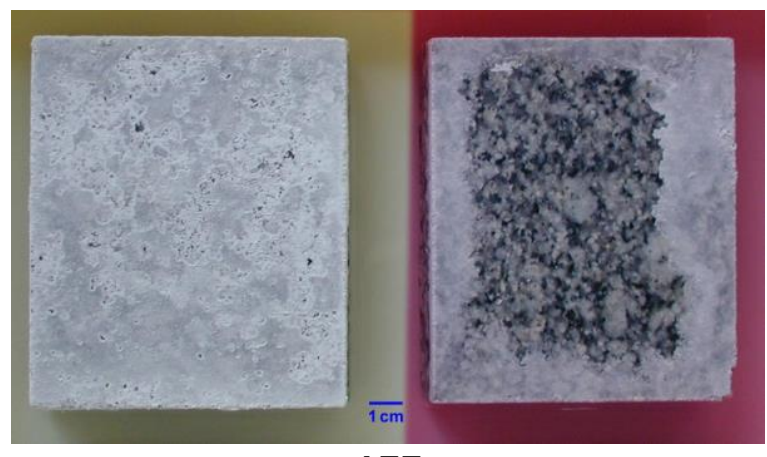

AZF

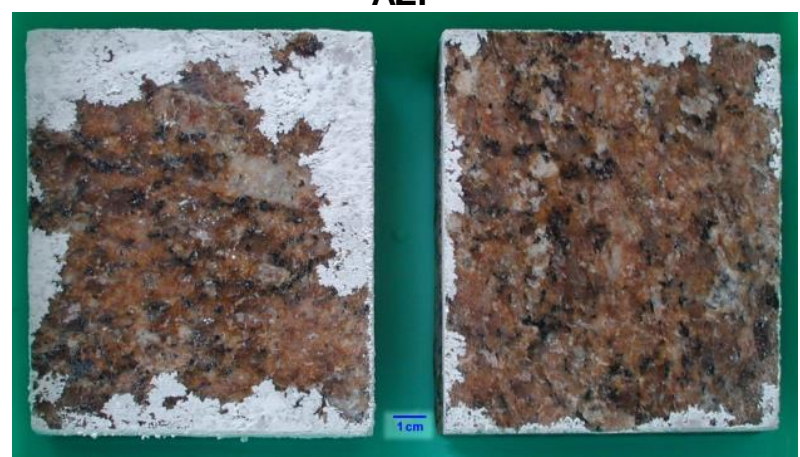

GVN

Figura 6.89 - Aspectos da cristalização salina, em crostas, sobre os corpos-de-prova parcialmente imersos em solução alcalina. Os corpos-de-prova à direita foram lavados periodicamente, durante o ensaio, para melhor observação dos possíveis efeitos. Aqueles à esquerda deixaram de ser lavados cerca de 15 dias após o inicio dos ensaios.

Ressalta-se o comportamento anômalo das amostras ITN-1 e ITN-2 que, logo no início do ensaio, apresentaram intenso manchamento amarelo ferruginoso na área central da face emersa (Figura 6.90). Entretanto, surpreendentemente, cerca de 14 dias após seu aparecimento, começou a ocorrer a atenuação da coloração ferruginosa, com total desaparecimento cerca de 10 dias depois (30 dias do início do ensaio). 


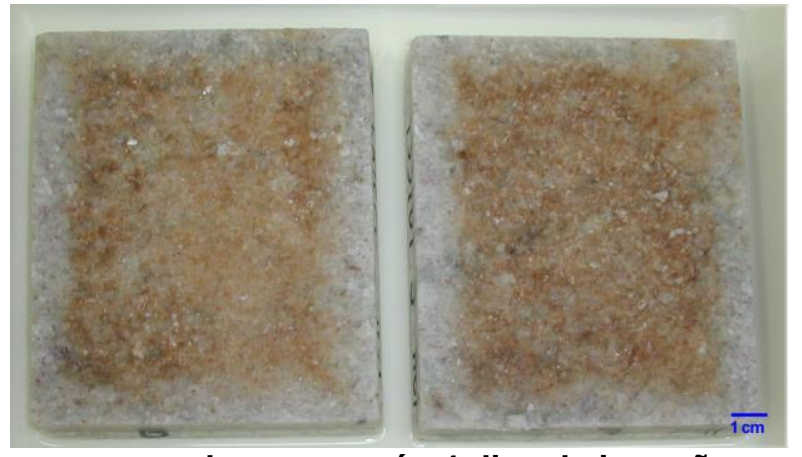

corpos-de-prova após 4 dias de imersão

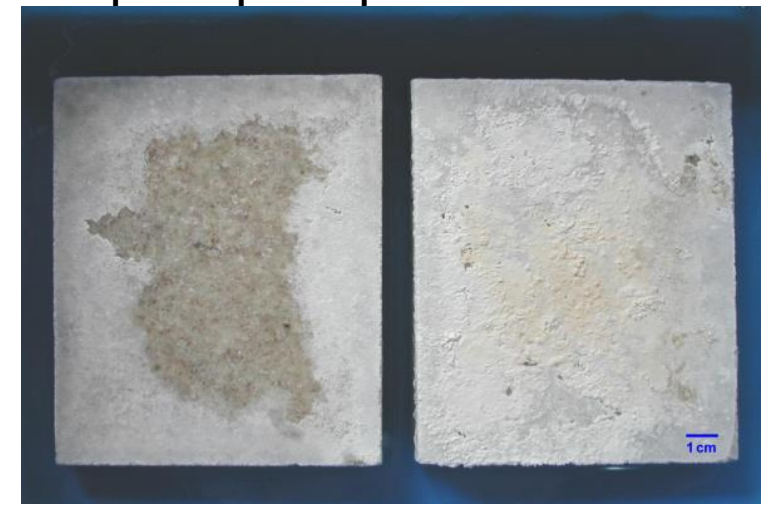

corpos-de-prova após 30 dias de imersão

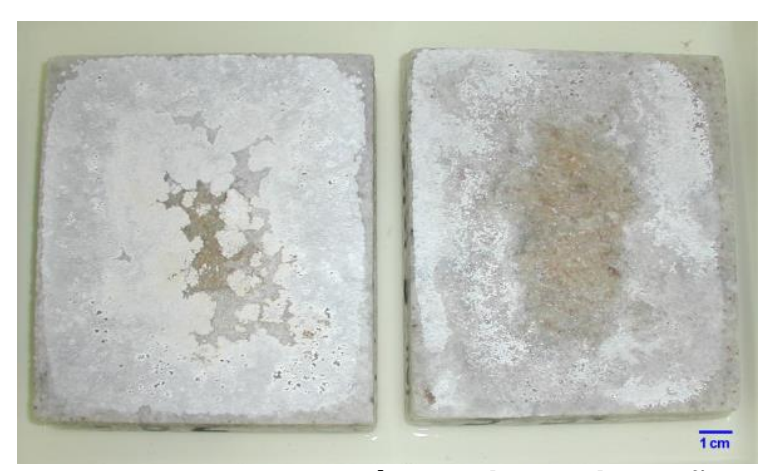

corpos-de-prova após 15 dias de imersão

Figura 6.90 - Amostra ITN-2. Evolução do manchamento amarelo ferruginoso, desde seu aparecimento (dois dias após a imersão), o inicio de seu retorno à cor original e ao final, já sem aparentar a modificações de cor.

Os sais formados foram termonatrita $\left(\mathrm{Na}_{2} \mathrm{CO}_{3} \cdot \mathrm{H}_{2} \mathrm{O}\right)$ e aphthitalita $\left(\mathrm{K}_{3} \mathrm{Na}\left(\mathrm{SO}_{4}\right)_{2}\right)$, conforme Tabela 6.46. Como não foram observadas deteriorações nas rochas, considerou-se que os tipos de sais formados são preferencialmente relativos à interação do reagente $(\mathrm{NaOH}) \mathrm{com}$ o meio ambiente.

Tabela 6.46 - Sais cristalizados, em crostas, nas amostras submetidas à imersão parcial em solução alcalina.

\begin{tabular}{ccc}
\hline \multirow{2}{*}{ Amostra } & \multicolumn{1}{c}{ Sais $^{*}$} & Ap \\
\cline { 2 - 3 } & Tn & - \\
\hline LBD & 100 & - \\
\hline VCB-3 & 100 & 50 \\
\hline RIC & 50 & $35-40$ \\
\hline BSV & $60-65$ & - \\
\hline BCR & 100 & - \\
\hline PIT & 100 & - \\
\hline AZF & 100 & - \\
\hline BCE & 100 & $<5$ \\
\hline ITN-1 & $>95$ & -10 \\
\hline ITN-2 & $90-95$ & - \\
\hline CVR & 100 & 20 \\
\hline CSB & 100 & $5-10$ \\
\hline FLS & 80 & 55 \\
\hline GVN & $90-95$ & $10-15$ \\
\hline ARB & 45 &
\end{tabular}

Nota: $\mathrm{Tn}=$ termonatrita $\left(\mathrm{Na}_{2} \mathrm{CO}_{3} \cdot \mathrm{H}_{2} \mathrm{O}\right) ; \mathrm{Ap}=$ aphtitalita $\left(\mathrm{K}_{3} \mathrm{Na}\left(\mathrm{SO}_{4}\right)_{2}\right)$.

* porcentagens estimadas pelas áreas principais dos picos de difração. 


\subsubsection{Ensaios de controle}

A verificação de modificações resultantes de ensaio de alteração acelerada foi feita visualmente e também por determinações de parâmetros físicos e/ou mecânicos. Dadas as dimensões definidas para os corpos-de-prova destinados aos ensaios de imersão parcial, não puderam ser realizados ensaios mecânicos. As degradações foram, então, controladas por determinações de massa e absorção d'água, e de velocidade de propagação de ondas antes e após os ensaios (Tabela 6.47).

Tabela 6.47 - Variações de velocidade de propagação de ondas após ensaios de imersão parcial.

\begin{tabular}{|c|c|c|c|}
\hline \multirow{2}{*}{ amostra } & \multicolumn{2}{|c|}{ VP } & \multirow{2}{*}{$\Delta_{\mathrm{VP}}$} \\
\hline & antes & depois & \\
\hline LBD & $\begin{array}{c}3.348 \pm 253 \\
(7,5)\end{array}$ & $\begin{array}{c}4.602 \pm 132 \\
(2,9)\end{array}$ & 37 \\
\hline VCB-3 & $\begin{array}{c}5.003 \pm 68 \\
(1,4)\end{array}$ & $\begin{array}{c}5.233 \pm 84 \\
(1,6)\end{array}$ & 5 \\
\hline RIC & $\begin{array}{c}4.167 \pm 166 \\
(4,0)\end{array}$ & $\begin{array}{c}4.689 \pm 232 \\
(4,9)\end{array}$ & 13 \\
\hline BCR & $\begin{array}{c}3.590 \pm 339 \\
(9,4)\end{array}$ & $\begin{array}{c}4.553 \pm 180 \\
(4,0)\end{array}$ & 27 \\
\hline BSV & $\begin{array}{c}3.603 \pm 110 \\
(3,0)\end{array}$ & $\begin{array}{c}4.588 \pm 135 \\
(3,0)\end{array}$ & 27 \\
\hline $\mathrm{PIT}-2 \mathrm{~cm}$ & $\begin{array}{c}4.506 \pm 58 \\
(1,3)\end{array}$ & $\begin{array}{c}4.898 \pm 97 \\
(2,0)\end{array}$ & 9 \\
\hline PIT - $3 \mathrm{~cm}$ & $\begin{array}{c}4.343 \pm 144 \\
(3,3)\end{array}$ & $\begin{array}{c}4.833 \pm 77 \\
(1,6)\end{array}$ & 11 \\
\hline AZF & $\begin{array}{c}4.188 \pm 135 \\
(3,2)\end{array}$ & $\begin{array}{c}4.657 \pm 131 \\
(2,8)\end{array}$ & 11 \\
\hline BCE & $\begin{array}{c}4.821 \pm 96 \\
(2,0)\end{array}$ & $\begin{array}{c}5.051 \pm 51 \\
(1,0)\end{array}$ & 5 \\
\hline ITN-1 & $\begin{array}{c}3.747 \pm 192 \\
(5,1)\end{array}$ & $\begin{array}{c}4.513 \pm 237 \\
(5,2)\end{array}$ & 20 \\
\hline ITN-2 & $\begin{array}{c}3.823 \pm 233 \\
(6,1)\end{array}$ & $\begin{array}{c}4.683 \pm 110 \\
(2,3)\end{array}$ & 23 \\
\hline CRV & $\begin{array}{c}4.515 \pm 105 \\
(2,3)\end{array}$ & $\begin{array}{c}4.923 \pm 87 \\
(1,8)\end{array}$ & 9 \\
\hline CSB & $\begin{array}{c}3.248 \pm 290 \\
(8,9)\end{array}$ & $\begin{array}{c}4.041 \pm 309 \\
(7,6)\end{array}$ & 24 \\
\hline FLS & $\begin{array}{c}3.399 \pm 336 \\
(9,9)\end{array}$ & $\begin{array}{c}4.039 \pm 327 \\
(8,1)\end{array}$ & 19 \\
\hline GVN & $\begin{array}{c}4.205 \pm 75 \\
(1,8)\end{array}$ & $\begin{array}{c}4.772 \pm 220 \\
(4,6)\end{array}$ & 13 \\
\hline ARB & $\begin{array}{c}4.058 \pm 239 \\
(5,9)\end{array}$ & $\begin{array}{c}4.680 \pm 278 \\
(6,0)\end{array}$ & 15 \\
\hline scc & $\begin{array}{c}4.694 \pm 126 \\
(2,7)\end{array}$ & $\begin{array}{c}4.876 \pm 266 \\
(5,5)\end{array}$ & 4 \\
\hline
\end{tabular}

Nota: $V P=$ velocidade de propagação de ondas; $\Delta_{\mathrm{VP}}=$ variação da velocidade de propagação de ondas após ensaios de imersão parcial em soluções ácida e alcalina. 
As variações de velocidade de propagação de ondas obtidas foram todas positivas o que a princípio indica um "aumento" da coesão da rocha, no caso, por possível cristalização de sais em descontinuidades do interior dos corpos-de-prova.

As variações de massa e de absorção d'água (Tabela 6.48) foram muito irregulares. Na sua maioria, indicaram incipiente modificação da massa e diminuição da absorção d'água, o que aparentemente não condiz com as modificações observadas, especialmente por imersão parcial em ácido sulfúrico, que chegou a causar graves danos à região emersa, em algumas rochas.

Mais uma vez, os dados apontam para uma provável cristalização de sais no interior da rocha, que "mascara" as perdas de massa e o aumento de absorção d'água.

De qualquer forma, na Tab. 6.48 pode ser verificada a perda de massa por imersão parcial nas soluções químicas utilizadas, muito mais perceptível nas situações de imersão em ácido sulfúrico.

Quanto às variações de absorção d'água, as rochas parcialmente imersas em hidróxido de sódio exibiram diminuição da absorção, em geral, entre 15\% e 35\%, o que também pode ser entendido como a presença de sais em poros e descontinuidades anteriormente acessíveis à água.

As modificações de absorção d'água das rochas que foram parcialmente imersas em ácido sulfúrico foram muito irregulares, com a maioria exibindo diminuição de absorção, mas algumas delas aumento (LBD, SCC e RIC). Também não é observada correspondência com os resultados para imersão em hidróxido de sódio.

Segundo Perry; Duffy (1997), os sais cristalizam tanto de soluções saturadas como insaturadas que estejam no interior dos espaços porosos da rocha. A precipitação de sais a partir de soluções insaturadas, como no caso de evaporação do solvente, não resulta na atuação de tensões na rocha; mas pode resultar no bloqueio de poros e redução da permeabilidade da rocha, levando ao aprisionamento da água e aceleração da degradação devido à dissolução interna da rocha.

Aparentemente, esse fenômeno justifica os dados obtidos e corrobora a interpretação de que ambas simulações levaram à cristalização de sais no interior da rocha, que não foram detectados visualmente ou por microscopia óptica, mas indicados nas determinações de velocidade de propagação de ondas e absorção d'água. 
Tabela 6.48 - Variações de massa e de absorção d'água, após ensaios de imersão parcial.

\begin{tabular}{|c|c|c|c|c|}
\hline & \multicolumn{2}{|c|}{$\Delta_{\text {massa }}(\%)$} & \multicolumn{2}{|c|}{$\Delta_{\text {absorção }}(\%)$} \\
\hline & $\mathrm{NaOH}$ & $\mathrm{H}_{2} \mathrm{SO}_{4}$ & $\mathrm{NaOH}$ & $\mathrm{H}_{2} \mathrm{SO}_{4}$ \\
\hline \multirow{2}{*}{ LBD } & 0,01 & $-0,40$ & $-6,0$ & 25,6 \\
\hline & 0,06 & $-0,40$ & $-11,7$ & 17,2 \\
\hline \multirow{2}{*}{ VCB-3 } & 0,03 & $-0,21$ & $-33,4$ & 0,2 \\
\hline & 0,02 & $-0,19$ & $-33,4$ & 0,2 \\
\hline \multirow{2}{*}{ RIC } & 0,00 & $-0,14$ & $-12,8$ & 6,5 \\
\hline & 0,03 & $-0,12$ & $-18,8$ & 12,9 \\
\hline \multirow{2}{*}{ BCR } & 0,03 & $-0,09$ & $-35,3$ & $-24,9$ \\
\hline & 0,00 & $-0,09$ & $-26,7$ & $-13,2$ \\
\hline \multirow{2}{*}{ BSV } & $-0,04$ & $-0,10$ & $-23,5$ & $-17,5$ \\
\hline & 0,00 & $-0,12$ & $-20,3$ & $-17,5$ \\
\hline \multirow{2}{*}{ PIT - $2 \mathrm{~cm}$} & 0,00 & $-0,12$ & $-15,7$ & 0,1 \\
\hline & $-0,03$ & $-0,10$ & $-16,6$ & $-0,1$ \\
\hline \multirow{2}{*}{ PIT - $3 \mathrm{~cm}$} & 0,02 & $-0,09$ & $-16,1$ & $-11,7$ \\
\hline & 0,01 & $-0,11$ & $-12,1$ & $-5,0$ \\
\hline \multirow{2}{*}{$A Z F$} & $-0,01$ & $-0,14$ & $-23,0$ & $-12,3$ \\
\hline & 0,00 & $-0,11$ & $-19,9$ & $-15,9$ \\
\hline \multirow{2}{*}{ ITN-1 } & $-0,04$ & $-0,12$ & $-12,3$ & $-0,1$ \\
\hline & 0,00 & $-0,05$ & $-8,8$ & $-3,7$ \\
\hline \multirow{2}{*}{ ITN-2 } & $-0,06$ & 0,00 & $-14,2$ & $-20,7$ \\
\hline & $-0,08$ & $-0,03$ & $-17,2$ & $-18,1$ \\
\hline \multirow{2}{*}{ CRV } & $-0,02$ & $-0,57$ & $-6,7$ & $-33,0$ \\
\hline & 0,00 & $-0,19$ & $-6,2$ & $-24,9$ \\
\hline \multirow{2}{*}{ BCE } & 0,01 & 0,02 & $-3,0$ & $-3,5$ \\
\hline & 0,00 & 0,01 & 0,7 & $-6,7$ \\
\hline \multirow{2}{*}{ CSB } & $-0,03$ & $-0,01$ & $-12,6$ & $-12,1$ \\
\hline & $-0,03$ & $-0,06$ & $-12,0$ & $-16,6$ \\
\hline \multirow{3}{*}{ FLS } & $-0,03$ & 0,01 & $-6,2$ & $-8,8$ \\
\hline & 0,00 & $-0,04$ & $-9,5$ & $-15,9$ \\
\hline & $-0,03$ & $-0,01$ & $-14,7$ & $-3,2$ \\
\hline \multirow{2}{*}{ GVN } & 0,01 & $-0,04$ & $-14,4$ & $-7,4$ \\
\hline & 0,00 & $-0,05$ & $-7,4$ & $-3,6$ \\
\hline \multirow{2}{*}{ ARB } & $-0,02$ & $-0,19$ & $-13,1$ & 0,4 \\
\hline & $-0,03$ & $-0,14$ & $-23,5$ & 0,3 \\
\hline \multirow{2}{*}{ SCC } & $-0,03$ & $-0,10$ & $-23,0$ & 8,5 \\
\hline & $-0,01$ & $-0,15$ & $-22,8$ & 4,0 \\
\hline
\end{tabular}

A dispersão dos resultados de absorção de água também foi verificada por Mancini et al. (1994) ao investigarem a durabilidade de duas rochas metassedimentares (clorita xisto e metapelito) utilizadas no revestimento de fachadas, em Turin (Itália), após testes de envelhecimento acelerado por exposição à névoa 
ácida (dióxido de enxofre em $\mathrm{pH}$ 2) conjugado a ciclos de congelamento e degelo. Também atribuem esse comportamento à presença de sais preenchendo poros, o que não seria inesperado; consideram que, como os sais de sulfato são solúveis, tenderiam a ser lixiviados, em condições naturais. 


\section{CAPÍTULO 7}

\section{CONSIDERAÇÕES FINAIS}

A indicação dos usos mais adequados para as rochas estudadas não foi alvo desta pesquisa, uma vez que se tratam de materiais clássicos, de grande aceitação nos mercados consumidores doméstico e internacional de revestimento de edificações, independentemente de suas propriedades petrográficas, físicas e mecânicas.

Efetivamente, o que se buscou foi, por meio do conjunto de ensaios realizados para a avaliação da alterabilidade de rochas representativas dos materiais pétreos graníticos para revestimento em potenciais situações de uso, obter informações que virão a subsidiar a escolha das técnicas de fixação, manutenção e conservação para este tipo de rocha, prevenir deteriorações e incrementar a sua durabilidade.

As determinações das propriedades petrográficas, físicas e mecânicas das rochas graníticas selecionadas ensejou o conhecimento de suas características tecnológicas, focadas naquelas que apresentam quando in natura (aqui denominado bloco) e após beneficiamento (aqui denominado ladrilho), com vistas ao reconhecimento das possíveis modificações neste produto e a influência das propriedades de um e de outro na alterabilidade destes materiais.

Com o incremento do uso de rochas no revestimento de edificações, esses parâmetros petrográficos, físicos e mecânicos, rotineiramente determinados em laboratório, são cada vez mais requeridos para a elaboração de projetos de engenharia, o que torna mais apropriada a denominação propriedades de engenharia (engineering properties, na literatura em inglês) do que o termo propriedades tecnológicas, correntemente em uso, no Brasil.

As especificações para uso de rochas ornamentais e para revestimento, como as da ASTM: C 503, C 568, C 615, C 616 (ASTM 1999a, b, c, d), têm sido utilizadas como guias para a avaliação das propriedades de engenharia e, eventualmente, para indicar a necessidade de investigações e/ou ensaios tecnológicos complementares. Em geral, juntamente com os fatores custos e segurança, têm subsidiado, a decisão da utilização, ou não, de determinado material rochoso.

A durabilidade, que também deveria estar em pautada, não têm sido considerada em razão da ausência de informações técnicas prévias sobre potenciais 
comportamentos do material em questão ante às novas situações ambientais e de uso. Há a tendência de se entender a boa qualidade tecnológica da rocha como sinônimo de alta durabilidade, o que muitas vezes não é correto.

Um aspecto ilustrativo, é que, apesar das variações observadas entre os valores de resistência mecânica e os recomendados na norma ASTM C 615 (ASTM 1999c), dirigida para rochas graníticas para fins ornamentais ou para revestimento, como já discutido no Capítulo 6 (item 6.3.3), os valores de absorção d'água de todas as rochas ensaiadas, obtidos tanto para bloco, como para ladrilho, acham-se nos patamares especificados:

$\alpha<0,40 \%$.

E, a despeito dos valores típicos de absorção, as rochas graníticas estudadas, foram diferentemente afetadas (alteradas e deterioradas) ao serem expostas às situações simuladas nos ensaios de alteração.

Essa foi a primeira evidência encontrada, neste estudo, de que as propriedades de engenharia não exibem correspondência direta com alterabilidade, ao menos quanto ao tipo litológico focado.

Como a capacidade da rocha de absorver água está relacionada ao sistema poroso, esperava-se que aquelas com valores relativamente mais altos de absorção mostrassem uma susceptibilidade maior à alteração.

Os ensaios de alteração simularam as intempéries (variações térmicas e umidade); ambientes poluídos, ricos em dióxido de enxofre; ambientes marinhos, por exposição à névoa rica em cloretos $(\mathrm{NaCl})$; e a ação da cristalização de sais e de ambientes quimicamente agressivos (imersão parcial em soluções de ácido sulfúrico e de hidróxido de sódio).

Para a visualização dos efeitos resultantes dessas simulações foi elaborado o diagrama da Figura 7.1, que exibe a somatória dos graus de modificações, conforme expostos nas Tabelas. 6.31, 6.37 e 6.42, estabelecidos por meio de inspeção visual das alterações ocorridas nas faces polidas das rochas graníticas em estudo. 


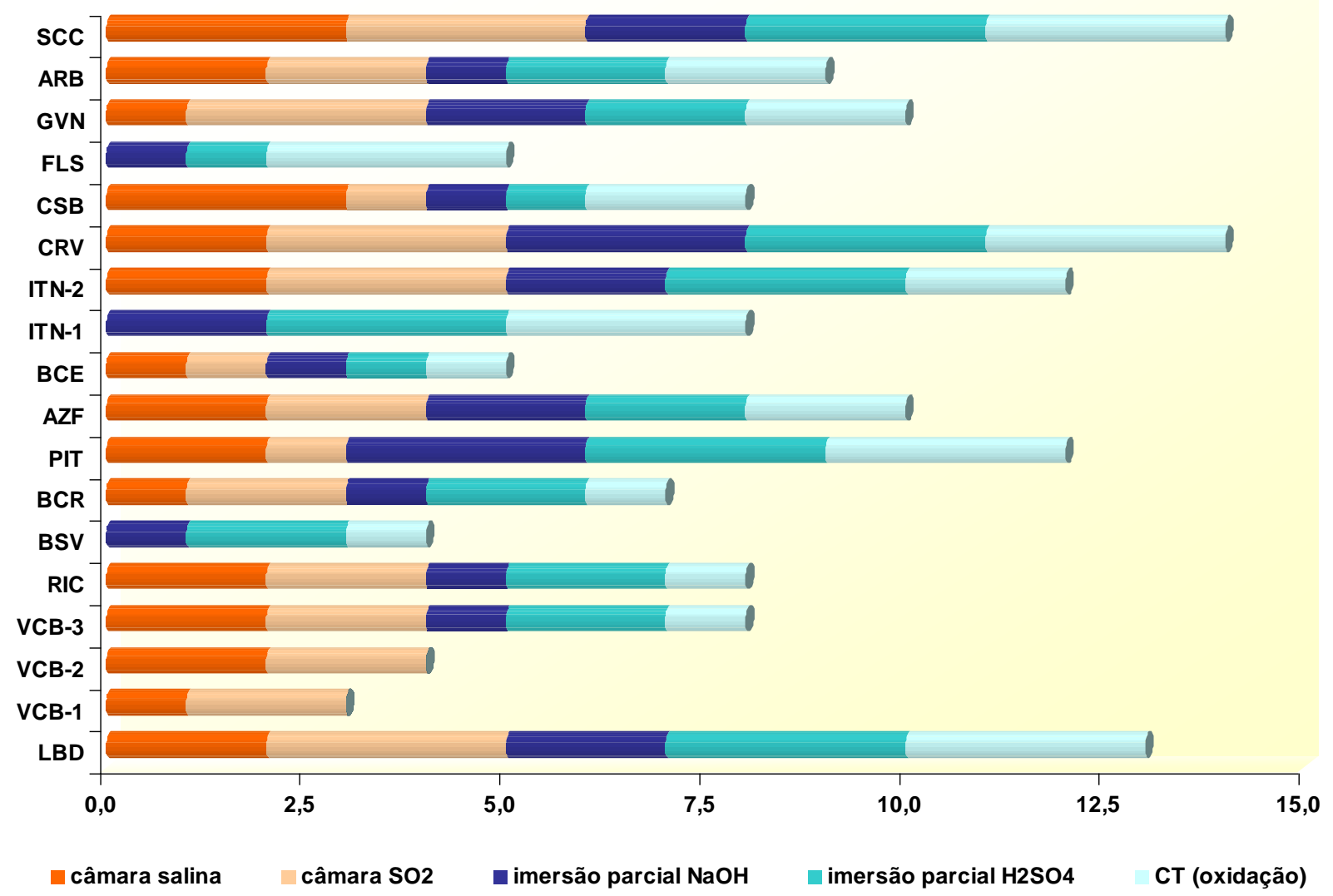

Nota: algumas amostras não foram submetidas a todos os ensaios, mas o comportamento delas, relativamente àquelas consideradas do mesmo grupo, permite inferir que seus resultados seriam semelhantes.

Figura 7.1 - Somatória dos graus relativos atribuídos às deteriorações observadas na face polida das rochas estudadas.

Como o grau 1 foi aquele atribuído a rochas visualmente inalteradas, somatórias de resultados $(\Sigma)$ igual a 5 indican que a rocha foi considerada inalterada; a única amostra que atingiu essa qualificação foi a BCE.

Considerando intervalos de 2,5, a partir de 5, são revelados quatro grupos de rochas, discriminados quanto à deterioração verificada na face polida, como a seguir:

- incipiente $(5<\Sigma<7,5)$ : BCR;

- $\operatorname{fraca}(7,5<\Sigma<10)$ : VCB-3 (VCB-2, VCB-1); RIC (BSV), AZF, CSB (FLS), ARB e GVN;

- moderada $(10,0<\Sigma<12,5)$ : PIT e ITN-2 (ITN-1);

- forte $(\Sigma>12,5)$ : SCC, CRV, LBD.

Nota: amostras entre parênteses estão com a graduação inferida. 
Os resultados obtidos nos ensaios de alteração acelerada não exibiram correlações estatisticamente significantes (por meio das técnicas adotadas nos capítulos anteriores) com as propriedades petrográficas, físicas e mecânicas. Mas, estes podem ser avaliados por meio de uma análise integrada.

Essa análise mostrou, em primeiro lugar, que o tratamento estatístico não foi possível porque não há coerência aparente dos resultados físicos e mecânicos com as degradações ocorridas nos diversos ensaios de alteração acelerada.

Analisando as amostras que acumularam as maiores deteriorações (SCC, CRV e LBD) e a que praticamente não exibiu modificação (BCE), foram verificadas as características reproduzidas na Tabela 7.1 .

Tabela 7.1 - Principais propriedades físicas e mecânicas de rochas com forte e incipiente modificações após ensaios de alteração acelerada.

\begin{tabular}{ccccc}
\hline amostra & LBD & SCC & CRV & BCE \\
\hline$\sigma_{f}$ & baixa & baixa & elevada & elevada \\
\hline$\sigma_{c}$ & baixa & baixa & elevada & elevada \\
\hline$\alpha$ & baixa a média & média & média & alta \\
\hline Alteração & moderada & fraca a moderada & fraca a moderada & incipiente \\
\hline Fissuramento & forte & moderado a forte & fraco a moderado & incipiente \\
\hline Granulação & grossa & média a grossa & fina a média & fina a média \\
\hline
\end{tabular}

Nota: $\alpha$ = absorção d'água aparente; $\sigma_{c}=$ resistência à compressão uniaxial (MPa); $\sigma_{f}=$ resistência à flexão (MPa).

Pelo exposto, uma rocha com alta resistência mecânica e alta absorção (BCE), relativamente ao grupo considerado, praticamente não exibiu alterações e outra rocha (CRV), também com alta resistência mecânica e absorção moderada, apresentou as maiores deteriorações observadas, nesta pesquisa. As feições que as diferenciaram foram os graus de alteração e de microfissuramento.

Com base no exame microscópico pôde-se verificar que nas amostras com moderada a forte deterioração, os minerais de alteração tanto dispostos pela rocha como presentes nos minerais constituintes (e g. argilominerais, carbonato e sericita, em plagioclásio) e as microfissuras constituíram os locais em que puderam ser observadas a maior parte das alterações.

No caso da CRV, as deteriorações se manifestaram pela oxidação ou despegamento dos argilominerais de alteração, intersticiais, identificados como caulinita e, possivelmente, esmectitas. O confinamento desses nos espaços 
intergranulares, aparentemente, permitiu que a pressão de cristalização dos sais rompesse com maior intensidade as paredes dos poros, levando inclusive, à quebra das arestas.

Em síntese, a observação visual e microscópica dos efeitos dos ambientes simulados, nas rochas ensaiadas, evidenciou alguns mecanismos de deterioração, conforme descrito a seguir:

- oxidação da rocha e de minerais: observado em praticamente todas as simulações. Está relacionada ao comportamento do ferro, em virtude de seu potencial de oxidação nos ambientes exógenos, nesse caso, de pH ácido (exposição ao dióxido de enxofre e imersão parcial em ácido sulfúrico) ou sob influência da temperatura e umidade (ensaio de resistência ao choque térmico). Como para as demais propriedades, também não se obteve correlação estatística entre os teores de $\mathrm{Fe}^{2+}$ e $\mathrm{Fe}^{3+}$ e as alterações verificadas. $\mathrm{O}$ amarelamento de algumas rochas, nessas mesmas condições também foi relacionado à oxidação e provável remobilização local do ferro;

- clareamento da rocha: observado em câmaras de dióxido de enxofre e ensaios de imersão parcial em ácido sulfúrico. Trata-se de um caso mais específico, em que rocha charnockítica exibiu notável branqueamento, por provável lixiviação do ferro, ao ser exposta a ambientes ácidos. A principal evidência é a ausência de hidróxidos de ferro em microfissuras, e presentes nas mesmas, nos materiais in natura.

Sem fornecer a impressão visual de clareamento da rocha, foi observado microscopicamente, em algumas amostras, plaquetas de biotita com lamelas descoloridas, provavelmente resultates da remobilização do ferro;

- cristalização de sais (eflorescências e subeflorescências): observado em câmaras de dióxido de enxofre e de imersão parcial em ácido sulfúrico. Evidenciado por inchamento, escamação e até esfoliação. A presença de sais em fissuras chegou a provocar locais despegamento em granada $\mathrm{e}$ feldspatos, mas a biotita foi o mineral que se revelou mais susceptível à esse processo. Sua estrutura cristalográfica deve facilitar a percolação e retenção de água (e elementos carreados), possibilitando reação com os componentes químicos do mineral e conseqüente cristalização de sais, quando as 
condições de supersaturação são alcançadas. A pressão de cristalização dos sais nos espaços interfoliares provoca seu destacamento.

Conforme Aires-Barros (1991), entre outros pesquisadores, a alterabilidade é função de fatores intrínsecos, extrínsecos e do tempo. Com base nos resultados apresentados e discutidos para as rochas graníticas estudadas, pôde-se aprofundar o entendimento dos fatores intrínsecos ligando-os, ainda que empiricamente, ao grau de alteração natural, ao grau de fissuramento e à presença de biotita e outros minerais contendo ferro. Estes configuram o sistema poroso e propiciam a exposição das superfícies, dos minerais e das rochas, à absorção e circulação da água carreando elementos que propiciarão as alterações e/ou cristalização dos sais.

As principais características dos ensaios de alteração experimentalmente conduzidos foram:

- exposição à névoa salina: efeitos visuais pouco perceptíveis, mas, como atestado pelas lâminas petrográficas, são microscopicamente visíveis os efeitos degradadores dos sais $(\mathrm{NaCl})$ dissolvidos no ambiente: aumento da turvação de cristais de plagioclásio já intempericamente alterados; alargamento de fissuras preexistentes; intensificação da oxidação e/ou surgimento de pontos oxidados e outros;

- imersão parcial em hidróxido de sódio: efeitos visuais pouco perceptíveis. Evidenciou que 0 ambiente alcalino, não foi deletério para as rochas ensaiadas. Mesmo as amostras ITN, que inicialmente exibiram modificação de cor, ao final do ensaio já haviam retornado à cor natural. Indiretamente, foi verificada possível cristalização de sais no interior dos corpos-de-prova, por meio do aumento da velocidade de propagação de ondas e das modificações de absorção após o ensaio;

- exposição a dióxido de enxofre: mostrou o papel degradador desse poluente e resultou em deteriorações que atingiram, diferencialmente, a depender das características intrínsecas, praticamente todas as rochas selecionadas e que variaram desde manchamento até escamação. Também pôde ser detectada a presença de sais no interior dos corpos-de-prova, por meio do aumento da velocidade de propagação de ondas e das modificações de absorção após o ensaio; 
- imersão parcial em ácido sulfúrico: é uma simulação muito agressiva, e possibilitou a verificação das deteriorações resultantes da cristalização de sais (eflorescência e subeflorescências) e da estabilidade dos materiais ante os reagentes químicos de caráter ácido, potenciais agentes degradadores de rochas;

- choque térmico: ensaio também bastante agressivo, forneceu informações sobre possíveis modificações estéticas, pela oxidação de minerais, e de resistência mecânica do material, por ação das intempéries e variações cíclicas de temperatura e umidade. O decaimento da resistência à flexão, após esse ensaio, mostrou-se diretamente proporcional às resistências obtidas nas determinações da rocha in natura; o que não se verificou quanto à susceptibilidade à oxidação. É um ensaio em vias de publicação, pela CEN, e sua adoção, com as modificações aqui incorporadas, incrementará o conjunto de dados para elaboração de projetos de revestimento de exteriores, especialmente de fachadas.

Conforme exposto, as influências das propriedades físicas e mecânicas, bem como as modificações na transformação de bloco para ladrilho não puderam ser estatisticamente correlacionadas aos resultados dos ensaios de alteração acelerada. Esta pesquisa evidenciou, porém, algumas informações relevantes, entre as quais destaca-se:

- aumento, muito heterogêneo, da capacidade de absorção de água de bloco para ladrilho e, em geral, tendendo a uma correlação negativa, ou seja, rochas com maiores valores de absorção determinada para bloco tenderam a exibir menores variações de bloco para ladrilho;

- os valores para as propriedades físicas (densidade, absorção, porosidade aberta e volume de poros abertos) mostraram-se dependentes do método de ensaio e do tamanho do corpo-de-prova. É um dado muito importante, que pode ser incorporado em futuros e necessários programas interlaboratoriais, pois demonstra que as determinações dessas propriedades devem seguir obrigatoriamente todos os passos dos procedimentos normativos, de forma a se poder, efetivamente, comparar e utilizar os dados disponíveis tanto comercialmente, como em trabalhos técnico-científicos. Com base nisso é proposto que: 
- o tamanho $10 \mathrm{~cm} \times 10 \mathrm{~cm} \times$ espessura de ladrilho, que se revelou estatisticamente mais adequado, seja adotado para a determinações dessas propriedades físicas do material rochoso beneficiado;

- corpos-de-prova com dimensões de 7,5 cm x 7,5 cm x 7,5 cm, para a determinação desses mesmos parâmetros, sejam utilizados na caracterização do material in natura;

- proporcionalidade entre as resistências mecânicas de bloco (compressão) e ladrilho (flexão), para as rochas maciças (isótropas). Para as rochas gnáissicas, no entanto, obteve-se tendência inversa (correlação negativa) entre essas propriedades, evidenciando a influência da estrutura nos resultados dessas propriedades, sugerindo que rochas com maiores resistências in natura tenderam a exibir, relativamente, menores resistências após modificação na geometria do material. Estudos complementares poderão esclarecer melhor essa verificação. 


\section{CAPÍTULO 8 CONCLUSÕES}

Entende-se que um material rochoso destinado à aplicação no revestimento de edificações deva ser tratado, propriamente, como um material de construção, que necessita-se do conhecimento de suas propriedades físicas e mecânicas, a serem tomadas como parâmetros ou critérios de escolha e de elaboração dos projetos de engenharia. Também por isto, há que se contar com estimativas sobre sua durabilidade.

O estudo realizado demonstra a possibilidade de serem estabelecidas rotinas laboratoriais para reconhecimento da alterabilidade de rochas para revestimento, a partir da simulação de situações ambientais reinantes em condições cotidianas de uso e aplicação.

Os resultados obtidos mostraram a susceptibilidade à deterioração das rochas graníticas escolhidas, representativas de materiais correntemente empregados pela construção civil, em formas e intensidades variáveis conforme suas propriedades intrínsecas e a situação simulada.

Tais rotinas estão cercadas de caráter, em grande parte, pioneiro, se consideradas as informações contidas na literatura nacional e internacional, e possibilitam a introdução de novos procedimentos para a previsão e estimativa da durabilidade desses materiais.

A extrapolação temporal do comportamento dos materiais ensaiados ante as condições de uso simuladas, para o relativamente longo período esperado de uso, ainda não é confiável e não foi objeto de investigação.

Embora tenham sido observadas correlações entre características físicas e mecânicas dos materiais selecionados, obtidas para bloco e ladrilho, respectivamente representantes da rocha in natura e beneficiada, não foi possível vinculá-las, em níveis estatisticamente aceitáveis, às alterações e degradações ocorridas nos ensaios de alteração acelerada.

Por sua vez, as rochas, ao serem transformadas em chapas e ladrilhos, revelaram variações nas características físicas e mecânicas, cuja intensidade mostrouse dependente daquelas do material in natura. 
As variações nos valores de absorção d'água indicaram que o processo de beneficiamento provoca modificações no sistema poroso da rocha que se reflete no provável aumento do grau de fissuramento, o que, pelos métodos de investigações adotados pode ser inferido, mas não comprovado.

A ausência de altas correlações, especialmente entre absorção, poros abertos e capilaridade e as deteriorações ocorridas nos ensaios realizados, pode também ser atribuída à inadequação dos métodos de ensaio utilizados para a determinação de parâmetros que qualifiquem o sistema poroso da rocha, do ponto de vista da alterabilidade.

As propriedades de engenharia e a alterabilidade ou durabilidade, então, constituem dois segmentos complementares, necessariamente caracterizáveis anteriormente à escolha e definição de material rochoso para revestimento de edificações. O primeiro trata da obtenção de parâmetros de resistência, precisamente definidos e que podem ser medidos em laboratório, por métodos diretos ou indiretos. No outro há a estimativa da durabilidade, que é a capacidade de resistir às condições aplicadas ao material na sua utilização.

Nessa abordagem, valores especificados pela ASTM, e outros, significam mais apropriadamente valores típicos das diversas propriedades da rocha em termos de resistência do que de alterabilidade.

Por isso, na avaliação da alterabilidade, se revelaram insuficientes, pois as propriedades petrográficas e a configuração do sistema poroso passaram a ter papel relevante, traduzidas neste estudo como sendo a intensidade e forma da alteração intempérica dos minerais constituintes e do microfissuramento.

Enfatiza-se, como já relatado, que as heterogeneidades intrínsecas aos materiais rochosos governam seu desempenho ante aos processos de alteração. A petrografia, até que estudos futuros propiciem quantitativamente as informações necessárias, mostrou-se como a principal técnica para o entendimento e explicação das deteriorações observadas em rochas para revestimento.

Salienta-se que o conjunto de ensaios propostos e realizados forneceu importantes indicações do desempenho do material selecionado que, por sua vez, deverão subsidiar a adoção de medidas para conservação dessas rochas. Antecipa-se que, certamente, são extrapoláveis para monumentos e edifícios históricos construídos em rochas de natureza semelhante. 
O caráter introdutório deste estudo, no campo experimental da alteração acelerada de rochas graníticas para revestimento, deixa antever a necessidade de trabalhos de futuros, dentre os quais podem ser destacados:

- continuidade das investigações para determinação do sistema poroso e da distribuição dos poros, em rochas graníticas, e sua aplicação no melhor entendimento da alterabilidade dessas rochas em situações semelhantes às aqui simuladas;

- pesquisas para adequação das técnicas de conservação de rochas, a partir do conhecimento prévio das possíveis deteriorações nos ambientes simulados, pois uma vez conhecidos os efeitos degradadores e as deteriorações de cada rocha submetida a ensaios de alteração acelerada, pode-se dispor desses parâmetros para a seleção de técnicas de fixação, assentamento, impermeabilização e outros;

- aprimoramento e futura normalização dos procedimentos aqui estabelecidos para os ensaios de alteração acelerada, em especial aqueles que se revelaram mais eficientes; exposição às câmaras de dióxido de enxofre e de névoa salina, e imersão parcial em ácido sulfúrico, como métodos de investigação da alterabilidade de rochas graníticas.

Finalmente, é possível considerar que, num futuro próximo, possa se ampliar o conceito de durabilidade de materiais rochosos, conforme definido por ASTM e outros, passando a se incorporar a "preservação das características naturais, também por meio da adoção de medidas preventivas ou de conservação". 


\section{REFERÊNCIAS BIBLIOGRÁFICAS}

ABNT - ASSOCIAÇÃO BRASILIEIRA DE NORMAS TÉCNICAS. (1983a) NBR 8096/83: material metálico revestido e não revestido; corrosão por exposição ao dióxido de enxofre. Rio de Janeiro

. (1983b) NBR 8094/83: material metálico revestido e não revestido; corrosão por exposição à névoa salina. Rio de Janeiro

. (1992a) NBR 12.766/92: rochas para revestimento; determinação da massa específica aparente, porosidade aparente e absorção d'água aparente. Rio de Janeiro.

(1992b) NBR 12.767/92: rochas para revestimento; determinação da resistência à compressão uniaxial. Rio de Janeiro. de Janeiro.

(1992c) NBR 12.768/92: rochas para revestimento; análise petrográfica. Rio . (no prelo). Projeto 02:105.45-012: rochas para revestimento - terminologia. Rio de Janeiro. (Em votação)

AIRES-BARROS, L. 1991. Alteração e alterabilidade de rochas. Lisboa: Universidade Técnica de Lisboa, Instituto Nacional de Investigação Cientifica. 384p.

ALMEIDA, F.F.M.; LETWINSKI, N. 1984. Província Mantiqueira; Setor Setentrional. In: AILMEIDA, F.F.M.; HASSUI, Y. (Coord.) Pré-cambriano no Brasil. São Paulo: Edgard Blücher. p.282-307.

AMOROSO, G.G.; FASSINA, V. 1983. Stone decay and conservation. Amsterdam: Elsevier. 453p. (Materials science monograph; v.11)

ASTM - AMERICAN SOCIETY FOR TESTING AND MATERIALS. (1990) C 170/90: standard method for compressive strength of dimension stone. Philadelphia.

Philadelphia.

. (1996) C 97/96: absorption and bulk specific gravity of dimension stone.

. (1997) B 117/97: standard practice for operating salt spray; fog; apparatus. Philadelphia.

. (1998) C 880/98: standard test method for flexural strength of dimension stone. Philadelphia.

. (1999a) C 503/99: standard specification for marble dimension stone; exterior. Philadelphia.

Philadelphia.

(1999b) C 568/99: standard specification for limestone dimension stone.

. (1999c) C 615/99: standard specification for granite dimension stone. Philadelphia.

. (1999d) C 616/99: standard specification for quartz-based dimension stone. Philadelphia.

. (2000) D 2845/00: standard method for laboratory determination of pulse velocities and ultrasonic elastic constants of rocks. Philadelphia. 
Philadelphia.

(2001a) C 119/01: standard terminology relating to dimension stone.

(2001b) G 169/01: standard guide for application of statistical methods to weathering tests. Philadelphia. 10p.

AZEVEDO, H.C.A.; COSTA, P.H.O. (Coord.) (1994) Catálogo de rochas ornamentais da Bahia, Brasil. Salvador: SGM. 146p.

BARBOSA, J.S.F.; DOMINGUEZ, J.M.L. (Coord.) (1996) Geologia da Bahia. texto explicativo. Salvador: SGM/UFBa/Fapex.

BENAVENTE, D.; GARCIA DEL CURA, M.A.; BERNABÉU, A.; ORDÓNÉZ, S. (2001) Quantification of salt weathering in porous; stones using na experimental continuous partial immersion method. Engineering Geology, v.59, p.313-325.

BENAVENTE, D.; GARCIA DEL CURA, M.A.; FORTE, R.; ORDÓÑEZ, S. (1999) Thermodynamic modelling of changes induced by salt pressure crystallization in porous media of stone. Journal of Crystal Growth, v.204, p.168-178.

BSI - BRITISH STANDARD INSTITUTION. (1999a) BS EN 1936: natural stone test methods; determination of real density and apparent density and of total and open porosity. London.

. (1999b) BS EN 1925: natural stone test methods; determination of water absorption coefficient by capillarity. London London. 8p.

(2000) BS EN 12407: natural stone test methods; petrographic examination.

CARDANI, G.; MEDA, A. (1999) Flexural strength and notch sensitivity in natural building stones: Carrara and Dionysos marble. Construction and Building Materials, v.13, p.393-403.

CARROLL, D. (1970) Rock weathering. New York: Plenum. 203p.

CEN - EUROPEAN COMMITTEE FOR STANDARDIZATION. (1998a) (draft). prEN WI 036: natural stone test methods; determination of water absorption at atmospheric pressure.

(1998b) prEN WI 016: natural stone test methods: determination of resistance to ageing by thermal shock. London. 8p.

(2000) BS EN 12407: natural stone test methods; petrographic examination.

CHIODI FILHO, C.; TAKAHASHI, A.T.; SILVA, C.R.R.; FERREIRA, J.C.G. (1983) Projeto Capão Bonito; relatório final. São Paulo: CPRM/Pró-Minério. v.1

DELGADO-RODRIGUES, J. (1996) Conservation of granitic rocks with application to the megalithic monuments; conclusion report. In: VICENTE, M.A., DELGADORODRIGUES, J., ACEVEDO, J. (Ed.) 1996. Degradation and conservation of granitic rocks in monuments. Brussels: European Commission. p.161-242. (Protection and conservation of the European Cultural Heritage, Research Report $n^{\circ} 5$ )

DIB, P.P.; FRASCÁ, M.H.B.O.; BETTENCOURT, J.S. (1999) Propriedades tecnológicas e petrográficas do "Granito Rosa Itupeva" ao longo dos estágios de extração e beneficiamento. In: SIMPÓSIO DE GEOLOGIA DO SUDESTE, 6., 1999, São Pedro. 
Boletim de Resumos... São Pedro: SBG/UNESP. p.154.

DIN - DEUTCHES INSTITUT FÜR NORMUNG. (1997) DIN 50018: sulphur dioxide corrosion testing in a saturated atmosphere. Berlin.

DNPM - DEPARTAMENTO NACIONAL DE PRODUÇÃO MINERAL (2002) Sumário mineral. Brasília: DNPM.

FEILDEN, B.M. (1994) Conservation of historic buildings. Oxford: Reed Educational and Professional Publish. 345p.

FIGUEIREDO, P.; AIRES-BARROS, L; TORQUATO, J.; BESSA, M.F.; LIMA, M.A.; FERNANDES, A.H. (2001) Determinação laboratorial de um índice de alterabilidade para o granito Rosa Iracema (Ceará, Brasil). In: CONGRESSO DE GEOQUÍMICA DOS PAíSES DE LÍNGUA PORTUGUESA, 6., SEMANA DE GEOQUÍMICA, 12. 2001, Faro. Actas... Faro, Portugal: Universidade de Algarve. p.384-387.

FIGUEIREDO, P.; AIRES-BARROS, L; TORQUATO, J.; BESSA, M.F.; LIMA, M.A.; FERNANDES, A.H.; MACHAQUEIRO, P. (2002) Contribuição para o estudo das propriedades petrofísicas do granito Asa Branca e Rosa Iracema do Ceará, Brasil. In: SIMPÓSIO BRASILEIRO DE ROCHAS ORNAMENTAIS, 1.; SIMPÓSIO BRASILEIRO DE ROCHAS ORNAMENTAIS DO NORDESTE, 2., 2001, Salvador. Anais... Rio de Janeiro: MCT/CETEM. p.31-36.

FRASCÁ, M.H.B.O. (2002a) Qualificação de rochas ornamentais e para revestimento de edificações: caracterização tecnológica e ensaios de alterabilidade. In: SIMPÓSIO BRASILEIRO DE ROCHAS ORNAMENTAIS, 1.; SIMPÓSIO BRASILEIRO DE ROCHAS ORNAMENTAIS DO NORDESTE, 2., 2001, Salvador. Anais... Rio de Janeiro: MCT/CETEM. p.128-135.

FRASCÁ, M.H.B.O. (2002b) Porosity and technological properties of granite dimension stone and polished tiles. In: INTERNATIONAL CONGRESS OF THE INTERNATIONAL ASSOCIATION OF ENGINEERING GEOLOGY AND THE ENVIRONMENT, 9., 2002, Durban, África do Sul. Proceedings... Pretoria: SAIEG. p.2475-2484. (CD-ROM).

FRASCÁ, M.H.B.O.; FRAZÃO, E.B. (2002) A normatização no setor de rochas para revestimento. Rochas de Qualidade, v.167, p.136-167.

FRASCÁ, M.H.B.O.; MELLO, I.S.C.; QUITETE, E.B. (2000). Rochas ornamentais e de revestimento do Estado de São Paulo. São Paulo: IPT. CD-ROM. (IPT. Pub. 2651)

FRASCÁ, M.H.B.O.; QUITETE, E.B. (1999) Estudos diagnósticos de patologias em rochas de revestimento. In: CONGRESSO IBERAMERICANO DE PATOLOGÍA DE LAS CONSTRUCCIONES, 7., 1999, Montevideo. Memorias... Montevideo: Asiconpat/CIB. v.2, p.1367-1373.

FRASCÁ. M.H.B.O.; SARTORI, P.L.P. (1998) Minerais e rochas. In: OLIVEIRA, A.M.S.; BRITO. S.N.A. (Ed.) Geologia de engenharia. São Paulo: ABGE. P.15-38

FRAZÃO, E.B. (2002) Tecnologia de rochas na construção civil. São Paulo: ABGE. 132p.

FRAZÃO, E.B.; FARJALLAT, J.E.S. 1996. Proposta de especificação para rochas silicáticas de revestimento. In: CONGRESSO BRASILEIRO DE GEOLOGIA DE ENGENHARIA, 8., 1996, Rio de Janeiro. Anais ... Rio de Janeiro: ABGE. v.1, p. 369380. 
FRAZÃO, E.B.; QUEIROZ, F.C., HACHIRO, J., FARJALLAT, J.E.S., CARUSO, L.G., FRASCÁ, M.H.B.O., OLIVEIRA, M.C.B., PINTO, C.P.; CASTANHEIRA, O., ZENÓBIO, H., SANTOS, P.R., SOUZA, R.P. (1993) Catálogo das rochas ornamentais do Estado do Espírito Santo. São Paulo: Sedes/IPT. 81p. (IPT. Publicação, 2048)

GIACOMELLI, V., PEREGO, G. (s.d.) Degradation of stone. Diponível em: $<$ http://www.eni.it/english/notizie/mediteca/specials/s_pietro/pietra.html>. Acesso em: 18/04/2003.

GOBBI, G; ZAPPIA, G.; SABBIONI, C. (1998) Sulphite quantification on damaged stones and mortar. Atmospheric Environment, v.32, n.4, p.783-789.

GOLDICH, S.S. (1938). A study in rock-weathering. Journal of Geology, v.46, p.17-58.

GONZÁLEZ-MESSONES, F.L. (2002) La interpretación de los ensayos de caracterización de la piedra natural, en el marco de la nueva normativa europea. In: Curso de rochas ornamentais. Recife. CD-ROM.

GROSSI, C.M.; ESBERT, R.M.; DÍAZ-PACHE, F. (1998) Degradación y durabilidad de materiales rocosos de edificación en ambientes urbanos. Materiales de Construcción, v.48, n.252, p.5-25.

GROSSI, C.M.; MURRAY, M. (1999) Characteristics of carbonate building stones that influence the dry deposition of acidic gases. Construction and Building Materials, v.1, p.101-08.

GUPTA, A.S.; RAO, S. (2000) Weathering effects on the strength and deformational behavior of crystalline rocks under uniaxial compression state. Engineering Geology, v.56, p.357-274.

HOUAISS, A.; VILLAR, M.S. (2001) Dicionário Houaiss da língua portuguesa. Rio de Janeiro: Instituto Houaiss. 2922p.

IPT - INSTITUTO DE PESQUISAS TECNOLÓGICAS DO ESTADO DE SÃO PAULO. (1995) Mapa geológico da Folha Itararé, escala 1:250.000. São Paulo. (inédito).

. (1996) Adequação e controle da mineração na bacia do Guarapiranga: levantamento geológico e geomorfológico. São Paulo. (IPT. Relatório IPT 34.540).

- (2000) Atualização e modernização do catálogo de rochas ornamentais do Estado de São Paulo. São Paulo. (IPT. Relatório IPT 45.508).

JCPDS - JOINT COMMITTEE ON POWDER DIFFRACTION STANDARDS. (1974) Selected powder diffraction data for minerals; data book. Swarthmore: International Centre for Diffraction Data. 835p.

. (1980) Mineral powder diffraction data file; search manuals. Swarthmore: International Centre for Diffraction Data. 484p.

. (1981) Selected powder diffraction data for minerals: data book supplement I. Swarthmore: International Centre for Diffraction Data. 463p.

JEFFERSON, D.P. (1993) The weathering of stone. Stone Industries, v.28, n.3, p.2429.

JOHNSON, R.B.; DeGRAFF, J.V. (1988) Principles of engineering geology. New York: John Wiley. 497p. 
JONES, M.P. (1987) Applied mineralogy: a quantitative approach. London: Graham and Trotman. 259p.

KAHRAMAN, S. 2002. The effects of fracture roughness on $P$-wave velocity. Engineering Geology, v.63, p.347-350.

KELLER, E.A. (1996) Environmental geology. New Jersey: Prentice Hall.

KESSLER, D.W.; INSLEY, H.; SLIGH, W.H. (1940) Physical, mineralogical, and durability studies on the building and monumental granites of the United States. Journal of Research of National Bureau of Standards, vol. 25: 161-206. (Research Paper RP1320)

KOBAYASHI, S., SAKAMOTO, T., KAKITANI, S. (1994) Effects of acid rain on granitic building stone. In: INTERNATIONAL CONGRESS OF THE INTERNATIONAL ASSOCIATION OF ENGINEERING GEOLOGY, 7., 1994, Lisbon. Proceedings... Rotterdam: A.A.Balkema. v.5, p.3651-3658.

KRUMBEIN, W.C.; GARRELS, R.M. (1952) Origin and classification of chemical sediments in terms of $\mathrm{pH}$ and oxidation-reduction potentials. Journal of Geology, v.60, n.1, p.1-33.

KUPCHELLA, C.E.; HYLAND, M.C. (1992) Environmental sciente: living with the system of nature. 3.ed. New Jersey: Prentice-Hall.

LA IGLESIA, A.; CONZÁLEZ, V. LÓPEZ-ACEVEDO, V.; VIEDMA, C. 1997. Salt crystallization in porous construction materials I: estimation of crystallization pressure. Journal of Crystal Growth, v.177, p.111-118.

LE MAITRE, R.W. (Ed.). (1989) A classification of igneous rocks and glossary of terms: recommendations of the International Union of Geological Sciences, Subcommission on the Systematics of Igneous Rocks. Oxford. Blackwell Scientific Publ. 193p.

LÓPEZ-ACEVEDO, V.; VIEDMA, C.; GONZALEZ, V. LA IGLESIA, A. (1997) Salt crystallization in porous construction materials II: mass transport and crystallization processes. Journal of Crystal Growth, v.182, p.103-110.

LÓPEZ JIMENO, C. (Ed.) (1996) Manual de rocas ornamentales: prospección, explotación, elaboración y colocación. Madrid: Entorno. 696 p.

MANCINI, R.; MORANDINI FRISA, A.; MARINI, P. (1994) On the importance of a careful characterisation of decorative Stones aimed to durability asseement: An example of faked aesthetic equivalence in stones use in public buildings lining in Turin. In: INTERNATIONAL CONGRESS OF THE INTERNATIONAL ASSOCIATION OF ENGINEERING GEOLOGY, 7., 1994, Lisbon. Proceedings... Rotterdam: A.A.Balkema. v.5, p.3671-3676.

MESQUITA, M.P.S. (2002) Composição, estruturas, propriedades tecnológicas e alterabilidade dos granitos ornamentais do Stock Morrinho, Santa Quitéria (CE). 169p. Tese (Doutorado) - Instituto de Geociências e Ciências Exatas, Campus de Rio Claro, Rio Claro.

MONTANI, C. (2002) Stone 2002: world marketing handbook. Faenza: Gruppo Editoriale Faenza Ed.

MURCK, B.A.; SKINNER, B.J. (1999) Geology today: understanding our planet. New York: John Wiley. 527p. 
PEITER, C.C. (Coord.) (2001) Rochas ornamentais no século XXI: bases para uma política de desenvolvimento sustentado das exportações brasileiras. Rio de Janeiro: Cetem/Abirochas. 159p.

PERRY, S.H.; DUFFY, A.P. (1997) The short-term effects of mortar joints on salt movement in stone. Atmospheric Environment, v.31, n.9, p.1297-1305.

ROBERTO, F.A.C. (1998) Rochas ornamentais do Ceará: geologia, pesquisa, lavra, beneficiamento e mercado. 225p. Dissertação (Mestrado) - Departamento de Geologia, Universidade Federal do Ceará, Fortaleza.

ROBINSON, D.A.L; WILLIAMS, R.B.G. (1994) Rock weathering and landform evolution. London: John Wiley. 519p.

RODRIGUES, E.P.; MORAES, M.C. (1978) Exemplo de aplicação de coloração seletiva de feldspatos potássicos e cálcicos, como técnica auxiliar no estudo de rochas. Cerâmica, v.24, n.97, jan. (Trabalho apres. no Congresso Brasileiro de Cerâmica, 21., 1977, Blumenau.).

SCHOBENHAUS, C. et al. (Coord.) (1984) Geologia do Brasil. Brasília: DNPM. 501p.

SKINNER, B.J.; PORTER, S.C.; BOTKIN, D.B. (1999) The blue planet: an introduction to Earth System Science. 2.ed. New York: John Wiley. 552p.

STRECKEISEN, A. (1975). To each plutonic rock its proper name. Earth-Sci. Rev., v.12, p.1-33.

THEOULAKIS, P.; MOROPOULOU, A. (1997) Microstructural and mechanical parameters determining the susceptibility of porous building stones to salt decay. Construction and Building Materials, v.11, n.1, p.65-71

THOREZ, J. (1976) Pratical identification of clay minerals. s.I.: Editions G. Lelotte. 90p.

UCHIDA, E.; OGAWA, Y.; MAEDA, N.; NAKAGAWA, T. 1999. Deterioration of stone materials in Angkor monuments, Cambodia. Engineering Geology, v.55, p.101-112.

VICENTE, M.A.; DELGADO-RODRIGUES, J.; ACEVEDO, J. (Ed.) (1996) Degradation and conservation of granitic rocks in monuments. Brussels: European Commission. 471p. (Protection and Conservation of the European Cultural Heritage, Research Report no 5)

VIDAL, F.W.H. (1999) Estudo dos elementos abrasivos de fio diamantado para a lavra de granitos do Ceará. Tese (Doutorado) - Escola Politécnica, Universidade de São Paulo, São Paulo.

VILES, H.A. (1997) Urban air pollution and the deterioration of buildings and monuments. In: BRUNE, D.; CHAPMAN, D.V.; GRUYNNE, M.D.; PACYNA, J.M. (Ed.) The global environment: science, technology and management. Weinheim: Scandinavian Science Publ.; VCH. p.599-609.

WARKE, P.A.; SMITH, B.J. (1998) Effects of direct and indirect heating on the validity of rock weathering simulation studies and durability tests. Geomorphology, v.22. p.347357.

WILSON, M.J. 1975. Chemical weathering of some primary rock-forming minerals. Soil Science, v.119, n.5, p.349-354.

WINKLER, E.M. (1997) Stone in architecture: properties, durability. 3.ed. Berlin: 
Springer-Verlag. 313p.

WINKLER, E.M.; SINGER, P.C. (1972) Crystallization pressure of salts in stone and concrete. Geological Society of America Bulletin, v.83, p.3.509-3.514.

WINKLER, H.G. (1976) Petrogenesis of metamorphic rocks. 4.ed. New York: SpringerVerlag. 334p.

ZIVICA, V.; BAJZA, A. (2001) Acidic attack of cement based materials; a review; part 1: principle of acidic attack. Construction and Building Materials, v.5, p.331-340. 
ANEXO A

Fichas de Campo 
FICHA DE CAMPO - $\mathbf{N}^{\circ} 1$

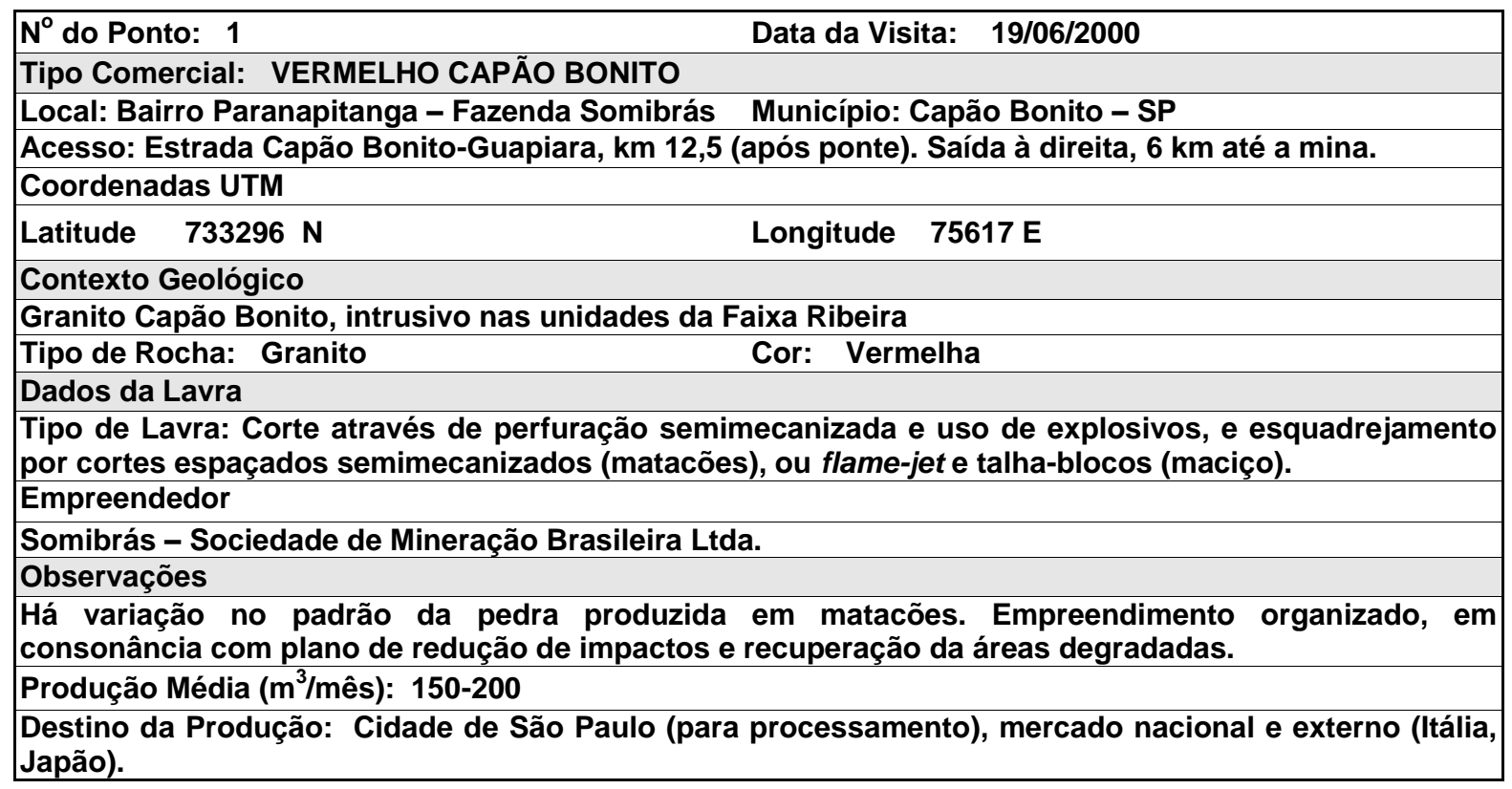

\section{FICHA DE CAMPO $-\mathrm{N}^{\circ} 2$}

\begin{tabular}{|c|}
\hline Data da Visita: $19 / 6 / 00$ \\
\hline Tipo Comercial: VERMELHO CAPÃO BONITO \\
\hline $\begin{array}{l}\text { Local: Bairro Areias - Fazenda Santa Madalena } \quad \text { Município: Capão Bonito } \\
\text { Acesso: Rodovia Capão Bonito - Guapiara, km 9. Estrada para Apiaí-Mirim, 9,5 km. Saída à esquerda } \\
\text { até a lavra. }\end{array}$ \\
\hline Coordenadas UTM \\
\hline Longitude $75428 \mathrm{E}$ \\
\hline Contexto Geológico \\
\hline Granito Capão Bonito, intrusivo nas unidades da Faixa Ribeira \\
\hline Tipo de Rocha: Granito $\quad$ Cor: Vermelha \\
\hline Dados da Lavra \\
\hline $\begin{array}{l}\text { Tipo de Lavra: Corte através de perfurações e uso de explosivos, e esquadrejamento manual de blocos. } \\
\text { Empreendimento rudimentar e bastante impactante ao meio físico. }\end{array}$ \\
\hline Empreendedor \\
\hline Granitos Brasileiros S.A. \\
\hline Observações: \\
\hline Mina de empresa verticalizada, com produção bastante diminuída em relação a épocas passadas. \\
\hline Produção Média ( $\left.\mathrm{m}^{3} / \mathrm{mês}\right):$ 60-80 \\
\hline $\begin{array}{l}\text { Destino da Produção: Cidade de São Paulo, para serragem e destino aos mercados nacional e } \\
\text { internacional. }\end{array}$ \\
\hline
\end{tabular}


FICHA DE CAMPO $-\mathrm{N}^{\circ} 3$

\begin{tabular}{|c|c|}
\hline $\mathrm{N}^{\circ}$ do Ponto: 4 & Data da Visita: 20/6/2000 \\
\hline \multicolumn{2}{|c|}{ Tipo Comercial: VERMELHO CAPÃO BONITO } \\
\hline \multirow{2}{*}{\multicolumn{2}{|c|}{$\begin{array}{l}\text { Acesso: Rodovia Capão Bonito - Guapiara, km 9. Estrada para Apiaí-Mirim, } 8 \text { km. Saída à esquerda até } \\
\text { a lavra (3km). } \\
\text { Coordenadas UTM }\end{array}$}} \\
\hline & \\
\hline Latitude $733378 \mathrm{~N}$ & Longitude $75545 \mathrm{E}$ \\
\hline \multicolumn{2}{|l|}{ Contexto Geológico } \\
\hline \multicolumn{2}{|c|}{ Granito Capão Bonito, intrusivo nas unidades da Faixa Ribeira } \\
\hline Tipo de Rocha: Granito & Cor: Vermelha \\
\hline \multicolumn{2}{|l|}{ Dados da Lavra } \\
\hline \multicolumn{2}{|c|}{$\begin{array}{l}\text { Tipo de Lavra: Corte através de perfurações e uso de explosivos, e esquadrejamento através de furos } \\
\text { espaçados manuais. Empreendimento rudimentar, de baixo rendimento. } \\
\text { Empreendedor }\end{array}$} \\
\hline \multicolumn{2}{|c|}{ Granitos Pires - Mineração e Comércio Ltda. } \\
\hline \multicolumn{2}{|l|}{ Observações } \\
\hline \multicolumn{2}{|c|}{ Produção quase paralisada. Quando em alta, exportação via portos de Rio de Janeiro e Paranaguá. } \\
\hline \multicolumn{2}{|c|}{ Produção Média ( $\left.\mathrm{m}^{3} / \mathrm{mês}\right): 100$} \\
\hline Destino da Produção: $\mathrm{M}$ & \\
\hline
\end{tabular}

\section{FICHA DE CAMPO - $\mathrm{N}^{\circ} 4$}

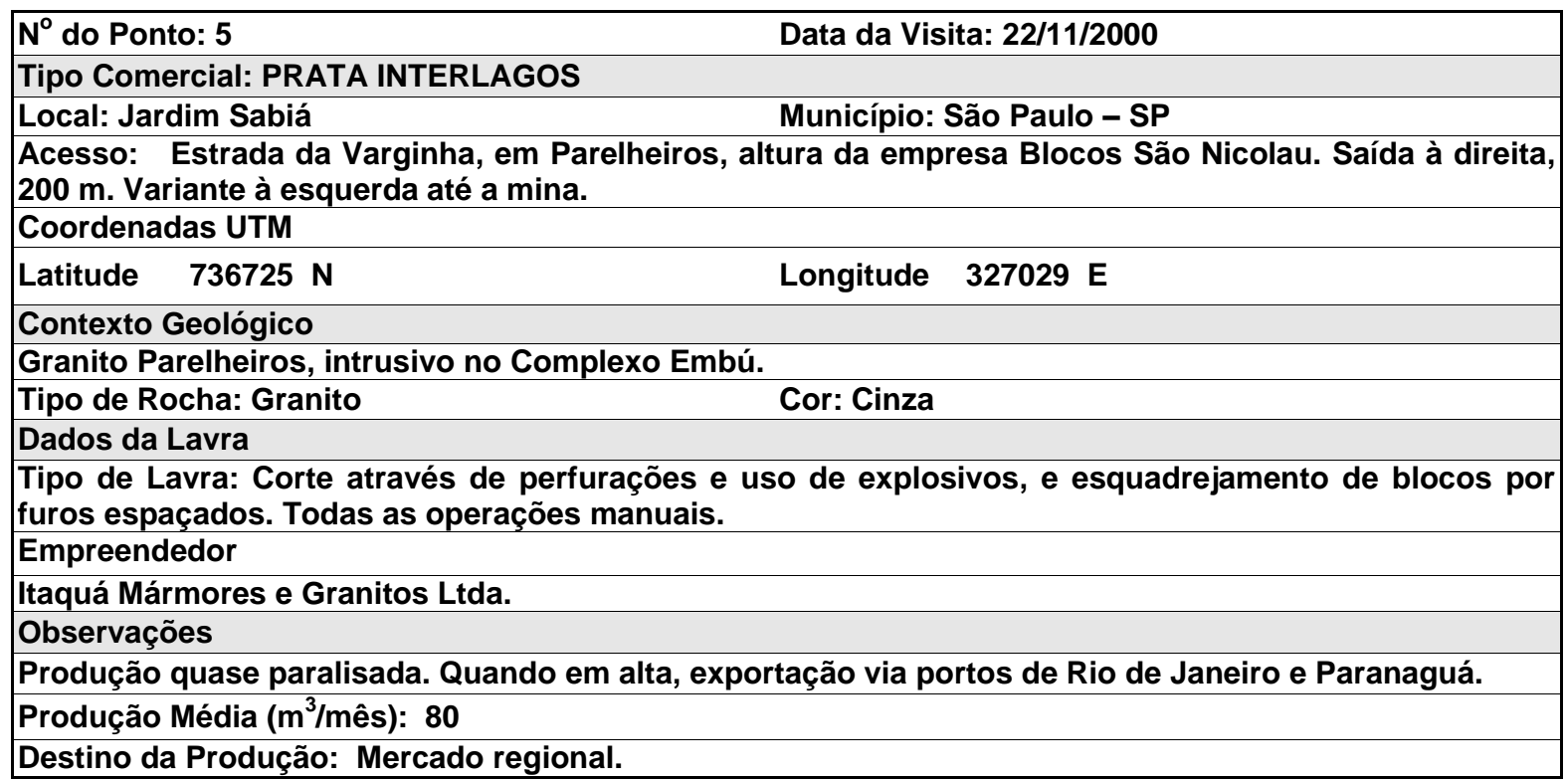


FICHA DE CAMPO - $\mathrm{N}^{\circ} 5$

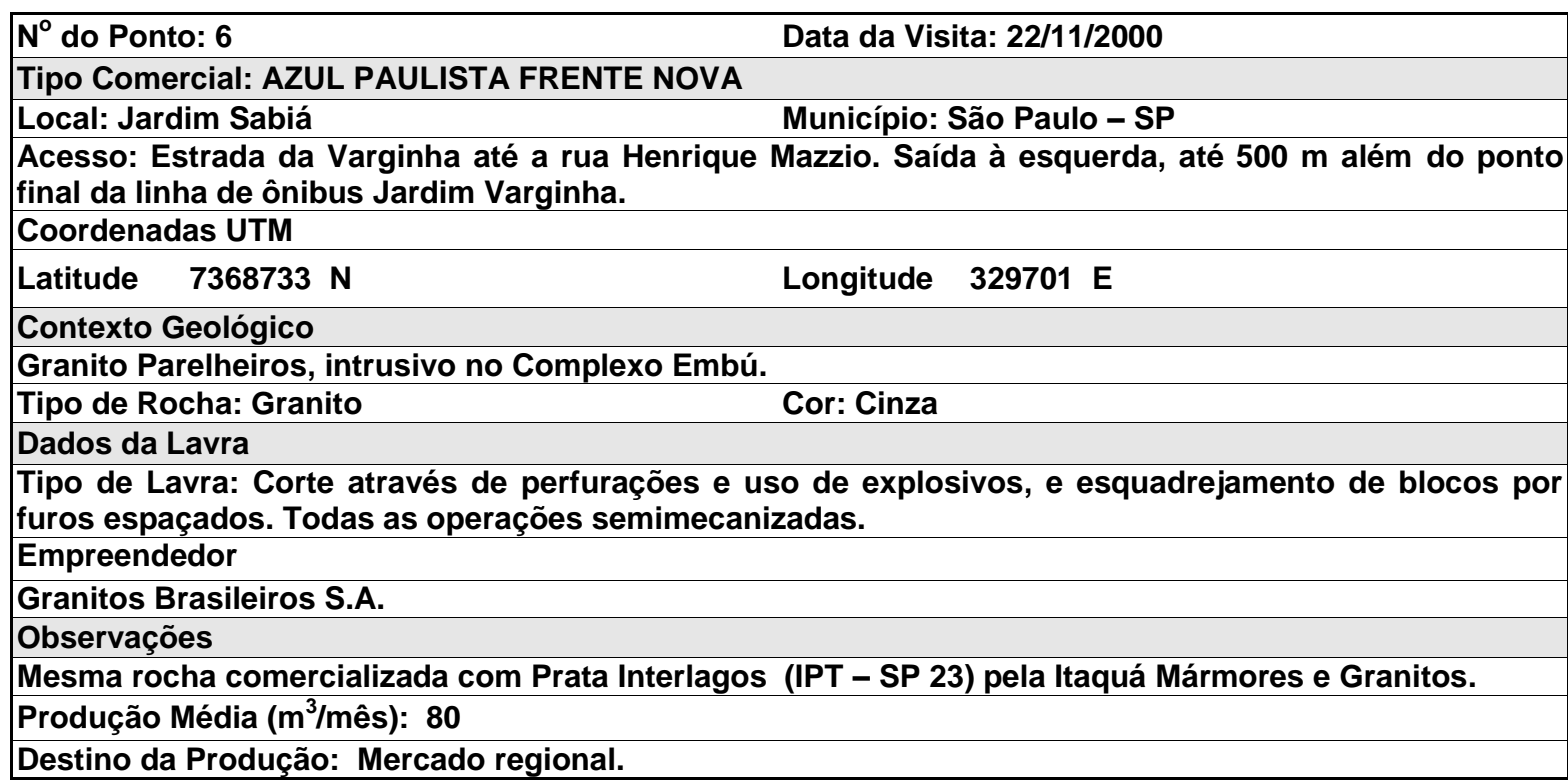

\section{FICHA DE CAMPO - $\mathrm{N}^{\circ} 6$}

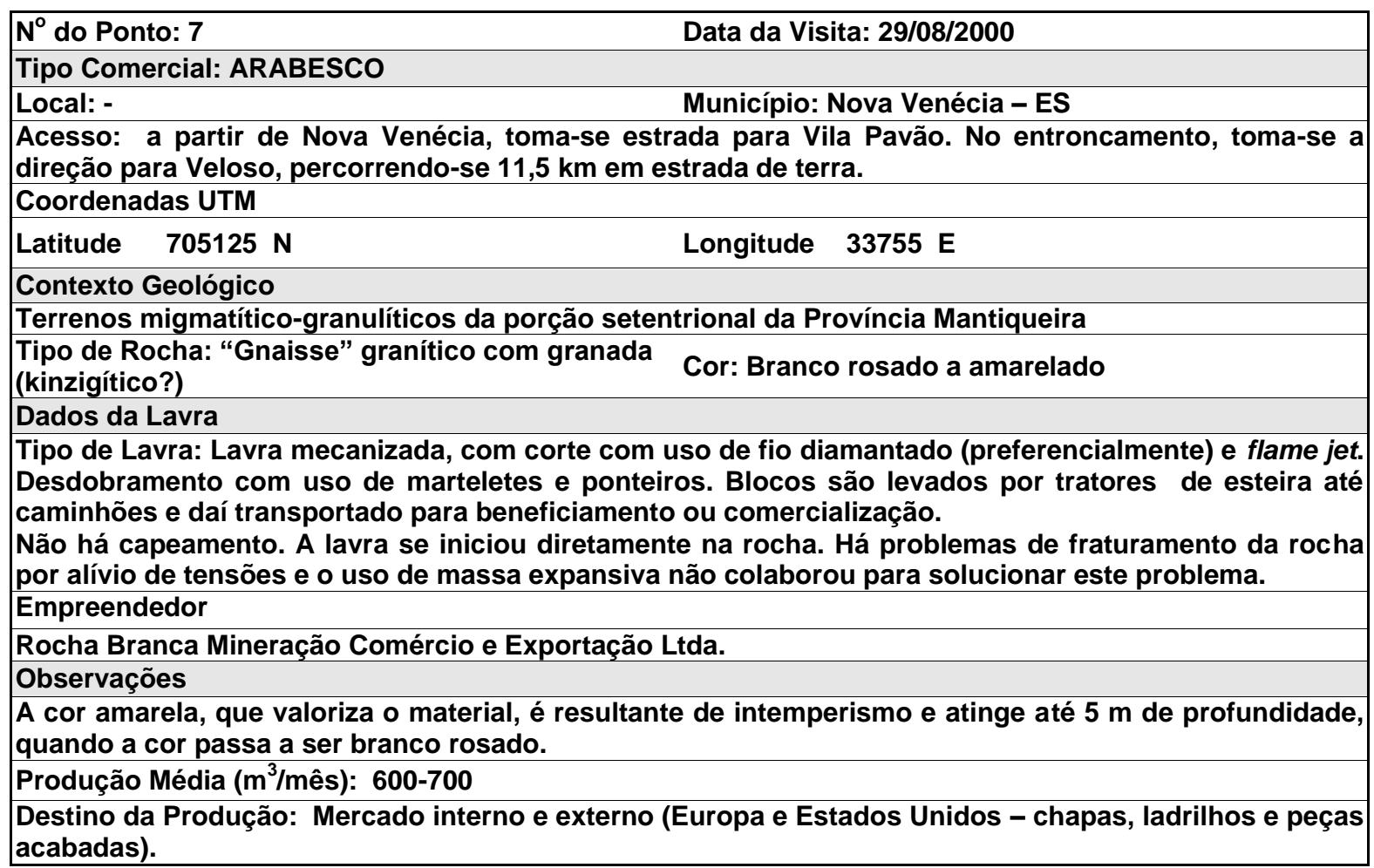


FICHA DE CAMPO - $\mathrm{N}^{\circ} 7$

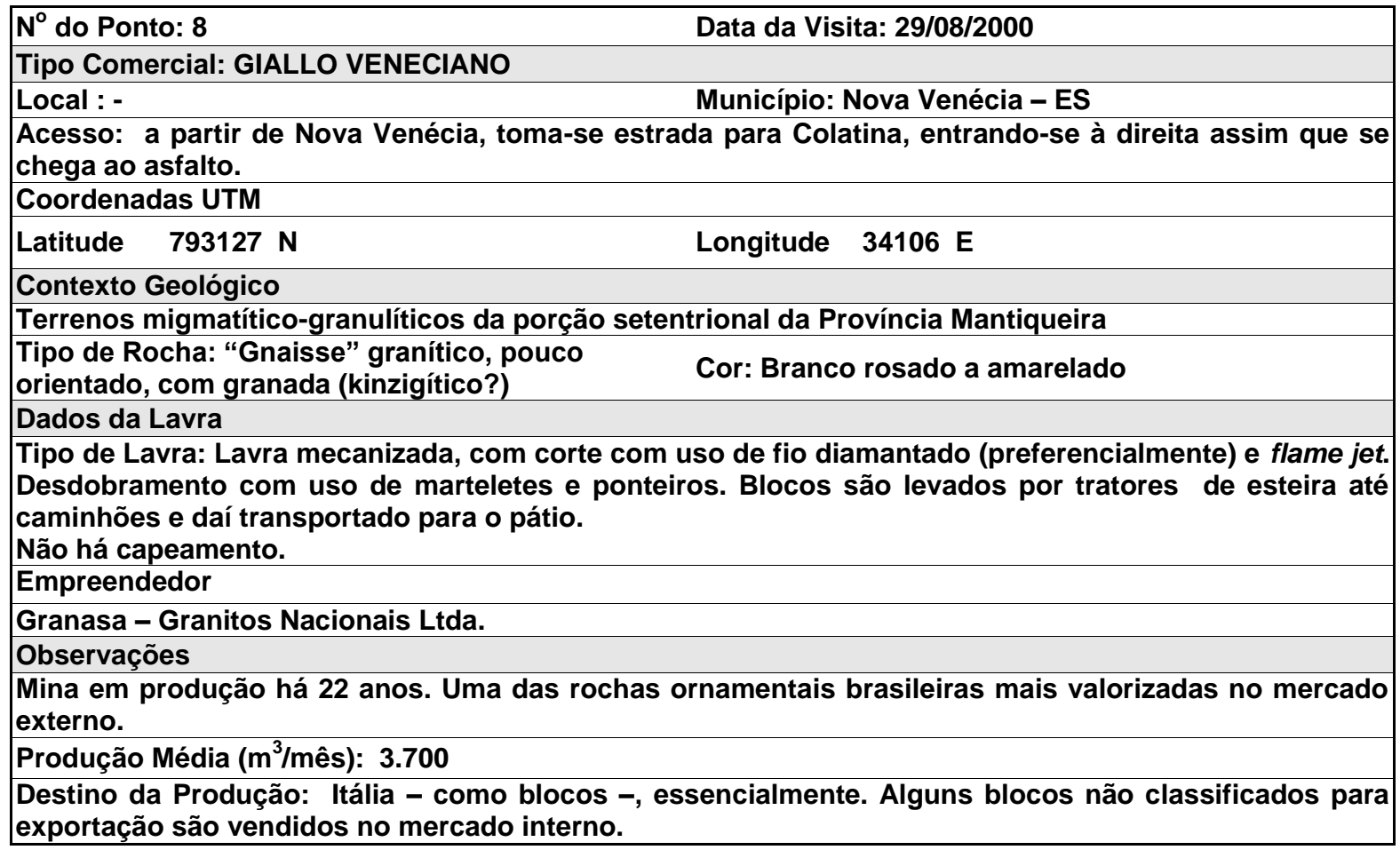

FICHA DE CAMPO - $N^{\circ} 8$

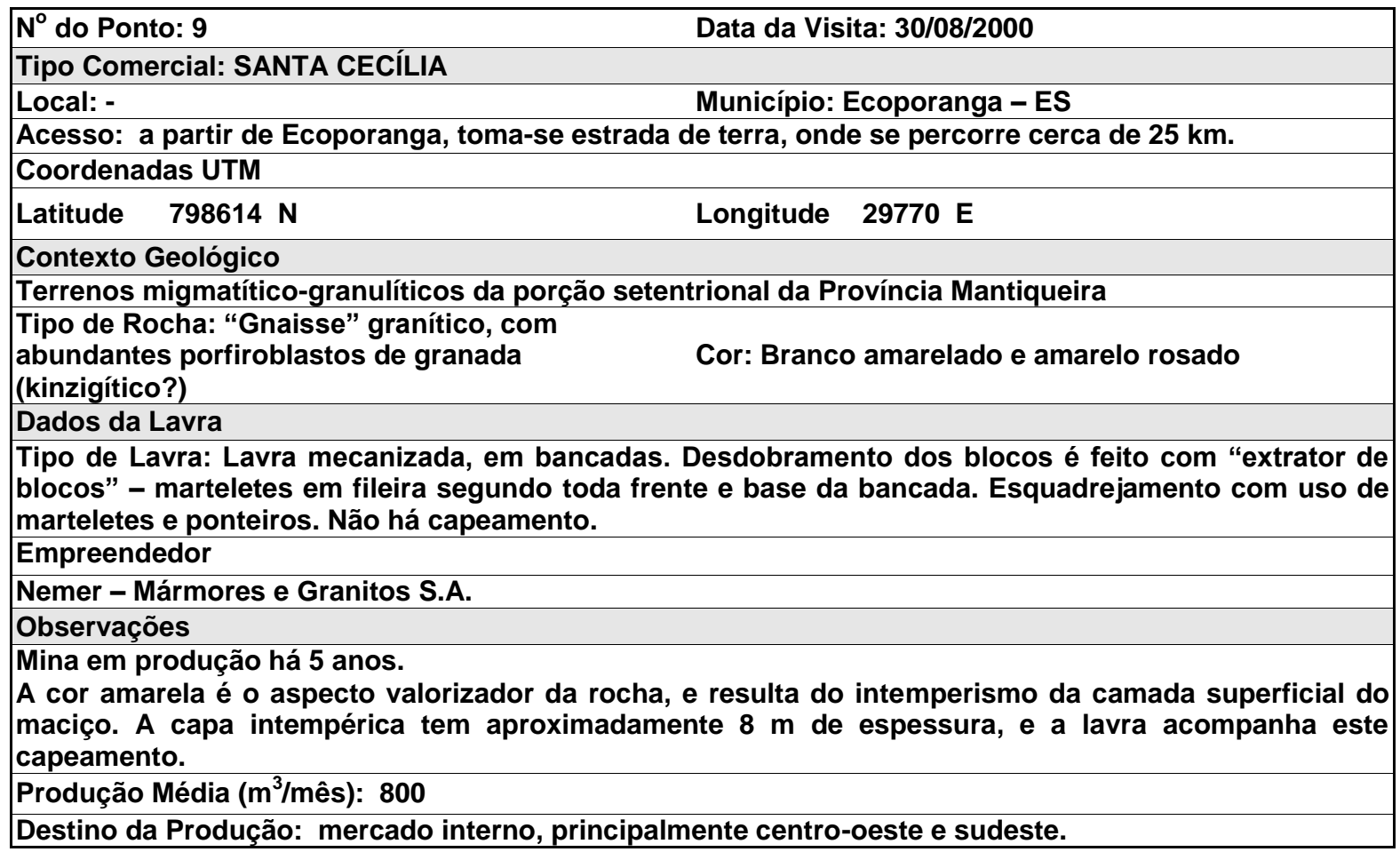


FICHA DE CAMPO $-\mathrm{N}^{\circ} 9$

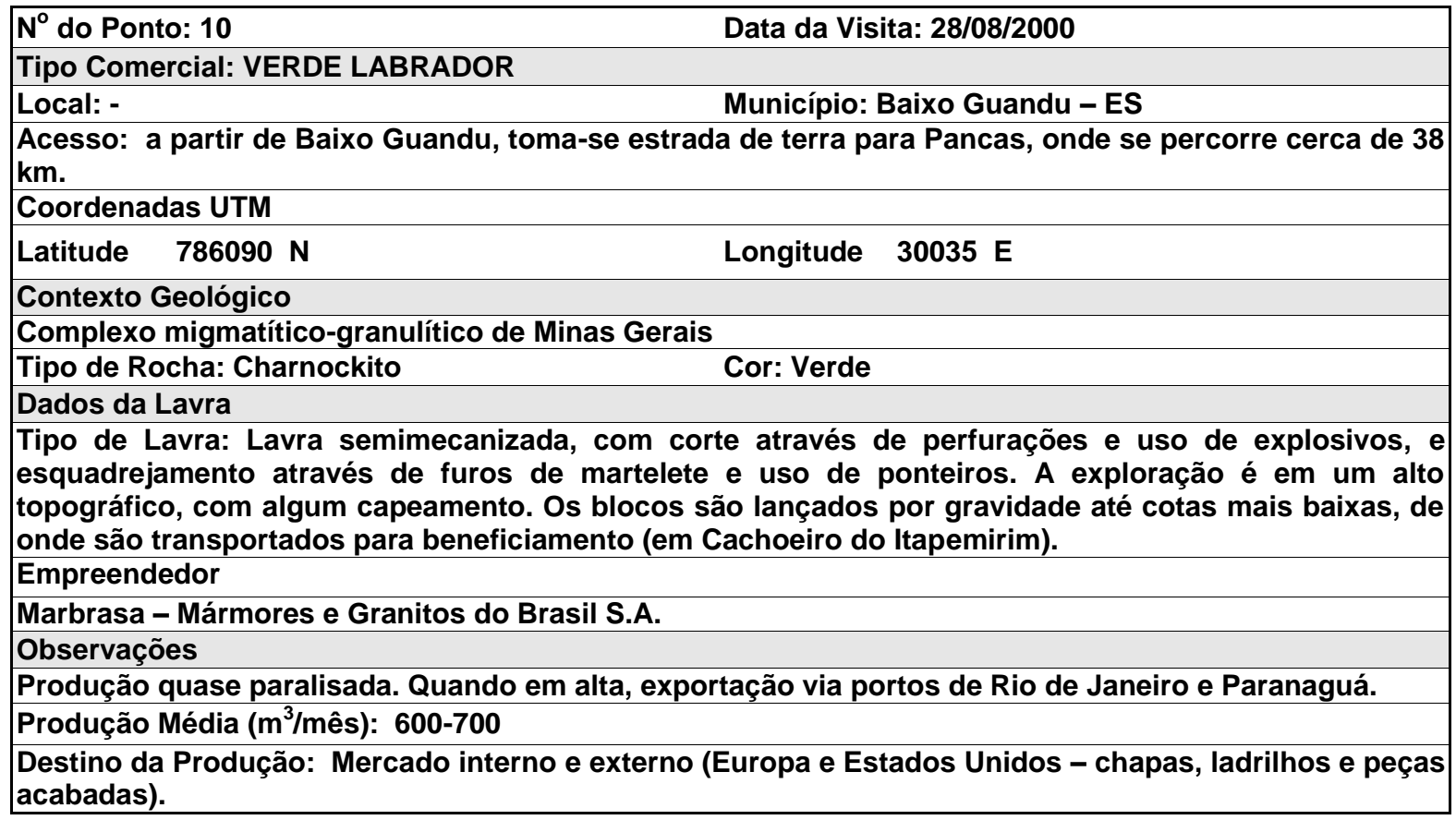

\section{FICHA DE CAMPO - $\mathbf{N}^{\circ} 10$}

\begin{tabular}{|c|}
\hline Data da Visita: 31/08/2000 \\
\hline Tipo Comercial: BRANCO ITAÚNAS \\
\hline Município: Medeiros Neto - BA \\
\hline $\begin{array}{l}\text { Acesso: a partir de Medeiros Neto, no entroncamento toma-se a direção Vereda. Após se percorrer } \\
\text { cerca de } 6 \mathrm{~km} \text {, toma-se à direita percorrendo-se mais } 6 \mathrm{~km} \text { em estrada de terra. } \\
\text { Coordenadas UTM }\end{array}$ \\
\hline Longitude $37854 \mathrm{E}$ \\
\hline Contexto Geológico \\
\hline Região de Dobramentos Araçuaí. Província kinzigítica do sul do Estado da Bahia. \\
\hline $\begin{array}{l}\text { Tipo de Rocha: "Gnaisse" granítico, com } \\
\text { abundantes porfiroblastos de granada }\end{array}$ \\
\hline Dados da Lavra \\
\hline $\begin{array}{l}\text { Tipo de Lavra: Lavra mecanizada, com uso de fio diamantado. Desdobramento dos blocos é feito com } \\
\text { marteletes, e o esquadrejamento com cunhas ou explosivos. } \\
\text { No início da lavra, houve extração de material granítico de cor amarela, logo abaixo do capeamento. } \\
\text { Empreendedor }\end{array}$ \\
\hline Mineração Corcovado Ltda. \\
\hline Observações \\
\hline $\begin{array}{l}\text { Existem } 2 \text { frentes de lavra, microponto II e microponto III, este últimó é um pouco mais grosso que o } \\
\text { Il e com maior tendência à modificação de cor (manchamento). É cortado por abundantes vênulas, } \\
\text { veios e bolsões pegmatóides (quartzo, feldspato - esverdeados - , com biotita). }\end{array}$ \\
\hline Produção Média (m³/mês): 250-300 (microponto II), 350-400 (microponto III) \\
\hline Destino da Produção: mercado extern \\
\hline
\end{tabular}


FICHA DE CAMPO - $\mathrm{N}^{\circ} 11$

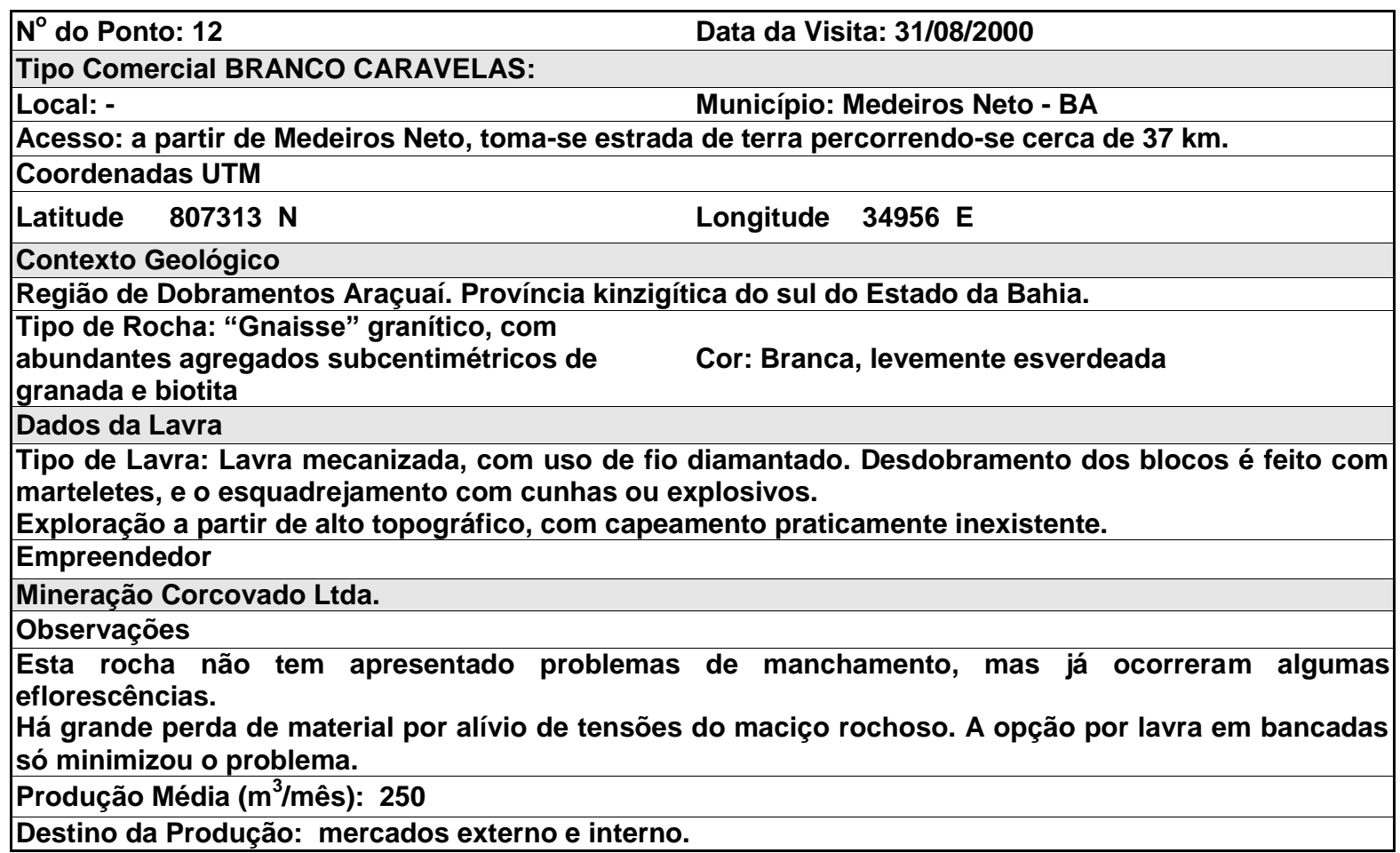

\section{FICHA DE CAMPO - $\mathrm{N}^{\circ} 12$}

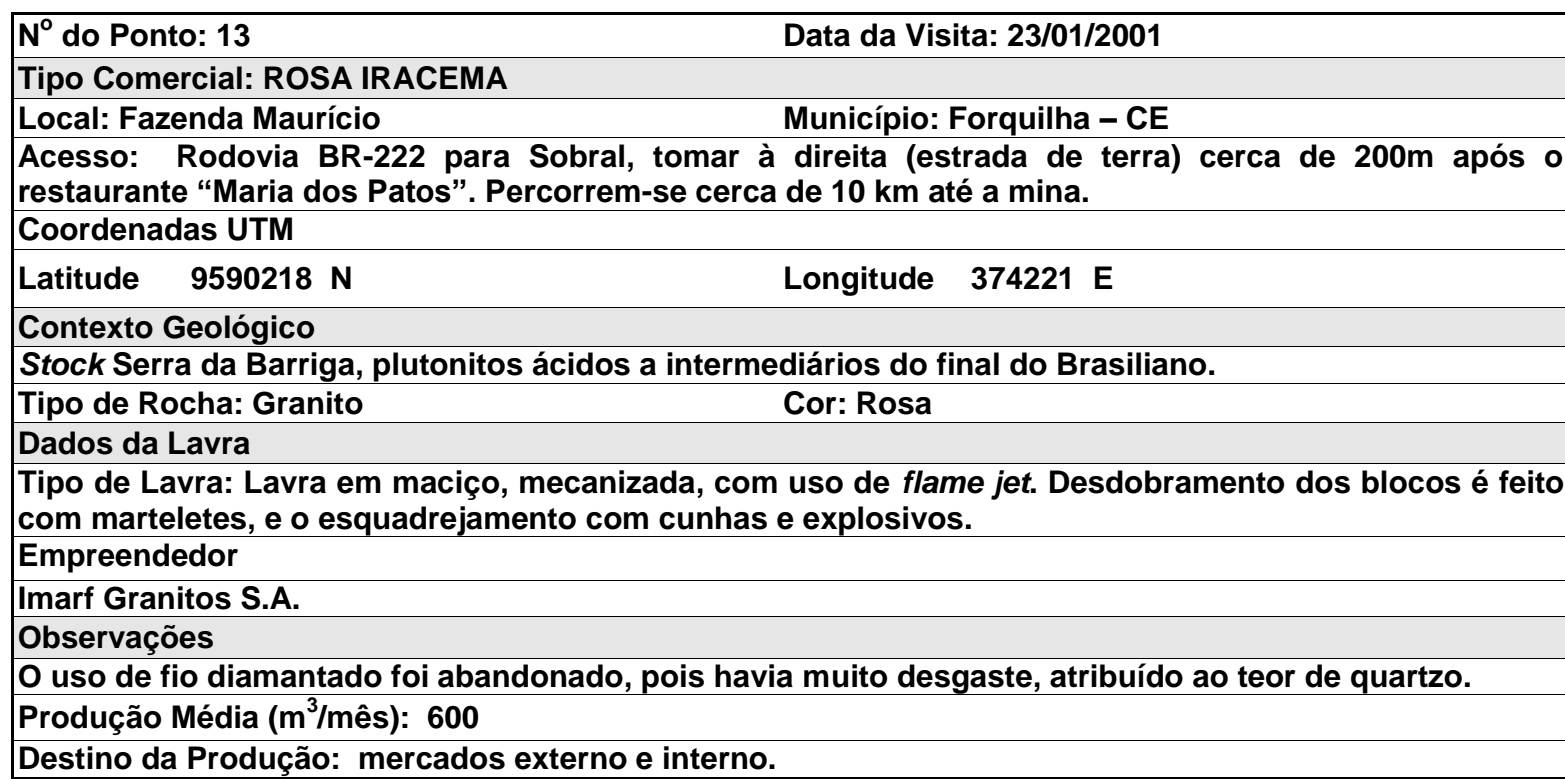


FICHA DE CAMPO - $\mathrm{N}^{\circ} 13$

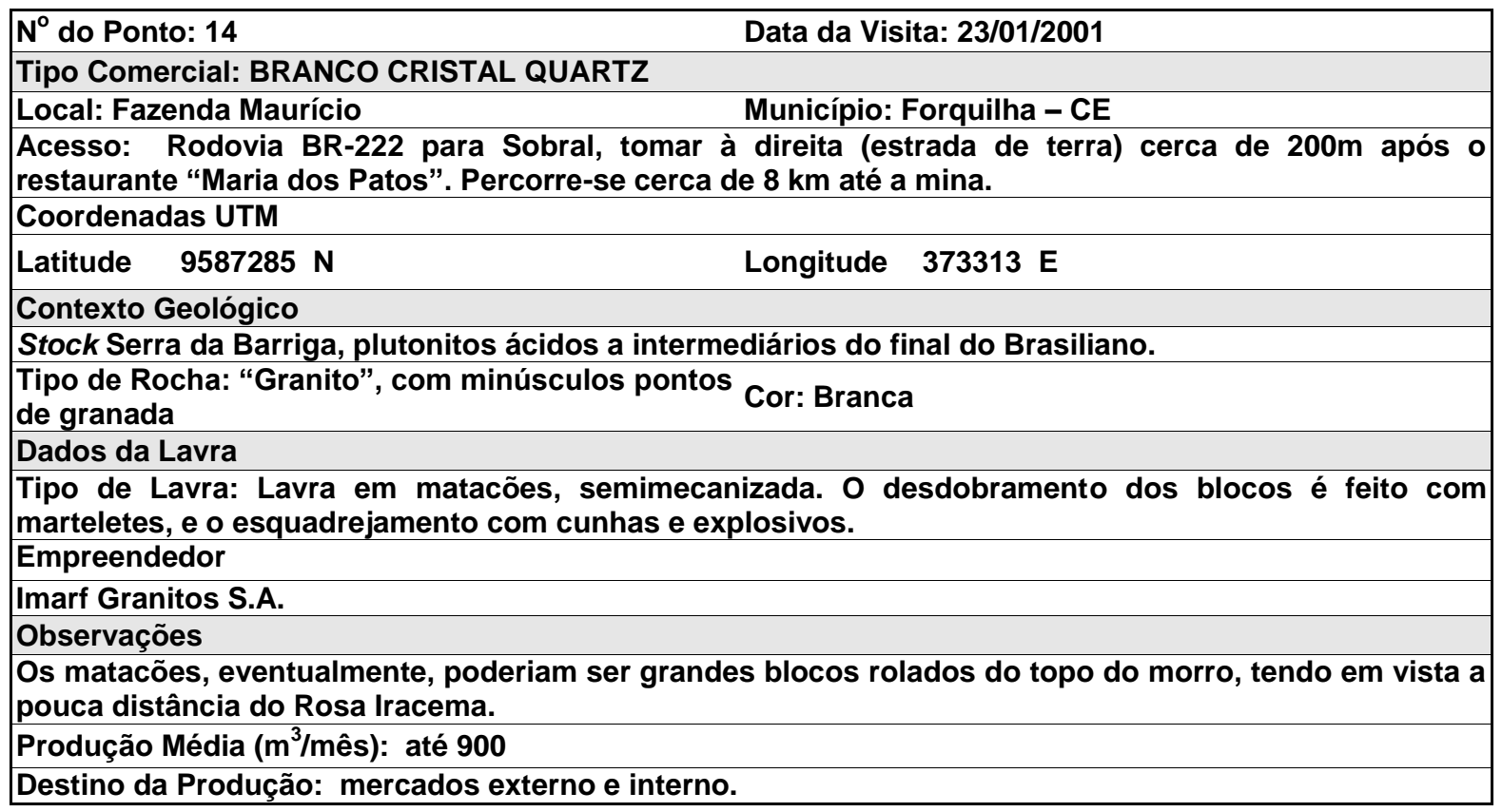

\section{FICHA DE CAMPO - $\mathrm{N}^{\circ} 14$}

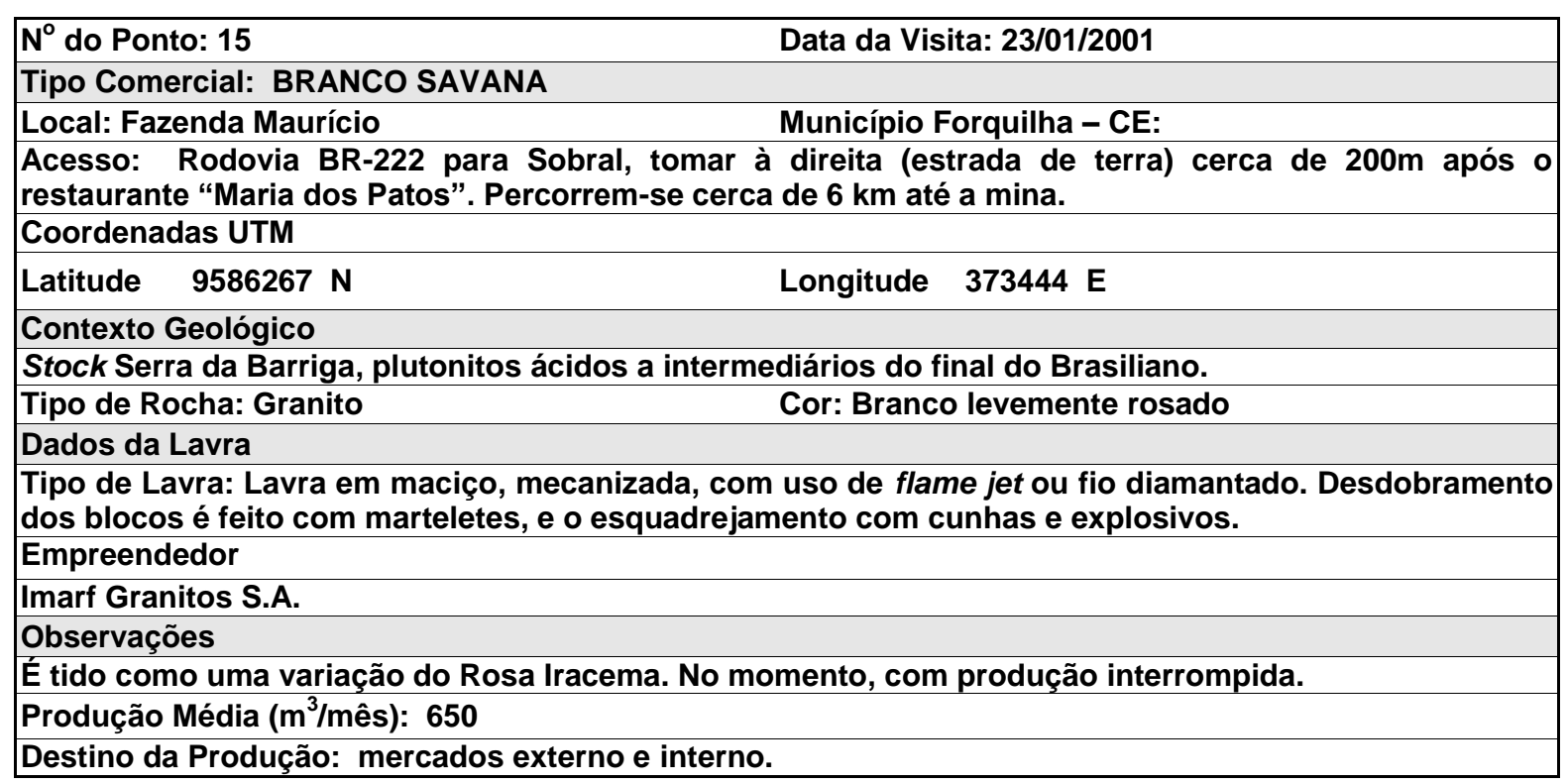


FICHA DE CAMPO - $\mathrm{N}^{\circ} 15$

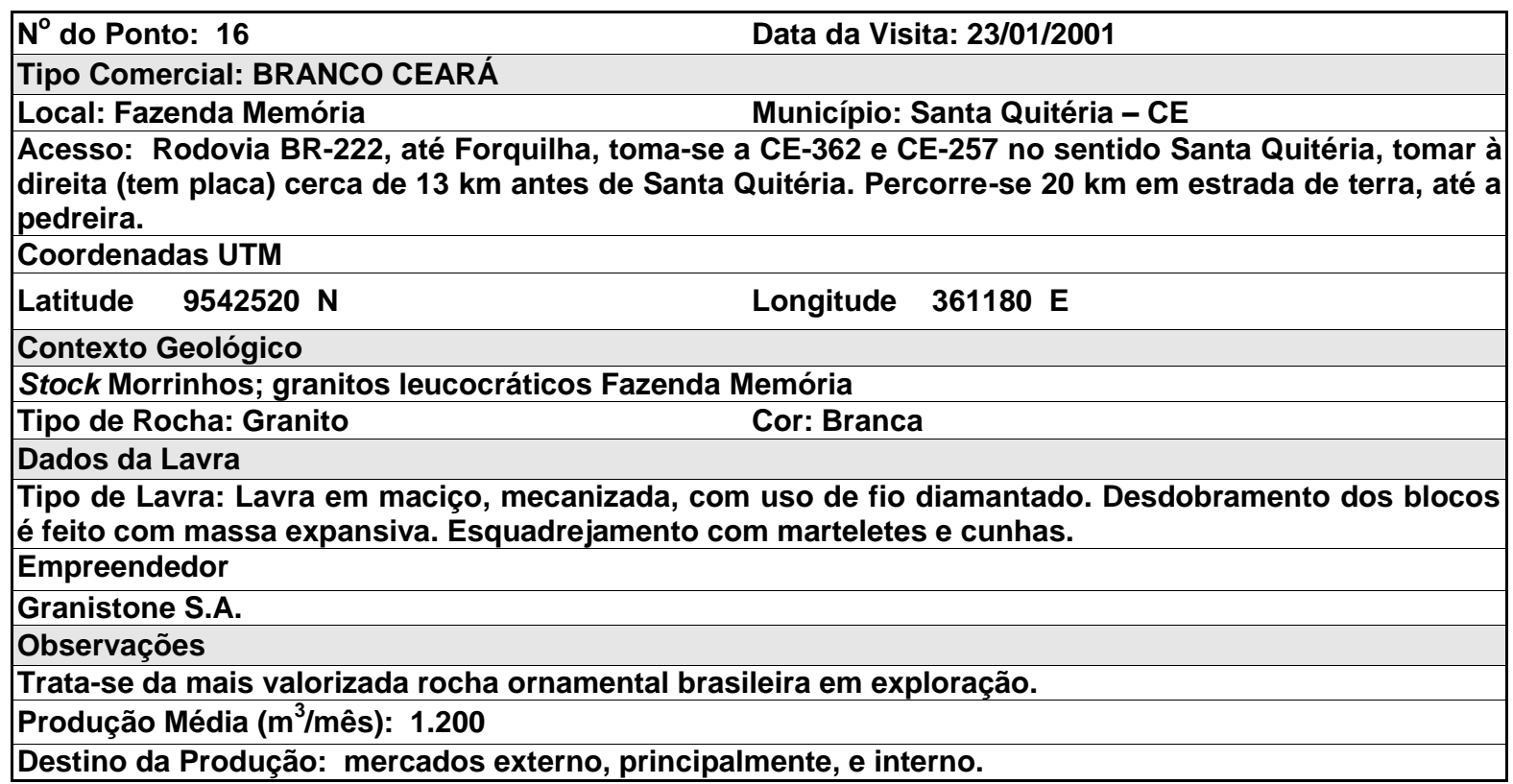

FICHA DE CAMPO - $\mathbf{N}^{\circ} 16$

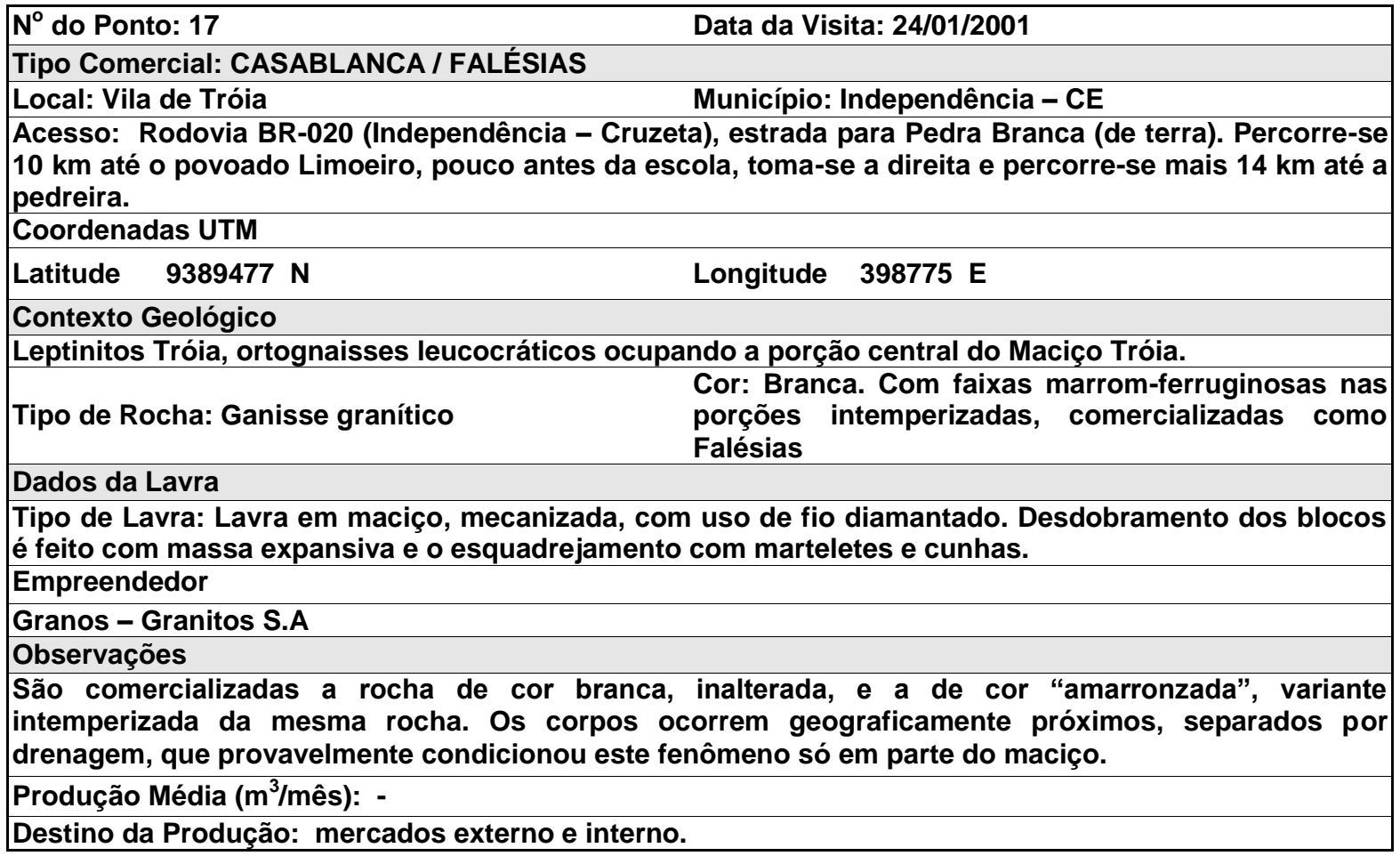


ANEXO B

Resultados de determinações de massa específica aparente, porosidade aparente e absorção d'água aparente (ABNT NBR 12766/92) 


\section{Legenda}

$\rho_{\text {sec }}=$ massa específica aparente seca $\left(\mathrm{kg} / \mathrm{m}^{3}\right)$;

$\bar{x}=$ média

$\eta$ = porosidade aparente (\%);

$S=$ desvio padrão

$\alpha$ = absorção d'água aparente (\%);

$C . V .=$ coeficiente de variação $(\%)$

\section{TAMANHOS DOS CORPOS-DE-PROVA: $10 \mathrm{~cm} \times 15 \mathrm{~cm}$}

\begin{tabular}{|c|c|c|c|}
\hline$\overline{\text { LBD }}$ & $\rho_{\mathrm{sec}}$ & $\eta$ & $\alpha$ \\
\hline 2 & 2.669 & 0,66 & 0,25 \\
\hline 3 & 2.659 & 0,64 & 0,24 \\
\hline 8 & 2.655 & 0,65 & 0,24 \\
\hline 9 & 2.668 & 0,63 & 0,23 \\
\hline 10 & 2.661 & 0,64 & 0,24 \\
\hline$\overline{\bar{x}}$ & 2.662 & 0,64 & 0,24 \\
\hline$S$ & 6 & 0,01 & 0,01 \\
\hline C.V. & 0,23 & 2,2 & 2,2 \\
\hline VCB-1 & $\overline{\rho_{\mathrm{sec}}}$ & $\eta$ & $\alpha$ \\
\hline 6 & 2.633 & 0,50 & 0,19 \\
\hline 7 & 2.633 & 0,51 & 0,19 \\
\hline 8 & 2.635 & 0,43 & 0,16 \\
\hline 9 & 2.633 & 0,48 & 0,18 \\
\hline 10 & 2.641 & 0,47 & 0,18 \\
\hline$\overline{\bar{x}}$ & 2.635 & 0,48 & 0,18 \\
\hline$S$ & 3 & 0,03 & 0,01 \\
\hline C.V. & 0,13 & 6,4 & 6,5 \\
\hline VCB-2 & $\overline{\rho_{\mathrm{sec}}}$ & $\eta$ & $\alpha$ \\
\hline 1 & 2.633 & 0,41 & 0,16 \\
\hline 3 & 2.633 & 0,41 & 0,16 \\
\hline 4 & 2.628 & 0,43 & 0,16 \\
\hline 5 & 2.631 & 0,41 & 0,16 \\
\hline 6 & 2.631 & 0,37 & 0,14 \\
\hline $\bar{x}$ & 2.631 & 0,41 & 0,15 \\
\hline$S$ & 2 & 0,02 & 0,01 \\
\hline C.V. & 0,09 & 5,7 & 5,8 \\
\hline
\end{tabular}

\begin{tabular}{|c|c|c|c|}
\hline VCB-3 & $\rho_{\mathrm{sec}}$ & $\eta$ & $\alpha$ \\
\hline 1 & 2.634 & 0,44 & 0,17 \\
\hline 2 & 2.646 & 0,44 & 0,17 \\
\hline 3 & 2.639 & 0,45 & 0,17 \\
\hline 4 & 2.635 & 0,46 & 0,18 \\
\hline 6 & 2.638 & 0,44 & 0,17 \\
\hline $\bar{x}$ & 2.639 & 0,45 & 0,17 \\
\hline$S$ & 5 & 0,01 & 0,00 \\
\hline C.V. & 0,18 & 1,9 & 2,0 \\
\hline RIC & $\rho_{\mathrm{sec}}$ & $\eta$ & $\alpha$ \\
\hline 1 & 2.622 & 0,45 & 0,17 \\
\hline 2 & 2.615 & 0,45 & 0,17 \\
\hline 3 & 2.626 & 0,45 & 0,17 \\
\hline 4 & 2.617 & 0,46 & 0,18 \\
\hline 5 & 2.619 & 0,47 & 0,18 \\
\hline 6 & 2.633 & 0,46 & 0,17 \\
\hline $\bar{x}$ & 2.622 & 0,46 & 0,17 \\
\hline$s$ & 7 & 0,01 & 0,00 \\
\hline C.V. & 0,26 & 1,9 & 1,9 \\
\hline BCR & $\rho_{\mathrm{sec}}$ & $\eta$ & $\alpha$ \\
\hline 1 & 2.609 & 0,87 & 0,34 \\
\hline 2 & 2.610 & 0,84 & 0,32 \\
\hline 3 & 2.610 & 0,87 & 0,33 \\
\hline 8 & 2.610 & 0,87 & 0,33 \\
\hline 9 & 2.610 & 0,87 & 0,33 \\
\hline 10 & 2.610 & 0,87 & 0,33 \\
\hline $\bar{x}$ & 2.610 & 0,87 & 0,33 \\
\hline$s$ & 1 & 0,01 & 0,01 \\
\hline C.V. & 0,02 & 1,6 & 1,7 \\
\hline BSV & $\rho_{\mathrm{sec}}$ & $\eta$ & $\alpha$ \\
\hline 1 & 2.616 & 0,65 & 0,25 \\
\hline 2 & 2.619 & 0,66 & 0,25 \\
\hline 3 & 2.615 & 0,73 & 0,28 \\
\hline 4 & 2.614 & 0,70 & 0,27 \\
\hline 5 & 2.619 & 0,66 & 0,25 \\
\hline $\bar{x}$ & 2.616 & 0,68 & 0,26 \\
\hline$s$ & 2 & 0,03 & 0,01 \\
\hline C.V. & 0,09 & 4,4 & 4,4 \\
\hline
\end{tabular}




\begin{tabular}{|c|c|c|c|}
\hline PIT-2cm & $\overline{\rho_{\mathrm{sec}}}$ & $\eta$ & $\alpha$ \\
\hline 1 & 2.624 & 0,77 & 0,30 \\
\hline 2 & 2.624 & 0,78 & 0,30 \\
\hline 3 & 2.623 & 0,79 & 0,30 \\
\hline $\bar{x}$ & 2.624 & 0,78 & 0,30 \\
\hline$s$ & 0 & 0,01 & 0,00 \\
\hline C.V. & 0,01 & 1,1 & 1,1 \\
\hline AZF & $\rho_{\mathrm{sec}}$ & $\eta$ & $\alpha$ \\
\hline 1 & 2.631 & 0,63 & 0,24 \\
\hline 2 & 2.630 & 0,63 & 0,24 \\
\hline 3 & 2.627 & 0,65 & 0,25 \\
\hline $\bar{x}$ & 2.629 & 0,64 & 0,24 \\
\hline$s$ & 2 & 0,01 & 0,01 \\
\hline C.V. & 0,07 & 2,2 & 2,3 \\
\hline BCE & $\rho_{\mathrm{sec}}$ & $\eta$ & $\alpha$ \\
\hline 1 & 2.616 & 0,63 & 0,24 \\
\hline 2 & 2.614 & 0,59 & 0,23 \\
\hline 3 & 2.615 & 0,62 & 0,24 \\
\hline 4 & 2.614 & 0,62 & 0,24 \\
\hline 5 & 2.615 & 0,58 & 0,22 \\
\hline $\bar{x}$ & 2.615 & 0,61 & 0,23 \\
\hline$s$ & 1 & 0,02 & 0,01 \\
\hline C.V. & 0,04 & 3,6 & 3,6 \\
\hline ITN-1 & $\rho_{\mathrm{sec}}$ & $\eta$ & $\bar{\alpha}$ \\
\hline 1 & 2.607 & 0,97 & 0,37 \\
\hline 2 & 2.614 & 0,91 & 0,35 \\
\hline 3 & 2.611 & 0,90 & 0,35 \\
\hline 4 & 2.610 & 0,94 & 0,36 \\
\hline 5 & 2.613 & 0,89 & 0,34 \\
\hline$\overline{\bar{x}}$ & 2.611 & 0,92 & 0,35 \\
\hline$S$ & 3 & 0,03 & 0,01 \\
\hline C.V. & 0,10 & 3,6 & 3,7 \\
\hline
\end{tabular}

\begin{tabular}{|c|c|c|c|}
\hline ITN-2 & $\rho_{\mathrm{sec}}$ & $\eta$ & $\alpha$ \\
\hline 1 & 2.613 & 0,82 & 0,31 \\
\hline 2 & 2.612 & 1,08 & 0,41 \\
\hline 3 & 2.603 & 0,91 & 0,35 \\
\hline 4 & 2.611 & 0,92 & 0,35 \\
\hline 5 & 2.610 & 0,95 & 0,36 \\
\hline 6 & 2.614 & 0,79 & 0,30 \\
\hline $\bar{x}$ & 2.610 & 0,91 & 0,35 \\
\hline$S$ & 4 & 0,10 & 0,04 \\
\hline C.V. & 0,15 & 11,1 & 11,1 \\
\hline CRV & $\rho_{\mathrm{sec}}$ & $\eta$ & $\alpha$ \\
\hline 1 & 2.620 & 0,82 & 0,31 \\
\hline 2 & 2.621 & 0,82 & 0,31 \\
\hline 3 & 2.621 & 0,85 & 0,33 \\
\hline 8 & 2.621 & 0,87 & 0,33 \\
\hline 9 & 2.619 & 0,87 & 0,33 \\
\hline 10 & 2.621 & 0,90 & 0,34 \\
\hline $\bar{x}$ & 2.621 & 0,86 & 0,33 \\
\hline$S$ & 1 & 0,03 & 0,01 \\
\hline C.V. & 0,03 & 3,4 & 3,4 \\
\hline CSB & $\rho_{\mathrm{sec}}$ & $\bar{\eta}$ & $\alpha$ \\
\hline 1 & 2.634 & 0,53 & 0,20 \\
\hline 2 & 2.629 & 0,72 & 0,28 \\
\hline 3 & 2.643 & 0,62 & 0,24 \\
\hline 8 & 2.630 & 0,60 & 0,23 \\
\hline 9 & 2.627 & 0,63 & 0,24 \\
\hline 10 & 2.631 & 0,61 & 0,23 \\
\hline $\bar{x}$ & 2.632 & 0,62 & 0,23 \\
\hline$S$ & 6 & 0,06 & 0,02 \\
\hline C.V. & 0,22 & 10,3 & 10,3 \\
\hline FLS & $\rho_{\mathrm{sec}}$ & $\bar{\eta}$ & $\alpha$ \\
\hline 1 & 2.632 & 0,68 & 0,26 \\
\hline 2 & 2.636 & 0,65 & 0,25 \\
\hline 3 & 2.607 & 0,69 & 0,26 \\
\hline 4 & 2.636 & 0,69 & 0,26 \\
\hline 5 & 2.609 & 0,72 & 0,28 \\
\hline $\bar{x}$ & 2.624 & 0,68 & 0,26 \\
\hline$S$ & 15 & 0,03 & 0,01 \\
\hline C.V. & 0,55 & 3,8 & 4,2 \\
\hline
\end{tabular}




\begin{tabular}{|c|c|c|c|}
\hline GVN & $\rho_{\mathrm{sec}}$ & $\eta$ & $\alpha$ \\
\hline 1 & 2.648 & 0,95 & 0,36 \\
\hline 2 & 2.645 & 0,93 & 0,35 \\
\hline 3 & 2.655 & 0,89 & 0,34 \\
\hline 4 & 2.648 & 0,87 & 0,33 \\
\hline 5 & 2.630 & 0,86 & 0,33 \\
\hline 6 & 2.636 & 0,84 & 0,32 \\
\hline$\overline{\bar{x}}$ & 2.644 & 0,89 & 0,34 \\
\hline$S$ & 9 & 0,04 & 0,02 \\
\hline C.V. & 0,35 & 4,7 & 4,6 \\
\hline ARB & $\rho_{\mathrm{sec}}$ & $\eta$ & $\alpha$ \\
\hline 1 & 2.641 & 0,75 & 0,28 \\
\hline 2 & 2.646 & 0,75 & 0,28 \\
\hline 3 & 2.641 & 0,79 & 0,30 \\
\hline 8 & 2.657 & 0,73 & 0,28 \\
\hline 9 & 2.651 & 0,73 & 0,28 \\
\hline 10 & 2.649 & 0,75 & 0,28 \\
\hline $\bar{x}$ & 2.648 & 0,75 & 0,28 \\
\hline$S$ & 6 & 0,02 & 0,01 \\
\hline C.V. & 0,24 & 2,6 & 2,8 \\
\hline SCC & $\overline{\rho_{\mathrm{sec}}}$ & $\bar{\eta}$ & $\bar{\alpha}$ \\
\hline 1 & 2.644 & 0,82 & 0,31 \\
\hline 2 & 2.642 & 0,74 & 0,28 \\
\hline 3 & 2.635 & 0,77 & 0,29 \\
\hline 8 & 2.646 & 0,61 & 0,23 \\
\hline 9 & 2.660 & 0,78 & 0,29 \\
\hline 10 & 2.634 & 0,79 & 0,30 \\
\hline $\bar{x}$ & 2.643 & 0,75 & 0,28 \\
\hline$S$ & 9 & 0,08 & 0,03 \\
\hline C.V. & 0,35 & 10,1 & 10,1 \\
\hline \multicolumn{4}{|c|}{ TAMANHOS DOS CORPOS DE PROVA: $10 \mathrm{~cm} \times 12 \mathrm{c}$} \\
\hline LBD & $\rho_{\mathrm{sec}}$ & $\eta$ & $\alpha$ \\
\hline $1 \mathrm{H}_{2} \mathrm{SO}_{4}$ & 2.655 & 0,70 & 0,26 \\
\hline $2 \mathrm{NaOH}$ & 2.659 & 0,69 & 0,26 \\
\hline $3 \mathrm{NaOH}$ & 2.655 & 0,67 & 0,25 \\
\hline $5 \mathrm{Pd}$ & 2.658 & 0,74 & 0,28 \\
\hline $5 \mathrm{H}_{2} \mathrm{SO}_{4}$ & 2.660 & 0,70 & 0,26 \\
\hline $\bar{x}$ & 2.658 & 0,70 & 0,26 \\
\hline$S$ & 2 & 0,03 & 0,01 \\
\hline C. V. & 0,09 & 3,6 & 3,6 \\
\hline
\end{tabular}

\begin{tabular}{|c|c|c|c|}
\hline VCB-1 & $\overline{\rho_{\mathrm{sec}}}$ & $\eta$ & $\alpha$ \\
\hline 6 & 2.634 & 0,60 & 0,23 \\
\hline 7 & 2.635 & 0,58 & 0,22 \\
\hline 8 & 2.635 & 0,54 & 0,21 \\
\hline 9 & 2.633 & 0,61 & 0,23 \\
\hline 10 & 2.641 & 0,56 & 0,21 \\
\hline$\overline{\bar{x}}$ & 2.636 & 0,58 & 0,22 \\
\hline$S$ & 3 & 0,03 & 0,01 \\
\hline C.V. & 0,13 & 4,7 & 4,7 \\
\hline VCB-2 & $\rho_{\mathrm{sec}}$ & $\bar{\eta}$ & $\bar{\alpha}$ \\
\hline 6 & 2.633 & 0,26 & 0,10 \\
\hline 7 & 2.636 & 0,29 & 0,11 \\
\hline 8 & 2.631 & 0,33 & 0,12 \\
\hline 9 & 2.631 & 0,31 & 0,12 \\
\hline 10 & 2.632 & 0,33 & 0,13 \\
\hline$\overline{\bar{x}}$ & 2.632 & 0,31 & 0,12 \\
\hline$S$ & 2 & 0,03 & 0,01 \\
\hline C.V. & 0,08 & 9,3 & 9,4 \\
\hline VCB-3 & $\rho_{\mathrm{sec}}$ & $\eta$ & $\alpha$ \\
\hline $1 \mathrm{NaOH}$ & 2.642 & 0,53 & 0,20 \\
\hline $2 \mathrm{H}_{2} \mathrm{SO}_{4}$ & 2.639 & 0,53 & 0,20 \\
\hline $3 \mathrm{NaOH}$ & 2.639 & 0,53 & 0,20 \\
\hline $4 \mathrm{H}_{2} \mathrm{SO}_{4}$ & 2.639 & 0,53 & 0,20 \\
\hline $5 \mathrm{Pd}$ & 2.637 & 0,56 & 0,21 \\
\hline$\overline{\bar{x}}$ & 2.639 & 0,54 & 0,20 \\
\hline$s$ & 2 & 0,01 & 0,01 \\
\hline C.V. & 0,07 & 2,4 & 2,5 \\
\hline RIC & $\rho_{\mathrm{sec}}$ & $\eta$ & $\alpha$ \\
\hline $1 \mathrm{H}_{2} \mathrm{SO}_{4}$ & 2.620 & 0,49 & 0,19 \\
\hline $2 \mathrm{NaOH}$ & 2.616 & 0,56 & 0,21 \\
\hline $3 \mathrm{Pd}$ & 2.612 & 0,59 & 0,23 \\
\hline $4 \mathrm{NaOH}$ & 2.619 & 0,55 & 0,21 \\
\hline $5 \mathrm{H}_{2} \mathrm{SO}_{4}$ & 2.619 & 0,53 & 0,20 \\
\hline $\bar{x}$ & 2.617 & 0,54 & 0,21 \\
\hline$s$ & 3 & 0,04 & 0,01 \\
\hline C.V. & 0,12 & 7,0 & 7,1 \\
\hline
\end{tabular}




\begin{tabular}{|c|c|c|c|}
\hline BCR & $\rho_{\mathrm{sec}}$ & $\eta$ & $\alpha$ \\
\hline $1 \mathrm{Pd}$ & 2.616 & 0,53 & 0,20 \\
\hline $2 \mathrm{NaOH}$ & 2.616 & 0,53 & 0,20 \\
\hline $3 \mathrm{H}_{2} \mathrm{SO}_{4}$ & 2.612 & 0,57 & 0,22 \\
\hline $4 \mathrm{NaOH}$ & 2.616 & 0,53 & 0,20 \\
\hline $6 \mathrm{H}_{2} \mathrm{SO}_{4}$ & 2.617 & 0,53 & 0,20 \\
\hline$\overline{\bar{x}}$ & 2.615 & 0,54 & 0,20 \\
\hline$S$ & 2 & 0,02 & 0,01 \\
\hline C.V. & 0,07 & 3,2 & 3,3 \\
\hline$\overline{B S V}$ & $\overline{\rho_{\mathrm{sec}}}$ & $\eta$ & $\alpha$ \\
\hline $1 \mathrm{HCL}$ & 2.619 & 0,63 & 0,24 \\
\hline $2 \mathrm{H}_{2} \mathrm{SO}_{4}$ & 2.620 & 0,67 & 0,25 \\
\hline $3 \mathrm{H}_{2} \mathrm{SO}_{4}$ & 2.620 & 0,63 & 0,24 \\
\hline $4 \mathrm{Pd}$ & 2.619 & 0,63 & 0,24 \\
\hline $5 \mathrm{NaOH}$ & 2.623 & 0,57 & 0,22 \\
\hline $\bar{x}$ & 2.620 & 0,62 & 0,24 \\
\hline$S$ & 2 & 0,03 & 0,01 \\
\hline C.V. & 0,06 & 5,3 & 5,3 \\
\hline PIT-2cm & $\rho_{\mathrm{sec}}$ & $\eta$ & $\alpha$ \\
\hline $4 \mathrm{H}_{2} \mathrm{SO}_{4}$ & 2.628 & 0,55 & 0,21 \\
\hline $5 \mathrm{NaOH}$ & 2.628 & 0,50 & 0,19 \\
\hline $5 \mathrm{PD}$ & 2.628 & 0,47 & 0,18 \\
\hline $6 \mathrm{H}_{2} \mathrm{SO}_{4}$ & 2.627 & 0,54 & 0,21 \\
\hline $7 \mathrm{NaOH}$ & 2.627 & 0,55 & 0,21 \\
\hline$\overline{\bar{x}}$ & 2.628 & 0,52 & 0,20 \\
\hline$S$ & 1 & 0,03 & 0,01 \\
\hline C.V. & 0,02 & 6,7 & 6,7 \\
\hline PIT-3cm & $\rho_{\mathrm{sec}}$ & $\eta$ & $\alpha$ \\
\hline $1 \mathrm{NaOH}$ & 2.623 & 0,79 & 0,30 \\
\hline $1 \mathrm{Pd}$ & 2.624 & 0,76 & 0,29 \\
\hline $1 \mathrm{H}_{2} \mathrm{SO}_{4}$ & 2.623 & 0,78 & 0,30 \\
\hline $2 \mathrm{H}_{2} \mathrm{SO}_{4}$ & 2.624 & 0,79 & 0,30 \\
\hline $2 \mathrm{NaOH}$ & 2.622 & 0,78 & 0,30 \\
\hline $\bar{x}$ & 2.623 & 0,78 & 0,30 \\
\hline$s$ & 1 & 0,01 & 0,01 \\
\hline C.V. & 0,03 & 1,8 & 1,8 \\
\hline
\end{tabular}

\begin{tabular}{|c|c|c|c|}
\hline AZF & $\rho_{\mathrm{sec}}$ & $\eta$ & $\alpha$ \\
\hline $\begin{array}{c}1 \mathrm{Pd} \\
2 \mathrm{NaOH} \\
3 \mathrm{NaOH} \\
4 \mathrm{H}_{2} \mathrm{SO}_{4} \\
5 \mathrm{H}_{2} \mathrm{SO}_{4}\end{array}$ & $\begin{array}{l}2.630 \\
2.630 \\
2.631 \\
2.628 \\
2.629 \\
\end{array}$ & $\begin{array}{l}0,65 \\
0,65 \\
0,62 \\
0,62 \\
0,65\end{array}$ & $\begin{array}{l}0,25 \\
0,25 \\
0,24 \\
0,24 \\
0,25\end{array}$ \\
\hline $\bar{x}$ & 2.630 & 0,64 & 0,24 \\
\hline$S$ & 1 & 0,02 & 0,01 \\
\hline C.V. & 0,03 & 2,5 & 2,5 \\
\hline BCE & $\rho_{\mathrm{sec}}$ & $\eta$ & $\alpha$ \\
\hline $\begin{array}{c}1 \mathrm{H}_{2} \mathrm{SO}_{4} \\
2 \mathrm{H}_{2} \mathrm{SO}_{4} \\
3 \mathrm{NaOH} \\
4 \mathrm{Pd} \\
5 \mathrm{NaOH}\end{array}$ & $\begin{array}{l}2.616 \\
2.612 \\
2.613 \\
2.614 \\
2.610\end{array}$ & $\begin{array}{l}0,75 \\
0,80 \\
0,82 \\
0,78 \\
0,83\end{array}$ & $\begin{array}{l}0,29 \\
0,31 \\
0,31 \\
0,30 \\
0,32\end{array}$ \\
\hline $\bar{x}$ & 2.613 & 0,80 & 0,30 \\
\hline$S$ & 2 & 0,03 & 0,01 \\
\hline C.V. & 0,08 & 3,9 & 4,0 \\
\hline$\rho_{\mathrm{sec}}$ & $\eta$ & $\alpha$ & $\rho_{\mathrm{sec}}$ \\
\hline $\begin{array}{c}1 \mathrm{H}_{2} \mathrm{SO}_{4} \\
1 \mathrm{Pd} \\
3 \mathrm{NaOH} \\
4 \mathrm{H}_{2} \mathrm{SO}_{4} \\
5 \mathrm{NaOH}\end{array}$ & $\begin{array}{l}2.614 \\
2.613 \\
2.619 \\
2.602 \\
2.613 \\
\end{array}$ & $\begin{array}{l}0,80 \\
0,83 \\
0,74 \\
0,76 \\
0,74\end{array}$ & $\begin{array}{l}0,30 \\
0,32 \\
0,28 \\
0,29 \\
0,28\end{array}$ \\
\hline $\bar{x}$ & 2.612 & 0,77 & 0,30 \\
\hline$S$ & 6 & 0,04 & 0,01 \\
\hline C.V. & 0,24 & 5,0 & 5,0 \\
\hline ITN-2 & $\rho_{\mathrm{sec}}$ & $\eta$ & $\alpha$ \\
\hline $\begin{array}{c}1 \mathrm{Pd} \\
2 \mathrm{NaOH} \\
3 \mathrm{NaOH} \\
5 \mathrm{H}_{2} \mathrm{SO}_{4} \\
6 \mathrm{H}_{2} \mathrm{SO}_{4} \\
\end{array}$ & $\begin{array}{l}2.617 \\
2.618 \\
2.614 \\
2.611 \\
2.610 \\
\end{array}$ & $\begin{array}{l}0,83 \\
0,79 \\
0,86 \\
0,94 \\
0,87 \\
\end{array}$ & $\begin{array}{l}0,32 \\
0,30 \\
0,33 \\
0,36 \\
0,33 \\
\end{array}$ \\
\hline$\overline{\bar{x}}$ & 2.614 & 0,86 & 0,33 \\
\hline$S$ & 3 & 0,05 & 0,02 \\
\hline C.V. & 0,13 & 6,4 & 6,5 \\
\hline
\end{tabular}




\begin{tabular}{|c|c|c|c|}
\hline CRV & $\overline{\rho_{\mathrm{sec}}}$ & $\bar{\eta}$ & $\alpha$ \\
\hline $1 \mathrm{H}_{2} \mathrm{SO}_{4}$ & 2.623 & 0,68 & 0,26 \\
\hline $3 \mathrm{NaOH}$ & 2.624 & 0,68 & 0,26 \\
\hline $4 \mathrm{H}_{2} \mathrm{SO}_{4}$ & 2.622 & 0,67 & 0,26 \\
\hline $5 \mathrm{Pd}$ & 2.622 & 0,68 & 0,26 \\
\hline $\mathrm{NaOH}$ & 2.622 & 0,72 & 0,27 \\
\hline $\bar{x}$ & 2.623 & 0,69 & 0,26 \\
\hline$S$ & 1 & 0,02 & 0,01 \\
\hline C.V. & 0,04 & 2,5 & 2,5 \\
\hline$\overline{C S B}$ & $\rho_{\mathrm{sec}}$ & $\bar{\eta}$ & $\bar{\alpha}$ \\
\hline $1 \mathrm{NaOH}$ & 2.630 & 0,75 & 0,28 \\
\hline $1 \mathrm{Pd}$ & 2.627 & 0,73 & 0,28 \\
\hline $2 \mathrm{H}_{2} \mathrm{SO}_{4}$ & 2.620 & 0,82 & 0,31 \\
\hline $7 \mathrm{NaOH}$ & 2.562 & 0,77 & 0,30 \\
\hline $8 \mathrm{H}_{2} \mathrm{SO}_{4}$ & 2.599 & 0,77 & 0,30 \\
\hline $8 \mathrm{Pd}$ & 2.598 & 0,75 & 0,29 \\
\hline$\overline{\bar{x}}$ & 2.606 & 0,76 & 0,29 \\
\hline$s$ & 26 & 0,03 & 0,01 \\
\hline C.V. & 0,98 & 4,1 & 4,3 \\
\hline FLS & $\rho_{\mathrm{sec}}$ & $\eta$ & $\alpha$ \\
\hline $1 \mathrm{NaOH}$ & 2.598 & 1,05 & 0,40 \\
\hline $2 \mathrm{H}_{2} \mathrm{SO}_{4}$ & 2.613 & 1,16 & 0,44 \\
\hline $2 \mathrm{Pd}$ & 2.601 & 1,12 & 0,43 \\
\hline $3 \mathrm{NaOH}$ & 2.595 & 0,98 & 0,38 \\
\hline $7 \mathrm{H}_{2} \mathrm{SO}_{4}$ & 2.623 & 1,07 & 0,41 \\
\hline $8 \mathrm{H}_{2} \mathrm{SO}_{4}$ & 2.616 & 1,04 & 0,40 \\
\hline $9 \mathrm{NaOH}$ & 2.614 & 1,09 & 0,42 \\
\hline $9 \mathrm{Pd}$ & 2.634 & 1,09 & 0,42 \\
\hline$\overline{\bar{x}}$ & 2.612 & 1,08 & 0,41 \\
\hline$S$ & 13 & 0,05 & 0,02 \\
\hline C.V. & 0,51 & 4,9 & 4,8 \\
\hline$\overline{G V N}$ & $\rho_{\mathrm{sec}}$ & $\eta$ & $\alpha$ \\
\hline $2 \mathrm{H}_{2} \mathrm{SO}_{4}$ & 2.636 & 0,74 & 0,28 \\
\hline $2 \mathrm{Pd}$ & 2.629 & 0,87 & 0,33 \\
\hline $3 \mathrm{NaOH}$ & 2.645 & 0,81 & 0,30 \\
\hline $8 \mathrm{Pd}$ & 2.636 & 0,77 & 0,29 \\
\hline $8 \mathrm{H}_{2} \mathrm{SO}_{4}$ & 2.633 & 0,81 & 0,31 \\
\hline $9 \mathrm{NaOH}$ & 2.638 & 0,80 & 0,30 \\
\hline $\bar{x}$ & 2.636 & 0,80 & 0,30 \\
\hline$S$ & 5 & 0,04 & 0,02 \\
\hline C.V. & 0,19 & 5,6 & 5,7 \\
\hline
\end{tabular}

\begin{tabular}{cccc}
\hline ARB & $\eta$ & $\alpha$ & $\rho_{\text {sec }}$ \\
\hline $1 \mathrm{H}_{2} \mathrm{SO}_{4}$ & 2.657 & 0,58 & 0,22 \\
$2 \mathrm{Pd}$ & 2.657 & 0,62 & 0,23 \\
$3 \mathrm{NaOH}$ & 2.645 & 0,58 & 0,22 \\
$8 \mathrm{H}_{2} \mathrm{SO}_{4}$ & 2.660 & 0,57 & 0,22 \\
$8 \mathrm{Pd}$ & 2.670 & 0,60 & 0,23 \\
$9 \mathrm{HCl}$ & 2.667 & 0,60 & 0,23 \\
\hline$\overline{\boldsymbol{x}}$ & 2.660 & 0,59 & 0,22 \\
$S$ & 9 & 0,02 & 0,01 \\
$C . V$. & 0,33 & 2,9 & 2,8 \\
\hline \hline $\mathrm{SCC}$ & $\eta$ & $\alpha$ & $\rho_{\text {sec }}$ \\
\hline $1 \mathrm{H}_{2} \mathrm{SO}_{4}$ & 2.638 & 0,68 & 0,26 \\
$3 \mathrm{NaOH}$ & 2.638 & 0,69 & 0,26 \\
$7 \mathrm{H} \mathrm{SO}_{4}$ & 2.643 & 0,73 & 0,27 \\
$8 \mathrm{NaOH}$ & 2.637 & 0,70 & 0,27 \\
$9 \mathrm{Pd}$ & 2.628 & 0,71 & 0,27 \\
\hline $\bar{x}$ & 2.637 & 0,70 & 0,27 \\
$S$ & 6 & 0,02 & 0,01 \\
$C . V$. & 0,21 & 2,6 & 2,6 \\
\hline
\end{tabular}

TAMANHO DOS CORPOS DE PROVA: $10 \mathrm{~cm} \times 10 \mathrm{~cm}$

\begin{tabular}{cccc}
\hline LBD & $\rho_{\text {sec }}$ & $\eta$ & $\alpha$ \\
\hline 1 & 2.656 & 0,70 & 0,26 \\
2 & 2.659 & 0,69 & 0,26 \\
3 & 2.668 & 0,72 & 0,27 \\
4 & 2.659 & 0,70 & 0,26 \\
$4 \mathrm{~A}$ & 2.663 & 0,70 & 0,26 \\
5 & 2.656 & 0,70 & 0,26 \\
\hline $\bar{x}$ & 2.660 & 0,70 & 0,26 \\
$S$ & 4 & 0,01 & 0,00 \\
$C . V$. & 0,17 & 1,5 & 1,4 \\
\hline \hline VCB-1 & $\rho_{\text {sec }}$ & $\eta$ & $\alpha$ \\
\hline 1 & 2.637 & 0,45 & 0,17 \\
2 & 2.636 & 0,46 & 0,17 \\
3 & 2.636 & 0,39 & 0,15 \\
4 & 2.640 & 0,42 & 0,16 \\
5 & 2.637 & 0,35 & 0,13 \\
\hline $\bar{x}$ & 2.637 & 0,41 & 0,16 \\
$S$ & 2 & 0,05 & 0,02 \\
$C . V$. & 0,07 & 11,3 & 11,3 \\
\hline
\end{tabular}




\begin{tabular}{|c|c|c|c|}
\hline VCB-2 & $\overline{\rho_{\mathrm{sec}}}$ & $\eta$ & $\alpha$ \\
\hline 1 & 2.633 & 0,28 & 0,11 \\
\hline 2 & 2.631 & 0,24 & 0,09 \\
\hline 3 & 2.643 & 0,31 & 0,12 \\
\hline 4 & 2.631 & 0,38 & 0,15 \\
\hline 5 & 2.631 & 0,38 & 0,14 \\
\hline $\bar{x}$ & 2.634 & 0,32 & 0,12 \\
\hline$S$ & 5 & 0,06 & 0,02 \\
\hline C.V. & 0,19 & 19,4 & 19,5 \\
\hline VCB-3 & $\rho_{\mathrm{sec}}$ & $\eta$ & $\bar{\alpha}$ \\
\hline 1 & 2.640 & 0,52 & 0,20 \\
\hline 2 & 2.646 & 0,53 & 0,20 \\
\hline 3 & 2.643 & 0,53 & 0,20 \\
\hline 4 & 2.641 & 0,50 & 0,19 \\
\hline 5 & 2.638 & 0,56 & 0,21 \\
\hline $5 \mathrm{~A}$ & 2.637 & 0,53 & 0,20 \\
\hline $\bar{x}$ & 2.641 & 0,53 & 0,20 \\
\hline$S$ & 3 & 0,02 & 0,01 \\
\hline C.V. & 0,12 & 4,2 & 4,3 \\
\hline RIC & $\rho_{\mathrm{sec}}$ & $\eta$ & $\alpha$ \\
\hline 1 & 2.619 & 0,66 & 0,25 \\
\hline $1 \mathrm{~A}$ & 2.618 & 0,67 & 0,26 \\
\hline 2 & 2.615 & 0,71 & 0,27 \\
\hline 3 & 2.617 & 0,66 & 0,25 \\
\hline 4 & 2.621 & 0,70 & 0,27 \\
\hline 5 & 2.618 & 0,68 & 0,26 \\
\hline $\bar{x}$ & 2.618 & 0,68 & 0,26 \\
\hline$S$ & 2 & 0,02 & 0,01 \\
\hline C.V. & 0,08 & 3,3 & 3,3 \\
\hline BCR & $\overline{\rho_{\mathrm{sec}}}$ & $\eta$ & $\alpha$ \\
\hline 1 & 2.614 & 0,69 & 0,26 \\
\hline 2 & 2.614 & 0,64 & 0,24 \\
\hline 3 & 2.614 & 0,63 & 0,24 \\
\hline 4 & 2.613 & 0,68 & 0,26 \\
\hline 5 & 2.614 & 0,63 & 0,24 \\
\hline 6 & 2.616 & 0,63 & 0,24 \\
\hline$\overline{\bar{x}}$ & 2.614 & 0,65 & 0,25 \\
\hline$S$ & 1 & 0,03 & 0,01 \\
\hline C.V. & 0,03 & 3,9 & 4,0 \\
\hline
\end{tabular}

\begin{tabular}{|c|c|c|c|}
\hline BSV & $\overline{\rho_{\mathrm{sec}}}$ & $\bar{\eta}$ & $\bar{\alpha}$ \\
\hline 1 & 2.620 & 0,74 & 0,28 \\
\hline 2 & 2.623 & 0,75 & 0,28 \\
\hline 3 & 2.621 & 0,75 & 0,28 \\
\hline 4 & 2.622 & 0,69 & 0,26 \\
\hline 5 & 2.624 & 0,74 & 0,28 \\
\hline $5 \mathrm{~A}$ & 2.623 & 0,73 & 0,28 \\
\hline $\bar{x}$ & 2.622 & 0,73 & 0,28 \\
\hline$S$ & 1 & 0,02 & 0,01 \\
\hline C.V. & 0,05 & 2,7 & 2,7 \\
\hline PIT-2cm & $\rho_{\mathrm{sec}}$ & $\eta$ & $\bar{\alpha}$ \\
\hline 4 & 2.628 & 0,76 & 0,29 \\
\hline 5 & 2.626 & 0,80 & 0,30 \\
\hline 6 & 2.626 & 0,79 & 0,30 \\
\hline $6 \mathrm{~A}$ & 2.624 & 0,75 & 0,29 \\
\hline 7 & 2.625 & 0,73 & 0,28 \\
\hline $7 \mathrm{~A}$ & 2.626 & 0,80 & 0,31 \\
\hline $\bar{x}$ & 2.626 & 0,77 & 0,29 \\
\hline$s$ & 1 & 0,03 & 0,01 \\
\hline C.V. & 0,06 & 4,0 & 4,0 \\
\hline$\overline{A Z F}$ & $\rho_{\mathrm{sec}}$ & $\eta$ & $\alpha$ \\
\hline 1 & 2.628 & 0,74 & 0,28 \\
\hline 2 & 2.629 & 0,73 & 0,28 \\
\hline 3 & 2.632 & 0,73 & 0,28 \\
\hline 4 & 2.629 & 0,73 & 0,28 \\
\hline 5 & 2.630 & 0,74 & 0,28 \\
\hline $\bar{x}$ & 2.629 & 0,73 & 0,28 \\
\hline$s$ & 1 & 0,01 & 0,00 \\
\hline C.V. & 0,05 & 0,9 & 1,0 \\
\hline BCE & $\rho_{\mathrm{sec}}$ & $\eta$ & $\alpha$ \\
\hline 1 & 2.612 & 0,84 & 0,32 \\
\hline 2 & 2.612 & 0,87 & 0,33 \\
\hline 3 & 2.613 & 0,84 & 0,32 \\
\hline 4 & 2.611 & 0,88 & 0,34 \\
\hline 5 & 2.611 & 0,83 & 0,32 \\
\hline $5 \mathrm{~A}$ & 2.611 & 0,82 & 0,31 \\
\hline $\bar{x}$ & 2.612 & 0,85 & 0,32 \\
\hline$s$ & 1 & 0,02 & 0,01 \\
\hline C.V. & 0,03 & 2,7 & 2,7 \\
\hline
\end{tabular}




\begin{tabular}{|c|c|c|c|}
\hline ITN-1 & $\rho_{\mathrm{sec}}$ & $\eta$ & $\alpha$ \\
\hline 1 & 2.606 & 1,08 & 0,42 \\
\hline 2 & 2.606 & 1,12 & 0,43 \\
\hline 3 & 2.606 & 1,08 & 0,42 \\
\hline 4 & 2.611 & 0,91 & 0,35 \\
\hline 5 & 2.618 & 0,91 & 0,35 \\
\hline 6 & 2.612 & 0,96 & 0,37 \\
\hline $\bar{x}$ & 2.610 & 1,01 & 0,39 \\
\hline$S$ & 5 & 0,09 & 0,04 \\
\hline C.V. & 0,18 & 9,3 & 9,4 \\
\hline ITN-2 & $\rho_{\mathrm{sec}}$ & $\eta$ & $\alpha$ \\
\hline 1 & 2.619 & 0,85 & 0,33 \\
\hline 2 & 2.611 & 0,85 & 0,32 \\
\hline 3 & 2.615 & 0,89 & 0,34 \\
\hline 4 & 2.608 & 0,90 & 0,34 \\
\hline 5 & 2.618 & 0,85 & 0,33 \\
\hline 6 & 2.612 & 0,94 & 0,36 \\
\hline $\bar{x}$ & 2.614 & 0,88 & 0,34 \\
\hline$S$ & 4 & 0,04 & 0,01 \\
\hline C.V. & 0,16 & 4,1 & 4,2 \\
\hline CRV & $\rho_{\mathrm{sec}}$ & $\eta$ & $\alpha$ \\
\hline 1 & 2.622 & 0,80 & 0,31 \\
\hline 2 & 2.622 & 0,75 & 0,29 \\
\hline 3 & 2.623 & 0,80 & 0,31 \\
\hline 4 & 2.621 & 0,79 & 0,30 \\
\hline 5 & 2.620 & 0,78 & 0,30 \\
\hline 6 & 2.620 & 0,84 & 0,32 \\
\hline $\bar{x}$ & 2.621 & 0,79 & 0,30 \\
\hline$S$ & 1 & 0,03 & 0,01 \\
\hline C.V. & 0,05 & 3,5 & 3,5 \\
\hline CSB & $\rho_{\mathrm{sec}}$ & $\eta$ & $\alpha$ \\
\hline 1 & 2.620 & 0,75 & 0,29 \\
\hline 2 & 2.641 & 0,69 & 0,26 \\
\hline 3 & 2.629 & 0,78 & 0,30 \\
\hline 7 & 2.594 & 0,68 & 0,26 \\
\hline 8 & 2.597 & 0,77 & 0,30 \\
\hline 9 & 2.591 & 0,68 & 0,26 \\
\hline $\bar{x}$ & 2.612 & 0,72 & 0,28 \\
\hline$S$ & 21 & 0,05 & 0,02 \\
\hline C.V. & 0,80 & 6,8 & 6,6 \\
\hline
\end{tabular}

\begin{tabular}{|c|c|c|c|}
\hline FLS & $\overline{\rho_{\mathrm{sec}}}$ & $\bar{\eta}$ & $\bar{\alpha}$ \\
\hline 1 & 2.623 & 1,01 & 0,38 \\
\hline 3 & 2.588 & 0,94 & 0,36 \\
\hline 7 & 2.622 & 0,99 & 0,38 \\
\hline 8 & 2.601 & 0,86 & 0,33 \\
\hline $8 \mathrm{~A}$ & 2.612 & 0,89 & 0,34 \\
\hline 9 & 2.615 & 0,86 & 0,33 \\
\hline $\bar{x}$ & 2.610 & 0,92 & 0,35 \\
\hline$s$ & 13 & 0,07 & 0,02 \\
\hline C.V. & 0,51 & 7,1 & 6,9 \\
\hline GVN & $\rho_{\mathrm{sec}}$ & $\eta$ & $\alpha$ \\
\hline 1 & 2.636 & 0,86 & 0,33 \\
\hline 2 & 2.627 & 0,91 & 0,34 \\
\hline 3 & 2.648 & 0,86 & 0,32 \\
\hline 7 & 2.643 & 0,85 & 0,32 \\
\hline 8 & 2.637 & 0,88 & 0,33 \\
\hline 9 & 2.643 & 0,87 & 0,33 \\
\hline$\overline{\bar{x}}$ & 2.639 & 0,87 & 0,33 \\
\hline$s$ & 7 & 0,02 & 0,01 \\
\hline C.V. & 0,28 & 2,2 & 2,5 \\
\hline ARB & $\rho_{\mathrm{sec}}$ & $\eta$ & $\alpha$ \\
\hline 1 & 2.664 & 0,74 & 0,28 \\
\hline 2 & 2.663 & 0,74 & 0,28 \\
\hline 3 & 2.652 & 0,69 & 0,26 \\
\hline 7 & 2.648 & 0,63 & 0,24 \\
\hline 8 & 2.648 & 0,68 & 0,26 \\
\hline 9 & 2.663 & 0,66 & 0,25 \\
\hline$\overline{\bar{x}}$ & 2.656 & 0,69 & 0,26 \\
\hline$s$ & 8 & 0,04 & 0,02 \\
\hline C.V. & 0,29 & 6,2 & 6,0 \\
\hline SCC & $\rho_{\mathrm{sec}}$ & $\eta$ & $\alpha$ \\
\hline 1 & 2.631 & 0,82 & 0,31 \\
\hline 2 & 2.640 & 0,82 & 0,31 \\
\hline 3 & 2.632 & 0,79 & 0,30 \\
\hline 7 & 2.639 & 0,85 & 0,32 \\
\hline 8 & 2.650 & 0,75 & 0,28 \\
\hline 9 & 2.651 & 0,71 & 0,27 \\
\hline $\bar{x}$ & 2.641 & 0,79 & 0,30 \\
\hline$S$ & 9 & 0,05 & 0,02 \\
\hline C. V. & 0,33 & 6,6 & 6,8 \\
\hline
\end{tabular}


ANEXO C

Resultados de determinações de densidade aparente e coeficiente de absorção de água a pressão atmosférica

(prEN WI 036:1998) 


\section{Legenda}

$\rho_{\text {sec }}=$ massa específica aparente seca $\left(\mathrm{kg} / \mathrm{m}^{3}\right) \quad \bar{x}=$ média

$S=$ desvio padrão

$C \cdot V .=$ coeficiente de variação $(\%)$ atmosférica (\%)

\section{TAMANHOS DOS CORPOS-DE-PROVA: $10 \mathrm{~cm} \mathrm{x} 12 \mathrm{~cm}$}

\begin{tabular}{|c|c|c|}
\hline LBD & $\rho_{\mathrm{sec}}$ & $A_{b}$ \\
\hline $1 \mathrm{H}_{2} \mathrm{SO}_{4}$ & 2.657 & 0,18 \\
\hline $2 \mathrm{NaOH}$ & 2.661 & 0,18 \\
\hline $3 \mathrm{NaOH}$ & 2.655 & 0,19 \\
\hline $5 \mathrm{H}_{2} \mathrm{SO}_{4}$ & 2.661 & 0,21 \\
\hline $5 \mathrm{Pd}$ & 2.659 & 0,21 \\
\hline$\underline{x}$ & 2.659 & 0,19 \\
\hline $\bar{S}$ & 3 & 0,01 \\
\hline C.V. & 0,11 & 6,4 \\
\hline VCB-1 & $\rho_{\mathrm{sec}}$ & $A_{b}$ \\
\hline 6 & 2.636 & 0,20 \\
\hline 7 & 2.636 & 0,20 \\
\hline 8 & 2.637 & 0,18 \\
\hline 9 & 2.635 & 0,21 \\
\hline 10 & 2.642 & 0,19 \\
\hline $\bar{x}$ & 2.637 & 0,20 \\
\hline$S$ & 3 & 0,01 \\
\hline C.V. & 0,1 & 4,5 \\
\hline VCB-2 & $\rho_{\mathrm{sec}}$ & $A_{b}$ \\
\hline 6 & 2.633 & 0,14 \\
\hline 7 & 2.637 & 0,16 \\
\hline 8 & 2.632 & 0,15 \\
\hline 9 & 2.633 & 0,14 \\
\hline 10 & 2.634 & 0,15 \\
\hline$x$ & 2.634 & 0,15 \\
\hline$S$ & 2 & 0,01 \\
\hline C.V. & 0,1 & 4,1 \\
\hline VCB-3 & $\rho_{\mathrm{sec}}$ & $A_{b}$ \\
\hline $1 \mathrm{NaOH}$ & & \\
\hline $2 \mathrm{H}_{2} \mathrm{SO}_{4}$ & 2.640 & 0,13 \\
\hline $3 \mathrm{NaOH}$ & 2.639 & 0,13 \\
\hline $4 \mathrm{H}_{2} \mathrm{SO}_{4}$ & 2.639 & 0,13 \\
\hline $5 \mathrm{Pd}$ & 2.639 & 0,13 \\
\hline$x$ & 2.640 & 0,13 \\
\hline$S$ & 2 & 0,00 \\
\hline C.V. & 0,07 & 0,1 \\
\hline
\end{tabular}

\begin{tabular}{|c|c|c|}
\hline RIC & $\rho_{\mathrm{sec}}$ & $A_{b}$ \\
\hline $1 \mathrm{H}_{2} \mathrm{SO}_{4}$ & 2.620 & 0,21 \\
\hline $2 \mathrm{NaOH}$ & 2.617 & 0,23 \\
\hline 3 PD & 2.612 & 0,25 \\
\hline $4 \mathrm{NaOH}$ & 2.618 & 0,23 \\
\hline $5 \mathrm{H}_{2} \mathrm{SO}_{4}$ & 2.619 & 0,22 \\
\hline $\bar{x}$ & 2.617 & 0,23 \\
\hline$S$ & 3 & 0,02 \\
\hline C.V. & 0,12 & 6,8 \\
\hline BCR & $\rho_{\mathrm{sec}}$ & $A_{b}$ \\
\hline $1 \mathrm{PD}$ & 2.615 & 0,22 \\
\hline $2 \mathrm{NaOH}$ & 2.612 & 0,25 \\
\hline $3 \mathrm{H}_{2} \mathrm{SO}_{4}$ & 2.611 & 0,23 \\
\hline $4 \mathrm{NaOH}$ & 2.614 & 0,22 \\
\hline $6 \mathrm{H}_{2} \mathrm{SO}_{4}$ & 2.616 & 0,22 \\
\hline$x$ & 2.614 & 0,23 \\
\hline$S$ & 2 & 0,01 \\
\hline C.V. & 0,08 & 5,9 \\
\hline BSV & $\rho_{\mathrm{sec}}$ & $A_{b}$ \\
\hline $1 \mathrm{NaOH}$ & 2.618 & 0,25 \\
\hline $2 \mathrm{H}_{2} \mathrm{SO}_{4}$ & 2.620 & 0,25 \\
\hline $3 \mathrm{H}_{2} \mathrm{SO}_{4}$ & 2.619 & 0,25 \\
\hline 4 PD & 2.619 & 0,24 \\
\hline $5 \mathrm{NaOH}$ & 2.624 & 0,22 \\
\hline$x$ & 2.620 & 0,24 \\
\hline$S$ & 2 & 0,02 \\
\hline C.V. & 0,08 & 6,5 \\
\hline PIT - $2 \mathrm{~cm}$ & $\rho_{\mathrm{sec}}$ & $A_{b}$ \\
\hline $4 \mathrm{H}_{2} \mathrm{SO}_{4}$ & 2.628 & 0,19 \\
\hline $5 \mathrm{NaOH}$ & 2.627 & 0,19 \\
\hline 5 PD & 2.628 & 0,18 \\
\hline $6 \mathrm{H}_{2} \mathrm{SO}_{4}$ & 2.627 & 0,19 \\
\hline $7 \mathrm{HC} \mathrm{NaOHI}$ & 2.627 & 0,18 \\
\hline $\bar{x}$ & 2.627 & 0,19 \\
\hline$S$ & 1 & 0,01 \\
\hline C.V. & 0,02 & 3,7 \\
\hline $\mathrm{PIT}-3 \mathrm{~cm}$ & $\rho_{\mathrm{sec}}$ & $A_{b}$ \\
\hline $1 \mathrm{NaOH}$ & 2.623 & 0,28 \\
\hline 1 PD & 2.622 & 0,30 \\
\hline $1 \mathrm{H}_{2} \mathrm{SO}_{4}$ & 2.624 & 0,28 \\
\hline $2 \mathrm{H}_{2} \mathrm{SO}_{4}$ & 2.623 & 0,29 \\
\hline 2 PD & 2.621 & 0,29 \\
\hline $2 \mathrm{NaOH}$ & 2.623 & 0,28 \\
\hline$x$ & 2.623 & 0,29 \\
\hline$S$ & 1 & 0,01 \\
\hline C.V. & 0,03 & 3,5 \\
\hline
\end{tabular}




\begin{tabular}{|c|c|c|}
\hline$A Z F$ & $\rho_{\mathrm{sec}}$ & $A_{b}$ \\
\hline 1 PD & 2.630 & 0,26 \\
\hline $2 \mathrm{NaOH}$ & 2.629 & 0,27 \\
\hline $3 \mathrm{NaOH}$ & 2.630 & 0,26 \\
\hline $4 \mathrm{H}_{2} \mathrm{SO}_{4}$ & 2.629 & 0,25 \\
\hline $5 \mathrm{H}_{2} \mathrm{SO}_{4}$ & 2.629 & 0,26 \\
\hline $\bar{x}$ & 2.630 & 0,26 \\
\hline$S$ & 1 & 0,01 \\
\hline C.V. & 0,02 & 3,0 \\
\hline BCE & $\rho_{\mathrm{sec}}$ & $A_{b}$ \\
\hline $1 \mathrm{H}_{2} \mathrm{SO}_{4}$ & 2.618 & 0,28 \\
\hline $2 \mathrm{H}_{2} \mathrm{SO}_{4}$ & 2.613 & 0,30 \\
\hline $3 \mathrm{NaOH}$ & 2.615 & 0,30 \\
\hline $4 \mathrm{Pd}$ & 2.614 & 0,31 \\
\hline $5 \mathrm{NaOH}$ & 2.610 & 0,32 \\
\hline$x$ & 2.614 & 0,30 \\
\hline$s$ & 3 & 0,01 \\
\hline C.V. & 0,10 & 4,9 \\
\hline ITN-1 & $\rho_{\mathrm{sec}}$ & $A_{b}$ \\
\hline 1 PD & 2.611 & 0,39 \\
\hline $1 \mathrm{H}_{2} \mathrm{SO}_{4}$ & 2.612 & 0,37 \\
\hline $3 \mathrm{NaOH}$ & 2.616 & 0,36 \\
\hline $4 \mathrm{H}_{2} \mathrm{SO}_{4}$ & 2.600 & 0,34 \\
\hline $5 \mathrm{NaOH}$ & 2.612 & 0,33 \\
\hline$x$ & 2.610 & 0,36 \\
\hline$s$ & 6 & 0,03 \\
\hline C.V. & 0,23 & 7,3 \\
\hline ITN-2 & $\rho_{\mathrm{sec}}$ & $A_{b}$ \\
\hline $1 \mathrm{PD}$ & 2.615 & 0,35 \\
\hline $2 \mathrm{NaOH}$ & 2.616 & 0,32 \\
\hline $3 \mathrm{NaOH}$ & 2.613 & 0,34 \\
\hline $5 \mathrm{H}_{2} \mathrm{SO}_{4}$ & 2.611 & 0,36 \\
\hline $6 \mathrm{H}_{2} \mathrm{SO}_{4}$ & 2.609 & 0,33 \\
\hline $\bar{x}$ & 2.613 & 0,34 \\
\hline$S$ & 3 & 0,02 \\
\hline C.V. & 0,11 & 4,8 \\
\hline CRV & $\rho_{\mathrm{sec}}$ & $A_{b}$ \\
\hline $1 \mathrm{H}_{2} \mathrm{SO}_{4}$ & 2.622 & 0,26 \\
\hline $3 \mathrm{NaOH}$ & 2.623 & 0,26 \\
\hline $4 \mathrm{H}_{2} \mathrm{SO}_{4}$ & 2.621 & 0,27 \\
\hline 5 PD & 2.608 & 0,28 \\
\hline $6 \mathrm{NaOH}$ & 2.622 & 0,27 \\
\hline$x$ & 2.619 & 0,27 \\
\hline$S$ & 6 & 0,01 \\
\hline C.V. & 0,24 & 2,9 \\
\hline
\end{tabular}

\begin{tabular}{|c|c|c|}
\hline CSB & $\rho_{\mathrm{sec}}$ & $A_{b}$ \\
\hline $\begin{array}{c}1 \mathrm{NaOH} \\
1 \mathrm{PD} \\
2 \mathrm{H}_{2} \mathrm{SO}_{4} \\
7 \mathrm{NaOH} \\
8 \mathrm{H}_{2} \mathrm{SO}_{4}\end{array}$ & $\begin{array}{l}2.631 \\
2.628 \\
2.622 \\
2.611 \\
2.600\end{array}$ & $\begin{array}{l}0,24 \\
0,23 \\
0,25 \\
0,25 \\
0,24\end{array}$ \\
\hline $\begin{array}{l}\bar{x} \\
S \\
C V\end{array}$ & $\begin{array}{c}2.618 \\
13 \\
0.49\end{array}$ & $\begin{array}{c}0,24 \\
0,01 \\
4,0\end{array}$ \\
\hline FLS & $\rho_{\mathrm{sec}}$ & $A_{b}$ \\
\hline $\begin{array}{c}1 \mathrm{NaOH} \mathrm{H}_{2} \mathrm{SO}_{4} \\
2 \mathrm{PD} \\
3 \mathrm{NaOH} \\
7 \mathrm{H}_{2} \mathrm{SO}_{4} \\
8 \mathrm{H}_{2} \mathrm{SO}_{4} \\
9 \mathrm{NaOH} \\
9 \mathrm{PD}\end{array}$ & $\begin{array}{l}2.600 \\
2.616 \\
2.604 \\
2.595 \\
2.624 \\
2.618 \\
2.615 \\
2.637 \\
\end{array}$ & $\begin{array}{l}0,33 \\
0,35 \\
0,36 \\
0,34 \\
0,34 \\
0,34 \\
0,36 \\
0,33\end{array}$ \\
\hline $\begin{array}{c}\bar{x} \\
S \\
C . V\end{array}$ & $\begin{array}{c}2.614 \\
14 \\
0,52 \\
\end{array}$ & $\begin{array}{c}0,34 \\
0,01 \\
3,0 \\
\end{array}$ \\
\hline GVN & $\rho_{\mathrm{sec}}$ & $A_{b}$ \\
\hline $\begin{array}{c}2 \mathrm{H}_{2} \mathrm{SO}_{4} \\
2 \mathrm{Pd} \\
3 \mathrm{NaOH} \\
8 \mathrm{H}_{2} \mathrm{SO}_{4} \\
8 \mathrm{Pd} \\
9 \mathrm{NaOH}\end{array}$ & $\begin{array}{l}2.636 \\
2.630 \\
2.645 \\
2.634 \\
2.636 \\
2.637\end{array}$ & $\begin{array}{l}0,28 \\
0,30 \\
0,29 \\
0,28 \\
0,28 \\
0,28\end{array}$ \\
\hline $\begin{array}{c}x \\
S \\
C . V .\end{array}$ & $\begin{array}{c}2.636 \\
5 \\
0,19\end{array}$ & $\begin{array}{c}0,29 \\
0,01 \\
3,3\end{array}$ \\
\hline ARB & $\rho_{\mathrm{sec}}$ & $A_{b}$ \\
\hline $\begin{array}{c}1 \mathrm{H}_{2} \mathrm{SO}_{4} \\
2 \mathrm{PD} \\
3 \mathrm{NaOH} \\
8 \mathrm{PD} \\
8 \mathrm{H}_{2} \mathrm{SO}_{4} \\
9 \mathrm{NaOH}\end{array}$ & $\begin{array}{l}2.654 \\
2.654 \\
2.645 \\
2.670 \\
2.658 \\
2.666\end{array}$ & $\begin{array}{l}0,25 \\
0,25 \\
0,24 \\
0,24 \\
0,26 \\
0,26\end{array}$ \\
\hline $\begin{array}{c}x \\
S \\
C . V\end{array}$ & $\begin{array}{c}2.658 \\
9 \\
0,34\end{array}$ & $\begin{array}{l}0,25 \\
0,01 \\
3,9\end{array}$ \\
\hline
\end{tabular}




\begin{tabular}{ccc}
\hline SCC & $\rho_{\text {sec }}$ & $A_{b}$ \\
\hline $1 \mathrm{H}_{2} \mathrm{SO}_{4}$ & 2.638 & 0,26 \\
$3 \mathrm{NaOH} \mathrm{HOH}_{2}$ & 2.638 & 0,27 \\
$8 \mathrm{NaOH}_{4}$ & 2.642 & 0,29 \\
$9 \mathrm{PD}$ & 2.637 & 0,28 \\
0 & 2.629 & 0,27 \\
$x$ & 2.637 & 0,27 \\
$S$ & 2.637 & 0,27 \\
$C . V$. & 4 & 0,01 \\
\hline
\end{tabular}

TAMANHO DOS CORPOS-DE-PROVA: $10 \mathrm{~cm}$ x $10 \mathrm{~cm}$

\begin{tabular}{ccc}
\hline LBD & $\rho_{\text {sec }}$ & $A_{b}$ \\
\hline 1 & 2.659 & 0,15 \\
2 & 2.662 & 0,16 \\
3 & 2.670 & 0,16 \\
4 & 2.662 & 0,15 \\
$4 A$ & 2.665 & 0,16 \\
5 & 2.659 & 0,17 \\
\hline $\bar{x}$ & 2.663 & 0,16 \\
$S$ & 4 & 0,01 \\
$C . V$. & 0,16 & 4,0 \\
\hline VCB-1 & $\rho_{\text {sec }}$ & $A_{b}$ \\
\hline 1 & 2.636 & 0,21 \\
2 & 2.634 & 0,22 \\
3 & 2.634 & 0,22 \\
4 & 2.639 & 0,21 \\
5 & 2.636 & 0,18 \\
\hline $\bar{x}$ & 2.636 & 0,21 \\
$S$ & 2 & 0,02 \\
$C . V$. & 0,07 & 8,3 \\
\hline VCB-2 & $\rho_{\text {sec }}$ & $A_{b}$ \\
\hline 1 & 2.630 & 0,17 \\
2 & 2.628 & 0,17 \\
3 & 2.639 & 0,18 \\
4 & 2.630 & 0,20 \\
5 & 2.629 & 0,21 \\
\hline $\bar{x}$ & 2.631 & 0,19 \\
$S$ & 4 & 0,02 \\
$C . V$. & 0,17 & 9,0 \\
\hline & &
\end{tabular}

\begin{tabular}{|c|c|c|}
\hline VCB-3 & $\rho_{\mathrm{sec}}$ & $A_{b}$ \\
\hline 1 & 2.642 & 0,12 \\
\hline 2 & 2.647 & 0,12 \\
\hline 3 & 2.643 & 0,15 \\
\hline 4 & 2.643 & 0,12 \\
\hline 5 & 2.639 & 0,15 \\
\hline $5 A$ & 2.639 & 0,14 \\
\hline $\bar{x}$ & 2.642 & 0,13 \\
\hline$S$ & 3 & 0,01 \\
\hline C.V. & 0,12 & 10,1 \\
\hline RIC & $\rho_{\mathrm{sec}}$ & $A_{b}$ \\
\hline 1 & 2.620 & 0,20 \\
\hline $1 \mathrm{~A}$ & 2.619 & 0,20 \\
\hline 2 & 2.617 & 0,22 \\
\hline 3 & 2.619 & 0,20 \\
\hline 4 & 2.623 & 0,22 \\
\hline 5 & 2.619 & 0,22 \\
\hline $\bar{x}$ & 2.620 & 0,21 \\
\hline$S$ & 2 & 0,01 \\
\hline C.V. & 0,08 & 4,9 \\
\hline BCR & $\rho_{\mathrm{sec}}$ & $A_{b}$ \\
\hline 1 & 2.616 & 0,25 \\
\hline 2 & 2.613 & 0,24 \\
\hline 3 & 2.614 & 0,24 \\
\hline 8 & 2.613 & 0,24 \\
\hline 9 & 2.613 & 0,24 \\
\hline 10 & 2.616 & 0,24 \\
\hline $\bar{x}$ & 2.614 & 0,24 \\
\hline$S$ & 1 & 0,00 \\
\hline C.V. & 0,05 & 0,7 \\
\hline BSV & $\rho_{\mathrm{sec}}$ & $A_{b}$ \\
\hline 1 & 2.621 & 0,26 \\
\hline 2 & 2.624 & 0,27 \\
\hline 3 & 2.622 & 0,27 \\
\hline 4 & 2.622 & 0,26 \\
\hline 5 & 2.624 & 0,26 \\
\hline $5 A$ & 2.625 & 0,26 \\
\hline $\bar{x}$ & 2.623 & 0,26 \\
\hline$S$ & 2 & 0,00 \\
\hline C.V. & 0,06 & 0,7 \\
\hline
\end{tabular}




\begin{tabular}{|c|c|c|}
\hline PIT - 2cm & $\rho_{\mathrm{sec}}$ & $A_{b}$ \\
\hline 4 & 2.629 & 0,20 \\
\hline 5 & 2.629 & 0,20 \\
\hline 6 & 2.628 & 0,20 \\
\hline $6 \mathrm{~A}$ & 2.626 & 0,21 \\
\hline 7 & 2.627 & 0,18 \\
\hline $7 \mathrm{~A}$ & 2.628 & 0,20 \\
\hline $\bar{x}$ & 2.628 & 0,20 \\
\hline$S$ & 1 & 0,01 \\
\hline C.V. & 0,05 & 4,8 \\
\hline AZF & $\rho_{\mathrm{sec}}$ & $A_{b}$ \\
\hline 1 & 2.630 & 0,21 \\
\hline 2 & 2.630 & 0,20 \\
\hline 3 & 2.634 & 0,19 \\
\hline 4 & 2.632 & 0,19 \\
\hline 5 & 2.632 & 0,19 \\
\hline $\bar{x}$ & 2.632 & 0,20 \\
\hline$S$ & 2 & 0,01 \\
\hline C.V. & 0,06 & 3,8 \\
\hline BCE & $\rho_{\mathrm{sec}}$ & $A_{b}$ \\
\hline 1 & 2.614 & 0,25 \\
\hline 2 & 2.613 & 0,26 \\
\hline 3 & 2.615 & 0,24 \\
\hline 4 & 2.614 & 0,25 \\
\hline 5 & 2.613 & 0,22 \\
\hline $5 A$ & 2.613 & 0,23 \\
\hline $\bar{x}$ & 2.614 & 0,24 \\
\hline$S$ & 1 & 0,01 \\
\hline C.V. & 0,03 & 5,9 \\
\hline ITN-1 & $\rho_{\mathrm{sec}}$ & $A_{b}$ \\
\hline 1 & 2.607 & 0,43 \\
\hline 2 & 2.607 & 0,43 \\
\hline 3 & 2.606 & 0,43 \\
\hline 4 & 2.610 & 0,37 \\
\hline 5 & 2.617 & 0,35 \\
\hline 6 & 2.613 & 0,37 \\
\hline $\bar{x}$ & 2.610 & 0,40 \\
\hline$S$ & 5 & 0,04 \\
\hline C.V. & 0,17 & 10,0 \\
\hline
\end{tabular}

\begin{tabular}{|c|c|c|}
\hline ITN-2 & $\rho_{\mathrm{sec}}$ & $A_{b}$ \\
\hline 1 & 2.617 & 0,34 \\
\hline 2 & 2.610 & 0,34 \\
\hline 3 & 2.615 & 0,34 \\
\hline 4 & 2.607 & 0,36 \\
\hline 5 & 2.617 & 0,33 \\
\hline 6 & 2.610 & 0,40 \\
\hline $\bar{x}$ & 2.613 & 0,35 \\
\hline$S$ & 4 & 0,02 \\
\hline C.V. & 0,16 & 7,0 \\
\hline CRV & $\rho_{\mathrm{sec}}$ & $A_{b}$ \\
\hline 1 & 2.624 & 0,25 \\
\hline 2 & 2.624 & 0,25 \\
\hline 3 & 2.625 & 0,28 \\
\hline 4 & 2.623 & 0,26 \\
\hline 5 & 2.621 & 0,28 \\
\hline 6 & 2.621 & 0,28 \\
\hline$\overline{\bar{x}}$ & 2.623 & 0,27 \\
\hline$S$ & 2 & 0,01 \\
\hline C.V. & 0,07 & 4,7 \\
\hline CSB & $\rho_{\mathrm{sec}}$ & $A_{b}$ \\
\hline 1 & 2.623 & 0,20 \\
\hline 2 & 2.643 & 0,19 \\
\hline 3 & 2.631 & 0,23 \\
\hline 8 & 2.596 & 0,20 \\
\hline 9 & 2.599 & 0,22 \\
\hline 10 & 2.593 & 0,20 \\
\hline $\bar{x}$ & 2.614 & 0,21 \\
\hline$S$ & 21 & 0,01 \\
\hline C.V. & 0,80 & 7,0 \\
\hline FLS & $\rho_{\mathrm{sec}}$ & $A_{b}$ \\
\hline 1 & 2.624 & 0,36 \\
\hline 3 & 2.589 & 0,31 \\
\hline 7 & 2.624 & 0,33 \\
\hline 8 & 2.603 & 0,30 \\
\hline $8 \mathrm{~A}$ & 2.614 & 0,30 \\
\hline 9 & 2.616 & 0,29 \\
\hline $\bar{x}$ & 2.612 & 0,32 \\
\hline$S$ & 13 & 0,02 \\
\hline C.V. & 0,51 & 7,8 \\
\hline
\end{tabular}




\begin{tabular}{ccc}
\hline GVN & $\rho_{\text {sec }}$ & $A_{b}$ \\
\hline 1 & 2.637 & 0,25 \\
2 & 2.628 & 0,26 \\
3 & 2.650 & 0,25 \\
7 & 2.645 & 0,25 \\
8 & 2.639 & 0,27 \\
9 & 2.645 & 0,26 \\
\hline $\bar{x}$ & 2.641 & 0,25 \\
$S$ & 8 & 0,01 \\
$C . V$. & 0,28 & 3,0 \\
\hline ARB & $\rho_{\text {sec }}$ & $A_{b}$ \\
\hline 1 & 2.664 & 0,26 \\
2 & 2.664 & 0,26 \\
3 & 2.653 & 0,26 \\
7 & 2.650 & 0,24 \\
8 & 2.649 & 0,24 \\
9 & 2.664 & 0,23 \\
\hline $\bar{x}$ & 2.657 & 0,25 \\
$S$ & 7 & 0,01 \\
$C . V$. & 0,27 & 5,2 \\
\hline SCC & $\rho_{\text {sec }}$ & $A_{b}$ \\
\hline 1 & 2.634 & 0,24 \\
2 & 2.643 & 0,22 \\
3 & 2.634 & 0,24 \\
7 & 2.642 & 0,26 \\
8 & 2.653 & 0,23 \\
9 & 2.655 & 0,22 \\
\hline $\bar{x}$ & 2.644 & 0,23 \\
$S$ & 9 & 0,01 \\
$C . V$. & 0,34 & 5,9 \\
\hline & &
\end{tabular}




\section{ANEXO D}

Resultados de determinações de densidade aparente, porosidade aberta e volume de poros abertos (BS EN 1936:1999) 


\section{Legenda}

$\rho_{b}=$ densidade aparente $\left(\mathrm{kg} / \mathrm{m}^{3}\right)$;

$V_{o}=$ volume de poros abertos $(\mathrm{mL})$;

$p_{o}=$ porosidade aberta $(\%)$.

$\bar{x}=$ média

$S=$ desvio padrão

$C . V$. = coeficiente de variação $(\%)$

\section{TAMANHOS DOS CORPOS-DE-PROVA: $10 \mathrm{~cm} \times 15 \mathrm{~cm}$}

\begin{tabular}{|c|c|c|c|}
\hline BLD & $\rho_{b}$ & $V_{o}$ & $p_{o}$ \\
\hline 1 & 2.660 & 2,9 & 0,71 \\
\hline 2 & 2.664 & 2,8 & 0,69 \\
\hline 3 & 2.653 & 2,9 & 0,71 \\
\hline 4 & 2.651 & 2,7 & 0,67 \\
\hline 5 & 2.663 & 2,5 & 0,63 \\
\hline 6 & 2.654 & 2,7 & 0,67 \\
\hline $\bar{x}$ & 2.657 & 2,8 & 0,68 \\
\hline$S$ & 6 & 0,2 & 0,03 \\
\hline C.V. & 0,21 & 5,5 & 4,7 \\
\hline VCB-1 & $\rho_{b}$ & $V_{o}$ & $p_{o}$ \\
\hline 6 & 2.632 & 2,0 & 0,44 \\
\hline 7 & 2.631 & 2,2 & 0,49 \\
\hline 8 & 2.632 & 1,8 & 0,39 \\
\hline 9 & 2.631 & 2,1 & 0,46 \\
\hline 10 & 2.640 & 1,7 & 0,37 \\
\hline $\bar{x}$ & 2.633 & 2,0 & 0,43 \\
\hline$S$ & 4 & 0,2 & 0,05 \\
\hline C.V. & 0,14 & 10,6 & 11,8 \\
\hline VCB-2 & $\rho_{b}$ & $\overline{V_{o}}$ & $\overline{p_{o}}$ \\
\hline 6 & 2.630 & 1,4 & 0,33 \\
\hline 7 & 2.632 & 1,5 & 0,36 \\
\hline 8 & 2.628 & 1,5 & 0,36 \\
\hline 9 & 2.629 & 1,4 & 0,32 \\
\hline 10 & 2.630 & 1,5 & 0,33 \\
\hline $\bar{x}$ & 2.629 & 1,5 & 0,34 \\
\hline$S$ & 1 & 0,1 & 0,02 \\
\hline C. V. & 0,06 & 3,8 & 5,4 \\
\hline VCB 3 & $\rho_{b}$ & $V_{o}$ & $p_{o}$ \\
\hline 1 & 2.630 & 2,3 & 0,51 \\
\hline 2 & 2.643 & 2,1 & 0,46 \\
\hline 3 & 2.636 & 2,1 & 0,47 \\
\hline 4 & 2.632 & 2,2 & 0,48 \\
\hline 6 & 2.634 & 2,1 & 0,46 \\
\hline$x$ & 2.635 & 2,2 & 0,48 \\
\hline$S$ & 5 & 0,1 & 0,02 \\
\hline C.V. & 0,19 & 4,1 & 4,1 \\
\hline
\end{tabular}

\begin{tabular}{|c|c|c|c|}
\hline RIC & $\rho_{b}$ & $V_{o}$ & $p_{o}$ \\
\hline 1 & 2.612 & 1,6 & 0,51 \\
\hline 2 & 2.613 & 1,4 & 0,45 \\
\hline 3 & 2.613 & 1,5 & 0,47 \\
\hline 4 & 2.612 & 1,6 & 0,51 \\
\hline 5 & 2.615 & 1,5 & 0,48 \\
\hline$x$ & 2.613 & 1,5 & 0,48 \\
\hline$S$ & 1 & 0,1 & 0,03 \\
\hline C. V. & 0,04 & 5,5 & 5,4 \\
\hline BCR & $\rho_{b}$ & $V_{o}$ & $p_{o}$ \\
\hline 1 & 2.604 & 2,3 & 0,69 \\
\hline 2 & 2.606 & 2,1 & 0,63 \\
\hline 3 & 2.606 & 2,1 & 0,63 \\
\hline 4 & 2.605 & 2,1 & 0,63 \\
\hline 5 & 2.604 & 2,2 & 0,66 \\
\hline 6 & 2.605 & 2,2 & 0,66 \\
\hline $\bar{x}$ & 2.605 & 2,2 & 0,65 \\
\hline$S$ & 1 & 0,1 & 0,03 \\
\hline C.V. & 0,03 & 3,8 & 4,0 \\
\hline BSV & $\rho_{b}$ & $V_{o}$ & $p_{o}$ \\
\hline 1 & 2.610 & 2,0 & 0,69 \\
\hline 2 & 2.614 & 1,9 & 0,66 \\
\hline 3 & 2.612 & 2,0 & 0,69 \\
\hline 4 & 2.609 & 2,0 & 0,70 \\
\hline 5 & 2.613 & 2,0 & 0,70 \\
\hline$x$ & 2.611 & 2,0 & 0,69 \\
\hline$s$ & 2 & 0,0 & 0,01 \\
\hline C.V. & 0,08 & 2,3 & 2,0 \\
\hline PIT - $2 \mathrm{~cm}$ & $\rho_{b}$ & $V_{o}$ & $p_{o}$ \\
\hline 1 & 2.618 & 2,0 & 0,64 \\
\hline 2 & 2.618 & 1,9 & 0,61 \\
\hline 3 & 2.618 & 2,0 & 0,63 \\
\hline$x$ & 2.618 & 2,0 & 0,63 \\
\hline$S$ & 0 & 0,1 & 0,02 \\
\hline C.V. & 0,01 & 2,9 & 2,5 \\
\hline AZF & $\rho_{b}$ & $V_{o}$ & $p_{o}$ \\
\hline 1 & 2.625 & 2,5 & 0,54 \\
\hline 2 & 2.624 & 2,5 & 0,55 \\
\hline 3 & 2.622 & 2,6 & 0,57 \\
\hline $\bar{x}$ & 2.624 & 2,5 & 0,55 \\
\hline$S$ & 1 & 0,1 & 0,01 \\
\hline C. $V$. & 0,05 & 2,3 & 2,5 \\
\hline
\end{tabular}




\begin{tabular}{|c|c|c|c|}
\hline BCE & $\rho_{b}$ & $V_{o}$ & $p_{o}$ \\
\hline 1 & 2.612 & 3,1 & 0,67 \\
\hline 2 & 2.611 & 3,1 & 0,67 \\
\hline 3 & 2.614 & 2,9 & 0,63 \\
\hline 4 & 2.620 & 3,0 & 0,65 \\
\hline 5 & 2.615 & 2,9 & 0,62 \\
\hline 6 & 2.609 & 3,2 & 0,67 \\
\hline$\overline{\bar{x}}$ & 2.613 & 3,0 & 0,65 \\
\hline$S$ & 4 & 0,1 & 0,02 \\
\hline C.V. & 0,15 & 4,0 & 3,5 \\
\hline ITN-1 & $\rho_{b}$ & $V_{o}$ & $p_{o}$ \\
\hline 1 & 2.603 & 2,8 & 0,94 \\
\hline 2 & 2.609 & 2,6 & 0,88 \\
\hline 3 & 2.607 & 2,6 & 0,87 \\
\hline 4 & 2.604 & 2,7 & 0,91 \\
\hline 5 & 2.609 & 2,6 & 0,89 \\
\hline$\overline{\bar{x}}$ & 2.606 & 2,7 & 0,90 \\
\hline$S$ & 3 & 0,1 & 0,03 \\
\hline C.V. & 0,10 & 3,4 & 3,1 \\
\hline ITN-2 & $\rho_{b}$ & $V_{o}$ & $p_{o}$ \\
\hline 1 & 2.608 & 2,9 & 0,92 \\
\hline 2 & 2.605 & 3,3 & 1,04 \\
\hline 3 & 2.603 & 3,1 & 0,98 \\
\hline 4 & 2.612 & 2,8 & 0,89 \\
\hline 5 & 2.603 & 3,0 & 0,95 \\
\hline 6 & 2.608 & 2,9 & 0,92 \\
\hline $\bar{x}$ & 2.606 & 3,0 & 0,95 \\
\hline$S$ & 3 & 0,2 & 0,06 \\
\hline C. $V$. & 0,13 & 6,0 & 5,8 \\
\hline CRV & $\rho_{b}$ & $V_{o}$ & $p_{o}$ \\
\hline 1 & 2.613 & 2,3 & 0,82 \\
\hline 2 & 2.617 & 2,1 & 0,75 \\
\hline 3 & 2.616 & 2,2 & 0,78 \\
\hline 4 & 2.616 & 2,1 & 0,76 \\
\hline 5 & 2.615 & 2,1 & 0,76 \\
\hline 6 & 2.616 & 2,1 & 0,76 \\
\hline $\bar{x}$ & 2.615 & 2,2 & 0,77 \\
\hline$S$ & 2 & 0,1 & 0,03 \\
\hline C.V. & 0,06 & 3,9 & 3,5 \\
\hline
\end{tabular}

\begin{tabular}{|c|c|c|c|}
\hline CSB & $\rho_{b}$ & $V_{o}$ & $p_{o}$ \\
\hline 1 & 2.626 & 1,8 & 0,59 \\
\hline 2 & 2.627 & 1,9 & 0,63 \\
\hline 3 & 2.639 & 1,8 & 0,59 \\
\hline 4 & 2.623 & 1,9 & 0,63 \\
\hline 5 & 2.621 & 1,9 & 0,63 \\
\hline 6 & 2.626 & 1,8 & 0,61 \\
\hline $\bar{x}$ & 2.627 & 1,9 & 0,61 \\
\hline$S$ & 6 & 0,1 & 0,02 \\
\hline C.V. & 0,24 & 3,0 & 2,8 \\
\hline FLS & $\rho_{b}$ & $V_{o}$ & $p_{o}$ \\
\hline 1 & 2.628 & 1,8 & 0,65 \\
\hline 2 & 2.631 & 1,8 & 0,65 \\
\hline 3 & 2.602 & 1,9 & 0,69 \\
\hline 4 & 2.632 & 1,8 & 0,65 \\
\hline 5 & 2.604 & 2,0 & 0,72 \\
\hline $\bar{x}$ & 2.619 & 1,9 & 0,67 \\
\hline$S$ & 15 & 0,1 & 0,03 \\
\hline C. V. & 0,6 & 4,8 & 4,8 \\
\hline GVN & $\rho_{b}$ & $V_{o}$ & $p_{o}$ \\
\hline 1 & 2.642 & 4,1 & 0,91 \\
\hline 2 & 2.653 & 3,7 & 0,84 \\
\hline 3 & 2.673 & 3,8 & 0,85 \\
\hline 4 & 2.676 & 3,7 & 0,83 \\
\hline 5 & 2.637 & 3,4 & 0,78 \\
\hline 6 & 2.632 & 3,4 & 0,77 \\
\hline $\bar{x}$ & 2.652 & 3,7 & 0,83 \\
\hline$S$ & 19 & 0,3 & 0,05 \\
\hline C.V. & 0,70 & 7,2 & 6,1 \\
\hline ARB & $\rho_{b}$ & $V_{o}$ & $p_{o}$ \\
\hline 1 & 2.635 & 2,2 & 0,72 \\
\hline 2 & 2.640 & 2,2 & 0,72 \\
\hline 3 & 2.637 & 2,2 & 0,72 \\
\hline 4 & 2.652 & 2,1 & 0,67 \\
\hline 5 & 2.645 & 2,3 & 0,73 \\
\hline 6 & 2.643 & 2,3 & 0,75 \\
\hline$x$ & 2.642 & 2,2 & 0,72 \\
\hline$S$ & 6 & 0,1 & 0,03 \\
\hline C. V. & 0,23 & 3,4 & 3,7 \\
\hline
\end{tabular}




\begin{tabular}{cccc}
\hline SCC & $\rho_{b}$ & $V_{o}$ & $p_{o}$ \\
\hline 1 & 2.638 & 3,3 & 0,73 \\
2 & 2.636 & 3,1 & 0,69 \\
3 & 2.631 & 2,6 & 0,59 \\
4 & 2.632 & 3,7 & 0,83 \\
5 & 2.656 & 2,8 & 0,63 \\
6 & 2.625 & 3,7 & 0,83 \\
\hline $\boldsymbol{S}$ & 2.636 & 3,2 & 0,72 \\
C.V. & 11 & 0,5 & 0,10 \\
\hline
\end{tabular}

TAMANHOS DOS CORPOS-DE-PROVA: $10 \mathrm{~cm} \times 12 \mathrm{~cm}$

\begin{tabular}{|c|c|c|c|}
\hline LBD & $\rho_{b}$ & $V_{o}$ & $p_{o}$ \\
\hline $1 \mathrm{H}_{2} \mathrm{SO}_{4}$ & 2.653 & 1,9 & 0,58 \\
\hline $2 \mathrm{NaOH}$ & 2.657 & 1,9 & 0,57 \\
\hline $3 \mathrm{NaOH}$ & 2.651 & 1,9 & 0,58 \\
\hline $4 \mathrm{H}_{2} \mathrm{SO}_{4}$ & 2.658 & 1,9 & 0,58 \\
\hline $5 \mathrm{PD}$ & 2.655 & 2,0 & 0,62 \\
\hline$x$ & 2.655 & 1,9 & 0,58 \\
\hline$S$ & 3 & 0,0 & 0,02 \\
\hline C. V. & 0,12 & 2,3 & 3,1 \\
\hline VCB-1 & $\rho_{b}$ & $V_{o}$ & $p_{o}$ \\
\hline 6 & 2.630 & 2,0 & 0,55 \\
\hline 7 & 2.630 & 2,0 & 0,55 \\
\hline 8 & 2.631 & 1,9 & 0,51 \\
\hline 9 & 2.628 & 2,1 & 0,58 \\
\hline 10 & 2.637 & 2,0 & 0,54 \\
\hline $\bar{x}$ & 2.631 & 2,0 & 0,55 \\
\hline$s$ & 3 & 0,1 & 0,02 \\
\hline C. V. & 0,13 & 3,5 & 4,3 \\
\hline VCB-2 & $\rho_{b}$ & $\overline{V_{o}}$ & $p_{o}$ \\
\hline 6 & 2.628 & 1,3 & 0,38 \\
\hline 7 & 2.631 & 1,4 & 0,41 \\
\hline 8 & 2.625 & 1,4 & 0,41 \\
\hline 9 & 2.626 & 1,5 & 0,43 \\
\hline 10 & 2.628 & 1,5 & 0,42 \\
\hline$x$ & 2.627 & 1,4 & 0,41 \\
\hline$s$ & 2 & 0,1 & 0,02 \\
\hline C.V. & 0,08 & 5,9 & 4,5 \\
\hline
\end{tabular}

\begin{tabular}{|c|c|c|c|}
\hline VCB-3 & $\rho_{b}$ & $V_{o}$ & $p_{o}$ \\
\hline $1 \mathrm{NaOH}$ & 2.639 & 1,3 & 0,39 \\
\hline $2 \mathrm{H}_{2} \mathrm{SO}_{4}$ & 2.636 & 1,4 & 0,41 \\
\hline $3 \mathrm{NaOH}$ & 2.636 & 1,4 & 0,41 \\
\hline $4 \mathrm{H}_{2} \mathrm{SO}_{4}$ & 2.635 & 1,4 & 0,41 \\
\hline $5 \mathrm{PD}$ & 2.636 & 1,4 & 0,41 \\
\hline$x$ & 2.636 & 1,4 & 0,41 \\
\hline$S$ & 2 & 0,0 & 0,01 \\
\hline C.V. & 0,06 & 3,2 & 3,1 \\
\hline RIC & $\rho_{b}$ & $V_{o}$ & $p_{o}$ \\
\hline $1 \mathrm{H}_{2} \mathrm{SO}_{4}$ & 2.614 & 1,5 & 0,56 \\
\hline $2 \mathrm{NaOH}$ & 2.613 & 1,5 & 0,56 \\
\hline 3 PD & 2.608 & 1,5 & 0,55 \\
\hline $4 \mathrm{NaOH}$ & 2.615 & 1,5 & 0,55 \\
\hline $5 \mathrm{H}_{2} \mathrm{SO}_{4}$ & 2.614 & 1,4 & 0,53 \\
\hline$x$ & 2.613 & 1,5 & 0,55 \\
\hline$S$ & 3 & 0,0 & 0,01 \\
\hline C. $V$. & 0,10 & 3,0 & 2,3 \\
\hline BCR & $\rho_{b}$ & $V_{o}$ & $p_{o}$ \\
\hline $1 \mathrm{PD}$ & 2.609 & 1,7 & 0,64 \\
\hline $2 \mathrm{NaOH}$ & 2.608 & 1,7 & 0,64 \\
\hline $3 \mathrm{H}_{2} \mathrm{SO}_{4}$ & 2.606 & 1,6 & 0,60 \\
\hline $4 \mathrm{NaOH}$ & 2.608 & 1,7 & 0,64 \\
\hline $6 \mathrm{H}_{2} \mathrm{SO}_{4}$ & 2.609 & 1,7 & 0,64 \\
\hline$x$ & 2.608 & 1,7 & 0,63 \\
\hline$s$ & 1 & 0,0 & 0,02 \\
\hline C.V. & 0,04 & 2,7 & 2,6 \\
\hline BSV & $\rho_{b}$ & $V_{o}$ & $p_{o}$ \\
\hline $1 \mathrm{NaOH}$ & 2.612 & 1,9 & 0,74 \\
\hline $2 \mathrm{H}_{2} \mathrm{SO}_{4}$ & 2.613 & 2,0 & 0,78 \\
\hline $3 \mathrm{H}_{2} \mathrm{SO}_{4}$ & 2.614 & 1,9 & 0,75 \\
\hline 4 PD & 2.614 & 1,9 & 0,74 \\
\hline $5 \mathrm{NaOH}$ & 2.618 & 1,8 & 0,69 \\
\hline$x$ & 2.614 & 1,9 & 0,74 \\
\hline$S$ & 2 & 0,1 & 0,03 \\
\hline C.V. & 0,08 & 3,7 & 4,6 \\
\hline $\mathrm{PIT}$ - 2cm & $\rho_{b}$ & $V_{o}$ & $p_{o}$ \\
\hline $4 \mathrm{H}_{2} \mathrm{SO}_{4}$ & 2.623 & 1,5 & 0,59 \\
\hline $5 \mathrm{NaOH}$ & 2.622 & 1,5 & 0,58 \\
\hline 5 PD & 2.621 & 1,5 & 0,59 \\
\hline $6 \mathrm{H}_{2} \mathrm{SO}_{4}$ & 2.621 & 1,6 & 0,62 \\
\hline $7 \mathrm{NaOH}$ & 2.622 & 1,5 & 0,59 \\
\hline $\bar{x}$ & 2.622 & 1,5 & 0,59 \\
\hline$S$ & 1 & 0,0 & 0,02 \\
\hline C.V. & 0,03 & 2,9 & 2,5 \\
\hline
\end{tabular}




\begin{tabular}{|c|c|c|c|}
\hline PIT - $3 \mathrm{~cm}$ & $\rho_{b}$ & $V_{o}$ & $p_{o}$ \\
\hline $1 \mathrm{NaOH}$ & 2.619 & 2,3 & 0,65 \\
\hline $1 \mathrm{PD}$ & 2.619 & 1,8 & 0,65 \\
\hline $1 \mathrm{H}_{2} \mathrm{SO}_{4}$ & 2.619 & 2,2 & 0,64 \\
\hline $2 \mathrm{H}_{2} \mathrm{SO}_{4}$ & 2.619 & 2,2 & 0,62 \\
\hline $2 \mathrm{NaOH}$ & 2.618 & 2,3 & 0,64 \\
\hline 2 PD & 2.617 & 2,2 & 0,64 \\
\hline$x$ & 2.619 & 2,2 & 0,64 \\
\hline$S$ & 1 & 0,2 & 0,01 \\
\hline C. V. & 0,03 & 8,6 & 1,6 \\
\hline AZF & $\rho_{b}$ & $V_{o}$ & $p_{o}$ \\
\hline $1 \mathrm{PD}$ & 2.626 & 2,0 & 0,54 \\
\hline $2 \mathrm{NaOH}$ & 2.626 & 2,0 & 0,54 \\
\hline $3 \mathrm{NaOH}$ & 2.626 & 2,0 & 0,54 \\
\hline $4 \mathrm{H}_{2} \mathrm{SO}_{4}$ & 2.624 & 2,0 & 0,54 \\
\hline $5 \mathrm{H}_{2} \mathrm{SO}_{4}$ & 2.626 & 1,9 & 0,51 \\
\hline$x$ & 2.626 & 2,0 & 0,53 \\
\hline$S$ & 1 & 0,0 & 0,01 \\
\hline C.V. & 0,03 & 2,3 & 2,3 \\
\hline BCE & $\rho_{b}$ & $V_{o}$ & $p_{o}$ \\
\hline $1 \mathrm{H}_{2} \mathrm{SO}_{4}$ & 2.613 & 2,3 & 0,60 \\
\hline $2 \mathrm{H}_{2} \mathrm{SO}_{4}$ & 2.609 & 2,5 & 0,65 \\
\hline $3 \mathrm{NaOH}$ & 2.611 & 2,5 & 0,64 \\
\hline 4 PD & 2.610 & 2,5 & 0,65 \\
\hline $5 \mathrm{NaOH}$ & 2.607 & 2,8 & 0,70 \\
\hline$x$ & 2.610 & 2,5 & 0,65 \\
\hline$S$ & 2 & 0,2 & 0,04 \\
\hline C. V. & 0,09 & 7,1 & 5,8 \\
\hline ITN-1 & $\rho_{b}$ & $V_{o}$ & $p_{o}$ \\
\hline $1 \mathrm{H}_{2} \mathrm{SO}_{4}$ & 2.607 & 2,5 & 0,99 \\
\hline $1 \mathrm{PD}$ & 2.606 & 2,6 & 1,03 \\
\hline $3 \mathrm{NaOH}$ & 2.612 & 2,4 & 0,94 \\
\hline $4 \mathrm{H}_{2} \mathrm{SO}_{4}$ & 2.597 & 2,3 & 0,88 \\
\hline $5 \mathrm{NaOH}$ & 2.607 & 2,3 & 0,89 \\
\hline $\bar{x}$ & 2.606 & 2,4 & 0,95 \\
\hline$S$ & 6 & 0,1 & 0,06 \\
\hline C. V. & 0,22 & 5,4 & 6,8 \\
\hline ITN-2 & $\rho_{b}$ & $V_{o}$ & $p_{o}$ \\
\hline $1 \mathrm{PD}$ & 2.611 & 2,4 & 0,95 \\
\hline $2 \mathrm{NaOH}$ & 2.612 & 2,3 & 0,91 \\
\hline $3 \mathrm{NaOH}$ & 2.610 & 2,4 & 0,94 \\
\hline $5 \mathrm{H}_{2} \mathrm{SO}_{4}$ & 2.606 & 2,6 & 1,02 \\
\hline $6 \mathrm{H}_{2} \mathrm{SO}_{4}$ & 2.604 & 2,5 & 0,99 \\
\hline $\bar{x}$ & 2.609 & 2,4 & 0,96 \\
\hline$S$ & 3 & 0,1 & 0,04 \\
\hline C.V. & 0,13 & 4,7 & 4,4 \\
\hline
\end{tabular}

\begin{tabular}{|c|c|c|c|}
\hline CRV & $\rho_{b}$ & $V_{o}$ & $p_{o}$ \\
\hline $1 \mathrm{H}_{2} \mathrm{SO}_{4}$ & 2.617 & 1,6 & 0,73 \\
\hline $3 \mathrm{NaOH}$ & 2.616 & 1,6 & 0,73 \\
\hline $4 \mathrm{H}_{2} \mathrm{SO}_{4}$ & 2.615 & 1,7 & 0,76 \\
\hline 5 PD & 2.612 & 1,9 & 0,86 \\
\hline $6 \mathrm{NaOH}$ & 2.616 & 1,7 & 0,76 \\
\hline$x$ & 2.615 & 1,7 & 0,77 \\
\hline$S$ & 2 & 0,1 & 0,05 \\
\hline C. V. & 0,07 & 7,2 & 7,1 \\
\hline CSB & $\rho_{b}$ & $V_{o}$ & $p_{o}$ \\
\hline $1 \mathrm{NaOH}$ & 2.628 & 2,3 & 0,61 \\
\hline 1 PD & 2.624 & 2,1 & 0,55 \\
\hline $2 \mathrm{H}_{2} \mathrm{SO}_{4}$ & 2.617 & 2,5 & 0,66 \\
\hline $7 \mathrm{NaOH}$ & 2.608 & 2,3 & 0,60 \\
\hline $8 \mathrm{H}_{2} \mathrm{SO}_{4}$ & 2.597 & 2,1 & 0,54 \\
\hline $8 \mathrm{PD}$ & 2.595 & 2,2 & 0,57 \\
\hline $\bar{x}$ & 2.611 & 2,3 & 0,59 \\
\hline$S$ & 14 & 0,2 & 0,05 \\
\hline C.V. & 0,53 & 6,7 & 7,8 \\
\hline FLS & $\rho_{b}$ & $V_{o}$ & $p_{o}$ \\
\hline $1 \mathrm{NaOH}$ & 2.595 & 3,1 & 0,84 \\
\hline $2 \mathrm{H}_{2} \mathrm{SO}_{4}$ & 2.611 & 3,3 & 0,89 \\
\hline $2 P D$ & 2.598 & 3,4 & 0,93 \\
\hline $3 \mathrm{NaOH}$ & 2.591 & 3,0 & 0,82 \\
\hline $7 \mathrm{H}_{2} \mathrm{SO}_{4}$ & 2.620 & 3,1 & 0,87 \\
\hline $8 \mathrm{H}_{2} \mathrm{SO}_{4}$ & 2.613 & 3,1 & 0,85 \\
\hline 9 PD & 2.632 & 3,1 & 0,85 \\
\hline $9 \mathrm{NaOH}$ & 2.611 & 3,2 & 0,87 \\
\hline$x$ & 2.609 & 3,2 & 0,87 \\
\hline$S$ & 14 & 0,1 & 0,03 \\
\hline C. . . & 0,52 & 4,1 & 4,0 \\
\hline GVN & $\rho_{b}$ & $V_{o}$ & $p_{o}$ \\
\hline $2 \mathrm{H}_{2} \mathrm{SO}_{4}$ & 2.632 & 2,5 & 0,69 \\
\hline 2 PD & 2.626 & 2,7 & 0,74 \\
\hline $3 \mathrm{NaOH}$ & 2.641 & 2,6 & 0,72 \\
\hline 8 PD & 2.631 & 2,7 & 0,74 \\
\hline $8 \mathrm{H}_{2} \mathrm{SO}_{4}$ & 2.629 & 2,6 & 0,70 \\
\hline $9 \mathrm{NaOH}$ & 2.632 & 2,7 & 0,74 \\
\hline$x$ & 2.632 & 2,6 & 0,72 \\
\hline$S$ & 5 & 0,1 & 0,02 \\
\hline C. $V$. & 0,19 & 3,1 & 3,0 \\
\hline
\end{tabular}




\begin{tabular}{cccc}
\hline ARB & $\rho_{b}$ & $V_{o}$ & $p_{o}$ \\
\hline $1 \mathrm{H}_{2} \mathrm{SO}_{4}$ & 2.656 & 1,5 & 0,62 \\
$2 \mathrm{PD}$ & 2.652 & 1,7 & 0,70 \\
$3 \mathrm{NaOH}$ & 2.640 & 1,6 & 0,66 \\
$8 \mathrm{PD}$ & 2.663 & 1,6 & 0,64 \\
$8 \mathrm{H}_{2} \mathrm{SO}_{4}$ & 2.655 & 1,6 & 0,65 \\
$9 \mathrm{NaOH}_{\boldsymbol{X}}$ & 2.662 & 1,6 & 0,64 \\
\hline$S$ & 2.655 & 1,6 & 0,65 \\
$\mathrm{C} . V$. & 8 & 0,1 & 0,03 \\
\hline $\mathrm{SCC}$ & 0,31 & 4,0 & 3,9 \\
\hline $1 \mathrm{H}_{2} \mathrm{SO}$ & $\rho_{b}$ & $V_{o}$ & $p_{o}$ \\
$3 \mathrm{NaOH}$ & 2.635 & 2,1 & 0,57 \\
$7 \mathrm{H} \mathrm{SO}_{4}$ & 2.634 & 2,3 & 0,63 \\
$8 \mathrm{NaOH}$ & 2.638 & 2,5 & 0,70 \\
$9 \mathrm{PD}$ & 2.633 & 2,3 & 0,65 \\
$\boldsymbol{x}$ & 2.623 & 2,4 & 0,68 \\
\hline$S$ & 2.632 & 2,3 & 0,65 \\
$C . V$. & 5 & 0,1 & 0,05 \\
\hline & 0,21 & 6,4 & 7,5 \\
\hline
\end{tabular}

TAMANHO DOS CORPOS-DE-PROVA: $10 \mathrm{~cm} \times 10 \mathrm{~cm}$

\begin{tabular}{cccc}
\hline LBD & $\rho_{b}$ & $V_{o}$ & $p_{o}$ \\
\hline 1 & 2.654 & 1,1 & 0,41 \\
2 & 2.657 & 1,2 & 0,44 \\
3 & 2.666 & 1,3 & 0,47 \\
4 & 2.657 & 1,1 & 0,40 \\
$4 \mathrm{~A}$ & 2.661 & 1,2 & 0,44 \\
5 & 2.655 & 1,2 & 0,44 \\
$\overline{\boldsymbol{x}}$ & 2.658 & 1,2 & 0,43 \\
$\boldsymbol{S}$ & 4 & 0,1 & 0,02 \\
$C . V$. & 0,16 & 6,4 & 5,7 \\
\hline VCB-1 & $\rho_{b}$ & $V_{o}$ & $p_{o}$ \\
\hline 1 & 2.633 & 1,4 & 0,45 \\
2 & 2.631 & 1,5 & 0,49 \\
3 & 2.633 & 1,3 & 0,42 \\
4 & 2.637 & 1,3 & 0,42 \\
5 & 2.633 & 1,2 & 0,38 \\
\hline $\boldsymbol{x}$ & 2.633 & 1,3 & 0,43 \\
$\boldsymbol{S}$ & 2 & 0,1 & 0,04 \\
$C . V$. & 0,08 & 8,5 & 9,7 \\
\hline
\end{tabular}

\begin{tabular}{|c|c|c|c|}
\hline VCB-2 & $\rho_{b}$ & $V_{o}$ & $p_{o}$ \\
\hline 1 & 2.629 & 0,8 & 0,28 \\
\hline 2 & 2.626 & 1,0 & 0,34 \\
\hline 3 & 2.639 & 1,0 & 0,34 \\
\hline 4 & 2.629 & 1,2 & 0,42 \\
\hline 5 & 2.627 & 1,2 & 0,41 \\
\hline$x$ & 2.630 & 1,0 & 0,36 \\
\hline$s$ & 5 & 0,2 & 0,06 \\
\hline C. V. & 0,20 & 16,1 & 16,0 \\
\hline VCB-3 & $\rho_{b}$ & $V_{o}$ & $p_{o}$ \\
\hline 1 & 2.638 & 0,9 & 0,31 \\
\hline 2 & 2.643 & 0,9 & 0,32 \\
\hline 3 & 2.640 & 1,0 & 0,35 \\
\hline 4 & 2.638 & 0,9 & 0,32 \\
\hline 5 & 2.636 & 1,0 & 0,35 \\
\hline $5 \mathrm{~A}$ & 2.635 & 1,0 & 0,36 \\
\hline $\bar{x}$ & 2.638 & 1,0 & 0,34 \\
\hline$S$ & 3 & 0,1 & 0,02 \\
\hline C.V. & 0,11 & 5,8 & 6,1 \\
\hline RIC & $\rho_{b}$ & $V_{o}$ & $p_{o}$ \\
\hline 1 & 2.615 & 1,1 & 0,49 \\
\hline $1 \mathrm{~A}$ & 2.613 & 1,1 & 0,49 \\
\hline 2 & 2.611 & 1,1 & 0,49 \\
\hline 3 & 2.612 & 1,1 & 0,49 \\
\hline 4 & 2.617 & 1,2 & 0,53 \\
\hline 5 & 2.615 & 1,1 & 0,50 \\
\hline $\bar{x}$ & 2.614 & 1,1 & 0,50 \\
\hline$S$ & 2 & 0,0 & 0,02 \\
\hline C.V. & 0,08 & 3,7 & 3,3 \\
\hline BCR & $\rho_{b}$ & $V_{o}$ & $p_{o}$ \\
\hline 1 & 2.612 & 1,3 & 0,60 \\
\hline 2 & 2.609 & 1,3 & 0,59 \\
\hline 3 & 2.609 & 1,3 & 0,59 \\
\hline 4 & 2.608 & 1,4 & 0,63 \\
\hline 5 & 2.608 & 1,4 & 0,63 \\
\hline 6 & 2.609 & 1,4 & 0,63 \\
\hline$x$ & 2.609 & 1,4 & 0,61 \\
\hline$s$ & 1 & 0,1 & 0,02 \\
\hline C.V. & 0,05 & 4,1 & 3,5 \\
\hline
\end{tabular}




\begin{tabular}{|c|c|c|c|}
\hline BSV & $\rho_{b}$ & $V_{o}$ & $p_{o}$ \\
\hline 1 & 2.614 & 1,6 & 0,74 \\
\hline 2 & 2.617 & 1,6 & 0,75 \\
\hline 3 & 2.615 & 1,5 & 0,70 \\
\hline 4 & 2.616 & 1,6 & 0,74 \\
\hline 5 & 2.616 & 1,7 & 0,78 \\
\hline $5 \mathrm{~A}$ & 2.617 & 1,6 & 0,73 \\
\hline$x$ & 2.616 & 1,6 & 0,74 \\
\hline$S$ & 1 & 0,1 & 0,03 \\
\hline C.V. & 0,04 & 4,0 & 3,5 \\
\hline PIT-2cm & $\rho_{b}$ & $V_{o}$ & $p_{o}$ \\
\hline 4 & 2.627 & 1,0 & 0,48 \\
\hline 5 & 2.625 & 1,0 & 0,47 \\
\hline 6 & 2.624 & 1,1 & 0,51 \\
\hline $6 \mathrm{~A}$ & 2.622 & 1,1 & 0,52 \\
\hline 7 & 2.623 & 0,9 & 0,44 \\
\hline $7 \mathrm{~A}$ & 2.624 & 1,0 & 0,47 \\
\hline $\bar{x}$ & 2.624 & 1,0 & 0,48 \\
\hline$S$ & 2 & 0,1 & 0,03 \\
\hline C. $V$. & 0,06 & 7,4 & 6,2 \\
\hline AZF & $\rho_{b}$ & $\overline{V_{o}}$ & $p_{o}$ \\
\hline 1 & 2.626 & 1,5 & 0,48 \\
\hline 2 & 2.627 & 1,5 & 0,47 \\
\hline 3 & 2.630 & 1,4 & 0,44 \\
\hline 4 & 2.627 & 1,5 & 0,48 \\
\hline 5 & 2.628 & 1,5 & 0,48 \\
\hline $\bar{x}$ & 2.627 & 1,5 & 0,47 \\
\hline$s$ & 1 & 0,0 & 0,02 \\
\hline C.V. & 0,06 & 3,0 & 3,6 \\
\hline BCE & $\rho_{b}$ & $V_{o}$ & $p_{o}$ \\
\hline 1 & 2.610 & 2,0 & 0,63 \\
\hline 2 & 2.610 & 2,1 & 0,65 \\
\hline 3 & 2.611 & 1,9 & 0,59 \\
\hline 4 & 2.610 & 2,0 & 0,63 \\
\hline 5 & 2.609 & 1,8 & 0,55 \\
\hline $5 A$ & 2.609 & 1,9 & 0,58 \\
\hline$x$ & 2.610 & 2,0 & 0,60 \\
\hline$s$ & 1 & 0,1 & 0,04 \\
\hline C. $V$. & 0,03 & 5,4 & 6,2 \\
\hline
\end{tabular}

\begin{tabular}{|c|c|c|c|}
\hline ITN-1 & $\rho_{b}$ & $V_{o}$ & $p_{o}$ \\
\hline 1 & 2.601 & 2,3 & 1,08 \\
\hline 2 & 2.602 & 2,3 & 1,07 \\
\hline 3 & 2.601 & 2,2 & 1,03 \\
\hline 4 & 2.606 & 1,9 & 0,86 \\
\hline 5 & 2.612 & 1,8 & 0,82 \\
\hline 6 & 2.608 & 2,0 & 0,91 \\
\hline$x$ & 2.605 & 2,1 & 0,96 \\
\hline$S$ & 5 & 0,2 & 0,11 \\
\hline C.V. & 0,17 & 10,3 & 11,6 \\
\hline ITN-2 & $\rho_{b}$ & $V_{o}$ & $p_{o}$ \\
\hline 1 & 2.612 & 1,9 & 0,90 \\
\hline 2 & 2.605 & 1,8 & 0,85 \\
\hline 3 & 2.609 & 1,9 & 0,89 \\
\hline 4 & 2.605 & 1,9 & 0,90 \\
\hline 5 & 2.613 & 1,7 & 0,80 \\
\hline 6 & 2.607 & 2,0 & 0,94 \\
\hline $\bar{x}$ & 2.608 & 1,9 & 0,88 \\
\hline$S$ & 3 & 0,1 & 0,05 \\
\hline C.V. & 0,13 & 5,5 & 5,3 \\
\hline CRV & $\rho_{b}$ & $V_{o}$ & $p_{o}$ \\
\hline 1 & 2.618 & 1,3 & 0,70 \\
\hline 2 & 2.618 & 1,3 & 0,70 \\
\hline 3 & 2.620 & 1,3 & 0,70 \\
\hline 4 & 2.617 & 1,3 & 0,68 \\
\hline 5 & 2.615 & 1,4 & 0,73 \\
\hline 6 & 2.614 & 1,4 & 0,73 \\
\hline$x$ & 2.617 & 1,3 & 0,71 \\
\hline$S$ & 2 & 0,1 & 0,02 \\
\hline C.V. & 0,08 & 3,9 & 2,9 \\
\hline CSB & $\rho_{b}$ & $V_{o}$ & $p_{o}$ \\
\hline 1 & 2.619 & 1,7 & 0,53 \\
\hline 2 & 2.639 & 1,6 & 0,50 \\
\hline 3 & 2.625 & 1,9 & 0,59 \\
\hline 4 & 2.592 & 1,6 & 0,49 \\
\hline 5 & 2.593 & 1,9 & 0,58 \\
\hline 6 & 2.587 & 1,7 & 0,52 \\
\hline$x$ & 2.609 & 1,7 & 0,54 \\
\hline$S$ & 21 & 0,1 & 0,04 \\
\hline C.V. & 0,81 & 7,9 & 7,9 \\
\hline
\end{tabular}




\begin{tabular}{|c|c|c|c|}
\hline FLS & $\rho_{b}$ & $V_{o}$ & $p_{o}$ \\
\hline 1 & 2.618 & 3,0 & 0,98 \\
\hline 3 & 2.583 & 2,8 & 0,91 \\
\hline 7 & 2.621 & 2,5 & 0,83 \\
\hline 8 & 2.596 & 2,5 & 0,83 \\
\hline $8 \mathrm{~A}$ & 2.607 & 2,6 & 0,86 \\
\hline 9 & 2.610 & 2,5 & 0,83 \\
\hline$x$ & 2.606 & 2,7 & 0,87 \\
\hline$S$ & 14 & 0,2 & 0,06 \\
\hline C.V. & 0,54 & 7,8 & 7,0 \\
\hline GVN & $\rho_{b}$ & $V_{o}$ & $p_{o}$ \\
\hline 1 & 2.633 & 2,1 & 0,69 \\
\hline 2 & 2.625 & 2,2 & 0,71 \\
\hline 3 & 2.645 & 2,1 & 0,69 \\
\hline 7 & 2.641 & 2,1 & 0,69 \\
\hline 8 & 2.634 & 2,2 & 0,74 \\
\hline 9 & 2.641 & 2,1 & 0,68 \\
\hline $\bar{x}$ & 2.636 & 2,1 & 0,70 \\
\hline$S$ & 7 & 0,1 & 0,02 \\
\hline C.V. & 0,28 & 2,4 & 3,2 \\
\hline ARB & $\rho_{b}$ & $V_{o}$ & $p_{o}$ \\
\hline 1 & 2.660 & 1,3 & 0,64 \\
\hline 2 & 2.658 & 1,3 & 0,64 \\
\hline 3 & 2.646 & 1,4 & 0,69 \\
\hline 7 & 2.644 & 1,3 & 0,63 \\
\hline 8 & 2.641 & 1,4 & 0,68 \\
\hline 9 & 2.657 & 1,3 & 0,62 \\
\hline$x$ & 2.651 & 1,3 & 0,65 \\
\hline$S$ & 8 & 0,1 & 0,03 \\
\hline C.V. & 0,31 & 3,9 & 4,3 \\
\hline SCC & $\rho_{b}$ & $V_{o}$ & $p_{o}$ \\
\hline 1 & 2.627 & 2,0 & 0,65 \\
\hline 2 & 2.636 & 1,9 & 0,62 \\
\hline 3 & 2.628 & 1,9 & 0,63 \\
\hline 7 & 2.634 & 2,2 & 0,75 \\
\hline 8 & 2.645 & 2,0 & 0,68 \\
\hline 9 & 2.647 & 1,8 & 0,61 \\
\hline$x$ & 2.636 & 2,0 & 0,66 \\
\hline$S$ & 8 & 0,1 & 0,05 \\
\hline C. V. & 0,31 & 6,9 & 7,7 \\
\hline
\end{tabular}


ANEXO E

Resultados dos ensaios de resistência à compressão uniaxial (NBR ABNT 12.767/92) 


\section{Legenda}

CP = corpo-de-prova

$h=\operatorname{altura}(\mathrm{cm})$

$A_{1}=\operatorname{aresta} 1(\mathrm{~cm})$

$A_{2}=\operatorname{aresta} 2(\mathrm{~cm})$

$P=$ carga de ruptura (kgf)

$\sigma_{C}=$ resistência à compressão $(\mathrm{MPa})$
$V P=$ velocidade de propagação de ondas $(\mathrm{m} / \mathrm{s})$

$\bar{x}_{\mathrm{sec}}=$ média (condição seca)

$\bar{x}_{\text {sat }}=$ média (condição saturada)

$S=$ desvio padrão

$C . V .=$ coeficiente de variação (\%)

$\Delta$ = variação entre resistência à compressão seca e saturada (\%)

\begin{tabular}{|c|c|c|c|c|c|c|c|}
\hline LBD & $\mathrm{CP}$ & $h$ & $A_{1}$ & $A_{2}$ & $P$ & $\sigma_{C}$ & $V P$ \\
\hline \multirow{5}{*}{ saturada } & 1 & 7,48 & 7,46 & 7,45 & 58.400 & 103 & 5.500 \\
\hline & 2 & 7,47 & 7,45 & 7,42 & 62.400 & 111 & 5.533 \\
\hline & 3 & 7,45 & 7,60 & 7,68 & 60.800 & 102 & 5.438 \\
\hline & 4 & 7,36 & 7,59 & 7,38 & 67.200 & 118 & 5.452 \\
\hline & 5 & 7,31 & 7,57 & 7,48 & 41.800 & 72 & 5.455 \\
\hline \multirow{9}{*}{ seca } & 6 & 7,41 & 7,40 & 7,47 & 56.800 & 101 & 5.449 \\
\hline & 7 & 7,49 & 7,51 & 7,52 & 64.800 & 113 & 5.428 \\
\hline & 8 & 7,50 & 7,53 & 7,56 & 53.600 & 92 & 5.396 \\
\hline & 9 & 7,45 & 7,45 & 7,63 & 71.200 & 123 & 5.438 \\
\hline & 10 & 7,59 & 7,46 & 7,59 & 78.400 & 136 & 5.581 \\
\hline & & & $\bar{x}_{s a t}$ & 101 & $\bar{x}_{\mathrm{sec}}$ & 113 & 5.467 \\
\hline & & & $S$ & 17 & $s$ & 17 & 55 \\
\hline & & & C.V. & 17,1 & C.V. & 15,3 & 1,0 \\
\hline & & & $\Delta$ & -10 & & & \\
\hline
\end{tabular}

\begin{tabular}{|c|c|c|c|c|c|c|c|}
\hline VCB-1 & $\mathrm{CP}$ & $h$ & $A_{1}$ & $A_{2}$ & $P$ & $\sigma_{C}$ & $V P$ \\
\hline \multirow{5}{*}{ saturada } & 1 & 7,45 & 7,82 & 7,79 & 80.800 & 130 & 5.399 \\
\hline & 2 & 7,63 & 7,85 & 7,87 & 72.800 & 116 & 5.450 \\
\hline & 3 & 7,66 & 7,77 & 7,80 & 70.400 & 114 & 5.511 \\
\hline & 4 & 7.60 & 7,87 & 7,88 & 67.200 & 106 & 5.352 \\
\hline & 5 & 7,61 & 7,88 & 7,91 & 68.400 & 108 & 5.285 \\
\hline \multirow{9}{*}{ seca } & 6 & 7,58 & 7,81 & 7,82 & 80.000 & 128 & 5.338 \\
\hline & 7 & 7,56 & 7,87 & 7,90 & 81.200 & 128 & 5.400 \\
\hline & 8 & 7,54 & 7,86 & 7,80 & 78.000 & 125 & 5.464 \\
\hline & 9 & 7,66 & 7,87 & 7,88 & 64.000 & 101 & 5.433 \\
\hline & 10 & 7,62 & 7,77 & 7,82 & 80.400 & 130 & 5.443 \\
\hline & & & $\bar{x}_{s a t}$ & 115 & $\bar{x}_{\mathrm{sec}}$ & 123 & 5.407 \\
\hline & & & $s$ & 9 & $s$ & 12 & 67 \\
\hline & & & C.V. & 8,2 & C.V. & 9,8 & 1,2 \\
\hline & & & $\Delta$ & -6 & & & \\
\hline
\end{tabular}

\begin{tabular}{|c|c|c|c|c|c|c|c|}
\hline VCB-2 & $\mathrm{CP}$ & $h$ & $A_{1}$ & $A_{2}$ & $P$ & $\sigma_{C}$ & $V P$ \\
\hline \multirow{5}{*}{ saturada } & 1 & 7,47 & 7,68 & 7,58 & 80.400 & 136 & 5.374 \\
\hline & 2 & 7,58 & 7,66 & 7,59 & 60.000 & 101 & 5.493 \\
\hline & 3 & 7,55 & 7,65 & 7,65 & 69.600 & 117 & 5.393 \\
\hline & 4 & 7,58 & 7,71 & 7,65 & 66.000 & 110 & 5.831 \\
\hline & 5 & 7,58 & 7,69 & 7,68 & 59.400 & 99 & 5.493 \\
\hline \multirow{8}{*}{ seca } & 6 & 7,55 & 7,71 & 7,68 & 90.400 & 150 & 5.355 \\
\hline & 7 & 7,47 & 7,58 & 7,65 & 90.000 & 152 & 5.493 \\
\hline & 8 & 7,48 & 7,57 & 7,63 & 85.800 & 146 & 5.420 \\
\hline & 9 & 7,46 & 7,70 & 7,63 & 78.800 & 132 & 5.217 \\
\hline & 10 & 7,53 & 7,73 & 7,72 & 78.000 & 128 & 5.379 \\
\hline & & & $\bar{x}_{s a t}$ & 112 & $\bar{x}_{\mathrm{sec}}$ & 141 & 5.445 \\
\hline & & & $S$ & 15 & $S$ & 11 & 159 \\
\hline & & & C.V. & 13,2 & C.V. & 7,7 & 2,9 \\
\hline
\end{tabular}




\begin{tabular}{|c|c|c|c|c|c|c|c|}
\hline VCB-3 & CP & $h$ & $A_{1}$ & $A_{2}$ & $P$ & $\sigma_{C}$ & $V P$ \\
\hline & 1 & 7,45 & 7,65 & 7,72 & 66.400 & 110 & 5.210 \\
\hline & 2 & 7,54 & 7,67 & 7,72 & 64.000 & 106 & 5.200 \\
\hline \multirow[t]{5}{*}{ saturada } & 3 & 7,52 & 7,73 & 7,68 & 64.800 & 107 & 5.333 \\
\hline & 4 & 7,49 & 7,72 & 7,78 & 90.800 & 148 & 5.428 \\
\hline & 5 & 7,62 & 7,82 & 7,80 & 69.600 & 112 & 5.329 \\
\hline & 6 & 7,43 & 7,73 & 7,67 & 82.000 & 136 & 5.504 \\
\hline & 7 & 7,55 & 7,69 & 7,70 & 82.800 & 137 & 5.317 \\
\hline \multirow[t]{7}{*}{ seca } & 8 & 7,56 & 7,71 & 7,71 & 74.400 & 123 & 5.250 \\
\hline & 9 & 7,74 & 7,82 & 7,87 & 86.400 & 138 & 5.338 \\
\hline & 10 & 7,56 & 7,87 & 7,86 & 74.800 & 119 & 5.178 \\
\hline & & & $\bar{x}_{\text {sat }}$ & 117 & $\bar{x}_{\mathrm{sec}}$ & 130 & 5.309 \\
\hline & & & $S$ & 18 & $S$ & 9 & 103 \\
\hline & & & C.V. & 15,3 & C.V. & 6,9 & 1,9 \\
\hline & & & $\Delta$ & -10 & & & \\
\hline \multirow[t]{3}{*}{ BCE } & CP & $h$ & $A_{1}$ & $A_{2}$ & $P$ & $\sigma_{C}$ & $V P$ \\
\hline & 1 & 7,64 & 7,78 & 7,79 & 82.000 & 133 & 4.494 \\
\hline & 2 & 7,59 & 7,74 & 7,80 & 118.400 & 193 & 4.897 \\
\hline \multirow[t]{5}{*}{ saturada } & 3 & 7,55 & 7,68 & 7,79 & 95.200 & 156 & 4.840 \\
\hline & 4 & 7,67 & 7,82 & 7,80 & 103.200 & 166 & 4.459 \\
\hline & 5 & 7,50 & 7,71 & 7,87 & 102.000 & 165 & 4.747 \\
\hline & 6 & 7,62 & 7,80 & 7,76 & 90.400 & 146 & 4.763 \\
\hline & 7 & 7,64 & 7,78 & 7,80 & 98.400 & 159 & 4.630 \\
\hline \multirow[t]{7}{*}{ seca } & 8 & 7,52 & 7,84 & 7,74 & 93.600 & 151 & 4.821 \\
\hline & 9 & 7,57 & 7,78 & 7,81 & 103.200 & 167 & 4.326 \\
\hline & 10 & 7,51 & 7,75 & 7,76 & 98.800 & 161 & 4.607 \\
\hline & & & $\bar{x}_{s a t}$ & 162 & $\bar{x}_{\mathrm{sec}}$ & 157 & 4.658 \\
\hline & & & $S$ & 22 & $S$ & 8 & 187 \\
\hline & & & C.V. & 13,3 & C.V. & 5,1 & 4,0 \\
\hline & & & $\Delta$ & 3 & & & \\
\hline
\end{tabular}

\begin{tabular}{|c|c|c|c|c|c|c|c|}
\hline ITN-1 & CP & $h$ & $A_{1}$ & $A_{2}$ & $P$ & $\sigma_{C}$ & $V P$ \\
\hline \multirow{5}{*}{ saturada } & 1 & 7,52 & 7,57 & 7,56 & 56.400 & 97 & 4.476 \\
\hline & 2 & 7,52 & 7,59 & 7,57 & 55.600 & 95 & 3.979 \\
\hline & 3 & 7,46 & 7,54 & 7,49 & 62.000 & 108 & 4.191 \\
\hline & 4 & 7,57 & 7,55 & 7,56 & 32.800 & 56 & 4.229 \\
\hline & 5 & 7,52 & 7,68 & 7,59 & 53.200 & 90 & 4.450 \\
\hline \multirow{9}{*}{ seca } & 6 & 7,39 & 7,68 & 7,67 & 68.800 & 115 & 4.152 \\
\hline & 7 & 7,51 & 7,53 & 7,56 & 67.200 & 116 & 4.444 \\
\hline & 8 & 7,46 & 7,56 & 7,54 & 72.000 & 124 & 4.440 \\
\hline & 9 & 7,47 & 7,62 & 7,54 & 65.200 & 111 & 4.368 \\
\hline & 10 & 7,50 & 7,57 & 7,54 & 59.200 & 102 & 4.190 \\
\hline & & & $\bar{x}_{\text {sat }}$ & 89 & $\bar{x}_{\mathrm{sec}}$ & 113 & 4.292 \\
\hline & & & $S$ & 19 & $S$ & 8 & 167 \\
\hline & & & C.V. & 21,8 & C.V. & 7,1 & 3,9 \\
\hline & & & $\Delta$ & -22 & & & \\
\hline ITN-2 & $\mathrm{CP}$ & $h$ & $A_{1}$ & $A_{2}$ & $P$ & $\sigma_{C}$ & $V P$ \\
\hline \multirow{5}{*}{ saturada } & 1 & 7,51 & 7,70 & 7,54 & 56.800 & 96 & 3.755 \\
\hline & 2 & 7,48 & 7,69 & 7,57 & 52.000 & 88 & 3.631 \\
\hline & 3 & 7,44 & 7,40 & 7,44 & 52.400 & 93 & 4.227 \\
\hline & 4 & 7,49 & 7,40 & 7,51 & 45.600 & 80 & 3.708 \\
\hline & 5 & 7,47 & 7,50 & 7,51 & 59.600 & 104 & 3.973 \\
\hline \multirow{9}{*}{ seca } & 6 & 7,36 & 7,58 & 7,57 & 74.000 & 127 & 3.573 \\
\hline & 7 & 7,35 & 7,51 & 7,45 & 51.600 & 91 & 3.621 \\
\hline & 8 & 7,41 & 7,58 & 7,42 & 62.400 & 109 & 3.761 \\
\hline & 9 & 7,48 & 7,48 & 7,40 & 62.000 & 110 & 4.110 \\
\hline & 10 & 7,44 & 7,73 & 7,53 & 78.000 & 132 & 3.701 \\
\hline & & & $\bar{x}_{\text {sat }}$ & 92 & $\bar{x}_{\mathrm{sec}}$ & 113 & 3.806 \\
\hline & & & $S$ & 9 & $S$ & 16 & 222 \\
\hline & & & C.V. & 9,5 & C.V. & 14,3 & 5,8 \\
\hline & & & $\Delta$ & -19 & & & \\
\hline
\end{tabular}




\begin{tabular}{|c|c|c|c|c|c|c|c|}
\hline CRV & CP & $h$ & $A_{1}$ & $A_{2}$ & $P$ & $\sigma_{C}$ & $V P$ \\
\hline & 1 & 7,49 & 7,67 & 7,63 & 79.800 & 134 & 4.864 \\
\hline & 2 & 7,46 & 7,63 & 7,65 & 86.000 & 145 & 4.844 \\
\hline \multirow[t]{5}{*}{ saturada } & 3 & 7,53 & 7,67 & 7,67 & 80.400 & 134 & 4.954 \\
\hline & 4 & 7,56 & 7,55 & 7,68 & 81.600 & 138 & 4.941 \\
\hline & 5 & 7,49 & 7,67 & 7,59 & 91.600 & 154 & 4.864 \\
\hline & 6 & 7,50 & 7,60 & 7,65 & 114.800 & 194 & 4.870 \\
\hline & 7 & 7,50 & 7,65 & 7,69 & 108.000 & 180 & 4.808 \\
\hline \multirow{7}{*}{ seca } & 8 & 7,48 & 7,70 & 7,64 & 114.000 & 190 & 4.921 \\
\hline & 9 & 7,51 & 7,75 & 7,66 & 93.200 & 154 & 4.908 \\
\hline & 10 & 7,52 & 7,57 & 7,61 & 78.000 & 133 & 4.915 \\
\hline & & & $\bar{x}_{s a t}$ & 141 & $\bar{x}_{\mathrm{sec}}$ & 170 & 4.889 \\
\hline & & & $S$ & 9 & $S$ & 26 & 46 \\
\hline & & & C.V. & 6,1 & C.V. & 15,3 & 0,9 \\
\hline & & & $\Delta$ & -17 & & & \\
\hline \multirow[t]{3}{*}{ PIT } & CP & $h$ & $A_{1}$ & $A_{2}$ & $P$ & $\sigma_{C}$ & $V P$ \\
\hline & 1 & 7,49 & 7,52 & 7,51 & 68.000 & 118 & 5.238 \\
\hline & 2 & 7,43 & 7,49 & 7,52 & 88.200 & 154 & 5.232 \\
\hline \multirow{5}{*}{ saturada } & 3 & 7,52 & 7,47 & 7,49 & 87.600 & 154 & 5.259 \\
\hline & 4 & 7,49 & 7,53 & 7,43 & 84.400 & 148 & 5.201 \\
\hline & 5 & 7,49 & 7,52 & 7,45 & 82.000 & 144 & 5.275 \\
\hline & 6 & 7,44 & 7,52 & 7,60 & 117.800 & 202 & 5.239 \\
\hline & 7 & 7,44 & 7,52 & 7,57 & 97.200 & 168 & 5.277 \\
\hline \multirow[t]{7}{*}{ seca } & 8 & 7,44 & 7,58 & 7,63 & 115.200 & 195 & 5.203 \\
\hline & 9 & 7,53 & 7,58 & 7,60 & 83.600 & 142 & 5.229 \\
\hline & 10 & 7,55 & 7,57 & 7,57 & 87.600 & 150 & 5.207 \\
\hline & & & $\bar{x}_{\text {sat }}$ & 143 & $\bar{x}_{\mathrm{sec}}$ & 171 & 5.236 \\
\hline & & & $S$ & 15 & $S$ & 27 & 28 \\
\hline & & & C.V. & 10,3 & C.V. & 15,5 & 0,5 \\
\hline & & & $\Delta$ & -16 & & & \\
\hline
\end{tabular}

\begin{tabular}{|c|c|c|c|c|c|c|c|}
\hline AZF & $\mathrm{CP}$ & $h$ & $A_{1}$ & $A_{2}$ & $P$ & $\sigma_{C}$ & $V P$ \\
\hline \multirow{5}{*}{ saturada } & 1 & 7,75 & 7,80 & 7,78 & 73.200 & 118 & 4.905 \\
\hline & 2 & 7,67 & 7,71 & 7,81 & 78.800 & 128 & 4.885 \\
\hline & 3 & 7,57 & 7,78 & 7,79 & 72.000 & 117 & 4.853 \\
\hline & 4 & 7,66 & 7,78 & 7,78 & 68.400 & 111 & 4.818 \\
\hline & 5 & 7,64 & 7,83 & 7,78 & 75.200 & 121 & 4.897 \\
\hline \multirow{9}{*}{ seca } & 6 & 7,79 & 7,77 & 7,85 & 74.000 & 119 & 4.779 \\
\hline & 7 & 7,62 & 7,75 & 7,74 & 101.600 & 166 & 4.885 \\
\hline & 8 & 7,56 & 7,76 & 7,77 & 82.400 & 134 & 4.909 \\
\hline & 9 & 7,70 & 7,79 & 7,77 & 88.800 & 144 & 4.873 \\
\hline & 10 & 7,53 & 7,79 & 7,75 & 76.800 & 125 & 4.620 \\
\hline & & & $\bar{x}_{s a t}$ & 119 & $\bar{x}_{\mathrm{sec}}$ & 138 & 4.842 \\
\hline & & & $S$ & 6 & $S$ & 19 & 88 \\
\hline & & & C.V. & 5,4 & C.V. & 13,5 & 1,8 \\
\hline & & & $\Delta$ & -14 & & & \\
\hline RIC & $\mathrm{CP}$ & $h$ & $A_{1}$ & $A_{2}$ & $P$ & $\sigma_{C}$ & $V P$ \\
\hline \multirow{5}{*}{ saturada } & 1 & 7,47 & 7,67 & 7,76 & 94.000 & 155 & 4.318 \\
\hline & 2 & 7,49 & 7,73 & 7,60 & 69.200 & 116 & 4.380 \\
\hline & 3 & 7,49 & 7,61 & 7,70 & 68.800 & 115 & 4.406 \\
\hline & 4 & 7,44 & 7,56 & 7,57 & 76.800 & 132 & 4.301 \\
\hline & 5 & 7,41 & 7,63 & 7,65 & 64.800 & 109 & 4.308 \\
\hline \multirow{9}{*}{ seca } & 6 & 7,51 & 7,60 & 7,54 & 86.800 & 149 & 4.418 \\
\hline & 7 & 7,47 & 7,50 & 7,74 & 78.000 & 132 & 4.394 \\
\hline & 8 & 7,55 & 7,57 & 7,72 & 80.200 & 135 & 4.364 \\
\hline & 9 & 7,45 & 7,67 & 7,66 & 93.400 & 156 & 4.515 \\
\hline & 10 & 7,42 & 7,57 & 7,71 & 65.600 & 110 & 4.314 \\
\hline & & & $\bar{x}_{s a t}$ & 125 & $\bar{x}_{\mathrm{sec}}$ & 136 & 4.372 \\
\hline & & & $s$ & 19 & $s$ & 18 & 67 \\
\hline & & & C.V. & 14,8 & C.V. & 12,9 & 1,5 \\
\hline & & & $\Delta$ & -8 & & & \\
\hline
\end{tabular}




\begin{tabular}{|c|c|c|c|c|c|c|c|}
\hline BCR & CP & $h$ & $A_{1}$ & $A_{2}$ & $P$ & $\sigma_{C}$ & $V P$ \\
\hline & 1 & 7,26 & 7,48 & 7,53 & 70.400 & 123 & 4.595 \\
\hline & 2 & 7,31 & 7,55 & 7,45 & 52.400 & 91 & 4.377 \\
\hline \multirow[t]{5}{*}{ saturada } & 3 & 7,32 & 7,56 & 7,62 & 76.800 & 131 & 4.357 \\
\hline & 4 & 7,40 & 7,54 & 7,60 & 68.000 & 116 & 4.353 \\
\hline & 5 & 7,30 & 7,56 & 7,55 & 79.600 & 137 & 4.371 \\
\hline & 6 & 7,18 & 7,51 & 7,44 & 69.600 & 122 & 4.724 \\
\hline & 7 & 7,36 & 7,43 & 7,52 & 89.200 & 157 & 4.407 \\
\hline \multirow[t]{7}{*}{ seca } & 8 & 7,23 & 7,52 & 7,49 & 96.400 & 168 & 4.463 \\
\hline & 9 & 7,30 & 7,49 & 7,53 & 70.800 & 123 & 4.591 \\
\hline & 10 & 7,20 & 7,61 & 7,49 & 78.600 & 135 & 4.615 \\
\hline & & & $\bar{x}_{s a t}$ & 120 & $\bar{x}_{\mathrm{sec}}$ & 141 & 4.485 \\
\hline & & & $S$ & 18 & $S$ & 20 & 134 \\
\hline & & & C.V. & 14,7 & C.V. & 14,5 & 3,0 \\
\hline & & & $\Delta$ & -15 & & & \\
\hline
\end{tabular}

\begin{tabular}{|c|c|c|c|c|c|c|c|}
\hline BSV & $\mathrm{CP}$ & $h$ & $A_{1}$ & $A_{2}$ & $P$ & $\sigma_{C}$ & $V P$ \\
\hline & 1 & 7,47 & 7,64 & 7,65 & 83.600 & 140 & 4.082 \\
\hline & 2 & 7,42 & 7,69 & 7,61 & 66.000 & 111 & 3.729 \\
\hline \multirow[t]{5}{*}{ saturada } & 3 & 7,53 & 7,83 & 7,65 & 61.600 & 101 & 4.160 \\
\hline & 4 & 7,53 & 7,68 & 7,68 & 74.000 & 123 & 3.803 \\
\hline & 5 & 7,48 & 7,82 & 7,68 & 81.200 & 133 & 4.065 \\
\hline & 6 & 7,55 & 7,67 & 7,79 & 74.800 & 123 & 4.148 \\
\hline & 7 & 7,49 & 7,68 & 7,64 & 80.400 & 134 & 3.745 \\
\hline \multirow[t]{7}{*}{ seca } & 8 & 7,54 & 7,76 & 7,65 & 80.800 & 134 & 3.827 \\
\hline & 9 & 7,42 & 7,70 & 7,66 & 90.800 & 151 & 4.099 \\
\hline & 10 & 7,45 & 7,62 & 7,73 & 86.800 & 145 & 3.582 \\
\hline & & & $\bar{x}_{s a t}$ & 121 & $\bar{x}_{\mathrm{sec}}$ & 137 & 3.924 \\
\hline & & & $S$ & 16 & $S$ & 11 & 209 \\
\hline & & & C.V. & 13,1 & C.V. & 7,9 & 5,3 \\
\hline & & & $\Delta$ & -12 & & & \\
\hline \multirow[t]{2}{*}{ GVN } & $\mathrm{CP}$ & $h$ & $A_{1}$ & $A_{2}$ & $P$ & $\sigma_{C}$ & $V P$ \\
\hline & 1 & 7,34 & 7,43 & 7,50 & 60.400 & 106 & 4.646 \\
\hline \multirow[t]{3}{*}{ Sat $\perp$} & 2 & 7,30 & 7,47 & 7,41 & 61.600 & 109 & 4.506 \\
\hline & 3 & 7,34 & 7,37 & 7,42 & 48.000 & 86 & 4.503 \\
\hline & 4 & 7,26 & 7,31 & 7,42 & 64.000 & 116 & 4.566 \\
\hline \multirow[t]{3}{*}{$\operatorname{Sec} \perp$} & 5 & 7,39 & 7,84 & 7,76 & 82.800 & 134 & 4.648 \\
\hline & 6 & 7,38 & 7,73 & 7,80 & 81.200 & 132 & 4.671 \\
\hline & 7 & 7,43 & 7,45 & 7,39 & 50.000 & 89 & 4.673 \\
\hline \multirow[t]{3}{*}{ Sat // } & 8 & 7,38 & 7,47 & 7,34 & 59.200 & 106 & 4.613 \\
\hline & 9 & 7,32 & 7,50 & 7,44 & 66.000 & 116 & 4.575 \\
\hline & 10 & 7,30 & 7,33 & 7,45 & 71.200 & 128 & 4.506 \\
\hline \multirow[t]{10}{*}{$\operatorname{Sec} / /$} & 11 & 7,41 & 7,43 & 7,41 & 69.200 & 123 & 4.690 \\
\hline & 12 & 7,34 & 7,40 & 7,37 & 65.200 & 117 & 4.559 \\
\hline & & & & $\bar{x}_{\mathrm{sec}}$ & $101(/ /)$ & $127(\perp)$ & 4590 \\
\hline & & & & $S$ & 13 & 10 & 75 \\
\hline & & & & C.V. & 13 & 8 & 2 \\
\hline & & & & $\Delta$ & & -21 & \\
\hline & & & & $\bar{x}_{\text {sat }}$ & $104(/ /)$ & $123(\perp)$ & 4603 \\
\hline & & & & $S$ & 14 & 5 & 70 \\
\hline & & & & C.V. & 13 & 4 & 2 \\
\hline & & & & $\Delta$ & & -16 & \\
\hline
\end{tabular}




\begin{tabular}{|c|c|c|c|c|c|c|c|}
\hline CSB & $\mathrm{CP}$ & $h$ & $A_{1}$ & $A_{2}$ & $P$ & $\sigma_{C}$ & $V P$ \\
\hline & 1 & 7,46 & 7,70 & 7,75 & 63.600 & 105 & 3.552 \\
\hline \multirow[t]{2}{*}{ Sat $\perp$} & 2 & 7,51 & 7,86 & 7,72 & 74.400 & 120 & 3.526 \\
\hline & 3 & 7,38 & 7,68 & 7,76 & 66.000 & 109 & 3.884 \\
\hline & 4 & 7,49 & 7,69 & 7,73 & 81.600 & 135 & 3.636 \\
\hline \multirow[t]{2}{*}{$\operatorname{Sec} \perp$} & 5 & 7,53 & 7,79 & 7,74 & 82.000 & 133 & 3.765 \\
\hline & 6 & 7,51 & 7,73 & 7,70 & 97.600 & 161 & 3.663 \\
\hline & 7 & 7,48 & 7,69 & 7,79 & 79.200 & 130 & 3.856 \\
\hline \multirow[t]{2}{*}{ Sat // } & 8 & 7,51 & 7,74 & 7,67 & 74.400 & 123 & 3.774 \\
\hline & 9 & 7,39 & 7,69 & 7,74 & 70.000 & 115 & 3.790 \\
\hline \multirow{11}{*}{$\operatorname{Sec} / /$} & 10 & 7,50 & 7,80 & 7,80 & 102.400 & 165 & 4.032 \\
\hline & 11 & 7,50 & 7,71 & 7,62 & 86.400 & 144 & 3.989 \\
\hline & 12 & 7,52 & 7,69 & 7,76 & 84.000 & 138 & 4.043 \\
\hline & & & & $\bar{x}_{\mathrm{sec}}$ & $111(/ /)$ & $143(\perp)$ & 3671 \\
\hline & & & & $S$ & 8 & 15 & 135 \\
\hline & & & & C.V. & 7 & 11 & 4 \\
\hline & & & & $\Delta$ & & -22 & \\
\hline & & & & $\bar{x}_{s a t}$ & $123(/ /)$ & $149(\perp)$ & 3914 \\
\hline & & & & $S$ & 7 & 14 & 122 \\
\hline & & & & C.V. & 6 & 9 & 3 \\
\hline & & & & $\Delta$ & & -18 & \\
\hline \multirow[t]{2}{*}{ FLS } & CP & $h$ & $A_{1}$ & $A_{2}$ & $P$ & $\sigma_{C}$ & $V P$ \\
\hline & 1 & 7,60 & 7,65 & 7,75 & 97.600 & 161 & 2.969 \\
\hline \multirow[t]{2}{*}{ Sat $\perp$} & 2 & 7,57 & 7,70 & 7,74 & 63.200 & 104 & 2.867 \\
\hline & 3 & 7,59 & 7,79 & 7,72 & 70.800 & 115 & 3.872 \\
\hline & 4 & 7,57 & 7,70 & 7,77 & 84.000 & 138 & 3.902 \\
\hline \multirow[t]{2}{*}{$\operatorname{Sec} \perp$} & 5 & 7,61 & 7,71 & 7,83 & 100.400 & 163 & 3.459 \\
\hline & 6 & 7,61 & 7,78 & 7,73 & 60.000 & 98 & 4.275 \\
\hline & 7 & 7,42 & 7,70 & 7,70 & 91.200 & 151 & 3.105 \\
\hline \multirow[t]{2}{*}{ Sat // } & 8 & 7,61 & 7,69 & 7,80 & 92.400 & 151 & 4.026 \\
\hline & 9 & 7,66 & 7,72 & 7,69 & 89.600 & 148 & 4.118 \\
\hline & 10 & 7,64 & 7,80 & 7,77 & 74.000 & 120 & 4.064 \\
\hline \multirow{10}{*}{$\mathrm{Sec} / /$} & 11 & 7,59 & 7,76 & 7,73 & 79.600 & 130 & 4.545 \\
\hline & 12 & 7,63 & 7,75 & 7,73 & 68.400 & 112 & 4.488 \\
\hline & & & & $\bar{x}_{\mathrm{sec}}$ & $127(/ /)$ & $133(\perp)$ & 3558 \\
\hline & & & & $S$ & 30 & 33 & 560 \\
\hline & & & & C.V. & 24 & 25 & 16 \\
\hline & & & & $\Delta$ & & -4 & \\
\hline & & & & $\bar{x}_{s a t}$ & $121(/ /)$ & $150(\perp)$ & 4058 \\
\hline & & & & $S$ & 9 & 2 & 517 \\
\hline & & & & C.V. & 8 & 1 & 13 \\
\hline & & & & $\Delta$ & & -20 & \\
\hline ARB & $\mathrm{CP}$ & $h$ & $A_{1}$ & $A_{2}$ & $P$ & $\sigma_{C}$ & $V P$ \\
\hline \multirow{3}{*}{ Sat // } & 1 & 7,66 & 7,78 & 7,72 & 54.000 & 88 & 4.728 \\
\hline & 2 & 7,61 & 7,77 & 7,86 & 53.600 & 86 & 4.114 \\
\hline & 3 & 7,48 & 7,88 & 7,68 & 56.800 & 92 & 4.110 \\
\hline & 4 & 7,52 & 7,71 & 7,74 & 67.600 & 111 & 4.273 \\
\hline \multirow[t]{2}{*}{$\mathrm{Sec} / /$} & 5 & 7,38 & 7,84 & 7,73 & 77.200 & 125 & 4.193 \\
\hline & 6 & 7,50 & 7,80 & 7,82 & 73.200 & 118 & 4.717 \\
\hline & 7 & 7,63 & 7,70 & 7,77 & 47.200 & 77 & 4.488 \\
\hline \multirow[t]{2}{*}{ Sat $\perp$} & 8 & 7,46 & 7,84 & 7,71 & 48.000 & 78 & 4.634 \\
\hline & 9 & 7,47 & 7,70 & 7,67 & 57.600 & 96 & 4.016 \\
\hline \multirow{11}{*}{$\operatorname{Sec} \perp$} & 10 & 7,42 & 7,73 & 7,86 & 36.000 & 58 & 4.216 \\
\hline & 11 & 7,35 & 7,73 & 7,82 & 50.800 & 82 & 4.083 \\
\hline & 12 & 7,47 & 7,67 & 7,85 & 62.800 & 102 & 4.500 \\
\hline & & & & $\bar{x}_{\mathrm{sec}}$ & $89(/ /)$ & $118(\perp)$ & 4356 \\
\hline & & & & $S$ & 3 & 7 & 290 \\
\hline & & & & C.V. & 3 & 6 & 7 \\
\hline & & & & $\Delta$ & & -25 & \\
\hline & & & & $\bar{x}_{s a t}$ & $84(/ /)$ & $81(\perp)$ & 4323 \\
\hline & & & & $S$ & 10 & 22 & 252 \\
\hline & & & & C.V. & 12 & 27 & 6 \\
\hline & & & & $\Delta$ & & 3 & \\
\hline
\end{tabular}




\begin{tabular}{|c|c|c|c|c|c|c|c|}
\hline scc & CP & $h$ & $A_{1}$ & $A_{2}$ & $P$ & $\sigma_{C}$ & $V P$ \\
\hline & 1 & 7,60 & 7,71 & 7,76 & 60.000 & 98 & 3.762 \\
\hline \multirow{2}{*}{ Sat $/ /$} & 2 & 7,45 & 7,65 & 7,74 & 64.400 & 107 & 3.763 \\
\hline & 3 & 7,54 & 7,83 & 7,86 & 51.200 & 82 & 3.660 \\
\hline & 4 & 7,52 & 7,79 & 7,87 & 70.000 & 112 & 3.817 \\
\hline \multirow{2}{*}{$\mathrm{Sec} / /$} & 5 & 7,58 & 7,87 & 7,76 & 85.600 & 138 & 3.790 \\
\hline & 6 & 7,43 & 7,75 & 7,70 & 68.800 & 113 & 3.753 \\
\hline \multirow{3}{*}{ Sat $\perp$} & 7 & 7,50 & 7,73 & 7,75 & 69.200 & 113 & 3.024 \\
\hline & 8 & 7,47 & 7,69 & 7,78 & 52.800 & 87 & 4.500 \\
\hline & 9 & 7,57 & 7,81 & 7,74 & 72.400 & 117 & 3.364 \\
\hline \multirow{11}{*}{$\operatorname{Sec} \perp$} & 10 & 7,51 & 7,63 & 7,82 & 73.200 & 120 & 3.209 \\
\hline & 11 & 7,47 & 7,73 & 7,65 & 69.200 & 115 & 3.491 \\
\hline & 12 & 7,47 & 7,77 & 7,77 & 84.000 & 137 & 3.165 \\
\hline & & & & $\bar{x}_{\mathrm{sec}}$ & $106(/ /)$ & $124(\perp)$ & 3757 \\
\hline & & & & $S$ & 17 & 11 & 53 \\
\hline & & & & C.V. & 16 & 9 & 1 \\
\hline & & & & $\Delta$ & & -15 & \\
\hline & & & & $\bar{x}_{s a t}$ & $95(/ /)$ & $121(\perp)$ & 3459 \\
\hline & & & & $S$ & 13 & 14 & 535 \\
\hline & & & & C.V. & 13 & 12 & 15 \\
\hline & & & & $\Delta$ & & -21 & \\
\hline
\end{tabular}


ANEXO $F$

Resultados dos ensaios de resistência à flexão (ASTM C 880/98) 


\section{Legenda}

$C P=$ corpo-de-prova

$d$ = espessura média $(\mathrm{mm})$

$b$ = largura média $(\mathrm{mm})$

$W=$ carga de ruptura $(\mathrm{N})$

$\sigma_{f}=$ resistência à flexão $(\mathrm{MPa})$

$V P=$ velocidade de propagação de ondas $(\mathrm{m} / \mathrm{s})$

$\Delta_{m}=$ variação de massa (\%)
$\Delta=$ decaimento da resistência à flexão após choque térmico (\%)

$\bar{x}_{c t}=$ média após choque térmico

$\bar{x}_{n a t}=$ média na condição natural

$S=$ desvio padrão

$C . V .=$ coeficiente de variação $(\%)$

\begin{tabular}{|c|c|c|c|c|c|c|c|c|}
\hline \multirow{2}{*}{ LBD } & \multirow{2}{*}{$\mathrm{CP}$} & \multirow[b]{2}{*}{$d$} & \multirow{2}{*}{$b$} & \multirow[b]{2}{*}{$W$} & \multirow[b]{2}{*}{$\sigma_{f}$} & \multirow{2}{*}{ VP } & \multicolumn{2}{|c|}{ CHOQUE TÉRMICO } \\
\hline & & & & & & & $V P$ & $\Delta_{m}$ \\
\hline \multirow{8}{*}{ natural } & 1 & 27,5 & 100,6 & $2.472,7$ & 7,33 & 4.696 & & \\
\hline & 2 & 27,5 & 101,3 & $2.513,7$ & 7,37 & 4.704 & & \\
\hline & 3 & 27,6 & 100,7 & $2.439,0$ & 7,15 & 4.739 & & \\
\hline & 4 & 27,0 & 101,5 & $2.337,3$ & 7,11 & 4.851 & & \\
\hline & 5 & 27,3 & 100,9 & $2.373,0$ & 7,12 & 4.798 & & \\
\hline & 9 & 30,5 & 100,9 & $4.189,0$ & 10,06 & 5.650 & & \\
\hline & $4^{\prime}$ & 30,6 & 101,3 & $3.151,7$ & 7,50 & 5.000 & & \\
\hline & $1 \mathrm{R}$ & 27,4 & 101,4 & $2.559,7$ & 7,58 & 4.851 & & \\
\hline \multirow{15}{*}{$\begin{array}{l}\text { choque } \\
\text { térmico }\end{array}$} & $6 \mathrm{~A}$ & 31,0 & 100,7 & $2.169,7$ & 5,05 & 5.646 & 2.747 & 0,04 \\
\hline & $7 A$ & 31,0 & 100,5 & $2.390,0$ & 5,59 & 5.589 & 2.673 & 0,06 \\
\hline & $10 \mathrm{~A}$ & 30,5 & 101,1 & $2.160,7$ & 5,16 & 5.573 & 2.553 & 0,05 \\
\hline & $1^{\prime \prime}$ & 27,2 & 101,6 & $1.445,0$ & 4,33 & 4.843 & 2.377 & 0,04 \\
\hline & $2^{\prime}$ & 27,3 & 101,7 & $1.354,0$ & 4,02 & 4.872 & 2.307 & 0,05 \\
\hline & $3^{\prime}$ & 27,3 & 101,6 & $1.530,3$ & 4,55 & 4.849 & 2.435 & 0,03 \\
\hline & $2 \mathrm{R}$ & 30,5 & 101,4 & $2.064,7$ & 4,92 & 5.569 & 2.680 & 0,04 \\
\hline & $4 \mathrm{R}$ & 31,0 & 101,1 & $1.734,0$ & 4,02 & 5.655 & 2.715 & 0,04 \\
\hline & & & & $\bar{x}_{n a t}$ & 7,65 & 5118 & 2.561 & 0,04 \\
\hline & & & & $S$ & 0,99 & 404 & 169 & 0,01 \\
\hline & & & & C.V. & 12,9 & 7,9 & 6,6 & 24,1 \\
\hline & & & & $\bar{x}_{C T}$ & 4,70 & $\Delta$ & -52 & \\
\hline & & & & $S$ & 0,57 & & & \\
\hline & & & & C.V. & 12,1 & & & \\
\hline & & & & $\Delta$ & -39 & & & \\
\hline \multirow[b]{2}{*}{ VCB-3 } & \multirow[b]{2}{*}{$\mathrm{CP}$} & \multirow[b]{2}{*}{$d$} & \multirow[b]{2}{*}{$b$} & \multirow[b]{2}{*}{$W$} & \multirow[b]{2}{*}{$\sigma_{f}$} & \multirow[b]{2}{*}{ VP } & \multicolumn{2}{|c|}{ CHOQUE TÉRMICO } \\
\hline & & & & & & & VP & $\Delta_{m}$ \\
\hline \multirow{5}{*}{ natural } & 1 & 30,1 & 94,5 & $5.105,0$ & 13,40 & 5.526 & & \\
\hline & 2 & 30,1 & 94,7 & $4.846,0$ & 12,73 & 5.560 & & \\
\hline & 3 & 30,0 & 94,7 & $4.943,3$ & 13,02 & 5.594 & & \\
\hline & 4 & 30,0 & 94,8 & $5.093,3$ & 13,41 & 5.585 & & \\
\hline & 5 & 29,8 & 94,8 & $4.657,0$ & 12,43 & 5.566 & & \\
\hline \multirow{12}{*}{$\begin{array}{l}\text { choque } \\
\text { térmico }\end{array}$} & 6 & 29,8 & 95,0 & $4.032,3$ & 10,80 & 5.579 & 4.499 & 0,04 \\
\hline & 7 & 29,6 & 95,0 & $3.481,7$ & 9,42 & 5.588 & 4.216 & 0,04 \\
\hline & 8 & 29,5 & 94,2 & $3.230,0$ & 8,87 & 5.588 & 4.316 & 0,04 \\
\hline & 9 & 30,4 & 94,0 & $3.277,3$ & 8,49 & 5.555 & 4.118 & 0,05 \\
\hline & 10 & 30,5 & 94,7 & $4.136,0$ & 10,60 & 5.561 & 4.424 & 0,04 \\
\hline & & & & $\bar{x}_{n a t}$ & 13,00 & 5.570 & 4.315 & 0,04 \\
\hline & & & & $S$ & 0,43 & 21 & 154 & 0,00 \\
\hline & & & & C.V. & 3,3 & 0,4 & 3,6 & 10,4 \\
\hline & & & & $\bar{x}_{C T}$ & 9,63 & $\Delta$ & -23 & \\
\hline & & & & $S$ & 1,03 & & & \\
\hline & & & & C.V. & 10,7 & & & \\
\hline & & & & $\Delta$ & -26 & & & \\
\hline
\end{tabular}




\begin{tabular}{|c|c|c|c|c|c|c|c|c|}
\hline \multirow{2}{*}{ BCE } & \multirow[b]{2}{*}{$\mathrm{CP}$} & \multirow[b]{2}{*}{$d$} & \multirow[b]{2}{*}{$b$} & \multirow[b]{2}{*}{$W$} & \multirow[b]{2}{*}{$\sigma_{f}$} & \multirow[b]{2}{*}{ VP } & \multicolumn{2}{|c|}{ CHOQUE TÉRMICO } \\
\hline & & & & & & & VP & $\Delta_{m}$ \\
\hline \multirow{5}{*}{ natural } & 1 & 31,6 & 101,3 & $7.450,7$ & 16,55 & 5209 & & \\
\hline & 2 & 31,7 & 101,4 & $7.358,0$ & 16,25 & 5212 & & \\
\hline & 3 & 31,9 & 102,0 & $7.998,3$ & 17,34 & 5230 & & \\
\hline & 4 & 31,9 & 101,0 & $7.704,3$ & 16,84 & 5193 & & \\
\hline & 5 & 32,9 & 100,1 & $8.398,3$ & 17,44 & 5143 & & \\
\hline \multirow{12}{*}{$\begin{array}{l}\text { choque } \\
\text { térmico }\end{array}$} & 6 & 32,7 & 102,7 & $6.479,7$ & 13,26 & 5114 & 4.285 & 0,03 \\
\hline & 7 & 32,5 & 101,2 & $6.254,3$ & 13,15 & 5122 & 4.283 & 0,02 \\
\hline & 8 & 32,5 & 100,6 & $6.959,3$ & 14,78 & 5108 & 4.253 & 0,03 \\
\hline & 9 & 32,2 & 100,9 & $6.397,3$ & 13,74 & 5116 & 4.303 & 0,03 \\
\hline & 10 & 32,3 & 100,7 & $6.714,7$ & 14,43 & 5100 & 4.321 & 0,02 \\
\hline & & & & $\bar{x}_{n a t}$ & 16,88 & 5155 & 4.289 & 0,02 \\
\hline & & & & $s$ & 0,51 & 50 & 25 & 0,01 \\
\hline & & & & C.V. & 3,0 & 1,0 & 0,6 & 26,2 \\
\hline & & & & $\overline{\bar{x}_{C T}}$ & 13,87 & $\Delta$ & -16 & \\
\hline & & & & $s$ & 0,71 & & & \\
\hline & & & & C.V. & 5,2 & & & \\
\hline & & & & $\Delta$ & -18 & & & \\
\hline \multirow[b]{2}{*}{ ITN-2 } & \multirow[b]{2}{*}{$\mathrm{CP}$} & & & & & & $\mathrm{CHO}$ & $\mathrm{nICO}$ \\
\hline & & $d$ & $b$ & $W$ & $\sigma_{f}$ & VP & $V P$ & $\Delta_{m}$ \\
\hline & 1 & 21,0 & 100,6 & $2.269,0$ & 7,66 & 3.890 & & \\
\hline & 2 & 21,1 & 100,9 & $2.202,3$ & 7,37 & 4.040 & & \\
\hline & 6 & 21,2 & 100,8 & $2.220,7$ & 7,35 & 3.800 & & \\
\hline & 9 & 21,3 & 100,8 & $3.325,0$ & 10,90 & 4.260 & & \\
\hline natural & $2 \mathrm{~A}$ & 21,3 & 100,5 & $3.416,0$ & 11,24 & 4.200 & & \\
\hline & $4 \mathrm{~A}$ & 21,1 & 101,5 & $3.091,0$ & 10,26 & 4.210 & & \\
\hline & $6 \mathrm{~A}$ & 21,4 & 101,2 & $3.339,7$ & 10,78 & 4.190 & & \\
\hline & $8 \mathrm{~A}$ & 21,5 & 100,9 & $3.570,3$ & 11,51 & 4.200 & & \\
\hline & 7 & 21,2 & 100,7 & $3.033,7$ & 10,03 & 4.270 & 3.645 & 0,06 \\
\hline & 10 & 21,0 & 100,7 & $2.650,7$ & 8,93 & 4.200 & 3.459 & 0,04 \\
\hline & 11 & 21,0 & 101,3 & $2.953,7$ & 9,90 & 4.250 & 3.568 & 0,05 \\
\hline choque & 12 & 21,1 & 101,4 & $2.761,3$ & 9,22 & 3.510 & 3.081 & 0,05 \\
\hline térmico & $1 \mathrm{~A}$ & 21,3 & 101,0 & $2.730,3$ & 8,94 & 4.240 & 3.610 & 0,02 \\
\hline & $3 A$ & 21,1 & 100,8 & $2.165,7$ & 7,27 & 4.230 & 3.552 & 0,03 \\
\hline & $5 \mathrm{~A}$ & 21,1 & 100,9 & $2.574,3$ & 8,62 & 4.230 & 3.571 & 0,02 \\
\hline & $7 \mathrm{~A}$ & 21,4 & 100,9 & $2.577,7$ & 8,39 & 4.180 & 3.557 & 0,02 \\
\hline & & & & $\bar{x}_{n a t}$ & 9,63 & 4119 & 3.506 & 0,04 \\
\hline & & & & $S$ & 1,84 & 211 & 180 & 0,02 \\
\hline & & & & C.V. & 19,1 & 5,1 & 5,1 & 44,5 \\
\hline & & & & $\bar{x}_{C T}$ & 8,91 & $\Delta$ & -15 & \\
\hline & & & & $s$ & 0,88 & & & \\
\hline & & & & C.V. & 9,8 & & & \\
\hline & & & & $\Delta$ & -7 & & & \\
\hline & & & & & & & $\mathrm{CHO}$ & $\overline{\mathrm{nICO}}$ \\
\hline ITN-1 & $\mathrm{CP}$ & $d$ & $b$ & $W$ & $\sigma_{f}$ & VP & $V P$ & $\Delta_{m}$ \\
\hline & 1 & 21,4 & 100,1 & $2.557,7$ & 8,39 & 3.840 & & \\
\hline & 2 & 21,4 & 100,6 & $2.422,3$ & 7,87 & 3.840 & & \\
\hline natural & 3 & 21,5 & 100,7 & $2.341,0$ & 7,58 & 3.880 & & \\
\hline natural & 4 & 22,0 & 100,4 & $2.409,3$ & 7,46 & 3.880 & & \\
\hline & 5 & 21,8 & 101,0 & $2.287,7$ & 7,17 & 3.850 & & \\
\hline & 6 & 21,7 & 101,1 & $2.453,3$ & 7,75 & 3.950 & & \\
\hline & 7 & 21,5 & 99,8 & $2.326,7$ & 7,57 & 3.850 & 3.060 & 0,05 \\
\hline & 8 & 21,6 & 100,4 & $2.288,7$ & 7,36 & 3.940 & 3.130 & 0,03 \\
\hline choque & 9 & 21,6 & 101,0 & $1.906,3$ & 6,07 & 3.910 & 3.050 & 0,06 \\
\hline térmico & 10 & 21,5 & 100,0 & $1.865,0$ & 6,08 & 4.050 & 3.280 & 0,04 \\
\hline & 11 & 21,5 & 100,7 & $2.445,7$ & 7,90 & 3.940 & 3.170 & 0,06 \\
\hline & 12 & 21,6 & 100,5 & $2.030,3$ & 6,53 & 3.810 & 3.090 & 0,04 \\
\hline & & & & $\bar{x}_{n a t}$ & 7,70 & 3.895 & 3.080 & 0,05 \\
\hline & & & & $S$ & 0,42 & 67 & 44 & 0,01 \\
\hline & & & & C.V. & 5,4 & 1,7 & 1 & 26,1 \\
\hline & & & & $\bar{x}_{C T}$ & 6,92 & $\Delta$ & -21 & \\
\hline & & & & $s$ & 0,80 & & & \\
\hline & & & & C.V. & 11,5 & & & \\
\hline & & & & $\Delta$ & -10 & & & \\
\hline
\end{tabular}




\begin{tabular}{|c|c|c|c|c|c|c|c|c|}
\hline \multirow{2}{*}{ CRV } & \multirow[b]{2}{*}{$\mathrm{CP}$} & \multirow[b]{2}{*}{$d$} & \multirow[b]{2}{*}{$b$} & \multirow{2}{*}{$W$} & \multirow[b]{2}{*}{$\sigma_{f}$} & \multirow[b]{2}{*}{ VP } & \multicolumn{2}{|c|}{ CHOQUE TERMICO } \\
\hline & & & & & & & $V P$ & $\Delta_{m}$ \\
\hline \multirow{9}{*}{ natural } & 1 & 18,6 & 100,4 & $3.611,7$ & 15,64 & 4.916 & & \\
\hline & 2 & 18,5 & 100,8 & $3.511,3$ & 15,23 & 4.945 & & \\
\hline & 3 & 18,5 & 100,9 & $3.446,3$ & 14,98 & 4.963 & & \\
\hline & 4 & 19,1 & 100,5 & $3.420,3$ & 14,03 & 4.881 & & \\
\hline & 5 & 19,0 & 100,6 & $3.427,0$ & 14,15 & 4.869 & & \\
\hline & 7 & 18,9 & 100,7 & $4.442,7$ & 18,58 & 5.121 & & \\
\hline & 11 & 18,6 & 100,8 & $4.125,0$ & 17,70 & 5.109 & & \\
\hline & $1 \mathrm{~A}$ & 18,9 & 100,7 & $4.701,3$ & 19,65 & 5.034 & & \\
\hline & $3 A$ & 18,8 & 100,9 & $4.395,7$ & 18,54 & 5.181 & & \\
\hline \multirow{14}{*}{$\begin{array}{l}\text { choque } \\
\text { térmico }\end{array}$} & 8 & 18,8 & 100,5 & $3.260,7$ & 13,80 & 5.100 & 4.344 & 0,03 \\
\hline & 9 & 18,8 & 101,1 & $3.426,3$ & 14,38 & 5.071 & 4.371 & 0,05 \\
\hline & 10 & 18,7 & 100,4 & $3.536,0$ & 15,11 & 5.079 & 4.302 & 0,05 \\
\hline & 12 & 18,7 & 101,1 & $3.520,0$ & 14,89 & 4.989 & 4.352 & 0,06 \\
\hline & $2 \mathrm{~A}$ & 18,7 & 100,9 & $3.283,3$ & 13,99 & 5.080 & 4.468 & 0,01 \\
\hline & $4 \mathrm{~A}$ & 18,6 & 100,8 & $3.262,0$ & 14,11 & 5.164 & 4.497 & 0,01 \\
\hline & $6 \mathrm{~A}$ & 18,7 & 101,1 & $3.535,0$ & 15,00 & 5.023 & 4.493 & 0,01 \\
\hline & & & & $\bar{x}_{n a t}$ & 16,50 & 5.033 & 4.404 & 0,03 \\
\hline & & & & $S$ & 2,12 & 97 & 80 & 0,02 \\
\hline & & & & C.V. & 12,9 & 1,9 & 1,8 & 80,8 \\
\hline & & & & $\overline{\bar{x}_{C T}}$ & 14,47 & $\Delta$ & -13 & \\
\hline & & & & $S$ & 0,53 & & & \\
\hline & & & & C.V. & 3,7 & & & \\
\hline & & & & $\Delta$ & -12 & & & \\
\hline \multirow[b]{2}{*}{ PIT } & \multirow[b]{2}{*}{$\mathrm{CP}$} & \multirow[b]{2}{*}{$d$} & & & & & $\mathrm{CHO}$ & $\mathrm{IICO}$ \\
\hline & & & $b$ & $W$ & $\sigma_{f}$ & VP & $V P$ & $\Delta_{m}$ \\
\hline & 1 & 29,6 & 99,9 & $5.809,0$ & 14,90 & 4.364 & & \\
\hline & 2 & 30,1 & 99,9 & $5.470,3$ & 13,60 & 4.402 & & \\
\hline & 4 & 21,3 & 99,9 & $4.948,3$ & 16,38 & 4.800 & & \\
\hline natural & 5 & 21,5 & 100,2 & $4.847,0$ & 15,66 & 4.962 & & \\
\hline & 6 & 21,4 & 100,3 & $4.936,7$ & 16,08 & 4.965 & & \\
\hline & 7 & 21,2 & 100,5 & $4.469,7$ & 14,87 & 4.904 & & \\
\hline & 3 & 30,4 & 100,0 & $5.233,0$ & 12,75 & 4.782 & 4.039 & 0,00 \\
\hline & 8 & 21,2 & 100,9 & $3.743,7$ & 12,41 & 4.923 & 4.067 & 0,04 \\
\hline choque & 9 & 21,2 & 99,7 & $4.075,3$ & 13,61 & 4.959 & 3.899 & 0,03 \\
\hline & 10 & 21,4 & 100,1 & $3.272,7$ & 10,76 & 5.003 & 3.936 & 0,05 \\
\hline & 11 & 21,4 & 100,1 & $3.929,7$ & 12,92 & 4.883 & 4.019 & 0,03 \\
\hline & & & & $\bar{x}_{n a t}$ & 15,32 & 4.813 & 3.992 & 0,03 \\
\hline & & & & $S$ & 1,12 & 224 & 71 & 0,02 \\
\hline & & & & C.V. & 7,3 & 4,6 & 1,8 & 58,0 \\
\hline & & & & $\bar{x}_{C T}$ & 12,49 & $\Delta$ & -20 & \\
\hline & & & & $S$ & 1,06 & & & \\
\hline & & & & C.V. & 8,5 & & & \\
\hline & & & & $\Delta$ & -18 & & & \\
\hline & & & & & & & $\mathrm{CHO}$ & $\mathrm{IICO}$ \\
\hline AZF & $\mathrm{CP}$ & $d$ & $b$ & $W$ & $\sigma_{f}$ & VP & $V P$ & $\Delta_{m}$ \\
\hline & 1 & 31,3 & 100,5 & $5.871,0$ & 13,47 & 4.737 & & \\
\hline & 2 & 31,3 & 101,4 & $5.559,3$ & 12,60 & 4.746 & & \\
\hline natural & 3 & 31,5 & 100,9 & $7.271,0$ & 16,35 & 4.949 & & \\
\hline & 4 & 31,6 & 100,5 & $7.033,7$ & 15,77 & 4.905 & & \\
\hline & 5 & 31,2 & 101,2 & $6.898,7$ & 15,73 & 4.905 & & \\
\hline & 6 & 31,2 & 101,4 & $6.252,0$ & 14,28 & 4.974 & 3.935 & 0,04 \\
\hline & 7 & 31,0 & 101,7 & $5.432,7$ & 12,51 & 4.957 & 3.846 & 0,05 \\
\hline choque & 8 & 30,5 & 101,4 & $4.476,0$ & 10,72 & 4.667 & 3.929 & 0,04 \\
\hline & 9 & 30,5 & 101,0 & $4.402,7$ & 10,58 & 4.730 & 3.581 & 0,04 \\
\hline & 10 & 30,6 & 101,4 & $4.728,7$ & 11,21 & 4.757 & 3.463 & 0,04 \\
\hline & & & & $\bar{x}_{n a t}$ & 14,78 & 4.833 & 3.751 & 0,04 \\
\hline & & & & $S$ & 1,65 & 115 & 216 & 0,00 \\
\hline & & & & C.V. & 11,1 & 2,4 & 5,8 & 9,2 \\
\hline & & & & $\overline{\bar{x}_{C T}}$ & 11,86 & $\Delta$ & -22 & \\
\hline & & & & $S$ & 1,55 & & & \\
\hline & & & & C.V. & 13,1 & & & \\
\hline & & & & $\Delta$ & -20 & & & \\
\hline
\end{tabular}




\begin{tabular}{|c|c|c|c|c|c|c|c|c|}
\hline \multirow[b]{2}{*}{ RIC } & \multirow[b]{2}{*}{$\mathrm{CP}$} & \multirow[b]{2}{*}{$d$} & \multirow[b]{2}{*}{$b$} & \multirow[b]{2}{*}{$W$} & \multirow[b]{2}{*}{$\sigma_{f}$} & \multirow[b]{2}{*}{ VP } & \multicolumn{2}{|c|}{ CHOQUE TERMICO } \\
\hline & & & & & & & $V P$ & $\Delta_{m}$ \\
\hline \multirow{5}{*}{ natural } & 1 & 22,5 & 100,6 & $4.037,3$ & 11,95 & 4689 & & \\
\hline & 2 & 22,5 & 100,2 & $3.534,3$ & 10,50 & 4736 & & \\
\hline & 3 & 22,7 & 100,8 & $3.773,0$ & 10,90 & 4682 & & \\
\hline & 4 & 22,8 & 100,5 & $4.047,0$ & 11,65 & 4694 & & \\
\hline & 5 & 22,2 & 100,2 & $4.132,3$ & 12,52 & 4696 & & \\
\hline \multirow{12}{*}{$\begin{array}{l}\text { choque } \\
\text { térmico }\end{array}$} & 6 & 22,3 & 101,1 & $2.606,0$ & 7,81 & 4680 & 3.592 & 0,03 \\
\hline & 7 & 22,2 & 100,6 & $3.054,0$ & 9,26 & 4721 & 3.641 & 0,03 \\
\hline & 8 & 22,2 & 100,3 & $2.875,3$ & 8,73 & 4706 & 3.674 & 0,03 \\
\hline & 9 & 22,5 & 100,5 & $2.990,3$ & 8,81 & 4627 & 3.736 & 0,02 \\
\hline & 10 & 22,5 & 101,0 & $2.724,0$ & 8,00 & 4713 & 3.626 & 0,02 \\
\hline & & & & $\bar{x}_{n a t}$ & 11,50 & 4694 & 3.654 & 0,02 \\
\hline & & & & $S$ & 0,81 & 30 & 54 & 0,00 \\
\hline & & & & C.V. & 7,1 & 0,6 & 1,5 & 17,9 \\
\hline & & & & $\bar{x}_{C T}$ & 8,52 & $\Delta$ & -22 & \\
\hline & & & & $S$ & 0,60 & & & \\
\hline & & & & C.V. & 7,1 & & & \\
\hline & & & & $\Delta$ & -26 & & & \\
\hline \multirow{2}{*}{ BCR } & \multirow{2}{*}{$\mathrm{CP}$} & & & & & & $\mathrm{CHO}$ & IICO \\
\hline & & $d$ & $b$ & $W$ & $\sigma_{f}$ & VP & $V P$ & $\Delta_{m}$ \\
\hline & 1 & 22,0 & 100,9 & $2.842,3$ & 8,77 & 3.803 & & \\
\hline & 2 & 22,0 & 101,6 & $3.047,0$ & 9,28 & 3.789 & & \\
\hline & 3 & 22,1 & 101,6 & $3.039,7$ & 9,23 & 3.780 & & \\
\hline & 4 & 22,1 & 101,3 & $2.963,0$ & 8,97 & 3.799 & & \\
\hline & 5 & 22,3 & 101,0 & $4.345,7$ & 13,04 & 4.328 & & \\
\hline natural & 6 & 22,2 & 101,3 & $4.445,7$ & 13,36 & 4.223 & & \\
\hline & 8 & 22,9 & 101,6 & $4.512,3$ & 12,68 & 4.160 & & \\
\hline & $2 \mathrm{~A}$ & 22,9 & 101,7 & $3.489,3$ & 9,82 & 4.031 & & \\
\hline & $4 \mathrm{~A}$ & 22,7 & 101,8 & $4.413,7$ & 12,68 & 4.263 & & \\
\hline & $6 A$ & 22,2 & 101,7 & $4.296,0$ & 12,92 & 4.106 & & \\
\hline & 7 & 22,2 & 100,9 & $4.352,3$ & 13,11 & 4.255 & 3.803 & 0,04 \\
\hline & 9 & 22,3 & 101,1 & $2.678,3$ & 8,01 & 4.324 & 3.438 & 0,04 \\
\hline & 10 & 22,8 & 101,4 & $2.934,3$ & 8,35 & 4.083 & 3.468 & 0,03 \\
\hline choque & 11 & 22,1 & 100,5 & $4.011,7$ & 12,26 & 4.315 & 3.468 & 0,03 \\
\hline & 12 & 22,1 & 100,5 & $3.413,7$ & 10,46 & 4.194 & 3.836 & 0,04 \\
\hline & $1 \mathrm{~A}$ & 22,8 & 101,5 & $2.933,3$ & 8,32 & 4.119 & 3.836 & 0,03 \\
\hline & $3 A$ & 22,7 & 101,2 & $3.795,7$ & 10,97 & 4.210 & 3.714 & 0,02 \\
\hline & $5 A$ & 22,2 & 101,6 & $3.774,7$ & 11,34 & 4.111 & 3.425 & 0,03 \\
\hline & & & & $\overline{\bar{x}_{\text {nat }}}$ & 11,07 & 4.105 & 3.643 & 0,03 \\
\hline & & & & $S$ & 1,99 & 191 & 171 & 0,01 \\
\hline & & & & C.V. & 17,97 & 4,7 & 4,7 & 26,8 \\
\hline & & & & $\bar{x}_{C T}$ & 10,35 & $\Delta$ & -13 & \\
\hline & & & & $S$ & 1,93 & & & \\
\hline & & & & C.V. & 18,68 & & & \\
\hline & & & & $\Delta$ & -7 & & & \\
\hline & & & & & & & $\mathrm{CHO}$ & IICO \\
\hline BSV & $\mathrm{CP}$ & $d$ & $b$ & $W$ & $\sigma_{f}$ & VP & $V P$ & $\Delta_{m}$ \\
\hline & 1 & 21,3 & 100,6 & $2.952,3$ & 9,73 & 3910 & & \\
\hline & 2 & 21,3 & 100,7 & $3.171,7$ & 10,41 & 3877 & & \\
\hline natural & 3 & 21,4 & 100,4 & $3.045,0$ & 9,96 & 3878 & & \\
\hline & 4 & 21,4 & 100,7 & $3.275,7$ & 10,68 & 3876 & & \\
\hline & 5 & 21,9 & 100,4 & $3.125,3$ & 9,78 & 3755 & & \\
\hline & 6 & 21,9 & 100,8 & $2.734,7$ & 8,49 & 3978 & 3.604 & 0,02 \\
\hline & 7 & 22,0 & 101,0 & $3.328,3$ & 10,19 & 4006 & 3.611 & 0,03 \\
\hline choque & 8 & 22,1 & 101,4 & $2.829,7$ & 8,57 & 3968 & 3.602 & 0,05 \\
\hline & 9 & 21,2 & 100,9 & $2.458,3$ & 8,15 & 3874 & 3.514 & 0,03 \\
\hline & 10 & 21,1 & 100,9 & $2.425,7$ & 8,12 & 3833 & 3.408 & 0,03 \\
\hline & & & & $\overline{\bar{x}_{n a t}}$ & 10,11 & 3895 & 3.548 & 0,03 \\
\hline & & & & $S$ & 0,42 & 74 & 88 & 0,01 \\
\hline & & & & C.V. & 4,1 & 1,9 & 2,5 & 36,5 \\
\hline & & & & $\bar{x}_{C T}$ & 8,70 & $\Delta$ & -10 & \\
\hline & & & & $S$ & 0,85 & & & \\
\hline & & & & C.V. & 9,8 & & & \\
\hline & & & & $\Delta$ & -14 & & & \\
\hline
\end{tabular}




\section{Legenda}

$V P / /$ = velocidade de propagação de ondas paralelo $(\mathrm{m} / \mathrm{s})$ $V P \perp=$ velocidade de propagação de ondas perpendicular $(\mathrm{m} / \mathrm{s})$

$\Delta / /=$ decaimento da resistência à flexão após choque térmico (determinação paralela à estrutura) (\%)

$\Delta \perp=$ decaimento da resistência à flexão após choque térmico (determinação perpendicular à estrutura) $(\%)$ $\bar{x}_{\text {nat// }}=$ média natural (determinação paralela à estrutura) (\%)

$\bar{x}_{n a t \perp}=$ média natural (determinação perpendicular à estrutura)

$\bar{x}_{c t / /}=$ média após choque térmico

$\bar{x}_{c t \perp}=$ média após choque térmico

\begin{tabular}{|c|c|c|c|c|c|c|c|c|c|c|}
\hline \multirow{2}{*}{ CSB } & \multirow{2}{*}{ CP } & \multirow{2}{*}{$d$} & \multirow{2}{*}{$b$} & \multirow{2}{*}{$W$} & \multirow[b]{2}{*}{$\sigma_{f}$} & \multirow{2}{*}{$V P / /$} & \multirow[b]{2}{*}{$V P \perp$} & \multicolumn{3}{|c|}{ CHOQUE TÉRMICO } \\
\hline & & & & & & & & $V P / /$ & $V P \perp$ & $\Delta_{m}$ \\
\hline \multirow{3}{*}{ Natural // } & 1 & 31,5 & 100,7 & $2.722,0$ & 6,12 & 3.510 & 3.209 & & & \\
\hline & 2 & 31,6 & 100,7 & $2.166,7$ & 4,86 & 3.472 & 3.218 & & & \\
\hline & 3 & 31,6 & 101,7 & $2.661,3$ & 5,90 & 3.670 & 3.281 & & & \\
\hline \multirow{3}{*}{$\begin{array}{l}\text { choque } \\
\text { térmico // }\end{array}$} & 4 & 32,2 & 100,2 & $1.430,0$ & 3,10 & 3.855 & 3.368 & 3.529 & 2.969 & 0,03 \\
\hline & 5 & 32,2 & 100,7 & $2.145,3$ & 4,64 & 3.675 & 3.359 & 3.558 & 3.087 & 0,02 \\
\hline & 6 & 32,2 & 100,8 & $1.169,7$ & 2,52 & 3.488 & 3.409 & 3.574 & 3.035 & 0,03 \\
\hline \multirow{3}{*}{ Natural $\perp$} & 7 & 32,3 & 100,4 & $3.280,0$ & 7,07 & 3.448 & 3.279 & & & \\
\hline & 8 & 32,2 & 100,7 & $4.057,3$ & 8,73 & 3.708 & 3.595 & & & \\
\hline & 9 & 32,4 & 101,2 & $3.745,3$ & 7,94 & 3.903 & 3.163 & & & \\
\hline \multirow{10}{*}{$\begin{array}{l}\text { choque } \\
\text { térmico } \perp\end{array}$} & 10 & 32,0 & 100,4 & $2.744,7$ & 6,02 & 3.732 & 3.733 & 3.320 & 3.475 & 0,03 \\
\hline & 11 & 32,1 & 101,2 & $1.234,7$ & 2,66 & 3.765 & 3.967 & 3.302 & 3.488 & 0,05 \\
\hline & 12 & 32,2 & 101,2 & $2.596,7$ & 5,58 & 3.524 & 3.431 & 3.091 & 3.057 & 0,05 \\
\hline & $\bar{x}_{n a \perp}$ & 7,92 & & $\bar{x}_{\text {nat } / /}$ & 5,62 & 3.646 & 3.418 & 3.396 & 3.185 & 0,03 \\
\hline & $S$ & 0,83 & & $s$ & 0,67 & 155 & 238 & 192 & 233 & 0,01 \\
\hline & C.V. & 10,5 & & C.V. & 12,0 & 4,3 & 7,0 & 5,6 & 7,3 & 38,0 \\
\hline & $\bar{x}_{C T \perp}$ & 4,75 & & $\bar{x}_{C T / 1}$ & 3,42 & & $\Delta$ & -7 & -7 & \\
\hline & $s$ & 1,39 & & $S$ & 1,10 & & & & & \\
\hline & C.V. & 29,3 & & C.V. & 32,1 & & & & & \\
\hline & $\Delta \perp$ & -40 & & $\Delta / /$ & -39 & & & & & \\
\hline \multirow{2}{*}{ FLS } & \multirow[b]{2}{*}{ CP } & \multirow[b]{2}{*}{$d$} & \multirow[b]{2}{*}{$b$} & \multirow[b]{2}{*}{$W$} & \multirow[b]{2}{*}{$\sigma_{f}$} & \multirow[b]{2}{*}{$V P / /$} & \multirow[b]{2}{*}{$V P \perp$} & \multicolumn{3}{|c|}{ CHOQUE TÉRMICO } \\
\hline & & & & & & & & $V P / /$ & $V P \perp$ & $\Delta_{m}$ \\
\hline \multirow{3}{*}{ Natural // } & 1 & 30,8 & 100,4 & $3.816,7$ & 9,00 & 3.071 & 3.769 & & & \\
\hline & 2 & 30,8 & 100,4 & $3.351,3$ & 7,94 & 2.998 & 3.587 & & & \\
\hline & 3 & 30,7 & 100,4 & $3.441,3$ & 8,20 & 3.107 & 3.474 & & & \\
\hline choque & 4 & 30,4 & 100,5 & $2.813,7$ & 6,83 & 3.372 & 3.988 & 2.973 & 3.640 & 0,03 \\
\hline térmico // & 5 & 30,4 & 99,8 & $2.989,0$ & 7,29 & 2.996 & 3.744 & 2.787 & 3.527 & 0,03 \\
\hline & 6 & 30,4 & 100,4 & $3.542,3$ & 8,60 & 3.282 & 4.048 & 2.813 & 3.538 & 0,02 \\
\hline Natural $\perp$ & 7 & 30,5 & 97,3 & $1.549,7$ & 3,85 & 2.883 & 3.799 & & & \\
\hline & 8 & 30,5 & 100,3 & $1.381,7$ & 3,34 & 2.825 & 3.673 & & & \\
\hline & 9 & 30,6 & 100,5 & $1.657,0$ & 3,96 & 2.930 & 3.514 & & & \\
\hline choque & 10 & 30,4 & 100,8 & $1.188,0$ & 2,88 & 3.008 & 4.049 & 2.652 & 3.720 & 0,03 \\
\hline térmico $\perp$ & 11 & 30,4 & 100,4 & 942,7 & 2,29 & 2.990 & 3.690 & 2.652 & 3.380 & 0,03 \\
\hline & 12 & 30,2 & 100,0 & $1.161,3$ & 2,86 & 2.997 & 3.876 & 2.666 & 3.367 & 0,02 \\
\hline & $\bar{x}_{n a \perp}$ & 8,38 & & $\bar{x}_{\text {nat } / 1}$ & 3,72 & 3.038 & 3.768 & 2.757 & 3.529 & 0,03 \\
\hline & $S$ & 0,55 & & $S$ & 0,33 & 156 & 195 & 127 & 140 & 0,01 \\
\hline & C.V. & 6,6 & & C.V. & 8,9 & 5,1 & 5,2 & 4,6 & 4,0 & 21,1 \\
\hline & $\bar{x}_{C T \perp}$ & 7,57 & & $\bar{x}_{C T / 1}$ & 2,68 & & $\Delta$ & -9 & -6 & \\
\hline & $S$ & 0,92 & & $S$ & 0,54 & & & & & \\
\hline & C.V. & 12,1 & & C.V. & 20,2 & & & & & \\
\hline & $\Delta \perp$ & -10 & & $\Delta / /$ & -28 & & & & & \\
\hline
\end{tabular}




\begin{tabular}{|c|c|c|c|c|c|c|c|c|c|c|}
\hline \multirow{2}{*}{ GVN } & \multirow[b]{2}{*}{ CP } & \multirow[b]{2}{*}{$d$} & \multirow{2}{*}{$b$} & \multirow[b]{2}{*}{ W } & \multirow[b]{2}{*}{$\sigma_{f}$} & \multirow[b]{2}{*}{$V P / /$} & \multirow[b]{2}{*}{$V P \perp$} & \multicolumn{3}{|c|}{ CHOQUE TERMICO } \\
\hline & & & & & & & & $V P / /$ & $V P \perp$ & $\Delta_{m}$ \\
\hline \multirow{3}{*}{ Natural // } & 1 & 30,7 & 100,4 & $3.048,0$ & 7,25 & 4.564 & 4.819 & & & \\
\hline & 2 & 30,7 & 100,4 & $2.928,0$ & 6,96 & 4.649 & 4.951 & & & \\
\hline & 3 & 30,5 & 100,9 & $2.819,7$ & 6,77 & 4.651 & 4.991 & & & \\
\hline \multirow{3}{*}{$\begin{array}{l}\text { choque } \\
\text { térmico // }\end{array}$} & 4 & 31,0 & 100,6 & $2.432,0$ & 5,66 & 4.815 & 4.940 & 3.713 & 3.578 & 0,02 \\
\hline & 5 & 31,1 & 101,1 & $2.451,7$ & 5,66 & 4.839 & 4.856 & 3.845 & 3.501 & 0,01 \\
\hline & 6 & 31,1 & 101,5 & $2.501,3$ & 5,75 & 4.789 & 4.913 & 3.733 & 3.506 & 0,02 \\
\hline \multirow{3}{*}{ Natural $\perp$} & 7 & 30,2 & 101,4 & $4.642,7$ & 11,30 & 4.702 & 4.827 & & & \\
\hline & 8 & 30,2 & 101,3 & $4.494,3$ & 10,95 & 4.841 & 4.868 & & & \\
\hline & 9 & 30,2 & 101,5 & $4.379,0$ & 10,66 & 4.822 & 4.975 & & & \\
\hline \multirow{10}{*}{$\begin{array}{l}\text { choque } \\
\text { térmico } \perp\end{array}$} & 10 & 29,5 & 100,6 & $3.534,3$ & 9,07 & 4.700 & 4.857 & 3.740 & 3.710 & 0,02 \\
\hline & 11 & 29,6 & 100,5 & $3.537,0$ & 9,06 & 4.621 & 4.525 & 3.668 & 3.537 & 0,00 \\
\hline & 12 & 29,6 & 101,1 & $3.533,7$ & 8,98 & 4.659 & 4.472 & 3.795 & 3.485 & 0,02 \\
\hline & $\bar{x}_{n a \perp}$ & 10,97 & & $\bar{x}_{n a t / /}$ & 6,99 & 4.721 & 4.833 & 3.749 & 3.553 & 0,01 \\
\hline & $S$ & 0,32 & & $s$ & 0,24 & 96 & 166 & 62 & 84 & 0,01 \\
\hline & C.V. & 2,9 & & C.V. & 3,4 & 2,0 & 3,4 & 1,7 & 2,4 & 56,3 \\
\hline & $\bar{x}_{C T \perp}$ & 9,04 & & $\bar{x}_{C T / /}$ & 5,69 & & $\Delta$ & -21 & -26 & \\
\hline & $S$ & 1,01 & & $S$ & 0,05 & & & & & \\
\hline & C.V. & 11,2 & & C.V. & 0,9 & & & & & \\
\hline & $\Delta \perp$ & -18 & & $\Delta / /$ & -19 & & & & & \\
\hline
\end{tabular}

\begin{tabular}{|c|c|c|c|c|c|c|c|c|c|c|}
\hline \multirow{2}{*}{ ARB } & \multirow{2}{*}{$\mathrm{CP}$} & \multirow[b]{2}{*}{$d$} & \multirow{2}{*}{$b$} & \multirow[b]{2}{*}{$W$} & \multirow[b]{2}{*}{$\sigma_{f}$} & \multirow[b]{2}{*}{$V P / /$} & \multirow{2}{*}{$V P \perp$} & \multicolumn{3}{|c|}{ CHOQUE TÉRMICO } \\
\hline & & & & & & & & $V P / /$ & $V P \perp$ & $\Delta_{m}$ \\
\hline \multirow[t]{3}{*}{ Natural // } & 1 & 20,3 & 101,1 & $2.213,7$ & 8,01 & 4.555 & 4.294 & & & \\
\hline & 2 & 20,4 & 101,1 & $1.756,3$ & 6,28 & 4.471 & 4.249 & & & \\
\hline & 3 & 20,4 & 101,1 & $2.143,7$ & 7,66 & 4.679 & 4.109 & & & \\
\hline choque & 4 & 20,9 & 101,0 & $1.309,7$ & 4,47 & 4.612 & 4.292 & 4.008 & 3.448 & 0,04 \\
\hline \multirow{2}{*}{ térmico // } & 5 & 20,8 & 101,1 & $1.204,3$ & 4,12 & 4.681 & 4.333 & 3.844 & 3.343 & 0,06 \\
\hline & 6 & 20,6 & 101,4 & $1.530,7$ & 5,32 & 4.715 & 4.261 & 4.121 & 3.410 & 0,04 \\
\hline \multirow[t]{3}{*}{ Natural $\perp$} & 7 & 20,6 & 100,9 & $3.427,0$ & 11,98 & 4.755 & 4.237 & & & \\
\hline & 8 & 20,8 & 101,0 & $2.752,0$ & 9,49 & 4.608 & 4.315 & & & \\
\hline & 9 & 20,9 & 101,3 & $3.132,0$ & 10,62 & 4.650 & 4.151 & & & \\
\hline choque & 10 & 20,4 & 101,2 & $2.901,3$ & 10,36 & 4.720 & 4.163 & 4.029 & 3.600 & 0,03 \\
\hline \multirow[t]{9}{*}{ térmico $\perp$} & 11 & 20,4 & 101,2 & $2.649,3$ & 9,41 & 4.729 & 4.326 & 4.056 & 3.654 & 0,03 \\
\hline & 12 & 20,8 & 101,6 & $3.152,3$ & 10,81 & 4.633 & 4.358 & 4.014 & 3.614 & 0,05 \\
\hline & $\bar{x}_{n a \perp}$ & 10,70 & & $\bar{x}_{n a t / /}$ & 7,32 & 4.651 & 4.257 & 4.012 & 3.511 & 0,04 \\
\hline & $S$ & 1,25 & & $S$ & 0,91 & 81 & 79 & 92 & 128 & 0,01 \\
\hline & C.V. & 11,6 & & C.V. & 12,5 & 1,7 & 1,9 & 2,3 & 3,6 & 29,5 \\
\hline & $\overline{\bar{x}_{C T \perp}}$ & 10,20 & & $\overline{\bar{x}}_{C T / 1}$ & 4,64 & & $\Delta$ & -14 & -18 & \\
\hline & $s$ & 0,59 & & $s$ & 0,62 & & & & & \\
\hline & C.V. & 5,8 & & C.V. & 13,3 & & & & & \\
\hline & $\Delta \perp$ & -5 & & $\Delta / /$ & -37 & & & & & \\
\hline
\end{tabular}




\begin{tabular}{|c|c|c|c|c|c|c|c|c|c|c|}
\hline \multirow{2}{*}{ ScC } & \multirow{2}{*}{$\mathrm{CP}$} & \multirow{2}{*}{$d$} & \multirow{2}{*}{$b$} & \multirow{2}{*}{$W$} & \multirow{2}{*}{$\sigma_{f}$} & \multirow{2}{*}{$V P / /$} & \multirow{2}{*}{$V P \perp$} & \multicolumn{3}{|c|}{ CHOQUE TERMICO } \\
\hline & & & & & & & & $V P / /$ & $V P \perp$ & $\Delta_{m}$ \\
\hline \multirow[t]{3}{*}{ Natural // } & 1 & 30,5 & 101,2 & $4.616,3$ & 11,05 & 5.196 & 4.984 & & & \\
\hline & 2 & 30,4 & 100,1 & $4.820,0$ & 11,73 & 5.294 & 5.004 & & & \\
\hline & 3 & 30,4 & 100,9 & $4.845,0$ & 11,73 & 5.292 & 5.097 & & & \\
\hline choque & 4 & 29,4 & 101,2 & $2.857,0$ & 7,36 & 5.138 & 4.958 & 3.985 & 3.774 & 0,03 \\
\hline \multirow{2}{*}{ térmico // } & 5 & 29,3 & 100,6 & $2.705,0$ & 7,07 & 5.259 & 5.054 & 4.005 & 3.781 & 0,02 \\
\hline & 6 & 29,3 & 101,6 & $2.809,3$ & 7,24 & 5.249 & 5.129 & 4.053 & 3.876 & 0,03 \\
\hline \multirow[t]{3}{*}{ Natural $\perp$} & 7 & 29,6 & 101,6 & $2.710,0$ & 6,86 & 5.159 & 5.163 & & & \\
\hline & 8 & 29,5 & 101,5 & $3.504,7$ & 8,91 & 5.285 & 5.184 & & & \\
\hline & 9 & 29,5 & 101,7 & $3.300,3$ & 8,42 & 5.298 & 5.183 & & & \\
\hline choque & 10 & 30,6 & 101,1 & $2.111,3$ & 5,04 & 5.104 & 5.000 & 4.010 & 3.617 & 0,04 \\
\hline \multirow[t]{9}{*}{ térmico $\perp$} & 11 & 30,7 & 101,4 & $1.551,7$ & 3,65 & 5.044 & 5.116 & 3.884 & 3.644 & 0,04 \\
\hline & 12 & 30,9 & 101,4 & $1.574,3$ & 3,66 & 5.147 & 4.907 & 4.105 & 3.542 & 0,02 \\
\hline & $\bar{x}_{n a \perp}$ & 11,50 & & $\bar{x}_{n a t / /}$ & 8,06 & 5.205 & 5.065 & 4.007 & 3.706 & 0,03 \\
\hline & $S$ & 0,39 & & $S$ & 1,07 & 86 & 94 & 74 & 125 & 0,01 \\
\hline & C.V. & 3,4 & & C.V. & 13,3 & 1,7 & 1,9 & 1,8 & 3,4 & 36,3 \\
\hline & $\overline{\bar{x}_{C T \perp}}$ & 7,23 & & $\overline{\bar{x}_{C T / /}}$ & 4,12 & & $\Delta$ & -23 & -27 & \\
\hline & $S$ & 0,15 & & $S$ & 2,11 & & & & & \\
\hline & C.V. & 2,0 & & C.V. & 51,2 & & & & & \\
\hline & $\Delta \perp$ & -37 & & $\Delta / /$ & -49 & & & & & \\
\hline
\end{tabular}

